\title{
National Research Program of the Water Resources Division, U.S. Geological Survey, Fiscal Year 1993
}

\section{United States Geological Survey Open-File Report} $15-12.5$

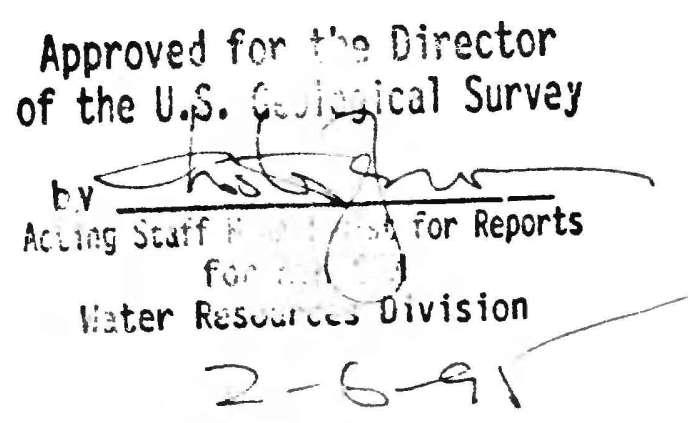



National Research Program of the

Water Resources Division,

U.S. Geological Survey,

Fiscal Year 1993

\section{United States Geological Survey Open-File Report 95-125}





\section{NATIONAL RESEARCH PROGRAM OF THE WATER RESOURCES DIVISION, U.S. GEOLOGICAL SURVEY, FISCAL YEAR 1993}

Compiled by MARTHA L. NICHOLS and LINDA C. FRIEDMAN

U.S. GEOLOGICAL SURVEY

Open-File Report 95-125

RESTON, VIRGINIA 1995 


\title{
U.S. \\ DEPARTMENT OF THE INTERIOR \\ $\cap$ BRUCE BABBITT, Secretary
}

\author{
U.S. GEOLOGICAL SURVEY \\ GORDON P. EATON, Director
}

Any use of trade, product, or firm names in this publication is for descriptive

purposes only and does not imply endorsement by the U.S. Government

For additional information write to:

Chief, Office of Hydrologic Research

U.S. Geological Survey

436 National. Center

12201 Sunrise Valley Drive

Reston, Virginia 22092
Copies of this report can be purchased from:

U.S. Geological Survey

Books and Open-File Reports Section

Federal Center, Box 25425,

Denver, Colorado 80225 


\section{CONTENTS}

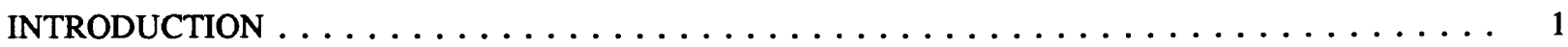

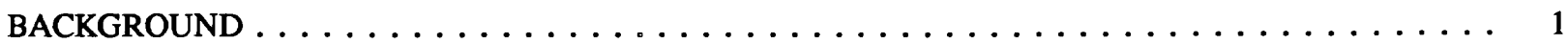

ORGANIZATION OF THE NATIONAL RESEARCH PROGRAM $\ldots \ldots \ldots \ldots \ldots \ldots \ldots \ldots$

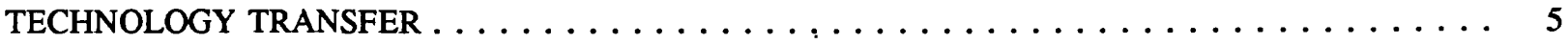

RESEARCH DISCIPLINES AND PROJECTS $\ldots \ldots \ldots \ldots \ldots \ldots \ldots \ldots \ldots \ldots \ldots \ldots$

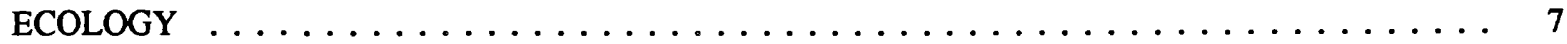

CR 84-286 Interactions Between Organic Solutes and Trace Metals in Natural Waters,

and Their Ecological Role ................... 8

Diane M. McKnight, Project Chief

CR 85-293 The Role of Chemical Fluxes in the Biogeochemistry of Inland Surface

Waters, Including Lakes, Reservoirs, and Wetlands . . . . . . . . . 13

James W. LaBaugh, Project Chief

CR 86-295 Microbial Transformation of Dissolved Organic Carbon in Aquatic

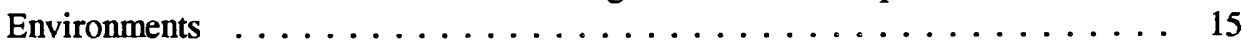

Richard L. Smith, Project Chief

CR 88-312 Ecological Interactions of Lakes and Streams . . . . . . . . . . . . . 19

Robert C. Averett, Project Chief

CR 91-320 Characterization of Biotic and Biogeochemical Interactions at Environmental

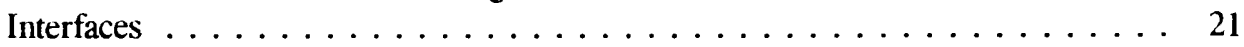

Robert G. Striegl, Project Chief

CR 90-323 Interdisciplinary Research Initiative (IRI) at the Shingobee Headwaters

Research Area, Minnesota . . . . . . . . . . . . . . . . . . . . 24

Thomas C. Winter, Project Chief

CR 91-325 Limnological Phenomena in Impounded Rivers $\ldots \ldots \ldots \ldots \ldots$

G. Richard Marzolf, Project Chief

CR 91-327 Interaction of Bacteria with Environmental Contaminants and Solid Surfaces

in the Aquatic Environment . . . . . . . . . . . . . . . . . . . 29

Ronald W. Harvey, Project Chief

CR 92-337 Effects of Toxic Substances on Aquatic Communities . . . . . . . . . . . 34

Harry V. Leland, Project Chief

NR 73-090 Remote Sensing and Ecological Research in Wetlands . . . . . . . . . 36

Virginia P. Carter, Project Chief

NR 87-136 Modeling of Microbially Catalyzed Geochemical Reactions in Aquatic

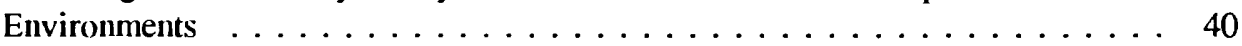

Derek R. Lovley, Project Chief 
NR 90-145 Vegetation and Hydrogeomorphic Relations Cliff R. Hupp, Project Chief

WR 61-012 Limnology: Controls on Distribution and Composition of Benthic

Communities of Inland Aquatic Ecosystems . . . . . . . . . . . . 48 Keith V. Slack, Project Chief

WR 68-046 Geochemistry of Riverine and Estuarine Waters $\ldots \ldots \ldots \ldots \ldots \ldots \ldots$ David H. Peterson, Project Chief

WR 71-068 Fate of Organic Chemicals in Subsurface Environments . . . . . . . . . 55 Edward M. Godsy, Project Chief

WR 75-125 Availability of Trace Elements in Sediments to Aquatic Organisms . . . . . . . 58 Samuel N. Luoma, Project Chief

WR 76-145 Biotic Response to Climatic Variability and Human Impacts in Arid Lands . . . 63 Julio L. Betancourt, Project Chief

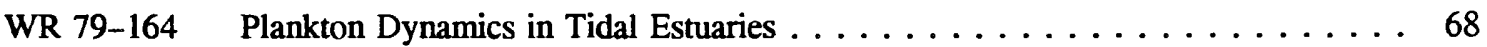
James E. Cloern, Project Chief

WR 81-174 Microbial Biogeochemistry of Aquatic Environments $\ldots \ldots \ldots \ldots \ldots \ldots \ldots$ Ronald S. Oremland, Project Chief

WR 84-186 Biotic Interface with Fluvial Transport: Processes Associated with Dissolved Solutes in Transport . . . . . . . . . . . . . . . . . . . 77 Frank J. Triska, Project Chief

WR 86-190 Solute Transport Involving Biological Processes in Surface Waters . . . . . . . 81 James S. Kuwabara, Project Chief

WR 86-192 Environmental Influences on Estuarine Benthic Community Dynamics . . . . . 85 Frederic $\mathrm{H}$. Nichols, Project Chief

GEOMORPHOLOGY AND SEDIMENT TRANSPORT . . . . . . . . . . . 89

CR 75-102 Movement and Storage of Sediment in River Systems $\ldots \ldots \ldots \ldots \ldots \ldots \ldots$ Robert H. Meade, Project Chief

CR 65-105 Effects of Water and Sediment Discharges on Channel Morphology . . . . . 93 Garnett P. Williams, Project Chief

CR 74-187 Hydraulics and Mechanics of Bedload-Transport Processes . . . . . . . . . 95 William W. Emmett, Project Chief

CR 82-273 River Mechanics . . . . . . . . . . . . . . . . . . . . 98 Edmund D. Andrews, Project Chief

CR 87-309 Sediment-Transported Pollutants in the Mississippi River . . . . . . . . . . . 102 Robert H. Meade, Jr., Project Chief 
CR 79-311 Sediment Impacts from Disturbed and Undisturbed Lands $\ldots \ldots \ldots \ldots \ldots$ Waite R. Osterkamp, Project Chief

CR 88-313 Sediment-Water Chemistry in Large River Systems: Biogeochemical,

Geomorphic, and Human Controls . . . . . . . . . . . . . . . . . 109 Robert F. Stallard, Project Chief

CR 91-324 Applications of Fluid and Sediment Mechanics to Basin and Regional Scale Hydrologic and Geomorphic Problems . . . . . . . . . . . . . . 113 J. Dungan Smith, Project Chief

WR $89-200 \quad$ Response of Fluvial Systems to Climatic Variability $\ldots \ldots \ldots \ldots \ldots \ldots \ldots$ Robert H. Webb, Project Chief

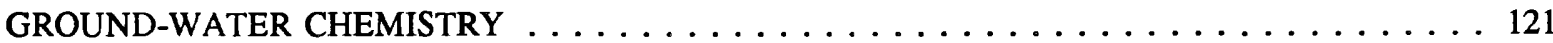

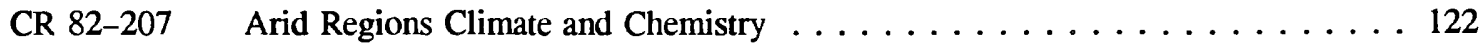
Larry V. Benson, Project Chief

CR 82-276 Geochemistry of Clay-Water Reactions $\ldots \ldots \ldots \ldots \ldots \ldots \ldots \ldots$ Dennis D. Eberl, Project Chief

CR 83-283 Environmental Dynamics of Persistent Organic Compounds . . . . . . . . 130 Cary T. Chiou, Project Chief

CR 89-318 Reaction-Transport Modeling in Ground-Water Systems . . . . . . . . . . . 135 David L. Parkhurst, Project Chief

CR 92-326 Chemical Modeling and Thermodynamic Data Evaluation of Major and

Trace Elements in Acid Mine Waters and Ground Waters . . . . . . . . . . 138 Darrell K. Nordstrom, Project Chief

NR 79-093 Chemical Models of Natural Systems . . . . . . . . . . . . . . . . . . 142 Donald C. Thorstenson, Project Chief

NR 69-020 Mineral-Water Interaction in Saline Environments . . . . . . . . . . . . . . 144 Blair F. Jones, Project Chief

NR 57-034 Spatial Distribution of Chemical Constituents in Ground Water . . . . . . . . 147 William Back, Project Chief

NR 74-041 Interface of Paleoclimatology and Aquifer Geochemistry . . . . . . . 152 Isaac J. Winograd, Project Chief

NR 76-056 Kinetics and Thermodynamics of Chemical Evolution in Ground-Water Systems . 154 L. Niel Plummer, Project Chief

NR 75-064 Physical Chemistry of Stable Isotope Fractionation in Hydrologic Processes $\ldots 160$ Tyler B. Coplen, Project Chief 
NR 78-092 Hydrogeochemical Controls on the Migration of Radionuclides from

Uranium Mill Tailings . . . . . . . . . . . . . . . . 166 Edward R. Landa, Project Chief

NR 81-122 Dispersion of Toxic and Radioactive Wastes in Ground-Water Systems $\ldots \ldots 169$ Warren W. Wood, Project Chief

NR 83-129 Comparative Study of Organic Degradation in Selected Hydrogeologic

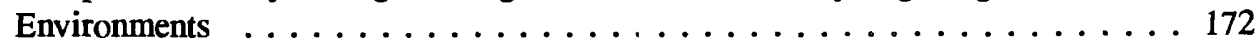
Mary Jo Baedecker, Project Chief

NR 79-132 Relationship Between Chemical Quality of Natural Waters and

Human Health and Disease . . . . . . . . . . . . . . 176 Gerald L. Feder, Project Chief

NR 82-138 Uranium-Thorium Series Radioisotopes in Ground-Water and

Surface-Water Systems . . . . . . . . . . . . . . . . . . . 178 Thomas F. Kraemer, Project Chief

NR 91-151 Transport and Biogeochemical Fate of Organic Substances in Aquatic

Environments ....................... 18 Robert P. Eganhouse, Project Chief

WR 68-036 Factors Determining Solute Transfer in the Unsaturated Zone . . . . . . . . . 184 Ronald V. James, Project Chief

WR 70-065 Partitioning of Solutes between Solid and Aqueous Phases $\ldots \ldots \ldots \ldots$ James A. Davis, III, Project Chief

WR 91-080 Stable Isotope Tracers of Biogeochemical and Hydrologic Processes . . . . . . 191 Carol Kendall, Project Chief

WR 76-139 Geochemistry of Water in Fine Grained Sediments . . . . . . . . . . . . . . 197 Yousif K. Kharaka, Project Chief

WR 79-165 Chemical and Isotope Studies of Thermal Waters of the Western United States . . 201 Robert H. Mariner, Project Chief

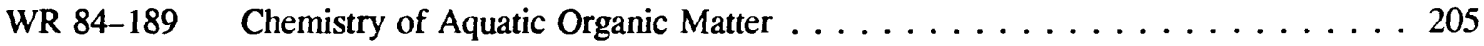
Donald F. Goerlitz, Project Chief

WR 88-196 Geochemical Reactions Between Water and Mineral Substrates . . . . . . . . 208 Arthur F. White, Project Chief

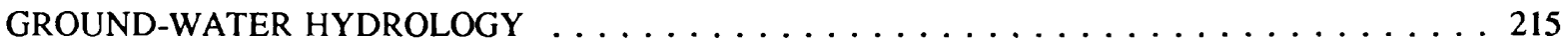

CR 73-085 The Mathematical Simulation of the Transport and Reaction of Chemical

Species in Ground Water . . . . . . . . . . . . . . 216

David B. Grove, Project Chief 
CR 74-090 The Role of Lakes in the Hydrologic System, with Emphasis on Their

Relation to Ground Water . . . . . . . . . . . . . . . . 218

Thomas C. Winter, Project Chief

CR 64-140 Borehole Geophysics as Applied to Geohydrology . . . . . . . . . . 222 Frederick L. Paillet, Project Chief

CR 76-191 Mathematical Simulation of Subsurface-Water Flow Using Uncertain and

Incomplete Data . . . . . . . . . . . . . . . . . . . . . . . 228

Richard L. Cooley, Project Chief

CR 69-200 Field Applications of Unsaturated Zone Flow Theory . . . . . . . . . . . 232 Edwin P. Weeks, Project Chief

CR 85-292 Ground-Water Solute-Transport Simulation $\ldots \ldots \ldots \ldots \ldots \ldots \ldots$ Kenneth L. Kipp, Project Chief

CR 90-319 Application of Stochastic Processes in Hydrogeology $\ldots \ldots \ldots \ldots \ldots \ldots 242$ Richard L. Naff, Project Chief

NR 81-035 Hydrologic Behavior of Cretaceous Shales Christopher E. Neuzil, Project Chief

NR 78-089 Investigations of Single and Multiphase Fluid Flow, Mass and

Energy Transport, and Fluid Phase Change in the Subsurface Environment . . . 247 Clifford I. Voss, Project Chief

NR 81-120 Digital Modeling of Transport in the Saturated Zone . . . . . . . . . . 250 Leonard F. Konikow, Project Chief

NR 84-130 Multivariate Statistical Techniques for Assessing Regional Ground-Water

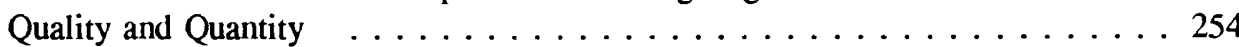
Charles E. Brown, Project Chief

NR 84-134 Transport Phenomena in Fractured Rock . . . . . . . . . . . . . . 256 Allen M. Shapiro, Project Chief

NR 91-152 Quantitative Analysis of Heterogeneous Hydrogeologic Controls on

Ground-Water Flow and Transport . . . . . . . . . . . . . . . . . . . 259 Thomas E. Reilly, Project Chief

NR 91-153 Reaction-Transport Phenomena in Hydrogeologic Settings . . . . . . . 263 Ward Sanford, Project Chief

WR 63-024 Application of the Unsaturated Flow Theory to the Phenomena of Infiltration and Drainage . . . . . . . . . . . . . . . . 265 David A. Stonestrom, Project Chief

WR 73-102 Modeling and Monitoring Heat and Fluid Flow in Geothermal Systems . . . . 268 Michael L. Sorey, Project Chief 
WR 72-108 Technical Coordination and Support of Water Resources Division

Geothermal Studies . . . . . . . . . . . . . . . . . 271 Michael L. Sorey, Project Chief

WR 74-121 Hydrologic Studies of Heat and Mass Transport $\ldots \ldots \ldots \ldots \ldots \ldots$ Steven E. Ingebritsen, Project Chief

WR 75-127 Analytical Modeling of Flow and Transport in Aquifers and Geothermal

Reservoirs ......................... 276 Allen F. Moench, Project Chief

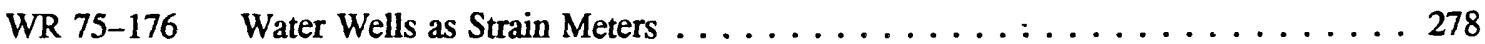
John D. Bredehoeft, Project Chief

WR $82-178$ Ground-water Monitoring Network Design $\ldots \ldots \ldots \ldots \ldots \ldots \ldots$ Brian J. Wagner, Project Chief

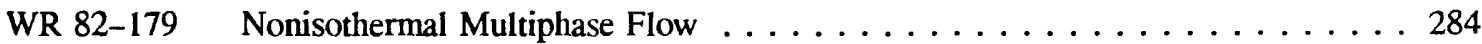
William N. Herkelrath, Project Chief

WR 82-180 Theories of Water Flow and of Solute Transport in the Unsaturated Zone . . . . 287 Jacob Rubin, Project Chief

WR 83-184 Hydrology of Fractured Rocks . . . . . . . . . . . . . . . . . . . . 290 Paul A. Hsieh, Project Chief

WR 87-193 Temperature Effects in the Unsaturated Zone . . . . . . . . . . . . . 293 James E. Constantz, Project Chief

WR 89-198 Physical Characteristics that Determine Flow in the Unsaturated Zone . . . . . 295 John R. Nimmo, Project Chief

WR 89-199 The Fate and Transport of Immiscible Contaminants in the Subsurface . . . . . 298 Hedeff I. Essaid, Project Chief

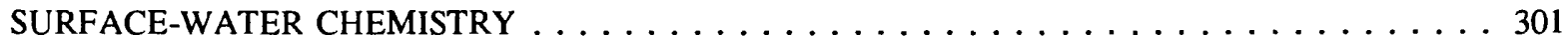

CR 68-046 Origin, Characterization, and Quantification of Natural Organic

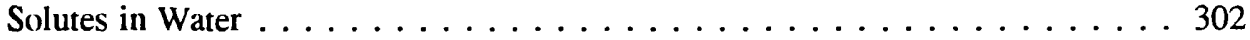
Ronald L. Malcolm, Project Chief

CR 68-132 Behavior of Natural Polyelectrolytes in Water . . . . . . . . . . . . 306 Robert L. Wershaw, Project Chief

CR 75-189 Geochemical Kinetics Studies of Silicate Rock Hydrologic Systems . . . . . . . 312 Hans C. Claassen, Project Chief

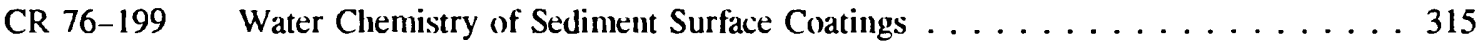
Marvin C. Goldberg, Project Chief 
CR 83-282 Research in Analytical Environmental Trace Element Chemistry and

Its Impact on Water Quality . . . . . . . . . . . . . . . . . 319

Howard E. Taylor, Project Chief

CR 83-284 Aqueous Crystal Growth and Dissolution Kinetics of Earth Surface Minerals _. 323 Michael M. Reddy, Project Chief

CR 84-285 Comprehensive Organic Analysis of Water . . . . . . . . . . . . 327 Jerry A. Leenheer, Project Chief

CR 93-331 Organic Carbon Migration in Aquatic Environments . . . . . . . . . 332 George R. Aiken, Project Chief

NR 76-065 Sedimentary Geochemical Processes Affecting the Exchange of Nutrients and Transition Metals Between Sediment and Water in Riverine, Estuarine, and Lacustrine Environments . . . . . . . . . . . . . . . . . . . . . 334 Edward Callender, Project Chief

NR 79-099 Carbon Fluxes in Hydrologic and Geologic Processes . . . . . . . . . . . . 338 Eric T. Sundquist, Project Chief

NR 81-109 Geochemical Cycling of Trace Elements and Nutrients in Natural

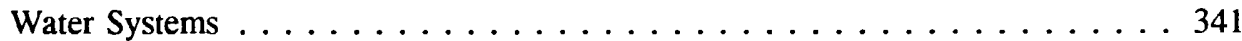
Owen P. Bricker, Project Chief

NR 86-135 Distribution and Speciation of Metals in Sedimentary Environments . . . . . 345 Nancy S. Simon, Project Chief

WR 57-076 Chemistry of Hydrosolic Metals and Related Constituents of Natural Water . . 348 John D. Hem, Project Chief

WR 83-204 Origin, Fate, and Transport of Organic Compounds in Surface and

Ground Waters and Their Effect on Water Quality . . . . . . . . 351 Wilfred E. Pereira, Project Chief

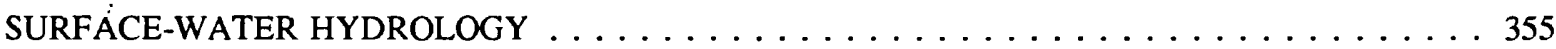

CR 77-228 Precipitation-Runoff Modeling of Watershed Systems $\ldots \ldots \ldots \ldots \ldots \ldots \ldots$ George H. Leavesley, Project Chief

CR 83-279 Statistical Analysis of Errors in Hydrologic Models . . . . . . . . . . . . 364 Brent M. Troutman, Project Chief

CR 77-301 Transport and Degradation of Organic Substances in Streams $\ldots \ldots \ldots \ldots$ Ronald E. Rathbun, Project Chief

CR 90-321 Paleohydrology and Climate Change $\ldots \ldots \ldots \ldots \ldots \ldots \ldots \ldots \ldots$ Robert D. Jarrett, Project Chief

CR 93-343 Mathematical Modeling Principles . . . . . . . . . . . . . . 374 James P. Bennett, Project Chief 
NR 69-019 Numerical Simulation of Hydrodynamic Processes in Rivers, Estuaries,

and Coastal Embayments . . . . . . . . . . . . . . . . . 375 Robert A. Baltzer, Project Chief

NR 80-104 Simulation Modeling of Hydrodynamic Systems $\ldots \ldots \ldots \ldots \ldots \ldots$. . . 378 Raymond W. Schaffranek, Project Chief

NR 82-125 Hydrologic Regression and Data-Network Design $\ldots \ldots \ldots \ldots \ldots$. . . . 382 Gary D. Tasker, Project Chief

NR $84-133 \quad$ Regional Hydrologic Processes . . . . . . . . . . . . . . . 386 Jurate M. Landwehr, Project Chief

NR 88-144 Continental Hydrology and Global Climate . . . . . . . . . . . . . . . . . 389 P.C.D. Milly, Project Chief

NR 90-147 Transport of Dissolved and Suspended Materials in Surface Waters . . . . . . . 391 Jonathan Lee, Project Chief

WR 70-064 Ice and Climate . . . . . . . . . . . . . . . . . . . . 393 William J. Campbell, Project Chief

WR 76-140 Hydrodynamics and Mathematical Modeling of Circulation and Transport Phenomena in Tidal Estuaries . . . . . . . . . . . . . . . . . . . . . . . . . 398 Ralph T. Cheng, Project Chief

WR 77-156 Research Vessel Polaris Operations in San Francisco Bay and Adjacent

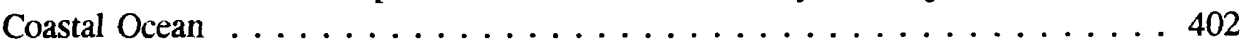
T. John Conomos, Project Chief

WR 83-183 Analysis and Modeling of Conservative and Nonconservative Transport Processes . . . . . . . . . . . . . . . . . . . 403 Roy A. Walters, Project Chief

WR 84-187 Coupled Transport and Geochemical Processes Determining the Fate of Chemicals in Surface Waters . . . . . . . . . . . . . . . . . . 405 Kenneth E. Bencala, Project Chief

WR 83-194 Fluvial Processes and River Mechanics . . . . . . . . . . . . 410 Cheng-lung Chen, Project Chief

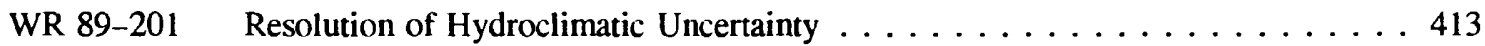
Marshall E. Moss, Project Chief

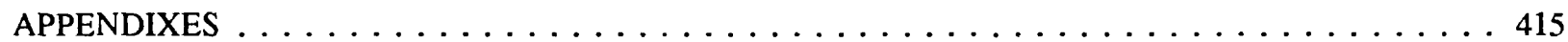

APPENDIX 1.-Alphabetical Listing by Project Chief $\ldots \ldots \ldots \ldots \ldots \ldots \ldots \ldots \ldots$

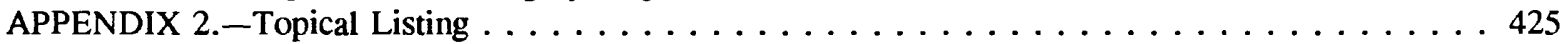




\title{
THE NATIONAL RESEARCH PROGRAM OF THE WATER RESOURCES DIVISION, U.S. GEOLOGICAL SURVEY FISCAL YEAR 1993
}

\author{
Compiled by MARTHA L. NICHOLS AND LINDA C. FRIEDMAN
}

\section{INTRODUCTION}

This report, one in a series of annual reports, provides current information about the National Research Program (NRP) of the U.S. Geological Survey's (USGS) Water Resources Division (WRD) during fiscal year 1993. Organized by NRP's six research disciplines, the volume contains a summary of the problem, objective, approach, and progress for each project that was active during fiscal year 1993. It also contains bibliographic information that, because of the long-term nature of the program, covers a 5-year period. The bibliographic information does not include abstracts or informal reports. Rather it contains those reports that are readily available in the form of journal articles, USGS publications, book chapters, or books.

\section{BACKGROUND}

The National Research Program has been an integral part of the U.S. Geological Survey's Water Resources Division since the late 1950's. The NRP conducts basic and problem-oriented research in support of the mission of the USGS. Relevant hydrologic information provided by the USGS is available today to assist the Nation in solving its water problems because of a conscious decision made in years past to invest in research. The NRP is designed to encourage pursuit of research topics aimed at providing new knowledge and insights into varied and complex hydrologic processes that are not well understood. The emphasis of these research activities changes through time, reflecting the emergence of promising new areas of inquiry and the demand for new tools and techniques with which to address water-resources issues. Knowledge gained and methodologies developed in this program apply to all of the hydrologic investigations of the USGS, to the water-oriented investigations and operations of other agencies, and to the general scientific community. Through the years, many of the U.S. Geological Survey's major research and resource assessment initiatives related to existing and emerging national water-resources problems have had their origins in the NRP.

Since its beginning in the late 1950's, the NRP has grown to encompass a broad spectrum of scientific investigations. The sciences of hydrology, mathematics, chemistry, physics, ecology, biology, geology, and engineering are used to gain a fundamental 
understanding of the processes that affect the availability, movement, and quality of the Nation's water resources. Results of NRP's long-term research investigations often lead to the development of new concepts, techniques, and approaches that are applicable not only to the solution of current water problems but also to future issues that may affect the Nation's water resources. Basic tools of hydrology that have been developed by the NRP include ground-water modeling, geochemical modeling, and regional flood-frequency analysis. These and other tools developed by the NRP are in common use today throughout the USGS, in other agencies, and in the private sector.

In consultation with NRP managers and research advisors, NRP projects set long-term research goals. Projects typically conduct research during a period of several years as studies progressively resolve questions of great complexity. In conducting such long-term efforts, most projects employ a combination of detailed field observations, laboratory experiments and analyses, and some kind of conceptual or mathematical modeling of the processes involved. Often, NRP projects cooperate with WRD District projects and other NRP projects to conduct multidisciplinary studies-combining, for example, ground-water flow with ground-water chemistry or surface-water chemistry and ecology.

\section{ORGANIZATION OF THE NATIONAL RESEARCH PROGRAM}

The NRP is located principally in Reston, Va.; Denver, Colo.; and Menlo Park, Calif. A Chief, Branch of Regional Research (BRR), at each location is responsible for managing the program and serves as a liaison with the WRD's operational program. The Chief, BRR, reports directly to the Chief, Office of Hydrologic Research, who oversees the entire program. The NRP is organized into about 120 projects, and has a permanent staff of approximately 290 individuals and a nonpermanent staff that is made up primarily of university students and faculty.

For technical administration, the NRP is subdivided into six disciplines, with a Research Adviser and Assistant Research Adviser assigned to each. The Research Advisers serve as a peer resource to the research projects and as a technical consultant to management. The six research disciplines, the scope of their activity, and the emphasis of current study are described below:

(1) Ecology.-Concerned with biological and microbiological processes that affect the quality of water. To improve understanding of the biological effects of stress, hydrologic events, and climatic trends, the solute composition of and solute transport in surface and subsurface waters are investigated and studies are made of the response of organisms to environmental factors. Current investigations include studies of the influence of microbial processes on the fate of hazardous substances in ground water; the effect of geochemical processes on the transfer of hazardous substances to food chains that could include humans; the effect of hydrologic processes and associated 
environmental variables on the composition of benthic and pelagic communities; the use of organisms to help quantify and identify hydrologic events, such as floods or stress inputs; and the effect of microbial production and transformations of organic materials in the carbon, nitrogen, and sulfur cycles. Most studies are process-oriented and emphasize the interaction of physical and chemical aspects of hydrology with biological processes. The types of hydrologic regimes included in these ecological investigations range from ground waters to lakes, rivers and estuaries, and from coastal wetlands to forests and deserts.

(2) Geomorphology and sediment transport.-Focuses on the understanding of channel morphology and erosional processes that govern the source, mobility, and deposition of sediment. Currently, research is aimed primarily at providing the capability for deterministic and stochastic modeling, modeling sediment transport in alluvial channels, and assessing the causes of changes in stream-sediment loads with time and the rates at which rivers adjust to changes in the quantity of water and sediment contributed to the channel.

(3) Ground-water chemistry.-Concerned with inorganic, organic, and biochemical reactions affecting natural and contaminated water in relation to mineralogic, geochemical, and hydrologic conditions in the ground-water environment. Laboratory research includes studies of the kinetics and mechanisms of electron-transfer reactions between mineral surfaces and aqueous solutions, the adsorption behavior of inorganic and organic solutes on particulate surfaces, the kinetics of silicate and carbonate mineral dissolution and crystal growth, isotopic fractionation in mineral-water-gąs systems, the speciation of transuranium elements in ground water, the exchange properties of clays, and the thermodynamics of solubility and coprecipitation phenomena. Field studies involve controls of mineral-water-gas reactions in a wide variety of hydrochemical environments including shallow ground-water systems, regional aquifer systems, deep sedimentary basins and subsurface brines, geothermal systems, freshwater-saltwater interfaces, and the unsaturated zone. Studies include investigations of the degradation of organic matter and attenuation of toxic metals in environmentally stressed hydrochemical environments, relations between water quality and human health and disease, and physical and chemical processes affecting dispersion of dissolved solutes. Extensive applications of isotopic data are made to identify water sources, cross-formational leakage, water age, paleoclimatic conditions, and reactants and products in the ground-water environment. Current modeling research focuses on the speciation of metals and other dissolved solutes in natural and contaminant waters; prediction of the thermodynamic properties of mineral-water reactions in ground-water systems, including brines and other highly saline fluids; prediction of chemical and isotopic evolution in water-rock systems, and age-dating ground water.

(4) Ground-water hydrology._-Focuses on developing understanding and techniques for evaluating and predicting the quantity and quality of water moving through porous and 
fractured media in order to effectively manage ground-water resources. Research into the role of the unsaturated zone is being conducted to provide information needed to evaluate ground-water conservation and management practices, such as artificial recharge, phreatophyte control, and the reduction of evapotranspiration. Currently, investigations of land subsidence are underway as are studies to determine how fracture zones, permeability distributions, and geothermal conditions affect, or are affected by, subsurface hydrologic processes. Comprehensive studies in borehole geophysics are being conducted to improve the resolution and effectiveness of these subsurface techniques. Efforts also are being made to develop new two- and three-dimensional models and to refine existing for use in understanding flow and solute transport in porous media in both the saturated and unsaturated zones. Parameter-estimation techniques to enhance and assess model accuracy also are being developed.

(5) Surface-water chemistry. - Involves an assessment of natural and contaminant chemicals in water and sediment, as well as the study of fundamental chemical and biochemical processes that affect the movement of organic and inorganic solutes and gases through primarily surface-water systems. Projects now underway include characterization of natural and manmade organic substances, identification of organic pollutants in natural waters, interaction of trace metals and radionuclides with natural organic substances and sediments, study of biodegradation processes of organic compounds, study of climate and carbon fluxes, hydrochemistry and paleoclimatology in arid regions, investigations of nutrient and metal fluxes in natural-water systems, the study of the effect of contaminated precipitation on corrosion of building materials, and the effects of acid rain on water quality.

(6) Surface-water hydrology._- Stresses the development of understanding and techniques needed to improve the ability to predict the occurrence, distribution, movement, and quantity of the Nation's surface-water resources, and to explain quantitatively how these resources may be affected by natural or human-induced changes. Ongoing projects generally can be grouped into studies of: (a) all hydrologic processes that govern the infiltration, evapotranspiration and runoff from basins, especially as they relate to an analysis of the effect of land uses such as surface mining, agriculture, and urbanization; (b) the laws of random processes and how these laws are related to the statistics of extreme events, such as floods, droughts, or other natural hazards; the areal distribution of hydrologic information; and the accuracy and reliability of deterministic models of hydrologic systems; (c) the hydraulics or hydrodynamics of flow in single or multidimensional surface-water systems, and how this flow is related to the safety and welfare of people that encroach on the water body; (d) the sources, transport, and fate of constituents that are related to water quality in surface waters; and (e) the accumulation, movement, and melting of snow or ice, particularly the ways in which the presence of snow and ice affects climate, water supply, and (or) safety. 


\section{TECHNOLOGY TRANSFER}

The dissemination of the new understanding and techniques that are developed by the research projects is considered an important NRP activity. Results from NRP studies are published in appropriate publication outlets to assure wide dissemination of research results. Outlets include refereed scientific journals and USGS Water-Supply Papers and Professional Papers. Knowledge of new techniques for hydrologic investigations, such as sampling methods, laboratory methods, or mathematical models, and other research results is transferred to the scientific community and to the public through presentations at professional society meetings and other scientific and public gatherings as well as through publications. Furthermore, to disseminate research knowledge within and throughout the USGS, project personnel conduct appropriate USGS training courses, collaborate and advise other USGS scientists, and provide technical programmatic advice to USGS management.

This report is intended to help with technology transfer by describing the work in progress, the expertise, and most importantly the publications produced by the NRP. Readers are encouraged to seek copies of these publications from the specific NRP project that prepared them. Addresses and phone numbers of Project Chiefs are provided in the text. For the reader's convenience two appendixes are provided. The first is arranged alphabetically by the name of the Project Chief and the second is arranged alphabetically by topics that we believe may be of interest. 
6 NATIONAL RESEARCH SUMMARY 1993 


\section{RESEARCH DISCIPLINES AND PROJECTS}

\section{ECOLOGY}




\section{ECOLOGY}

TITLE: Interactions Between Organic Solutes and Trace Metals in Natural Waters, and Their Ecological Role (CR 84-286)

PERSONNEL: Diane M. McKnight, Project Chief

Debra A. Litwin, Secretary

Richard A. Harnish, Hydrologist

Michael W. Anthony, Student

James McGutchen, student (Univ. Colorado)

Sarah A. Spaulding, Student, (Colo. St. Univ.)

ADDRESS: $\quad$ U.S. Geological Survey, 3215 Marine Street, Boulder, CO 80303

TELEPHONE: (303) 541-3015

PROBLEM: Aquatic humic substances and other classes of dissolved organic material in natural waters can control the biogeochemistry of trace metals and other solutes and can influence ecological processes in lakes and streams. The nature and reactivity of the dissolved organic material is, in turn, influenced by biological, chemical, and physical processes in the aquatic environment. Recent advances in isolating and characterizing different fractions of dissolved organic carbon (DOC) and in measuring rates of microbial processes can be used to advance the understanding of the dynamic relations among aquatic biota and dissolved organic material and trace metals in different environments.

OBJECTIVE: (1) Determine the processes involved in the biogeochemistry of dissolved organic material and selected trace metals in several aquatic environments; (2) describe the temporal and spatial dynamics controlling the concentration and chemical speciation of trace metals and DOC in aquatic environments; and (3) quantify carbon flux and feedback processes involving dissolved organic material in aquatic ecosystems.

APPROACH: (1) Use conventional and newly-developed methods to isolate and characterize aquatic and humic substances and other organic acids from samples collected at several ongoing field sites; (2) conduct potentiometric titrations and other laboratory experiments to determine the dependence of copper and iron complexation by humic substances and other organic fractions on $\mathrm{pH}$ and counterion complexation; (3) continue on-going field studies of biogeochemical interactions between dissolved organic material and trace metals. Field sites include two mountain streams, several lakes in Colorado and Minnesota and a bog in Massachusetts; (4) conduct field research at lakes and streams in the Dry Valleys in Antarctica to determine the carbon cycling and phytoplankton dynamics in ecosystems with only autochthonous production by algal and microbial processes; (5) evaluate global scale interactions involving dissolved organic material and trace metals. 


\section{ECOLOGY}

PROGRESS: Study of the chemistry of radionuclides in groundwater and surface waters at Rocky Flats has shown that for uranium humic complexes are the dominant phase, but for plutonium and americium particulate and colloidal phases are more important. These results have been presented at national meetings and in USGS publications.

A long term ecological research study has been funded in Antarctica. The transport of solutes in streams in the dry valleys of Antarctica is controlled by interactions in the hyporheic zone. Tracer experiments have been analysed using a computer program to quantify these interactions. Significant shifts in phytoplankton species have occurred in dry valley lakes probably reflecting effects of warming trends.

\section{REPORTS PUBLISHED 1988-1993:}

Aiken, G.R., McKnight, D.M., Wershaw, R.L., and Miller, L., 1991, Evidence for the diffusion of aquatic fulvic acids from the sediments of Lake Fryxell, Antarctica, in Baker, R.A., ed., Organic substances and sediments in water: Chelsea, Michigan, Lewis Publishers, p. 75-88.

Aiken, G.R., McKnight, D.M., Thorn, K.A., and Thurman, E.M., 1992, Isolation of hydrophilic organic acids from water using nonionic macroporous resins: Organic Geochemistry, v. 18, no. 4 , p. 567-573.

Baron, Jill, McKnight, Diane and Denning, Scott, 1991, Sources of dissolved and suspended organic material in Loch Vale Watershed, Rocky Mountain National Park, Colorado, U.S.A.: Biogeochemistry, v. 15, p. 89-110.

Bencala, K.E., Kimball, B.A., and McKnight, D.M., 1991, Use of variation in solute concentration to identify interactions of the substream zone with instream transport, in Mallard, G.E. and Aronson, D.A., eds., U.S. Geological Survey Toxics Substances Hydrology Program-Proceedings of the technical meeting, Monterey, Calif., March 11-15, 1991: Water-Resources Investigations Report 91-4034, p. 377-379.
Bencala, K.E., McKnight, D.M., and Zellweger, G.W., 1990, Characterization of transport in an acidic and metal-rich mountain stream based on a lithium tracer injection and simulations of transient storage: Water Resources Research, v. 26, no. 5, p. 989-1000.

Bencala, K.E., McKnight, D.M., Zellweger, G.W., and Kimball, B.A., 1988, Monitoring acidic stream for transport studies, in Mallard, G.E., ed., U.S. Geological Survey Toxic Substances Hydrology Progam-Proceedings of the Technical Meeting, Denver, Colo., February 2-4, 1987: U.S. Geological Survey Open-File Report 87-764, p. 119-124.

Harnish, R.A., Ranville, J.F., McKnight, D.M., and Spalding, S.A., 1992, Redox-mediated cycling of iron and manganese in Lake Fryxell, Antarctica-Associations with particulate, colloidal, and dissolved forms: U.S. Antarctic Journal, v. XXVI, no. 5, 230-232.

Kimball, B.A., Bencala, K.E., McKnight, D.M., and Maura, W.S., 1988, Geochemistry of dissolved metals in St. Kevin Gulch, an acidic mountain stream near Leadville, Colorado, in Mallard, G.E., ed., U.S. Geological Survey Toxic Substances Hydrology Progam-Proceedings of the Technical Meeting, Denver, Colo., February 


\section{ECOLOGY}

2-4, 1987: U.S. Geological Survey Open-File Report 87-764, p. 137-144.

Kimball, B.A., Broshears, R.E., Bencala, K.E., and McKnight, D.M., 1991, Comparison of rates of hydrologic and chemical processes in a stream affected by acid mine drainage, in Mallard, G.E., and Aronson, D.A., eds., U.S. Geological Survey Toxics Substances Hydrology Program-Proceedings of the technical meeting, Monterey, Calif., March 11-15, 1991: U.S. Geological Survey Water-Resources Investigations Report 91-4034, p. 407-412.

Kimball, B.A., Broshears, B.A., McKnight, D.M. and Bencala, K.E., 1992, Effect of instream pH modification on aluminum, in Kharaka, Y.K., and Maest, A.S., eds., Water Rock Interaction: Rotterdam, The Netherlands, Balkema, p. 393396.

Kimball, B.A., McKnight, D.M., Wetherbee, G.A., and Harnish, R.A., 1992, Mechanisms of iron photoreduction in a metal-rich, acidic stream (St. Kevin Gulch, Colorado, U.S.A.): Chemical Geology, v. 96, p. 227-239.

Leenheer, J.A., McKnight, D.M., Thurman, E.M., and MacCarthy, P., 1989, Structural components and proposed Structural models for Suwannee River fulvic acid, in Leenheer, J.A., Averett, R.C., McKnight, D.M., and Thorn, K.A., eds., Humic Substances in the Suwannee River, Georgia-Interactions, Properties, and Proposed Structures: U.S. Geological Survey Open-File Report 87-557, p. 331-359.

Malcolm, R.L., McKnight, D.M., and Averett, R.C., 1989, The Okefenokee Swamp: Origin of the Suwannee River, in Leenheer, J.A., Averett, R.C., McKnight, D.M., and Thorn, K.A., eds., Humic Substances in the Suwannee River, Georgia-Interactions, Properties, and Proposed Structures: U.S. Geological Survey Open-File Report 87-557, p. 1-21.
McKnight, D.M., 1988, Metal-Tolerant Algae in St. Kevin Gulch, Colorado, in Mallard, G.E., ed., U.S. Geological Survey Toxic Substances Hydrology Program-Proceedings of the Technical Meeting, Denver, Colo., February 2-4, 1987: U.S. Geological Survey Open-File Report 87764, p. 113-117.

1990, "How do organic acids interact with organisms, solutes, and particulate surfaces?" in Perdue E.M., and Gjessing, E.T., eds., Organic Acids in Aquatic Ecosystems: Dahlem Konferenzen, John Wiley and Sons, p. 223-243.

1991, Feedback mechanisms involving humic substances in aquatic ecosystems, in Schneider S.H., and Boston, P.J., eds., Scientists on Gaia: Cambridge, Massachusetts, The MIT Press, p. 330-338.

McKnight, D.M., Aiken, G.R., Andrews, E.D., Bowles, E.C., and Miller, L., 1993, Dissolved organic material in dry valley lakes-a comparison of Lake Fryxell, Lake Hoare and Lake Vanda, in Green, W.J., ed., Physical and biogeochemical processes in Antarctic lakes: Antarctic Research Series, v. 59, p. 119-133.

McKnight, D.M., Aiken, G.R., Andrews, E.D., Bowles, E.C., Smith, R.L., Duff, J.M., and Miller, L.G., 1988, Dissolved organic material in desert lakes in the McMurdo Dry Valleys:

- U.S. Antarctic Journal, p. 152-153.

McKnight, D.M., Aiken, G.R. and Smith, R.L., 1991. Aquatic fulvic acids in microbially based ecosystems-results from two desert lakes in Antarctica: Limnology and Oceanography, v. · 36, no. 5, p. 998-1006.

McKnight, D.M. and Bencala, K.E., 1988, Diel variations in iron chemistry in an acidic mountain stream in the Colorado Rocky Mountains, U.S.A.: Arctic and Alpine Research, v. 20, no. 4, p. $492-500$. 


\section{ECOLOGY}

1989, Reactive iron transport in an acidic mountain stream in Summit County, Colorado-a hydrologic perspective: Geochimica et Cosmochimica Acta, v. 55, no. 9, p. 2225-2234 p.

1990, The chemistry of iron, aluminum, and dissolved organic material in three acidic, metalenriched, mountain streams, as controlled by watershed and in-stream processes: Water Resources Research, v. 26, no. 12, p. 3087-3100.

McKnight, D.M., Bencala, K.E., Zellweger, G.W., Aiken, G.R., Feder, G.L., and Thorn, K.A., 1992, Sorption of dissolved organic carbon by hydrous aluminum and iron oxides occurring at the confluence of Deer Creek with the Snake River, Summit County, Colorado: Environmental Science and Technology, v. 26, no. 7, p. 1388-1396.

McKnight, D.M., Kimball, B.A., and Bencala, K.E., 1988 , Iron photoreduction and oxidation in an acidic mountain stream: Science, v. 240, p. 637-640.

1988, Photoreduction of hydrous iron oxides in acidic mountain streams in Colorado, in Mallard, G.A., ed., U.S. Geological Survey Toxic Substances Hydrology Program-Proceedings of the Technical Meeting, Denver, Colo., February 2-4, 1987: U.S. Geological Survey Open-File Report 87-764, p. 131-135.

McKnight, D., Miller, C., Smith, R., Baron, J., and Spaulding, S., 1988, Phytoplankton Populations in Lakes in Loch Vale, Rocky Mountain National Park, Colorado-sensitivity to Acidic Conditions and Nitrate Enrichment: U.S. Geological Survey Water-Resources Investigations Report $88-4115,102$ p.

McKnight, D.M., Ranville, J.F. and Harnish, R.A., 1991, Particulate and colloidal organic material and associated trace metals in Pueblo Reservoir, Colorado, in Mallard, G.E., and Aronson,
D.A., eds., U.S. Geological Survey Toxics Substances Hydrology Program-Proceedings of the technical meeting, Monterey, Calif., March 11-15, 1991: U.S. Geological Survey Water-Resources Investigations Report 91-4034, p. 428433.

McKnight, D.M., Smith, R.L., Bradbury, J.P., Baron, J.S., and Spaulding, Sarah, 1990, Phytoplankton dynamics in three Rocky Mountain Lakes, Colorado, U.S.A.: Arctic and Alpine Research, v. 22, no. 3, p. 264-274.

McKnight, D.M., Smith, R.L., Harnish, R.A.; Miller, C.L., and Bencala, K.E., 1993, Seasonal relationships between planktonic micro-organisms and dissolved organic material in an alpine stream: Biogeochemistry, v. 21, p. 39-59.

McKnight, D.M., Thorn, K.A., Wershaw, R.L., Bracewell, J.M. and Robertson, G.W., 1988, Rapid changes in dissolved humic substances in Spirit Lake and South Fork Castle Lake, Washington: Limnology and Oceanography, v. 33 no. 6, pt. 2, p. 1527-1541.

McKnight, D.M., and Werslaw, R.L., 1989, Complexation of copper by fulvic acid from the Suwannee River-effect of counter-ion concentration, in Leenheer, J.A., Averett, R.C., McKnight, D.M., and Thorn, K.A., eds., Humic Substances in the Suwannee River, Georgia-Interactions, Properties, and Proposed Structures: U.S. Geological Survey Open-File Report 87-557, p. 59-79.

McKnight, D.M., Wershaw, R.L., Bencala, K.E., and Feder, G.L., 1992, Humic substances and trace metals associated with $\mathrm{Fe}$ and $\mathrm{Al}$ oxides deposited in an acidic mountain stream: The Science of the Total Environment, v. 117/118, p. $485-498$.

Ranville, J.F., Harnish, R.A., and McKnight, D.M., 1991, Particulate and colloidal organic material 


\section{ECOLOGY}

in Pueblo Reservoir, Colorado-influence of autochthonous source on chemical composition, in Baker, R.A., ed., Organic Substances and Sediments in Water, Volume 1. Humics and Soils: Chelsea, Michigan, Lewis Publishers, p. 47-73.

Ranville, J.F., Smith, K.S., McKnight, D.M., Macalady, D.L., and Rees, T.F., 1991, Effect of organic matter coprecipitation and sorption and sorption with hydrous iron oxides on electrophoretic mobility of particles in acid mine drainage, in Mallard, G.E., and Aronson, D.A., eds., U.S. Geological Survey Toxics Substances Hydrology Program-Proceedings of the technical meeting, Monterey, Calif., March 11-15, 1991: U.S. Geological Survey Water-Resources Investigations Report 91-4034, p. 422-427.

Spaulding, S.A., 1991, Phytoplankton and zooplankton under ice-cover in a subalpine lake, The Loch, Rocky Mountain National Park, Colorado, 1987-89: U.S. Geological Survey Open-File Report 91-489, 33 p.

Tate, C.M., McKnight, D.M., and Spaulding, S.A., 1991, Phosphate uptake by algae in a stream contaminated by acid mine drainage, St. Kevin Gulch, Leadville, Colorado, in Mallard, G.E., and Aronson, D.A., eds., U.S. Geological Survey Toxics Substances Hydrology ProgramProceedings of the technical meeting, Monterey, Calif., March 11-15, 1991: U.S. Geological Survey Water-Resources Investigations Report 91-4034, p. 387-391.

Wissmar, R.C., McKnight, D.M., and Dahm, C.N., 1990, Contribution of organic acids to alkalinity in lakes within the blast zone of Mount St.

Helens, Washington: Limnology and Oceanography, v. 35 , no. 2 , pp. 535-542.

Zellweger, G.W., Bencala, K.E., McKnight, D.M., Hirsch, R.M., and Kimball, B.A., 1988, Practical aspects of tracer experiments in acidic, metal enriched streams, in Mallard, G.A., ed., U.S. Geological Survey Toxic Substances Hydrology Program-Proceedings of the Technical Meeting, Denver, Colo., February 2-4, 1987: U.S. Geological Survey Open-File Report 87-764, p. 125-130. 


\section{ECOLOGY}

TITLE: $\quad$ The Role of Chemical Fluxes in the Biogeochemistry of Inland Surface Waters, Including Lakes, Reservoirs, and Wetlands (CR 85-293)

PERSONNEL: James W. LaBaugh, Project Chief

Evelyn R. Warren, Office Auto. Assist.

Lạna K. Gerlick, Office Auto. Clerk

ADDRESS: U.S. Geological Survey, P.O. Box 25046, MS 413, Denver Federal Center, Denver, CO 80225

TELEPHONE: (303) 236-4989

PROBLEM: Most studies of the biogeochemistry of inland aquatic ecosystems have been confined to processes within the water body. The effect of ground-water fluxes to the water body on ecosystem biogeochemical processes has been ignored. Detailed studies of all external chemical fluxes and their relationship to the supply and loss of biologically important chemical elements are virtually nonexistent, particularly for aquatic ecosystems lacking channelized surface-water inflow and outflow. Research on these external fluxes and their quantitative significance is critical for decision makers responsible for water quality and biological productivity of lakes, reservoirs and wetlands.

OBJECTIVE: The primary objective of hydrological-biogeochemical interaction research is to understand relative contribution of all hydrologic processes controlling fluxes of biologically important chemical elements between surface waters and their watersheds. The importance of different transport pathways affecting the supply and loss of those elements from surface water will be quantified. Although this research will emphasize experimental field work, conceptual models of hydrological-biological interactions will be used to identify important mechanisms to be investigated further in the field.

APPROACH: The supply and loss of biologically important chemical elements in surface waters (lakes, reservoirs, wetlands) will be quantified by field sampling and experimental studies at existing experimental field sites that have been the subject of intensive hydrologic research including onsite measurement of the entire hydrologic cycle. Field data will be used to develop empirical models and calibrate conceptual models of hydrological-biogeochemical interactions. 


\section{ECOLOGY}

PROGRESS: Two reports were written for publication as articles in scientific journals and one report was written for a U.S. Geological Survey Water-Supply Paper on the Interdisciplinary Research Initiative (IRI). One article focused on the contribution of groundwater to hydrological and chemical budgets of Williams Lake, Minnesota, over a 12 year period (1980 to 1991). The other article examined the relation of one measure of algal biomass, chlorophyll a, to actual microscopic determination of biomass within lakes and wetlands at Nebraska, North Dakota, and Minnesota field sites. Intensive studies of chemical fluxes, including determination of ground-water flux and in-lake chemical and biological investigations, continued at Cottonwood Lake area wetlands, North Dakota; and Shingobee and Williams Lakes (IRI site), Minnesota.

\section{REPORTS PUBLISHED 1988-1993:}

LaBaugh, J.W., 1988, Relation of hydrogeologic setting to chemical characteristics of selected lakes and wetlands within a climate gradient in the North-Cèntral United States: Verhandlungen Internationale Vereinigung Limnologie, v. 23, p. 131-137.

1989, Chemical characteristics of water in northern prairie wetlands, in van der Valk, A., ed., Northern Prairie Wetlands: Ames, Iowa, Iowa State University Press, p. 56-90.

1991, Spatial and temporal variation in chemical characteristics of ground water adjacent to selected lakes and wetlands in the north-central United States: Verhandlungen Internationale Vereinigung Limnologie, v. 24, p. 1588-1594.

LaBaugh, J.W. and Swanson, G.A., 1988, Algae and invertebrates in the water column of selected prairie wetlands in the Cottonwood Lake area, Stutsman County, North Dakota, 1984: U.S. Geological Survey Open-File Report 88-451, 96 p.

1992, Changes in chemical characteristics of water in selected wetlands in the Cottonword Lake area, North Dakota, U.S.A., 1967-1989, in Robarts, R.D., and Bothwell, M.L., eds., Aquatic Ecosystems in semi-arid regions: Saska- toon, Saskatchewan, Environment Canada, The National Hydrology Research Institute Symposium Series 7, p. 149-162.

Swanson, G.A., Winter, T.C., Adomaitis, V.A., and LaBaugh, J.W., 1988, Chemical characteristics of prairie lakes in South-Central North Dakota, their potential for influencing use by fish and wildlife: U.S. Fish and Wildlife Service Technical Report 18, 44 p.

Winter, T.C., LaBaugh, J.W., and Rosenberry, D.O., 1988, Direct measurement of differences in hydraulic head between ground water and surface water using a hydraulic potentiomanometer: Limnology and Oceanography, v. 33, p. 1209-1214. 


\section{ECOLOGY}

TITLE: $\quad$ Microbial Transformation of Dissolved Organic Carbon in Aquatic Environments (CR 86-295)

PERSONNEL: Richard L. Smith, Project Chief

Betty L. Callahan, Secretary

Myron H. Brooks, Research Chemist

ADDRESS: $\quad$ U.S. Geological Survey, 3215 Marine Street, Boulder, CO 80303

TELEPHONE: (303) 541-3032

PROBLEM: Although it is recognized that micro-organisms play an important role in the transformation of organic compounds in aquatic habitats, very little is known about the exact nature of these transformations in either pristine or contaminated environments. Within the context of in situ environmental conditions, the mechanisms, pathways, rates, and factors controlling carbon cycling by micro-organisms are poorly understood; however, these particular processes can significantly affect the entire range of biogeochemical and geochemical processes occurring within the aquatic environment.

OBJECTIVE: Study the mechanisms, pathways, and rates of transformation of organic compounds (natural and contaminant) mediated by micro-organisms in aquatic habitats and identify some of the factors controlling these transformations. Examine the effect that these transformations have upon other biogeochemical processes.

APPROACH: Select a pristine alpine stream, an amictic Antarctic lake, and a sewagecontaminated aquifer as the habitats of primary focus. Determine microbial processes in both water and sediment samples by use of tracer techniques for laboratory and field studies. Develop sample-handling techniques needed to maintain in situ conditions. Employ . experiments with isolated cultures of micro-organisms, when necessary, to help interpret the results obtained with natural samples.

PROGRESS: (1) A field trial was begun to investigate the potential to utilize denitrification as a bioremediation mechanism to treat nitrate contamination in ground water. Our research has demonstrated that hydrogen and formate oxidizing, denitrifying bacteria are commonly found in the subsurface, that they have a high affinity for hydrogen and that they produce innocuous end products. Consequently, a continuous injection tracer test is being conducted in a nitrate-contaminated aquifer in an attempt to stimulate these organisms to consume the nitrate 


\section{ECOLOGY}

in situ. (2) A study was completed and submitted for publication which assessed the effect that ground-water contamination has upon the adenylate energy charge, the total adenine nucleotide content, and the DNA content of the free-living populations of micro-organisms present in groundwater. Collectively these parameters can be used to estimate the metabolic status of the microbial community. We found that these micro-organisms were metabolically stressed throughout a large contaminant plume despite the eutrophication that was occurring as a result of the contamination. (3) A study investigating the relationship between the abundance and activity of micro-organisms and the amount and nature of dissolved organic carbon (DOC) in a Rocky Mountain alpine stream was also concluded and published. Seasonal variation of heterotrophic microbial activity was predominantly controlled by the availability of labile DOC and the hydrologic flowpath bringing water into the stream and not by water temperature.

\section{REPORTS PUBLISHED 1988-1993:}

Brooks, M.H., 1991, Development and Evaluation of a Technique for Measuring Denitrification Enzyme Activity in Nitrate-Contaminated Ground Water: Golden, Colo., Colorado School of Mines, M.S. Thesis, 94 p.

Brooks, M.H., and Smith, R.L., 1989, Total adenylate and adenylate energy charge measurements from bacterial communities in ground water, in Mallard, G.E., and Ragone, S.E., eds., U.S. Geological Survey Toxic Substances Hydrology Program-Proceedings of the technical meeting, Phoenix, Ariz., September 26-30, 1988: U.S. Geological Survey Water-Resources Investigations Report 88-4220, p. 541-545.

Brooks, M.H., Smith, R.L., and Macalady, D.L., 1992, Inhibition of exisiting denitrification enzyme activity by chloramphenicol: Applied and Environmental Microbiology, v. 58, p. 17461753.

Ceazan, M.L., Thurman, E.M., and Smith, R.L., 1989, Cation exchange as a retardation mechanism in an ammonium and nitrate-contaminated sand and gravel aquifer: Environmental Science and Teclinology, v. 23, no. 11, p. 1402-1408.
Harvey, R.W., Garbedian, S.P., Smith, R.L., Barber, L.B., Metge, D.W., and Scholl, M.A., 1991, The role of physical and chemical heterogeneity in the interpretation of small-scale tracer tests involving microorganisms, in Mallard, G.E., and Aronson, D.A., eds., U.S. Geological Survey Toxic Substances Hydrology ProgramProceedings of the technical meeting, Monterey, Calif., March 11-15, 1991: U.S. Geological Survey Water-Resources Investigations Report 91-4034, p. 148-151.

Harvey, R.W., George, L.H., Smith, R.L., and LeBlanc, D.R., 1989, Transport of microspheres and indigenous bacteria through a sandy aquifer-Results of natural and forced-gradient groundwater tracer experiments: Environmental Science and Technology, v. 23, no. 1, p. 51-56.

Howes, B.L., and Smith, R.L., 1990, Sulfur cycling in a permanently ice covered amictic Antarctic lake, Lake Fryxell: Antarctic Journal of the U.S., v. 25, p. 230-233.

Krumme, M.L., Smith, R.L., and Dwyer, D.F., 1990 , Survival of genetically engineered microorganisms and their ability to catabolize substituted benzoates in aquifer microcosms, in Fliermans, C.B., and Hazen, T.C., eds., Proceedings 


\section{ECOLOGY}

of the First International Symposium on Microbiology of the Deep Subsurface: Aiken, S.C., Westinghouse Savannah River Co. Information Services, p. 7-117 to 7-126.

1991, Survival of a model pollutant-degrading micro-organism in a sand and gravel aquifer and in microcosms, in Mallard, G.E., and Aronson, D.A., eds., U.S. Geological Survey Toxic Substances Hydrology Program-Proceedings of the technical meeting, Monterey, Calif., March 11-15, 1991: U.S. Geological Survey WaterResources Investigations Report 91-4034, p. 144-147.

McKnight, D.M., Aiken, G.R., Andrews, E.D., Bowles, E.C., and Smith, R.L., 1988, Dissolved organic material in desert lakes in the McMurdo Dry Valleys: Antarctic Journal of the United States, v. 23, no. 5, p. 152-153.

McKnight, D.M., Aiken, G.R., and Smith, R.L., 1991, Aquatic fulvic acids in microbially-based ecosystems-results from two Antarctic desert lakes: Limnology and Oceanography, v. 36, p. 998-1006.

McKnight, D.M., Miller, C., Smith, R.L., Baron, J., and Spaulding, Sarah, 1988, Phytoplankton populations in lakes in Loch Vale, Rocky Mountain National Park, Colorado-sensitivity to acidic conditions and nitrate enrichment: U.S. Geological Survey Water-Resources Investigations Report $88-4115,102 \mathrm{p}$.

McKnight, D.M., Smith, R.L., Bradbury, J.P., Baron, J.J., and Spaulding, S., 1990, Phytoplankton dynamics in Rocky Mountain lakes, Colorado, U.S.A.: Arctic and Alpine Research, v. 22 , no. 3 , p. $264-274$.

McKnight, D. M., Smith, R. L., Harnish, R. A., Miller, C.L., and Bencala, K.E., 1993, Seasonal relationships between planktonic micro-- organisms and dissolved organic material in an alpine stream: Biogeochemistry, v. 21, p. 39-59.

Metge, D.W., Brooks, M.H., Smith, R.L., and Harvey, R.W., 1993, Effect of treated sewage contamination upon bacterial energy charge, adenylates, and DNA content in a sandy aquifer on Cape Cod: Applied and Environmental Microbiology, v. 59, no. 7, p. 2304-2310.

Oremland, R.S., Miller, L.G., Culbertson, C.W., Robinson, S.W., Smith, R.L., Lovley, D.R., Whiticar, M.J., King, G.M., Kiene, R.P., Iversen, N., and Sargent, M., 1993, Aspects of the biogeochemistry of methane in Mono Lake and the Mono Basin of California, in Oremland, R.S., ed., Biogeochemistry of global change, radioactively active trace gases: New York, Chapman and Hall, p. 704-41.

Smith, R.L., Brooks, M.H., and Ceazan, M.L., 1992, The use of natural gradient tracer tests to identify and quantify microbial processes occurring in groundwater, in Stanford, J.A., and Simons, J.J., eds., Proceedings of the First International Conference on Ground-Water Ecology: American Water Resources Association, p. 5965.

Smith, R.L., and Ceazan, M.L., 1991, Isolation and characterization of autotrophic, hydrogen-oxidizing, denitrifying bacteria from groundwater as potential agents for bioremediation of nitrate contamination, in Mallard, G.E., and Aronson, D.A., eds., U.S. Geological Survey Toxic Substances Hydrology Program-Proceedings of the teclnical meeting, Monterey, Calif., March 11-15, 1991: U.S. Geological Survey Water-Resources Investigations Report 91-4034, p. 123127.

Smith, R.L., and Duff, J.H., 1988, Denitrification in contaminated groundwater: Applied and Environmental Microbiology, v. 54, no. 5, p. 10711078. 


\section{ECOLOGY}

Smith, R.L. and Harvey, R.W., 1990, Development of sampling techniques to measure in situ rates of microbial processes in a contaminated sand and gravel aquifer, in Fliermans, C. B., and Hazen, T.C., eds., Proceedings of the First International Symposium on Microbiology of the Deep Subsurface: Aiken, South Carolina, Westinghouse Savannah River Co. Information Services, p. 2-19 to 2-32.

Smith, R.L., Harvey, R.W., and LeBlanc, D.R., 1991, Importance of close-interval vertical sampling in delineating chemical and microbiological gradients in groundwater studies: Journal of Contaminant Hydrology, v. 7, p. 285-300.

Smith, R.L., and Howes, B.L., 1990, Bacterial biomass and heterotrophic activity in the water column of an amictic Antarctic lake: Antarctic Journal of the United States, v. XXV, p. 233235.

Smith, R.L., Howes, B.L., and Duff, J.H., 1989, The use of tracer tests to measure the transport and consumption of methane in a contaminated aquifer, in Mallard, G.E., and Ragone, S.E. eds., U.S. Geological Survey Toxic Substances Hydrology Program-Proceedings of the technical meeting, Phoenix, Ariz., Sept. 26-30, 1988: U.S. Geological Survey Water-Resources Investigations Report 88-4220, p. 167-175.

1991, Denitrification in nitrate-contaminated groundwater-occurrence in steep vertical geochemical gradients: Geochimica et Cosmochimica Acta, v. 55, no. 7, p. 1815-1822.

1991, Effects of denitrification on nitrogen geochemistry in a nitrate-contaminated sand and gravel aquifer, Cape Cod, Massachusetts, in Mallard, G.E., and Aronson, D.A., eds., U.S. Geological Survey Toxic Substances Hydrology Program-Proceedings of the technical meeting, Monterey, Calif., March 11-15, 1991: U.S.
Geological Survey Water-Resources Investigations Report 91-4034, p. 128-134.

Smith, R.L., Howes, B.L., and Garabedian, S.P., 1991, In situ measurement of methane oxidation in groundwater using natural gradient tracer tests: Applied and Environmental Microbiology, v. 57, p. 1997-2004.

Smith, R.L., Miller, L.G., and Howes, B.L., 1993, The geochemistry of methane in Lake Fryxell, an amictic, permanently ice-covered, antarctic lake: Biogeochemistry, v. 21, p. 95-115.

Walton-Day, K., Macalady, D.L., Brooks, M.H., and Tate, V.T., 1990, Field methods for determination of groundwater redox chemical parameters: Ground-Water Monitoring Review, v. 10, p. 81-89 


\title{
ECOLOGY
}

TITLE: $\quad$ Ecological Interactions of Lakes and Streams (CR 88-312)

\author{
PERSONNEL: Robert C. Averett, Project Chief \\ Puhr, Darlene, Secretary \\ Wesley L. Campbell, Hydrologist
}

\begin{abstract}
ADDRESS:
U.S. Geological Survey, P.O. Box 25046, MS 458, Denver Federal Center, Denver, CO 80225
\end{abstract}

PROBLEM: Much aquatic habitat in North America is or has been destroyed by development or by extracting natural resources. Little is known concerning the requirements for aquatic life in streams or lakes, especially from a geomorphic standpoint. In this regard, it is difficult also to separate natural from man-caused changes in aquatic ecosystems.

OBJECTIVE: To determine the effects that geomorphic and other physical as well as chemical and biological changes have on aquatic habitat and upon the distribution and abundance of aquatic organisms.

APPROACH: Several sites, on lakes and their tributaries, will be selected and instrumented for flow temperature and mapped for geomorphic features. The aquatic flora and fauna will be measured. Alterations in hydrologic regime, including geomorphic changes, will be made and their effect upon stream and lake organisms determined.

PROGRESS: Our work continues on streams and stream habitat in Yellowstone National Park. A new parkwide project on stream benthos, physical and chemical habitat was initiated in Fiscal Year 1992. Laboratory analysis of samples from streams in the Catskill Mountains continues. Analysis of data from the Colorado River continues, although funding for water-quality work on the Colorado River was curtailed in Fiscal Year 1992.

\section{REPORTS PUBLISHED 1988-1993:}

Averett, R.C. 1991, Channels, Impoundments and Epitaphs, in R.J. Ravne, ed., Proceedings of the workshop on Impoundments: U.S. Tennessee Valley Authority, 8 p.

Averett, R.C. and Emmett, W.W., 1993, The phytoplankton of Fremont Lake, Wyoming: U.S.
Geological Survey Water-Resources Investigations Report 92-4071, 68 p.

Averett, R.C., and Iwatsubo, R.T., in press, Aquatic biology of the Redwood Creek drainage, Redwood National Park, California, in Nolan, K.M. and Hardin, D., eds., Geomorphic processes in 


\section{ECOLOGY}

aquatic habitat in the Redwood Creek Basin, northwestern California: U.S. Geological Survey Professional Paper 1454, (in press since 1984).

Averett, R.C., Leenheer, J.A., McKnight, D.M., and Thorn, K.A., eds., 1988, Humic substances in the Suwannee River, Georgia-Interactions, properties, and proposed structures: U.S. Geological Survey Open-File Report, 87-557, 377 p.

Malcolm, R.L., McKnight, D.M., and Averett, R.C., 1989, History and description of the Okefenokee Swamp-origin of the Suwannee River, in Averett, R.C., Leenheer, J.A., McKnight, D.M., and Thorn, K.A., eds., Humic substances in the Suwannee River, Georgia-Interactions, properties, and proposed structures: U.S. Geological Survey Open-File Report, 87-557, p $1-21$.

Slack, K.V., Ferreira, R.F., Averett, R.C., and Kennelly, S.S., 1988, Effects of spatial orientation of multiple plate artificial substrates on invertebrate colonization: Water Resources Bulletin (American Water Resources Association), v. 24, no. 4 , p. 781-789.

Steele, T.D., Kunkel, J.R., and Averett, R.C., 1991, A Comparative Assessment of Nutrient-Biological Conditions in Selected Reservoirs in the Denver Metropolitan Area, Colorado, in Jennings, M.E., ed., Symposium on Urban Hydrology: American Water Resources Association, $20 \mathrm{p}$.

Taylor, H.E., and Averett, R.C., 1991, Description of water-quality synoptic experiments in the Colorado River, in Mallard, G.E., and Aronson, D.A., eds., U.S. Geological Survey Toxic Substances Hydrology Program-Proceedings of the technical meeting, Monterey, Calif., March, 1991: U.S. Geological Survey Water-Resources Investigations Report 91-4034, p. 576-578. 


\section{ECOLOGY}

TITLE: Characterization of Biotic and Biogeochemical Interactions at Environmental Interfaces (CR 91-320)

PERSONNEL: Robert G. Striegl, Project Chief

Evelyn R. Warren, Secretary

Edward A. McConnaughey, Hydrologist

Kimberly Wickland, Biologist

Patrick G. Hern, Student (Univ. of Colorado)

Catherine Michmerhuizen, Student (Univ. of Minn.

Lana K. Gerlick, Clerk

ADDRESS: $\quad$ U.S. Geological Survey, P.O. Box 25046, MS 413, Denver Federal Center, Denver, CO 80225

TELEPHONE: (303) 236-4993

PROBLEM: Recent increases in the atmospheric concentrations of carbon dioxide and methane have emphasized the need for a more complete understanding of the processes that control carbon transfer among air, land, and water. Knowledge of the amount, rate and chemical form of carbon transfer across environmental interfaces, such as the land-air and water-air interfaces, is of particular importance. These fluxes are commonly controlled by a combination of physical, biological, and chemical processes at or near the interface. Isolation of the primary mechanisms that determine carbon transfer across the interface allows for development of process-based models that can be used for carbon mass-transfer estimates at the ecosystem or landscape scale. This process-based knowledge is also useful for prediction of the long-term effects of land- or water-use change on carbon mass transfer rates.

OBJECTIVE: Characterize and quantify the carbon transfers that naturally occur across environmental interfaces, and isolate the physical, biological and chemical controls of those fluxes. Where possible, evaluate the effects of environmental change on the observed interactions. Develop process based models that explain field and laboratory observations.

APPROACH: Select field sites that represent a range in abiotic and biotic conditions that control carbon transfer across environmental interfaces, and systematically measure relevant control variables and fluxes. Conduct field and laboratory experiments to test hypothesized interactions. Current investigations are focused on characterization of carbon dioxide and methane transfer across land-air and water-air interfaces. Emphasis is placed on the physical and geochemical properties that control carbon dioxide and methane transport and on factors that control the production and consumption of these gases by microbiota in soil, fresh water, and sediments. 


\section{ECOLOGY}

PROGRESS: Field study of atmospheric carbon dioxide exchange with desert soils indicate periods of $\mathrm{CO}_{2}$ uptake and emission that are related to soil wetting and drying cycles. Time series of the gas exchange process and of the variation in the isotopic composition of soil $\mathrm{CO}_{2}$ were determined at six locations at the Nevada Test Site and the Amargosa Desert during seasonal wetting and drying during 1993. Measurements of deep unsaturated zone $\mathrm{CO}_{2}$ in the Amargosa Desert identify ground water as a potential continuous source of $\mathrm{CO}_{2}$ to the atmosphere.

Study of methane cycling in North temperate lakes indicate that up to 80 percent of $\mathrm{CH}_{4}$ released from lake sediments is oxidized in the water column. The remainder is released to the atmosphere. Spring release of $\mathrm{CH}_{4}$ accumulated in lake water under-ice cover was measured at 20 lakes in Minnesota and Wisconsin during the Spring of 1993. The magnitude of these fluxes was related to lake landscape position and hydrogeologic setting. Springtime $\mathrm{CH}_{4}$ flux estimates are being made for United States portions of the north temperate lakes region. Measurements of atmospheric $\mathrm{CO}_{2}$ exchange with lakes at the Interdisciplinary Research Initiative (IRI) site indicate that some lakes in the same watershed continually de-gas $\mathrm{CO}_{2}$ during ice-free periods, while others uptake $\mathrm{CO}_{2}$. Chemical and biological control of these processes are being studied.

Numerical modeling of gas movements in and near static chambers placed on the soil surface indicates that the chambers substantially under-measure actual flux. The chambers actually disrupt the gradient (and decrease the flux) that they are intended to measure. Field measurements verify the predicted decrease.

Research plans were made and field sites were selected for Water Resources Division (WRD) participation in $\mathrm{CO}_{2}$ and $\mathrm{CH}_{4}$ land-atmosphere flux studies as part of the United States/Canada Boreal Ecosystem Atmosphere Study (BOREAS).

\section{REPORTS PUBLISHED 1990-1993:}

McConnaughey, T.A., 1991, Calcification in Chara corallina- $-\mathrm{CO}_{2}$ hydroxylation generates protons for bicarbonate assimilation: Limnology and Oceanography, v. 36, p. 619-628.

McConnaughey, T.A., and Falk, R.H., 1991, Calcium-proton exchange during algal calcification: Biological Bulletin, v. 180, p. 180-195.
Peters, C.A., Striegl, R.G., Mills, P.L. and Healy, R.W., 1991, Effects of low-level radioactivewaste disposal on water chemistry in the unsaturated zone at a site near Sheffield, Illinois: U.S. Geological Survey Water-Supply Paper 2390, 74 p.

Shen, G.T., Cole, J.E., Lea, D.W., Linn, L.J., McConnaughey, T.A., and Fairbanks, R.G., 1992, Surface ocean variability at Galapagos 


\section{ECOLOGY}

from 1936-1982-Calibration of geochemical tracers in corals: Paleoceanography, v. 7, no. 5, p. 563-588.

Striegl, R.G., 1990, Radioactive gases at low-level radioactive-waste repository sites, in Bedinger, M.S., and Stevens, P.R., eds., Safe disposal of radionuclides in low-level radioactive-waste repository sites: U.S. Geological Survey Circular 1036, p. 40-44.

1991, Gases in the unsaturated zone, in Ryan, B.J., ed., Results of hydrologic research at a low-level radioactive waste disposal site near Sheffield, Illinois: U.S. Geological Survey Water-Supply Paper 2367. p. 69-80.

1991, Processes controlling the transfer of carbon-14 at radioactive waste disposal sites, in Trask, N.J., and Stevens, P.R., eds., U.S. Geological Survey Research in Radioactive Waste Disposal: U.S. Geological Survey WaterResources Investigations Report 91-4084, p. 71-72.

1993, Diffusional limits to the consumption of atmospheric methane by soils: Chemosphere, $v$. 26, p. 715-720.

1993, Consumption of atmospheric methane in unsaturated soils, in Kelmelis, J.A., and Snow, M., eds., Proceedings of the U.S. Geological Survey Global Change Research Forum, March 18-20, 1991: U.S. Geological Survey Circular 1086, p. 111-112.

Striegl, R.G. and Armstrong, D.E., 1990, Carbon dioxide retention and carbon exchange on unsaturated quaternary sediments: Geochimica et Cosmochimica Acta, v. 54, no. 8, p. 2277-2283.

Striegl, R.G. and Healy, R.W., 1990, Transport of 14-carbon dioxide in unsaturated glacial and eolian sediments, in Bassett, R.L. and Melchoir, D.C., eds., Chemical Modeling in Aqueous
Systems II: American Chemical Society Symposium Series, no. 416, chap. 15, p. 202-210.

Striegl, R.G., McConnaughey, T.A., Thorstenson, D.L., Weeks, E.P. and Woodward, J.C.; 1992, Consumption of atmospheric methane by desert soils: Nature, v. 357, p. 145-147.

Tate, C.M., and Striegl, R.G., 1993, Methane consumption and carbon dioxide emission in tallgrass prairie-effects of biomass burning and conversion to agriculture: Global Biogeochemical Cycles, v. 7, no. 3 . 


\section{ECOLOGY}

TITLE: Interdisciplinary Research Initiative (IRI) at the Shingobee Headwaters Research Area, Minnesota (CR 90-323)

PERSONNEL: Thomas C. Winter, Project Chief Dennis Merk, Technician

ADDRESS: $\quad$ U.S. Geological Survey, P.O. Box 25046, MS 413, Denver Federal Center, Denver, CO 80225

TELEPHONE: (303) 236-4987

PROBLEM: Many advances in hydrologic research are limited by the lack of communication between specialists in the large number of disciplines involved in studying the hydrologic system. For example, nearly all specialists need estimates of the fluxes to and from the component of the hydrologic system with which they are dealing. Lack of interaction of specialists studying the interfaces of hydrologic components such as at the ground watersurface water interface, or at the terrestrial atmospheric interface has stymied progress in understanding the mutual interdependence of physical, chemical and biological processes on the site scale as well as on the landscape scale. Ecosystems that integrate all components of the hydrologic system and all phases of matter, such as lakes, are in greatest need of interdisciplinary research.

OBJECTIVE: The Interdisciplinary Research Initiative (IRI) was designed to focus attention on lakes and their contiguous watersheds. Lakes were selected because they are important aquatic systems that integrate a large number of processes within their watersheds, and they have great importance to society. Initial efforts will be focused on the carbon cycle at two contrasting lakes and a few wetlands.

APPROACH: The basic question with respect to comparing carbon cycling processes is based on lake water residence time; that is, how do lakes that have a short residence time because of large streams entering and leaving them and that are presumably dominated by external fluxes, differ from those that have a long residence time because they have no streams or very small streams entering and leaving them and that are presumably dominated by internal cycling. Field experiments for both terrestrial and aquatic systems will be selected jointly by all interested specialists and sampled for physical, chemical, and biological characteristics so that all involved will be working with a common data base on common problems. 


\section{ECOLOGY}

PROGRESS: A climate station to collect data on solar radiation, air temperature, wind speed and direction, and humidity was maintained with no loss of data. Water samples were collected for a wide range of inorganic, organic, trace, and isotopic constituents from the atmosphere, 2 lakes, 3 streams and 15 wells. Specific research efforts, reported herein in individual projects, concentrated on evaluation of evaporation and methane transfer across the air water interface, water and chemical transport across the ground water and lake interface, and solute transport in the Shingobee River.

\section{REPORTS PUBLISHED 1990-1993:}

Cloern, J.E., Alpine, A.E., and Cole, B.E., and Heller, T., 1992, Seasonal changes in the spatial distribution of phytoplankton in small, temperature-zone lakes: Journal of Plankton Research, $v$. 14, no. 7, p. 1017-1024.

LaBaugh, J.W., 1990, Spatial and temporal variation in chemical characteristics of ground water adjacent to selected lakes and wetlands in the northcentral United States: Verhandlungen Internationale Vereinigung Limnologie, v. 24, p. 15881594.

Parkhurst, R.S., Merk, D.A., Rosenberry, D.O., and Winter, T.C., 1992, Climatic data for Williams Lake, Hubbard County, Minnesota 1987-1988: U.S. Geological Survey Open-File Report 92$475,39 \mathrm{p}$.

1993, Climatic data for Shingobee Lake and Williams Lake, Hubbard County, Minnesota, - 1989-91: U.S. Geological Survey Open-File Report 93-127, 34 p.

Rosenberry, D.O., Sturrock, A.M., and Winter, J.C., 1993, Evaluation of the energy budget method of determining evaporation at Williams Lake, Minnesota, using alternative instrumentation and study approaches: Water Resources Research, v. 29 , no. 8 , p. $2473-2483$.

Sturrock, A.M., Winter, T.C., and Rosenberry, D.O., 1992, Energy-budget evaporation from
Williams Lake-a closed lake in north-central Minnesota: Water Resources Research, v. 28, no. 6 , p. 1605-1617. 


\section{ECOLOGY}

TITLE: $\quad$ Limnol@gical Phenomena in Impounded Rivers (CR 91-325)

PERSONNEL: G. Richard Marzolf, Project Chief

Darlene Puhr, Secretary

ADDRESS: U.S. Geological Survey, P.O. Box 25046, MS 458, Denver Federal Center, Denver, CO 80225

TELEPHONE: (303) 541-3040

PROBLEM: Dams have been built in this century that impound virtually all major rivers in the United States. The purposes vary and include flood control, navigation, hydropower generation, and storage for irrigation and domestic uses. About 2,500 reservoirs of 5,000 acre-feet or more, store about 480 million acre-feet, about 1/4 of the annual runoff. Storage capacity is dominated by large reservoirs such that the 600 largest store more than 90 percent of the total. Lake Powell, behind Glen Canyon dam, stores water (about 27 million acre-feet) in the upper basin of the Colorado River for controlled release according to the Colorado River Compact ( 8.23 million acre-ft per year) and to generate electricity for sale to consumers in the southwestern United States (about 80 percent of the generating capacity of the Colorado River Storage Project). Phenomena that control the quantity (evaporation, losses to ground water, consumptive uses in the basin, regional drought or El Niño effects, and so forth) and quality (salinity, productivity, sediment-water column exchange, and so forth) of reservoir waters are not understood.

OBJECTIVE: General: To continue review of literature and of historic data sets, to continue field reconnaissance, and to develop of long-term monitoring and research with the National Park Service and the Bureau of Reclamation, the agencies with management and regulatory responsibility for Lake Powell.

Specific: To initiate investigation of basic processes that mediate water quality in Lake Powell; and, to couple understanding of processes in Lake Powell to management of water quality of the Colorado River in the Grand Canyon National Park.

APPROACH: Several approaches have been explored, including (1) using of LANDSAT imagery, (2) examining sediment and benthic chemistry, (3) examining productivity and water chemistry work in the tailwaters of Glen Canyon Dam, and (4) initiating of work on nutrient and trophic gradients in Navajo Canyon. 


\section{ECOLOGY}

PROGRESS: Three reconnaissance trips were conducted resulting in a data set from a total of six trips distributed over the annual cycle. A significant result involves the revelation of extensive complexity from advective flows. These are dominated by the inflowing mainstem Colorado River and modified by intermittent signals from tributaries. Presently the interpretation of these data is limited to thermal, conductivity, and oxygen profiles. There is great potential for further identifying advective sources by examining trace element ratios. Field collections of surficial sediments and benthos were made in March 1993 when Lake Powell was at its historic low level since filling in 1981. This means that we have samples in hand for analysis that represent the conditions following extensive winter inflows of 1993 and resuspension of the exposed Colorado River deltaic sediments in Lake Powell. Those samples are in the process of being analyzed. If the results are compelling we will seek to publish them, but our objectives were aimed more at reconnaissance and logistic "shakedown." We will not be premature and will follow this trip with another more complete sample series that includes sediments from the San Juan delta as well.

Two proposals are complete and pending.

1. Inter-agency plan for long-term monitoring and research on Lake Powell.

2. A proposal with Jim Elser (Arizona State University) on the application of stoichiometry of limiting nutrients in the plankton along gradients in Lake Powell has been invited by the National Geographic Society.

Preparation of a third proposal that is more of a recommendation than a proposal at this time has been initiated. Nevertheless it is potentially the most significant one. Title: An analysis of an experimental high flow release from Glen Canyon Dam to reconstruct sediment deposits in the Grand Canyon National Park. This work involves about ten USGS scientists from the National Research Program (NRP) and the Arizona District, as well as an array of scientists from the National Park Service, the Bureau of Reclamation, and from several universities. The experiment is the first in a series of experimental manipulations to use the discharge flow from a major hydropower dam to achieve management objectives in the tailwaters, in this case a National Park.

This work has taken on additional importance because of the passage and signing of the Grand Canyon Protection Act. The act mandates a long-term program of monitoring and research and will bring the application of science (thus the design of investigations) into close proximity with management of the National Park and, thus, involvement with hydropower and water allocation policy. There is frustration in such proximity, but the relevance to many issues in 


\section{ECOLOGY}

water resource management is extraordinary. More time has been spent at this (meetings, correspondence, and reporting) than could be imagined useful, but there is no doubt that we are having a positive effect on the use of science to aid policy.

The report of the Survey's Lake and Reservoir Committee was summarized and submitted as a Fiscal Year 1995 Initiative Paper. The full report is now under review. 


\section{ECOLOGY}

TITLE: Interaction of Bacteria with Environmental Contaminants and Solid Surfaces in the Aquatic Environment (CR 91-327 formerly WR 86-191)

PERSONNEL: Ronald W. Harvey, Project Chief

Betty L. Callahan, Secretary

David W. Metge, Hydrologist

ADDRESS: $\quad$ U.S. Geological Survey, 3215 Marine Street, Boulder, CO 80303-1066

TELEPHONE: (303) 541-3034

PROBLEM: Although efforts have been made to explain the behavior of heavy metals and refractory organic contaminants in aquatic habitats in the framework of known geophysical and geochemical processes, much remains to be learned about the role of bacteria in such behavior. Of particular interest are bacteria-contaminant interactions in ground water. Because of the persistence of some contaminants in the subsurface environment and because of increasing demands for both high-quality ground water and on-land disposal of toxic chemicals and radioisotopes, these interactions should remain important environmental problems for the next few decades. Because significant biotransformation/biodegradation of many environmental contaminants in aquifers and particle-laden surface waters can occur at particle surfaces, explanations for bacteria-contaminant interactions in such environments should take the presence of particles into account.

OBJECTIVE: Provide some of the microbiological information necessary for realistic predictions of contaminant behavior in aquatic environments. Obtain information on specific mechanisms of interactions between environmental contaminants and aquatic bacteria, taking into account adsorption, active uptake, competition, biotransformation reactions, interaction with extracellular polymers, effects of nutrient and physicochemical gradients, and effects of particle surfaces. Investigate the effect of nutrient and physicochemical conditions on subsurface transport of bacteria (because the role of bacterial transport on the fate of environmental contaminants in ground water is unknown).

APPROACH: (1) Study the influence of solid surfaces on microbial activity and mobility in particle-laden aquatic environments, particularly freshwater aquifers; (2) study the effect of organic contaminants on the distribution, transport, and activity of the bacterial population and the nature of the microbial community in ground-water habitats; and (3) conduct flow-through column experiments to assess the role of adherent bacteria on the mobility and fate of selected inorganic and organic contaminants in simulated aquifer environments. Conduct flow-through 


\section{ECOLOGY}

column experiments to investigate factors affecting sorption and movement of bacteria in porous media.

PROGRESS: Three invited book chapters were published involving bacterial transport and microbial ecology in ground-water environments. Research was largely completed on a collaborative National Science Foundation (NSF) grant (Principal Investigators: Nancy Kinner, University of New Hampshire; Ronald Harvey, U.S. Geological Survey; and Colin Curds, The Natural History Museum, London). The NSF-funded research involves the distribution, community structure, ecology, and transport behavior of ground-water protozoa at the USGS ground-water study site at Cape Cod, Massachusetts. Results were published from a recent field experiment assessing the transport behavior of indigenous ground-water protozoa (a previously unexplored subject) at the Cape Cod site. The results suggest that protozoa within aquifer sediments move in a much different (slower, more discontinuous) manner than, the bacteria upon which these organisms are thought to feed. Collaborative researchers in London reported a number of new protozoan species inhabiting the sandy aquifer sediments at the Cape Cod site and a much higher species diversity in the contaminated zones relative to the uncontaminated areas of the aquifer. A new research grant, funded by the U.S. Environmental Protection Agency (USEPA) and the National Water Research Institute and involving viral transport in ground water, was competitively awarded to the USGS and the University of Colorado at Boulder (Principal investigators: Ronald Harvey, USGS, and Joseph Ryan, University of Colorado.) This work involves laboratory-, intermediate-, and field-scale experiments designed to assess the transport behavior of viruses and virus-sized microspheres under different geochemical and physical conditions. Resulting data will be used to evaluate (and recalibrate) models describing subsurface microbial transport and will be used by the USEPA in implementing the new Ground Water Disinfection Rule.

\section{REPORTS PUBLISHED 1988-1993:}

Bitton, G. and Harvey, R.W., 1992, Transport of pathogens through soil, in Mitchell, R., ed., New Concepts in Environmental Microbiology: New York, Wiley Interscience, chap. 7, p. 103124.

Harvey, R.W., 1989, Considerations for modeling transport of bacteria in contaminated aquifers, in Abriola, L., ed., Groundwater Contamination: Wallingford, Oxfordshire, United Kingdom, IAHS Press, No. 185 , p. 75-82.
1989, Transport of bacteria in a contaminated aquifer, in Mallard, G.E., and Ragone, S.E., eds., U.S. Geological Survey Toxic Substances Hydrology Program-Proceedings of the technical meeting, Phoenix, Ariz., Sept. 26-30, 1988: U.S. Geological Survey Water-Resources Investigations Report 88-4220, p. 183-188.

1989, Transport of bacteria in a contaminated aquifer, in McCarthy, J.F., and Wobber, F.J., eds., Mobility of colloidal particles in the subsurface, Chemistry and hydrology of colloid- 


\section{ECOLOGY}

aquifer interactions-Proceedings of the technical meeting, Manteo, North Carolina, October 4-6, 1988: U.S. Department of Energy Report No. ER-0425, p. 72-76.

1991, Evaluation of particulate and solute tracers for investigation of bacterial transport behavior in groundwater, in Fliermans, C.B., and Hazen, T.C., eds., Proceedings of the First International Symposium on Microbiology of the Deep Subsurface, January 15-19, 1990, Orlando, Florida: Aiken, South Carolina, WSRC Information Services, p. 7-159 to p. 7-163.

1991, Parameters involved in modeling movement of bacteria in groundwater, in Hurst, C.J., ed., Modeling the environmental fate of micro-organisms: Washington, D.C., American Society for Microbiology, p. 89-114.

1993, Fate and transport of bacteria injected into aquifers: Biotechnology [Current Opinion], v. 4, p. 312-317.

Harvey, R.W., and Barber, L.B., 1992, Associations of free-living bacteria and dissolved organic compounds in a plume of contaminated groundwater: Journal of Contaminant Hydrology, v. 9, p. 91-103.

Harvey, R.W., and Bouwer, E.J., 1992, Limits on quantitative descriptions of biocolloid mobility in contaminated groundwater, in McCarthy, J.F., and Wobber, F.J., eds., Concepts in Manipulating Groundwater Colloids for Environmental Restoration: London, Lewis Publishers, p. 5764.

Harvey, R.W., and Garabedian, S., 1991, Use of colloid filtration theory in modeling movement of bacteria through a contaminated sandy aquifer: Environmental Science and Technology, v. 25, p. $178-185$.
1992, Comnent on Use of Colloid filtration theory in modeling movement of bacteria through a contaminated sandy aquifer: Environmental Science and Technology, v. 26, p. 401-402.

Harvey, R.W., Garabedian, S.P., Smith, R.L., Barber, L.B., Metge, D.W., and Scholl, M.A., 1991, The role of physical and chemical heterogeneity in the interpretation of small-scale tracer tests involving micro-organisms, in Mallard, G.E., and Aronson, D.A., eds., U.S. Geological Survey Toxic Substances Hydrology ProgramProceedings of the technical meeting, Monterey, Calif., March 11-15, 1991: U.S. Geological Survey Water-Resources Investigations Report 91-4034, p. 148-151.

Harvey, R.W., George, L.H., Smith, R.L., LeBlanc, D.R., 1989, Transport of microspheres and indigenous bacteria through a sandy aquiferResults of natural and forced-gradient tracer experiments: Environmental Science and Technology, v. 23, p. 51-56.

Harvey, R.W., Kinner, N., Bunn, A., MacDonald, D., 1993, Transport of protozoa through an organically contaminated sandy aquifer, in Stanford, J., and Simon, J., eds., Proceedings of the First International Conference on Ground Water Ecology, Tampa, Florida, April 26-29: Huntsville, Alabama, American Water Resource Association, p. 111-118.

Harvey R.W., Kinner, N.E., MacDonald, D., Metge, D.W., and Bunn, A., 1993, Role of physical heterogeneity in the interpretation of small-scale laboratory and field observations of bacteria, microbial-sized microsphere and bromide transport through aquifer sediments: Water Resources Research, v. 29, p. 2713-2721.

Harvey, R.W., and Widdowson, M., 1992, Microbial distributions, activities, and movement in the terrestrial subsurface: experimental and theoretical studies, in Wagenet, R.J., Baveye, P., and 


\section{ECOLOGY}

Stewart, B.A., ed., Interacting processes in soil science: Ann Arbor, Michigan, Lewis Publishers, p. 185-225.

Kinner, N.E., Bunn, A.L., Harvey, R.W., Warren, A., and Meeker, L.D., 1991, Preliminary evaluation of the relations among protozoa, bacteria, and chemical properties in sewage-contaminated ground water near Otis Air Base, Massachusetts, in Mallard, G.E., and Aronson, D.A., eds., U.S. Geological Survey Toxic Substances Hydrology Program-Proceedings of the technical meeting, Monterey, Calif., March 11-15, 1991: U.S. Geological Survey Water-Resources Investigations Report 91-4034, p. 141-143.

Kuwabara, J.S., and Harvey, R.W., 1990, Application of a hollow-fiber tangential-flow device for sampling suspended bacteria and particles from natural waters: Journal of Environmental Quality, v. 19, p. 625-629.

Metge, D.W., 1991, DNA determination and bacterial biomass estimation in a contaminated and uncontaminated shallow sandy aquifer: San Francisco, California, San Francisco State University, M.S. thesis, $163 \mathrm{p}$.

Metge, D.W., Brooks, M., Smith, R., and Harvey, R.W., 1993, Effect of treated-sewage contamination upon bacterial energy charge adenine nucleotides, and DNA in a sandy aquifer on Cape Cod: Applied and Environmental Microbiology, v. 59 , p. $2304-2310$.

Metge, D.W., and Harvey, R.W., 1989, Partitioning, distribution, and recovery of DNA (deoxyribonucleic acid) from water and sediment in a contaminated aquifer in Cape Cod, Massachusetts, in Mallard, G.E., and Ragone, S.E., eds., U.S. Geological Survey Toxic Substances Hydrology Program-Proceedings of the technical meeting, Phoenix, Ariz., September 26-30, 1988: U.S. Geological Survey Water-Resources Investigations Report 88-4220, p. 547-554.
1991, Deoxyribonucleic acid distributions and recovery in estimation of biomass in a sand and gravel aquifer on Cape Cod, Massachusetts, in Mallard, G.E., and Aronson, D.A. eds., U.S. Geological Survey Toxic Substances Hydrology Program-Proceedings of the technical meeting, Monterey, Calif., March 11-15, 1991: U.S. Geological Survey Water-Resources Investigation Report 91-4034, p. 135-140.

Oremland, R.S., Cloern, J.E., Smith, R.L., Culbertson, C.W., Zehr, J., Miller, L.C., Cole, B., Harvey, R., Iverson, N., Klug, M., DesMarais, D.J., Rau, G., and Sofer, Z., 1988, Microbial and biochemical processes in Big Soda Lake, Nevada, in Fleet, A.J., Kelts, K., and Talbot, M.R., eds., Lacustrine Petroleum Source Rocks: Boston, Blackwell Scientific, p. 59-75.

Scholl, M.A., and Harvey, R.W., 1991, Laboratory studies of bacterial sorption to aquifer sediments from the Cape Cod toxic-substances-hydrology site, in Mallard, G.E., and Aronson, D.A., eds., U.S. Geological Survey Toxic Substances Hydrology Program-Proceedings of the technical meeting, Monterey, Calif., March 11-15, 1991: U.S. Geological Survey Water-Resources Investigations Report 91-4034, p. 152-154.

1992, Laboratory investigations on the role of sediment surface and groundwater chemistry in transport of bacteria through a contaminated sandy aquifer: Environmental Science and Technology, v. 26, no. 7 , p. 1410-1417.

Smith, R.L., and Harvey, R.W., 1991, Development of sampling techniques to measure in situ rates of microbial processes in a contaminated sand and gravel aquifer, in Fliermans, C. B., and Hazen, T.C., eds., Proceedings of the First International Symposium on Microbiology of the Deep Subsurface, January 15-19, 1990, Orlando, Florida: Aiken, South Carolina, WSRC Information Services, p. 2-19 to $2-27$. 


\section{ECOLOGY}

Smith, R.L., Harvey, R.W., and LeBlanc, D.R., 1991, Importance of closely spaced vertical sampling in delineating chemical and microbiological gradients in groundwater studies: Journal of

Contaminant Hydrology, v. 7, p. 285-300. 


\title{
ECOLOGY
}

TITLE: $\quad$ Effects of Toxic Substances on Aquatic Communities (CR 92-337 formerly WR 75-137)

\author{
PERSONNEL: Harry V. Leland, Project Chief \\ Debra A. Litwin, Secretary
}

ADDRESS: $\quad$ U.S. Geological Survey, 3215 Marine Street, Boulder, CO 80303.

TELEPHONE: (303) 541-3021

PROBLEM: Water pollution is principally a biological problem in that its primary effect is on aquatic organisms. Yet, most pollution assessment emphasizes the measurement of chemical . and physical variables rather than responses of aquatic organisms to these variables. There are several reasons for this contradictory emphasis on physiochemical variables, but perhaps the most compelling is the lack of predictive information on responses of aquatic organisms, singly or in association, to specific environmental factors. There is a need to evaluate the predictability of measurements based on such biological responses with a view towards their greater acceptance in water-quality assessment and towards development of methods for objectively defining relationships among biological and physiochemical variables in aquatic ecosystems.

OBJECTIVE: Determine through detailed studies of organisms, simplified ecosystems, and natural sites, the extent to which waterborne contaminants and (or) disturbance affect the production and structure of aquatic plant assemblages and the growth and reproductive capacity of aquatic animals. Evaluate methods assessing effects of chronic exposure to contaminants and (or) disturbances on individual species and natural aquatic communities.

APPROACH: Evaluate methods for assessing effects of waterborne contaminants released to the environment, including tests of embryogenesis and growth in fishes, survival of critical life stages of aquatic invertebrates, and population growth rate of algae. Determine physiochemical factors affecting responses and bioaccumulation of these contaminants. Evaluate methods and results of laboratory studies by field experiments. Determine the utility of biological test methods for detecting and monitoring environmental concentrations of toxicants. Examine the factors (physiochemical and biological) influencing responses of natural aquatic communities.

PROGRESS: Project staff provided continuing support to national, regional and study-unit National Water Quality-Assessment (NAWQA) personnel in the development and implementation of habitat assessment and ecological survey elements of the program. A 


\section{ECOLOGY}

workshop on in-stream and riparian physical characterization methods for streams and rivers of the western United States was convened in 1993 for Central Region biologists. A study to evaluate in-stream and riparian characterization approaches appropriate for streams of the western Great Plains was initiated. Project activity included two primary elements: (1) the integration of data bases on large-scale (reach, segment, and sub-basin) physical characteristics, water-quality, and biogeographic distributions of benthic assemblages, and (2) the description and measurement of large-scale physical attributes appropriate for trend assessment in river water quality.

An integrated analysis of biological, chemical, and physical data from the Yakima River Basin pilot (NAWQA) studies was completed. The report "Distribution of phytobenthos in the Yakima River Basin, Washington, in relation to geology, land use and other environmental factors" describes the approach proposed for integrating biogeographic, physical, and water-quality data in other synoptic NAWQA studies.

\section{REPORTS PUBLISHED 1988-1993:}

Cain, D.J., Fend, S.V., and Carter, J.L., 1988, Arsenic concentrations of selected benthic insects in Whitewood Creek and the Belle Fourche River, South Dakota, in Mallard, G.E., ed., U.S. Geological Survey Toxic Substances Hydrology Program-Surface Water Contamination, Denver, Colo., Proceedings of the technical meeting: U.S. Geological Survey Open-File Report 87764, p. 55-60.

1989, Temporal and spatial variability of arsenic in benthic insects from Whitewood Creek, South Dakota, in Mallard, G.E., ed., U.S. Geological Survey Toxic Substances Hydrology ProgramProceedings of the technical meeting, Phoenix, Ariz.: U.S. Geological Survey Water-Resources Investigations Report 88-4220, p. 257-268.

Leland, H.V., Fend, S.V., Dudley, T.L., and Carter, J.L., 1989, Effects of copper on species composition of benthic insects in a Sierra Nevada, California, stream: Freshwater Biology, v. 21, p. 163-179.
Leland, H.V., and Scudder, B.C., 1990, Trace elements in Corbicula fluminea from the San Joaquin River, California: Science of the Total Environment, v. 97/98, p. 641-672.

Scudder, B.C., Carter, J.L., and Leland, H.V., 1988, Effects of copper on development of the fathead minnow, Pimephales promelas Rafinesque: Aquatic Toxicology, v. 12, p. 107-124. 


\title{
ECOLOGY
}

TITLE: $\quad$ Remote Sensing and Ecological Research in Wetlands (NR 73-090)

\author{
PERSONNEL: Virginia P. Carter, Project Chief \\ Carol L. Padgett, Secretary \\ Nancy B. Rybicki, Hydrologist \\ Christopher Lewis, Hydrologic Aid
}

$\begin{array}{ll}\text { ADDRESS: } & \text { U.S. Geological Survey, } 430 \text { National Center, } 12201 \text { Sunrise Valley Drive, } \\ & \text { Reston, VA } 22092\end{array}$

TELEPHONE: (703) 648-5897

PROBLEM: Wetlands are hydrologically controlled ecosystems essential to estuarine, marine, lacustrine, and riverine productivity. To improve our understanding of these ecosystems we need information on (1) wetland hydrologic variables/budgets and their relation to wetland vegetation and nutrient cycling; (2) wetland dynamics and boundary fluctuations; (3) wetland functions and values; and (4) short- and long-term temporal changes. Wetland plants may serve as sensitive hydrologic indicators of water-quality parameters such as salinity, turbidity, $\mathrm{pH}$, nutrients; presence of various pollutants; or frequency and duration of inundation.

Submersed aquatic wetlands have many functions including (1) habitat for invertebrate species; (2) food and (or) shelter for juvenile and adult fish, waterfowl, and other wildlife; (3) retarding flow velocities, stabilizing bottom sediments, and slowing erosion; and (4) oxygenating the water, recycling or transforming nutrients and heavy metals. Decline or disappearance of aquatic plant communities or overgrowth of submersed vegetation under nutrient-enriched conditions is of concern to scientists, ecologists, environmentalists, and managers. The factors affecting distribution and abundance of submersed aquatic vegetation and the effect of submersed aquatic vegetation on water quality are poorly understood.

OBJECTIVE: (1) Determine factors responsible for the changing distribution of submersed macrophyte beds in the tidal Potomac River and other lacustrine and riverine environments; (2) study processes controlling the survival, expansion, and decline of macrophyte populations; (3) determine the effect of submersed macrophytes on water velocity, water quality, and carbon flux; (4) characterize wetland transition zones and relate distribution of vegetation to soils, hydrology and elevation; (5) examine seasonal and long-term changes in wetland ecology as related to changes in environmental parameters including hydrology, water quality and land use; and (6) aid in the development of models that utilize biological, hydrologic, and remotely sensed wetland data as part of their primary data base. 


\section{ECOLOGY}

APPROACH: (1) Conduct field and laboratory investigations of the factors affecting survival and growth of submerged aquatic plants, (2) conduct field and laboratory experiments to measure productivity and to determine the effect of submersed macrophytes on water quality and carbon flux, (3) develop models illustrating relationships between plant success and other environmental factors, (4) conduct studies on the hydrology and ecology of selected wetlands in the local area, at the Shingobee-Williams Lake Watershed in Minnesota, and at the Water, Energy, and Biogeochemical Budgets (WEBB) program site in Wisconsin.

PROGRESS: Conducted vegetation survey of the wetlands in the Allequash watershed, Wisconsin, as part of the Water, Energy and Biogeochemical Budget (WEBB). Our work in cooperation with John Elder and Dave Krabbenhoft of the Wisconsin District is focused on nutrient cycling in the four watersheds entering Trout Lake, a Long Term Ecological Research (LTER) site. There are essentially four carbon pools in the Allequash watershed: the ground water, the peat, the above-ground biomass and litter in wetlands and uplands, and the submersed aquatic vegetation. Wetlands and lakes cover about 20 percent of the watershed. Wetlands in the watershed are dominated by emergent plants (sedges, grasses, and forbs), by shrubs (alder, leatherleaf and Laborador tea are most common), and trees (tamarack and black spruce). The upland portion of the watershed is forested. There is no carbonate rock in the watershed, so fluxes of carbon are associated primarily with carbon released from decomposing plant biomass and atmospheric exchange.

Conducted vegetation surveys at Shingobee and Williams Lakes and Little Shingobee Fen at the Integrated Research Initiative (IRI) site in Minnesota, and cored the fen peats for stratigraphic profiling. One focus of research in the IRI site is carbon cycling; submersed macrophytes in both lakes comprise a large carbon pool which is stored or recycled in Williams Lake and lost through streamflow, stored or recycled in Shingobee Lake. In both lakes, submersed macrophytes may profoundly affect water chemistry during the growing season through photosynthesis and respiration and in the winter through plant decomposition. Drainage from the Little Shingobee Fen, a ground-water discharge wetland, carries carbon originating in the peat and marl deposits underlying the fen into Shingobee Lake. The size of this carbon pool can be estimated from our cores.

Coauthored two significant publications. The first, "Chesapeake Bay Submerged Aquatic Vegetation Habitat Requirements and Restoration Goals: A Technical Synthesis," represents a cooperative effort by those groups (Virginia Institute of Marine Science, University of Maryland, Environmental Protection Agency, and USGS) conducting long-term research on submersed macrophytes in Chesapeake Bay and its tributaries and is summarized briefly in a published article in Bioscience (see Bibliography). The second is our final manuscript on the 


\section{ECOLOGY}

ecology and hydrology of the western transition zone of the Great Dismal Swamp of Virginia and North Carolina and the use of vegetation, hydrology, and soils to establish wetland boundaries. This is in press in Ecological Applications.

\section{REPORTS PUBLISHED 1988-1993:}

Barko, J.W., Godshalk, G.L., Carter, Virginia and Rybicki, N.B., 1988, Effects of submersed aquatic macrophytes on physical and chemical properties of surrounding water: Department of the Army Waterways Experiment Station Technical Report A-99-11, 28 p.

Batiuk, Richard, Heasley, Patsy, Orth, Robert, Moore, Kenneth, Stevenson, J.C. Dennison, William, Staver, Lori, Carter, Virginia, Rybicki, N.B., Hickman, R.E., Kollar, Stan, Bieber, Steven, Bergstrom, Peter, 1993, Chesapeake Bay submerged aquatic vegetation habitat requirements and restoration goals-A Technical Synthesis: USEPA CBP/TRS 83/92, 162 p.

Carter, Virginia, 1988, Relation of hydrogeology, soils and vegetation on the wetland-to-upland transition zone of the Great Dismal Swamp, Virginia and North Carolina: Washington, D.C., George Washington University, Ph.D. dissertation, $307 \mathrm{p}$.

1990, The Great Dismal Swamp-an illustrated case study, in Lugo, A.E., Brinson, Mark, and Brown, Sandra, eds., Ecosystems of the World 15: Forested Wetlands, Elseviers Publishing company, Amsterdam, chap. 8, p. 201-21l.

1990, Importance of hydrologic data for interpreting wetland maps and assessing wetland loss and mitigation, in Kiraly, S.J. Cross, F.A., and Buffington, J.D., eds., Federal Coastal Wetland Mapping Programs: U.S. Fish and Wildlife Biological Report 90 (18), p. 79-85.

Carter, Virginia, Barko, J.W., Godshalk, G.L., and Rybicki, N.B., 1988, Effects of submersed macrophytes on water quality in the tidal Potomac River, Maryland: Journal of Freshwater Ecology, v. 4, no. 4, p. 493-501.

Carter, Virginia, Gammon, P.T., and Garrett, M.K., 1993, Ecotone dynamics and boundary determination in the Great Dismal Swamp, Virginia and North Carolina: Ecological Applications, v 4, no. 1.

Carter, Virginia, and Rybicki, N.B., 1991, Light attenuation in Back Bay, Virginia, in Marshall H.G., and Norman M.D., eds., Proceedings of the Back Bay Symposium, Department of Biological Sciences: Old Dominion University , Norfolk, Va., p. 20-28.

1991, Light attenuation and submersed macrophyte distribution in the tidal Potonac and Estuary: Estuaries, v. 13, no. 4, p. 441-452.

Carter, Virginia, Rybicki, N.B., and Hammerschlag, Richard, 1991, Effects of submersed macrophytes on dissolved oxygen, $\mathrm{pH}$, and temperature under different conditions of wind, tide and bed structure: Journal of Freshwater Ecology, v. 6, no. 2, p. 121-133.

Carter, Virginia, Rybicki, N.B., Jones, R.C., Barko, J.W., Dresler, P.V., Hickman, R.E., and Anderson, R.T., 1989, Data on physical, chemical, and biological data and characteristics of Hydrilla beds, mixed beds, and unvegetated sites in the tidal Potomac River, Maryland and Virginia, 1987: U.S. Geological Survey Open-File Report 88-709, 196 p. 


\section{ECOLOGY}

Carter, Virginia, Rybicki, N.B., and Turtora, Michael, 1991, Population dynamics of submersed macrophytes in the tidal Potomac River, in 25th Annual Meeting, Aquatic Plant Control Research Program: U.S. Army Corps of Engineers, Miscellaneous Paper A-91-3, [Proceedings], p. 41-53.

Dennison, W.C., Orth, R.J., Moore, K.A., Stevenson, J.C., Carter, Virginia, Kollar, Stan, Bergstrom, P.W., and Batiuk, R.A., 1993, Assessing water quality with submersed aquatic vegetation: Bioscience, v. 43 , no. 2 , p. 86-94.

Jenter, H.L., Rybicki, Nancy, Baltzer, R.A., and Carter, Virginia, 1990, Tidal mass exchange between a submerged aquatic vegetation bed and the main channel of the Potomac River: American Society of Civil Engineers Hydraulic Conference, Nashville, Tennessee, p. 298-304.

Killgore, K.J., Morgan, R.P., II, and Rybicki, N.B., 1989, Seasonal and temporal distribution and abundance of fishes associated with submersed aquatic plants: North American Journal of Fisheries Management, v. 9, no. 1, p. 101-111.

Orth, Robert, Moore, Kenneth, Batiuk, Richard, Heasly, Patsy, Dennison, William, Stevenson, J.C., Staver, Lori, Carter, Virginia, Rybicki, Nancy, Kollar, Stan, Hickman, R.E., and Bieber, Steven, 1991, Water quality standards based on species' habitat requirements-a case study from the Chesapeake Bay using submerged aquatic vegetation, in Proceedings of Water Quality Standards for the 21st Century: U.S. Environmental Protection Agency, Office of Water WH-553, p. 177-181.

Robbins, E.1., D'Agostino, J.P., Ostwald, J., Fanning, D.S., Carter, Virginia, and Van Hoven, R.L., 1993, Manganese nodules and microbial oxidation of manganese in the Huntley Meadows Wetland, Virginia, U.S.A.: Catena, Supplement 21, p. 170-202.
Rybicki, Nancy, Anderson, R.T., and Carter, Virginia, 1988, Data on the distribution and abundance of submersed aquatic vegetation in the tidal Potomac River and transition zone of the Potomac Estuary, Maryland, Virginia and the District of Columbia, 1987: U.S. Geological Survey OpenFile Report 88-307, 31 p.

Rybicki, Nancy, and Schening, M.R., 1990, Data on the distribution and abundance of submersed aquatic vegetation in the tidal Potomac River and transition zone of the Potomac Estuary, Maryland and Virginia, and the District of Columbia, 1988: U.S. Geological Survey Open-File Report 90-123, 19 p. 


\section{ECOLOGY}

TITLE: $\quad$ Modeling of Microbially Catalyzed Geochemical Reactions in Aquatic Environments (NR 87-136)

PERSONNEL: Derek R. Lovley, Project Chief

Carol L. Wakelee, Secretary

Elizabeth J. Phillips, Biologist

Debra Lonergan, Microbiologist

Peggy Widman, Microbiologist

Joan C. Woodward, Physical Science Technician

ADDRESS: U.S. Geological Survey, 430 National Center, 12201 Suntise Valley Drive, Reston, VA 22092

TELEPHONE: (703) 648-5825

PROBLEM: Micro-organisms catalyze most of the natural redox reactions involving carbon, sulfur, nitrogen, and metals. Thus, geochemical models of the distribution and fate of natural and contaminant compounds must include a microbiological component, which requires an understanding of the physiological characteristics of micro-organisms that control the rate and extent of microbially catalyzed reactions.

OBJECTIVE: (1) Quantify the rates of microbial processes that influence the geochemistry of surface water and ground water; (2) determine the physiological characteristics that control the rate and extent of microbial processes; and (3) develop mathematical models of the distribution of microbial processes in surface water and ground water.

APPROACH: Quantify rates and pathways of microbial processes with radiotracer, stableisotope and inhibitor techniques. Determine microbial physiological characteristics with experimental manipulations of natural, mixed populations and pure cultures. Combine data on physiological characteristics with appropriate geochemical models to generate models for the . distribution of microbial processes.

PROGRESS: The first enzyme from an anaerobic microorganism known to catalyze the dissimilatory reduction of metals was purified and identified. The enzyme converted iron oxide to magnetite and precipitated uranium from water. Furthermore, it reduced chromium from the highly toxic and highly soluble $\mathrm{Cr}(\mathrm{VI})$ state to less toxic, less soluble $\mathrm{Cr}(\mathrm{III})$. Gold was reductively precipitated from solution. This enzyme provides the first model for the enzymatic reduction and biomineralization of iron, uranium, and gold in anaerobic sedimentary environments and has significant potential for the bioremediation of contaminant metals. 


\section{ECOLOGY}

Furthermore, the gene for this protein has been cloned and over-expressed, suggesting that it may be possible to engineer micro-organisms with enhanced metal-reducing capabilities.

Novel links between the iron and sulfur cycles in marine and estuarine sediments were discovered. Desulfuromonas acetoxidans, which was previously known as an sulfur-reducing organism was found to be the first example of a marine organism capable of conserving energy to support growth by oxidizing organic compounds with the reduction of Fe(III). Evidence that dissimilatory sulfate reducers may function as the dominant Fe(III)-reducing microorganisms was reported in Nature and Marine Geology. These findings revised our concepts about the mechanisms for metal reduction in marine and estuarine sediments and have led to a new model about the interaction between sulfate- and Fe(III)-reducing populations in sedimentary environments in general.

It was demonstrated that $\mathrm{H}_{2}$ dissolved in ground water can be used to predict the distribution of microbial decomposition processes in aquifers contaminated with organic compounds. This is the first method ever developed in which it is possible to discern from a simple water measurement which microbial redox processes are taking place in contaminated aquifers. Such a technique is useful in attempting to predict the fate and mobility of organic contaminants in ground water. A manuscript describing these studies has been prepared for Water Resources Research.

A novel technique for stimulating the degradation of organic contaminants in ground water was discovered. Laboratory investigations demonstrated that iron chelators could stimulate the degradation of toluene in aquifer material containing ferric oxides. The chelators work by making the $\mathrm{Fe}(\mathrm{III})$ in the sediments more available for microbial reduction.

Our studies on microbial freon uptake were published during this period and received wide-spread media attention including being designated Popular Science's Grand Prize winner in Environmental Technology for 1992.

\section{REPORTS PUBLISHED 1988-1993:}

Caccavo, F., Blakemore, R.P, and Lovley, D.R., 1992, A hydrogen-oxidizing, iron-reducing micro-organism from the Great Bay Estuary, New Hampshire: Applied Environmental Microbiology, v. 58, p. 3211-3216.
Chapelle, F.H., and Lovley, D.R., 1990, Rates of microbial metabolism in deep coastal plain aquifers: Applied Envirommental Microbiology, v. 56, p. $1858-1864$.

1992, Competitive exclusion of sulfate reduction by $\mathrm{Fe}$ (III)-reducing bacteria: a mechanism for 


\section{ECOLOGY}

producing discrete zones of high-iron ground water: Ground Water, v. 30, p. 29-36.

Coleman, M.L., Hedrick, D.B., Lovley, D.R., White, D.C., and Pye, K., 1993, Reduction of $\mathrm{Fe}$ (III) in sediments by sulphate-reducing bacteria: Nature, v. 361, p. 436-438.

Gorby, Y., and Lovley, D.R., 1991, Electron transport in the dissimilatory iron-reducer, GS-15: Applied and Environmental Microbiology, v. 57, p. 867-870.

Gorby, Y.A., and Lovley, D.R., 1992, Enzymatic uranium precipitation: Environmental Science Technology, v. 26, p. 205-207.

Landa, E.R., Phillips, E.J.P., and Lovley, D.R., 1992 , Release of 226Ra from uranium mill tailings by microbial $\mathrm{Fe}(\mathrm{III})$ reduction: Applied Geology, v. 6, p. 647-652.

Lonergan, D.J., and Lovley, D.R., 1991, Microbial oxidation of natural and anthropogenic aromatic compounds coupled to $\mathrm{Fe}$ (III) reduction, in Baker, R.A., ed., Organic Substances and Sediments in Water: Chelsea, Michigan, Lewis Publishers, Inc., p. 327-338.

Lovley, D.R., 1990, Magnetite Formation during Dissmilatory $\mathrm{Fe}$ (III) Reduction, in Frankel, R.B., and Blakemore, R.P., eds., Iron Biominerals: New York: Plenum Press, p. 151-166.

1991, Dissimilatory Fe(III) and Mn(IV) reduction: Microbiological Reviews, v. 55, p. 259287.

1992, Microbial oxidation of organic matter coupled to the reduction of $\mathrm{Fe}$ (III) and $\mathrm{Mn}$ (IV) oxides: Catena, v. 21, p. 101-114.

Lovley, D. R., 1993, Microbes into Heavy MetalTrends in Ecology and Evolution, v. 8, p. 213217.
Lovley, D. R., 1993, Dissimilatory metal reduction: Annual Review Microbiology, v. 47, p. 263290.

Lovley, D.R., Baedecker, M.J., Lonergan, D.J., Cozzarelli, I.M., Phillips, E.J. P., and Siegel, D.I., 1989, Oxidation of aromatic contaminants coupled to microbial iron reduction: Nature, $v$. 339 , p. 297-299.

Lovley, D.R., Chapelle, F.H., and Phillips E.J.P., 1990, Recovery of $\mathrm{Fe}$ (III)-reducing bacteria from deeply buried sediments of the Atlantic Coastal Plain: Geology, v. 18, p. 954-957.

Lovley, D.R., Giovannoni, S.J., White, D.C., Champine, J.E., Phillips, E.J.P., Gorby, Y.A., and Goodwin, S., 1993, Geobacter metallireducens gen. nov. sp. nov., a micro-organism capable of coupling the complete oxidation of organic compounds to the reduction of iron and other metals: Arch. Microbiol., v. 159, p. 336344.

Lovley, D.R., and Goodwin, S., 1988, Hydrogen concentrations as an indicator of the predominant terminal electron accepting reactions in aquatic sediments: Geochimica et Cosmochimica Acta, v. 52, p. 2993-3003.

Lovley, D.R., and Lonergan, D.J., 1990, Anaerobic oxidation of toluene, phenol, and p-cresol by the dissimilatory $\mathrm{Fe}(\mathrm{III})$-reducing organism, GS-15: Applied Environmental Microbiology, v. 56, p. 1858-1864.

Lovley, D.R., and Phillips, E.J.P., 1988, Manganese inhibition of nicrobial iron reduction in anaerohic sediments: Geomicrobiology Journal, v. 6, p. 145-155.

1988, Novel mode of microbial energy metabolism: organic carbon oxidation coupled to dissimilatory reduction of iron or manganese: Ap- 


\section{ECOLOGY}

plied Environmental Microbiology, v. 54, p. 1472-1480.

1989, Requirement for a microbial consortium to completely oxidize glucose in $\mathrm{Fe}$ (III)-reducing sediments: Applied Environmental Microbiology, v. 55, p. $3234-3236$.

1992, Reduction of Uranium by Desulfovibrio desulfuricans: Applied Environmental Microbiology, v. 58, p.850-856.

1992, Bioremediation of uranium contamination with enzymatic uranium reduction: Environmental Science Technology, v. 26, p. 2228-2234.

Lovley, D.R., Phillips, E.J.P., and Caccavo, F. Jr., 1992, Acetate oxidation by dissimilatory Fe(III) reducers: Applied and Environmental Microbiology, v. 58, p. 3205-3206.

Lovley, D.R., Phillips, E.J.P., Gorby, Y.A., and Landa, E.R., 1991, Microbial reduction of uranium: Nature, v. 350, p. 413-416.

Lovley, D.R., Phillips, E.J.P., and Lonergan, D.J., 1989, Hydrogen and formate oxidation coupled to dissimilatory reduction of iron or manganese by Alteromonas putrefaciens: Applied Environmental Microbiology, v. 55, p. 700-706.

1991, Enzymatic versus nonenzymatic mechanisms for $\mathrm{Fe}(\mathrm{III})$ reduction in aquatic sediments: Environmental Science and Technology, v. 25, p. 1062-1067.

Lovley, D.R., Roden, E.E., Phillips E.J.P., and Woodward, J.C., 1993, Enzymatic iron and uranium reduction by sulfate-reducing bacteria: Marine Geology, v. 113, p. 41-553.

Lovley, D.R., and Stolz, J.F., 1989, Origin of soil magnetite: Nature, v. 340, p. 106.
Lovley, D.R., Widman, P.K., and Woodward, J.C., 1993, Reduction of uranium by cytochrome $C_{3}$ of Desulfovibrio vulgaris: Applied and Environmental Microbiology, v. 55, p. 3572-3576.

Lovley, D.R., and Woodward, J.C., 1992, Consumption of freons CFC-11 and CFC-12 by anaerobic sediments and soils: Environmental Science Technology, v. 26, p. 925-929.

Moskowitz, B.M., Frankel, R.B., Bazylinski, D.A., Jannasch, H.W., and Lovley, D.R., 1989, A comparison of magnetite particles produced anaerobically by magnetotactic and dissimilatory iron-reducing bacteria: Geophysical Research Letters, v. 16, p. 665-668.

Oremland, R.S., Miller, L.G., Culbertson, C.W., Robinson, S.W., Smith, R.L., Lovley, D.R., Whiticar, M.J., King, G.M., Kiene, R.P., Iversen, M., and Sargent, M., 1993, Aspects of the biogeochemistry of methane in Mono Lake and the Mono basin of California, U.S.A., in Oremland, R.S., ed., Biogeochemistry of Global Change-Radiative Trace Gases: New York, Chapman and Hall, p. 704-741.

Phillips, E.J.P., Lovley, D.R., and Roden, E.E., 1993. Composition of non-microbially reducible $\mathrm{Fe}(\mathrm{III})$ in aquatic sediments: Applied Environmental Microbiology, v. 59, p. 2727-2729.

Roden, E.E., and Lovley, D.R., 1993, Dissimilatory $\mathrm{Fe}$ (III) reduction by the marine micro-organism, Desulfuromonas acetoxidans: Applied Environmental Microbiology, v. 59, p. 734-742.

1993, An evaluation of ${ }^{55} \mathrm{Fe}$ as a tracer for $\mathrm{Fe}(\mathrm{III})$ reduction in aquatic sediments: Geomicrobiology Journal, v. 11, p. 49-56.

Sparks, N.H.C., Mann, S., Bazylinski, D.A., Lovley, D.R., Jannasch, H.W., and Frankel, R.B., 1990, Structure and morphology of magnetite formed by a marine magnetotactic bacterium 


\section{ECOLOGY}

and dissimilatory iron-reducing bacteria: Earth and Planet Science Letters, v. 98, p. 14-22.

Stolz, J.F., Lovley, D.R., and Haggerty, S.E., 1990, Biogenic magnetite and magnetization of sediments: Journal of Geophysical Research, v. 95, p. 4335-4361. 


\title{
ECOLOGY
}

TITLE: Vegetation and Hydrogeomorphic Relations (NR 90-145)

\author{
PERSONNEL: Cliff R. Hupp, Project Chief \\ Carolyn Wakelee, Secretary \\ Thomas M. Yanosky, Botanist \\ Michael Schening, Ecologist
}

$\begin{array}{ll}\text { ADDRESS: } & \text { U.S. Geological Survey, } 430 \text { National Center, } 12201 \text { Sunrise Valley Drive, } \\ & \text { Reston, VA } 22092\end{array}$

TELEPHONE: (703) 648-5206

PROBLEM: Many hydrogeomorparc processes are poorly understood. Botanical studies can improve flood or debris flow prediction for streams with short or no gaging-station records. Improvement of our understanding of the relations among fluvial geomorphology, sedimentation, mass wasting, plant chemistry, and plant ecology will provide insight into such problems as assessment of water quality, wetland loss, long-term effects of climatic variation, and the frequency and magnitude of destructive hydrogeomorphic phenomena. Botanical and geomorphic analyses may provide substantial information about variable source areas of runoff production and ground-water recharge.

OBJECTIVE: (1) Continue development of the combined use of botanical evidence and maximum likelihood estimators in flood-frequency prediction; (2) conduct basic research in the analysis and interpretation of the role of vegetation in natural and disturbed fluvial systems, including riparian and wetlands systems; (3) conduct basic research in the hydrogeomorphicplant ecological aspects of watershed dynamics, including the delineation of variable source areas of runoff production and ground-water recharge, and analyses of nonpoint source pollution and basic plant-landform relations; and (4) conduct basic research into tree-ring chemistry as an indication of ground- and surface-water quality.

APPROACH: The approach is broadly interdisciplinary, employing techniques from the hydrologic, geomorphic, chemical and ecologic sciences. Dendrogeomorphic (tree-ring landform analyses), hydrologic (stream flow modeling, step-backwater analyses), and statistical (maximum likelihood estimator, time series) techniques are used in the paleohydrologic (floods, debris flows, landsliding) aspects of the project. The above techniques are combined with plant ecological analyses (plot and plotless sampling, species/landform mapping, multivariate biostatistical analyses), geomorphic analyses, and sedimentologic analyses to 


\section{ECOLOGY}

accomplish objectives 2 and 3 . Objective 4 is accomplished by investigating the relationship between pollutants in water and sediments, and subsequent levels in plant tissues.

PROGRESS: The Project assisted in the development of a National Water Quality-Assessment (NAWQA) regional synthesis topic (sedimentation and trace element trapping in low gradient streams) that will continue over the next 2-3 years.

The Project expanded studies of saltwater intrusion and global sea-level rise using element analysis of tree rings in the Cape Fear estuary, North Carolina. These studies, along with an earlier effort, should assist the development of predictive models that will be useful in long-term planning in these and similar areas.

The Project completed a multi-year interdisciplinary investigation (with the Tennessee District and the U.S. Environmental Protection Agency (USEPA)) of environmental degradation related to contamination from a wood-preserving facility in Jackson, Tennessee. A detailed report (U.S. Geological Survey Water-Resources Investigations Report (WRIR)) was drafted and is now in colleague review, and a related journal article is in preparation.

The Project expanded in-house attempts to determine element concentrations within tree rings and sediments using direct-current plasma (DCP) and graphite furnace atomic absorption spectrometry techniques.

The Project completed analyses of data generated last spring and summer of element concentrations within discrete portions of individual tree rings. The basic research should permit greater refinement of the calculated transport time of contaminants in ground water. A manuscript is in outline form.

The Project has continued earlier efforts, and assumed new efforts, with District personnel in Virginia, Maryland, Colorado, Minnesota, South Carolina, Rhode Island, Massachusetts, Arkansas, California, and Louisiana, concerning wetlands and (or) fluvial geomorphology and vegetation process and form using dendrogeomorphic, ecological, and trace-element analyses.

\section{REPORTS PUBLISHED 1988-1993:}

Bazemore, D.E., and Hupp, C.R., 1991, Flood-plain sedimentation rates near bridge crossings, in Fan, S.S., and Kuo, Y.H., eds., Proceedings of the Fifth Federal Interagency Sedimentation
Conference: Washington, D.C., Federal Energy Regulatory Commission, v. 1, p. 48-54.

Bazemore, D.E., Hupp, C.R., and Diehl, T.H., 1991, Wetland sediment deposition and vegeta- 


\section{ECOLOGY}

Hon patterns near selected highway crossings in west Tennessee: U.S. Geological Survey, WaterResources Investigations Report 91-4106, p. 46.

Carey, W.P., Lyverse, M.A., and Hupp, C.R., 1990, Hillslope erosion Kentucky: U.S. Geological Survey, Water-Resources Investigations Report 89-4199, p. 38.

Hupp, C.R., 1988, Plant ecological aspects of flood geomorphology and paleoflood history, in Baker, V.R., Kochel, R.C., and Patton, P.C., eds., Flood Geomorphology: New York, Wiley and Sons, Ltd., p. 335-356.

1990, Vegetation patterns in relation to basin hydrogeomorphology, in, Thornes, J.B., ed., Vegetation and erosion: Chichester, England, Wiley and Sons Ltd., p. 217-237.

1992, Riparian vegetation recovery patterns following stream channelization-A geomorphic perspective: Ecology, v. 73, p. 1209-1226.

Hupp, C.R., and Bazemore, D.E., 1991, Dendrogeomorphic analysis of wetland sedimentation in Fan, S.S., and Kuo, Y.H., eds., Proceedings of the Fifth Federal Interagency Sedimentation Conference: Washington, D.C., Federal Energy Regulatory Commission, v. 1, p. 40-47.

1993, Spatial and temporal aspects of sediment deposition in west Tennessee forested wetlands: Journal of Hydrology, v. 141, p. 179-196.

Hupp, C.R., and Carey, W.P., 1990, Dendrogeomorphic approach to slope retreat, Maxey Flats, Kentucky: Geology, no. 18, p. 658-661.

Hupp, C.R., and Morris, E.E., 1990, A dendrogeomorphic approach to measurement of sedimentation in a forested wetland, Black Swamp, Arkansas: Wetlands, no. 10, p. 107-124.
Hupp, C.R., and Simon, A., 1991, Bank accretion and the development of vegetated depositional surfaces along modified alluvial channels: Geomorphology, no. 4, p. 111-124.

Hupp, C.R., Woodside, M.D., and Yanosky, T.M., 1993, Sediment and trace element trapping in a forested wetland, Chickahominy River, Virginia: Wetlands, v. 13, p. 95-104.

Simon, A., and Hupp, C.R., 1990, The recovery of alluvial systems in response to imposed channel modifications, west Tennessee, in, Thornes, J.B., ed., Vegetation and erosion: Chichester, England, Wiley and Sons Ltd., p. 145-160.

Simon, A., Larsen, M.C., and Hupp, C.R., 1990, The role of soil processes in determining mechanisms of slope failure and hillslope development in a humid tropical forest, eastern Puerto Rico: Proceedings of the 21st Geomorphology Symposium, Geomorphology 3, p. 263-286.

Vroblesky, D.A., and Yanosky, T.M., 1990, Use of tree-ring chemistry to document historical ground-water contamination events: Ground Water, v. 28 , p. $677-684$.

Vroblesky, D.A., Yanosky, T.M., and Siegel, F.R., 1992, Increased concentrations of potassium in heartwood of trees in response to groundwater contamination: Environmental Geology and Water Science, v. 19, p. 71-74.

Yanosky, T.M., and Vroblesky, D.A., 1993, Relation of nickel concentrations in tree rings to groundwater contamination: Water Resources Research, v. 28 , p. $2077-2083$. 


\section{ECOLOGY}

TITLE: Limnology: Controls on Distribution and Composition of Benthic Communities of Inland Aquatic Ecosystems (WR 61-012)

PERSONNEL: Keith V. Slack, Project Chief

Maria M. Watts, Secretary

Larry J. Tilley, Biologist

ADDRESS: U.S. Geological Survey, 345 Middlefield Road, MS 421, Menlo Park, CA 94025

TELEPHONE: (415) 329-4549

PROBLEM: Benthic invertebrates are the aquatic organisms most widely used as indicators of stream quality. Although many factors are known to affect the abundance and distribution of species, it is usually not possible to predict changes in benthic communities caused by a given environmental perturbation. Improved understanding is needed of factors that control temporal and spatial distribution, abundance, and species composition of benthic-invertebrate associations in different types of streams. In particular, greater knowledge of the functional relations between benthic invertebrates and other components of stream ecosystems is required.

OBJECTIVE: Study the organization and dynamics of benthic-invertebrate species associations in streams. Study the relationships between environmental factors in streams-such as water and sediment chemistry, detritus, biotic interactions, and instream physical conditions-to the macroscale, mesoscale, and microscale distribution and the composition of biotic communities in streams.

APPROACH: Sample benthic invertebrates in a variety of small to large streams and relate their spatial and temporal distribution and species composition to environmental differences by use of multivariate analysis. Test relations derived from field studies in field and laboratory experiments.

PROGRESS: Completed the first quality assurance/quality control (QA/QC) analysis for invertebrate samples collected during a National Water Quality-Assessment (NAWQA) ecological survey: Illinois River 1989-1990. Results indicated sample preservative leakage was a problem and contractors made fewer errors of identification with the common species in samples versus difficult groups of species such as Acari, worms, and midge larvae. Completed design for two biology QA/QC laboratories in Denver, Colorado, one for 1993 and a new version tentatively scheduled for 1996 or 1997 . Experiments with different mesh nets in drift 


\section{ECOLOGY}

of benthic invertebrates in small streams showed that early instar midge (Chironomidae: Diptera) larvae reacted differently to light than did later instar larvae. First and second instar larvae (younger) were positively phototactic and third and fourth instar larvae (older) were negatively phototactic. Data from acid streams indicated that possibly owing to lack of competition within the benthic community, species that were rare in nearby neutral streams became dominants in the acid streams. In these streams the organic detritus fraction of drift-net samples was especially abundant at daybreak and nightfall.

\section{REPORTS PUBLISHED 1988-1993:}

Hahn, S.S., 1988, Method for identification of immature Simuliidae, in Britton, L.J., and Greeson, P.E., eds., Methods for collection and analysis of aquatic biological and microbiological samples: Techniques of water-resources investigations of the United States Geological Survey, book 5, chap. A4, p. 189-193.

1988, Permanent- and semipermanent-slide method for aquatic Acari, in Britton, L.J., and Greeson, P.E., eds., Methods for collection and analysis of aquatic biological and microbiological samples: Techniques of water-resources investigations of the United States Geological Survey, book 5, chap. A4, p. 195-198.

Slack, K.V., 1988, Benthic invertebrates: Faunal surveys. Numerical assessment. Distribution and abundance. Invertebrate drift, in Britton, L.J., and Greeson, P.E., eds., Methods for collection and analysis of aquatic biological and microbiological samples: Techniques of waterresources investigations of the United States Geological Survey, book 5, chap. A4, p. 151183.

1988, Part 3: Selected Taxonomic references, in Britton, L.J., and Greeson, P.E., eds., Methods for collection and analysis of aquatic biological and microbiological samples: Techniques of water-resources investigations of the United States Geological Survey, book 5, chap. A4, p. 311-339 and p. 341-363.
Slack, K.V., Ferreira, R.F., Averett, R.C., and Kennelly, S.S., 1988, Effects of spatial orientation of multiple plate artificial substrates on invertebrate colonization: Water Resources Bulletin, v. 24, no. 4, p. 781-789.

Slack, K.V., and Greeson, P.E., 1988, Seston. Glassfiber filter method, in Britton, L.J., and Greeson, P.E., eds., Methods for collection and analysis of aquatic biological and microbiological samples: Techniques of water-resources investigations of the United States Geological Survey, book 5, chap. A4, p. 127-130.

Slack, K.V., Tilley, L.J., and Hahn, S.S., 1988, Collection of benthic invertebrates by drift net and dip net, Little Boulder Creek, Idaho: Selected papers in the Hydrologic Sciences 1987, U.S. Geological Survey Water Supply Paper 2330, p. 11-17.

Slack, K.V., Tilley, L.J., and Kennelly, S.S., 1991, Mesh-size effects on drift sample composition as determined with a triple net sampler: Hydrobiologia, v، 209, p. 215-226.

Stephens, D.W., and Slack, K.V., 1988, Diel oxygen-curve method for estimating primary productivity, in Britton, L.J., and Greeson, P.E., eds., Methods for collection and analysis of aquatic biological and microbiological samples: Techniques of water-resources investigations of 


\section{ECOLOGY}

the United States Geological Survey, book 5 , chapter A4, p. 259-263.

Tilley, L.J., 1988, Selected Taxonomic References: Chironomidae, in Britton, L.J., and Greeson, P.E., eds., Methods for collection and analysis of aquatic biological and microbiological samples: Techniques of water-resources investigations of The United States Geological Survey, book 5, chap. 4A, p. 339-341.

1988, Inverted microscope method for phytoplankton analysis, in Britton, L.J., and Greeson, P.E., eds., Methods for collection and analysis of aquatic biological and microbiological samples: Techniques of water-resources investigations of the United States Geological Survey, book 5, chap. A4, p. 109-111.

1988, Permanent slide method for larvae of Chironomidae, in Britton, L.J., and Greeson, P.E., eds., Methods for collection and analysis of aquatic biological and microbiological samples: Techniques of water-resources investigations of the United States Geological Survey, book 5, chap. A4, p. 185-188.

1989. Diel drift of chironomidae larvae in a pristine Idaho mountain stream: Hydrobiologia, $v$. 174 , p. $133-149$.

Tilley, L.J., Slack, K.V., and Kennelly, S.S., 1991, Transport of invertebrates and detritus in streams, in Fan, S.S., and Kuo, Y.H., eds., Proceedings of the Fifth Federal Interagency Sedimentation Conference, v. II, Aquatic Ecology Section no. 13, p. 9-17. 


\title{
ECOLOGY
}

TITLE: Geochemistry of Riverine and Estuarine Waters (WR 68-046)

PERSONNEL: David H. Peterson, Project Chief

Lucenia Thomas, Secretary

James R. Slack, Mathematician

Richard E. Smith, Research Oceanographer

Laurence E. Schemel, Oceanographer

Stephen W. Hager, Oceanographer

Daniel R. Cayan, Meteorologist

Jane Caffrey, National Research Council Postdoctoral Assoc.

\begin{abstract}
ADDRESS: $\quad$ U.S. Geological Survey, 345 Middlefield Road, MS 496, Menlo Park, CA 94025
\end{abstract}

TELEPHONE: (415) 354-3366

PROBLEM: The physical and chemical variability in our riverine-estuaries system is large, but causes and interactions are not clearly defined. Weather and climate forced variations appear to be very important, but we don't yet understand how riverine-estuarine systems operate on very short and moderately long time scales. Furthermore, the effect of anthropogenic activities also may be important. Without such information we cannot understand and predict how these systems respond to variations in climate and human activities including changes in the amount, character, and timing of freshwater, toxic-waste, sediment and plant-nutrient inflows to these environments.

OBJECTIVE: To better understand the variability of the physics (circulation) and chemistry (primarily oxygen, carbon, silicon, nitrogen and phosphorous dynamics) in riverine and estuarine environments. Furthermore, to discriminate between natural variations due to atmospheric/ oceanic forcing and human-caused impacts.

APPROACH: Defining temporal/spatial variability in riverine/estuarine systems is largely observational, using shipboard and in situ instrumentation as well as large meteorological/ hydrological/oceanographical data bases. Analysis methods include statistical and numerical simulation models of physical, chemical and biological processes influencing these systems over a broad spectrum of space and time scales. Major estuaries, such as San Francisco Bay, will be used as models for understanding and comparing behavior in others. Regional watershed variability will be interpreted vis-a-vis large scale regional-atmospheric, globalatmospheric and oceanic conditions including circulation, temperature, and precipitation. Intermediate linkage to watershed hydrology will be incorporated. 


\section{ECOLOGY}

PROGRESS: Nutrient dynamics in rivers and estuaries are linked to and (or) covary with sediment dynamics. Over a decade of daily Sacramento-San Joaquin River suspended sediment observations collected by the California District illustrate several scales of variability: in addition to the relatively well-documented effects of reservoirs (long-term) and annual cycles (which in the San Joaquin River are often dominated by agricultural waste flows, especially in dry years), sediment concentration-flow relations depend on antecedent conditions.

First storms of the year tend to produce the highest suspended sediment concentrations per unit flow. For dissolved inorganic plant nutrients, such as nitrate, this effect also is apparent on interannual time scales; first storm effects on concentration are greater per unit flow following dry years. In contrast (to rivers), a major gap in understanding San Francisco Bay sediment dynamics is the lack of field observations. Limited observations from northern San Francisco Bay show suspended sediment concentrations are influenced by (1) peak (storm-event) river flows; (2) the fortnightly spring/neap tidal cycle; and (3) semidiurnal tides. Even less is known about the role of wind episodes and diurnal winds (short-time scale) and gravitational circulation (longer time scales).

\section{REPORTS PUBLISHED 1988-1993:}

Carlton, J.T., Thompson, J.K., Schemel, L.E., and Nichols, F.H., 1990, The remarkable invasion of San Francisco Bay (California, U.S.A.) by the Asian clam Potamocorbula amurensis-I. Introduction and dispersal: Marine Ecology Progress Series, v. 66, p. 81-94.

Cayan, D.R., Gardner, J.V., Landwehr, J.M., Namias, J., and Peterson, D.H., 1989, Introduction, in Peterson, D.H., ed., Aspects of Climate Variability in the Pacific and the Western Americas: Washington, D.C., American Geophysical Union, Monograph 55, p. 13-16.

Cayan, D.R., McClain, D.R., Nichols, W.D., DiLeo-Stevens, J., 1991, The monthly climate time series data for the Pacific Ocean and western Americas: U.S. Geological Survey Open-File Report No. 91-92, p. 380.

Cayan, D.R., and Peterson, D.H., 1989, The Influence of North Pacific Atmospheric Circulation on Stream Flow in the West, in Peterson, D.H., ed., Aspects of Climate Variability in the Pacific and the Western Americas: Washington, D.C., American Geophysical Union, Monograph 55, p. 375-397.

Cayan, D.R., and Webb, R.H., 1992, El Niño/Southern Oscillation and streamflow in the western United States, in Diaz, H.F., and Markgraf, V. eds., El Niño-Historical and Paleoclimatic Aspects of the Southern Oscillation: Cambridge, Mass., Cambridge University Press, p. 29-68.

Cifuentes, L.A., Schemel, L.E., and Sharp, J.H., 1990, Qualitative and numerical analyses of the effects of river inflow variations on mixing diagrams in estuaries: Estuarine, Coastal and Shelf Science, v. 30, p. 411-427.

Cole, B.E., Hager, S.W., and Hollibaugh, J.T., 1990, Hydrographic, biological and nutrient properties of Tomales Bay, California, March 1985 to May 1986: U.S. Geological Survey Open-File Report 90-178, p. 93. 


\section{ECOLOGY}

Ebbesmeyer, C., Cayan, D.R., McClain, D.R., Nichols, F.H., Peterson, D.H., and Redmond, K., 1991, Sensitivity of marine biology to climate change in a North Pacific Swath in Bentancourt, J., and Tharp, V., eds., Proceedings of Seventh Annual Pacific Climate (PACLIM) Workshop, Asilomar, Calif., April 10-30, 1990, p. 115-126.

Hager, S.W. and Schemel, L.E., 1992, Sources of nitrogen and phosphorus to northern San Francisco Bay: Estuaries, v. 15, no. 1, p. 40-52.

Hollibaugh, J.T., and Cole, B.E., Dollar, S.J., Hager, S.H., Vink, S.M., Kimmerer, W.J., Obrebski, S., Smith, S.V., Valentino, M., and Walsh, T.W., 1988, Tomales Bay, California-A macroscosm for examining biogeochemical coupling at the land-sea interface: EOS, v. 69 , no. 36 , p. $843-845$.

Nichols, F.H., Thompson, J.K., and Schemel, L.E., 1990, The remarkable invasion of San Francisco Bay (California, U.S.A.) by the Asian clam, Potamocorbula amurensis-II. Displacement of a former community: Marine Ecology Progress Series, v. 66, p. 95-101.

Ota, A.Y., Schemel, L.E., and Hager, S.W., 1989, Physical and chemical properties of San Francisco Bay, California, 1980: U.S. Geological Survey Open-File Report 89-421, p. 251.

Peterson, D.H., Bencala, K.E., Perry, M.J., and Talbot, M.K., 1987, Phytoplankton productivity in relation to light intensity-a simple equation: Estuarine, Coastal and Shelf Science, v. 24, p. 813-832.

Peterson, D.H., Cayan, D.R., Festa, J.F., Nichols, F.H., Walters, R.A. Slack, J.R., Hager, S.W., and Schemel, L.E., 1989, Climate variability in an estuary-Effects of riverflow on San Francisco Bay, in Peterson, D.H., ed., Aspects of Climate Variability in the Pacific and Western Ame- ricas: Washington, D.C., American Geophysical Union, Monograph 55, p. 419-442.

Peterson, D.H., Hager, S.W., Schemel, L.E., and Cayan, D.R., 1988, Riverine C, N, Si and P Transport to the Coastal Ocean-an overview, in Jansson, Bengt-Owe, ed., Coastal-Offshore Ecosystem Interactions: Springer-Verlag, Berlin, Lecture Notes on Coastal and Estuarine Studies, v. 22.

Peterson, D.H., Schemel, L.E., Smith, R.E., Harmon, D.D., and Hager, S.W., 1987, The flux of particulate organic carbon in estuariesPhytoplankton productivity and oxygen consumption, in Subitzky, S., ed., Selected Papers in the Hydrologic Sciences: U.S. Geological Survey Water-Supply Paper 2330, p. 41-49.

Schemel, L.E., Ota, A.Y., Hager, S.W., and Swithenbank, A.N., 1989, Sources of dissolved and particulate substances to the Sacramento River near Sacramento, California, Summer 1985: U.S. Geological Survey Open-File Report $45-89$, p. 62

Schemel, L.E., Ota, A.Y., Harmon, J.G., Shay, J.M., and Adorador, R.N., 1988, Benthic macrofauna and ancillary data for San Francisco Bay, California, March to November 1987: U.S. Geological Survey Open-File Report 88-192, 73 p.

1989, Benthic macrofauna and ancillary data for San Francisco Bay, California, January to November 1988: U.S. Geological Survey Open-File Report 89-596, $65 \mathrm{p}$.

Slack, J.R., and Landwehr, J.M., 1992, Hydro-climatic data network (HCDN)-A U.S. Geological Survey streamflow data set for the United States for the study of climate variations during the last century: U.S. Geological Survey Open-file Report 92-129, $193 \mathrm{p}$. 


\section{ECOLOGY}

Smith, S.V., Wiebe, W.J., Hollibaugh, J.T., Dollar, S.J., Hager, S.W., Cole, B.E., Tribble, G.W., and Wheeler, P.A., 1987, Stoichiometry of C, $\mathrm{N}, \mathrm{P}$, and Si fluxes in a temperature-climate embayment: Journal Marine Research, v. 45, p. 427-460. 


\section{ECOLOGY}

TITLE: $\quad$ Fate of Organic Chemicals in Subsurface Environments (WR 71-068)

PERSONNEL: Edward M. Godsy, Project Chief

Kim N. Bui, Secretary

Timothy E. Sullivan, Hydrology Technician

Ean Warren, Environmental Engineer

ADDRESS: $\quad$ U.S. Geological Survey, 345 Middlefield Road, MS 458, Menlo Park, CA 94025

TELEPHONE: (415) 329-4504

PROBLEM: Release of various synthetic organic compounds to the environment has caused soil and ground-water pollution in many places. The processes that control the persistence and movement of these compounds are not well understood. A better understanding is necessary to aid in construction of models to predict movement and fate of pollutants in the subsurface and for design of control and abatement techniques.

OBJECTIVE: (1) Determine the transformation pathways of selected organic compounds by means of a combination of field observations and laboratory simulations of environmental conditions; (2) assess the relative importance of physical, chemical, and biochemical processes in the transformation of these compounds under ambient conditions; and (3) study relevant biotransformation processes in the subsurface.

APPROACH: Select one or more field sites where ground water has become contaminated with organic compounds. Collect and analyze water samples to discover the chemical transformations that are occurring in the subsurface environment. Use laboratory-simulation studies to elucidate the controls on these transformations.

PROGRESS: The project consists of field and laboratory studies of creosote and crude oil contaminated ground water at the USGS Hazardous Waste Sites at Pensacola, Florida, and Bemidji, Minnesota, respectively, with the aim of elucidating the various microbial and physical processes, and factors that influence them, affecting separate groups of water soluble creosote and crude-oil derived compounds during down gradient travel in the aquifer. Determination of the kinetics of substrate utilization and transformation pathways of the major aromatic biodegradable components of the water soluble fraction of creosote and crude oil using single compounds as carbon and energy sources under aerobic, sulfate reducing, iron reducing, and denitrifying conditions is presently being investigated. The kinetics of 


\section{ECOLOGY}

biodegradation of the creosote derived compounds under methanogenic conditions has been completed. Laboratory columns have been developed and the abiotic factors that affect movement of the major components of the creosote-derived compounds during down gradient travel with the ground water have been determined. A solute transport model utilizing the laboratory determined Monod kinetic substrate utilization parameters and sorption characteristics has been developed and has successfully modeled the transport of phenol, 2-, 3-, and 4-methylphenol in the aquifer at the Pensacola study site. Work continues for the crude oil-derived compounds found at the Bemidji study site.

\section{REPORTS PUBLISHED 1988-1993:}

Arvin, Erik, Godsy, E.M., Grbic-Galic, Dunja, and Jensen, Bjorn, 1988, Microbial degradation of oil- and creosote-related aromatic compounds under aerobic and anaerobic conditions:, in $\mathrm{Wu}$, Y.C., ed., Proceedings of the International Conference on Physiochemical and Biological Detoxification of Hazardous Wastes, May 3-5, 1988, Atlantic City, New Jersey: Pennsylvania, Technomic Publishing, Lancaster, p. 829-847.

Beakins, B.A., Godsy, E.M., and Goerlitz, D.F., in press, Steady-state methanogenic kinetics of phenolic compounds in ground water-Inferences from modeling: Journal of Contaminant Hydrology, v. 14.

Godsy, E.M., and Goerlitz, D.F., 1988, Determination of the rates of anaerobic degradation of the water soluble fraction of creosote, in Ragone, S.E., ed., U.S. Geological Survey Toxic WasteGround Water Contamination Program-Proceedings of the second technical meeting, Cape Cod, Mass., Oct. 21-25, 1985: U.S. Geological Survey Open-File Report 86-481, p. A27-A32.

Godsy, E. M., Goerlitz, D. F., and Grbic-Galic, Dunja, 1989, Transport and degradation of water-soluble creosote-derived compounds, in Allen, D.T., ed., Intermedia Pollutant Transport-Modeling and Field Measurements: New York, Plenum Publishing, p. 112-143.
1990, Anaerobic biodegradation of creosote contaminants in natural and simulated groundwater ecosystems: Falls Church, Va., Symposium on Bioremediation of Hazardous Wastes, EPA's Biosystems Technology Development Program, 1990, p. 39-42.

1991, Methanogenic degradation kinetics of phenolic compounds: Falls Church, Va., Symposium on Bioremediation of Hazardous Wastes, EPA's Biosystems Technology Development Program, 1991, p. 67-69.

1992, Anaerobic biodegradation of creosote contaminants in nafural and simulated ground water ecosystems: Ground Water, v. 30, p.232-242.

1992, Methanogenic degradation of heterocyclic aromatic compounds by aquifer derived microcosms: Chicago, Illinois, Symposium on Bioremediation of Hazardous Wastes, EPA Biosystems Technology Development Program, p. 120-125.

1992, Methanogenic degradation kinetics of phenolic compounds in aquifer-derived microcosms: Biodegradation, v. 2, p. 211-221.

Godsy, E.M., and Grbic-Galic, Dunja, 1989, Biodegradation pathways for benzothiophene in methanogenic microcosms, in Mallard, G. E, and Ragone, S. E., eds., U.S. Geological Survey Toxic Substances Hydrology Program-Proceed- 


\section{ECOLOGY}

ings of the technical meeting, Phoenix, Ariz., September 26-30, 1988: U.S. Geological Survey Water-Resources Investigations Report 88-4220, p. 559-564.

Grbic-Galic, Dunja, Henry, S. M., Godsy, E. M., Edwards, Elizabeth, and Mayer, K. P., 1991, Anaerobic degradation of aromatic hydrocarbons and aerobic degradation of trichloroethylene by subsurface micro-organisms, in Baker, R.A., ed., Organic substances and sediments in water, Volume III, Biological: Boca Raton, Fla., Lewis Publishers, Inc., p. 239-266. 


\section{ECOLOGY}

TITLE: Availability of Trace Elements in Sediments to Aquatic Organisms (WR 75-125)

PERSONNEL: Samuel N. Luoma, Project Chief J. Stacey, Andrews, Secretary James L. Carter, Hydrologist Steven V. Fend, Hydrologist

Susan S. Kennelly, Hydrologist

Daniel J. Cain, Biologist Alexander Van Geen, Chemist Cynthia L. Brown, Physical Scientist Michelle I. Hornberger, Physical Scientist

ADDRESS: $\quad$ U.S. Geological Survey, 345 Middlefield Road, MS 465, Menlo Park, CA 94025

TELEPHONE: (415) 329-4481

PROBLEM: Concentrations of potentially toxic elements in sediments are orders of magnitude higher than concentrations of these elements in water. The ability of the aquatic environment to assimilate many toxic wastes depends upon how available this concentrated sediment-bound pool of elements is to aquatic organisms. Development of realistic pollution regulations, in turn, depends on prediction of assimilation capacities. Assessment of biological-indicator data for mineral exploration and pollution assessment also depend upon the understanding of factors affecting the biological availability of trace elements bound to sediments. It is established that the same biota in different environments may differ widely in their susceptibility or their response to trace elements, and that these differences may be at least partly related to the differences in the availability of metals in sediments; however, little is known about the geochemical and physiological factors that influence the transport of metals from sediments to organisms.

OBJECTIVE: (1) Study the partitioning of trace metals among the components of sediments and identify the processes that control partitioning; (2) study the influence of geochemical partitioning of trace metals in sediments on metal uptake by and effects of metals in organisms that contact sediments directly; (3) study physiological characteristics of aquatic organisms that uptake metal; (4) improve methodology that makes use of biota and sediments as indicators of geochemical conditions; (5) develop indices or models for predicting the bioavailability of metals after their release to the aquatic environment; and (6) develop methods for assessing the presence of biological effects from toxic wastes in aquatic communities in nature.

APPROACH: (1) Collect organisms and sediments from rivers, lakes, or estuaries across spatial or temporal gradients of physicochemical conditions; analyze geochemical partitioning through the use of chemical extractions, mathematical models, and statistics; and statistically 


\section{ECOLOGY}

assess relation of metal concentrations in organisms to aspects of the specific geochemical gradient under study. (2) Use laboratory studies on metal burdens in animals to assess biological influences such as animal size, intraspecific differences in metal tolerance, and physiological controls on metal uptake and metabolism. (3) Geochemically modify sediments or use well-defined model sediments in laboratory studies of metal uptake by organisms to identify physicochemical factors that affect metal availability and to test models derived from field studies.

PROGRESS: Clark Fork River, Montana: Showed that metal concentrations in sediments and insects in Clark Fork vary as much as fourfold from year-to-year over a wide range of flow conditions. Highest precipitation/flow years are years of greatest food web contamination and greatest downstream penetration of contamination. Preliminary seasonal data show highest concentrations of metals in sediments and animals after high flow and (or) episodic inflows to river.

San Francisco Bay: Demonstrated that iron oxides and humic substances-bound $\mathrm{Cr}$ is a nonbioavailable sink for the element, with regard to detritus feeding bivalves. In contrast, $\mathrm{Cd}$ is assimilated from iron oxides, and from humic complexes when in high concentrations. Cadmium from these nonliving sources is of similar availability to $\mathrm{Cd}$ from diatoms or bacteria. Physiological flux models explain why two detritus feeders differ in $\mathrm{Cd}$ concentrations in natural systems. These same deposit feeders were sampled and analyzed from Suisun Bay during a season of high river flows and low salinities. Most data is now collected to begin model and field verifications predicting the relative importance of salinity change, change in $\mathrm{Cd}$ concentrations in water, and bioaccumulation from food in determining temporal variability and interspecies differences in $\mathrm{Cd}$ uptake. Ongoing time series at Palo Alto mudflat showed a large episode of contaminant input into South Bay occurred in March 1992. Metal bioaccumulation that followed this episode coincided with a cessation of glycogen storage (associated with preparation for reproduction) in clams. This is one of the clearest demonstrations we have seen linking specific physiological changes with a contamination event in a natural system. Progress in studies of sediment cores demonstrate differences in histories of different contaminants in the Bay. Studies in Tomales Bay indicate that system was also subject to some previous metal input, perhaps related to mining in the watershed in the late 1800 's; but preliminary indications from surface sediments suggest little recent atmospheric input of metals. Studies of $\mathrm{Pb}$ isotope ratios indicate a lead smelter active in the early 1900's had an extensive influence on contamination of San Pablo Bay.

Yakima, Oregon: Interpretation of data from Yakima National Water-Quality Assessment pilot site demonstrate importance of altitude in determining ecological community structure in the 


\section{ECOLOGY}

system. Methods were demonstrated for separating influences of coincident controlling variables, the most important of which are low altitude and human agricultural activities.

Bioassays: Two interpretive reviews and an editorial were published this year explaining. why laboratory-based reductionist bioassay studies are an insufficient basis for rational management of contaminants in aquatic ecosystems. Experimental and creative observational studies in natural systems are an essential, but underrepresented approach to understanding what role contaminants play as a variable affecting structure and function in ecosystems.

\section{REPORTS PUBLISHED 1988-1993:}

Axtmann, E.V., and Luoma, S.N., 1991, Large scale distribution of metal contamination in the fine grained sediments of the Clark Fork River, Montana, U.S.A.: Applied Geochemistry, v. 6, p. 75-88.

Cain, D., 1991, Studies using the clam Macoma balthica to identify bioavailable trace metals in San Francisco Bay, in Gunther A.J., ed., Bioavailability of Toxic Contaminants in the San Francisco Bay-Delta: San Francisco Bay-Delta Aquatic Habitat Institute, Report AHI-90-01, p. 55-69.

Cain, D.J., Fend, S.V., and Carter, J.L., 1988, Temporal and spatial variability of arsenic in benthic insects from Whitewood Creek, South Dakota, in Mallard G.E., and Ragone S.E., eds., U.S. Geological Survey Toxic Substances Hydrology Program-Proceedings of the technical meeting, Phoenix, Ariz., September 26-30, 1988: U.S. Geological Survey Water-Resources Investigations Report 88-4220, p. 257-268.

Cain, D.J., and Luoma, S.N., 1990, Influence of seasonal growth, age and environmental exposure on $\mathrm{Cu}$ and $\mathrm{Ag}$ in a bivalve indicator, Macoma balthica, in San Francisco Bay: Marine Ecology Progress Series, v. 60, p. 45-55.

1991, Benthic insects as indicators of large-scale trace metal contamination in the Clark Fork River, Montana, in Mallard G., ed., U.S. Geo- logical Survey Toxics Substances Hydrology Program-Proceedings of the technical meeting, Monteray, Calif.: U.S. Geological Survey Water-Resources Investigation Report 91-4034.

Cain D.J., Luoma, S.N., Carter, J.L., and Fend, S.V., 1992, Aquatic insects as bioindicators of trace element contamination in cobble-bottom rivers and streams: Canadian Journal Fisheries and Aquatic Science, v. 49, p. 2141-2154.

Campbell, P., Lewis, A., Chapman, P., Crowder, A., Fletcher, W., Imber, B., Luoma, S., Stokes, P., and Winfrey, M., 1988, Biologically available metals in sediments, in National Research Council Canada Publication No. NRCC 27694, NRCC/ CNRC, Ottawa, Canada, 300 p.

Crawford, J.K., and Luoma, S.N., 1992, Guidelines for studies of contaminants in biological tissues for the National Water Quality Assessment Program: U.S. Geological Survey Open-File Report 92-494, $71 \mathrm{p}$.

Decho, A.W., and Luoma, S.N., 1991, Time-courses in the retention of food material in the bivalves Potamocorbula amurensis and Macoma balthica-Significance to the absorption of carbon and chromium: Marine Ecology Progress Series, v. 78, p. 303-314.

Hostettler, F.D., Rapp, J.B., Kvenvolden, K.A., and Luoma, S.N., 1989, Organic markers as source 


\section{ECOLOGY}

discriminants and sediment transport indicators in south San Francisco Bay, California: Geochimica et Cosmochimica Acta, v. 53, p. 1563-1576.

Johns, C., and Luoma, S.N., 1988, Selenium accumulation in benthic bivalves and fine sediments of San Francisco Bay, the Sacramento-San Joaquin Delta, and selected tributaries: Estuarine, Coastal, and Shelf Science, v. 27, p. 381-396.

1990, Arsenic in benthic bivalves of San Francisco Bay and the Sacramento/San Joaquin Delta: Science of the Total Environment, v. 97/98, p. 673-684.

Kuwabara, J.S., Chang, C.C.Y., Cloern, J.E., Fries, T.L., Davis, J.A., and Luoma, S.N., 1989, Trace metal associations in the water column of south San Francisco Bay: Estuarine Coastal and Shelf Science, v. 28, p. 307-325.

Luoma, S.N., 1988, Research for San Francisco Bay (editorial by Luoma, S.N., in Bay tidings): San Francisco Bay Conservation and Development Commission.

1989, Can we determine the biological availability of sediment-bound trace elements?: Hydrobiologia, v. 176/177, p. 379-396.

1990, Teaching environmental science (Review of Environmental ecology: The impacts of pollution and other stresses on ecosystem structure and function): Bioscience, v. 40, p. 612-613.

1990, Processes affecting metal concentrations in estuarine and coastal marine sediments, in Furness, R., and Rainbow, P., eds., Heavy metals in marine environment, chap. 4, p. 5162: Boca Raton, Fla., CRC Press, p. 51-66.

1991, Environment for the uninformed-Book Review of Imperiled Planet: Bioscience, October, $643 \mathrm{p}$.
Luoma, S.N., and Carter, J.L., 1991, Effects of trace metals on aquatic benthos, in Newman, M.C., and McIntosh, A.W., Metal Ecotoxicology: Concepts and Applications: Lewis Publishers, Chelsea, Michigan, p. 261-287.

Luoma, S.N., Carter, J., Brown, C., 1991, Assessing adverse effects of contaminants on benthic species at the San Francisco Toxics Site, in Mallard, G., ed., U.S. Geological Survey Toxics Substances Hydrology Program-Proceedings of the technical meeting, Monteray, Calif.: U.S. Geological Survey Water-Resources Investigation Report 91-4034.

Luoma, S.N., and Carter, J.L., 1993, Understanding the toxicity of contaminants in sedimentsBeyond the bioassay-based paradigm: Environmental Toxicology and Chemistry, v. 12, p. 793-796.

Luoma, S.N., Dagovitz, R., and Axtmann, E.V., 1990 , Temporally intensive study of trace metals in sediments and bivalves from a large riverestuarine system-Suisun Bay/delta in San Francisco Bay: The Science of the Total Environment, v. 97/98, p. 685-712.

Luoma, S.N., Johns, C., Fisher, N.S., Steinberg, N.A., Oremland, R.S., and Reinfelder, J., 1992, Determination of selenium bioavailability to a benthic bivalve from particulate and solute pathways: Environmental Science and Technology, v. 26, p. 485-491.

Luoma, S.N., and Phillips, D.J.H., 1988, Distribution, variability and impacts of trace elements in San Francisco Bay: Marine Pollution Bulletin, v. 19, p. 413-425.

Moore, J.N., and Luoma, S.N., 1990, Hazardous wastes from large-scale metal extraction: Environmental Science and Technology, v. 24, p. 1279-1285. 


\section{ECOLOGY}

Moore, J.N., Luoma, S.N., and Peters, D., 1990, Effects of acid mine drainage on the Blackfoot River, Montana: Canadian Journal of Fisheries and Aquatic Sciences, v. 60, p. 45-55.

Van Geen, A., Luoma, S.N., Fuller, C.C., Anima, R., Clifton, H.E., and Trumbore, S., 1992, Evidence from $\mathrm{Cd} / \mathrm{Ca}$ ratios in foraminifera for greater upwelling off California 4,000 years ago: Nature, v. 358, pp. 54-56. 


\section{ECOLOGY}

TITLE: Biotic Response to Climatic Variability and Human Impacts in Arid Lands (WR 76-145)

PERSONNEL: Julio L. Betancourt; Project Chief

Ana M. MacKay, Admin. Ops. Assist. Elizabeth A. Pierson, Botanist

Douglas Wellington, Comp. Prog. Analysist Diane K. Aasen-Rylander, Biological Technician

ADDRESS: U.S. Geological Survey, Desert Laboratory, 1675 W. Anklam Road, Tucson, AZ 85745

TELEPHONE: (602) 670-6821

PROBLEM: Biotic responses to climatic change or human manipulation are inherently complex because of wide differences in organism sensitivities and response times, the influence of history and scale, and the various interactions between organisms and with the physical system. In arid and semiarid lands, which cover about 12.5 percent of the Earth's land surface, the effects of climatic variability on vegetation are greatly magnified, particularly because most plants exist near their physiological limits. How arid land vegetation might in turn affect climate is uncertain, though there is some indication that decreasing cover and increasing albedo could promote regional drought. Whether in response to projected Greenhouse climates or intensified land use, vegetation in such critical watersheds̀ as the Rio Grande and Colorado River basins is apt to change in the near future. There is a need to understand the direction and rate of this change and how it might affect water use and availability in the region.

OBJECTTIVE: To achieve a dynamic understanding of vegetation change and its relation to water resources; to develop such an understanding in a manner appropriate to the hierarchy of spatial and temporal scales implicit in a study of global change; and to determine whether responses of dryland vegetation to global change are predictable from the past and present behavior of vegetation.

APPROACH: The primary task of the project is to document vegetation and hydrological responses to climate variability on millennial to decadal time scales. The research entails monitoring of vegetation plots, analysis of instrumental records, and development of proxy data for times and places where direct measurements are unavailable. Plant demographic data will be collected to test hypotheses about short-term (decadal) vegetation responses to climatic variability in the 20th century. Paleoclimatological data will be developed for the southwestern region for the past 40,000 years. These data can be used to illustrate the influence of climatic 


\section{ECOLOGY}

change on arid ecosystems; to anticipate how these ecosystems are apt to change in the future; and to test and validate outputs from global circulation models.

PROGRESS: (1) A 30,000-year chronology of limber pine needles from packrat middens in the Great Basin shows stomatal densities and carbon isotopic content decreasing from Glacial to Holocene, coincident with a 40 percent increase in atmospheric carbon dioxide levels. Theory and experimental results predict the reduction in stomatal densities, but not the decrease in carbon isotopic content. A manuscript was submitted to Science. (2) In the American Southwest, the 1950's drought caused massive vegetation dieoffs from the lowland deserts well into conifer woodlands of the uplands, resetting demographic clocks and creating disequilibria in carbon and nutrient cycling. Climate reconstructions from tree rings indicate up to 500-year return periods for droughts of similar magnitude. We are using the 1950's event as a model system for studying the direct impacts of catastrophic drought across vegetation types and geographic scales, as well as 40 years of ecological adjustments. The episodic nature of tree establishment and mortality presents a challenge to strategies for ecosystem management that rely on steady-state models. These models assume relatively constant and equal mortality and recruitment rates. A review paper on the influence of climate and history on pinyon-juniper woodlands, which cover 40 million ha in the Southwest, was completed. (3) Saguaro populations, like those of many long-lived species with episodic establishment and mortality, fluctuate on decadal scales; capturing this variability requires multi-decadal monitoring, and, in the absence of actual tree rings, modèls of plant growth (height) for estimating age of individual plants. At the Desert Laboratory in Tucson, all plants within four 11-ha plots on Tumamoc Hill were surveyed and measured in 1964, 1970, and 1993 to develop and verify a predictive age-height model and to compare the effect of slope aspect on plant growth, patterns of biomass allocation and demography. Differences between plots discriminate specific climatic events or trends with variable impact across slope. Several papers are in progress. (4) Fieldwork and laboratory analyses have been completed towards a 40,000-year vegetation history of the Sevilleta Long-Term Ecological Research Site in the central Rio Grande Basin, New Mexico. The study serves as a guide to current long-term monitoring efforts by documenting the relative instabilities of individual plant species over different spatial and temporal scales. (5) Biodiversity is an elusive concept that is now driving policy. For reasons having to do with history and chance, biological inventories, no matter what the organism, are in a sorry state of development worldwide. This inadequacy now forestalls our understanding of biodiversity, particularly at the regional level, and makes issues, such as accelerating rates of extinction, difficult to address empirically. To demonstrate the importance of adequate biological inventories, we analyzed relatively large and complete inventories for vascular plants in the Sonoran Desert, United States and Mexico, and Northern Territory, Australia. These are probably two of the best databases in arid lands worldwide; each contains about 100,000 records on about 3,000 species over about 1001 degree latitude 


\section{ECOLOGY}

by 1 degree longitude cells. Our first cut at examining plant diversity in these two areas revealed that 75 percent of the variance in species richness (the number of species in each cell) can be explained by the number of observations (for example, concentration of field investigations). This is a cautionary note to those contemplating international and national biological inventories (for example, the National Biological Survey). An Atlas of Sonoran Desert Plants has been accepted as a book by the University of Arizona Press. The Atlas played a key role in developing a proposal funded for Fiscal Years 1993-97 by the National Park Service Global Change Program (now part of the National Biological Survey) to construct a climate-plant distributional model for the Sonoran Desert.

\section{REPORTS PUBLISHED 1988-1993:}

Betancourt, J.L., 1990, Late Quaternary biogeography of the Colorado Plateau, in Betancourt, J.L.., Van Devender, T.R., and Martin, P.S., eds., Packrat middens-The last 40,000 years of biotic change: Tucson, Ariz., University of Arizona Press, p. 259-292.

1990, Introduction, in Betancourt, J.L., and MacKay, A.M., eds., Proceedings of the Sixth Annual Pacific Climate (PACLIM) Workshop, Asilomar, Calif., March 5-8,1989: California Department of Water Resources, Interagency Ecological Studies Program, Technical Report 23 , p. 1-4.

Betancourt, J.L. and MacKay, A.M., eds., 1990, Proceedings of the Sixth Annual Pacific Climate (PACLIM) Workshop, Asilomar, Calif., March 5-8, 1989: California Department of Water Resources, Interagency Ecological Studies Program, Technical Report 23, p. 147.

Betancourt, J.L., Pierson, E.A., Rylander, K., Aasen, J., Fairchild-Parks, J., and Dean, J.S., 1993, Influence of history and climate on New Mexico pinyon-juniper woodlands-Proceedings of Symposium on Managing Pinyon-Juniper Ecosystems for Sustainability and Social Needs, April 26-30, 1993, Santa Fe, New Mexico: U.S. Department of Agriculture Forest Service, General Technical Report.
Betancourt, J.L., Schuster, W.S., Mitton, J.B., and Anderson, R.S., 1991, Fossil and genetic history of a pinyon pine (Pinus edulis) isolate: Ecology v. 72 , p. 1685-1697.

Betancourt, J.L. and Tharp, V.L., eds., in press, Proceedings of the Eight Annual Pacific Climate (PACLIM) Workshop, Asilomar, Calif., April, 1990: California Department of Water Resources, Interagency Ecological Studies Program, Technical Report 26, 257 p.

Betancourt, J.L., Van Devender, T.R., and Martin, P.S., eds., 1990, Packrat middens-The last 40,000 years of biotic change: Tucson, University of Arizona Press, $467 \mathrm{p}$.

1990, Introduction, in Betancourt, J.L., Van Devender, T.R., and Martin, P.S., eds., Packrat middens-The last 40,000 years of biotic change: Tucson, Ariz., University of Arizona Press, p. 2-11.

1990, Synthesis and prospectus, in Betancourt, J.L., Van Devender, T.R., and Martin, P.S. eds., Packrat middens-The last 40,000 years of biotic change: Tucson, Ariz., University of Arizona Press, p. 435-447.

Bowers, J.E., 1990, Vegetation change at Organ Pipe Cactus National Monument, in Bennett, P.S., Johnson, R.R., and McCarthy, M.M., eds., 


\section{ECOLOGY}

Assessment of Scientific Information and Activities at Organ Pipe Cactus National Monument Biosphere Reserve: Tucson, Ariz., Cooperative National Park Resources Studies Unit, Special Report No 10, p. 85-132.

1990, William A. Cannon: The Sonoran Desert's first resident ecologist: Madrono, v. 37, p. 6-27.

1990, A debt to the future: Scientific achievements of the Desert Laboratory, Tumamoc Hill, Tucson, Ariz.: Desert Plants, v 10, p. 9-12, 35-47.

Burgess, T.L., Bowers, J.E., and Turner, R.M., 1991, Exotic plants at the Desert Laboratory, Tucson, Ariz.: Madrono, v. 38, p. 96-114.

Long, A., Warnecke, L., Betancourt, J.L., and Thompson, R.S., 1990, Deuterium variations in plant cellulose from packrat middens, in Betancourt, J.L., Van Devender, T.R., and Martin, P.S., eds., Packrat middens-The last 40,000 years of biotic change: Tucson, Ariz., University of Arizona Press, p. 381-396.

Lowenstein, J.M., Rainey, W.N., and Betancourt, J.L., 1991, Immunospecific albumin in fossil packrat, porcupine and hyrax urine: Naturwissenschaften v. 78, p. 26-27.

McLaughlin, Steven P., and Bowers, J.E., 1990, A floristic analysis and checklist for the northern Santa Rita Mountains, Pima County, Ariz.: Southwestern Naturalist, v. 35, p. 61-75.

Spaulding, W.G., Betancourt, J.L., Cole, K.L., and Croft, L., 1990. Packrat middens, their composition and methods of analysis, in Betancourt, J.L., Van Devender, T.R., and Martin, P.S., eds., Packrat middens-The last 40,000 yearsof biotic change: Tucson, Ariz., University of Arizona Press, p. 59-84.

Swetnam, T.W., and Betancourt, J.L., 1992, Temporal patterns of ENSO-wildfire teleconnections in the southwestern United States, in Diaz, H.F., and Markgraf, V., El Niño, Historical and paleoclimatic aspects of the Southern Oscillation: Cambridge, England, Cambridge University Press, p. 259-270.

1990, Fire-Southern Oscillation relations in the southwestern United States: Science v. 24, p. 1017-1020.

1990, El Nino-Southern Oscillation (ENSO) phenomena and forest fires in the southwestern United States, in Betancourt, J.L., and MacKay, A.M., eds., Proceedings of the Sixth Annual Pacific Climate (PACLIM) Workshop, Asilomar, Calif., March 5-8, 1989: California Department of Water Resources, Interagency Ecological Study Program, Technical Report 23, p. 129135.

Thompson, L., Mosley-Thompson, E., Betancourt, J.L., Love, D. W., Wilson, A., Leonard, G., and Anderson, R.S, 1991, Laminated ice bodies in collapsed lava tubes at El Malpais National Monument, central New Mexico, in Julian, B. and Zidek, J., eds., Field guide to geologic excursions in New Mexico and adjacent areas of Texas and Colorado: New Mexico Bureau of Mines and Mineral Resources Bulletin 137, p. 149.

Turner, R.M., 1990, Long-term vegetation change at a fully protected Sonoran Desert site: Ecology v. 71, p. 464-467.

Van Devender, T.R., Burgess, T.L., Felger, R.S. and Turner, R.M., 1990, Holocene vegetation of the Hornaday Mountains of northwestern Sonora, Mexico: Proceedings of the San Diego Society of Natural History, v. 2, p. 1-19.

Van Devender, T.R., Toolin, L.J., and Burgess, T.L., 1990, The ecology and paleoecology of grasses in selected Sonoran Desert plant communities, in Betancourt, J.L., Van Devender, T.R., and Martin, P.S., eds., Packrat middens-The 


\section{ECOLOGY}

last 40,000 years of biotic change: Tucson,

Ariz., University of Arizona Press, p. 326-349.

Webb, R.H., and Betancourt, J.L., 1990, The spatial distribution of radiocarbon ages from packrat middens, in Betancourt, J.L., Van Devender, T.R., and Martin, P.S., eds., Packrat middensThe last 40,000 years of biotic change: Tucson, Ariz., University of Arizona Press, p. 85-102.

1990, Climatic effects on flood frequency-An example from southern Arizona, in Betancourt, J.L., and MacKay, A.M., eds., Proceedings of the Sixth Annual Pacific Climate (PACLIM) Workshop, Asilomar, Calif., March 5-8, 1989: Califyrnia Department of Water Resources, Interagency Ecological Studies Program, Technical Report 23, p. 61-66.

1992, Climatic variability and flood frequency of the Santa Cruz River, Pima County, Ariz.: U.S Geological Survey Water-Supply Paper 2379. 


\title{
ECOLOGY
}

TITLE: $\quad$ Plankton Dynamics in Tidal Estuaries (WR 79-164)

\author{
PERSONNEL: James E. Cloern, Project Chief \\ Carolyn L. McLeod, Secretary \\ Thomas M. Powell, Hydrologist \\ Brian E. Cole, Oceanographer
}

\begin{abstract}
ADDRESS: $\quad$ U.S. Geological Survey, 345 Middlefield Road, MS 496, Menlo Park, CA 94025
\end{abstract}

TELEPHONE: (415) 354-3357

PROBLEM: Phytoplankton photosynthesis is the ultimate engine that drives many biogeochemical and ecological processes in lakes, estuaries, and the ocean. For example, dynamic changes in $\mathrm{pH}$, trace metal speciation, and concentrations of dissolved gases (oxygen, carbon dioxide, methane), inorganic nutrients (nitrate, phosphate, silicate), and organic compounds (amino acids, organosulfur compounds) are closely associated with fluctuations in phytoplankton photosynthesis. Trophic linkages also exist, between the phytoplankton as primary producers and populations of consumer organisms including bacteria, zooplankton, benthic invertebrates, and fish. Our scientific understanding of lakes and estuaries as dynamic ecosystems is therefore dependent upon a mechanistic understanding of both natural and human-induced variability of phytoplankton abundance, community composition, productivity, and connections to geochemical processes and other biological communities. These topics are central to poorly resolved issues such as: the growing worldwide incidence of toxic algal blooms and associated fish mortality; coastal eutrophication and increasing frequency and extent of hypoxia or anoxia; long-term and cyclic changes in fish stocks; the global significance of phytoplankton to the cycling of key elements such as $\mathrm{C}$ and $\mathrm{N}$; and ecosystem-scale responses to both species extinctions and introductions of exotic species.

OBJECTIVE: (1) Study the distribution, abundance, species composition, and productivity of planktonic microalgae, animals, and bacteria in estuaries; (2) define and quantify processes that regulate population dynamics and productivity of planktonic organisms in estuaries; (3) define and quantify processes through which the plankton alter and reflect water quality in estuaries; (4) define and quantify benthic processes that affect plankton dynamics and productivity of estuaries; and (5) define anthropogenic impacts on estuarine ecosystems.

APPROACH: Integrate descriptive and experimental field studies and develop simulation models. Field studies indicate important mechanisms that must be taken into account in models and provide a data base for model calibration and subsequent verification. Conversely, 


\section{ECOLOGY}

evolving ecological models indicate processes and environmental factors that deserve particular emphasis by field studies. Feedback between model development and fieldwork will accelerate understanding of the natural system and should produce ecological models having sufficient realism to predict gross effects of human-induced perturbations.

PROGRESS: Project research activities were focused entirely on San Francisco Bay, with the following objectives: (1) To map weekly and monthly changes in the vertical and horizontal distributions of dissolved oxygen, salinity, temperature, turbidity, chlorophyll, and suspended sediments (this measurement program was supported with funds from local dischargers; it involved acquisition of new instruments and development of new protocols; results of this pilot program will be used to design a permanent regional monitoring program in San Francisco Bay). (2) To characterize phytoplankton-nutrient dynamics in South San Francisco Bay around the spring bloom, a period of intense biogeochemical activity, adding a 16th year to this observational record. (3) To measure seasonal changes in benthic fluxes of oxygen and nutrients (J. Caffrey). (4) To measure seasonal changes in phytoplankton photosynthesis and community composition along the river-ocean gradient (B. Cole). (5) To measure seasonal changes in system metabolism, as oxygen respiration, along the river-ocean gradient ( $\mathrm{J}$. Rudek). (6) To collect sediment and seston samples for later analysis to characterize seasonal changes in the origin and composition of organic matter (E. Canuel). Papers were published on the following: (1) Interannual variability in the sources of organic carbon to the San Francisco Bay ecosystem (collaboration with A. Jassby and T. Powell, University of California-Davis)-Marine Ecology Progress Series. (2) Interannual variability in the seasonal pattern of phytoplankton biomass change in South San Francisco Bay-book chapter, (J.H. Steele editor, Chapman Hall publisher). (3) Analysis of decades-long changes in biological populations in San Francisco Bay, using generalized additive modeling to establish empirical relations between these population declines and human manipulations of estuarine hydrology through diversions of fresh water (with A. Jassby and others)-Ecological Applications. (4) Use of a one-dimensional model of phytoplankton population dynamics and vertical mixing to define the combinations of physical-biological conditions necessary for the initiation of algal blooms in tidal estuaries (with J. Koseff and S. Monismith, Stanford University)-Journal of Marine Research. (5) Seasonal contrasts in the composition, concentration, and sedimentation of seston in Williams and Shingobee Lakes (a component of USGS research at the Interdisciplinary Research Initiative (IRI) site in Minnesota) - chapter in USGS circular to be edited by T. Winter. USGS Open-File Data reports were published on (1) hydrographic measurements in San Francisco Bay during 1992; and (2) isotopic composition and lipid composition of seston and tissues of the clam Potamocorbula amurensis in San Francisco Bay, 1990-1992. 


\section{ECOLOGY}

\section{REPORTS PUBLISHED 1988-1993:}

Alpine, A.E., and Cloern, J.E., 1988, Phytoplankton growth rates in a light-limited environment, San Francisco Bay: Marine Ecology Progress Series, v. 44, page $167-173$.

1992, Trophic interactions and direct physical effects control phytoplankton biomass and production in an estuary: Limnology and Oceanography, v. 37, p. 946-955.

Cloern, J.E., 1989, Phytoplankton: in Britton, L.J. and Greeson, P.E., eds., Methods for collection and analysis of aquatic biological and microbiological samples: Techniques of Water-Resources Investigations of the U.S. Geological Survey, Chapter A-4, p. 99-115.

Cloern, J.E., 1991, Annual variations in river flow and primary production in the South San Francisco Bay Estuary, in Elliott, M., and Ducrotoy, D., eds., Estuaries and coasts: Spatial and temporal intercomparisons: Denmark, Olsen and Olsen Publishers, p. 91-96.

1991, Tidal stirring and phytoplankton bloom dynamics in an estuary: Journal of Marine Research, v. 49, p. 203-221.

Cloern, J.E., Alpine, A.E, Cole, B.E. and Heller, T., 1992, Seasonal changes in the spatial distribution of phytoplankton in small, temperate-zone lakes: Journal of Plankton Research, v. 14, p. $1017-$ 1024.

Cloern, J.E., Canuel, E.A., and Wienke, S.M., 1993, Particulate organic matter in the San Francisco Bay estuary, California-chemical indicators of its origin and assimilation into the benthic food web: U.S. Geological Survey Open-File Report 93-146, $42 \mathrm{p}$.
Cloern, J.E. and Jassby, A.D., in press, Yearly fluctuation of the spring phytoplankton bloom in South San Francisco Bay: An example of ecological variability at the land-sea interface, in Steele, J.H, Powell, T.M., and Levin, S., eds., Ecological Time Series: Chapman Hall.

Cloern, J.E., Powell, T.M., and Huzzey, L.M., 1989, Spatial and temporal variability in south San Francisco Bay, II. Temporal changes in salinity, suspended sediments, and phytoplankton biomass and productivity over tidal time scales: Estuarine, Coastal, and Shelf Science, v. 28, p. 599-613.

Cole, B.E., 1989, Carbon-14 light- and dark-bottle method for phytoplankton, in Britton, L.H., and Greeson, P.E., eds., Methods for collection and analysis of aquatic biological and microbiological samples: Techniques of Water-Resources Investigations of the U.S. Geological Survey, book 5 , chap. A4, p. 483-504.

1989, Temporal and spatial patterns of phytoplankton production in Tomales Bay, California, U.S.A.: Estuarine, Coastal and Shelf Science, v. 28, p. 103-115.

Cole, B.E., Hager, S.W., and Hollibaugh, J.T., 1990, Hydrographic, biological, and nutrient properties of Tomales Bay, California, March 1985 to May 1986: U.S. Geological Survey Open-File Report 90-178.

Cole, B.E., Thompson, J.K., and Cloern, J.E., 1992, Measurement of filtration rates by infaunal bivalves in a recirculating flume: Marine Biology, v. 113, p. $219-225$. 


\section{ECOLOGY}

Hollibaugh, J.T., Cole, B.E., Dollar, S.W., Hager, S.W., Vink, S.M., Kimmerer, W.J., Obrebski, S., Smith, S.V., Valentino, M., and Walsh, T.W., 1988, Tomales Bay, California-A macrocosm for examining biogeochemical coupling at the land-sea interface: EOS, Transactions of American Geophysical Union, v. 69, p. 844846.

Huzzey, L.M., Cloern, J.E., and Powell, T.M., 1990, Episodic changes in lateral transport and phytoplankton distribution in south San Francisco Bay: Limnology and Oceanography, v. 35, p. 472-478.

Jassby, A.D., Cloern, J.E., and Powell, T.M., 1993, Organic carbon sources and sinks in San Francisco Bay-variability induced by river flow: Marine Ecology Progress Series, v. 95, p. 3954.

Khorram, S., Catts, G.P., Cloern, J.E., and Knight, A.W., 1987, Modeling of chlorophyll a from an airborne scanner: IEEE Transactions on GeoScience and Remote Sensing, v. GE-25, p. $662-$ 669.

Kuwabara, J.S., Chang, C.C.Y., Cloern, J.E., Fries, T.L., Davis, J.A., and Luoma, S.N., 1989, Trace metal associations in the water column of south San Francisco Bay, California: Estuarine, Coastal and Shelf Science, v. 28, p. 307-325.

McBride, G.B., Vant, W.N., Cloern, J.E., and Liley, J.B., 1993, Development of a model of phytoplankton blooms in Manukau Harbour: Hamilton, New Zealand, NIWA Ecosystems Publication No. 3.

Oremland, R.S., Cloern, J.E., Sofer, Z., Smith, R.L., Culbertson, C.W., Zehr, J., Miller, L., Cole, B.E., Harvey, R., Iversen, N., Klug,
M., Des Marais, D.J., and Rau, G., 1988, Microbial and biogeochemical processes in Big Soda Lake, Nev., in Fleet, A.J., Kelts, K., and Talbot, M.R., eds., Lacustrine petroleum source rocks: Geological Society of London Special Publication no. 40, p. 59-75.

Powell, T.M, Cloern, J.E., and Huzzey, L.M., 1989, Spatial and temporal variability in south San Francisco Bay, I. Horizontal distributions of salinity, suspended sediments, and phytoplankton biomass and productivity: Estuarine, Coastal and Shelf Science, v. 28, p. 583-597.

Powell, T.M., Willmot, S., Murray, J.D., Manoranjan, V.S., and Cloern, J.E., 1988, Transient spatial patterns in plankton communities: blooms and travelling waves of phytoplankton in estuaries, in Hallam, T.G., Gross, L.J., and Levin, S.A., eds., 1986, Proceedings of Trieste Research Conference on Mathematical Ecology: World Scientific Publishing, p. 236-267.

Wienke, S.M., Alpine, A.E., Cloern, J.E.. and Cole, B.E., 1990, Plankton studies in San Francisco Bay, X. Chlorophyll distributions and hydrographic properties in San Francisco Bay, 1987: U.S. Geological Survey Open-File Report 90 $145,50 \mathrm{p}$.

Wienke, S.M., Cloern, J.E., and Cole, B.E., 1990, Plankton studies in San Francisco Bay, XI. Chlorophyll distributions and hydrographic properties in San Francisco Bay, 1988-1989: U.S. Geological Survey Open-File Report 90-562, 212 p.

Wienke, S.M., Cole, B.E., Cloern, J.E., and Alpine, A.E., 1991, Plankton studies in San Francisco Bay. XIl. Chlorophyll distributions and hydrographic properties in San Francisco Bay, 1990: U.S. Geological Survey Open-File Report 91$476,85 \mathrm{p}$. 


\section{ECOLOGY}

Wienke, S.M., Cole, B.E., Cloern, J.E., and Alpine, A.E., 1992, Plankton studies in San Francisco Bay. XIII. Chlorophyll distributions and hydrographic properties in San Francisco Bay, 1991: U.S. Geological Survey Open-File Report 92$158,116 \mathrm{p}$.

Wienke, S.M., Cole, B.E., and Cloern, J.E., 1993, Plankton studies in San Francisco Bay, XIV. Chlorophyll distributions and hydrographic properties in San Francisco Bay, 1992: U.S. Geological Survey Open-File Report 93-, 175 p. 


\title{
ECOLOGY
}

TITLE: Microbial Biogeochemistry of Aquatic Environments (WR 81-174)

PERSONNEL: Ronald S. Oremland, Project Chief

Charles W. Culbertson, Hydrologist

Frances E. Strohmaier, Physical Science Techician

Jodi Switzer Blum, Physical Scientist

Laurence G. Miller, Oceanographer

\begin{abstract}
ADDRESS: $\quad$ U.S. Geological Survey, 345 Middlefield Road, MS 465, Menlo Park, CA 94025
\end{abstract}

TELEPHONE: (415) 329-4482

PROBLEM: Micro-organisms alter the chemistry and productivity of aquatic environments by performing complex transformations of organic and inorganic molecules. In many cases, microbes can affect the speciation, mobility, bioavailability, and toxicity of toxic elements, such as $\mathrm{Se}, \mathrm{Hg}$, and As. The mechanisms by which these reactions proceed, the in situ rates of the transformation, their quantitative significance to element cycling, the responsible micro-organisms and their physiology are poorly understood.

OBJECTIVE: Develop conceptual models of biogeochemical transformations by combining lab and field experimental work. Focus lab work on identification of biochemical pathways, and on isolation and physiological characterization of relevant microbes. Measure in situ rates of transformations, based on methods developed in the lab. Quantify physical exchanges between components, such as the flux of biogenic gases between the atmosphere and water or soil.

APPROACH: Microbial pathways will be studied in the lab using materials from various field locations. Biochemical experiments will be performed on isolated cultures of important micro-organisms. The findings from these investigations will guide the methodology employed in field work to assess in situ rates of these transformations as well as physical exchange (flux) of important materials (for example, reduced gases) between components.

PROGRESS: The degradation of HCFCs and methylbromide was found to be achieved by aerobic methane-oxidizing bacteria. These gases are competitive inhibitors of methane monooxygenase. Field and laboratory studies indicate that anaerobic processes are also involved. Methylbromide was found to react with other halides (I- and $\mathrm{Cl}-$ ) in an exchange reaction which generates methylchloride or methyliodide. All these gases undergo nucleophilic 


\section{ECOLOGY}

attack by sulfide to form methanethiol and dimethylsulfide. These methylated sulfur gases serve as substrates for methanogenic bacteria. The significance of these reactions to the global cycling of these ozone-destroying gases will be pursued during Fiscal Year 1994.

The respiratory reduction of selenate to more reduced states was investigated.

\section{REPORTS PUBLISHED 1988-1993:}

Cicerone, R.J., and Oremland, R.S., 1988, Biogeochemical aspects of atmospheric methane: Global Biogeochemical Cycles, v. 2, p. 299-328.

Culbertson, C.W., Strohmaier, F.S., and Oremland, R.S., 1988, Acetylene as a substrate in the development of primordial microbial communities: Origins of Life and Evolution of the Biosphere, v. 18, p. $397-407$.

Dubrovsky, N.M., Neil, J.M., Fujii, R., Oremland, R.S., and Hollibaugh, J.T., 1990, Influence of redox potential on selenium distribution in ground water, Mendota, Western San Joaquin Valley, California: U.S. Geological Survey Open-File Report 90-138, p. 24.

Fischer, C.R., Childress, J.J., Oremland, R.S., and Bidigare, R.R., 1988, The importance of methane and thiosulfate in the metabolism of the bacterial symbionts of two deepsea mussels: Marine Biology, v. 96, p. 59-71.

Luoma, S.N., Johns, C., Fischer, N.S., Steinberg, N.A., Oremland, R.S., and Reinfelder, J.A., 1992, Determination of selenium bioavailability to a benthic bivalve from particulate and solute pathways: Environmental Science and Technology, v. 26, p. $485-491$.

Miller, L.G., Coulatkis, M.D., Oremland, R.S., and Ward, B.B., 1993, Selective inhibition of ammonium oxidation and nitrification-linked $\mathrm{N}_{2} \mathrm{O}$ for- mation by methyl fluoride and dimethyl ether: Applied Environmental Microbiology, v. 59, p. 2447-2464.

Miller, L.G., Jellison, R., Oremland, R.S., and Culbertson, C.W., 1993, Meromixis in hypersaline Mono Lake, California, 3. Biogeochemical response to stratification and overturn: Limnology and Oceanography, v. 38, p. 1040-1051.

Miller, L.G., and Oremland, R.S., 1988, Methane efflux from the pelagic regions of four lakes: Global Biogeochemical Cycles, v. 2, p. 269-277.

Oremland, R.S., 1988, The biogeochemistry of methanogenic bacteria, in Zehnder, A.J.B., ed., The biology of anaerobic micro-organisms: New York, J. Wiley and Sons, p. 405-447.

1989. Present day activities of anaerobic bacteria and their relevance to future exobiological investigations: Advances in Space Research, v. 9, p. 127-136.

1990. Nitrogen fixation dynamics of two diazotrophic communities in Mono Lake, California: Applied and Environmental Microbiology, v. 56, p. 614-622.

Oremland, R.S., and Capone, D.G., 1988, Use of "specific" inhibitors in microbial biogeochemistry and ecology, in Marshall, K.C., ed., Ad- 


\section{ECOLOGY}

vances in microbial ecology: New York, Plenum Publishing Co., v. 10., p. 59-71.

Oremland, R.S., Cloern, J.E., Sofer, Z., Smith, R.L., Culbertson, C.W., Zehr, J., Miller, L., Cole, B., Harvey, R., Iversen, N., Klug, M., Des Marais, D.J., and Rau, G., 1988, Microbial and biogeochemical processes in Big Soda Lake, Nev., in Klets, K., Talbot, M., and Fleet, A., eds., Lacustrine petroleum source rocks: Geological Society of London, Special Publication no. 40 , p. $59-75$.

Oremland, R.S., and Culbertson, C.W., 1992, Importance of methane-oxidizing bacteria in the methane budget as revealed by the use of a specific inhibitor: London, Nature v. 356, p. 421423.

1992, Evaluation of methyl fluoride and dimethylether as inhibitors of aerobic methane oxidation: Applied and Environmental Microbiology, v. 58, p. 2983-2992.

Oremland, R.S., Culbertson, C.W., and Winfery, M.R., 1991, Methylmercury decomposition in sediments and bacterial cultures: involvement of methanogens and sulfate reducers in oxidative demethylation: Applied and Environmental Microbiology, v. 57, p. 130-137.

Oremland, R.S., Hollibaugh, J.T., Maest, A., Presser, T., Miller, L., and Culbertson, C., 1989. Selenate reduction to elemental selenium by anaerobic bacteria in sediments and culture: biogeochemical significance of a novel, sulfateindependent respiration: Applied and Environmental Microbiology, v. 55, p. 2333-2343.

Oremland, R.S., Kiene, R.P., Mathrani, I., Whiticar, M.J., and Boone, D., 1989, Description of an estuarine methylotrophic methanogen which grows on dimethylsulfide: Applied and Environmental Microbiology, v. 55, p. 994-1002.

Oremland, R.S., and King, G.M., 1989, Methanogenesis in hypersaline environments, in Cohen Y., and Rosenberg E., ed., Microbial matsphysiological ecology of benthic microbial communities: Washington, D.C., American Society for Microbiology, p. 180-190.

Oremland, R.S., Miller, L.G., Culbertson, C.W., Robinson, S.W., Smith, R.L., Lovley, D., Whiticar, M.J., and others, 1993, Aspects of the biogeochemistry of methane in Mono Lake and the Mono Basin of California, U.S.A., in Oremland, R.S., ed., Biogeochemistry of global change-Active trace gasses: New York, Chapman and Hall.

Oremland, R.S., Steinberg, N.A., Maest, A.S., Miller, L.G., and Hollibaugh, J.T., 1990, Measurement of in situ rates of selenate removal by dissimilatory bacterial reduction in sediments: Environmental Science and Teclmology, v. 24, p. 1157-1164.

Oremland, R.S., Steinberg, N.A., Presser, T.S., and Miller, L.G., 1991, In situ bacterial selenate reduction in the agricultural drainage systems of Western Nevada: Applied and Environmental Microbiology, v. 57, p. 615-617.

Oremland, R.S., Whiticar, M.J., Strohmaier, F.S., and Kiene, R.P., 1988, Bacterial formation of ethane from ethylated reduced sulfur compounds in anoxic sediments: Geochimica et Cosmochimica Acta, v. 52, p. 1895-1904.

Oremland, R.S., and Zehr, J.P., 1986, Formation of methane and carbon dioxide from dimethylselenide in anoxic sediments and by a pure culture of 


\section{ECOLOGY}

an estuarine methanogen: Applied and Environmental Microbiology, v. 52, p. 1031-1036.

Steinberg, N.A., and Oremland, R.S., 1990, Dissimilatory selenate reduction potentials in a diversity of sediment types: Applied and Environmental Microbiology, v. 56, p. 3550-3557.

Steinberg, N.A., Switzer Blum, J., Hochstein, L., and Oremland, R.S., 1992, Nitrate is a preferred electron acceptor for growth of freshwater selenate-respiring bacteria: Applied and Environmental Microbiology, v. 58, p. 426-428. 


\section{ECOLOGY}

TITLE: $\quad$ Biotic Interface with Fluvial Transport: Processes Associated with Dissolved Solutes in Transport (WR 84-186)

PERSONNEL: Frank J. Triska, Project Chief Carolyn Harden, Secretary

Alan P. Jackman, Chemical Engineer

Ronald J. Avanzino, Chemist

John H. Duff, Hydrologist

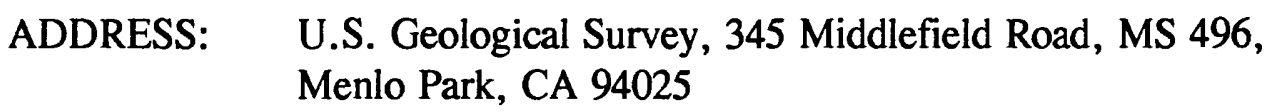

TELEPHONE: (415) 354-3333

PROBLEM: Biogeochemical processes associated with the microbial community (algae, bacteria, fungi) constitute the interface between solute transport and biotic production in riverine environments. Identifying and estimating the role of biotic processes such as nitrification and denitrification by bacteria, nutrient uptake and production by epilithic algal films and decomposition of particulate and dissolved organic matter, as well as abiotic processes such as absorption, are important for understanding the linkage between terrestrial, riparian, hyporheic and in-channel contributions to the nutrient chemistry of a drainage network. Relative biotic response to solutes in transport between pristine and anthropogenically modified riverine environments is poorly understood, but necessary for long-term management of surface waters.

OBJECTIVE: Identify and determine rates of biotic transformations of transported solutes at chemical-biotic interfaces in fluvial environments, including seepage areas, riparian zones, sediment/surface-water interfaces, intragravel-subsurface flow interfaces (hyporheic zone) and floodplains.

APPROACH: Laboratory experiments using communities collected from small to large streams and in situ field experiments are used to estimate biotic transformation of dissolved solutes. Field experiments are conducted at background concentrations and with mixtures of conservative and nonconservative solutes injected into both pristine and man-impacted fluvial environments. Cycling of elements which have high assimilative demand and (or) are subsequently passed to higher trophic levels are emphasized (that is, C, N, P). 


\section{ECOLOGY}

PROGRESS: 1. The fate of transported dissolved inorganic nitrogen (DIN) along a lowland, virgin rain forest stream (Salto Creek) in Costa Rica was examined by separate injections of ammonium and DOC (sucrose) with conservative tracer (Rhodamine WT). The ammonium amendment raised $\mathrm{NH}_{4}-\mathrm{N}$ from 16 to 165 microgram of nitrogen per liter $(\mu \mathrm{gN} / \mathrm{L})$ at the head of an 800-meter reach and to $65 \mu \mathrm{gN} / \mathrm{L}$ at the base. Ammonium amendment resulted in a simultaneous increase in nitrate from $170-180 \mu \mathrm{gN} / \mathrm{L}$. In contrast, sucrose amendment (10 milligrams per liter DOC) resulted in a nitrate decrease from 166 to $153 \mu \mathrm{gN} / \mathrm{L}$. The results indicate a rapid and coupled response to suitable carbon and nitrogen substrates by the microbial community.

2. An ammonium sorption study, using bags of 0.5 millimeter-2.0 millimeter sediment, from Little Lost Man Creek, California, indicated a spatial and temporal response in the exchangeable ammonium pool in stream and bankside sediments. Exchangeable ammonium (2.0 M KCl extraction) was approximately 0.01 milliquivalent per 100 grams (milliquivalent per 100 grams) sediment in channel sediments, but up to an order of magnitude higher in sediment bags incubated in ground water 10-20 meters from the bank. Temporally exchangeable ammonium was highest during summer-autumn base flow, lowest during winter storm flow and intermediate during spring.

REPORTS PUBLISHED 1988-1993:

Avanzino, R.J., and Kennedy, V.C., 1993, Longterm frozen storage of stream water samples for dissolved orthophosphate, nitrate plus nitrite, and ammonia analysis: Water Resources Research, v. 29 , no. 10 , p. $3357-3362$.

Duff, J.H., 1989, Nitrate reduction with epilithic algal communities, San Francisquito Creek, San Mateo County, California: U.S. Geological Sur-

- vey Open-File Report 89-416, p. 113.

Duff, J.H., and Triska, F.J., 1990, Denitrification in sediments from the hyporheic zone adjacent to a small forested stream: Canadian Journal of Fisheries and Aquatic Sciences v. 47, no. 6, p. 11401147.
Kim, B.K., Jackman, A.P., and Triska, F.J., 1990, Modeling transient storage and nitrate uptake kinetics in a flume containing a natural periphyton community: Water Resources Research, v. 26 , no. 3 , p. 505-515.

1992, Modeling biotic uptake by periphyton and transient hyporheic storage of nitrate in a natural stream: Water Resources Research, v. 28, p. 2743-2752.

McKnight, D.M., Aiken, G.R., Bowles, E.C., Smith, R.L., Duff, J.H., and Miller, L.G., 1988, Dissolved organic material in desert lakes in the dry valleys: Antarctic Journal, v. vxiii, no. 5, p. 152-153. 


\section{ECOLOGY}

Osborne, L.L., Bayley, P.B., Higler, L.W.G., Statzner, B., Triska, F. and Iverson, T.M., 1993, Restoration of lowland streams-An introduction: Freshwater Biology, v. 29, p. 187-194.

Pringle, C.M., Rowe, C.L., Triska, F.J., Fernandez, J.F. and West, J., 1993, Landscape linkages between geothermal activity, solute composition, and ecological response in surface waters draining the Atlantic slope of Costa Rica: Limnology and Oceanography, v. 38, p. 753-774.

Pringle, C.M., and Triska, F.J., 1991, Effects of geothermal groundwater on nutrient dynamics of a lowland Costa Rican stream: Ecology v. 72, no. 3 , p. 951-965.

1991, Variation in phosphate concentrations of small order streams draining volcanic landscapes in Costa Rica-Sources and implications for nutrient cycling, in Tiessen, H., Lopez-Hernandez, D., and Salcedo, I.H., eds., Phosphorus cycles in terrestrial and aquatic ecosystems, Regional Workshop 3-South and Central America, Organized by the Scientific Committee of Problems of the Environment (SCOPE) and the United Nations Environmental Programme (UNEP): Maracay, Venezuela, 1989, TurnerWarwick Communications, Saskatoon, Canada, [257 p.] p. 70-83.

Pringle, C.M., Triska, F.J., and Browder, G., 1990, Spatial variation in basic chemistry of streams draining a volcanic landscape on Costa Rica's Caribbean slope: Hydrobiologia, v. 206, p. 7385.

Smith, R.L., and Duff, J.H., 1988, Denitrification in a sand and gravel aquifer: Applied and Environmental Microbiology, v. 54, p. 1071-1078.
Smith, R.L., Howes, B.L. and Duff, J.H., 1989, Use of tracer tests to measure the transport and consumption of methane in a contaminated aquifer, in Mallard, G.E., and Ragone, S.E. eds., U.S. Geological Survey Toxic Substances Hydrology Program-Proceedings of the techical meeting, Phoenix, Ariz., September 26-30, 1988: U.S. Geological Survey Water-Resources Investigations Report 88-4220, p. 167-175.

1991, Denitification in nitrate-contaminated groundwater-Occurrence in steep vertical geochemical gradients: Geochemica et Cosmochimica Acta v. 55, p. 1815-1825.

Smith, R.L.., Howes, B.L. and Duff, J.H., 1991, Effects of denitrifcation on nitrogen geochemistry in a nitrate-contaminated sand and gravel aquifer, Cape Cod, Massachusetts, in Mallard. G.E., ed., U.S. Geological Survey Toxic Substances Hydrology Program-Proceedings of the technical meeting, Monterey, Calif., March 11-15, 1991: U.S. Geological Survey WaterResources Investigations Report 91-4034, p. 128-134.

Stream Solute Workshop, 1990, Concepts and methods for assessing solute dynamics in stream ecosystems: Journal of the North American Benthological Society, v. 9, no. 2, p. 95-119.

Triska, F.J., Duff, J.H., and Avanzino, R.J., 1990, Influence of exchange flow between the channel and hyporheic zone on nitrate production in a small mountain stream: Canadian Journal of Fisheries and Aquatic Sciences, v. 47, no. 11, p. 2099-2111.

1993. The role of water exchange between a stream channel and its hyporheic zone on nitrogen cycling at the terrestrial-aquatic interface: Hydrobiologia, v. 251, p. 167-184. 


\section{ECOLOGY}

1993, Patterns of hydrological exchange and nutrient transformation in the hyporheic zone of a gravel bottom stream: Examining terrestrial aquatic linkages: Freshwater Biology, v. 29, p. 259-274.

Triska, F.J., Kennedy, V.C., Avanzino, R.J., Zellweger, G.W., and Bencala, K.E., 1989, Retention and transport of nutrients in a third-order stream-Channel processes: Ecology, v. 70, no. 6, p. 1877-1892.

1990 , In situ retention-transport response to nitrate loading and storm discharge in a thirdorder stream: Journal of the North American Benthological Society, v. 9, no. 3, p. 229-239.

1989, Retention and transport of nutrients in a third-order stream in northwest Californiahyporheic processes: Ecology v. 70, no. 6, p. 1893-1905.

Triska, F.J., Kennedy, V.C., Avanzino, R.J., and Stanley, K.C., in press, Inorganic nitrogen uptake and regenenration in a small stream at summer base flow-Long-term clearcutting and short-term storm related impacts: U.S. Geological Survey Professional Paper 1454.

Triska, F.J., Pringle, C.M., Zellweger, G.W., Duff, J.H., and Avanzino, R.J., 1993, Dissolved inorganic nitrogen composition, transformation, retention, and transport in naturally phosphaterich and phosphate poor tropical streams: Canadian Journal of Fisheries and Aquatic Sciences, v. 50 , p. $665-675$. 


\title{
ECOLOGY
}

TITLE: $\quad$ Solute Transport Involving Biological Processes in Surface Waters

(WR 86-190)

\author{
PERSONNEL: James S. Kuwabara, Project Chief \\ Susan P. Bartaluzzi, Secretary \\ Cecily C. Chang, Hydrologist \\ Yvonne R. Hunter, Student, (San Jose, State University) \\ Anne Khechfe, Volunteer
}
ADDRESS: $\quad$ U.S. Geological Survey, 345 Middlefield Road, MS 465, Menlo Park, CA 94025

TELEPHONE: (415) 329-4485

PROBLEM: Availability of toxic substances and nutrients to biota is dependent on their chemical form or speciation. Toxicological models, for example, have emphasized the effect of solute speciation on biological processes. Conversely, it has been demonstrated that partitioning of contaminants and nutrients can be affected by biological processes. Chemical processes that control chemical speciation in natural waters are solute complexation, precipitation and dissolution, sorption, and redox. Each of these processes affects and is affected by biological activity. Therefore, understanding and quantifying solute interactions with biota can be important in developing accurate water-quality models. Although inorganic and organic complexation have been emphasized in previous toxicological studies in chemically defined media, it is clear that chemical processes suppressed in these experiments can be important in natural water systems. The effects of biological processes on solute uptake and transport need to be quantified and incorporated in transport models.

OBJECTIVE: Study transport of trace inorganic solutes between particulates and primary producers. Examine and quantify processes controlling that transport (for example, adsorption onto and desorption from particles, and uptake and release from plankton and periphyton.) Establish how biological processes may contribute to the overall behavior of trace inorganic contaminants in surface-water systems.

APPROACH: Conduct field sampling and laboratory analyses to assess the chemical character of particulate and dissolved phases and to identify potentially important biological-transport processes. Determine trace-metal, macronutrient, and organic carbon and trace sulfide 


\section{ECOLOGY}

concentrations by means of various analytical and preparative techniques. Use chemically defined media, suspensions and algal cultures to describe processes controlling solute uptake and release by cells. Conduct laboratory culture experiments with field samples and isolates from natural planktonic and periphyton communities and generate biological transport models for testing and eventual incorporation into comprehensive water-quality models.

PROGRESS: Studies conducted at Whitewood Creek, South Dakota (Surface Water Toxics Program) demonstrated time lags in diel soluble reactive phosphorus (SRP) cycles relative to fluctuations in dissolved arsenic redox species. Biological uptake effects on SRP fluctuations contrasted abiotic sorption controls on dissolved arsenate (contrast between two chemically similar anions).

Work in Lake Tahoe in collaboration with the University of California at Davis (UCD) demonstrated phosphate limitation and a potential secondary iron limitation on planktonic biomass using chemically defined cultures of phytoplankton isolated from the lake. This represents a major temporal shift in macronutrient limitation from nitrogen. This shift has been subsequently verified in a publication by A. Jassby using macronutrient time series and bioassay data from UCD.

Square-wave voltammetry was used to determine trace dissolved sulfide concentrations in oxic waters from San Francisco Bay and in benthic flux experiments. Benthic flux data supports our initial water column observations that a major benthic source of dissolved sulfides exist. The work highlights the need to consider, even in oxic waters, the competition between dissolved sulfide complexation and chemical interactions with dissolved organic material in regulating the bioavailability of trace inorganic contaminants.

Major dissolved organic carbon sources to the northern and southern components of San Francisco Bay have been analyzed over a salinity (ionic strength) range between freshwater and seawater. Using a low-temperature, ultraviolet, persulfate oxidation method, minimal ionic strength effects up to seawater salinity was observed for these various organic carbon types, including fulvic acid standards. These results differ from recent claims by some marine chemists that interferences due to chloride cause inefficient oxidation of organic carbon at high (seawater) ionic strengths using low-temperature methods. 


\section{ECOLOGY}

\section{REPORTS PUBLISHED 1988-1993:}

Chang, C.C.Y., Kuwabara, J.S., and Pasilis, S.P., 1990, Trace-metal concentrations in three streams during spring runoff in the Tahoe Basin, California/ Nevada, in Poppoff, I.G., Goldman, C.R., Loeb, S.L. and Leopold, L.B., eds., Proceedings of the International Watershed Symposium, Lake Tahoe, June 8-10, 1988: Tahoe Research Conservation District, p. 103-115.

1992, Phosphate and iron limitation of phytoplankton biomass in Lake Tahoe: Canadian Journal of Fisheries and Aquatic Sciences, v. 49, p. 1206-1215.

Hunter, Y.R., and Kuwabara, J.S., in press, Ionic strength and DOC determinations from various freshwater sources to the San Francisco Bay: Bulletin of Environmental Contamination and Toxicology, v. 51, no. 6.

Kuwabara, J.S., 1992, Associations between benthic flora and diel changes in dissolved arsenic, phosphorus, and related physico-chemical parameters: Journal of the North American Benthological Society, v. 11, p. 218-228.

Kuwabara, J.S. and Baker, J.E., in press, Trace contaminants and nutrients in estuaries: the importance of process interdependence: Estuaries, v. 16 , no. 3.

Kuwabara, J.S., Cain, D.J., Carter, J.L., and Fend, S.V., 1988, Biological investigations-SurfaceWater Toxics Program, Whitewood Creek and the Belle Fourche and Cheyenne Rivers, South Dakota, in Goddard, K.E., ed., U.S. Geological Survey Applied Research Studies of the Cheyenne River System, South Dakota: Description and Collation of Data, Water Years 1985-86:

\section{U.S. Geological Survey Open File Report 88-} 484 , p. $148-158$.

Kuwabara, J.S., Chang, C.C.Y., Cloern, J.E., Fries, T.L., Davis, J.A., and Luoma, S.N., 1989, Trace metal associations in the water column of South San Francisco Bay, California: Estuarine, Coastal, and Shelf Science, v. 26, p. 307-325.

Kuwabara, J.S., Chang, C.C.Y., and Pasilis, S.P., 1988, Effects of algal growth on arsenic transport in Whitewood Creek, South DakotaPreliminary Results, in Mallard, G.E., ed., U.S. Geological Survey Toxic Substance Hydrology Program-Surface-Water ContaminationProceedings of the technical meeting, Denver, Colo., February 2-4, 1987: U.S. Geological Survey Open File Report 87-764, p. 33-37.

1989, Periphyton effects on arsenic transport in Whitewood Creek, South Dakota, in Mallard, G.E., and Ragone, S.E., eds., U.S. Geological Survey Toxic Substances Hydrology ProgramProceedings of the technical meeting, Phoenix, Ariz., September 26-30, 1988: U.S. Geological Survey Water-Resources Investigations Report $88-4220$, p. 247-256.

1990, Effects of benthic flora on arsenic transport: Journal of Environmental Engineering, v. 116 , p. 394-409.

Kuwabara, J.S., and Harvey, R.W., 1990, Application of a hollow-fiber tangential-flow device for sampling suspended bacteria and particles from natural waters: Journal of Environmental Quality, v. 19, p. 625-629.

Kuwabara, J.S., and Helliker, P., 1988, Trace contaminants in streams, in Cheremisinoff, P.N., 


\section{ECOLOGY}

Cheremisinoff, N.P., and Cheng, S.L., eds., Encyclopedia of Civil Engineering Practice, Chapter 26: Technomic Press, v. 5, p. 739-766.

Kuwabara, J.S., and Luther, G.W. III, in press, Dissolved sulfides in the oxic water column of San Francisco Bay, California: Estuaries, v. 16, no. 3.

Kuwabara, J.S., and Robinson, J.R., 1988, Development of a hollow fiber tangential flow filtration system for concentration of suspended sediment samples from natural waters, in Mallard, G.E., ed., U.S. Geological Survey Toxic Substance Hydrology Program-Surface-Water Contamination-Proceedings of the technical meeting, Denver, Colo., February 2-4, 1987: U.S. Geological Survey Open-File Report 87-764, p. 157-160.

Stream Solute Workshop, 1990, Concepts and methods for assessing solute dynamics in stream ecosystems: Journal of the North American Benthological Society, v. 9, p. 95-119. 


\title{
ECOLOGY
}

TITLE: Environmental Influences on Estuarine Benthic Community Dynamics (WR 86-192)

\author{
PERSONNEL: Frederic H. Nichols, Project Chief \\ Janet K. Thompson, Marine Biologist \\ Francis Parchaso, Biologist \\ Thomas F. Duda, Biologist
}

\begin{abstract}
ADDRESS: $\quad$ U.S. Geological Survey, 345 Middlefield Road, MS 472, Menlo Park, CA 94025
\end{abstract}

TELEPHONE: (415) 329-4411

PROBLEM: (1) Benthic invertebrate communities, composed of sessile, relatively long-lived species, provide a record of effects of short- and long-term environmental changes through species composition and abundance changes. Thus they are often used as water-quality indicators. However, their use in water-quality studies requires assumptions that communities remain at steady state except when influenced by human activity. Long-term studies show that natural variation over a variety of time scales often masks human-induced changes. (2) Estuarine benthic communities, often dominated by suspension feeders, have an unknown but potentially large controlling effect on phytoplankton biomass, and thus may be important in limiting eutrophication.

OBJECTIVE: (1) Characterize long-term patterns in estuarine and coastal benthic communities, in order to determine the contribution of natural factors (climatic events, seasonal/interannual patterns of runoff, water chemistry and circulation, sediment texture and stability, and food availability) to community variability, and to assess the contribution of human activity (waste contamination, control of river runoff) to the remaining unexplained variability in community dynamics. (2) Measure, through field and laboratory studies, the processes which determine the rates at which invertebrates remove phytoplankton from the water column.

APPROACH: (1) Quantitatively sample the benthos at regular intervals through time (and obtain access to data that have been collected by others) at fixed locations in various estuaries and nearshore habitats. Statistically analyze data from these samples for short- and long-term patterns of change in community structure and correlate these patterns through time-series 


\section{ECOLOGY}

analysis with both natural environmental factors and anthropogenic factors associated with the water column and sediment. (2) Determine the link between benthic community processes (feeding, respiration, substrate disturbance and stabilization) and changes in the water column (changes in planktonic biomass, nutrients, and organic matter) through field-manipulation experiments with transplanted animals and through laboratory experiments with individual species and intact infaunal communities in flumes that simulate changing field conditions.

PROGRESS: To quantify ecological responses to natural environmental perturbations-for example, responses to short- and long-term variations in river flow and to contaminant inputs-we continue to characterize long-term patterns in the structure and functioning of the benthic community at fixed sites in both northern and southern San Francisco Bay.

We completed a study of reproduction in the recently introduced, numerically dominant Asian clam, Potamocorbula amurensis, under varying salinity, temperature, and food regimes demonstrating major differences in reproductive seasonality between north and șouth San Francisco Bay that may be related to a combination of food availability and osmotic stress. Such reproductive adaptability is a key to the invasive success of this species. We also completed a study of genetic variability in Potamocorbula at sites throughout the bay demonstrating that this species has high within-population genetic variability and limited genetic differentiation among sites. These features are indicative of a "general purpose" genetic strategy that provides this species with an inherent ability to invade and colonize new localities.

Now that the long California drought is over, we are poised to answer the question about the effect of Potamocorbula on phytoplankton abundance in the northern bay: by the end of summer 1993 we should know whether the reduction in the phytoplankton is due to (1) an increase in grazing pressure by the arrival of the new clam or (2) is due to some physical or chemical change related to the reduction in freshwater inflow into the bay during the drought. A phytoplankton bloom would not be expected until late summer, but the clam has survived the return of high winter inflows, probably in part because the salinity of interstitial water remained sufficiently high.

We are continuing the study of the growth of Potamocorbula and other filter feeding bivalves in south San Francisco Bay to determine how the spring phytoplankton bloom is linked to the growth cycle of individual species. Initial results show the growth is correlated with the 


\section{ECOLOGY}

phytoplankton bloom in spring and with some unknown food source (possibly nonliving particulate and dissolved organic carbon) in the fall of each year.

Finally, our studies of bivalve filtration rates in the flume have demonstrated clearly that these benthic filter feeder clams change their feeding behavior in response to varying water velocities; for example, elevate their position in the sediments in slower water currents thereby increasing the turbulence and transport of food to each individual.

\section{REPORTS PUBLISHED 1988-1993:}

Cariton, J.T., Thompson, J.K., Schemel, L.E., and Nichols, F.H., 1990, The remarkable invasion of San Francisco Bay (California, U.S.A) by the Asian clam Potamocorbula amurensis, I. Introduction and dispersal: Marine Ecology Progress Series, v. 66, p. 81-94.

Cole, B.E., Thompson, J.K., and Cloern, J.E., 1992, Measurement of filtration rates by infaunal bivalves in a recirculating flume: Marine Biology, v. 113, p. 219-225.

Ebbesmeyer, C.C., Cayan, D.R., McLain, D.R., Nichols, F.H., Peterson, D.H., Redmond, K.T., 1991, 1976 Step in the Pacific climate-forty environmental changes between 1968-1975 and 1977-1984, in Betancourt, J.L., and Tharp, V.L., eds., Seventh Annual Pacific Climate (PACLIM) Workshop, Asilomar, Calif., April 1990 [Proceedings]: Interagency Ecological Studies Program for the Sacramento-San Joaquin Estuary, Technical Report 26, p. 115-126.

Kuivila, K.M., and Nichols, F.H., 1991, Overview of San Francisco Bay estuary toxic contaminants study, U.S. Geological Survey Toxic Substances Hydrology Program Technical Meeting, Monterey, Calif., March 1991 [Proceedings]: WaterResources Investigations Report No. 91-4034, p. $659-663$.
Monismith, S.G., Koseff, J.R., Thompson, J.K., O'Riordan, C.A., and Nepf, H.M., 1990, A study of model bivalve siphonal currents: Limnology and Oceanography, v. 35, p. 680-696.

Nichols, F.H., 1988, Long-term changes in a deep Puget Sound benthic community-local or basinwide?: 1st Annual Meeting on Puget Sound Research [Proceedings], v. 1, p. 65-71.

1989. The San Francisco Bay estuary-an overview: Biennial Oceanic Society State of the Bay Conference, 4th, San Francisco, Calif., April 1989, [Proceedings], p. 11-18.

Nichols, F.H., Cacchione, D.A., Drake, D.E., and Thompson, J.K., 1989, Emergence of burrowing urchins from California continental shelf sediments-a response to alongshore current reversals?: Estuarine, Coastal, and Shelf Science, v. 29 , p. 171-182.

Nichols, F.H., and Pamatmat, M.M., 1988. The ecology of the soft-bottom benthos of San Francisco Bay-a community profile: U.S. Fish Wildlife Service Biology Report 85(7.19), p. 1-73.

Nichols, F.H., Thompson, J.K., and Schemel, L.E., 1990, The remarkable invasion of San Francisco Bay (California, U.S.A) by the Asian clam Potamocorbula amurensis, II. Displacement of a 


\section{ECOLOGY}

former community: Marine Ecology Progress

Series, v. 66, p. 95-101.

Peterson, D.H., Cayan, D.R., Festa, J.F., Nichols, F.H., Walters, R.A., Slack, J.V., Hager, S.E., Schemel, L.E., 1989, Climate variability in an estuary-effects of riverflow on San Francisco Bay: American Geophysical Union, Geophysical Monograph, v. 55, p. 419-442.

Schubel, J.R., Nichols, F.H., and others, 1988, Marine environmental monitoring in Chesapeake Bay: Report of the Chesapeake Bay Panel of the Committee on a Systems Assessment of Marine Environmental Monitoring, Marine Board Commission on Engineering and Technical Systems, National Research Council, Washington, D.C., $81 \mathrm{p}$.

Thompson, J.K., and Nichols, F.H., 1988, Food availability controls seasonal cycle of growth in Macoma balthica (L.) in San Francisco Bay, Calif.: Journal of Experimental Marine Biology Ecology, v. 116, p. 43-61. 


\section{GEOMORPHOLOGY AND SEDIMENT TRANSPORT}




\title{
GEOMORPHOLOGY AND SEDIMENT TRANSPORT
}

TITLE: $\quad$ Movement and Storage of Sediment in River Systems (CR 75-102)

\author{
PERSONNEL: Robert H. Meade, Project Chief \\ Aleta R. Moores, Secretary \\ Jacquelyn Walters, Clerk \\ ADDRESS: $\quad$ U.S. Geological Survey, P.O. Box 25046, MS 413, Denver Federal Center, \\ Denver, CO 80225
}

TELEPHONE: (303) 236-5009

PROBLEM: Sediment moves through a river system in response to specific events and changing conditions in the drainage basin. The movement of sediment is usually discontinuous. Episodes of movement are separated by periods of storage that can range from less than 1 year to more than 1,000 years. Understanding the movement and storage of sediment in rivers is important to navigation, flood control, and other aspects of river engineering, as well as to the prediction of the fate of contaminants absorbed on sediment particles.

OBJECTIVE: Assess (1) changes in river-sediment loads over periods of decades or longer and the factors (natural or artificial) that cause the changes; (2) rates at which sediment is stored in river systems and the residence times of sediment particles in storage; and (3) sources, pathways, and sinks of sediment particles in river systems.

APPROACH: (1) Assess long-term changes in sediment loads from data previously collected by U.S.Geological Survey and other agencies; (2) assess sediment storage by repeated (annual) surveys of selected river channels and by comparing old and new maps and aerial photographs of rivers and their flood plains; and (3) assess sources, pathways, and sinks by intensive field studies of selected large and small rivers.

PROGRESS: Spring runoff of 1993 was the greatest on Powder River since the 50-year flood of 1978. The velocity and discharge data collected during the 1993 runoff season will enhance our understanding of mechanisms of the channel changes that have been measured biennially (1975-77, 1980-82, 1982-84) or annually (all other years) since 1975.

Technical assistance was provided to Argentina's National Institute of Limnology concerning field methods and equipment for water-quality sampling of large rivers. 


\section{GEOMORPHOLOGY AND SEDIMENT TRANSPORT}

Technical assistance was provided to the Venezuelan (governmental) Corporation for Guayana (CVG) in developing a field program to evaluate mercury pollution from gold mining on the Guayana Shield.

\section{REPORTS PUBLISHED 1988-1993:}

Gomez, Basil, and Marron, D.C., 1991, Neotectonic effects on sinuosity and channel migration, Belle Fourche River, western South Dakota: Earth Surface Processes and Landforms, v. 16 , p. 227-235.

Johnsson, M.J., and Meade, R.H., 1990, Chemical weathering of fluvial sediments during alluvial storage-the Macuapanim Island point bar, Solimoes River, Brazil: Journal of Sedimentary Petrology, v. 60 , p. $827-842$.

Johnsson, M.J., Stallard, R.F., and Meade, R.H., 1988, First-cycle quartz arenites in the Orinoco River basin, Venezuela and Colombia: Journal of Geology, v. 96, p. 263-277.

Marron, D.C., 1988, Field and laboratory data describing physical and chemical characteristics of metal-contaminated flood-plain deposits downstream from Lead, west-central South Dakota: U.S. Geological Survey Open-File Report 88-349, 32 p.

1989, The transport of mine tailings as suspended sediment in the Belle Fourche River, west-central South Dakota, U.S.A., in Hadley, R.F., ed., Sediment and the environment: International Association of Hydrologic Sciences Publication 184, p. 19-26.

1989, Physical and chemical characteristics of a metal-contaminated overbank deposit, westcentral South Dakota, U.S.A.: Earth Surface Processes and Landforms, v. 14, p. 419-432.

1992, Floodplain storage of mine tailings in the Belle Fourche River system-Sediment budget approach: Earth Surface Processes and Landforms, v. 17, p. 675-685.

Meade, R.H., 1988, Movement and storage of sediment in river systems, in Lerman, A., and Meybeck, M., eds., Physical and chemical weathering in geochemical cycles: Dordrecht, Kluwer Academic Publishers, p. 165-179.

Meade, R.H., and Koehnken, Lois, 1991, Distribution of the river dolphin, tonina Inia geoffre$n s i s$, in the Orinoco River basin of Venezuela and Colombia: Interciencia, v. 16, p. 300312.

Meade, R.H., Rayol, J.M., Conceicao, S.C. da, and Natividade, J.R.G., 1991, Backwater effects in the Amazon River basin of Brazil: Environmental Geology and Water Sciences, v. 18, p. $105-114$.

Meade, R.H., Weibezahn, F.H., Lewis, W.M., Jr., and Perez-Hernandez, David, 1990, Suspended-sediment budget for the Orinoco River, in Weibezahn, F.H., Alvarez, H., and Lewis, W.M., Jr., eds., The Orinoco River as an ecosystem: Caracas, Impresos Rubel, p. 5579.

Meade, R.H., Yuzyk, T.R., and Day, T.J., 1990, Movement and storage of sediment in rivers of the United States and Canada, in Wolman, M.G., and Riggs, H.C., eds., Surface water hydrology: Geological Society of America, The Geology of Nortl America, v. O-1, p. 255-280. 


\section{GEOMORPHOLOGY AND SEDIMENT TRANSPORT}

Moody, J.A., and Meade, R.H., 1990, Channel changes at cross sections of the Powder River between Moorhead and Broadus, Montana, 1975-88: U.S. Geological Survey Open-File Report 89-407, 252 p. 


\section{GEOMORPHOLOGY AND SEDIMENT TRANSPORT}

TITLE: $\quad$ Effects of Water and Sediment Discharges on Channel Morphology (CR 65-105)

PERSONNEL: Garnett P. Williams, Project Chief

Aleta R. Moores, Secretary

Jackie Walters, Clerk

ADDRESS: U.S. Geological Survey, P.O. Box 25046, MS-413, Denver Federal Center, Denver, CO 80225

TELEPHONE: (303) 236-5001

PROBLEM: Channels on alluvial streams change with time. Bed elevations and channel widths may change, meander bends shift both laterally and downstreamward, the sizes of the bed particles may change, instream bars grow and migrate, and the amount and type of vegetation along the river may increase or decrease. Sometimes the change is minor and insignificant, even over decades, but in other cases catastrophic modifications occur in minutes. The transformations can be natural or man-induced, and they can have significant effects on man and the environment.

OBJECTIVE: Determine and analyze the influence of the major governing variables, particularly water and sediment discharges, on channel morphology, and evaluate how the many relevant variables and results change with time.

APPROACH: (1) Identify the major variables that govern channel morphology; (2) Obtain data sets that span as long a time period as possible; (3) Isolate the effects of different variables and analyze stream channels as dynamical systems, with an eye toward prediction of channel changes.

PROGRESS: Geomorphic and sediment aspects of channel morphology vary with time, but usually in a nonlinear or irregular way. The newly emerging fields of nonlinear dynamics and chaos may be able to provide new tools for, and insights into, heretofore-intractable geomorphic and hydrologic problems. However, most researchers find the concepts underlying those new fields to be too confusing and complex. For example, some of the standard chaos-type analyses include Lyapunov exponents, Kolmogorov-Sinai entropy, correlation dimension, and mutual information. These and related concepts are totally unknown to nearly all geomorphologists (and to most other scientists, for that matter). The main reason 


\section{GEOMORPHOLOGY AND SEDIMENT TRANSPORT}

why most scientists and engineers find those concepts so baffling is that there is no understandable textbook explaining them. Therefore, I am preparing such a textbook. As of July 1993 the required background study is about 80 percent complete, the outline of the book is complete, and the first draft of the manuscript is about 80 percent complete.

REPORTS PUBLISHED 1988-1993:

Waythomas, C.F., and Williams, G.P., 1988, Sediment yield and spurious correlation-toward a better portrayal of the annual sediment load of rivers: Geomorphology, v. 1, no. 4, p. 309316.

Williams, G.P., 1988, Paleofluvial estimates from dimensions of former channels and meanders, in Baker, V.R., Kochel, R.C., and Patton, P.C. eds., Flood Geomorphology: New York, Wiley, p. 321-334.

1988, Stream-channel changes and pond formation at the 1974-76 Manti landslide, Utah: U.S. Geological Survey Professional Paper 1311-C, p. 43-69.

1989, Sediment concentration versus water discharge during single hydrologic events in rivers: Journal of Hydrology, v. 111, no. 1-4, p. 89-106.

Williams, G.P., and Costa, J.E., 1988, Geomorphic measurements after a flood, in Baker, V.R., Kochel, R.C., and Patton, P.C. eds., Flood Geomorphology: New York, Wiley, p. 65-77.

Williams, G.P., and Rosgen, D.L., 1989, Measured total sediment loads (suspended loads and bedloads) for 93 United States streams: U.S. Geological Survey Open-File Report 89-67, 128 p.

Williams, G.P., and Troutman, B.M., 1990, Comparison of structural and least-squares lines for estimating geologic relations: Mathematical Geology, v. 22, no. 8, p. 1027-1049. 


\section{GEOMORPHOLOGY AND SEDIMENT TRANSPORT}

TITLE: $\quad$ Hydraulics and Mechanics of Bedload-Transport Processes (CR 74-187)

PERSONNEL: William W. Emmett, Project Chief

Aleta R. Moores, Secretary R.M. Myrick, Volunteer (retired, USGS)

J. Walters, Clerk

P. Sparks, Volunteer (former HFA, USGS)

J.P. Doerner, Student (Denver University)

L.B. Leopold, Volunteer (retired, USGS)

R. Egemeier, Volunteer (student, Denver University)

ADDRESS: $\quad$ U.S. Geological Survey, P.O. Box 25046, MS-413, Denver Federal Center, Denver, CO 80225

TELEPHONE: (303) 236-5008

PROBLEM: Of all processes operating in river channels, and especially of those of practical concern to engineers and others interested in river-channel behavior, perhaps the least information is available regarding the hydraulics and mechanics of bedload transport. As scientific knowledge of river behavior advances and is applied to management of the nation's rivers, additional understanding of bedload-transport processes will be necessary.

OBJECTIVE: (1) Define (a) spatial and temporal variations in transport rate and particle size of bedload; and (b) the average magnitudes of transport rate and particle size throughout a range of geographic locations, channel geometries, and river hydraulics. (2) Evaluate the adequacy of sampling equipment and field procedures, provide interpretation of bedloadtransport processes, and assess the applicability of existing or new predictive techniques in river hydrology. (3) Demonstrate the value of sediment data in designing hydrologic networks and in evaluating regional and temporal trends in water-resources information. (4) Assess the usefulness of numerical simulations as hydrologic tools in fluvial geomorphology. (5) Provide interdiscipline perspectives in evaluation of environmental resources (for example, fishery habitat), impact assessments (for example, alluvial mining), and management alternatives (for example, operating policy). (6) Apply the information to operational programs of the USGS and other organizational units to assist in the solution of practical problems.

APPROACH: (1) Use continuous sampling of bedload (for example, conveyor-belt bedload trap on the East Fork River near Pinedale, Wyoming) as a control to evaluate spatial and temporal variability factors in bedload transport and to evaluate general relations between sediment movement and river hydraulics. (2) Field calibrate the sediment-sampling efficiency of the Helley-Smith bedload sampler simultaneously with operation of the bedload trap. (3) Use the calibrated Helley-Smith sampler and the concurrent measurements of streamflow 


\section{GEOMORPHOLOGY AND SEDIMENT TRANSPORT}

hydraulics in the systematic collection of bedload samples from a variety of sand- and gravelbed streams, and within the laws of general physics, stochastically develop empirical relations of bedload transport and interpret the physical significance of the developed relations. (4) At the conveyor-belt bedload-trap research facility, initiate a tracer study using fluorescent particles (sand to fine gravel) to evaluate (a) residence time of sediment (b) average speed of various sizes of particles (c) depth of bed material involved in transport (d) dispersion of bed material (e) short-term channel changes accompanying sediment transport (f) influence of availability of sediment on transport rate and $(\mathrm{g})$ other related aspects of sediment transport. (5) Extend the fluorescent-tracer study to larger particles (coarse gravel to cobbles) by implanting microradio transmitters in individual rocks and, by periodic and (or) continuous detection by receivers/data loggers, provide time-sequence data on motion and location of separately identifiable particles. (6) Establish field sites for bedload sampling that document varying characteristics of geographic coverage (factors of hydrology, meteorology, soils, biology, and so forth); maintain one or more bedload stations as long-term observation sites so that time-trend data can be evaluated. (7) Initiate and participate, as needed, in studies comparing sampler types, sampling procedures, and analytical techniques to formulate and modify guidelines on equipment needs and field/laboratory practices; provide emphasis on relevancy to WRD mission and on need for consistency of data collection. (8) In conjunction with biologists, chemists, and other scientists, develop a field-oriented strategy for comprehensive environmental assessments; apply developed strategy to specific sites to demonstrate and document sediment-related variables as important ecological factors.

PROGRESS: (1)- Field work at the East Fork River, Wyoming, bedload trap and for the fluorescent-tracer study is complete. Bedload-transport rates, measured synoptically, vary along a river reach; bedload tonnage, measured seasonally, is about constant throughout the reach. Mean bedload-transport rates relate to streampower (about the 1.6 power of streampower in excess of streampower at initiation of motion), mean bedload-particle speeds are slow (about 0.1 percent of water speed), and lengths of particle movement may be seasonally limited. (2) Total load data collection continued for the 12th year at Little Granite Creek, Wyoming (in cooperation with the Corps of Engineers). The measured total-sediment loads are among the longest data sets available and are a principal basis in the design of new predictive techniques in river mechanics. (3) Instrumentation established more than 30 years ago at Arroyo Frijoles, New Mexico, was relocated and measured. More than 80 percent of the originally installed instrumentation was located and provides extensive documentation of geomorphic processes in semiarid areas. (4) Began new studies in techniques of streamchannel monitoring (in cooperation with the U.S. Forest Service). Studies will be useful in establishing protocols for, and insight to interpretation of, stream-channel habitat studies in a variety of environmental programs. 


\section{GEOMORPHOLOGY AND SEDIMENT TRANSPORT}

\section{REPORTS PUBLISHED 1988-1993:}

Averett, R.C., and Emmett, W.W., 1992, Geomorphic assessment of stream physical habitat: Colorado Water, v. 9, no. 6, p. 11.

Averett, R.C., and Emmett, W.W., 1993, The phytoplankton of Fremont Lake, Wyoming: U.S. Geological Survey Water-Resources Investigation Report 92-4071, 68 p.

Chacho, E.F., Jr., Burrows, R.L., and Emmett, W.W., 1989, Detection of coarse sediment movement using radio transmitters-Proceedings of the XXIII Congress on Hydraulics and the Environment, August 2125, 1989, Ottawa, Canada: International Association for Hydraulic Research, p. B-367 to B-373.

1990, Detection of coarse sediment movement using radio receivers: The Nortlern Engineer, v. 22 , no. 3, p. 5-9.

Emmett, W.W., and Averett, R.C., 1989, Fremont Lake, Wyoming-Some aspects of the inflow of water and sediment: U.S. Geological Survey Water-Resources Investigations Report 88-4021, 25 p.

Gomez, Basil and Emmett, W.W., 1990, Data that describe at-a-point temporal variations in the transport rate and particle-size distribution of bedload-East Fork River, Wyoming and Fall River, Colorado: U.S. Geological Survey Open-File Report 90-193, 53 p.

Gomez, Basil, Emmett, W.W., and Hubbell, D.W., 1991, Comments on sampling bedload in small rivers: Federal Inter-Agency Sedimentation Conference, Fifth, Las Vegas, Nevada, March 18-21, [Proceedings], p. 2-65 to 2-72.
Long, Yuqian, Emmett, W.W., and Janda, R.J., 1989, Comparison of some methods for particle-size analyses of suspended-sediment samples-Proceedings of Fourth International Symposium on River Sedimentation, November 1-5, 1989, Beijing, China: China Ocean Press, p. 1503-1508.

Nelson, J.M., Emmett, W.W., and Smith, J.D., 1991, Flow and sediment transport in rough channels: Federal Inter-Agency Sedimentation Conference, Nevada, Fifth Las Vegas, March 18-21, [Proceedings], p. 4-55 to 4-62.

Osterkamp, W.R., and Emmett, W.W., 1992, The Vigil Network-Long-term monitoring to assess landscape changes, in Erosion and Sediment Transport Monitoring Programmes in River Basins, Oslo, Norway, August 1992, Proceedings: International Association of $\mathrm{Hy}-$ drological Sciences, Publication no. 210, p. 397-404.

Osterkamp, W.R., Emmett, W.W., and Leopold, L.B., 1990, The Vigil Network-A reviving of interest: American Geophysical Union, Transactions, EOS (March 20, 1990), v. 71, no. 12, p. 338 .

Osterkamp, W.R., Emmett, W.W., and Leopold, L.B., 1991, The Vigil Network-a means of observing landscape change in drainage basins: International Association of Hydrological Sciences Journal, v. 36, no. 4, p. 331-344.

Shen, H.W., and Tabias, G.O., II, 1990, Evaluation of bed-material tracer data collected by U.S. Geological Survey in the East Fork River, Wyoming, in 1979 and 1980: Berkeley, Calif., University of California, Progress Report, $261 \mathrm{p}$. 


\section{GEOMORPHOLOGY AND SEDIMENT TRANSPORT}

TITLE: $\quad$ River Mechanics (CR 82-273)

PERSONNEL: Edmund D. Andrews, Project Chief

Eva Brown, Secretary

Jonathan M. Nelson, Hydrologist

R.R. McDonald, Hydrologist

ADDRESS: U.S. Geological Survey, P.O. Box 25046, MS 458, Denver Federal Center, Denver, CO 80225

TELEPHONE: (303) 541-3002

PROBLEM: The geometry and pattern of river channels adjust to significant changes in the water discharge, size, and quantity of sediment supplied to the channel. When the quantity of water and sediment over a period of years remains relatively constant, the channel geometry and pattern vary about a mean or quasi-equilibrium condition. Major watershed alterations that change the supply of water, sediment, and size of sediment reaching the channel necessitate an adjustment of the channel geometry and pattern. That is, the channel is transformed from one quasi-equilibrium state to another. Between the two quasi-equilibrium states, there is a period of instability and adjustment. Existing techniques for examining and predicting river channel adjustment have been developed primarily from investigation of quasiequilibrium rivers. As a result, it is frequently possible to predict with a modest range of uncertainty the future quasi-equilibrium hydraulic characteristics of a river following a change in its watershed. The dynamics and rate of river channel adjustment during the period of instability, however, have rarely been studied, and are rather poorly understood. The length of time required for the complete adjustment is commonly a few decades to a century or more. In many instances, such as surface mines, reservoirs, and urbanization, the adjustment period may, in fact, be longer than the duration of the watershed change. In watersheds where various land-use changes occur every several years, river channels may be continually adjusting to different contributions of water and sediment, and thus, never reach a quasiequilibrium condition. In these rivers, instability and adjustment are the prevailing condition. The primary focus of this research project is to understand the dynamics and rate of river channel change and develop numerical models to make predictions of river channel characteristics given a particular change in flow regime and sediment supply. The greatest deficiencies in our present knowledge of river channel adjustment are (1) the longitudinal sorting of bed material, especially gravel, (2) the formation and stability of bed forms, (3) adjustment of 


\section{GEOMORPHOLOGY AND SEDIMENT TRANSPORT}

channel width through the erosion and deposition of bank material, and (4) the rates at which the several hydraulic variables adjust.

OBJECTIVE: Develop physically-based numerical models to describe the processes and rate at which a river channel adjusts in response to a change in the water discharge, sediment size and sediment load supplied to the channel. Emphasize the adjustment of those aspects of river channels known to significantly influence the aquatic ecosystem, that is, the bed-material size distribution, occurrence of bars, and channel width. Describe the hydraulic processes controlling these characteristics of river channels as well as the rate at which they function. Formulate mathematical models of the processes as required for longitudinal routing of water and sediment. Develop new analytical tools for describing river-channel adjustment.

APPROACH: The development of physically-based hydrodynamics models involves an iterative process of model formulation, testing model predictions using field and laboratory measurements, and then model refinement. Precise field and laboratory measurements are essential. Ideally, one would study in great detail the transition of a river channel from one quasi-equilibrium state through a period of instability to another quasi-equilibrium state as a result of a known change in the supply of water and sediment. Unfortunately, this approach is impractical for several reasons including the need to maintain a high level of effort over the period of adjustment, which may last for a few decades to a century or more. Instead, one must limit the detailed study of processes to a duration much less than would normally be required for channel adjustment. These studies, however, can lead to a precise description of physical processes. Although historical information is incomplete and less precise, the course and rate of river channel adjustment through time can only be understood by studying historical examples. Thus, reconstructions of the sequence and rate of channel adjustment using historical examples of river channel change are necessary components of this research. Better understanding of river channel adjustment requires a combination of precise field and laboratory studies, the reconstruction of historical examples using available information, and carefully formulated physically-based models.

PROGRESS: During Fiscal Year 1993, an investigation of the rates of erosion and deposition of sand bars in lateral separation zones at various discharges made significant progress. A numerical model for the advection and diffusion of suspended sediment has been developed and is being tested. The model is general and applicable to a wide variety of situations where boundary shear stress is increasing or decreasing and suspended sand is transported (for example, deposition of channel margin levees and deltas). In addition, a computational model for flow in channels with lateral separation zones solving the fully coupled vertically averaged momentum equations with secondary flows has been developed. 


\section{GEOMORPHOLOGY AND SEDIMENT TRANSPORT}

Results of the computations compare well with laboratory data, and will be applied to the Colorado River in Grand Canyon as soon as topographic data is available (by summer of 1993). The approach uses very flexible boundary conditions, allowing the presence of sudden expansion and constriction of the channel, islands, braiding, etc. Based, in part, on the work, several experimental releases from Glen Canyon in excess of powerplant capacity are being planned over the next decade to rebuild historical flood deposits and riparian ecosystems within Grand Canyon National Park.

\section{REPORTS PUBLISHED 1988-1993:}

Andrews, E.D., 1990, Effects of streamflow and sediment on channel stability of the Colorado River-A perspective from Lees Ferry, Arizona, in Wolman, M.G., and Riggs, H.C., eds., The Geology of North America: Surface Water Hydrology, Geological Society of America, v. 0-1, p. 304-310.

1991, Sediment transport in the Colorado River basin, in Marzolf, G.R., ed., Colorado River Ecology and Dam Management: Washington, D.C., National Academy Press, p. 54-74.

Andrews, E.D. and Nelson, J.M., 1989, Topographic response of a bar in the Green River, Utah, to variation in discharge, in Ikeda, Syunsuke, and Parker, Gary, eds., River Meandering: American Geophysical Union, Water Resources Monograph, v. 12, p. 463-485.

Andrews, E.D., and Smith, J.D., 1992, A theoretical model for calculating marginal bedload transport rates of gravel, in Hey, R.D., Thorne, C.R., and Billi, P., eds., Gravel-Bed Rivers III: New York, John Wiley and Sons, p. $267-281$.

Erman, D.C., Andrews, E.D., and Yoder-Williams, Michael, 1988, Effects on winter floods on fish in the Sierra Nevada, California: Canadian Journal of Fisheries and Aquatic Sciences, v. 45 , no. 12 , p. $2195-2200$.
Helsel, D.R., and Andrews, E.D., 1991, Discussion of "Trends in freshwater inflow to San Francisco Bay from the Sacramento-San Joaquin Delta" by Fox, J.P., Mongon, T.R., and Miller, W.J., 1990: Water Resources Bulletin, v. 27, no. 2, p. 317-319.

McKnight, D.M., Aiken, G.R., Andrews, E.D., Bowles, C., and Harnish, R.A., 1993, Dissolved organic material in Dry Valley lakes: A comparison of Lake Fryxell, Lake Hoare, and Lake Vanda, in Green, William, ed., Physical and biogeochemical processes in Antarctic lakes: Washington, D.C., American Geophysical Union, Monograph Series 59, p. 119-133.

McKnight, D.M., Aiken, G.R., Andrews, E.D., Bowles, E.C., Smith, R.L., Duff, J.M., and Miller, L.C., 1988, Dissolved organic material in desert lakes in the dry valleys: U.S. Antarctic Journal, v. XXXIII, p. 152-153.

Nelson, J.M., 1991, The initial instability and finite-amplitude stability of alternate bars in straight channels: Earth-Science Review, v. 29 , p. 97-115.

Nelson, J.M., Emmett, W.W., and Smith, J.D., 1991, Flow and sediment transport in rough channels: Proceedings Fifth Federal Interagency Sedimentation Conference, March 18-21, 1991, chap. R, p. 55-62. 


\section{GEOMORPHOLOGY AND SEDIMENT TRANSPORT}

Nelson, J.M., and Smith, J.D., 1989, Flow in meandering channels with natural topography, in Ikeda, Syunsuke, and Parker, Gary, eds., River Meandering: Washington, D.C., American Geophysical Union Monograph 12, p. 69-102.

1989, Evolution and stability of erodible channel beds, in Ikeda, Syunsuke, and Parker. Gary, eds., River Meandering: Washington, D.C., American Geophysical Union Monograph 12, p. 321-377.

1989, Mechanics of flow over ripples and dunes: Journal of Geophysical Research, v. 94 no. C6, p. 8146-8162.

Shimizu, Y., Smith, J.D., and Nelson, J.M., 1989, Comparison of models for single thread streams, in Wang, S.Y., ed., Proceedings of the International Symposium on Sediment Transport Modeling: New York, American Society of Civil Engineers, p. 524-529.

Smith, J.D., and Nelson, J.M., 1989, Mechanics of mud flows in curved channels with uneven beds, in Wang, S.Y., ed., Proceedings of the International Symposium on Sediment Transport Modeling: New York, American Society of Civil Engineers, p. 518-523.

Wiberg, P.L., and Nelson, J.M., 1992, Unidirectional flow over asymmetric and symmetric ripples: Journal of Geophysical Research, v. 97, no. C8, p. 12745-12761. 


\title{
GEOMORPHOLOGY AND SEDIMENT TRANSPORT
}

\author{
TITLE: $\quad$ Sediment-Transported Pollutants in the Mississippi River (CR 87-309) \\ PERSONNEL: Robert H. Meade, Jr., Project Chief \\ Aleta R. Moores, Secretary \\ J. Walters, Clerk \\ John A. Moody, Hydrologist
}

\begin{abstract}
ADDRESS: $\quad$ U.S. Geological Survey, P.O. Box 25046, MS 413, Denver Federal Center, Denver, CO 80225
\end{abstract}

TELEPHONE: (303) 236-5009

PROBLEM: The source and fate of many pollutant substances in the Nation's largest river system are closely tied to suspended sediment. Accurate prediction of the fate of these pollutants will require more than our present understanding of the interactions between sediments and pollutants and the ways in which large rivers store and remobilize suspended sediment.

OBJECTIVE: Define and understand (1) processes by which pollutant substances, organic and inorganic, are adsorbed onto sediment particles; (2) downstream mixing of pollutants below the confluence of large tributaries with the mainstem; and (3) seasonal storage and remobilization of sediment and pollutants in the Mississippi River system.

APPROACH: One to two boat trips per year, beginning at Minneapolis, Minnesota, and ending at New Orleans, Louisiana, will be made to sample 15-20 cross sections of the Mississippi River and its principal tributaries. Cross sections will be sampled with a largevolume suspended-sediment sampler by the equal-width-increment method. Suspended sediment will be concentrated and analyzed for a large number of organic and inorganic constituents, both natural and manmade. New methods for sampling and analyzing pollutants attached to sediment particles will be developed in the field and in the laboratory.

PROGRESS: For the general-reader report (the "Congressional Report") on contaminants in the Mississippi River, draft chapters have been completed on heavy metals, nutrients, pesticides, polychlorinated biphenyls (PCBs), sewage and industrial contaminants (organic), and trihalomethanes. First-level editing of most of these chapters has been completed, and samples of edited chapters have been sent to the Branch of Scientific Publications in Reston for preliminary approval of their formats. 


\section{GEOMORPHOLOGY AND SEDIMENT TRANSPORT}

A dozen or so data reports are in various stages of preparation, review, "and revision in hopes of their being approved in time to be referenced in the Congressional Report.

\section{REPORTS PUBLISHED 1988-1993:}

Goolsby, D.A., Coupe, R.C., and Markovchick, D.J., 1991, Distribution of selected herbicides and nitrate in the Mississippi River and its major tributaries, April through June 1991: U.S. Geological Survey Water-Resources Investigations Report 91-4163, 35 p.

Hayes, H.C., 1993, Metal associations in suspended sediments and bed sediments from the Mississippi River: Golden, Colorado School of Mines, Department of Chemistry and Geochemistry, M.S. Thesis, $131 \mathrm{p}$.

Leenheer, J.A., 1991, Organic substance structures that facilitate contaminant transport and transformations in aquatic sediments, in Baker, R.A., ed., Organic substances and sediments in water, volume 1: Chelsea, Mich., Lewis Publishers, p. 3-22.

Leenheer, J.A., Meade, R.H., Taylor, H.E., and Pereira, W.E., 1989, Sampling, fractionation, and dewatering of suspended sediment from the Mississippi River for geochemical and trace-contaminant analysis, in Mallard, G.E., and Ragone, S.E., eds., U.S. Geological Survey Toxic Substances Hydrology Program-Proceedings of the Technical Meeting, Phoenix, Ariz., September 26-30, 1988: U.S. Geological Survey Water-Resources Investigations Report 88-4420, p. 501-512.

Leenheer, J.A., Wershaw, R.L., Brown, P.A., and Noyes, T.I., 1991, Detection of polyethyleneglycol residues from nonionic surfactants in surface water by $\mathrm{H}$ - and $\mathrm{C}$-nuclear magnetic resonance spectrometry: Environmental Science and Technology, v. 25, p. 161-168.
Leiker, T.J., Rostad, C.E., Barnes, C.R., and Pereira, W.E., 1991, A reconnaissance study of halogenated organic compounds in catfish from the lower Mississippi River and its major tributaries: Chemosphere, v. 23, p. 817-829.

Leiker, T.J., Rostad, C.E., Barnes, C.R., and Pereira, W.E., 1991, A reconnaissance study of halogenated organic compounds in catfish from the lower Mississippi River and its major tributaries, in Dhamotharan, Dhamo, ed., Resource Development in the Lower Mississippi River Symposium Proceedings: American Water Resources Association Technical Publication Series TPS 91-3, p. 185-194.

Meade, R.H., 1989, Sediment-transported pollutants in the Mississippi River: U.S. Geological Survey Yearbook 1988, p. 20-23.

Meade, R.H., and Stevens, H.H., Jr., 1990, Strategies and equipment for sampling suspended sediment and associated toxic chemicals in large rivers-with emphasis on the Mississippi River: Science of the Total Environment, v. 97/98, p. 125-135.

Moody, J.A., 1993, Evaluation of the Lagrangian scheme for sampling the Mississippi River during 1987-90: U.S. Geological Survey Water-Resources Investigations Report 93$4042,31 \mathrm{p}$.

Moody, J.A., and Meade, R.H., 1992, Hydrologic and sedimentologic data collected during three cruises at low water on the Mississippi River and some of its tributaries, July 1987-June 1988: U.S. Geological Survey Open-File Report $91-485,143 \mathrm{p}$. 


\section{GEOMORPHOLOGY AND SEDIMENT TRANSPORT}

Moody, J.A., and Meade, R.H., 1993, Hydrologic and sedimentologic data collected during four cruises at high water on the Mississippi River and some of its tributaries, March 1989-June 1990: U.S. Geological Survey Open-File Report 92-651, $227 \mathrm{p}$.

Moody, J.A., and Troutman, B.M., 1992, Evaluation of the depth-integration method of measuring water discharge in large rivers: Amsterdam, Netherlands, Journal of Hydrology, v. 135 , p. 201-236.

Pereira, W.E., and Rostad, C.E., 1990, Occurrence, distributions, and transport of herbicides and their degradation products in the Lower Mississippi River and its tributaries: Environmental Science and Technology, v. 24, p. $1400-1406$.

Pereira, W.E., Rostad, C.E., and Leiker, T.J., 1989, Preliminary assessment of the fate and transport of synthetic organic agrochemicals in the lower Mississippi River and its tributaries, in Mallard, G.E., and Ragone, S.E., eds., U.S. Geological Survey Toxic Substances Hydrology Program-Proceedings of the Technical Meeting, Phoenix, Arizo., September 26-30, 1988: U.S. Geological Survey WaterResources Investigations Report 88-4220, p. 453-464.

1990, Determination of trace levels of herbicides and their degradation products in surface and ground waters by gas chromatography-ion trap mass spectrometry: Analitica Chimica Acta, v. 228, p. 69-75.

1990, Distributions of agrochemicals in the Lower Mississippi River and its tributaries: Science of the Total Environment, v. 97/98, p. 41-53.

Pereira, W.E., Rostad, C.E., and Leiker, T.J., 1992, Synthetic organic agrochemicals in the lower Mississippi River and its major tributaries-Distribution, transport and fate: Journal of Contaminant Hydrology, v. 9, p. 175-188.

Rathbun, R.E., and Bishop, L.M., 1993, Trihalomethane and nonpurgeable total organic halide formation potentials for the Mississippi River and some of its tributaries, June-August 1991: U.S. Geological Survey Open-File Report 93-158.

Rees, T.F., 1990, Comparison of photon correlation spectroscopy with photosedimentation analysis for the determination of aqueous colloid size distributions: Water Resources Research, v. 26, p. 2777-2781.

Rees, T.F., Leenheer, J.A., and Ranville, J.F., 1991, Use of a single-bowl continuous-flow centrifuge for dewatering suspended sediments-effect on sediment physical and chemical characteristics: Hydrological Processes, v. 5. p. 201-214.

Rees, T.F., and Ranville, J.F., 1989, Characterization of colloids in the Mississippi River and its major tributaries, in Mallard, G. E., and Ragone, S.E., eds., U.S. Geological Survey Toxic Substances Hydrology Program-Proceedings of the Technical Meeting, Phoenix, Ariz., Sept. 26-30, 1988: U.S. Geological Survey Water-Resources Investigations Report 88-4220, p. 513-522.

1990, Collection and analysis of colloidal particles transported in the Mississippi River, U.S.A.: Journal of Contaminant Hydrology, v. 6, p. 241-250.

Rostad, C.E., Pereira, W.E., and Leiker, T.J., 1989, Determination of herbicides and their degradation products in surface waters by gas chromatography/positive chemical ionization/tandem mass spectrometry: Biomedical 


\section{GEOMORPHOLOGY AND SEDIMENT TRANSPORT}

and Environmental Mass Spectrometry, v. 18, p. $820-827$.

Tabor, C.F., Jr., 1993, The occurrence and fate of linear alkylbenzene sulfonate in the Mississippi River-a molecular indicator of sewage contamination: Boulder, University of Colorado, Department of Geology, M.S. Thesis, 78 p.

Taylor, H.E., Garbarino, J.R., and Brinton, T.I., 1990 , Occurrence and distribution of trace metals in the lower Mississippi River and its tributaries: Science of the Total Environment, v. $97 / 98$, p. $369-384$.

Writer, J.H., 1992, Sewage contamination in the Upper Mississippi River as measured by the fecal sterol coprostanol: Boulder, Colo., University of Colorado, Department of Civil, Architectural, and Environmental Engineering, M.S. Thesis, 99 p. 


\title{
GEOMORPHOLOGY AND SEDIMENT TRANSPORT
}

TITLE: $\quad$ Sediment Impacts from Disturbed and Undisturbed Lands (CR 79-311)

PERSONNEL: Waite R. Osterkamp, Project Chief

Aleta R. Moores, Secretary

J. Walters, Clerk

William P. Carey, Hydrologist

Andres J. Miller, Hydrologist, student, (University of Maryland)

J.P. Doerner, Hydrology Technician, student, (University of Denver)

\begin{abstract}
ADDRESS: U.S. Geological Survey, P.O. Box 25046, MS-413, Denver Federal Center, Denver, CO 80225
\end{abstract}

TELEPHONE: (303) 236-5036

PROBLEM: The acquisition and meaningful interpretation of sediment data from areas disturbed by land-use activities or natural processes are two of the most deficient areas of recognizing nonpoint-source pollution in the United States. The comparison of sediment data from disturbed and undisturbed areas provides a means to (1) evaluate the effects that landuse activities cause, (2) investigate the geomorphic processes that regulate the detachment and transport of sediment, and (3) develop strategies for remedial action to reduce excessive sediment discharges. This information is especially necessary to minimize sediment discharges and sorbed chemical loads from surface-mine, industrial, agricultural, and urban areas.

OBJECTIVE: (1) Evaluate the extent and utility of sediment data from a variety of land-use areas; (2) predict the movement of sediment from drainage basins affected by those land uses; and (3) assess existing techniques and develop new ones based on geomorphic principles and the application of statistics, geochemistry, and botany to the limited data available as aids in improving our interpretive capabilities.

APPROACH: Field investigations are being conducted to evaluate available techniques for predicting sediment yields. Of particular interest are the Water Erosion Prediction Project model and the U.S. Department of Agriculture (USDA) rainfall simulation model. Research is to be conducted to develop technology for determining (1) pre-disturbance sedimentdelivery ratios (proportion of gross erosion that appears as sediment yield at some place in the watershed) based on factors such as land use, contributing drainage area, runoff, basin morphology, relief, vegetation, and geochemical tracers, (2) sediment yields during disturbance, which are influenced by sediment-control measures used during land-use activity, and (3) sediment-delivery ratios for the post-disturbance period. In cooperation with other 


\section{GEOMORPHOLOGY AND SEDIMENT TRANSPORT}

agencies and field offices of the Survey, available sediment and related hydrologic and chemical data are being acquired and interpreted to develop techniques and possibly models to aid in the prediction of sediment impacts from land disturbance.

PROGRESS: Analysis and report preparation was completed on a study to evaluate groundwater recharge rates in Oman and Abu Dhabi using a transmission-loss model, an uplandrecharge model and geomorphic inputs to estimate streamflows. A manuscript draft was completed for a similar on-going study in the Amargosa River Basin, Nevada and California, to estimate modern and paleo rates of ground-water recharge. Field activities were completed to evaluate erosion rates from disturbed surfaces in southern Arizona.

\section{REPORTS PUBLISHED 1988-1993:}

Lane, L.J., and Osterkamp, W.R., 1991, Estimating upland recharge in the Yucca Mountain area: Irrigation and Drainage Division Proceedings, American Society of Civil Engineers, p. $170-176$.

Miller, A. J., 1991, Channel instability in a stripmined basin: Fifth Federal Inter-Agency Sedimentation Conference, Las Vegas, Nevada, [Proceedings], p. 10-1 to 10-8.

Osterkamp, W.R., 1989, Book Review, Fluvial processes in river engineering: EOS, Transactions, American Geophysical Union, v. 20, no. 4 , p. 51 .

(compiler), 1989, A tribute to John T. Hack by his friends and colleagues, in Tinkler, Keith ed., History of geomorphology from James Hutton to John Hack: Boston, Allen and Unwin, p. 283-291.

1989, Sediment storage and movement on the southern High Plains of Texas as indicated by beryllium-ten in sediment and the environment: International Association of Hydrological Sciences Publication 184, p. 173-182.

1990, Gentry Playa-origin by hydrologic processes in Gustavson, T.C., ed., Tertiary and Quaternary stratigraphy and vertebrate paleontology of parts of northwestern Texas and eastern New Mexico: Bureau of Economic Geology Guidebook 24, The University of Texas at Austin, p. 32-35.

1990, Seepage weathering and sapping of the southern High Plains escarpments, Texas and New Mexico, in Higgins, C.G., and Coates, D.R., eds., Groundwater geomorphology; The role of subsurface water in Earth-surface processes and landforms: Boulder, Colo., Geological Society of America Special Paper 252, p. 300-305.

1991, The Vigil Network-a means of observing landscape change in drainage basins: International Association of Hydrological Sciences Journal, v. 36 , no. 4 , p. 331-344.

1992, Book Review, Hydrological research basins and the environment: Hydrological Sciences Journal, International Association of Hydrological Sciences, v. 37, no. 3, p. 331344.

Osterkamp, W.R., Day, T.J., and Parker, R.S., 1992, A sediment monitoring program for North America: International Symposium on Sediment Transport Monitoring Programmes 


\section{GEOMORPHOLOGY AND SEDIMENT TRANSPORT}

in Rivers, International Association of Hydrologic Sciences, p. 391-396.

Osterkamp, W.R., and Emmett, W.W., 1992, The Vigil Network-long-term monitoring to assess landscape changes: International Symposium on Sediment Transport Monitoring Programmes in Rivers, International Association of Hydrological Sciences, p. 397-404.

Osterkamp, W.R., Emmett, W.W., and Leopold, L.B., 1990, The Vigil Network, a reviving of interest: EOS, v. 71 , no. 12 , p. 338.

Osterkamp, W.R., Hack, J.T., Hupp, C.R., Olson, C.G., and Sherwood, W. C., 1989, Geomorphology and plant ecology of the Shenandoah Valley; Field Trip Guidebook T350, 28th International Geological Congress: Washington, D.C., American Geophysical Union, 18 p.

Osterkamp, W.R., and Parker, R.S., 1991, Sediment monitoring in the United States: Federal Inter-Agency Sedimentation Conference, Fifth, Las Vegas, Nevada, [Proceedings], p. 1-15 to 1-23.

Parker, R.S., and Osterkamp, W.R., in press, Sensitivity of sediment discharge to alterations in upstream land use, in Sediment Problems-Strategies of Monitoring, Prediction, and Control: International Association of $\mathrm{Hy}-$ drological Sciences Symposium H4, [Proceedings], Yokohama, Japan, 14 p.

Simanton, J.R., Osterkamp, W.R., and Renard, K.G., in press, Sediment yield in a semiarid basin-sampling equipment impacts, in Sediment Problems-Strategies of Monitoring, Prediction, and Control: International Association of Hydrological Sciences Symposium H4, [Proceedings], Yokohama, Japan, 10 p.
Toy, T.J., Osterkamp, W.R., and Renard, K.G., in press, Prediction by regression and intra-range data scatter in surface-process studies: Environmental Geology and Water Sciences, v. 22, no. 2.

Waythomas, C. F., Jarrett, R. D., and Osterkamp, W. R., 1991, Late Quaternary fluvial activity and climate variability in the Colorado Front Range Foothills and Piedmont: Current Research in the Pleistocene, v. 8 p. 122-124. 


\section{GEOMORPHOLOGY AND SEDIMENT TRANSPORT}

TITLE: $\quad$ Sediment-Water Chemistry in Large River Systems: Biogeochemical, Geomorphic, and Human Controls (CR 88-313)

PERSONNEL: Robert F. Stallard, Project Chief

Elizabeth L. Callahan, Secretary

Ellen Axtmann, Hydrologist

Matthew C. Larsen, Research Hydrologist

Deborah A. Martin, Hydrologist

Eli D. Esser, Hydrologic Aid, student

(University of Colorado)

John E. Ewing, Hydrologic Aid, student

(University of Colorado)

ADDRESS: $\quad$ U.S. Geological Survey, P.O. Box 25046, MS 413, Denver Federal Center, Denver, CO 80225

TELEPHONE: (303) 541-3022

PROBLEM: Rivers are a major pathway to the ocean for erosion products and human wastes. The mechanisms that control the composition of river-borne materials are only imperfectly understood because erosion and the subsequent transport of material by rivers are mediated by a wide variety of closely linked chemical, biological, and physical processes. Moreover, in developed river systems such as those in the United States, these processes are subject to pervasive human-related perturbations. There is a need to develop, through field and theoretical studies, a comprehensive and integrated description of these processes for large river systems in a form that is useful to researchers in many disciplines.

OBJECTIVE: Describe how the biogeochemical and physical aspects of erosion and transport processes are reflected in the composition of river-borne materials for particular large river systems and develop general theoretical models that can be applied to rivers in general; evaluate the extent to which human activity has affected the river systems. Study how various chemical phases, natural or human-introduced, organic or inorganic, are partitioned between solid and dissolved loads in rivers and estuaries as the result of weathering, particlesurface reactions, biological uptake or release, atmospheric exchange, and storage during transit. Evaluate the dispersal pathways of river-borne substances through river systems and estuaries into and across the coastal marine environment.

APPROACH: Assemble, primarily from maps and data bases, current and historic chemical, geomorphic, biological, and demographic data for an entire river system. Identify phenomena that are especially important in controlling the composition of phases containing the major elements $(\mathrm{H}, \mathrm{C}, \mathrm{O}, \mathrm{Na}, \mathrm{Mg}, \mathrm{Al}, \mathrm{Si}, \mathrm{S}, \mathrm{Cl}, \mathrm{K}, \mathrm{Ca}, \mathrm{Ti}, \mathrm{Fe})$ and certain minor indicator elements (N, F, P, Mn, Sr, $\mathrm{Zr}$ ) to provide the conceptual framework for solving 


\section{GEOMORPHOLOGY AND SEDIMENT TRANSPORT}

specific research objectives. Undertake field surveys, design sampling and analytical procedures, and create computer tools to manipulate and model data as part of these investigations. Formulate small scale field and laboratory studies to aid data interpretation as deemed necessary.

PROGRESS: During Fiscal Year 1993, project efforts encompassed four areas: (1) research for the Water, Energy, and Biogeochemical Budgets (WEBB) Project in eastern Puerto Rico and related work in Panama; (2) similar research in the South Cascade Glacier Basin, Washington, (3) development and testing of methodologies for extrapolating from regional geomorphic and biogeochemical studies to the global scale; and (4) characterization of estuarine processes. Two important basic research papers were published. One, in Science with Harden, Sundquist, and Mark as co-authors, discusses the effect of pedogenesis on the sequestration of carbon in soils during deglaciation. This paper uses a GIS-based model to demonstrate that carbon sequestration by soils is probably important on glacial time scales (millennia), but not technological time scales (decades). The second paper, with Jewell and Mellor as co-authors, explores how bottom shear affects the distribution of sediments in the Amazon River estuary. The model uses a robust, physically based, three-dimensional, timedependent circulation model of the Amazon Shelf. The model can be easily modified for other estuarine systems.

Research in Puerto Rico and Panama is part of the USGS Global Change Program. Sites are in northeastern Puerto Rico, at the Luquillo Experimental Forest, and in central Panama, at the Barro Colorado Nature -Monument. The Smithsonian Tropical Research Institute shares funding for the work in Panama. These studies are designed to compare geologically matched natural and developed environments. The studies of weathering and erosion use long-term chemical sampling and physical monitoring to characterize the processes that control the distribution and transport of major, important-minor, and nutrient elements through soils, downslope, and out of the watershed. Exchange of methane and carbon dioxide with the atmosphere is being studied. Phenomena of interest to global-change research include the fixation, storage, and export of carbon and nutrients as related to biogeochemical and geomorphic processes.

Work in the South Cascade Glacier basin is designed to study weathering and erosion in a wet glacial basin and to examine glacial hydrology. Runoff rates and bedrock are similar to sites in Puerto Rico, but chemical weathering here is minimally influenced by biology. Several major hypotheses are being tested to gain understanding the impact of chemical weathering on atmospheric carbon dioxide for glacial and tectonic (millions of years) time scales. Results indicate that water chemistry can be a powerful tool to disentangle glacial 


\section{GEOMORPHOLOGY AND SEDIMENT TRANSPORT}

hydrology and that the products of subglacial chemical weathering are quite unlike those from any nonglacial watersheds that have been studied.

\section{REPORTS PUBLISHED 1988-1993:}

Harden, J.W., Sundquist, E.T., Stallard, R.F., and Mark, R.K., 1992, Dynamics of soil carbon during deglaciation of the Laurentide Ice Sheet: Science, v. 258, p. 1921-1924.

Jewell, P.W., and Stallard, R.F., 1990, Geochemistry and paleooceanographic setting of central Nevada bedded barites: Journal of Geology, v. 99, p. 151-170.

Jewell, P.W., Stallard, R.F., and Mellor, G.L., in press, Numerical studies of bottom shear stress and sediment distribution on the Amazon continental shelf: Journal of Sedimentary Petrology, v. 63 , no. 4 .

Johnsson, M.J. and Stallard, R.F., 1989, Physiographic controls on the composition of sediments derived from volcanic and sedimentary terrains on Barro Colorado Island, Panama: Journal of Sedimentary Petrology, v. 59, p. 768-781.

1990, Physiographic controls on the composition of sediments derived from volcanic and sedimentary terrains on Barro Colorado Island, Panama-Reply: Journal of Sedimentary Petrology, v. 60, p. $799-801$.

Johnsson, M.J., Stallard, R.F., and Lundberg, Neil, 1990, Petrology of fluvial sands from the Amazonian foreland basin, Peru and Bolivia. Discussion: Geological Society of America Bulletin, v. 102, p. 1727-1729.

1991, Controls on the composition and texture of fluvial sands from a tropical weathering environment: Sands of the Orinoco River drainage basin, Venezuela and Colombia:
Geological Society of America Bulletin, v. 103, p. 1622-1647.

Johnsson, M.J., Stallard, R.F., and Meade, R.H., 1988 , First-cycle quartz arenites in the Orinoco River basin, Venezuela and Colombia: Journal of Geology, v. 96, p. 263-277.

Keller, Michael, Mitre, M.E., and Stallard, R:F., 1990, Consumption of atmospheric methane in soils of central Panama-Effects of agricultural development: Global Biogeochemical Cycles, v. 4 p. 21-27.

Koehniken Hernandez, Lois, and Stallard, R.F., 1988, Sediment sampling through ultrafiltration: Journal of Sedimentary Petrology, v. 54, p. 758-759.

Larsen, M.C., Collar, P.D., and Stallard, R. F., 1993, Research plan for the investigation of water, energy, and biogeochemical budgets in the Luquillo Mountains, Puerto Rico: U.S. Geological Survey Open-File Report 92-150, p. 20.

Maest, A.S., Crerar, D.A., Stallard, R.F., and Ryan, J.N., 1990, Metal and nutrient behavior in the Raritan estuary, New Jersey, U.S.A., the effect of multiple freshwater and industrial waste inputs: Chemical Geology, v. 81, p. 133-149.

Murnane, R.J., Leslie,, Bret, Hammond, D.E., and Stallard, R.F., 1989, Germanium geochemistry in the southern California borderlands: Geochemica et Cosmocimica Acta, v. 53, p. 2863-2882. 


\section{GEOMORPHOLOGY AND SEDIMENT TRANSPORT}

Murnane, R.J., and Stallard, R.F., 1988, Germani$\mathrm{um} / \mathrm{silicon}$ fractionation during biogenic opal formation: Paleoceanography, v. 3, p. 461469.

1990, Germanium and silicon in rivers of the Orinoco drainage basin, Venezuela and Colombia: Nature, v. 344, p. 749-752.

Stallard, R.F., 1988, Weathering and erosion in the humid tropics, in Lerman, A., and Meybeck, M., eds., Physical and Chemical Weathering in Geochemical Cycles: Dordrecht, Holland, Kluwer Academic Publishers, p. 225-246.

Stallard, R.F., 1992, Tectonic processes, continental freeboard, and the rate-controlling step for continental denudation, in Global Biogeochemical Cycles, in Butcher, S.S., Charlson, R.J., Orians, G.H., and Wolfe, G.V., eds., Global biogeochemical cycles: New York, Academic Press, p. 93-121.

Stallard, R.F., Koehnken, Lois, and Johnsson, M.J., 1990, Weathering processes and the composition of inorganic material transported through the Orinoco River system, Venezuela and Colombia, in Weibezahn, F.H., Alvarez, Haymara, Lewis, W.M., Jr., eds., El Rio Orinoco como Ecosistema/The Orinoco River as an Ecosystem: Impresos Rubel, C.A., Caracas, Venezuela, p. 81-119.

1991, Weathering processes and the composition of inorganic material transported through the Orinoco River system, Venezuela and Colombia: Geoderma, v. 51, p. 133-165.

Yan, L., Stallard, R.F., Crerar, D.A., and Key, R.M., 1992, Experimental evidence on the behavior of metal-bearing colloids in low-salinity estuarine water: Chemical Geology, v. 100 , p. $163-174$.
Yan, Lusheng, Stallard, R.F., Key, R.M., and Crerar, D.A., 1990, The chemical behavior of trace metals and 226Rn during estuarine mixing in the Mullica River estuary, New Jersey, U.S.A., a comparison between field observations and equilibrium calculation: Chemical Geology, v. 85, p. 369-381.

Yan, Lusheng, Stallard, R.F., Key, R.M., And Crerar, D.A., 1991, Trace metals and dissolved organic carbon in estuaries and offshore waters of New Jersey, U.S.A.: Geochimica et Cosmochimica Acta, v. 55, p. 3647-3656. 


\section{GEOMORPHOLOGY AND SEDIMENT TRANSPORT}

TITLE: $\quad$ Applications of Fluid and Sediment Mechanics to Basin and Regional Scale Hydrologic and Geomorphic Problems (CR 91-324)

PERSONNEL: J.' Dungan Smith, Project Chief

Eva Brown, Secretary Eleanor Griffin, Hydrologist, student, (Univ. of Colo.)

Stephen M. Wiele, Hydrologist David Topping, Hydrologist, student, (Univ. of Wash.)

ADDRESS: $\quad$ U.S. Geological Survey, P.O. Box 25046, MS 458, Denver Federal Center, Denver, CO 80225

TELEPHONE: (303) 541-3004

PROBLEM: Stream systems function as integrated units from the zero-order basins at their heads to their terminations at the sea. Interior adjustments to changes in their headwaters or along their lengths occur in a variety of ways, some of which leave sedimentary deposits that provide important information with regard to the sensitivity of the systems to disturbances of various magnitudes and with respect to the nature of past disturbances. The former type of information is crucial to reliable interpretation of paleoflood deposits and the latter knowledge is essential for testing hydrologic predictions derived from climate models. In order to interpret fluvial deposits properly, however, an extremely accurate knowledge of stream system mechanics is required.

OBJECTIVE: The long-term goal of this project is to develop precise, process-based algorithms for flow, sediment transport, stream channel adjustment, erosion, and deposition in characteristic segments of a wide variety of fluvial systems. These algorithms then can be used to assess local environmental problems along particular types of stream segments, or they can be coupled with each other and with analogous algorithms for hill slope processes in order to produce models for erosion, sediment transport, and deposition on a regional scale and, thereby, provide a sound, process-based connection between regional hydrology and the salient characteristics of the sedimentary deposits in a wide variety of stream systems.

APPROACH: Stream systems are far too complex to be understood using empirical data only, but mathematical models that are to be used to provide reliable information from extreme or past events must be predictive in character and they must be devoid of parameters that make calibration of the models necessary. These models must be thoroughly tested using data from comprehensive studies of carefully chosen natural systems. The complex morphology of river channels and the intricate topography of hill slopes is generally not well known, and, thus, cannot be treated effectively in a completely deterministic fashion. In contrast, the flow and sediment transport over these surfaces usually can be computed with 


\section{GEOMORPHOLOGY AND SEDIMENT TRANSPORT}

reasonable accuracy from available fluid mechanical theory if the topography is known. Comprehensive, processes-based flow and sediment transport models for rivers and hill slopes, therefore, must represent the topographic elements in an appropriate stochastic manner while treating the response of the flow to this topography in a proper deterministic fashion. Models that are useful for environmental reconstruction require the judicious combination of modern fluid mechanical theory with a carefully crafted statistical treatment of the surface over which fluid is moving, so that the dominant nonlinear interactions between the topography and the flow are fully characterized and the evolution of the landscape is accurately represented.

PROGRESS: Owing to the sensitivity of fluvial processes in arid regions to variations in climatic parameters, the importance of water for irrigation and hydroelectric power in the arid West, and the need for models that clearly and conclusively show what environmental effects are produced by natural causes and what ones are the result of engineering works, the Colorado River System was chosen for detailed examination. As a consequence of uplift of the Colorado Plateau in the late Tertiary, many segments of this system are deeply cut into bedrock, and there is substantial present interest on the part of various agencies of the Department of Interior in improving the current understanding of processes in the incised reaches of this system. Of particular note in this regard are the U.S. Geological Survey and U.S. Bureau of Reclamation (USGS-BOR) project in the Black Canyon of the Gunnison and the extremely important, multi-agency project in the Marble and Grand Canyons (called GCES-II). Reliable models for the fluvially driven processes in such systems are lacking.

Funding from the U.S. Bureau of Reclamation for U.S. Geological Survey research on the Colorado River between Lake Powell and Lake Mead has made possible a major thrust toward understanding flow, sediment transport, erosion, channel adjustment, and deposition not only in this important segment of the Colorado River, but also in deeply incised systems in general. The Arizona District Office of the Water Resources Division (WRD), and several National Research Project (NRP) and Geological Division Projects all are contributing in a major way to this research effort. The primary role of this project (Flow and Sediment Mechanics) has been, and continues to be, fluid mechanically based analysis of the main channel flow and sediment transport data, and the development of flow, sediment transport, channel adjustment, erosion, and deposition algorithms. These efforts are tightly coupled to comprehensive field data collection programs being superbly carried out by personnel from the Arizona District. Work to date on these topics is summarized in a manuscript entitled "Flow and Sediment Transport in the Colorado River Between Lake Powell and Lake Mead" by J. Dungan Smith and Stephen Wiele. Two additional manuscripts on our models and their application to the Colorado River System currently are in preparation. Local investigations of 


\section{GEOMORPHOLOGY AND SEDIMENT TRANSPORT}

flow and sediment transport in the neighborhood of the National Canyon and Grand Canyon gage sites also are underway. In these, studies velocity and suspended sediment fields measured at the cable ways by Arizona District personnel are being used to test the predictions of process-based, quasi three-dimensional models derived specifically for the sites. Once verified, the suspended sand transport models for these sites will be used to produce sediment rating curves for each location. The sediment rating curve for the National Canyon site will be used to provide a boundary condition for the less sophisticated whole segment sediment transport model and the suspended sand rating curve for the Grand Canyon gage site will be used to confirm the validity of this model. This work will be presented in manuscripts by Smith, Christiansen, Wiele, Schmeeckle, and Graf; and by Smith, Wiele, and Graf during the coming year.

Flow in the Colorado River originally was controlled by snow melt in its headwaters; whereas, the sediment input always has been of a more local origin. Currently the major sources of sediment to the Marble and Grand Canyon reaches of the Colorado are the Paria and the Little Colorado Rivers. In both cases, the dominant contribution of material is as suspended load, and in order to provide a more accurate means of determining the amount of sand added to the Colorado below the Glen Canyon Dam, process-based methods for calculating suspended sediment input from these two major tributaries are being developed. These models ultimately will be tested against data from other major sand transporting tributaries of the Colorado River and then will be used to calculate sediment inputs from ungaged tributaries, as well as variations in sediment input with land use and climate from the gaged ones. This work will appear in manuscripts by Topping and Smith. Suspended sand input to the Colorado from the Paria and Little Colorado Rivers by floods on these tributaries and the consequent deposition and the re-erosion of sand bars below the mouths of these tributaries have been carefully monitored during the past year, and manuscripts on this work by Graf, Wiele, and Smith also are in preparation.

Another investigation relevant to the Marble and Grand Canyon reaches of the Colorado River involves the mechanics of erosion of bedrock and of particle size reduction by pulverization at the downstream sides of debris fans. Also, it is believed by the project chief that this is the dominant mechanism through which rapid incision occurs in the steep headwaters of tectonically active systems. Finally, work is continuing on the mechanics of debris flows. This research by Schmeeckle and Smith was initiated at the University of Washington, under funding from the Office of Naval Research, in order to understand slumping on silty faces of large deltas, but it also is directly relevant to the development and structure of debris fans in the Grand Canyon and to the rapid movement of lahars down valleys on the flanks of active volcanoes. 


\section{GEOMORPHOLOGY AND SEDIMENT TRANSPORT}

\section{REPORTS PUBLISHED 1988-1993:}

Andrews, E.D., and Smith, J.D., 1992, A theoretical model for calculating marginal bedload transport rates of gravel, in Hey, R.D., Thorne, C.R., and Billi, P., eds., Gravel-Bed Rivers III: New York, p. 267-281.

Nelson, J.M., Emmett, W.W., and Smith, J.D., 1991, Flow and sediment transport in rough channels: Fifth Federal Interagency Sedimentation Conference, March 18-21, 1991 [Proceedings], v. 1, sec. 4, p. 55-62.

Smith, J.D., and Andrews, E.D., 1993, Channel margin and eddy bar deposition along the Colorado River in Grand Canyon National Park, in Matthews, Jean, ed., Park Science, A Resource Management Bulletin: Corvallis, Oregon, National Park Service, v. 13, no. 1, p. 3-4.

Smith, J.D., and Webb, R.H., 1992, Glen Canyon Environmental Study: U.S. Geological Survey Yearbook, Fiscal Year 1992, p. 47-51. 


\section{GEOMORPHOLOGY AND SEDIMENT TRANSPORT}

TITLE: Response of Fluvial Systems to Climatic Variability (WR 89-206)

PERSONNEL: Robert H. Webb, Project Chief

Ana M. MacKay, Admin. Operations Assistant

Janice E. Bowers, Botanist

Douglas D. Wellington, Computer Analyst

Theodore S. Melis, Hydrologist
Marilyn B. Murov, Hydrology Technician

Thomas W. Wise, Physical Scientist

Peter G. Griffiths, Hydrologic Aid

ADDRESS: $\quad$ U.S. Geological Survey, 1675 W. Anklam Road, Tucson, AZ 85745

TELEPHONE: (602) 670-6821

PROBLEM: Understanding the effects of climatic variability is important to development of water resources, mitigation of flood hazards, and interpretation of geomorphic surfaces.

Climatic variability, which is characterized by temporal changes in variability of seasonal climate that spans decades or centuries, may be more important to water-resources evaluations than changes in mean climatic conditions. Changes in variability of climate has a large effect on the probability of occurrence of extreme events, such as floods or droughts. Understanding of climatic variability and its effect on the landscape is of paramount importance for estimation of flood frequency, sediment transport rates, and long-term watershed and channel changes.

OBJECTIVE: The objective of this project is to define historic climatic variability in the western United States over the past century; to identify specific time periods of statistically stationary precipitation, discharge, flood frequency, and sediment transport; and to assess the net effects of climatic variability on watershed conditions and fluvial systems.

APPROACH: Historic climatic variability will be assessed through regionalization of temporal climatic signals including temperature and precipitation amounts and intensity. Proxy synthetic records such as tree-ring widths, varved ocean sediments, and nonanthropogenic changes in vegetation will be determined. General circulation of the atmosphere will be examined for long-term changes in precipitation-generating mechanisms. that affect the western United States. Generation mechanisms for specific storm types, which include tropical cyclones and winter frontal storms, will be examined for frequency changes in time and space. Paleoflood records will be developed for rivers that are sensitive to climatic variability. Regional flood frequency, streamflow, and precipitation models will be used to assess the effects of variability changes. The stability of desert vegetation will be 


\section{GEOMORPHOLOGY AND SEDIMENT TRANSPORT}

assessed to determine possible interactions among climate, vegetation chănge, and storm runoff.

PROGRESS: Use of repeat photography to evaluate changes in desert vegetation related to climate and (or) land use practices has been substantially advanced using historical photographs from Grand Canyon. Use of repeat photography to evaluate geomorphic and ecological changes in Grand Canyon has yielded significant results for historic changes in riparian and desert vegetation, alluvial sand deposits, and debris fans. A book reporting the findings is in review. Data obtained using paleohydrologic techniques can be used to augment more traditional flood frequency analyses. Paleoflood data suggest the possibility that an upper-bounding enveloping curve relating peak discharge to drainage area may exist for the Colorado River drainage. Monte Carlo analyses, designed to simulate the information obtained from paleoflood deposits, suggests that paleoflood information of high quality can improve estimates of long-recurrence interval floods. The floods of 1993 in Arizona indicate that flood frequency in the southwestern United States may be responding to low frequency increases in high pressure during winter over the Pacific Northwest.

\section{REPORTS PUBLISHED 1988-1993:}

Bowers, J. E., 1991, The Mountains Next Door: Tucson, University of Arizona Press, 196 p.

1992, Plant World and its metamorphosis from a popular journal into Ecology: Bulletin of the Torrey Botanical Club, v. 119, p. 333-341.

1993, A Full Life in a Small Place and Other Essays from a Desert Garden: Tucson, University of Arizona Press, $166 \mathrm{p}$.

Bowers, J.E., and McLaughlin, S.P., 1993, Noteworthy collections: Arizona, Madroño, v. 40, p. 132-133.

Burgess, T.L., Bowers, J.E., and Turner, Raymond M., 1991, Exotic plants at the Desert Laboratory, Tucson, Ariz., Madroño, v. 38 , p. $96-114$.

Cayan, D.R., and Webb, R.H., 1992, El Niño/ Southern Oscillation and streamflow in the western United States, in Diaz, H.F., and
Markgraf, V., eds., El Niño, historical and paleoclimatic aspects of the Southern Oscillation: Cambridge, England, Cambridge University Press, p. 29-68.

Ely, L.L., Webb, R.H., and Enzel, Y., 1992, Accuracy of post-bomb ${ }^{137} \mathrm{Cs}$ and ${ }^{14} \mathrm{C}$ in dating fluvial deposits: Quaternary Research, v. 37, p. 196-204.

Enzel, Yehouda, Ely, L.L., House, P.K., Baker, V.R., and Webb, R.H., 1993, Paleoflood evidence for a natural upper bound to flood magnitudes in the Colorado River basin: Water Resources Research, v. 29, p. 2287-2297.

Graf, J.B., Hereford, Richard, and Webb, R.H., 1991, Relation of sediment load and floodplain formation to climatic variability, Paria River drainage basin, Utah and Arizona: Geological Society of America Bulletin, v. 103, p. 1405-1415. 


\section{GEOMORPHOLOGY AND SEDIMENT TRANSPORT}

Gray, J.R., and Webb, R.H., 1991, Radionuclides in the Puerco and lower Little Colorado River basins, New Mexico and Arizona, before 1987, in Gunderson, L.C.S., and Wanty, R.V., eds., Field studies of radon in rocks, soils, and water: U.S. Geological Survey Bulletin 1971, p. 297-311.

Gray, J.R., Webb, R.H., and Hyndman, D.W., 1991, Low-flow sediment transport in the Colorado River, in Fan, S.S., and Kuo, Y.H., eds., Proceedings of the Fifth Federal Interagency Sedimentation Conference, Volume 1: Washington, D.C., Federal Energy Regulatory Commission, p. 4-63 to 4-71.

Hereford, Richard, and Webb, R.H., 1992, Historic variation in warm-season rainfall on the Colorado Plateau, U.S.A.: Climatic Change, v. 22 , p. 239-256.

Hyndman, D.W., Roberts, R.A., and Webb, R.H., 1991, Modeling sediment transport in an ephemeral river, in Fan, S.S., and Kuo, Y.H., editors, Proceedings of the Fifth Federal Interagency Sedimentation Conference, Volume 2: Washington, D.C., Federal Energy Regulatory Commission, p. 8-101 to 8-108.

Nelson, D.J., Webb, R.H., and Long, Austin, 1990, Stick-nest rat (Leporillus: Muridae) middens from central Australia, in Betancourt, J.L., Van Devender, T.R., and Martin, P.S. eds., Fossil packrat middens-The last 40,000 years of biotic change: Tucson, Ariz., The University of Arizona Press, p. 428-434.

O'Connor, J.E., and Webh, R.H., 1988, Hydraulic modeling for paleoflood analysis, in Baker, V.R., Kochel, R.C., and Patton, P.C. eds., Flood geomorphology: New York, John Wiley and Sons, p. 393-402.

Webb, R.H., and Betancourt, J.L., 1990, The spatial and temporal distribution of radiocar- bon ages from packrat middens, in Betancourt, J.L., Van Devender, T.R., and Martin, P.S., eds., Fossil packrat middens-The last 40,000 years of biotic change: Tucson, Ariz., The University of Arizona Press, p. 85-102

1990, Climatic effects on flood frequency-An . example from southern Arizona, in Betancourt, J.L., and MacKay, A.M., eds., Proceedings of the Sixth Annual Pacific Climate (PACLIM) Workshop, March 5-8, 1989: California Department of Water Resources, Interagency Ecological Studies Program Technical Report 23, p. 61-66.

1992, Climatic variability and flood frequency of the Santa Cruz River, Pima County, Arizona: U.S. Geological Survey Water-Supply Paper 2379, 40 p.

Webb, R.H., and Bowers, J.E., 1993, Changes in frost frequency and desert vegetation assemblages in Grand Canyon, Arizona, in Redmond, K.T., ed., Proceedings of the Ninth Annual Pacific Climate (PACLIM) Workshop, April 21-24, 1992: California Department of Water Resources, Interagency Ecological Studies Program Technical Report 34, p. 71-82.

Webb, R.H., O'Connor, J.E., and Baker, V.R., 1988, Paleohydrologic reconstruction of flood frequency on the Escalante River, south-central Utah, in Baker, V.R., Kochel, R.C., and Patton, P.C., eds., Flood geomorphology: New York, John Wiley and Sons, p. 403-418.

Webb, R.H., Pringle, P.T., Reneau, S.L., and Rink, G.R., 1988, The 1984 Monument Creek debris flow-Implications for the formation of rapids on the Colorado River in Grand Canyon National Park: Geology, v. 16, p. 50-54.

Webb, R.H., Pringle, P.T., and Rink, G.R., 1989 , Debris flows in tributaries of the Colorado River in Grand Canyon National Park, Arizo- 


\section{GEOMORPHOLOGY AND SEDIMENT TRANSPORT}

na: U.S. Geological Survey Professional Paper $1492,39 \mathrm{p}$.

Webb, R.H., and Rathburn, S.L., 1989, Paleoflood hydrologic research in the southwestern United States: Transportation Research Board Record 1201, p. 9-21.

Webb, R.H., Smith, S.S., and McCord, V.A.S., 1991, Historic channel change of Kanab Creek, southern Utah and northern Arizona: Grand Canyon Natural History Association Monograph, no. 9, 91 p.

Webb, R.H., Steiger, J.W., and Newman, E.B., 1988, The effects of disturbance on desert vegetation in Death Valley National Monument, California: U.S. Geological Survey Bulletin 1793, 103 p. 


\section{GROUND-WATER CHEMISTRY}




\section{GROUND-WATER CHEMISTRY}

TITLE: $\quad$ Arid Regions Chmate and Chemistry (CR 82-207)

PERSONNEL: Larry V. Benson, Project Chief

Eva Brown, Secretary

Steven W. Hostetler, Hydrologist

ADDRESS: $\quad$ U.S. Geological Survey, 3215 Marine Street, Boulder, CO 80303

TELEPHONE: (303) 447-2505

PROBLEM: Few guidelines have been established for the quantitative characterization of past climates in terms of proxy-climate data obtained from paleolacustrine systems. The connection between astronomical forcing of climate and change in the energetics of hydrologic systems has yet to be established. In particular, the application of stable isotopes to an understanding of the timing and magnitude of past changes in the Great Basin terrestrial hydrologic cycle is in its infancy.

OBJECTIVE: Determination of: (1) the frequency and magnitude of change in the hydrologic cycle of the Great Basin, (2) the type and magnitude of change in the synoptic climate responsible for change in the hydrologic cycle, and (3) the cause of climatic change.

APPROACH: (1) Core closed-basin lakes such as Pyramid and Walker Lakes in Nevada; (2) analyze organic and inorganic materials (for example, oxygen-18) from lake-sediment cores in order to establish time-series proxy-records of change in lake size; (3) perform real-time studies of the behavior of oxygen-18 in the hydrologic system in order to establish the relation between oxygen-18, lake temperature, size, and climate; (4) apply oxygen-18/climate model to core data in order to establish quantitative record of climate change for the past few hundred thousand years; (5) develop record of lake-size change based on outcrop data; (6) compare core-based record of lake-size change with outcrop-based record of lake-size change.

PROGRESS: Stable-isotope analyses of a 75-meter core from the north end of the Pyramid Lake indicate that between 150,000 and 20;000 yr B.P. (years before present), Pyramid Lake was often an open system that spilled to one of three adjoining basins. Stable-isotope analyses of a 7-meter outcrop of lake sediment in the Mono Lake basin indicates that Mono Lake did not spill between 37,000 and 12,000 years before present (yr B.P.). In an ongoing study of the behavior of ${ }^{18} \mathrm{O}$ and ${ }^{2} \mathrm{H}$ in the Truckee River-Pyramid Lake system, we have established the relationship between change in hydrologic balance of the lake and its effect on 


\section{GROUND-WATER CHEMISTRY}

the spatial and temporal distribution of ${ }^{18} \mathrm{O}$. The behavior of ${ }^{18} \mathrm{O}$ has been successfully simulated using a coupled lake-thermal/isotope model. The behavior of ${ }^{13} \mathrm{C}$ in the surfacewater system continued to be monitored in an attempt to understand the effect of productivity and gas exchange on its fractionation. A 3-year study on the elevational distribution and sequence of formation of carbonates in the Pyramid Lake area has been completed. U-series and ${ }^{14} \mathrm{C}$ age determinations on carbonates from the large tufa mounds in Pyramid Lake basin indicate they were formed between 40,000 and 10,000 yr B.P.

\section{REPORTS PUBLISHED 1988-1993:}

Bartlein, P.J., Webb, T., III, and Hostetler, S.W., 1989, Climatology, in Hunter, R.L., and Mann, C.J., eds., Techniques for determining probabilities of events and processes affecting the performance of geologic repositories: Washington, D.C., U.S. Nuclear Regulatory Commission, p. 53-85.

1992, Climatology, in Hunter, R.L, and Mann, J., eds., Determining probabilities of geologic processes and events, monographs in mathematical geology: Oxford, United Kingdom, Oxford University Press, p. 99-122.

Bates, G.T., Giorgi, F., and Hostetler, S.W., 1993. Toward the simulation of the effects of the Great Lakes on regional climate: Monthly Weather Review, v. 121, no. 5, p. 13731387.

Benson, L.V., 1988, Preliminary paleolimnologic data for the Walker Lake subbasin, California and Nevada: U.S. Geological Survey WaterResources Investigations Report 87-4258, 50 p.

Benson, L.V., 1991, Timing of the last highstand of Lake Lahontan: Journal of Paleolimnology 5, p. 115-126.

Benson, L.V., 1993, Factors affecting ${ }^{14} \mathrm{C}$ ages of lacustrine carbonates-Timing and duration of the last highstand lake in the Lahontan basin: Quaternary Research, v. 39, 163-174.

Benson, L.V., Currey, D.R., Dorn, R.I., Lajoie, K.R., Oviatt, C.G., Robinson, S.W., Smith, G.I., and Stine, S., 1990, Chronology of expansion and contraction of four Great Basin lake systems during the past 35,000 years, in Meyers, P.A., and Benson, L.V., eds., Paleolakes and Paleo-oceans: Palaeogeography, Palaeoclimatology, Palaeoecology, v. 78, p. 241-286.

Benson, L. V., Currey, D., Lao, Y., and Hostetler, S., 1992, Lake-size variations in the Lahontan and Bonneville basins between 13,000 and $9,000{ }^{14} \mathrm{C}$ yr B.P.: Palaeogeography, Palaeoclimatology, Palaeoecology, v. 95, p. 19-32.

Benson, L.V., and Klieforth, H.K., 1988, Stable isotopes in precipitation and ground water in the Yucca Mountain region, southern Nevadapaleoclimatic implications, in Peterson, David, ed., Aspects of Climate Variability in the Pacific and the Western Americas: American Geophysical Union Monograph 55, p. 41-59.

Benson, L.V., Meyers, P.A., and Spencer, R.J., 1991. Change in the size of Walker Lake during the past 5000 years: Palaeogeography, Palaeoclimatology, Palaeoecology, v. 81, p. 189-214. 


\section{GROUND-WATER CHEMISTRY}

Benson, L.V., and Paillet, F.L., 1989, The use of total lake-surface area as an indicator of climatic change-Examples from the Lahontan basin: Quaternary Research, v. 32, p. 262275.

Hostetler, S.W., 1991, Simulation of lake ice and its effect on the late-Pleistocene evaporation rate of Lake Lahontan: Climate Dynamics, v. 6, p. 43-48.

1992, Analysis and modeling of long-term water temperature on the Steamboat Creek basin, Oregon-Implications for land use and fish habitat: Water Resources Bulletin, v. 27, no. 4, p. 637-647.

1993, Modeling the late-Pleistocene paleo hydrology of the Great Basin, in Proceedings of the U.S. Geological Survey Global Change Forum, Herndon, Va., March 18-20, 1991: U.S. Geological Survey Circular 1086, p. 90.

Hostetler, S.W., and Bartlein, P.J., 1990, Modeling climatically determined lake evaporation with application to simulating lake-level variations of Harney-Malheur Lake, Oregon: Water Resources Research, v. 26 , no. 10 , p. 26032612.

Hostetler, S.W., Bates, G.T., and Giorgi, F., 1993, Coupling of a lake model with a regional climate model: Journal of Geophysical Research, v. 98 , no. D3, p. 5045-5058.

1993, Coupling of a lake model with a highresolution climate model for climate-change studies, in Proceedings of the workshop on the Effects of Global Climate Change on Hydrology and Water Resources at the Catchment Scale, Japan-U.S. Committee on Hydrology, Water Resources and Global Climate Change: Tsukuba, Japan, Public Works Reserach Institute, p. 161-177.
Hostetler, S., and Benson, L.V., 1990, Paleoclimatic implications of the high stand of Lake Lahontan derived from models of evaporation and lake level: Climate Dynamics, v. 4, p. 207-217.

Hostetler, S.W., and Benson, L.V., 1993, Meteorological and water-temperature data for Pyramid Lake, Nevada, 1987-89: U.S. Geological Survey Open-File Report 92-W-309, 15 p.

Hostetler, S.W., and Giorgi, F., 1992, Use of a regional atmospheric model to simulate lakeatmosphere feedbacks associated with Pleistocene Lakes Lahontan and Bonneville: Climate Dynamics, v. 7, p. 39-44.

1993, Use of high-resolution climate model data in landscape-scale hydrologic models-A demonstration: Water Resources Research, v. 29 , no. 6 , p. 1685-1695.

Hostetler, S.W., and Varley, J., 1993, Preliminary results of simulating the thermal regime of Yellowstone Lake: Invited paper for a special issue of Park Science, v. 13, no. 1, p. 16.

McKinley, P.W., Long, M.P., and Benson, L.V., 1990. Chemical analyses of water from selected wells and springs in the Yucca Mountain area, Nevada, and southeastern California: U.S. Open-File Report 90-355, 47 p.

Meyers, P.A., and Benson, L.V., 1988, Sedimentary biomarker and isotopic indicators of the paleo-climatic history of the Walker Lake basin, western Nevada: Organic Geochemistry, v. 13 , p. $807-813$.

Noorishad, J., Carnahan, C.L., and Benson, L.V., 1989, Simulation of the fractionation of ${ }^{13} \mathrm{C}$ during nonequilibrium reactive solute transport in geologic systems-Formulation and example calculation: Water Resources Research, v. 25, p. 754-756. 


\section{GROUND-WATER CHEMISTRY}

Smith, G.I., Benson, L.V., and Currey, D.R., 1989, Quaternary Geology of the Great Basin, Inglewood, California to Salt Lake City, Utah, June 27-July 8, 1989: 28th International Geological Congress Field Trip Guidebook T117, 78 p. 


\section{GROUND-WATER CHEMISTRY}

TITLE: Geochemistry of Clay-Water Reactions (CR 82-276)

PERSONNEL: Dennis D. Eberl, Project Chief

Debra Litwin, Secretary

Howard M. May, Chemist

Tung-Ming Lai, Volunteer

ADDRESS: U.S. Geological Survey, P.O. Box 25046, MS 458, Denver, Federal Center, Denver, CO 80225

TELEPHONE: (303) 541-3028

PROBLEM: Clay minerals can influence the chemistry of ground water and other aqueous solutions through precipitation, dissolution, and ion-exchange reactions. An understanding of these reactions is crucial for predicting the behavior of toxic wastes in disposal areas. How do the various clays react with waters of varying composition at different temperatures and pressures? After the fundamentals of these processes are understood, how can they be applied to prediction, maintenance, and (or) improvement of water quality?

OBJECTIVE: (1) Develop a theory for ion exchange that would allow prediction of the exchange properties of a clay on the basis of clay's crystal chemistry; (2) gather basic information on clay-mineral structure and chemistry; and (3) try to understand the precipitation and alteration of clay minerals in natural and synthetic systems.

APPROACH: Test and develop theoretical models through laboratory experiments (for example, measurement of exchange isotherms with well-characterized clay minerals). Study clay-water reactions in natural systems in the field.

PROGRESS: The Management Systems Evaluation Areas (MSEA) site in Missouri is testing our slow-release $\mathrm{N}$-fertilizer in the field, comparing it to other slow-release systems. The preliminary results indicate that $\mathrm{N}$-release from our system is not slow enough, and that the product requires further development (for example, clay coatings in zeolite chips to further slow the release of urea). We also discovered and are patenting a slow-release P-fertilizer that uses low-grade P-rock (calcined Al-phosphates) and should give excellent results in tropical and sandy soils. This fertilizer can be used in conjunction with the slow-release $\mathrm{N}$-fertilizer. A previous invention of ours, a slow-release fertilizer that uses zeolite and apatite, is going to be sent up on the space shuttle by National Aeronautics and Space Administration (NASA) to test it for use as an artificial soil for space colonies. Our 


\section{GROUND-WATER CHEMISTRY}

laboratory research for these fertilizers is being carried out part time on a volunteer basis by Tung-Ming Lai, who has retired. The results of our fertilizer research were presented as an invited talk at the International Zeolite Conference in Boise in June 1993, and a paper was submitted for the conference volume.

Our project has developed a new theory about how shales react in sedimentary basins, and the paper was published in the January issue of Clays and Clay Minerals. This theory was developed when Eberl was a visiting scientist in Strasbourg during the spring of 1992 . We also applied a metallurgical X-ray technique (Warren-Averbach) to measuring the thickness of illite crystals, and a paper was written and accepted for publication. We published a paper on the effect of wetting and drying reactions on clay minerals, and continued these experiments with a visiting Israeli clay chemist (Lisa Heller-Kallai). We are developing the capability for quantitative mineral analysis by $\mathrm{X}$-ray diffraction, using the Rietveld technique, a technique that should be useful to many projects in the Survey, as well as other X-ray techniques with visiting Polish geologist Jan Srödon and Russian crystallographer Victor Dits. We continue development work with the Atomic Force Microscope (with Alex Blum) and Field Flow Fractionation (with Howard Taylor) to measure the particle sizes of clay minerals. We were awarded a research grant with Slovak scientist V. Sucha to study mixed-layer clays, but this money will be used in Slovakia, assuming that the Slovakian government upholds its share of the award.

Our project (May) is completing development of a high-precision dissolution calorimeter for determining or improving as-yet unknown or imprecise thermodynamic properties of clays, zeolites and other aquifer minerals. May also is developing and testing computerized, mobile water analysis laboratory vehicles for a USGS/NRP group and for the National Radioactive Waste Agency of Spain.

\section{REPORTS PUBLISHED 1988-1993:}

Barbarick, K.A., Eberl, D.D., and Lai, T.M., 1991, Pine Ridge zeolite and Fort Hall mill shale $P$ effects on sorghum-sudangrass: Technical Bulletin TB91-2, Department of Agronomy, Colo., Colorado State University, $47 \mathrm{p}$.

Barharick, K.A., Lai, T.M., and Eberl, D.D., 1988, Response of sorghum-sudangrass in soils amended with phosphate rock and NH4exchanged zeolite (clinoptilolite): Technical
Bulletin TB88-1, Department of Agronomy, Colorado State University, 62 p.

1990, Exchange fertilizer (phosphate rock plus ammonium-zeolite) effects on sorghum-sudangrass: Soil Science Society of America Journal, v. 54, p. 911-916.

Blum, A.E., and Eberl, D.D., 1992, Determination of clay particle thickness and morphology 


\section{GROUND-WATER CḦEMISTRY}

using scanning force microscopy, in Kharaka, Y.K., and Maest, A.S., eds., 7th International Symposium Water-Rock Interactio [Proceedings]: Rotterdam, A.A. Balkema, v. 1, p. 133-136.

Byler, D.M., Gerasinowicz, W.V., Stockette, V.M., and Eberl, D.D., 1991, Infrared spectroscopic examination of the interaction of area with the naturally occurring zeolite clinoptilolite: Microchemical Journal, v. 44, p. 130139.

Eberl, D.D., 1992, Slow-release nitrogen fertilizer and soil conditioner: U.S. Patent Application US 789,206, 15 April, 1992.

1992, Three zones for burial metamorphism, in Kharaka", Y.K., and Maest, A.S., 7th International Symposium on Water-Rock Interaction [Proceedings]: Rotterdam, A.A. Balkema, v. 2, p. 1165-1167.

1993, Three zones for illite formation during burial diagenesis and metamorphism: Clays and Clay Minerals, v. 41, p. 26-37.

1993, Zeo-agriculture: Small Mining International Bulletin, Numbers 5-6, p. 10.

Eberl, D.C., and Blum, A., 1993, Illite crystallite thickness by X-ray diffraction in Reynolds, R.C., Jr., and Walker, J.R., Clay Mineral Society workshop lectures, v. 5, A, p. 123154.

Eberl, D.D., and Srodon, J., 1988, Ostwald ripening and interparticle-diffraction effects for illite crystals: American Mineralogist, v. 73, p. 1335-1345.

Eberl, D.D. Srodon, J., Kralik, M., Taylor, B.E., and Peterman, Z.E., 1990, Ostwald ripening of clays and metamorphic minerals: Science, v. 248 , p. $474-477$.
Eberl, D.D., Srodon, J., Lee, M., and Nadeau, P.H., 1988, Sericite from the Silverton caldera, Colorado-Reply: American Mineralogist, v. 73, p. $1475-1477$.

Eberl, D.D., and Velde, B., 1992, Synthesis of illite/smectite from smectite at Earth surface temperatures and high $\mathrm{pH}$ : Clay Minerals, v. 28 , p. $49-60$.

Eberl, D.D., Velde, B., and McCormick, T., 1993, Synthesis of illite-smectite from smectite at Earth surface temperatures and high $\mathrm{pH}$ : Clay Minerals, v. 28, p. 49-60.

May, H., 1992, The hydrolysis of aluminum-Conflicting models and the interpretation of aluminum geochemistry in Kharaka, Y.K., and Maest, A.S., 7th International Symposium on Water-Rock Interaction, Park City, Utah: Rotterdam, A.A. Balkema, v. 1, p. 13-21.

May, H.M., and Nordstrom, D.K., 1991, Assessing the solubilities and reaction kinetics of aluminous minerals in soils, in Ulrich, B., and Sumner, eds., Soil Acidity: Berlin, Springer Verlag, p. 123-148.

Nordstrom, D.K., and May, H.M., 1989, Aqueous equilibrium data for mononuclear aluminum species, in Sposito, G., ed.: The environmental chemistry of aluminum: Raton, Fla., CRC Press, chap. 2, p. 27-53.

Nordstrom, D.K., Plummer, L.N., Langmuir, D.L., Busenberg, E., May, H.M., Jones, B.F., and Parkhurst, D.L., 1990, Revised chemical equilibrium data for major watermineral reactions and their limitations, in Melchior, D.C., and Bassett, R.L., eds., Chemical modeling in aqueous systems, II: American Chemical Society Symposium Series, v. 416, chap. 31 , p. $398-413$. 


\section{GROUND-WATER CHEMISTRY}

Sucha, V., and Eberl, D.D., 1992, Postsedimentarna premena sedimentov permu severneho gemerika a hronika Zapadnych Karpat (Postsedimentary alteration of the Permian sediments in the northern Gemericum and Hronicum Units, West Carpathians): Mineralia Slovaca, v. 24 , p. $399-405$. 


\title{
GROUND-WATER CHEMISTRY
}

TITLE: $\quad$ Environmental Dynamics of Persistent Organic Compounds (CR 83-283)

\author{
PERSONNEL: Cary T. Chiou, Project Chief \\ Cathy M. Rubin, Secretary \\ Daniel E. Kile, Research Chemist \\ David W. Rutherford, Chemist
}

ADDRESS: U.S. Geological Survey, P.O. Box 25046, MS 408, Denver, Federal Center, Denver, CO 80225

TELEPHONE: (303) 467-8260

PROBLEM: Many persistent organic compounds are hazardous to human and ecological health. The transport characteristics of these compounds across environmental interfaces are strongly influenced by adsorption and partition interactions with the individual phases. Quantification of process rates and partition constants of organic pollutants in air, water, soil, and biota is an important step in defining the level of organic contaminants in environmental systems and their potential effects on environmental quality.

OBJECTIVE: Delineate and quantify processes affecting the movement and distribution of persistent organic compounds in hydrogeologic systems. (1) Determine the sorptive capacity of soil and sediment for organic compounds that are in air and water; (2) identify the roles of soil and sediment organic matter, mineral components, and moisture in sorption of organic compounds; (3) establish the physical basis of bioconcentration and lipophilicity of organic compounds; and (4) characterize the effect of dissolved organic matter on the solubility and mobility of organic contaminants in natural water.

APPROACH: Make laboratory measurements to determine the sorption of various organic compounds from water, analyzing data in terms of the properties of the compounds and soil constituents. Study sorption from the vapor phase to determine the effect of soil moisture. Make measurements to determine the alteration of the apparent water solubility of solutes by dissolved organic matter from various sources. Measure the partition coefficients of solutes in solvent and lipid-water systems to obtain information related to bioconcentration. Collaborate with field researchers to relate laboratory findings with field data obtained from organic-contamination sites.

PROGRESS: To characterize the various sorptive interactions of vapors with natural solids, the isotherms of nonpolar nitrogen $\left(\mathrm{N}_{2}\right)$ and polar ethylene glycol monoethyl ether (EGME) 


\section{GROUND-WATER CHEMISTRY}

vapors on dry soils, clays, and mineral oxides were measured. An analytical procedure was established to quantify effects by surface adsorption, partition in soil organic matter (SOM), and solvation with clay cations. For such samples as sand, aluminum oxide, kaolinite, hematite, and iron oxide that are free of organic impurity and solvating clays, the polar vapor (EGME) uptake can be accounted for solely by surface adsorption using the $\mathrm{N}_{2}$ adsorption data and the BET equation. In this case, the EGME and $\mathrm{N}_{2}$ sorption data lead to consistent surface areas of the samples. For other solids (soil, peat, illite, and montmorillonite), the total polar vapor uptake exceeds the surface adsorption capacity from a moderate to a large extent, depending on the sample; the excess amount results from vapor solubility in SOM and (or) from the cation solvation of the solvating clay (such as montmorillonite and to a lesser extent illite). The surface area determination method for soils and minerals in soil science based on the amount of polar solvent (EGME) retention (assuming monolayer formation of the solvent) may give seriously erroneous results due to the high solubility of polar solvents in SOM and their strong solvation of clay cations. Accordingly, the concept of "internal surface area" adopted in soil science to denote the difference between the "total surface area" of a sample by the solvent retention method and the (external) surface area by standard BET $\left(\mathrm{N}_{2}\right)$ method has a trivial physical meaning because it requires a series of ad hoc explanations to fit each new set of data. On the other hand, for organic-free minerals, the use of EGME and $\mathrm{N}_{2}$ isotherms provides a rapid analysis of the solvating-clay content in the sample. In a cooperative work with Mike Reddy, this method was applied to determine the solvating-clay content in welded tuff.

Because the cation solvation capacity of a swelling clay would depend on the type of exchangeable cation(s), we prepared a series of montmorillonite clays with different exchanged inorganic and organic cations and studied their vapor uptakes of $\mathrm{N}_{2}$ and EGME. Our isotherm method allows accurate determinations of the specific stoichiometric relations of polar solvent-cation solvation complexes as a function of relative pressure. No other empirical methods give the same kind of accuracy. The work is still in progress.

In another on-going study, the partition (sorption) coefficients of 1,2-dichlorobenzene and carbon tetrachloride between soil/sediment and water are being determined on a wide variety of samples from the United States and China, including those from the Mississippi River, Ohio River, Illinois River, Yellow River, and Yangtze River. The data obtained so far show a clear trend that nonpolar organic pollutants partition (sorb) more effectively to sediment organic matter than to soil organic matter. The higher partition coefficient with sediment organic matter is ascribed to the lower polarity of sediment organic matter, which likely results from the selective release of polar organic components in soil when the soil is carried 


\section{GROUND-WATER CHEMISTRY}

into aquatic environments. Further investigations are planned to substantiate the finding in order to give a better account of organic solute interactions with soils and sediments.

\section{REPORTS PUBLISHED 1988-1993:}

Boyd, S.A., Mortland, M.M., and Chiou, C.T., 1988, Sorption characteristics of organic compounds on hexadecyltrimethylammonium-smectite: Soil Science Society of America Journal, v. 52 , p. $652-657$.

Chin, Y.P., Weber, W.J., Jr., and Chiou, C.T., 1991, A thermodynamic partition model for binding of nonionic organic compounds by organic colloids and implications for their sorption to soils and sediment, in Baker, R.A., ed., Organic substances and sediments in water, v. I: Chelsea, Michigan, Lewis Publishers, p. 251-273.

Chiou, C.T., 1989, Partition and adsorption on soil and mobility of organic pollutants and pesticides, in Gerstl, Z., Chen, Y., Mingelgrin, U., and Yaron, B., eds., Toxic organic chemicals in porous media: Berlin, Springer-Verlag, p. $163-175$.

1989, Theoretical considerations of the partition uptake of nonionic organic compounds by soil organic matter, in Sawhney, B.J., and Brown, K., eds., Reactions and movement of organic chemicals in soils: Madison, Wis., Soil Science Society of America, p. 1-29.

1990, roles of organic matter, minerals and moisture in sorption of nonionic compounds and pesticides by soil, in MacCarthy, P., Clapp, C.E., Malcolm, R.L., and Bloom, P.R., eds., Humic substances in soil and crop sciences-Selected readings: Madison, Wis., American Society of Agronomy and Soil Science Society of America, p. 111-160.
Chiou, C.T., Kile, D.E., and Malcolm, R.L., 1988, Sorption of vapors of some organic liquids by soil humic acid and its relation to partitioning of organic compounds in soil organic matter: Environmental Science and Technology, v. 22, p. 298-303.

Chiou, C.T. Kile, D.E., and Rutherford, D.W., 1991, The neutral oil in commercial linear alkylbenzenesulfonate and its impact on organic solute solubility in water: Environmental Science and Technology, v. 25, p. 660-665.

Chiou, C.T., Lee, J.F., and Boyd, S.A., 1990, The surface area of soil organic matter: Environmental Science and Technology, v. 24, p. 1164-1166.

1992, Reply to comment on The surface area of soil organic matter: Environmental Science and Technology, v. 25, p. 404-406.

Chiou, C.T., and Leenheer, J.A., 1988, Properties of Calcasieu River and Suwannee River humic substances that affect contaminant solubility enhancement, in Mallard, G.E., ed., U.S. Geological Survey Toxic Substances Hydrology Program-Surface water contamina tionProceedings of the technical meeting, Denver, Colo., February 2-4, 1987: U.S. Geological Survey Open-File Report 87-764, p. 81-84.

Chiou, C.T., and Manes, M., 1990, Comment on Temperature dependence of the aqueous solubilities of highly chlorinated dibenzo-p-dioxins: Environmental Science and Technology, v. 24, p. $1755-1756$. 


\section{GROUND-WATER CHEMISTRY}

Chiou, C.T., Rutherford, D.W., and Manes, M., 1993, Sorption of $\mathrm{N}_{2}$ and EGME vapors on some soils, clays, and mineral oxides and determination of sample surface areas by use of sorption data: Environmental Science and Technology, v. 27, p. 1587-1594.

Kile, D.E., and Chiou, C.T., 1989, Water solubility enhancements of nonionic organic contaminants by dissolved humic substances, in Suffet, I.H., and MacCarthy, P., eds., Influence of aquatic humic substances on the fate and treatment of pollutants: Washington D.C., Advances in Chemistry Series, American Chemical Society, v. 219, p. 131-157.

1989, Water solubility enhancements of DDT and trichlorobenzene by some surfactants below and above the critical micelle concentration: Environmental Science and Technology, v. 23 , p. $932-838$.

1991, The effect of surfactants and emulsions on water solubility of organic contaminants, in Mallard, G.E., and Aronson, D.A., eds., U.S. Geological Survey Toxic Substances Hydrology Program-Proceedings of the technical meeting, Monterey, Calif., March 11-15, 1991: U.S. Geological Survey Water-Resources Investigations Report 91-4034, p. 562-567.

Kile, D.E., Chiou, C.T., and Brinton, T.I., 189, Interactions of organic contaminants with fulvic and humic acids from the Suwamee River and other Humic substances in aquatic systems, with inferences to the structures of humic molecules, in Averett, R.C., Leenheer, J.A., McKnight, D.M., and Thorn, K.A., eds., Humic substances in the Suwannee River, Georgia and Florida-Interactions, properties, and proposed structures: U.S. Geological Survey Open-File Report 87-55, p. 37-57.

Kile, D.E., Chiou, C.T., and Helburn, R.S., 1990 , Effect of some petroleum sulfonate surfactants on the apparent water solubility of organic compounds: Environmental Science and Technology, v. 23, p. 205-208.

Lee, J.F., Mortland, M.M., Boyd, S.A., and Chiou, C.T., 1989, Shape-selective adsorption of aromatic molecules by tetramethylammonium-smectite: Journal of Chemical Society, Faraday Transactions I, v. 85, p. 2953-2962.

Lee, J.F., Mortland, M.M., Chiou, C.T., Kile, D.E., and Boyd, S.A., 1990, Adsorption of benzene, toluene and xylene by two tetramethylammonium-smecties having different charge densities: Clays and Clay Minerals, v. 38, no. 2, p. 113-120.

Pereira, W.E., Rostad, C.E., Chiou, C.T., 1988, Contamination of estuarine sediments, water and biota by halogenated organic compounds, Calcasieu River Estuary, Louisiana, in Mallard, G.E., ed., U.S. Geological Survey Toxics Substance Hydrology ProgramSurface-Water Contamination, Proceedings of the technical meeting, Denver, Colo., February 2-4, 1987: U.S. Geological Survey OpenFile Report 87-764, p. 87-97.

Pereira, W.E., Rostad, C.E., Chiou, C.T., Brinton, T.I., Barber, L.B., Demcheck, D., and Demas, C.R., 1988, Contamination of estuarine water, biota and sediment by haloarenesA field study: Environmental Science and Technology, v. 22, p. 772-778.

Rutherford, D.W., and Chiou, C.T., 1992, Effect of water saturation in soil organic matter on the partition of organic compounds: Environmental Science and Technology, v. 26, p. 965-970.

Rutherford, D.W., Chiou, C.T., and Kile, D.E., 1992, Influence of soil organic matter composition on the partition of organic compounds: 


\section{GROUND-WATER CHEMISTRY}

Environmental Science and Technology, v. 26, p. 336-340.

Smith, J.A., Chiou, C.T., Kammer, J.A., and Kile, D.E., 1990, Effect of soil moisture on the sorption of trichloroethene vapor to vadose-zone soil at Picatinny Arsenal, New Jersey: Environmental Science and Technology, v. 24, p. $676-683$.

Smith, J.A., Jaffe, P.R., and Chiou, C.T., 1990, Effect of ten quaternary ammonium cations on tetrachloromethane sorption to clay from water: Environmental Science and Technology, v. 24, p. $1167-1172$.

Smith, J.A. Witkowski, P.J., and Chiou, C.T., 1988, Partition of nonionic organic compounds in aquatic systems: Reviews of Environmental Contamination and Toxicology, v. 103, p. 127-151. 


\section{GROUND-WATER CHEMISTRY}

TITLE: $\quad$ Reaction-Transport Modeling in Ground-Water systems (CR 89-318)

PERSONNEL: David L. Parkhurst, Project Chief

Jeanea Shown, Secretary

ADDRESS: U.S. Geological Survey, P.O. Box 25046, MS 418, Denver, Federal Center, Denver, CO 80225

TELEPHONE: (303) 236-5098

PROBLEM: In order to address urgent problems in contaminant migration and to understand many natural geologic processes, we need to be able to model the movement of substances undergoing chemical reactions in ground-water systems. Predictive modềs will be used to assess the risks of nuclear- and chemical-waste disposal, to analyze contaminant migration from pollution sources, and to determine the susceptibility of aquifers to contamination. Models also are needed to investigate many rock-water interactions, such as the formation of ore deposits and the evolution of ground-water chemistry.

OBJECTIVE: The long-range goals of the project are (1) to develop reaction-transport models with varying levels of complexity and data requirements, providing guidelines for the appropriate application of these models given field conditions and limited resources; (2) to incorporate the effects of surface-chemistry phenomena into reaction-transport modeling; (3) to develop methods to identify and quantify important chemical and biological reactions affecting transport of inorganic and organic substances; and (4) to compile estimates of reaction rates and reaction-rate laws for chemical and biological reactions.

APPROACH: The fundamental approach of the project is to develop computer models describing the movement of chemical substances in reacting systems that can be applied to field and experimental data. The project will begin by enhancing and streamlining geochemical-reaction models to make them suitable for inclusion in reaction-transport codes while studying the available literature on solute transport and reaction modeling. Two models will then be developed to test the pure differential equation approach and the coupled reaction and transport approach.

PROGRESS: A Water-Supply Paper for the central Oklahoma National Water-Quality Assessment (NAWQA) project received Director's approval and is in press. The paper describes one of the first times a ground-water model has been calibrated using carbon-14 


\section{GROUND-WATER CHEMISTRY}

dates of ground-water age. The paper presents an analysis of the important geochemical reactions occurring in the aquifer and the rates and directions of ground-water flow. A chapter reviewing the state of geochemical modeling has been published in "Regional Ground-Water Quality" (Alley, 1993).

Significant progress has been made in developing a replacement for the geochemical reaction-path model, PHREEQE. The new model is capable of speciation and mineral-equilibration calculations and these functions will be taught in this year's geochemistry training course. The new model will ultimately be coupled to a transport model, which will have the capability of modeling water-rock interactions in flowing ground-water systems.

REPORTS PUBLISHED 1988-1993:

Glynn, Pierre D., and Parkhurst, D.L., 1992, Modeling non-ideal solid-solution aqueous-solution reactions in mass-transfer computer codes, in Kharaka, Y.K., and Maest, A.S., eds., 7th International Symposium on WaterRock Interaction, Park City, Utah [Proceedings]: Rotterdam, A.A. Balkema, v. 1, p. 175-179.

Nordstrom, D.K., Plummer, L.N., Langmuir, Donald, Busenberg, Eurybiades, May, H.M., Jones, B.F., and Parkhurst, D.L., 1990, Revised chemical equilibrium data for major water-mineral reactions and their limitations, in Bassett, R.L., and Melchior, D., eds., Chemical modeling in aqueous systems II: Washington, D.C., American Chemical Society Symposium Series 416 , p. 398-413.

Parkhurst, D.L., 1990, Ion-association models and mean-activity coefficients of various salts, in Bassett, R.L., and Melchior, D., eds., Chemical modeling in aqueous systems II: Washington D.C., American Chemical Society Symposium Series 416, p. 30-43.

1992, The geochemical evolution of ground waters in the Central Oklahoma aquifer, in
Christenson, Scott, and Carpenter, Lyn, eds., Ground-water quality of the central Oklahoma (Garber-Wellington) aquifer conference, Oklahoma City, Okla., February 20, 1992, Proceedings: U.S. Geological Survey Open-File Report 92-116, p. 7-9.

Parkhurst, D.L., Christenson, Scott, and Breit, G.N., in press, Ground-water quality assessment of the central Oklahoma aquifer, Oklahoma-Geochemical and geohydrologic investigations: U.S. Geological Survey Open-File Report 92-642 (pending publication as WaterSupply Paper 2357-C).

Parkhurst, D.L., Christenson, S.C., and Schlottmann, J.L., 1989, Ground-water quality assessment of the central Oklahoma aquifer, Oklahoma-Analysis of available water-quality data through 1987: U.S. Geological Survey Open-File Report 88-728, 80 p. (Publication pending as Water-Supply Paper 2357B.)

Parkhurst, D.L., and Plummer, L.N., 1993, Geochemical models, in William Alley, ed., Regional ground-water quality: New York, Van Nostrand Reinhold, chap. 9, p. 199-225. 


\section{GROUND-WATER CHEMISTRY}

Plummer, L.N., and Parkhurst, D.L., 1990, Geochemical calculations in brines-Application of the Pitzer model to PHREEQE, in Bassett,

R.L., and Melchior, D., eds., Chemical modeling in aqueous systems II: Washington,

D.C., American Chemical Society Symposium Series 416, p. 128-137.

Plummer, L.N., Parkhurst, D.L., Fleming, G.W., and Dunkle, S.A., 1988, A computer program incorporating Pitzer's equations for calculation of geochemical reactions in brines: U.S. Geological Survey Water-Resources Investigations Report 88-4153, 310 p.

Plummer, L.N., Prestemon, E.C., and Parkhurst, D.L., 1991, An interactive code (NETPATH) for modeling net geochemical reactions along a flow path: U.S. Geological Survey Water-Resources Investigations Report 91-4087, 227 p.

Plummer, L. Niel, Prestemon, Eric C., and Parkhurst, David L., 1992, NETPATH-An interactive code for interpreting NET geochemical reactions from chemical and isotopic data along a flow PATH, in Kharaka, Y.K., and Maest, A.S., eds., 7th International Symposium on Water-Rock Interaction, Park City, Utah [Proceedings]: Rotterdam, Balkema, p. 239-242. 


\section{GROUND-WATER CHEMISTRY}

TITLE: $\quad$ Chemical Modeling and Thermodynamic Data Evaluation of Major and Trace Elements in Acid Mine Waters and Ground Waters (CR 92-326 formerly WR 75-128)

PERSONNEL: Darrell K. Nordstrom, Project Chief

Betty L. Callahan, Secretary

Kirkwood M. Cunningham, Research Chemist James W. Ball, Chemist

Heidi Koehler, Office Automation Clerk

ADDRESS: $\quad$ U.S. Geological Survey, 3215 Marine Street, Boulder, CO 80303

TELEPHONE: (303) 541-3037

PROBLEM: Aqueous chemical models have become popular tools for the interpretation of natural water chemistry. Unfortunately, these models have deficiencies because of (1) incorrect or inconsistent thermodynamic data, (2) invalid assumptions regarding the equilibrium state, (3) inappropriate or unvalidated corrections for nonideality, (4) inadequate expressions for temperature dependence, (5) unvalidated limitations for ionic strength, composition and temperature, and (6) lack of data on solid solution solubility. The plethora of models and databases has prompted federal agencies, especially hazardous waste and nuclear waste managers, to request geochemical code validation. Acid mine waters are a major source of water pollution and provide one of the best challenges to the application of trace element speciation models.

OBJECTIVE: Develop, test, evaluate and make field applications of chemical models for equilibrium speciation and mass transfer of major and trace constituents in acid mine waters and ground waters.

APPROACH: (1) Compile and evaluate physical and chemical data for individual constituents and for reaction equilibria pertinent to natural waters. (2) Test applicability of current models to interpret natural water chemistry in acid mine waters and ground waters in field situations. (3) Identify limitations of current models in terms of ionic strength, composition, temperature and inhibitions to equilibrium. (4) Develop a chemical model based on mean activity coefficient data and reliable reaction equilibria to evaluate relevant chemical reactions in natural waters over a wide range of ionic strength. (5) Test the equilibrium assumption of current or new models against field data where both water and mineralogical analyses can be obtained. (6) Measure mineral solubilities or other reaction equilibria in the lab or in the field where necessary data are lacking from the literature. 


\section{GROUND-WATER CHEMISTRY}

PROGRESS: (1) Design and construction of mobile lab unit for the Spanish Nuclear Waste Management Agency is nearly completed and it has become a high-profile aspect of their radioactive waste research program. (2) In collaboration with Martin Schoonen, a geochemist from SUNY-Stony Brook, and with Pieter Visscher, a microbiologist from University of Miami, we have determined thiosulfate concentrations in ground-water springs and drainage. It has formed from the oxidation of $\mathrm{H}_{2} \mathrm{~S}$ abiotically even though thiosulfate-utilizing microbes are present. This work could only have been accomplished with our mobile lab truck. (3) Work is beginning on the characterization of sediments formed by the precipitation of metals from acid mine drainage upon neutralization by the Sacramento River, the receiving waters for drainage from the Iron Mountain Superfund site. (4) Evaluation of the chemical model in WATEQ4F has begun with a comparison of calculated and measured activity coefficients.

\section{REPORTS PUBLISHED 1988-1993:}

Alpers, C.N., and Nordstrom, D.K., 1990, Stoichiometry of mineral reactions from mass balance computations for acid mine waters, Iron Mountain, California, in Gadsby, J.W., Malick, J.A., and Day, S.J., eds., Acid mine drainage-Designing for closure: Vancouver, B.C., BiTech Publishers Ltd, p. 13-21.

1991, Geochemical evolution of extremely acid mine waters at Iron Mountain, California-Are there any lower limits to $\mathrm{pH}$ ?: Second International Conference on the Abatement of Acidic Drainage, Mine Environment Neutralization Drainage (MEND), Montreal, Canada, v. 2, p. 321-342.

Alpers, C.N., Nordstrom, D.K., and Ball, J.W., 1989 , Solubility of jarosite solid solutions precipitated from acid mine waters, Iron Mountain, California, U.S.A.: Sciences Geologiques Bulletin no. 42, p. 281-298.

Alpers, C.N., Nordstrom, D.K., and Burchard, J.M., 1992, Compilation and interpretation of water quality and discharge data for acid mine waters at Iron Mountain, Shasta County, California, 1940-91: U.S. Geological Survey
Water-Resources Investigations Report, 91$4160,173 \mathrm{p}$.

Alpers, C.N., Rye, R.O., Nordstrom, D.K., White, L.D., and King, B.-S., 1992, Chemical, crystallographic and isotopic properties of alunite and jarosite from acid hypersaline Australian lakes: Chemical Geology, v. 96, p. 203-226.

Andrews, J.N., Fontes, J.-C., Fritz, P., and Nordstrom, D. K., 1988, Hydrochemical assessment of crystalline rock for radioactive waste disposal-The Stripa experience: Stripa Project Technical Report no. 88-05, 26 p.

Ball, J.W., and Nordstrom, D.K., 1989, Final revised analyses of major and trace elements from acid mine waters in the Leviathan Mine drainage basin, California and NevadaOctober 1981 to October 1982: U.S. Geological Survey Water-Resources Investigations Report 89-4138, 46 p.

1991, User's manual for WATEQ4F with revised thermodynamic data base and test cases for calculating speciation of major, trace and 


\section{GROUND-WATER CHEMISTRY}

redox elements in natural water: U.S. Geological Survey Open-File Report 91-183, 185 p.

Ball, J.W., Parks, G.A., Haas, J.L., Jr., and Nordstrom, D.K., 1988, A personal computer version of PHAS20, a program for the simultaneous multiple regression of thermochemical data: U.S. Geological Survey Open-File Report 88-489A, 119 p. (OFR 88-489B is diskette of program).

Cross, J.E., Haworth, A., Lichtner, P.C., Mackenzie, A.B., Moreno, L., Neretnieks, I., Nordstrom, D.K., Read, D., Romero, L., Scott, R.D., Sharland, S.M., and Tweed, C.J., 1991, Testing models of redox front migration and geochemistry at the Osamu Utsumi mine and Morro de Ferro analogue study sites, Pocos de Caldas, Brazil: NAGRA Techechnical Report NTB 90-21, 79 p.

Kwong, Y.T.K.J., and Nordstrom, D.K., 1989, Copper-arsenic mobilization and attenuation in an acid mine drainage environment: International Water-Rock Interaction Symposium, 6th, Malvern, United Kingdom [Proceedings], p. 397-399.

Maest, A.S., Pasilis, S.P., Miller, L.G., and Nordstrom, D.K., 1992, Redox geochemistry of arsenic and iron in Mono Lake, California, U.S.A., in Kharaka, Y.K., and Maest, A.S., eds., 7th International Symposium on WaterRock Interaction, July 13-18, Park City, Utah [Proceedings]: Rotterdam, A.A. Balkema, p. 507-511.

May, H.M., and Nordstrom, D.K., 1991, Assessing the solubilities and reaction kinetics of aluminous minerals in soils, in Ulrich, B., and Sumner, M.E., eds., Soil Acidity: Berlin, Germany, Springer-Verlag, p. 125-148.

Nordstrom, D.K., 1988, Book Review, Coupled processes associated with nuclear waste reposi- tories, Tsang, C.-F., ed.: Geochimica et Cosmochimica Acta, v. 52, p. 2185.

1989, Application of a cation-exchange massbalance model to the interpretation of saline groundwater chemistry evolved from Holocene seawater entrapped in rapakivi granite at Hastholmen, Finland: International Water-Rock Interaction Symposium, 6th, Malvern, United Kingdom [Proceedings], p. 521-523.

1991, Chemical modeling of acid mine waters in the western United States, in Mallard, G.E., and Aronson, D.A., eds., U.S. Geological Survey Toxic Substances Hydrology Program-Proceedings of the technical meeting, Monterey, Calif., March 11-15, 1991: U.S. Geological Survey Water-Resources Investigations Report 91-4034, p. 534-538.

Nordstrom, D.K., and Alpers, C.N., 1991, Geochemical evaluation of acid mine waters at Iron Mountain, California, 1990: U.S. Geological Survey Administrative Report, 36 p.

Nordstrom, D.K., and Ball, J.W., 1989, Mineral saturation states in natural waters and their sensitivity to thermodynamic and analytical errors: Sciences Geologiques Bulletin, no. 42, p. 269-280.

Nordstrom, D.K., Ball, J.W., Donahoe, R.J., and Whittemore, D., 1989, Groundwater chemistry and water-rock interactions at Stripa: Geochimica et Cosmochimica Acta, v. 53, p. 17271740.

Nordstrom, D.K., Burchard, J.M., and Alpers, C.N., 1990, The production and variability of acid mine drainage at Iron Mountain, California, in Gadsby, J.W., Malick, J. A., and Day, S.J., eds., Acid mine drainage--Designing for closure: Vancouver, B.C., BiTech Publishers, Ltd, 13-21. 


\section{GROUND-WATER CHEMISTRY}

Nordstrom, D.K., Lindblom, S., Donahoe, R.J., and Barton, C.C., 1989, Fluid inclusions in the Stripa Granite and their possible influence on the groundwater chemistry: Geochimica et Cosmochimica Acta, v. 53, 1741-1756.

Nordstrom, D.K., and May, H.M., 1989, Aqueous equilibrium data for mononuclear aluminum species, in Sposito, G., ed., The environmental chemistry of aluminum: Boca Raton, Fla., CRC Press, chap. 2, p. 27-53.

Nordstrom, D.K., McNutt, R.H., Puigdomenech, I., Smellie, J.A.T., and Wolf, M., 1992, Groundwater chemistry and geochemical modeling of water-rock interactions at the Osamu Utsumi mine and the Morro do Ferro analogue study sites, Pocos de Caldas, Minas Gerais, Brazil: Journal of Geochemical Exploration, v. 45 , p. 249-287.

Nordstrom, D.K., Olsson, T. Carlsson, L., and Fritz, P., 1989, Introduction to the hydrogeochemical investigations within the International Stripa Project: Geochimica et Cosmochimica Acta, v. 53, 1717-1726.

Nordstrom, D.K., Plummer, L.N., Langmuir, D., Busenberg, E., May, H.M., Jones, B.F., and Parkhurst, D.L., 1990, Revised chemical equilibrium data for water-mineral reactions and their limitations, in Bassett, R.L., and Melchior, D.,eds., Chemical modeling in aqueous systems II: American Chemical Society Symposium Series 416, chap. 31, p. 398413.

Nordstrom, D.K., Puigdomenech, I., and McNutt, R.H., 1990, Geochemical modeling of waterrock interactions at the Osamu Utsumi mine and Morro de Ferro analogue study sites, Pocos de Caldas, Brazil: NAGRA Technical Report, NTB 90-23, 33 p.
Nordstrom, D.K., Smellie, J.A.T., and Wolf, M., 1990, Chemical and isotopic composition of groundwaters and their seasonal variability at the Osamu Utsumi mine and Morro de Ferro analogue study sties, Pocos de Caldas, Brazil: NAGRA Techical Report NTB 90-24, 111 p.

Puigdomenech, I., and Nordstrom, D.K., 1987, Geochemical interpretation of groundwaters from Finnsjonn, Sweden: SKB Technical Report no. $87-15,36 \mathrm{p}$.

Stipp, S.L., Parks, G.A., Nordstrom, D.K., and Leckie, J.O., 1993, Solubility product constant and thermodynamic properties for synthetic otavite, $\mathrm{CdCO}_{3}(\mathrm{~s})$, and aqueous association constants for the $\mathrm{Cd}(\mathrm{II})-\mathrm{CO}_{2}-\mathrm{H}_{2} \mathrm{O}$ system: Geochimica et Cosmochimica Acta, v. 57, p. 2699-2713.

Waber, Niklaus, and Nordstrom, D.K., 1992, Geochemical modeling of granitic ground waters at the Stripa site (Sweden) using a mass balance approach, in Kharaka, Y.K. and Maest, A.S. eds., 7th International Symposium on WaterRock Interaction, July 13-18, Park City, Utah [Proceedings]: Rotterdam, A.A. Balkema, p. 243-246.

Wanty, R.C., and Nordstrom, D.K., 1993, Natural radionuclides, in Alley, W.M., ed., Regional Ground-Water Studies: New York, Van Nostrand Reinhold, p. 423-441. 


\section{GROUND-WATER CHEMISTR'Y}

TITLE: $\quad$ Chemical Models of Natural Systems (CR 79-336 formerly NR 79-093)

PERSONNEL: Donald C. Thorstenson, Project Chief

Jeanea Shown, Secretary

Herbert Haas, Hydrologist, Desert Research Institute, Las Vegas, NV

ADDRESS: U.S. Geological Survey, P.O. Box 25046, MS 421, Denver Federal Center, Denver, CO 80225

TELEPHONE: (303) 236-6229

PROBLEM: The increasing need for understanding the effects of human activity on the chemistry of natural systems requires a continually increasing degree of sophistication in the models used to describe the processes through which these effects occur. Such models include thermodynamic and (or) kinetic models of aqueous speciation, the chemistry of dissolved gases, gaseous and aqueous diffusion, transport of constituents across interfaces, redox processes, mineral-water interactions, the chemistry of anthropogenic inputs to natural systems, and isotope effects associated with these processes.

OBJECTIVE: (1) Identify the factors influencing the reactions and transport of solutes in natural waters; (2) evaluate reactions and transport processes for volatile constituents in unsaturated zones; (3) identify processes occurring at the interface of the saturated and unsaturated zones (the capillary fringe); and (4) investigate the application of isotope effects as a tool for understanding these processes.

APPROACH: (1) Conduct field studies at sites selected for investigation of particular processes; (2) analyze gaseous and (or) dissolved constituents (and their isotopes) as needed; (3) develop theoretical reaction and (or) transport models for specific processes under investigation; and (4) apply these theoretical models to natural systems.

PROGRESS: Gas samples were collected from shallow boreholes in Jackass Flats, on the Nevada Test Site, and near Beatty, Nevada. The samples were analyzed for carbon dioxide and methane content, and for the carbon isotope signature of the carbon dioxide. The carbon-14 content of gases from these alluvial sites is significantly lower than the carbon-14 content of carbon dioxide in gases from equivalent shallow depths in the open blowing boreholes at Yucca Mountain crest. The changes with depth of the carbon isotope signatures from the shallow gases at the alluvial sites suggest at least some reaction with soil carbonate minerals. The absence of similar chemical and isotopic changes in the gases exiting the open 


\section{GROUND-WATER CHEMISTRY}

boreholes at Yucca Mountain implies that the gases at Yucca Mountain are advecting through the top 100 meters of the mountain with little or no reaction with the carbonate minerals that are present in the fractured tuffs of Yucca Mountain. In the deeper Topopah Spring tuffs at Yucca Mountain, the carbon-14 content of carbon dioxide decreases systematically with depth. Preliminary steady state transport models show that the depth distribution of carbon-14 can be produced by a combination of diffusive transport and radioactive decay. Thus, there may be little or no advective transport of gases in the deeper portions of Yucca Mountain.

\section{REPORTS PUBLISHED 1988-1993:}

Striegl, R.G., McConnaughey, T.A., Thorstenson, D.C., Weeks, E.P., and Woodward, J.C., 1992, Consumption of Atmospheric methane by desert soils: Nature, v. 357, p. 145-147.

Thorstenson, D.C., 1990, Chemical modeling of regional aquifer systems-Implications for chemical modeling of low-level radioactivewaste repository sites, in Bedinger, M.S., and Stevens, P.R., eds., Safe disposal of radionuclides in low-level radioactive-waste disposal workshop, U.S. Geological Survey, Big Bear Lake, Calif., July 11-16, 1987 [proceedings]: U.S. Geological Survey Circular 1036, p. $110-113$.

1993, The composition and $\mathrm{CO}_{2}$ carbon isotope signature of gases from borehole USW UZ-6, Yucca Mountain, Nevada, in Workshop on flow and transport through unsaturated fractured rock-Related to high-level radioactive waste disposal: Tucson, Arizona, University of Ariz., January 7-10, 1991, U.S. Nuclear Regulatory Commission, NUREG/ CP-0040, p. 184-188.

Thorstenson, D.C., and Pollock, D.W., 1989, Gas transport in unsaturated zonesMulticomponent systems and the adequacy of Fick's Laws: Water Resources Research, v. 25 , p. $477-507$.
1989, Gas transport in unsaturated porous media-The adequacy of Fick's Law: Reviews of Geophysics, v. 27, p. 61-78.

Thorstenson, D.C., Weeks, E.P., Haas, H., and Woodward, J.C., 1990, Physical and chemical characteristics of topographically affected airflow in an open borehole at Yucca Mountain, Nevada, in Nuclear waste isolation in the unsaturated zone, Focus ' 89 [Proceedings]: La Grange Park, Ill., American Nuclear Society, p. $256-270$.

Yang, I.C., Peters, C.A., and Thorstenson, D.C., 1993, Carbon isotopic data from test hole USW UZ-1, Yucca Mountain, Nevada: Fourth Annual International High Level Radioactive Waste Management Conference (HLRWMC), Las Vegas, Nev., April 26-30, [Proceedings], p. 401-405. 


\title{
GROUND-WATER CHEMISTRY
}

TITLE: $\quad$ Mineral-Water Interaction in Saline Environments (NR 69-020)

\author{
PERSONNEL: Blair F. Jones, Project Chief \\ Margery M. Shapira, Secretary \\ Daniel M. Webster, Hydrologist \\ Brenda Libby, Chemist
}

$\begin{array}{ll}\text { ADDRESS: } & \text { U.S. Geological Survey, } 432 \text { National Center, } 12201 \text { Sunrise Valley Drive, } \\ \text { Reston, VA } 22092\end{array}$

TELEPHONE: (703) 648-5854

PROBLEM: Saline hydrologic systems provide a wide range of conditions within which to examine hydrochemically important mineral reactions (alteration or genesis) and to define reactants and products controlling the chemical composition of many natural waters. The effects of complex reactions, in addition to simple solution and hydrolysis, are reflected in relatively gross chemical change and interaction with fine-grained sediment.

OBJECTIVE: Use saline environments to determine mechanisms and relative importance of mineralogic processes that influence the solute composition of natural waters.

APPROACH: Study in the field and make laboratory analyses of saline waters and associated deposits, mostly from surficial sites or shallow cores in selected pilot or problem areas. Separate and examine solid and solution phases by use of high-speed and gradient centrifugation, microscopy, X-ray diffractometry, and special potentiometric apparatus, as well as detailed constituent analysis of both solids and solutions. Relate composition of these materials to the hydrochemical environment, thermodynamic conditions, and structural elements of associated mineral species.

PROGRESS: After technically minor but time-consuming revision and coordination with Australian colleagues, the manuscript on the normative and isotopic study of saline ground waters in the central Murray Basin of Australia detailing the problems of salinization in a major agricultural area has been accepted by "Chemical Geology." Also, revision is nearing completion after USGS review of the journal manuscript with R.I. Tilling (Geologic Division) on the waters of the Kilauea borehole, Hawaii. With Scott Anderholm of the New Mexico District, further work has been done on documentation and added details in interpretation of constituent and normative brine data from the Salado and underlying strata at the Waste Isolation Pilot Plant (WIPP) site, southeast New Mexico. Preparation of extensive plot and 


\section{GROUND-WATER CHEMISTRY}

tabular material is constituting a major effort in the attempt to show that inclusion brines can be distinguished from very slowly moving intergranular fluids.

With Briant Kimball of the Utah District, a field guide was prepared and a trip was led around the Great Salt Lake for the 7th International Symposium on Water-Rock Interaction. Special investigations of interstitial fluid chemistry and sedimentology have been undertaken in support of the Utah District's Bureau of Land Management-funded study of the hydrology of the Bonneville Salt Flats. Our contribution is in the extraction and analysis of pore fluids from the sediments, limited bulk and clay mineralogy, normative interpretation of the brine chemistry and its relation to the Great Salt Lake history. With Jill Banfield of the University of Wisconsin, a proposal has been developed to support TEM examination of Bonneville basin core ultrafine mineralogy as representative of other deep sedimentary basins. Similar efforts went into advising a University of Illinois study of the mineralogy and chemistry of playa clays and pore fluids in Oregon desert closed basins.

For closed-basin silicate aquifer mineral-water interaction, further work with C.J. Bowser of the University of Wisconsin on personal computer (PC) spreadsheet hydrochemical mass balance modeling has continued exploring the effects of silicate solid solution and compositional variation on reactants and products by contrasting data for crystalline and clastic systems for areas of wide-ranging hydrologic conditions. The results have elucidated and emphasized particularly important dissolution and reaction mechanisms involving major rock-forming minerals, especially feldspar and smectite clays. Further work on similar modeling applied to the Madrid and Ebro Basins with Spanish co-workers and Bertrand Fritz, head of the CNRS Centre of Geochemistry in Strasbourg, has proceeded sporadically. Such considerations were also applied to mineralogical controls on the hydrochemistry of the intermediate aquifer of Florida.

A final version of the first report on the paleoclimate implications of the magnesian clay minerals and cycles in lacustrine sediments from Double Lakes, West Texas, with Dan Webster has gone to press in Journal Sedimentary Petrology, and further development of additional mineralogical and chemical data is well along.

\section{REPORTS PUBLISHED 1988-1993:}

Banfield, J.F., Veblen, D.R., and Jones, B.F., 1990, Transmission electron microscopy of subsolidus oxidation and weathering of olivine: Contributions to Mineralogy and Petrology, v. 106, p. $110-123$.
Banfield, J.F., Jones, B.F., and Veblen, D.R., 1991, An AEM-TEM study of weathering and diagenesis, Abert Lake, Oregon-II. Diagenetic modification of the sedimentary assem- 


\section{GROUND-WATER CHEMISTRY}

blage: Geochimica et Cosmochimica Acta, v. 55, p. 2795-2810.

1991, An AEM-TEM study of weathering and diagenesis, Abert Lake, Oregon-I. Weathering reactions in the volcanics: Geochimica et Cosmochimica Acta, v. 55, p. 2781-2793.

Bodine, M.W., Jr., and Jones, B.F., 1990, Normative analysis of ground waters from the Rustler formation associated with the Waste Isolation Pilot Plant (WIPP), southeastern New Mexico, in Spencer, R.J., and Chou, I.M., Fluid-Mineral Interactions-A Tribute to H.P. Eugster: The Geochemical Society Special Publication no. 2, p. 213-269.

Clark, A.E., Herman, J.S., and Jones, B.F., 1992, The chemical influence of clay minerals on groundwater composition in a lithologically heterogenous carbonate aquifer, in Kharaka, Y.K., and Maest, A.S., eds., 7th International Symposium on Water-Rock Interaction, July 13-18, Park City, Utah [Proceedings]: Rotterdam, A.A. Balkema, p. 779-782.

Domagalski, J., Eugster, H.P., and Jones, B.F., 1990 , Trace metal geochemistry of Walker, Mono, and Great Salt Lakes, in Spencer, R.J., and Chou, I.M., Fluid-Mineral InteractionsA Tribute to H.P. Eugster: The Geochemical Society, Special Publication no. 2, p. 315353.

Jones, B.F., and Galan, E., 1988, Sepiolite and Palygorskite, in Reviews in Mineralogy: Mineralogical Society of America, v. 19, p. 631674.

Jones, B.F., and Llamas, M.R., 1989, Normative analysis of ground waters from the Madrid Basin, Spain: International Symposium on Water-Rock Interaction, Sixth, Malvern, United Kingdom [Proceedings], p. 341-347.
Jones, B.F., Vicente, R., and Sastre, A., 1987, Analisis normativo del agua subterranea de la depresion del Campo Aranuelo, region central Espanola, in IV Symposio de Hidrogeologia: Asociasion Espanola de Hidrologia Subterranea, seccion 6, p. 919-929.

Manzano, M., Custodio, E., and Jones, B.F., 1990 , Progress in the understanding of ground water flow through the aquitard of the Llobregat delta (Barcelona, Spain): Livro de Homenagem a Carlos Romariz, Seccao de Geologia Economica e Aplicada, Lisboa, Portugal, p. 115-126.

Nordstrom, D.K., Plummer, L.N., Langmuir, D., Busenberg, E., May, H.M., Jones, B.F., and Parkhurst, D.L., 1990, Revised chemical equilibrium data for major water-mineral reactions and their limitations-Chemical Modeling of Aqueous Systems I: American Chemical Society Symposium Series 416 , chap. 31 , p. 398 413.

Tilling, R.I., and Jones, B.F., 1991, Composition of waters from the research drill hole at summit of Kilauea Volcano and of selected thermal and non-thermal groundwaters, Hawaii: U.S. Geological Survey Open-File Report 91-133-A, 27 p.

Wood, W.W., and Jones, B.F., 1990, Origin of solutes in saline lakes and springs on the southern High Plains of Texas and New Mexico, in Gustavson, T.C., ed., Geologic Framework and Regional Hydrology-Upper Cenozoic Blackwater Draw and Ogallala Formations, Great Plains: Bureau of Economic Geology, University of Texas, p. 193-208. 


\section{GROUND-WATER CHEMISTRY}

TITLE: Spatial Distribution of Chemical Constituents in Ground Water (NR 57-034)

PERSONNEL: William Back, Project Chief

Janet Herman, Associate Professor, University of Virginia

Carol Wicks, Assistant Professor, University of Missouri

ADDRESS: U.S. Geological Survey, 431 National Center, 12201 Sunrise Valley Drive, Reston, VA 22092

TELEPHONE: (703) 648-5856

PROBLEM: Reactions and processes that control the chemical character of ground water need to be identified to predict physical and chemical changes that occur in natural and stressed environments. This project focuses on effects of these reactions in (1) regional limestone aquifers, (2) contaminated environments, and (3) coastal aquifers.

OBJECTIVE: Study hydrogeologic phenomena reactions that relate to (1) geologic processes; (2) generation, migration, and attenuation of contaminants; and (3) processes of isotopic fractionation, (4) demonstrate contributions that can be made to science by study of historical aspects, (5) demonstrate role of hydrogeology for sustainable development of this environment and water resources.

APPROACH: Design field studies for the collection and interpretation of chemical and isotopic data within the hydrogeologic framework. Select areas that are feasible to demonstrate the occurrence, extent, rate, and consequences of chemical reactions. (1) Study changes in porosity and permeability by karstification of coastal aquifers; (2) investigate the degradation and migration of organic compounds and isotopic fractionation at contamination sites and in sulfide-rich ground water; and (3) undertake comparative studies of regional systems in order to evaluate the environmental impact on the hydrogeologic processes and geochemical reactions.

PROGRESS: Studies are under way on the importance of the mixing zone in coastal aquifers. This concept, which was developed by this project, is becoming increasingly important every year as researchers from various institutions in several parts of the world identify additional reactions that are particularly effective in increasing the permeability and transforming the minerals of coastal aquifers. The results of these phenomenon are being used to document sea-level changes. We (Back, Herman, Wicks) edited one book, wrote a 


\section{GROUND-WATER CHEMISTRY}

chapter for another, and coauthored several oral and poster presentations at American Geophysical Union, Geological Society of America, Water-Rock Interaction Symposia-7, and Unversity Council of Water Resources (UCOWR).

\section{REPORTS PUBLISHED 1988-1993:}

Back, William, 1988, West Indies, in Back, W., Rosenshein, J.S., and Seaber, P.R., eds., Hydrogeology: Boulder, Colo., Geological Society of America, The Geology of North America, v. 0-2, p. 243-254.

1989, Review of Paleokarst, James, N.P., and Choquette P.W., eds., Episodes, v. 12, no. 2, p. 140 .

1989, Early Concepts of the Role of Microorganisms in Hydrogeology: Ground Water, guest editorial, v. 27, no. 5, p. 618-619.

1990, Hydrologic ancient history and archaeology of the southwestern shore of Turkey, Supplement to Field Guide Book: International Symposium and Field Seminar on Hydrogeologic Processes in Karst Terranes, Antalya, Turkey, $35 \mathrm{p}$.

1991, Ground Water: Encyclopedia on Earth Systems Science: Academic Press, v. 2, p. 429-439.

1991, Presentation of the O.E. Meinzer Award to John D. Hem, Citation, Geological Society of America Bulletin, p. 586-587.

1991, Review of Opportunities in the Hydrologic Sciences: EOS, Transactions, American Geophysical Union, v. 72, no. 5, p. 491.

1992, Coastal karst formed by ground-water discharge, Yucatan, Mexico, in Back, William, Herman, Janet S., and Paloc, H., eds., Hydrogeology of Selected Karst Regions of the
World, International Association of Hydrogeologists, v. 13, p. 461-466.

1992, Introduction to Hydrogeology of Selected Karst Regions of the World, International Association of Hydrogeologists v. 13, p. 1-9.

1992, Opportunities in hydrogeology: National Symposium on New Directions in Clean Water Policy and UCOWR 1992 Annual Meeting, July 28-31, 1992, p. 50-54.

Back, William, and Arenas, A.D., 1989, Karst terrains: Resources and Problems: Nature and Resources, Special Issue, UNESCO, Paris, p. 19-26 (in English, French, and Spanish)

Back, William, and Arenas, A.D., 1990, Rationale for karst investigations, in Fuxing. Wang, Xinhong, Lin, and Zaihua, Liu, eds., Geology, Climate, Hydrology and Karst Formation: IGCP 299 Newsletter, Institute of Karst Geology, Guilin, China, p. 21-32.

Back, William, and Baedecker, M.J., 1989, Chemical hydrogeology in natural and contaminated environments: Journal of Hydrology, v. 106, p. 1-28.

Back, William, Baedecker, M.J., and Wood, W.W., 1993, Scales in Chemical Hydrogeology-A Historical Perspective, in Alley, William M., ed., Regional Ground-Water Quality: New York, Van Nostrand Reinhold, chap. 5.

Back, William, and Gunay, Gultekin, 1992, Tectonic influences on ground-water flow systems 


\section{GROUND-WATER CHEMISTRY}

in karst of the southwestern Taurus Mountains, Turkey, in Back, William, Herman, Janet S., and Paloc, H., eds., Hydrogeology of Selected Karst Regions of the World, International Association of Hydrogeologists v. 13, p. 263-272.

Back, William, and Herman, J.S., 1990, Significance of chemical boundaries to ground-water management of coastal aquifers, in Krishna, J. Hari, Quinones-Aponte, Vicente, Gomez-Gomez, Fernando, and Morris, Gregory, eds., Proceedings of the International Symposium on Tropical Hydrogeology and the Fourth Caribbean Islands Water Resources Congress: American Water Resources Association, San Juan, Puerto Rico, p. 31-38.

Back, William. and Herman, Janet S., 1991, Geochemical consequences of saltwater intrusion into carbonate aquifers: International Association of Hydrogeologists, XXIII International Congress, Aquifer Overexploitation, General Papers, Extended Abstracts and Posters, April 1991, Canary Islands, Spain, v. 1, p. 35-38.

Back, William, Herman, Janet S., and Paloc, H., eds., 1992, Hydrogeology of Selected Karst Regions of the World: International Association of Hydrogeologists, v. 13, 439 p.

Back, William, and Landa, E.R., 1992, Ingesting the consequences of water-rock interactionHistorical notes on bottled water and spas, in Kharaka, Y.K., and Maest, A.S., eds, 7th International Symposium on Water-Rock Interaction, Park City, Utah, [Proceedings]: Rotterdam, A.A. Balkema, p. 767-770.

Back, William, Rosenshein, J., Seaber, P., eds., 1988, Hydrogeology: Geology of North America, Geological Society of America, v. 02, 524 p.
Gultekin, G., Johnson, A.I., and Back, W., eds., 1993, Hydrogeological processes in karst terranes: Wallingford, U.K., IAHS Publication no. 207,412 p.

Herman, Janet S., 1989, Review of Geomorphology and Hydrology of Karst Terrains, by William B. White: Water Resources Bulletin, v. 25 , p. 221-222.

1989, Review of Processes in Karst Systems Physics, Chemistry, and Geology, by Wolfgang Dreybodt: Hydrological Sciences Journal, v. 34, p. $729-730$.

1989, A geochemical model of carcite precipitation and $\mathrm{CO}_{2}$ outgassing in karst streams: 6 th International Symposium on Water-Rock Interaction, Malvern, United Kingdom, p. 301304.

1989, Review of Karst Hydrology-Concepts from the Mammoth Cave Area, in White, Elizabeth L., and White, William B., eds.: Water Resources Bulletin, v. 25, p. 10981099.

Herman, Janet S., and Hubbard, David A., Jr., 1990, A Comparative study of travertinemarl-depositing streams in Virginia, in Herman, Janet S., and Hubbard, David A., Jr., eds., Travertine-Marl: Stream Deposits in Virginia: Virginia Division of Mineral Resources Publication 101, p. 43-64.

Herman, Janet S., and Hubbard, Jr., David A., eds., 1990, Travertine-Marl-Stream Deposits in Virginia: Virginia Division of Mineral Resources Publication 101, $184 \mathrm{p}$.

Herman, Janet S., and Hubbard, Jr., David A., 1992, The role of ground water in the deposition of travertine-marl, in Back, William, Herman, Janet S., and Paloc, H., eds., Hydrogeology of Selected Karst Regions of the 


\section{GROUND-WATER CHEMISTRY}

World: International Association of Hydrogeologists, v. 13, p. 421-434.

Herman, Janet S., and Lorah, Michelle M., 1988, Calcite precipitation rates in the field-Measurement and prediction for a travertine-depositing stream: Geochimica et Cosmochimica Acts, v. 52, p. 2347-2355.

Hoffer, Kimberly J., and Herman, Janet S., 1990, $\mathrm{A} \mathrm{CO}_{2}$ outgassing model for Falling Springs Run, Augusta County, Virginia, in Herman, Janet S., and Hubbard, David A., Jr., eds., Travertine-Marl-Stream Deposits in Virginia: Virginia Division of Mineral Resources Publication 101, p. 6-15.

Hoffer-French, Kimberly J., and Herman, Janet S., 1989, Evaluation of hydrological and biological influences on $\mathrm{CO}_{2}$ fluxes from a karst stream: Journal of Hydrology, v. 108, p. 189-212.

Hubbard, David A., Jr., and Herman, Janet S., 1990, Overview of travertine-marl volume, in Herman, Janet S., and Hubbard, David A., Jr., eds., Travertine-Marl: Stream Deposits in Virginia: Virginia Division of Mineral Resources Publication 101, p. 1-4.

Hubbard, David A., Jr., Herman, Janet S., and Bell, Pamela E., 1990, Speleogenesis in a travertine scarp: observations of sulfide oxidation in the subsurface, in Herman, Janet S., and Hubbard, David A., Jr., eds., TravertineMarl-Stream Deposits in Virginia: Virginia Division of Mineral Resources Publication 101, p. 177-184.

Llamas, M.R., and Back W., 1989, Tendencias en hidrogeoquimica, in Homenaje, Tomo, a Martin, Jorge Porras, eds., Hidrogeologia $Y$ Recursos Hidraulico: Asociacion Espanola de Hidrologia Subterranea, Madrid, Spain, v. 14, p. 315-323.
Llamas, Ramon, Back, W., and Margat, J., 1992, Groundwater use-Equilibrium between social benefits and potential environmental costs: Applied Hydrogeology, v. 1, no. 2, p. 1-14.

Lorah, Michelle M., and Herman, Janet S., 1988, The chemical evolution of a travertine-depositing stream-Geochemical processes and mass transfer reactions: Water Resources Research, v. 24, p. 1541-1552.

1990, Geochemical evolution and calcite precipitation rates in Falling Spring Creek, Virginia, in Herman, Janet S., and Hubbard, David A., Jr., eds., Travertine-Marl: Stream Deposits in Virginia: hitginia Division of Mineral Resources Publication 101, p. 177184.

Norris, Robert M., 1990, Erosion of seacliffs by groundwater, with a case study by Back, W., in Higgins, C.G., and Coates, D.R., eds., Groundwater geomorphology; The role of subsurface water in Earth-surface processes and landforms: Boulder, Colo., Geological Survey of America Special Paper 252.

Price, Rene M., and Herman, Janet S., 1991, Geochemical investigation of saltwater intrusion into a coastal carbonate aquifer: Mallorca, Spain, Geological Society of America Bulletin, v. 103 , no. 10 , p. $1270-1279$.

Sacks, L.A., Herman, J.S., Konikow, L.F., and Vela, A.L., in press, Seasonal dynamics of groundwater-lake interactions at Donana $\mathrm{Na}-$ tional Park, Spain: Journal of Hydrology, v. 136 , no. 2 , p. 123-154.

Wicks, Carol, and Grove, Chris, 1993, Acidic mine drainage in carbonate terrains-Geochemical processes and rates of calcite dissolution: Journal of Hydrology, $v$. 146, p. 13-27. 


\section{GROUND-WATER CHEMISTRY}

Yuan, Daoxian, and Back, William, 1991, International Geologic Correlation Program Project 299: Geology, climate, hydrology and karst formation: Episodes, March. 


\section{GROUND-WATER CHEMISTRY}

TITLE: $\quad$ Interface of Paleoclimatology and Aquifer Geochemistry (NR 74-041)

PERSONNEL: Isaac J. Winograd, Project Chief

Laura A. Bricker, Clerial Assistant

Alan C. Riggs, Hydrologist

Peter T. Kolesar, Professor, Utah State University

ADDRESS: $\quad$ U.S. Geological Survey, 432 National Center, 12201 Sunrise Valley Drive, Reston, VA 22092

TELEPHONE: (703) 648-5849

PROBLEM: Reconstructions of continental paleoclimates of the Pleistocene Epoch have relied almost exclusively on packrat midden, lacustrine, and speleothem records; such records are typically discontinuous and (or) are difficult to date. The isotopic (deuterium, oxygen-18, carbon-13) records of calcitic veins marking the sites of fossil ground water discharge, have not been utilized. Preliminary work indicates that such veins contain continuous dateable records of Pleistocene paleoclimate and paleohydrology. The paleohydrologic interpretations should also be pertinent to selection of sites for the disposal and long term isolation of toxic wastes.

OBJECTIVE: (1) Infer paleoclimate and paleohydrology of selected regions based on variations in isotopic content of calcitic veins of ground water origin; (2) attempt correlation of inferred local variations in continental paleoclimate with global variations deduced from marine and polar ice core studies; (3) differentiate between, and determine relative magnitude of, summer and winter recharge to major uplands.

APPROACH: Sample: (1) water from regional aquifers for which quantitative hydrogeologic and geochemical studies have been completed; (2) rain, snow, snowmelt, and springs in major upland recharge areas; (3) calcite veins at modern and fossil springs. The water and calcite deposits will be analyzed for $\mathrm{D},{ }^{18} \mathrm{O},{ }^{13} \mathrm{C}$, and will be dated using the TIMS U-Series methods. Initial work will be in the southern Great Basin where a major fossil spring discharge area (with a modern analogue, the Ash Meadows region) has been exhumed by uplift and erosion.

PROGRESS: (1) The first two of a series of papers on the Devils Hole 500,000-year climate record were published in Science, one as a lead article. Our principle findings are that Pleistocene climate shifts were aperiodic, that interglacial climates lasted about 20,000 


\section{GROUND-WATER CHEMISTRY}

years (twice as long as commonly believed), and that the Milankovitch hypothesis does not explain the origin of Pleistocene glacial cycles.

(2) Under the leadership of Alan C. Riggs, we obtained new specimens from Devils Hole which will bring our climate record forward from 60,000 to 20,000 years.

\section{REPORTS PUBLISHED 1988-1993:}

Edwards, R.L., Gallup, C.D., Ludwig, K.R., Simmons, K.R., Winograd, I.J., Szabo, B.J., and Riggs, A.C., 1993, Dating of the Devils Hole calcite vein: Science, v. 259, p. 16261627.

Ludwig, Kenneth R., Simmons, Kathleen R., Szabo, Barney J., Winograd, Isaac J., Landwehr, Jurate M., Riggs, Alan C., and Hoffman, Ray J., 1992, Mass-spectrometric ${ }^{230} \mathrm{Th}$ ${ }^{234} \mathrm{U}-{ }^{238} \mathrm{U}$ dating of the Devils Hole calcite vein: Science, v. 258, 284-287.

Shackleton, N.J., Ludwig, K.R., Simmons, K.R., Winograd, I.J., Szabo, B.J., Landwehr, J.M., and Riggs, A.C., 1993, Last interglacial in Devils Hole: Nature, v. 362, p. 596.

Winograd, I.J., 1990, The Yucca Mountain Project-Another perspective: Environmental Science and Technology, v. 24, no. 9, p. 1291-1293.

1991, Yucca Mountain as a nuclear waste repository-Neither myth' nor millennium: U.S. Geological Survey, Open-file Report 91-170, 25 p.

Winograd, I.J., Coplen, B.J., Landwehr, J.M., Riggs; A.C., Ludwig, K.R., Szabo, B.J., Kolesar, P.T., and Revesz, K.M., 1992, Continuous 500,000-year climate record from vein calcite in Devils Hole, Nevada: Science, v. 258, p. 255-260.
Winograd, I.J., and Szabo, B.J., 1988, Water-table decline in the southcentral Great Basin during the Quaternary Period-Implications for toxicwaste disposal, in Carr, M.D., and Yount, J.C., eds., Geology and hydrology of a proposed high level nuclear waste repository: U.S. Geological Survey Bulletin 1790, chap. 13, p. 147-152.

Winograd, I.J., Szabo, B.J., Coplen, T.B., and Riggs, A.C., 1988, A 250,000-year climatic record from Great Basin vein calcite-Implications for the Milankovitch theory: Science, v. 242 , p. 1275-1280. [Discussion in v. 246, p. 262-2631. 


\section{GROUND-WATER CHEMISTRY}

TITLE: Kinetics and Thermodynamics of Chemical Evolution in Ground-Water Systems (NR 76-056)

PERSONNEL: L. Niel Plummer, Project Chief

Bonnie H. Hower, Secretary

Eurybiades Busenberg, Hydrologist

Pierre D. Glynn, Hydrologist

Eric C. Prestemon, Hydrologist

Julian E. Wayland, Hydrologist

Raymond L. Van Hoven, Chemist

Rosalynd A. Williams, Chemist

Stephanie A. Dunkle, Hydrologist (student, Lamont-Doherty Earth Observatory)

ADDRESS: $\quad$ U.S. Geological Survey, 432 National Center, 12201 Sunrise Valley Drive, Reston, VA 22092

TELEPHONE: (703) 648-5841

PROBLEM: The responsible use of our Nation's ground-water resources requires an ability to predict changes in water quality as a result of human impacts. Prediction of chemical quality in the ground-water environment depends on a detailed understanding of both chemical and hydrologic processes. To determine the spatial and temporal variability of ground-water quality, it is necessary to identify reactions occurring in the system, to define their kinetic and thermodynamic properties, and to determine how the configuration of the hydrologic regime influences ground-water quality.

OBJECTIVE: (1) Identify chemical reactions in ground-water systems using observed chemical and isotopic composition of dissolved solutes and minerals; (2) develop geochemical models to aid in interpretation of chemical and isotopic data from ground-water systems; (3) develop tools for age-dating groundwaters; (4) determine rates of chemical reactions in ground-water systems from field hydrochemical data and modeled water-ages; (5) conduct laboratory experiments to obtain thermodynamic data for mineral-water systems for use in geochemical models; (6) obtain laboratory kinetic data on rates of mineral dissolution and precipitation for comparison with field rates and (7) study the fundamental mechanisms of mineral dissolution and precipitation as they apply to pure phases and to solid-solution -minerals.

APPROACH: Flow paths in ground-water systems are sampled extensively for chemical and isotopic composition. Geochemical mass balance calculations are used to interpret reaction possibilities, test reaction sensitivity to stable isotope data for aquifer minerals and dissolved solutes, and to obtain adjusted carbon-14 water ages. Rates of reactions are calculated from 


\section{GROUND-WATER CHEMISTRY}

modeled mass transfers and water ages. Tools developed for age-dating of groundwaters include interpretation of chlorofluorocarbon (CFC) content in recharge areas and unconfined aquifers. Mathematical models are developed to (1) calculate speciation and thermodydnamic properties of a wide range of water compositions from dilute to highly saline formation waters, (2) model water-rock evolution, (3) test sensitivity of chemical evolution to advection and hyrodynamic dispersion in ground-water environments, and (4) model dissolution and precipitation reactions for water-rock systems containing solid-solution minerals. In the laboratory, synthetic solid-solution minerals are prepared using constant composition, constant growth-rate techniques. The stoichiometric solubilities of solid-solution minerals are measured to estimate the thermodynamic mixing properties of the minerals. Laboratory kinetic studies are conducted to investigate (1) fundamental mechanisms of dissolution and crystal growth of rock-forming minerals in relatively pure water-rock systems and (2) the effects of added inorganic and organic solutes on mineral-water reaction kinetics in hydrochemical environments.

PROGRESS: Research continued on the study of applications of chlorofluorocarbons (CFCs) as tracers and age-dating tools for shallow ground water. Three reports were published that detailed methods of sampling and analysis, reviewed and compared age-dating methods for young ground water and applied the methods to waters from central Oklahoma and the Snake River Plain aquifer at the Idaho National Engineering Laboratory (INEL), Idaho. The Oklahoma study demonstrated applications of CFCs as tracers of recharge from rivers into alluvial sediments and as tools for detecting leakage of shallow water into deep production wells (well head protection). Studies at INEL indicated that recharge to the Snake River Plain aquifer must be rapid and bypass equilibration of water with the unsaturated zone air. Most of the water at the water table at INEL appears to have been recharged locally, as indicated by recharge temperatures determined from dissolved nitrogen and argon.

Three other reports were completed that investigate CFC dating on the Delmarva Peninsula of Delaware, Maryland, and Virginia. These studies show that CFC ages can agree within several years when determined independently from CFC-11 and CFC-12. The CFC ages also agreed with ground-water ages determined from ${ }^{3} \mathrm{H} /{ }^{3} \mathrm{He}$ and ${ }^{85} \mathrm{Kr}$ dating on Delmarva. The CFC ages were used to reconstruct the tritium input to Delmarva. Further studies identified some limitations to CFC dating of older ground water that can easily be contaminated with trace amounts of CFCs introduced from the sampling equipment. Several studies were conducted on Delmarva and southern New Jersey that showed very similar ages between CFC dating and dating by the ${ }^{3} \mathrm{H} /{ }^{3} \mathrm{He}$ method. These studies were combined with simulation of ground-water flow and showed that the effect of hydrodynamic dispersion on CFC and ${ }^{3} \mathrm{H} /{ }^{3} \mathrm{He}$ dating was very small. 


\section{GROUND-WATER CHEMISTRY}

Significant concentrations of CFCs were found in air from the unsaturated zone of Yucca Mountain, Nevada, sampled in March 1992 and March 1993. Other sampling was conducted in the fractured rock study site at Mirror Lake, New Hampshire, and the Pinal Creek site at Globe, Arizona. Large excesses of nitrogen gas were found in ground water in crystalline rock at Mirror Lake. The CFC ages suggest an approximately 6-year delay in recharge through the glacial drift at Mirror Lake which shifts recharge ages, some 6 years younger than the mid-1960's ages recorded in tritium data. CFC-12 was found a useful tracer of recharge from the Withlachoochee River, near Valdosta, Georgia, but CFC concentrations appear to have been significantly affected by sorption and (or) microbial degradation processes. Monthly sampling of dissolved gases for determination of ground-water recharge temperatures along two flow paths from the sink hole area near Valdosta was initiated. Other evidence of microbial degradation was found along flow paths beneath organic-rich sediments at Lake Barco, Florida.

Revisions to procedures used to process CFC data continued. These included calibration on the National Oceanic and Atmospheric Administration (NOAA) CFC scale which is based on gravimetric standards. An atmospheric input function for CFC-113 was constructed which enabled preliminary assignment of recharge ages based on CFC-113. Work continued on the refinement of the NETPATH geochemical mass balance code. The code was modified to use a generalized aqueous model, simulate fractionation processes with nitrogen isotopes and treat more mixing problems. Dissolved nitrogen and argon were determined on paleowaters from the Floridan aquifer in southeast Georgia and showed an average cooling in the recharge temperature of 5.3 degrees Celcius during the last glacial maximum. A report was completed interpreting paleoclimatic conditions in the southeast United States during the last glacial maximum. A major paper on the thermodynamics and kinetics of dissolution of strontianite-aragonite solid solutions in nonstoichiometric aqueous solutions was published.

A report was also published, detailing how the geochemical model PHREEQE could be modified, adding capability to calculate binary nonideal solid-solution aqueous-solution equilibria, and giving examples of systems where this capability was important. Ground waters from the Pinal Creek Toxic Waste site were sampled for $\mathrm{CFC}-11, \mathrm{CFC}-12,{ }^{13} \mathrm{C},{ }^{18} \mathrm{O}$, $\mathrm{D},{ }^{3} \mathrm{H}$ and dissolved gases. CFC-11 concentrations are being used to age-date both contaminated and uncontaminated ground waters at the site, while CFC-12 measurements provide an indicator of ground water contamination. Unsaturated-zone gas was collected for both chemical (CFC, Ar, $\mathrm{CO}_{2}, \mathrm{O}_{2}, \mathrm{~N}_{2}$ ) and ${ }^{13} \mathrm{C}$ analysis. Preliminary results show a linear $\mathrm{CO}_{2}$ gradient, with high concentrations near the water table, decreasing toward the ground surface, and a reverse linear $\mathrm{O}_{2}$ gradient. Together with the very high $\mathrm{CO}_{2}$ partial pressures measured in ground-water samples, these measurements point to the importance of carbonate 


\section{GROUND-WATER CHEMISTRY}

dissolution in the neutralization of the acidic ground-water plume. The results enable the estimation of $\mathrm{CO}_{2}$ exsolution fluxes from and $\mathrm{O}_{2}$ dissolution fluxes to the ground water for incorporation into a solute transport model of the site. Carbon- 13 values at ground surface and close to the water table show a difference of 4.4 per mil, the fractionation theoretically predicted assuming a steady-state diffusion model. Until now, there has been little field evidence supporting this theoretical model. Solute-transport modeling of the Pinal Creek site is in progress. Because of the complexity of the occurring physical and chemical processes, the site offers a major challenge to existing reactive solute transport codes. The site is being used for intercomparison and verification of existing public-domain codes. A sensitivity analysis is also being conducted to identify chemical and physical assumptions which can be made together with code modifications and improvements needed for a satisfactory model of the Pinal Creek site and more generally any acidic ground-water contamination site. A reaction kinetics capability is being added to the PHREEQM geochemical transport code (radioactive decay has been added thus far).

Geochemical characterization of the Asp Hard-Rock Laboratory site, Sweden, is in progress. Goals are to use the geochemical information to determine the origin and possibly the age of the different ground waters encountered at the site, and to combine this information with geologic and hydrologic knowledge of the site to obtain a more comprehensive understanding of the past, and possibly future, geochemical and hydrologic evolution of the site. The research conducted will be used by regulatory agencies in Sweden to determine the suitability of sites similar to Asp for storing high-level nuclear waste. More generally, the research will determine the types of geochemical, hydrologic, and geologic information useful in making siting decisions.

\section{REPORTS PUBLISHED 1988-1993:}

Busby, J.F., Plummer, L.N., Lee, R.W., and Hanshaw, B.B., 1991, Geochemical evolution of water in the Madison aquifer in parts of Montana, South Dakota, and Wyoming: U.S. Geological Survey Professional Paper 1273-F, 89 p.

Busenberg, E., and Plummer, L.N., 1989, Thermodynamics of magnesian calcite solid-solutions at $25^{\circ} \mathrm{C}$ and $1 \mathrm{~atm}$ total pressure: Geochimica et Cosmochimica Acta, v. 53, p. 1189-1208.
1991, Chlorofluorocarbons $\left(\mathrm{CCl}_{3} \mathrm{~F}\right.$ and $\mathrm{CC}$ $\mathrm{l}_{2} \mathrm{~F}_{2}$ ) - Use as an age-dating tool and hydrologic tracer in shallow ground-water systems, in Mallard, G.E., and Aronson, D.A., eds., U.S. Geological Survey Toxic Substances Hydrology Program-Proceedings of the technical meeting, Monterey, Calif., March 1115, 1991: U.S. Geological Survey Water-Resources Investigations Report 91-4034, p. 542-547.

1992, Use of chlorofluorocarbons $\left(\mathrm{CCl}_{3} \mathrm{~F}\right.$ and $\left.\mathrm{CCl}_{2} \mathrm{~F}_{2}\right)$ as hydrologic tracers and age-dating 


\section{GROUND-WATER CHEMISTRY}

tools, Example-The alluvium and terrace system of central Oklahoma: Water Resources Research, v. 28, no. 9, p. 2257-2284.

Busenberg, E., Weeks, E.P., Plummer, L.N., and Bartholemay, R.C., 1993, Age dating ground water by use of chlorofluorocarbons $\left(\mathrm{CCl}_{3} \mathrm{~F}\right.$ and $\mathrm{CCl}_{2} \mathrm{~F}_{2}$ ), and distribution of chlorofluorocarbons in the unsaturated zone, Snake River Plain aquifer, Idaho National Engineering Laboratory, Idaho: U.S. Geological Survey Water-Resources Investigations 93-4054, 47 p.

Dunkle, S.A., Plummer, L.N., Busenberg, E., Phillips, P.J., Denver, J.M., Hamilton, P.A., Michel, R.L., and Coplen, T.B., 1993, Chlorofluorocarbons $\left(\mathrm{CCl}_{3} \mathrm{~F}\right.$ and $\left.\mathrm{CCl}_{2} \mathrm{~F}_{2}\right)$ as dating tools and hydrologic tracers in shallow ground water of the Delmarva Peninsula, Atlantic Coastal Plain, United States: Water Resources Research, v. 29 , no. 12 , p. 3837-3860.

Glynn, P.D., 1990, Modeling solid-solution reactions in low-temperature aqueous systems, in Melchoir, D.C., and Bassett, R.L., eds., Chemical modeling of aqueous systems II: American Chemical Society, American Chemical Society Symposium Series 416, Washington, D.C., p. 74-86.

1991, Effect of impurities in gypsum on contaminant transport at Pinal Creek, Arizona, in Mallard, G.E., and Aronson, D.A., eds., U.S. Geological Survey Toxic Substances Hydrology Program-Proceedings of the technical meeting, Monterey, Calif., March 11-15, 1991: U.S. Geological Survey Water-Resources Investigations Report 91-4034, p. 466-474.

1991, MBSSAS - A code for the computation of Margules parameters and equilibrium relations in binary solid-solution aqueous-solution systems: Computers and Geosciences, v. 17, no. 7, p. 907-966.
Glynn, P.D., Engesgaard, Peter, and Kipp, K.L., 1991, Use and limitations of two computer codes for simulating geochemical mass transport at the pinal creek toxic-waste site, in Mallard, G.E., and Aronson, D.A., eds., U.S. Geological Survey Toxic Substances Hydrology Program-Proceedings of the technical meeting, Monterey, Calif., March 11-15, 1991: U.S. Geological Survey Water-Resources Investigations Report 91-4034, p. 454-460.

Glynn, P.D., and Parkhurst, D.L., 1992, Modeling non-ideal solid-solution aqueous-solution reactions in mass transfer computer codes, in Kharaka, Y.K. and Maest, A.S., ed., 7th International Symposium on Water-Rock Interaction, Park City, Utah, July 9-23, 1992 [Proceedings]: Rotterdam, v. 1, A.A. Balkema, p. 175-179.

Glynn, P.D., and Reardon, E.J., 1990, Solid-solution aqueous-solution equilibria: Thermodynamic theory and representation: American Journal of Science, v. 290, p. 164-201.

1992, Reply to a Comment by Knigsberger, E., and Gamsjger, H., on Solid-solution aqueous-solution equilibria-Thermodynamic theory and representation: American Journal Science, v. 292, p. 215-225.

Glynn, P.D., Reardon, E.J., Plummer, L.N., and Busenberg, E., 1990, Reaction paths and equilibrium end-points in solid-solution aqueoussolution systems: Geochimica et Cosmochimica Acta, v. 54, p. 267-282.

1992, Reply to Dr. Stoessell's comment on Reaction paths and equilibrium end-points in solid-solution aqueous-solution systems: Geochimica Cosmochimica Acta, v. 56, p. 25592572.

McCartan, L., Plummer, L.N., Hosterman, J.W., Busenberg, E., Dwornik, E.J., Duerr, A.D., 


\section{GROUND-WATER CHEMISTRY}

Miller, R.L., and Kiesler, J.L., in press, Celestine $\left(\mathrm{SrSO}_{4}\right)$ in Hardee and De Soto Counties, Florida, in Gohn, G.S., ed., Proceedings of the 1988 U.S. Geological Survey Workshop on the Geology and Geohydrology of the Atlantic Coastal Plain: U.S. Geological Survey Circular 1059, p. 129-137.

Nordstrom, D.K., Plummer, L.N., Langmuir, D., Busenberg, E., May, H.M., Jones, B.F., and Parkhurst, D.L., 1990, Revised chemical equilibrium data for major water-mineral reactions and their limitations, in Melchoir, D.C., and Bassett, R.L., eds., Chemical modeling of aqueous systems II: American Chemical Society, American Chemical Society Symposium Series 416, Washington, D.C., p. 398-413.

Parkhurst, D.L., and Plummer, L.N., 1993, Geochemical Models, in Alley, W.M., ed., Regional Ground-water Quality: Van Nostrand Reinhold, chap. 9, p. 199-225.

Plummer, L.N., 1992, Geochemical Modeling-Past, Present, Future, in Kharaka, Y.K., and Maest, A.S., ed., 7th International Symposium on Water-Rock Interaction, Park City, Utah, July 9-23, 1992 [Proceedings]: Rotterdam, A.A. Balkema, p. 23-33.

Plummer, L.N., Busby, J.F., Lee, R.W., and Hanshaw, B.B., 1990, Geochemical modeling of the Madison aquifer in parts of Montana, Wyoming, and South Dakota: Water Resources Research, v. 26, no. 9, p. 1981-2014.

Plummer, L.N., and Busenberg, E., 1993, CFC's-Tools for Age-Dating and Tracing Shallow Ground Water: U.S. Geological Survey Yearbook Fiscal Year 1992, p. 45-47.

Plummer, L.N., Busenberg, E., Glynn, P.D., and Blum, A.E., 1992, Dissolution of aragonitestrontianite solid solutions, in non-stoichiometric $\mathrm{Sr}\left(\mathrm{HCO}_{3}\right)_{2}-\mathrm{Ca}\left(\mathrm{HCO}_{3}\right)_{2}-\mathrm{CO}_{2}-\mathrm{H}_{2} \mathrm{O}$ solutions: Geochimica Cosmochimica Acta, v. 56. no. 7, p. 3045-3072.
Plummer, L.N., Michel, R.L., Thurman, E.M., and Glynn P.D., 1993, Environmental Tracers for age-dating young ground water, in Alley, W.M., ed., Regional Ground-water Quality: Van Nostrand Reinhold, chap. 11, p. 255-294.

Plummer, L.N. and Parkhurst, D.L., 1990, Application of the Pitzer Equations to the PHREEQE geochemical model, in Melchoir, D.C., and Bassett, R.L., eds., Chemical modeling of aqueous systems II: American Chemical Society, American Chemical Society Symposium Series 416, Washington, D.C., p. 128-137.

Plummer, L.N., Parkhurst, D.L., Fleming, G.W., and Dunkle, S.A., 1988, A computer program incorporating Pitzer's equations for calculation of geochemical reactions in brines: U.S. Geological Survey, Water-Resources Investigations Report 88-4153, 310 p.

Plummer, L.N., Prestemon, E.C., and Parkhurst, D.L., 1991, An interactive code (NETPATH) for modeling NET geochemical reactions along a flow PATH: U.S. Geological Survey WaterResources Investigations Report 91-4078, 227 p.

1992, NETPATH-An interactive code for interpreting NET geochemical reactions from chemical and isotopic data along a flow PATH, in Kharaka, Y.K., and Maest, A.S., ed., 7th International Symposium on Water-Rock Interaction, Park City, Utah, July 9-23, 1992 [Proceedings]: Rotterdam, A.A. Balkema, p. 239242.

Vacher, H.L., Bengtsson, T.O., and Plummer, L.N., 1990, Hydrology of meteoric diagenesisResidence time of meteoric ground water in island fresh-water lenses with application to aragonite-calcite stabilization rate in Bermuda: Geological Society of America, v. 102, p. 223-232. 


\section{GROUND-WATER CHEMISTRY}

TITLE: Physical Chemistry of Stable Isotope Fractionation in Hydrologic Processes (NR 75-064)

PERSONNEL: Tyler B. Coplen, Project Chief

Paula McMahon, Secretary

Johnkarl Böhlke, Hydrologist

Jeanne Jaseschke, Physical Scientist

Janet Hannon, Phy. Sci. Technician

Robert L. Michel, Research Chemist

Kinga M. Revesz, Chemist

Jessica A. Hopple, Chemist

Joe D. Wildman, Electronics Technician

Janet Prosser, Phy. Sci. Aid

Rebecca Morgan, Phy. Sci. Aid

Mark A. Farnsworth, computer 'clerk

K. Christiana Grim, Physical Science Aid

Professor H. Steffen Peiser, Volunteer

Michael E. O'Connell, Volunteer

Wendy Coplen, Volunteer, High School

student

ADDRESS: $\quad$ U.S. Geological Survey, 431 National Center, 12201 Sunrise Valley Drive, Reston, VA 22092

TELEPHONE: (703) 648-5873

PROBLEM: Several light stable isotopes $(\mathrm{H}, \mathrm{C}, \mathrm{N}, \mathrm{O}, \mathrm{Si}$, and $\mathrm{S}$ ) show variations in their isotope abundances and offer great promise for study of evaporation, ground-water mixing, biotransformations, lake or reservoir circulation and stratification, and associated hydrochemical phenomena. These isotope fractionations are related to: (1) purely physical processes; (2) heterogeneous chemical equilibria; and (3) reaction kinetics. Many of these processes are not sufficiently understood or quantified to make the most effective use of stable isotope techniques in hydrologic research.

OBJECTIVE: Develop theoretical and instrumental mass spectrometric techniques through experimental investigation, and test in suitable field locations, such as intermontane ground-water reservoirs, closed-lake basins, and suitable surface reservoir, lake, ground water, or estuarine systems, to aid in more complete utilization of light stable-isotope phenomena in hydrologic studies.

APPROACH: Water and mineral samples from experimental studies, from evaporating surface water bodies, and from ground-water basins, will be analyzed for light stable isotope abundances. These experimental results and field data will then be related to other measurement factors such as relative humidity, temperature, density, and water chemistry, in an attempt to develop an understanding and a theoretical predictive model of the processes involved. 


\section{GROUND-WATER CHEMISTRY}

PROGRESS: Under the leadership of R. Michel, tritium, with its half-life of 12 years, has been used in recharge rate and residence-time studies in:

(1) A Regional Aquifer System Assessment (RASA) program in southern California. Tritium and freon data from the Oxnard Plain were used to determine the rate of seawater intrusion into the Oxnard Aquifer. Tritium data are also being used to trace flow along faults in the Mojave Basin.

(2) An Interior Department irrigation drainage program in southern California. Tritium data from a monitoring station on the Colorado River at Imperial Dam have been used to study the movement of irrigation water through the Imperial Valley.

(3) Finger Lakes, New York. Tritium is being combined with radium isotope data and stable isotope data to determine water retention times for these lakes.

(4) The Fremont Ice Core. This ice core was collected from Fremont Glacier in Wyoming as part of the climate change program. Tritium has been measured throughout the upper 50 meters of the ice core to date ice layers and detect any percolation of younger water into deeper layers.

Sulfur-35, a short-lived isotope of sulfur that occurs naturally was measured in the following programs for the purpose of studying processes that occur on time scales shorter than one year:

(1) Samples of precipitation and throughfall are being measured at the Water, Energy and Biogeochemical Balance (WEBB) sites in Penola, Georgia, and the Sleeper River watershed in Vermont to see if there is any difference in the age of the sulfate being collected.

(2) Water samples from small lakes and ground-water seeps from various locations in the Rocky Mountains have been analyzed with the purpose of estimating the age of the sulfate pool. Initial results from this program were presented at the 1993 Geological Society of America (GSA) Meeting.

Continuing studies by J.K. Böhlke involving the nitrogen isotope laboratory fall mainly into two major categories: (1) exploring methods and field applications of nitrogen isotope analyses in hydrogeology; and (2) using a variety of isotopic, chemical, and chronologic data to assess the history and fate of nitrate contamination in selected ground water-surface water 


\section{GROUND-WATER CHEMISTRY}

systems. In support of those studies, the nitrogen isotope laboratory has produced relevant data from a variety of soil and organic solids, dissolved ammonium, nitrate, and nitrogen gas in waters, and nitrogen in mixed gases.

Major effort has been given to several collaborative field projects investigating the fate of nonpoint source nitrate contamination along ground-water flow paths in diverse hydrogeologic settings, and involving the use of a variety of geochemical and isotopic analytical tools. Flow-path studies in eastern Maryland have been completed and similar studies in Minnesota and Colorado are well underway with district and Geologic Division collaborators. An investigation of anthropogenic nitrate transport through the unsaturated zone in southern California is underway, and is supported by an isotope survey of some natural desert nitrates.

The first phase of a new project was begun by K. Revesz, J. K. Böhlke, and Hungarian researchers to study the effect of Danube River recharge on a thick gravel aquifer in northwestern Hungary. Preliminary results indicate that the ground waters out to a distance of 20 kilometers from the river contain a preserved record of river contamination of the aquifer with chlorofluorocarbon (CFC) spanning a period of about 40-60 years. Regionally mixed atmospheric CFC records apparently cannot be used to date the waters, but locally-generated input curves may be used within the area of the gravel aquifer for ground-water dating.

New reference materials for nitrogen isotope analysis were distributed along with several of the previously distributed reference materials for a major international intercomparison test. Results continue to be received from the participating laboratories. Carbon 13 variations in vein calcite from Devils Hole, Nevada, record fluctuations in the ${ }^{13} \mathrm{C}$ content of dissolved inorganic carbon of water recharging in the Ash Meadows, Nevada, ground-water basin. Major minima in ${ }^{13} \mathrm{C}$ content $414,334,246$, and 133 thousand years ago, contemporaneous with attainment of interglacial climate, may mark times of maximum vegetation or (and) times of low ${ }^{13} \mathrm{C}$ content of atmospheric carbon dioxide.

A major effort by J. Wildman, T. Coplen, and M. Farnsworth succeeded in automating a Geologic Division mass spectrometer for Water Resources Division use.

Minor element analysis of Devils Hole, Nevada, calcite cores by A. Riggs and T. Coplen indicates significant variations over time about 130 thousand years ago in silicon, magnesium, iron, manganese, zinc, barium, and strontium. 


\section{GROUND-WATER CHEMISTRY}

\section{REPORTS PUBLISHED 1988-1993:}

Böhlke, J.K., and Irwin, J.J., 1992, Laser microprobe analyses of noble gas isotopes and halogens in fluid inclusions-Analyses of microstandards and synthetic inclusions in quartz: Geochimica et Cosmochimica Acta, v. 56, p. 187-201.

1992, Brine history indicated by argon, krypton, chlorine, bromine, and iodine analyses of fluid inclusions from the $\mathrm{Pb}$-fluorite deposits at Hansonburg, New Mexico: Earth and Planetary Science Letters, v. 110, p. 51-66.

1992, Laser microprobe analyses of $\mathrm{Cl}, \mathrm{Br}, \mathrm{I}$, and $\mathrm{K}$ in fluid inclusions-Implications for sources of salinity in some ancient hydrothermal fluids: Geochimica et Cosmochimica Acta, v. 56, p. $203-225$.

Böhlke, J.K., Gwinn, C. J., and Coplen, T. B., 1993, New reference materials for nitrogenisotope-ratio measurements: Geostandards Newsletter, v. 17, p. 159-164.

Böhlke, J.K., and Shanks, W.C., III, in press, O, $\mathrm{H}$, and $\mathrm{S}$ isotope study of hydrothermal vents at Escanaba Trough, northeast PacificObserved and calculated effects of sedimentseawater interaction: U.S. Geological Survey Bulletin 2202.

Cecil, L.D., Pittman, J.R., Beasley, T.M., Michel, R.L., Kubik, P.W., Sharma, P., Fehn, U., and Gove, H.E., 1992, Water infiltration in the unsaturated zone at the Idaho National Engineering Laboratory estimated from chlorine-36 and tritium profiles, and neutron logging, in Kharaka, Y., and Maest, A., eds., 7th International Symposium on Water-Rock Interaction, Park City, Utah, July 9-23, 1992 [Proceedings]: Rotterdam, A.A. Balkema, p. 709-714.
Coplen, T.B., 1988, Normalization of oxygen and hydrogen isotope data: Chemical Geology (Isotope Geosciences Section), v. 72, p. 293297.

1993, Uses of environmental isotopes, in Alley, W.M., ed., Regional ground-water quality: New York, Van Nostrand Reinhold, p. 227-254.

Coplen, T.B., Krouse, H.R., and Böhlke, J.K., 1992, Reporting of nitrogen-isotope abundances: Pure and Applied Chemistry, v. 64, p. 907-908.

Coplen, T.B., Wildman, J.D., and Chen, J., 1991, Improvements in the gaseous hydrogen-Water equilibration technique for hydrogen isotoperatio analysis: Analytical Chemistry, v. 63, p. 910-912.

Davis, G.H., and Coplen, T.B., 1989, Late Cenozoic paleohydrogeology of the Western San Joaquin Valley, California, as related to structural movements in the Central Coast Ranges: Geological Society of America Special Paper 234,40 p.

Irwin, J.J., and Böhlke, J.K., 1991, Microanalysis of trace elements and noble gas isotopes in minerals and fluid inclusions, in Howitt, D.G., ed., Microbeam Analysis-1991: Microbeam Analysis Conference, 26th, San Francisco Press, p. 35-40.

Izbicki, J., Michel, R.L., and Martin, P., 1992, $\mathrm{H}-3$ and C-14 as tracers of ground-water recharge, in Proceedings of the American Society of Civil Engineers 1992 National Conference: p. 122-127. 


\section{GROUND-WATER CHEMISTRY}

Keir, R.S., and Michael, R.L., and Weiss, R.F., 1992, Ocean mixing versus gas exchange in Antarctic shelf waters near $150^{\circ} \mathrm{E}$ : Deep-Sea Research, v. 39, p. 97-119.

Keir, R.S., and Michael, R.L., 1993, Interface dissolution control of the ${ }^{14} \mathrm{C}$ profile in marine sediment: Geochemica et Cosmochemica Acta, v. 57, p. 3563-3574.

Kendall, C., and Grim, E., 1990, Combustion tube method for measurement of nitrogen isotope ratios using calcium oxide for total removal of carbon dioxide and water: Analytical Chemistry, v. 62., p. 526-529.

Landwehr, J.M., Winograd, I.J., Coplen, T.B., Riggs, A.C., Ludwig, K.R., and Szabo, B.J., 1993, Stochastic analysis of delta ${ }^{18} \mathrm{O}$ and delta ${ }^{13} \mathrm{C}$ time series found in a continuous 500,000-year climatic record from Great Basin vein calcite, in Proceedings of the U.S. Geological Survey Global Change Forum: U.S. Geological Survey Circular 1086, 86 p.

Michel, R.L., 1989, Tritium deposition over the continental United States, 1953-1983, in Delleur, J.W., ed., Atmospheric Deposition Symposium-Proceedings of the Third Scientific Assembly of the International Association of Hydrological Sciences: Baltimore, Md., p. 109-115.

1989, Tritium Deposition in the Continental United States: U.S. Geological Survey WaterResources Investigation Report 89-4072, 46 p.

1992, Residence times in river basins as determined by analyses of long-term tritium records: Journal of Hydrology, v. 130, p. 367378.

Michel, R.L., and Schroeder, R.A., 1990, Stable Isotope Results, Wilkes Land Oceanographic
Expedition, Antarctic Journal of the United States, v. 25, p. 107-109.

Plummer, L.N., Michel, R.L., Thurman, E.M., and Glynn, P.D., 1993, Environmental tracers for age-dating young ground water, in Alley, W.M., ed., Regional ground-water quality: New York Van Nostrand Reinhold, p. 255294.

Revesz, K., and Coplen, T.B., 1990, Gas chromatographic separation of carbon dioxide and nitrous oxide for stable isotopic analysis of carbon dioxide: Analytical Chemistry, v. 62, p. 972-973.

1991, Caution on the use of Viton or FETFE O-rings in carbon dioxide sample containers for delta ${ }^{18} \mathrm{O}$ analysis: Chemical Geology (Isotope Geoscience Section), v. 86, p. 259261.

Revesz, K., and Woods, P., 1990, A method to extract soil water for stable isotope analysis: Journal of Hydrology, v. 115, p. 397-406.

Schroeder, R.A., Martin, P., and Böhlke, J.K., 1993. Chemical, isotopic, and microbiological evidence for denitrification during transport of domestic wastewater through a thick unsaturated zone in the Mojave Desert, San Bernardino County, California: U.S. Geological Survey Open-File Report 93-414, 10 p.

Sturchio, N.C., Böhlke, J.K., and Markun, F.J., 1993, Radium isotope geochemistry of thermal waters, Yellowstone National Park, Wyoming: Geochimica et Cosmochimica Acta, v. 57, p. 1203-1214.

Winograd, I.J., and Coplen, T.B., 1989, Comment on Johnson, R.G., and Wright, H.E., Jr., Great Basin calcite vein and the Pleistocene time scale: Science, v. 246 , p. 262-263. 


\section{GROUND-WATER CHEMISTRY}

Winograd, I.J., Coplen, T.B., Ludwig, K.R., Riggs, A.C., Landwehr, J.M., Szabo, B.J., Kolesar, P.T., and Revesz, K.M., 1992, Continuous 500,000-year global climatic record from vein calcite in Devils Hole, Nevada: Science, v. 258, p. 255-260.

Winograd, I.J., Szabo, B.J., Coplen, T.B., and Riggs, A.C., 1988, A 250,000-year climatic record from Great Basin vein calcite-Implications for Milankovitch Theory: Science, $v$. 242 , p. $1275-1280$. 


\section{GROUND-WATER CHEMISTRY}

TITLE: $\quad$ Hydrogeochemical Controls on the Migration of Radionuclides from Uranium Mill Tailings (NR 78-092)

PERSONNEL: Edward R. Landa, Project Chief

C.L. Wakelee, Secretary

T.B. Councell, Hydrologist

ADDRESS: U.S. Geological Survey, 430 National Center, 12201 Sunrise Valley Drive, Reston, VA 22092

TELEPHONE: (703) 648-5898

PROBLEM: Uranium mill tailings and related forms of low-level radioactive waste contain elevated contents of naturally occurring radionuclides that have been brought to the surface, processed for the recovery of uranium and other components, and then disposed of in near-surface impoundments. The long-term fate of the tailings and their constituents will be determined by surficial earth processes.

OBJECTIVE: Study the chemical form in which radionuclides and selected stable elements are retained in surficial earth materials, particularly uranium mill tailings, and identify processes operating in natural aqueous and terrestrial systems that may influence the transport of these constituents from these earth materials.

APPROACH: Determine the partitioning of nuclides and elements of interest in tailings, ores, soils, rocks, and waters through the use of leaching and sorption studies, particle sizing, radon emanation measurements, and nuclear emulsion microscopy.

PROGRESS: A review of uranium mill tailings research during the past decade was completed and will be published in 1993 in a Society of Economic Geologists series. This represents a sequel to USGS Circular 814 (1980).

Results to date on possible microbial reduction of plutonium in cooperation with Derek Lovley and Jess Cleveland have been ambiguous. With the loss of the Denver transuranics project, this effort is on hold.

Reports are in progress on (1) microbial reduction of iodate, (2) intense alpha-active particles in uranium mill waste, and (3) extraction of uranium from soils and earth materials 


\section{GROUND-WATER CHEMISTRY}

and its precipitation by microbial reduction. Coediting of a special issue of the journal Environment International focused on environmental contamination associated with the use of naturally-occurring radioactive materials has been completed, the issue will be published in 1993. The project chief, in his role as DOI Science Panel member of the Committee on Interagency Radiation Research and Policy Coordination, has participated as a working group-author in preparation of report to OSTP tentatively titled "Balancing Radiation Benefits and Risks: The Needs for an Informed Public"; publication in 1994 is anticipated.

Work in cooperation with Derek Lovley has just begun on the microbial reduction of rhenium/technetium, and the coprecipitation of radioactive contaminants by biogenic uraninite.

\section{REPORTS PUBLISHED 1988-1993:}

Back, W., and Landa, E.R., 1992, Ingesting the consequences of water-rock interactionHistorical notes on bottled water and spas in Kharaka, Y., and Maest, A., eds., 7th International Symposium on Water-Rock Interactions, Park City, Utah, 1992 [Proceedings]: Rotterdam, A.A. Balkema, p. 767-770.

Landa, E.R., 1991, Radon emanation from uranium mill tailings, in Field Studies of Radon in Rocks, Soils and Water: U.S. Geological Survey Bulletin 1971, p. 145-154.

1991, Uranium mill tailings-Radium geochemistry, in U.S. Geological Survey research in radioactive waste disposal, Fiscal years 19861990: Water-Resources Investigations Report 91-4084, p. 88-90.

1992, Leaching of ${ }^{226} \mathrm{Ra}$ from components of uranium mill tailings: Hydrometallurgy, v. 26 , p. $361-368$.

1992, The International Chernobyl Project: World Meteorological Organization Bulletin, v. 41 , no. 1 , p. 63-66.
Landa, E.R., and Bush, C.A., 1988, Sorption of radionuclides by components of uranium mill tailings: Proceedings of the First International Conference on Hydrometallurgy, Beijing, Oct. 12-15, 1988, Pergamon Press, p. 661-665.

1990, Geochemical hosts of solubilized radionuclides in uranium mill tailings: Hydrometallurgy, v. 24, p. 361-372.

Landa, E.R., and Councell, T.B., 1992, Leaching of uranium from glass and ceramic foodware and decorative items: Health Physics, v. 63, p. 343-348.

Landa, E.R., Miller, C.L., and Brich, R., 1988, Radioactive and nonradioactive solutes in drinking waters from radon-charging devices: Health Physics, v. 54, p. 99-106.

Landa, E.R., Phillips, E.J.P., and Lovley, D.R., 1991 , Release of ${ }^{226} \mathrm{Ra}$ from uranium mill tailings by microbial $\mathrm{Fe}(\mathrm{III})$ reduction: Applied Geochemistry, v. 6, p. 647-652.

Lovley, D.R., Phillips, E.J.P., Gorby, Y.A., and Landa, E.R., 1991, Microbial reduction of uranium: Nature, v. 350 , p. 413-41. 


\section{GROUND-WATER CHEMISTRY}

1991, Microbial reduction of uranium: U.S. Geological Survey Toxic Substances Hydrology Program, U.S. Geological Survey WaterResources Investigations Report 91-4034, p. 548-551.

Miller, C.L., Landa, E.R., and Updegraff, D.M., 1987, Ecological aspects of microorganisms inhabiting uranium mill tailings: Microbial Ecology, v. 14, no. 2, p. 141-155. 


\title{
GROUND-WATER CHEMISTRY
}

TITLE: Dispersion of Toxic and Radioactive Wastes in Ground-Water Systems (NR 81-122)

\author{
PERSONNEL: Warren W. Wood, Project Chief \\ Mellissa Schomody, Secretary \\ Terry B. Councell, Hydrologist \\ Kris Dennen, Geologist \\ Steve Killingsworth, Hydrologic Tech., student \\ (Texas Tech University) \\ C.C. Reeves, Professor (Texas Tech University)
}

\begin{abstract}
ADDRESS: $\quad$ U.S. Geological Survey, 431 National Center, 12201 Sunrise Valley Drive, Reston, VA 22092
\end{abstract}

TELEPHONE: (703) 648-5875

PROBLEM: Movement of toxic and radioactive substances in aquifer systems occurs in all gaseous, liquid, and solid phases and is controlled by hydrologic and chemical forces. Solute movement can be greatly affected not only by physical dispersion but also by other factors such as exchange, sorption, chemical kinetics, and ionic distributions. Movement of gases and particulate material in the unsaturated zone is controlled by many additional factors. Knowledge of how these physical and geochemical factors affect prediction of movement of toxic and radioactive wastes is only generally known for ideal systems.

OBJECTIVE: Develop field methods and techniques that will yield values for physical and geochemical factors of regional significance in a ground-water system.

APPROACH: Undertake studies in which appropriately developed field methods and techniques are applied to stressed systems. Define the importance of the various factors and find a means for measuring the magnitude of each.

PROGRESS: Published first and second part (with Ward Sanford) of a proposed three-part series on the role of basin leakage in controlling evaporite mineralogy and accumulation.

Ward Sanford and Warren Wood have continued to develop our infrastructure at our saline lake research facility at Double Lakes in West Texas with the drilling of two deep wells. These wells are instrumented for discrete vertical sampling at 1.5 meter intervals to test our concepts of diffusion transport. Preliminary sampling has been completed and samples are being analyzed. Our first work was published at Water-Rock Interaction Conference, 1992. 


\section{GROUND-WATER CHEMISTRY}

This site is believed to be an excellent natural analog to the disposal of toxic waste in thick shales.

Samples of material from the unsaturated zone at the Double Lake site support our eolian transport hypothesis that the huge 50 kilometer long ground-water solute plumes, observed downgradient form the saline lakes, are a function of efflorescent salts transported out of the lake by eolian activity, blown down the wind gradient and then recharged to the ground water. This has several important water resources ramifications for the southern High Plains and offers a viable explanation for the origin of these plumes observed in arid areas elsewhere on earth. This eolian transport concept and its impact on ground-water geochemistry is being tested in Australia and in a sabkhah of Abu Dhabi.

A new hypothesis was published on the origin of the 50-60 saline lake basins that exist on the southern High Plains of Texas and New Mexico. This hypothesis suggest that bedrock highs caused ground water to mound over them, thus preventing calcrete from forming. At a later stage when the ground-water table declined, wind eroded the uncemented material forming the basins. This work resolves a 100-year-old controversy on the origin of these features.

Data collected with Allen Shapiro at Mirror Lake toxic waste research site in New Hampshire have demonstrated that diffusion is the major mechanism supplying and removing solutes to the ground water from this granite terrain. Use of Hydrogen-3/Helium-3 dating techniques of the flowpath in this fractured rock system is in cooperation with Tom Torgerson, University of Connecticut and Martin Stute, Lamont-Doherty, Columbia University.

REPORTS PUBLISHED 1988-1993:

Back, William, Baedecker, M.J., and Wood, W.W., 1993, Scales in chemical hydrogeology-A historical perspective, in Alley, W.M., ed., Regional Ground-Water Quality: New York, Van Nostrand Reinhold, 634 p.

Le Blanc, D.R., Garabedian, S.P., Hess, K.M., Gelhar, L.W., Quadri, R.D., Stollenwerk, K.G., and Wood, W.W., 1991, Large-scale natural-gradient tracer test in sand and gravel, Cape Cod, Massachusetts-1. Experimental design and observed tracer movement: Water Resources Research, v. 27, no. 5, p. 895-910.
Rosenshein, J.S., Moore, J.E., and Wood, W.W., 1991, Hydrogeology: Geotimes, v. 36, no. 2, p. 51-52.

Sanford, W.E., and Wood, W.W., 1991, Brine evolution and mineral deposition in hydro logically open evaporite basins: American Journal of Science, v. 291, p. 687-710.

Sanford, W.E., Wood, W.W., and Councell, T.B., 1992, Calcium chloride-dominated brines-An ion-exchange model, in Kharaka, Yousif K., and Maest, Ann S., eds., 7th Symposium on 


\section{GROUND-WATER CHEMISTRY}

Water Rock Interaction [Proceedings]: Rotterdam, A.A. Balkema, p. 669-672.

Wood, W.W., 1988, Hydrologic development of playa-lake basins in the southern High Plains: U.S. Geological Survey Yearbook Fiscal Year 1987, p. 39-40.

1989, Birdsall Lecture Report: Groundwater, v. 27 , no. 5 , p. $729-730$.

1990, Case study: Solution and piping development of playa-lake basins on the Llano Estacado of Texas and New Mexico, in Charles, Higgins, ed., Groundwater Geomorphology, Piping and pseudokarst in drylands: Geological Society of America Special Paper 252 , chap. 4 , p. 101-110. .

Wood, W. W., and Fernandez, L. A., 1988, Volcanic rocks: The Geology of North AmericaHydrology, DNAG, Geological Society of America, chap. 39, v. 0-2, p. 353-365.

Wood, W.W., Hearn, P.P.; and Kraemer, T.F., 1988, Solute diffusion within sand of the Cape Cod Massachusetts aquifer, in Mallard, G.E., and Ragone, S.E., eds., U.S. Geological Survey Toxic Substance Hydrology ProgramProceedings of the technical meeting, Phoenix, Ariz., September 26-30 1988: U.S. Geological Survey Open-File Report 88-4220, p. 163-166.

Wood, W.W., and Jones, B.F., 1990, Origin of solutes in saline lakes and springs on the Southern High Plains of Texas and New Mexico, in Gustavson, Thomas C. ed., Geologic Framework and Regional Hydrology: Upper Cenozoic Blackwater Draw and Ogallala Formations, Great Plains: Texas Bureau of Economic Geology, p. 193-208.

Wood, W.W., Kraemer, T.F., and Hearn P.P. Jr., 1990, Intergranular diffusion-An important mechanism influencing solute transport in clastic aquifers?: Science, v. 247, p. 15691572.

Wood, W.W., and Low, W.H., 1988, Solute geochemistry of the Snake River Plain Regional Aquifer System, Idaho and eastern Oregon: U.S. Geological Survey Professional Paper 1408-D, 79 p.

Wood, W.W., and Sanford, W.E., 1990, Groundwater control of evaporite deposition: Economic Geology, v. 85, p. 1226-1235.

Wood W.W., and Sanford, W.E., 1991, The origin of Evaporite deposits-A model based on a hydrologically open system, in Good, E.E., Slack, J.F., and Kotra, R.K., eds., Research on minerals resources-1991: U.S. Geological Survey Circular 1062, p. 79-80.

Wood, W.W., Sanford, W.E., and Reeves, C.C., 1992, Large lake basins of the southern High Plains-Ground-water control of their origin?: Geology, v. 20, p. 535-538. 


\section{GROUND-WATER CHEMISTRY}

TITLE: $\quad$ Comparative Study of Organic Degradation in Selected Hydrogeologic Environments (NR 83-129)

PERSONNEL: Mary Jo Baedecker, Project Chief

Kathrine E. Devine, Secretary

Isabelle M. Cozzarelli, Hydrologist

Curtis S. Phinney, Physical Scientist

My-Chau Tran, Chemist

ADDRESS: $\quad$ U.S. Geological Survey, 431 National Center, 12201 Sunrise Valley Drive, Reston, VA 22092

TELEPHONE: (703) 648-5858

PROBLEM: Degradation of organic material produces organic compounds that both alter the quality of water and affect the inorganic reactions. The hydrogeologic controls on organic-inorganic reactions, their rates, and progress are not well understood. This project focuses on the occurrence and fate of organic compounds in (1) contaminated aquifers, (2) soils, and (3) lake sediments.

OBJECTIVE: Increase our understanding of reactions involving organic matter and evaluate the significance of these reactions in geochemical studies. Specific objectives are (1) to identify organic and inorganic compounds that are present as a result of the degradation of organic material; (2) to study the interaction of organic compounds with soil and aquifer materials; and (3) to develop geochemical models in organic-rich environments.

APPROACH: Several organic-rich environments with chemical and hydrologic background data will be selected from which samples can be obtained and analyzed for organic and inorganic constituents. In these areas, where degradative processes are primarily anaerobic, the extent and effects of chemical reactions and processes will be investigated. Of interest is the type of organic material present, the interaction of organic compounds with sediment, the migration of organic compounds, the fractionation of isotopes and generation of gases, and the fate of inorganic constituents in association with organic material.

PROGRESS: Field investigations and laboratory experiments were conducted to understand processes in shallow sand and gravel aquifers contaminated with petroleum products. Work continued on identifying the nature of the organic compounds dissolved in ground water and the controlling biogeochemical reactions that occur in contaminant plumes downgradient from hydrocarbon sources. At the study site near Bemidji, Minnesota, the transport of monoaromatic hydrocarbons and the distributions of products that result from degradation 


\section{GROUND-WATER CHEMISTRY}

reactions were examined on a small scale. The findings verify the chemical heterogeneity of the contaminant plume. The conditions that affect the extent of plume migration were evaluated and it was determined that natural biodegradation is the major control on contaminant attenuation.

At the study site in Galloway Township, New Jersey, an investigation of low-molecular-weight organic acids in ground water was undertaken to understanct the distribution and fate of the acids under various geochemical conditions. Aliphatic, aromatic, and alicyclic organic acids were associated with hydrocarbon degradation in oxygen-depleted zones of the aquifer. Laboratory microcosm experiments demonstrated that the biogeochemical fate of specific organic acids observed in ground water varied with the structure of the acid and the availability of electron acceptors.

The cycling of iron and the formation of authigenic minerals was investigated in shallow sand and gravel aquifers that are contaminated with organic compounds. An integrated study of the water chemistry, microbial degradation, and authigenic mineral formation was undertaken. The authigenic iron-bearing minerals pyrite, siderite, magnetite, and ferroan calcite were found in three shallow aquifers contaminated with phenols and (or) hydrocarbons. The cycling of large concentrations of iron from oxidized to reduced forms and precipitation of iron minerals results in changes in the mineralogy and geochemistry of an aquifer that can affect transport and local water quality.

REPORTS PUBLISHED 1988-1993:

Back, William, and Baedecker, M.J., 1989, Chemical hydrogeology in natural and contaminated environments: Journal of Hydrology, v. 106, p. 1-28.

Back, William, Baedecker, M.J., and Wood, W., 1993, Scales in chemical hydrogeology: An historical perspective, in Alley, W., ed., Regional Ground Water Quality: New York, Van Nostrand'Reinhold, p. 111-129.

Baedecker, M.J., and Cozzarelli, I.M., 1991, Geochemical modeling of organic degradation reactions in an aquifer contaminated with crude oil in Mallard, G.E., and Aronson, D.A., eds., U.S. Geological Survey Toxic Substances Hydrology Program-Proceedings of the technical meeting, Monterey, Calif., 1991: U.S. Geological Survey Water-Resources Investigations Report 91-4034, p. 627-632.

1992, The determination and fate of unstable constituents in contaminated ground water, in Lesage, S., and Jackson R., ed., Groundwater Quality and Analysis at Hazardous Waste Sites: New York, Marcel Dekker, Inc., p. 425-461.

Baedecker, M.J., Cozzarelli, I.M., Evans, J.R., and Hearn, P.P., 1992, Authigenic mineral formation in aquifers rich in organic material in Kharaka, Yousif K., and Maest, Ann S., eds., 7th International Symposium on WaterRock Interaction, Park City, Utah, July 9-23, 


\section{GROUND-WATER CHEMISTRY}

1992 [Proceedings]: Rotterdam, A.A. Balkema, p. 257-261.

Baedecker, M.J., Cozzarelli, I.M., and Phinney, C.S., 1991, Distribution of organic and inorganic constituents in ground water at Galloway Township, New Jersey in Mallard, G.E., and Aronson, D.A., eds., U.S. Geological Survey Toxic Substances Hydrology Program-Proceedings of the technical meeting, Monterey, Calif., 1991: U.S. Geological Survey Water-Resources Investigations Report 91-4034, p. 287-293.

Baedecker, M.J., Cozzarelli, I.M., Siegel, D.I., Bennett, P.C., and Eganhouse, R.P., in press, Crude oil in a shallow sand and gravel aquifer-III. Biogeochemical reactions and mass balance modeling in anoxic groundwater: Applied Geochemistry, v. 8.

Baedecker, M.J., Siegel, D.I., Bennett, P.C., and Cozzarelli, I.M., 1989, The fate and effects of crude oil in a shallow aquifer-I. The distribution of chemical species and geochemical facies in Mallard, G.E., and Ragon, S.E., eds., U.S. Geological Survey, Toxic Substances Hydrology Program-Proceedings of the technical meeting, Phoenix, Ariz., September 26-30, 1988,: U.S. Geological Survey WaterResources Investigations Report 88-4220, Pp. 21-34.

Bennett, P.C., Siegel, D.I., Baedecker, M.J., and Hult, M.F., 1993, Crude oil in a shallow sand and gravel aquifer-I. Hydrgeology and inorganic geochemistry: Applied Geochemistry, v. 8 , p. $529-549$.

Cozzarelli, I.M., and Baedecker, M.J., 1992, Oxidation of hydrocarbons coupled to reduction of inorganic species in groundwater in Kharaka, Yousif K., and Maest, Ann S., eds., 7th International Symposium on Water-Rock Interaction, Park City, Utah, July 9-23, 1992 [Pro- ceedings]: Rotterdam, A.A. Balkema, p. 275278.

Cozzarelli, I.M., Baedecker, M.J., Eganhouse, R.P., and Goerlitz, D.F., in press, The geochemical evolution of low-molecular-weight organic acids derived from the degradation of petroleum contaminants in ground water: Geochimica et Cosmochimica Acta, v. 57.

Cozzarelli, I.M., Baedecker, M.J., and Hopple, J.A., 1991, Geochemical gradients in shallow ground water caused by the microbial degradation of hydrocarbons at Galloway Township, New Jersey in Mallard, G.E., and Aronson, D.A., eds., U.S. Geological Survey Toxic Substances Hydrology Program-Proceedings of the technical meeting, Monterey, Calif.: U.S. Geological Survey Water-Resources Investigations Report 91-4034, p. 256-262.

Cozzarelli, I.M., Eganhouse, R.P., and Baedecker, M.J., 1989, The fate and effects of crude oil in a shallow aquifer, II. Evidence of anaerobic degradation of monoaromatic hydrocarbons in Mallard, G.E., and Ragone, S.E., eds, U.S. Geological Survey, Toxic Substances Hydrology Program-Proceedings of the technical meeting:, Phoenix, Ariz., September 26-30, 1988: U.S. Geological Survey Water-Resources Investigations Report, 88-4220, p. 21-34.

1990. Transformation of monoaromatic hydrocarbons to organic acids in anoxic ground-water environments: Environmental Geology and Water Sciences, v. 16, p. 135-141.

Eganhouse, R.P., Baedecker, M.J., Cozzarelli, I.M., Aiken, G.R., Thorn, K.A., and Dorsey, T.F., 1993, Crude oil in a shallow sand and gravel aquifer-II. Organic geochemistry: Applied Geochemistry, v. 8, p. 551-567.

Lindsay, S.S., and Baedecker, M.J., 1988, Determination of aqueous sulfide in contaminated 


\section{GROUND-WATER CHEMISTRY}

and natural water using the methylene blue method, in Collins, A.G., and Johnson, A.I., eds., Ground-Water Contamination-Field Methods, ASTM/ST963: American Society for Testing Materials, Philadelphia, Pennsylvania, p. 349-357.

Lovley, D.R., Baedecker, M.J., Lonergan, D.J., Cozzarelli, I.M., Phillips, E.J.P., and Siegel, D.I., 1989, Oxidation of aromatic contaminants coupled to microbial iron reduction: Nature, v. 339, p. 297-299.

Mallard, G.E., and Baedecker, M.J., 1993, Hydrocarbon transport and degradation in ground water-U.S. Geological Survey Proceedings of the Air Combat Command Environmental Quality T93 Symposium, March 1-5, 1993, Denver, Colo.: U.S. Geological Survey Water-Resources Investigations, p. 102-108.

Phinney, C.S., 1993, Enhancement of molecular ion detection by variation of mass analyzer thermal energy for $\mathrm{C}^{10}-\mathrm{C}^{28}$ alkanes by ion-trap mass spectrometry: ASMS Conference on Mass Spectrometry and Allied Topics, 41st, San Francisco, Calif., May 30-June 4, 1993 [Proceedings], p. 632A-632B.

Phinney, C.S., and Cozzarelli, I.M., 1992, A comparison of analytical techniques for measurement of volatile hydrocarbons in ground water, in ASMS Conference on Mass Spectrometry and Allied Topics, 40th, Washington, D.C., May 31-June 5, 1992 [Proceedings], p. 659-660.

Sigleo, A.C. and Shultz, D.J., in press, Amino acid composition of suspended particles, sediment trap material, and benthic sediment in the Potomac estuary: Estuaries, v. 16 


\section{GROUND-WATER CHEMISTRY}

TITLE: $\quad$ Relationship Between Chemical Quality of Natural Waters and Human Health and Disease (NR 79-132)

PERSONNEL: Gerald L. Feder, Project Chief

Bonnie H. Hower, Secretary

ADDRESS: $\quad$ U.S. Geological Survey, 432 National Center, 12201 Sunrise Valley Drive, Reston, VA 22092

TELEPHONE: (703) 648-5830

PROBLEM: In recent years, there has been increasing interest and study concerned with the possible relations between the chemical quality of natural waters and human health and disease. Medical researchers recognize areal patterns of health and disease in the United States and suspect that these patterns may be controlled by environmental and nonenvironmental factors. After excluding nonenvironmental factors, local and regional differences in water quality appear to have an effect on health and disease. Such differences influence the total dietary intake of necessary major and trace elements and the concentration of certain potentially toxic chemical constituents.

OBJECTIVE: Discover and quantify relations between the chemical quality of natural waters and human health and disease.

APPROACH: Identify chemical constituents in natural waters that are most likely to affect health and disease and those medical conditions most likely to be affected by water quality. Determine the temporal and spatial associations between specific chemical characteristics of water and specific states of health and disease. Exclude known high-risk factors related to geographic areas (for example, urban environment, mining activity) to increase the likelihood of detecting risk factors associated with natural water quality. Initially, use existing data from sources such as the U.S. Geological Survey and the Bureau of Vital Statistics for the medical and hydrologic aspects of the study. Collect new data in the field if data are lacking. Supplement data collection through cooperative programs with District and aquifer-study water-quality specialists. Obtain information on chemical composition of soils, rocks, and plants through cooperation with the Branch of Regional Chemistry, Geologic Division. Cooperate with Dr. Howard C. Hopps, Curators Professor of Pathology, University of Missouri Medical School, throughout this study. 


\section{GROUND-WATER CHEMISTRY}

PROGRESS: Showed that well waters from households with Balkan endemic nephropathy in Yugoslavia have distinctive excitation-emission fluorescence spectra when compared to spectra from households in nonendemic villages.

Low grade lignite samples from endemic areas in Yugoslavia were collected by a colleague, and preparation of samples for Nuclear Magnetic Resonance Spectroscopic analysis has been completed: the samples will be analyzed shertly.

Preliminary work with epidemiologists at the National Center for Health Statistics indicates there are strong geographic, and possibly hydrologic, differences in the distribution of the United States counties with the highest and lowest death rates from ischemic heart disease and stroke. The high death rate area also has an interesting pattern that seems to stop at the Florida State line. This difference might be real and related to magnesium content of drinking water.

Field sites in the United States and Hungary were chosen for the study of the relationship between high nitrate concentrations in drinking water and human health.

\section{REPORTS PUBLISHED 1988-1993:}

Feder, G.L., Finkleman, R.B., Radovanovic, Zoran, 1991, Relationship between weathered coal deposits and the etiology on Balkan endemic nephropathy: Kidney International, v. 40, supp. 34 (1991), p. S-9 through S-11.

Finkleman, R.B., Feder, G.L., Orem, W.H., Radovanovic, Zoran, 1991, Relation between low-rank coal deposits and Balkan endemic nephropathy: AGID News, no. 65, February 1991, p. 23.

McKnight, D.M., Bencala, K.E., Zellweger, G.W., Aiken, G.R., Feder, G.L., Thorn, K.A., 1992, Sorption of dissolved organic carbon by hydrous aluminum and iron oxides occuring at confluences of Deer Creek with the Snake River, Summit County, Colorado: Environmental Science and Technology, v. 26, no. 7 , p. 1388-1396.
McKnight, D.M., Wershaw, R.L., Bencala, K.E., Zellweger, G.W., Feder, G.L., 1992, Humic substances and trace metals associated with $\mathrm{Fe}$ and $\mathrm{Al}$ oxides deposited in an acidic mountain stream: The Science of the Total Environment, v. $117 / 118$, p. $485-498$.

McNeal, J.M., Feder, G.L., Wilber, W.G., Deverel, S.J., 1990, Environmental concerns related to selenium in the western United States, in Doe, B.R., ed., Proceedings of a U.S. Geological Survey Workshop on Environmental Geochemistry: U.S. Geological Survey Circular 1033, p. 177-178. 


\section{GROUND-WATER CHEMISTRY}

TITLE: $\quad$ Uranium-Thorium Series Radioisotopes in Ground-Water and Surface-Water Systems (NR 82-138)

PERSONNEL: Thomas F. Kraemer, Project Chief Joseph Albiston, Physical Science Technician

Daniel Chian, Hydrologic Technician, student (University of Virginia)

ADDRESS: $\quad$ U.S. Geological Survey, 431 National Center, 12201 Sunrise Valley Drive, Reston, VA 22092

TELEPHONE: (703) 648-5868

PROBLEM: Naturally occurring uranium and thorium series radioisotopes possess great potential as natural tracers for examining movement and mixing of water bodies. At present, however, not enough is known of their geochemical behavior to use them even semiquantitatively for this purpose. In addition, new analytical techniques are being developed which will allow determination of isotopes of chlorine, krypton, iodine and other elements. These isotopes will also be of use in the hydrologic sciences as tracers, if sufficient understanding of their geochemical behavior can be achieved.

OBJECTIVE: Learn enough about the geochemical behavior of uranium and thorium series radioisotopes to permit their use as naturally occurring tracers to solve hydrological problems. Keep abreast of developments in the field of chlorine, krypton, iodine, and so forth, geochemistry and isotope analysis for possible application to hydrologic sciences.

APPROACH: Studies of uranium and thorium series radioisotopes will be carried out in a variety of well known surface and subsurface conditions and their behavior related to specific physical and chemical conditions and processes. Laboratory studies will be carried out as needed under carefully controlled conditions to examine specific aspects of behavior. When behavior of these radioisotopes is well known, these principles can be applied to hydrologic problems of less well-defined systems to determine if methods developed can contribute answers which are at least reasonable with respect to results from other hydrologic approaches. As confidence is gained through these processes, methods will be applied to poorly constrained hydrologic problems not amenable to solution by standard hydrologic techniques. 


\section{GROUND-WATER CHEMISTRY}

PROGRESS: A. A new sampling system has been developed which allows the collection of samples to far out-strip the ability to analyze them. With this technique the lakes can be sampled for radium isotopes in greater detail than ever before. Results to date reveal complex structure present in the water masses of the Finger Lakes, New York, which changes throughout the year. The 1993 spring all-time record inflow into the lakes was sampled, and preliminary results show tremendous changes in isotopic signature of the lake waters (Cayuga). Stable isotope, and tritium data have also been collected in an effort to understand the hydrology and hydrodynamics of the Finger Lakes.

B. Spikes have been received and techniques development has proceeded well in the effort to determine $\mathrm{U}$ and $\mathrm{Ra}$ isotopes by mass spectrometry. Development of these techniques will enable isotopic measurements of unprecedented accuracy and will further enhance the use of these isotopes in hydrologic investigations.

C. Sediments from Lake Baikal, Russia, have been analyzed for $U$ and Th isotopes and found to be very unusual. They have high uranium content and a high ${ }^{234} \mathrm{U} /{ }^{238} \mathrm{U}$ activity ratio with a low ${ }^{230} \mathrm{Th} /{ }^{234} \mathrm{U}$ ratio. The data will allow establishment of lake sediment accumulation rates and dating of glacial-interglacial events-both very important to those working on the paleoclimatology of the Lake Baikal area.

D. Significant seasonal variation has been found in the uranium content of runoff from the Walnut Creek, Iowa, Management Systems Evaluation Areas (MSEA) site. The reason for this is not understood at present, but may be related to the application of U-rich phosphate fertilizer to the fields.

REPORTS PUBLISHED 1988-1993:

Goode, D.J., Hsieh, P.A., Shapiro, A.M., Wood, W.W., and Kraemer, T.F., in press, Concentration history during pumping from a leaky aquifer with stratified initial concentration, in Shen, H.W., ed., Hydraulic Engineering, National Conference, San Francisco, July 25-30, 1993, Proceedings: New York, American Society of Civil Engineers.

Kraemer, T.F., 1990, Geological factors governing radon concentration in natural gas, in Smith, J., ed., Proceedings of Gas Quality Measure- ment Symposium: Institute of Gas Technology, Chicago, Illinois, July, 1990, 41 p.

1991, Uranium, radium and radon in deeply buried sediments of the U.S. Gulf Coast, in Wanty R., and Gundersen, L., eds., Field Study of Radon in Rocks, Soils, and Water: U.S. Geological Survey Bulletin 1971, p. 125-130.

Kraemer, T.F., and Curwick, P.B., 1991, Radium isotopes in the Lower Mississippi River: Jour- 


\section{GROUND-WATER CHEMISTRY}

nal of Geophysical Research (Oceans), v. 96, no. C2, p. 2797-2806.

Miller, R.L., Kraemer, T.F., and McPherson, B.J., 1990, Radium and radon in Charlotte Harbor estuary, Florida: Estuarine, Coastal and Shelf Science, v. 31, p. 439-457.

Wood, W.W., Kraemer, T.F., and Hearn, P.P., Jr., 1990, Intragranular diffusion-An important mechanism influencing solute transport in clastic aquifers?: Science, v. 247, no. 4950, p. 1569-1572. 


\section{GROUND-WATER CHEMISTRY}

TITLE: $\quad$ Transport and Biogeochemical Fate of Organic Substances in Aquatic Environments (NR 91-151)

PERSONNEL: Robert P. Eganhouse, Project Chief

Bonnie Hower, Secretary

Wendy Bryant, Chemist

ADDRESS: $\quad$ U.S. Geological Survey, 432 National Center, 12201 Sunrise Valley Drive, Reston, VA 22092

TELEPHONE: (703) 648-5879

PROBLEM: Organic substances are transported in both particulate and dissolved phases in aquatic environments. However, our understanding of the processes affecting phase exchange and removal are incomplete. In order to predict the short-and long-term fate of toxic organic substances in a variety of aquatic environments, it is necessary to determine the physical properties of these compounds and establish kinetic data on their removal rates using a combination of field studies and laboratory experiments.

OBJECTIVE: The objective is to investigate the composition and concentration of organic matter associated with dissolved and particulate phases in surface and subsurface waters and compare these data with distributions based on laboratory partitioning experiments and physical partitioning (for example, fugacity) models. I wish to develop data on the rates at which organic matter is transformed (and remineralized) and the products that result in aquatic environments. This information will be used to establish the relative importance of different removal processes under a variety of environmental conditions. Ultimately these results will be incorporated into particle and solute transport models.

APPROACH: Studies will be carried out at one or more field sites that present favorable opportunities for examining the transport and fate of organic contaminants in different aquatic environments. Particulate and dissolved phases will be analyzed for the presence and concentration of a variety of natural and anthropogenic organic substances and their variation over time. Experiments will be performed in the laboratory to determine the equilibrium phase partitioning, desorption rates and biodegradation potential (and rates) of selected organic compounds. These equilibrium and kinetic data will be compared with the results of field studies and models that predict physical partitioning. 


\section{GROUND-WATER CHEMISTRY}

PROGRESS: I have published one paper as lead author in Journal of Chromatography on the determination of volatile monoaromatic hydrocarbons in water (especially ground water), another as co-author in the Journal of Chemical and Engineering Data on the physical properties (for example, aqueous solubilities, vapor pressures and octanol-water partition coefficients) of the long-chain linear alkylbenzenes, and have had a manuscript published in Applied Geochemistry that provides an overview of the organic geochemistry of the Bemidji ground-water research site in Minnesota. I was also a co-author on another (companion) manuscript in the same overview series (also published in Applied Geochemistry) and on a manuscript currently in press in Geochimica et Cosmochimica Acta. The latter manuscript was lead authored by Isabelle Cozzarelli and discusses the production and fate of the oxygenated products of the hydrocarbons at Bemidji. Finally, I am lead co-author of a chapter in a book about to be published (December 1993, University of California Press) on the Ecology of the Southern California Bight (my chapter was entitled the Chemical Oceanography and Geochemistry).

As part of work funded by the National Oceanic and Atmospheric Administration (NOAA), I participated in three scientific cruises for a total of 4.5 weeks, attended six meetings in California to plan same, constructed a high resolution whole-core porewater extraction system and built a modern trace organic analytical facility in Reston, Virginia. In addition to working on my studies of porewater and sediment chemistry for the NOAA project, I acted as consultant to the project on all matters related to geochemistry. I presently have brought on line methods for the determination of polychlorinated biphenyls (PCBs) (congener-specific), DDTs, dissolved organic carbon, and linear alkylbenzenes.

In the course of all these activities I have hired and trained a technician, Wendy Bryant. I have also reviewed numerous manuscripts and proposals from internal sources, peer-reviewed journals and funding agencies. Finally, I was an outside reviewer for Environment Canada on their efforts to develop sediment quality objectives.

\section{REPORTS PUBLISHED 1991-1993:}

Baedecker, M.J., Cozzarelli, J.M., Eganhouse, R.P., Siegel, D.I., and Bennett, P.C., 1993, Crude oil in a shallow sand and gravel aquifer-III. Biogeochemical reactions and mass balance modeling in anoxic ground water: Applied Geochemistry, v. 8, p. 569-586.

Eganhouse, R.P., Baedecker, M.J., Cozzarelli, J.M., Aiken, G.R., Thorn, K.A., and Dorsey,
T.F., 1993, Crude oil in a shallow sand and gravel aquifer-II. Organic geochemistry: Applied Geochemistry, v. 8, p. 551-567.

Eganhouse, R.P., Dorsey, T.F., Phinney, C.S., and Westcott, A.M., 1993, Determination of $\mathrm{C}_{6}-\mathrm{C}_{10}$ aromatic hydrocarbons in water by purge-and-trap capillary gas chromatography: Journal of Chromatography, v. 628, p. 81-92. 


\section{GROUND-WATER CHEMISTRY}

Eganhouse, R.P., and Gossett, R.W., 1991, Sources and magnitude of bias associated with determination of polychlorinated biphenyls (PCB) in environmental samples: Analytical Chemistry, v. 63 , p. $2130-2137$.

1991, Historical deposition and biogeochemical fate of polycyclic aromatic hydrocarbons in sediments near a major submarine wastewater outfall in Southern California, in Baker, R.A., ed., Organic substances and sediments in water: Boca Raton, Fla., Lewis Publishers, v. 2, p. 191-220.

Eganhouse, R.P., and Venkatesan, M.I., in press, Chemical Oceanography and Geochemistry, in Frazier, Rebecca, ed., Ecology of the Southern California Bight: Minerals Management Service, University of California Press, chap. $3,250 \mathrm{p}$.

Olmez, I., Sholkovitz, E.R., Hermann, D., and Eganhouse, R.P., 1991, Rare earth elements in sediments off southern California-A new anthropogenic indictor: Environmental Science and Technology, v. 25, p. 310-316.

Sherblom, P.M., and Eganhouse, R.P., 1991, Bioaccumulation of molecular markers for municipal wastes by Mytilus edulis, in Baker, R.A., ed., Organic substances and sediments in water: Boca Raton, Fla., Lewis Publishers, v. 3, p. 139-158.

Sherblom, P.M., Gschwend, P.M., and Eganhouse, R.P., 1992, Aqueous solubility, vapor pressure and 1-octanol-water partition coefficients for $\mathrm{C}_{9-14}$ linear alkylbenzenes: Journal of Chemical and Engineering Data, v. 37, p. 394-399. 


\section{GROUND-WATER CHEMISTRY}

TITLE: Factors Determining Solute Transfer in the Unsaturated Zone (WR 68-036)

PERSONNEL: Ronald V. James, Project Chief

ADDRESS: $\quad$ U.S. Geological Survey, 345 Middlefield Road, MS 472, Menlo Park, CA 94025

TELEPHONE: (415) 329-4521

PROBLEM: Quality of ground and surface waters often is influenced significantly by chemical and solute-dispersion processes of the unsaturated zone. Frequently, these influences are impossible to predict because the effects of certain relevant, unsaturated-zone factors (for example, changes in water content or in the nature of solid surfaces) are understood imperfectly and because the current transport-modeling methods may not be well adapted to the situations encountered in practice. As a result, it may be impossible to assess properly the availability and quality of a given water resource or to predict the effects of certain human activities or management practices upon such water quality.

OBJECTIVE: Develop and test theories and mathematical models of reacting-solute transport to enhance the usefulness of such theories and models for assessing the effects of solute transport in the unsaturated zone on water resources and environment quality. Include in the study chemical reactions involving radioactive nuclides as well as reactions of certain solutes found in industrial and agricultural effluents. Develop mathematical models aimed at managing subsurface water quality.

APPROACH: Develop new mathematical models to predict transport of reacting solutes through porous media or at media boundaries, with consideration of the special conditions encountered in the unsaturated zone. Use theory, numerical methods, and controlled experiments. Use the interaction between theory and experiment to enhance the understanding of processes involved. Stress unidirectional transport. Study water-saturated systems with slow, steady water flows and a single, primarily equilibrium-controlled chemical reaction; study steady but unsaturated flows, paying special attention to the influence of water content on chemical and dispersion parameters; and study fast, perhaps transient, flows and chemical-kinetics influences and interactions among several reactions. Develop ground-water pollutant management models that combine numerical-simulation models and management techniques such as linear programming. Initially focus on pollutant-source management in transient one-dimensional systems with linear chemistry. Subsequently, investigate pollutant- 


\section{GROUND-WATER CHEMISTRY}

source management in two dimensions with nonlinear, one-component chemical systems. Use existing simulation models and management models to enhance joint management and simulation capabilities.

PROGRESS: Solute transport studies using water-saturated columns of Delhi sand were carried out in the laboratory using chlorine-36 and tritium tracers. Solutions of calcium and sodium chloride in varying concentrations and proportions were used to observe the effects of solution concentration and composition on the transport of nonreactive and anionic solutes. Anionic exclusion volumes, dispersion coefficients, and hydraulic conductivities were measured. As expected from previous studies, lower concentrations and higher sodium adsorption ratios lowered the soil hydraulic conductivity. The lower conductivity was accompanied by only small increases in anionic exclusion volumes. Under conditions of very low hydraulic conductivity, Darcy's Law was no longer obeyed. A procedure was developed for manually packing small laboratory columns of soil or sediments. The method involves prewetting the soil to an optimum water content and packing the soil in the column so as to insure homogeneity. Initial experiments were carried out to study the transport of lithium bromide in sediments from Cape Cod, Massachusetts. Based on the results, further experiments were designed that will maximize the effects of the kinetics of adsorption of lithium. This study augments previous work by the collaborators in this study: Allen Moench and Warren Wood. . Developed sampling protocol for Lower Fox River bottom sediment samples designed to preserve the anaerobic nature of the sediments until they can be brought to the laboratory for study of the release of polychlorinated biphenyl compounds. The procedure is necessary to maintain sample integrity and insure that study results apply to the natural system and not to some artificial system created by our procedures. 


\section{GROUND-WATER CHEMISTRY}

TITLE: $\quad$ Partitioning of Solutes between Solid and Aqueous Phases (WR 70-065)

PERSONNEL: James A. Davis, III, Project Chief

Stacey J. Andrews, Secretary

Christopher C. Fuller, Hydrologist

Douglas B. Kent, Hydrologist

Linda D. Anderson, Hydrologist

Jennifer A. Coston, Physical Scientist

Brigid A. Rea, Chemist

$\begin{array}{ll}\text { ADDRESS: } & \text { U.S. Geological Survey, } 345 \text { Middlefield Road, MS 465, } \\ & \text { Menlo Park, CA } 94025\end{array}$

TELEPHONE: (415) 329-4484

PROBLEM: When solutes are introduced into a ground-water system or into surface waters, physicochemical reactions can occur between the dissolved solutes and native solid materials. Detailed knowledge of the chemical reactions that occur at solid surfaces is required to assess the effects of such inputs on water quality. In addition, the geochemical cycling of some trace elements may be controlled by the distribution between solid and aqueous phases. A fundamental understanding of the surface-chemistry reactions is needed to incorporate a mathematical description of these processes into chemical-equilibrium and solute-transport models.

OBJECTIVE: (1) Study the adsorption behavior of inorganic and organic solutes on particulate materials that are important in natural systems, including aluminosilicate minerals, model colloids (such as hydrous oxides of aluminum, silicon, iron, or manganese), and solids of biogenic origin; (2) derive stability constants for the partitioning of solutes between a particular solid surface and the aqueous phase and understand the mechanisms of surface bonding from a theoretical perspective, including electrical double-layer theory; and (3) generate a surface-stability-constant data base that is compatible with existing computer models of chemical equilibrium and that could be used in the field evaluation of solutetransport models.

APPROACH: (1) Conduct experiments in the laboratory, of physical-chemical techniques to characterize surfaces and to measure adsorption behavior as the type of solute, type of surface, and water composition are varied; (2) use controlled laboratory solutions in both kinetic and equilibrium studies to evaluate the importance of surface reactions for a given solute in a given geochemical environment; (3) develop quantitative phenomenological models to describe observed laboratory results and predict the behavior of solutes under other 


\section{GROUND-WATER CHEMISTRY}

experimental conditions with the aid of a computer; and (4) conduct field studies periodically to assess the applicability of the models to natural aqueous systems.

PROGRESS: Our laboratory investigations of the bulk and surface structure of ferrihydrite, a poorly crystalline iron oxide phase, represent a significant advance in environmental geochemistry. The results show that the rate of release of a contaminant from the solid phase is very dependent on whether the contaminant was first bound to the phase by an adsorption or precipitation process. For example, ferrihydrite often forms in surface waters as a result of the discharge of mining wastes, and contaminants that are bound during precipitation of the phase are released at a much slower rate than if they were bound later by adsorption. The results suggest that it may typically be difficult to model reactive transport of contaminants with an assumption of chemical equilibrium. The results were published in a series of articles, two in the journal Geochimica et Cosmochimica Acta, and one in Clays and Clay Minerals.

Additional progress was made on studies of reactive transport in ground water at the Cape Cod Toxics site. A model has been formulated to describe $\mathrm{Cr}(\mathrm{VI})$ transport in the sewagecontaminated portion of the shallow, sand and gravel aquifer. The model describes both the rates of $\mathrm{Cr}(\mathrm{VI})$ reduction in batch experiments (described in a report accepted by Environmental Science and Technology) and the observations of $\mathrm{Cr}$ transport in field tracer tests (report submitted to Water Resources Research). The rate of $\mathrm{Cr}(\mathrm{VI})$ reaction in the field is much slower than that observed in the laboratory. The transport model calculations give rise to the hypothesis that the rate of $\mathrm{Cr}(\mathrm{VI})$ reduction in the field is controlled by a diffusion from zones of mobile fluid to zones of immobile fluid that preferentially contain the reducing agents, particle surfaces of mineral phases containing reduced iron. This rate limitation does not exist in the laboratory experiments, and it would be virtually impossible to design a laboratory experiment that accurately predicted the rate of $\mathrm{Cr}(\mathrm{VI})$ reaction in the field. Based on these results and studies of the transport of metal-EDTA complexes, a new large-scale tracer test was begun in April 1993. This experiment will be the most complex and detailed investigation of multi-species, multi-reaction transport ever conducted in a field setting.

\section{REPORTS PUBLISHED 1988-1993:}

Anderson, L.D., Kent, D.B., and Davis, J.A., 1991, Adsorption and reduction of $\mathrm{Cr}(\mathrm{VI})$ under oxic conditions-Studies of $\mathrm{Cr}(\mathrm{VI})$ reactions with sand from a shallow aquifer at Cape Cod, Massachusetts, in Mallard, G.E., and Aronson, D.A., eds., U.S. Geological Survey
Toxic Substances Hydrology ProgramProceedings of the technical meeting, Monterey, Calif., March 11-15, 1991: U.S. Geological Survey Water-Resources Investigations Report 91-4304, p. 63-71. 


\section{GROUND-WATER CHEMISTRY}

Anderson, L.C.D., Kent, D.A. and Davis, J. A., 1992 , Reduction of $\mathrm{Cr}(\mathrm{VI})$ under mildly reducing conditions in a sand and gravel aquifer, in Kharaka, Y.K., and Maest, A.S., eds., 7th International Symposium on Water-Rock Interaction, WRI-7, Park City, Utah [Proceedings]: Rotterdam, A.A. Balkema, p. 495-498.

Coston, J.A., Fuller, C.C., and Davis, J.A., 1992, The search for a geochemical indicator of lead and zinc sorption in a sand and gravel aquifer, Falmouth, Massachusetts, U.S.A., in Kharaka, Y.K., and Maest, A.S., eds, 7th International Symposium on Water-Rock Interaction, WRI-7, Park City, Utah [Proceedings]: Rotterdam, A.A. Balkema, p. 41-44.

Davis, J.A., Fuller, C.C., Coston, J.A., Hess, K.M., and Dixon, E., 1993, Spatial heterogeneity of geochemical and hydrologic parameters affecting metal transport in ground water: Enviromental Research Brief, EPA/ 600/S-93/066, U.S. Environmental Protection Agency, Ada, Okla., 22 p.

Davis, J.A., Fuller, C.C., Rea, B.A., and Claypool-Frey, R.G., 1989, Sorption and coprecipitation of arsenate by ferrihydrite, in Miles, D.L., ed., Sixth International Meeting on Water-Rock Interaction, Proceedings: Balkema, Rotterdam, p. 187-189.

Davis, J.A., and Hem, J.D., 1989, The surface chemistry of aluminum oxides and hydroxides, in Sposito, G., ed., The environmental chemistry of aluminum: Boca Raton, Fla., CRC Press, Inc., chap. 7, p. 185-219.

Davis, J.A., and Kent, D.B., 1990, Surface complexation modeling in aqueous geochemistry, in Hochella, M.F., and White, A.F., eds., Mineral-water interface geochemistry: Washington, D.C., Mineralogical Society of America, Reviews in Mineralogy, v. 23, p. 177260.
Davis, J.A., Kent, D.B., and Rea, B.A., 1989, Field and laboratory studies of coupled flow and chemical reactions in the ground-water environment, in Mallard, G.E., and Ragone, S.E., eds., U.S. Geological Survey Toxic Substances Hydrology Program-Proceedings of the technical meeting, Phoenix, Ariz., Sept. 26-30, 1988: U.S. Geological Survey WaterResources Investigations Report 88-4220, p. 189-198.

Davis, J.A., Kent, D.B., Rea, B.A., Garabedian, and Anderson, L.C.D., 1991, Effect of the geochemical environment on heavy metal transport in groundwater, in Mallard, G.E., and Aronson, D.A., eds., U.S. Geological Survey Toxic Substances Hydrology Program-Proceedings of the technical meeting, Monterey, Calif., March 11-15, 1991: U.S. Geological Survey Water-Resources Investigations Report 91-4304, p. 53-62.

Davis, J.A., Kent, D.B., Rea, B.A., Maest, A.S., and Garabedian, S.P., 1993, Influence of redox environment and aqueous speciation on metal transport in ground water: Preliminary results of tracer injection studies, in Allen, H.E., Perdue, E.M., and Brown, D.S., eds., Metals in Groundwater: Lewis Publishers, p. 223-273.

Davis, J.A., Waite, T.D., Kent, D.B., and Anderson, L.C.D., 1991, Reduction of $\mathrm{Cr}(\mathrm{VI})$ under mildly reducing conditions in a shallow, sand and gravel aquifer, in Mallard, G.E., and Aronson, D.A., eds., U.S. Geological Survey Toxic Substances Hydrology Program-Proceedings of the technical meeting, Monterey, California, March 11-15, 1991: U.S. Geological Survey Water-Resources Investigations Report 91-4304, 72-77.

Dempsey, B., Davis, J.A., and Singer, P., 1988, A review of solid-solution interactions and implications for the control of trace inorganic mate- 


\section{GROUND-WATER CHEMISTRY}

rials in water treatment: Journal of the American Water Works Association, v. 80, p. 5664.

Fuller, C.C., Coston, J.A., Hess, K.M., and Davis, J.A., 1991, Spatial heterogeneity of geochemical and hydrologic properties of subsurface materials in a sand and gravel aquifer, Cape Cod, Massachusetts, in Mallard, G.E., and Aronson, D.A., eds., U.S. Geological Survey Toxic Substances Hydrology Program-Proceedings of the technical meeting, Monterey, California, March 11-15, 1991: U.S. Geological Survey Water-Resources Investigations Report 91-4304, p. 84-87.

Fuller, C.C., and Davis, J.A., 1989, Influence of coupling of sorption and photosynthetic processes on trace element cycles in natural waters: Nature, v. 340, p. 52-54.

Fuller, C.C., Davis, J.A., Cain, D.J., Lamothe, P.J., Fries, T.L., Fernandez, G., Vargas, J.A., and Murillo, M.M., 1990, Distribution and transport of sediment-bound metal contaminants in the Rio Grande de Tarcoles, Costa Rica (Central America): Water Research, v. 24, p. 805-812.

Fuller, C.C., Davis, J.A., and Claypool-Frey, R.G., 1988, Desorption of arsenic from iron hydroxide precipitates in Whitewood Creek, in Goddard, K.E., ed., U.S. Geological Survey Applied Research Studies of the Cheyenne River System: U.S. Geological Survey OpenFile Report 88-484, p. 118-147.

Fuller, C.C., Davis, J.A., Zellwegger, G.W., and Goddard, K.E., 1989, Coupled chemical, biological and physical processes in Whitewood Creek, South Dakota-Evaluation of the controls of dissolved arsenic, in Mallard, G.E., and Ragone, S.E., eds., U.S. Geological Survey Toxic Substances Hydrology Program-P roceedings of the technical meeting, Phoenix,
Ariz., Sept. 26-30, 1988: U.S. Geological Survey Water-Resources Investigations report 88-4220, p. 235-246.

Fuller, C.C., Davis, J.A., and Waychunas, G.A., 1993, Surface chemistry of ferrihydrite, 2. Kinetics of arsenate adsorption and coprecipitation: Geochimica Cosmochimica Acta, v. 57, p. 2271-2282.

Gruebel, K.A., Davis, J.A., and Leckie, J.O., 1988 , The feasibility of using sequential extraction techniques for As and Se in soils and sediments: Journal of the Soil Science Society of America, v. 52, p. 390-397.

Kent, D.B., Davis, J.A., Anderson, L.D., and Rea, B.A., 1991, Transport of $\mathrm{Zn}$ in ground water in the presence of a strong complexing agent-Competing roles of sorption, complexation, and mineral dissolution, in Mallard, G.E., and Aronson, D.A., eds., U.S. Geological Survey Toxic Substances Hydrology Program-Proceedings of the technical meeting, Monterey, Calif., March 11-15, 1991: U.S. Geological Survey Water-Resources Investigations Report 91-4304, p. 78-83.

Kent, D.B., Davis. J.A., Anderson, L.D., and Rea, B.A., 1992, Ligand-enhanced transport of strongly adsorbing metal ions in the ground-water environment, in Kharaka, Y.K., and Maest, A.S., eds., 7th International Symposium on Water-Rock Interaction, Park City, Utah [Proceedings]: U.S. Geological Survey Water Resources Investigations Report 7, p. 805-808.

Kent, D.B., Davis, J.A., Maest, A.S., and Rea, B.A., 1989, Field and laboratory studies of transport of reactive solutes in groundwater, in Miles, D.L., ed., Miles, D.L., ed., Sixth International Meeting on Water-Rock Interaction, Proceedings: Rotterdam, A.A. Balkema, p. 381-383. 


\section{GROUND-WATER CHEMISTRY}

Kuwabara, J.S., Chang, C.C.Y., Cloern, J.E., Fries, T.L., Davis, J.A., and Luoma, S.N., 1989, Trace metal associations in the water column of south San Francisco Bay, California: Estuarine, Coastal and Shelf Science, v. 28 , p. $307-325$.

Mehr, S.R., Eatough, D.J., Hanson, L.D., Lewis, E.A., and Davis, J.A., 1989, Calorimetry of heterogeneous systems- $\mathrm{H}$ binding to $\mathrm{TiO}$ in $\mathrm{NaCl}$ : Thermochimica Acta, v. 154, p. 129 143.

Payne, T.E., Sekine, K., Davis, J. A., and Waite, T. D., 1992, Modeling of radionuclide sorption processes in the weathered zone of Koongarra ore body: Third Annual Report, Alligator Rivers Analogue Project, Australian Nuclear Science and Technology Organization, p. 57-86.

Rea, B.A., Kent, D.B., LeBlanc, D.R., and Davis, J.A., 1991, Mobility of $\mathrm{Zn}$ in a sewage-contaminated aquifer, Cape Cod, Massachusetts, in Mallard, G.E., and Aronson, D.A., eds., U.S. Geological Survey Toxic Substances Hydrology Program-Proceedings of the technical meeting, Monterey, Calif., March 1115, 1991: U.S. Geological Survey Water-Resources Investigations Report 91-4304, p. 88-95.

VanGeen, A., Luoma, S.N., Fuller, C.C., Anima R., Clifton, H.E., Trumbore, S., 1992, Evidence from $\mathrm{Cd} / \mathrm{Ca}$ ratios in foraminifera for greater upwelling off California 4,000 years ago: Nature, v. 358 , p. $54-56$

Waychunas, G.A., Rea, B.A., Fuller, C.C., and Davis, J.A., 1993, Surface chemistry of ferrihydrite, I. EXAFS studies of the geometry of coprecipitated and adsorbed arsenate: Geochimica Cosmochimica Acta, v. 57, p. 22512269. 


\section{GROUND-WATER CHEMISTRY}

TITLE: $\quad$ Stable Isotope Tracers of Biogeochemical and Hydrologic Processes (WR 91-080)

PERSONNEL: Carol Kendall, Project Chief

Gloria M. Castagne, Secretary

Steven R. Silva, Hydrologist

Jo M. Burchard, Phys. Science Technician

Stephanie M. Swann, Phys. Science Aid
Shawn M. Johnson, Phys. Science Aid

John C. Radyk, Hydrological Technician

Lloyd D. White, Chemist

Mark Huebner, Hydrologist

ADDRESS: $\quad$ U.S. Geological Survey, 345 Middlefield Road, MS 434, Menlo Park, CA 94025

TELEPHONE: (415) 329-4576

PROBLEM: Light stable isotopes such as oxygen, hydrogen, carbon, nitrogen and sulfur have proved to be extremely useful tracers of hydrologic pathways and biogeochemical processes. However, use of these isotopes as tracers is presently hampered by our limited understanding of the physical processes and chemical reactions influencing isotopic compositions. The unsaturated zone, particularly the soil zone and the top of the water table, is probably the portion of the hydrologic system most responsible for alteration of the isotopic compositions of potential isotope tracers; this environmental component is also one of the least studied.

OBJECTIVE: The overall goal is to increase our understanding of reactions involving stable isotopes and to evaluate the significance of these reactions in geochemical and hydrologic modeling. This will be accomplished by field and laboratory investigations of processes and reactions which may fractionate isotopes and affect their utilization as tracers of processes, flowpaths, and sources of water and solutes.

APPROACH: Define the processes which could affect the use of isotopes as tracers; identify suitable field areas for collaborative research; develop field sampling techniques and laboratory analytical methods which do not fractionate the isotopic compositions; investigate the extent and effects of isotope exchange between gases, water, bound-water, dissolved species, and matrix materials through field studies, and laboratory and field experiments; develop conceptual models for infiltration, streamflow generation, unsaturated and saturated zone flow, and biogeochemical reactions; test biogeochemical-process and hydrologic-flow models with isotope tracers; establish guidelines for application of stable isotope techniques to problems of national importance. 


\section{GROUND-WATER CHEMISTRY}

PROGRESS: North American Water Isotope Database (NAWID): In collaboration with T. Coplen's project, we have implemented a plan to create a database of all oxygen and hydrogen isotope analyses generated by either of Water Resources Division's (WRD) two stable isotope laboratories for samples collected from North America (about 30,000 waters). Starting in January 1992 water samples submitted to either laboratory will be analyzed only if minimal field data are made available to us for eventual incorporation into our database. Our project is currently making good progress towards a goal of assembling locality, date, and sample-type data for samples submitted to either laboratory prior to 1992. We are also attempting to assemble isotope data generated by district scientists, much of which has not been entered into district databases. We plan to eventually release this database on CD roms, updated periodically. This database will be of great use to WRD, university, private industry scientists by reducing unnecessary duplication of efforts; prior to future hydrological studies, researchers will easily have access to all the WRD data previously generated. The database will also be very valuable for climate modelers because the isotopic compositions of meteoric water are directly related to present and past climate patterns.

Fractionation of Water by Interception with Tree Canopy: As part of a collaboration with the Panola (Georgia) Water, Energy and Biogeochemical Balance (WEBB) project, we have found that throughfall under coniferous canopy is generally enriched relative to throughfall under deciduous canopy, and that both types of throughfall are almost always significantly enriched (on average, by 0.5 permil in $\mathrm{O}-18$ and 3 permil in D) relative to rain at Panola. This work suggests that using rain in the open instead of throughfall as the indicator of recharge composition can potentially cause about a 1 degree error in temperature estimates in isotop-paleoclimatic studies. Interestingly, the throughfall samples do not plot along evaporation lines (despite the fact that about 20 percent has evaporated), but instead the slopes greater than 8 suggest appreciable exchange with evaporated waters with higher d-excess values. These finding will significantly impact global climate models developed using stable isotopes.

Nitrogen and Oxygen Isotopes of Nitrate: One of the main reasons for limited use of nitrogen isotopes by hydrologists is the high cost of analyses. In collaboration with members of the Missouri Management Systems Evaluation Areas (MSEA) project, we have developed a method which reduces the usual labor by at least a factor of 5 , has a precision of 0.05 per mil for $\mathrm{N}-15$, and samples can be stored chilled for at least 6 months. This technique, which involves field concentration of nitrate onto disposable resin columns, will allow analysis of samples much smaller than can typically be analyzed commercially. The nitrate prepared by this new technique can be analyzed for $\mathrm{O}-18$ using a simple, nontoxic method that we have recently developed; the precision for $\mathrm{O}-18$ is about 0.10 per mil. Because different nitrate 


\section{GROUND-WATER CHEMISTRY}

sources frequently have distinctive $\mathrm{N}-15$ and $\mathrm{O}-18$ contents, our ability to analyze nitrate samples for both $\mathrm{O}-18$ and $\mathrm{N}-15$ with lower labor costs will allow expanded use of these isotopes by the National Water-Quality Assessment (NAWQA) program to trace sources of nitrate.

Isotope Hydrograph Separation: As part of a collaboration between WRD and the Chinese Ministry of Water Resources to study surface water hydrology, we have been working at the intensively instrumented $500 \mathrm{~m}^{2}$ Hydrohill artificial catchment near Nanjing. We have been able to get closure on our water budgets for the catchment, allowing an isotope mass balance to be calculated for a storm. Hydrologic models made for various subsurface waters and for the catchment as a whole agree well with oxygen isotope hydrograph separations, and do not match chemical hydrograph separations. In contrast to most studies, at all levels in the catchment the water is mostly new quickflow. Hydrograph separations made using silica and chloride, while similar to each other, suggest a much larger contribution of old slowflow. This study provides very convincing evidence of how and why chemical species make such poor conservative tracers in watersheds. During storm events, changes in flowpath result in large ranges of isotopic composition in vadose and ground water; this variability persists after stormflow ceases and makes assumptions of constant soil-water composition for the next storm highly problematic. These findings have significant impact on how we use isotopes to estimate percentages of new and old water in streams.

Laboratory Automation: Our automated $\mathrm{CO}_{2}$-water equilibration system is now working, and we can now analyze 48 water samples per day for oxygen isotopic composition (an 8 -fold improvement). Work is progressing on automating the system for analyzing waters for hydrogen isotopic composition. Because of the dramatic increase in sample throughput, we have been able to analyze over a thousand samples in collaboration with the Panola, Sleepers River, North Temperate Lakes, and Loch Vale WEBB projects; this work has resulted in six presentations at AGU (American Geophysical Union) this year.

Textbook on Isotope Hydrology: There is a lack of a suitable textbook for the Isotope Hydrology training course we teach yearly at the National Training Center because existing books focus on deep ground-water issues that are unrelated to public water supplies. Therefore, J.J. McDonnell (SUNY Syracuse) and C. Kendall are coediting a book entitled "Isotope Tracers in Catchment Hydrology," to be published by Elsevier in Fall 1994: 


\section{GROUND-WATER CHEMISTRY}

\section{REPORTS PUBLISHED 1988-1993:}

Adams, M.C., Mink, L.L., Moore, J.N., White, L.D., and Anchissi, A.C., 1990, Geochemistry and hydrology of the Zunil geothermal system, Guatemala: Geothermal Resources Council Transactions, August 1990, v. 14, pt. II, p. 837-844.

Adams, M.C., Moore, J.N., White, L.D., Mink, L.L., Leiva, O., Ramirez, S., and Anchissi, A.C., 1992, Fluid recharge of the Zunil, Guatemala Geothermal System: Geothermal Resources Council Transactions, v. 16. p. 113.

Barnes, I., Evans, W.C., and White, L.D., 1988, The role of mantle $\mathrm{CO}_{2}$ in Volcanism: Applied Geochemistry, v. 3, p. 281-285.

Böhlke, J.K., Coveney, R.M., Jr., Rye, R.O., and Barnes, I., 1988, Stable isotope investigation of gold quartz veins at the Oriental mine, Alleghany district, California: U.S. Geological Survey Open-File Report 88-0279, 24 p.

Evans, W.C., Kling, G.W., Tuttle, M.L., Tanyileke, G., and White, L.D., 1993, Gas buildup in Lake Nyos, Cameroon-The recharge process and its consequences: Applied Geochemistry, v. 8, p. $207-221$.

Evans, W.C., White, L.D., and Kharaka, Y.K., 1988, Dissolved gases in the DOSECC Cajon Pass well-First year results: Geophysical Research Letters, v. 14, no. 9, p. 1041-1044.

Evans, W.C., White, L.D., and Rapp, J.B., 1988, Geochemistry of some gases in hydrothermal fluids from the southern Juan de Fuca Ridge: Journal of Geophysical Research, v. 93, no. B12, p. 305-315.
Hearn, P.P., Jr., Steinkampf, W.C., Horton, D.G., Solomon, G.C., White L.D., and Evans, J.R., 1989, Oxygen-isotope composition of ground water and secondary minerals in Columbia Plateau basalts; implications for the paleohydrology of the Pasco Basin: Geology (Boulder), v. 17, no. 7, p. 606-610.

Hearn, P.P., Steinkampf, W.C., White, L.D., and Evans, J.R., 1990, Geochemistry of RockWater Reaction in Basalt Aquifers of the Columbia River Plateau, in Doe, Bruce R., ed., U.S. Geological Survey workshop on Environmental Geochemistry, Proceedings: U.S. Geological Survey Circular 1033, p. 63-68.

Hein, J.R., Gray, S.C., Richmond, B.M., and White, L.D., 1992, Dolomitization of Quaternary reef limestone, Aitutaki, Cook Islands: Sedimentology, v. 39, 645-661.

Huntington, T.G., Hooper, R.P., Peters, N.E., Bullen, T.D., and Kendall, C., 1993, Water energy, and biogeochemical budgets investigation at Panola Mountain Research Watershed, Stockbridge, Georgia-A research plan: U.S. Geological Survey Open-File Report 93-55.

Kendall, C., and Gu, W., 1992, Development of isotopically heterogeneous infiltration waters in an artificial catchment in Chuzhou, China, in Proceedings of Isotope Techniques in Water. Resources Development Symposium, Vienna, March 1991, p. 61-73.

Kendall, C., Mast, A.M., and Rice, K.C., 1992, Tracing watershed weathering reactions with Delta C-13, in Kharaka, Y.K., and Maest, A.S., eds., 7th International Symposium on Water-Rock Interaction, Park City, Utah, July 9-23, 1992 [Proceedings]: Rotterdam, A.A. Balkema, p. 569-572. 


\section{GROUND-WATER CHEMISTRY}

Kendall, C., and McDonnell, J.J., 1993, Effect of intrastorm heterogeneities of rainfall, soil water and ground water on runoff modeling, in Peters, N.E., and others, eds., Tracers in Hydrology Symposium, International Association of Hydrology, Scientific Publication no. 215, July 11-23, 1993, Yokohama, Japan, p. 41-49.

Kharaka, Y.K., Ambats, G., Evans, W.C., and White, A.F., 1988, Geochemistry of water at Cajon Pass, California-Preliminary results: Geophysical Research Letters, v. 15, p. 10371040.

Kharaka, Y.K., Evans, W.C., Ambats, Gil, and White, L.D., 1989, California origin of water and solutes in granitic rocks at Cajon Pass, California, U.S.A., in Miles, D.L., ed., 6th International Meeting on Water-Rock Interaction, Malvern, United Kingdom, [Proceedings]: U.S. Geological Survey Water Resources Water Investigations Report, p. 385-388.

Kharaka, Y.K., Mariner, R.H., Ambats, Gil, Evans, W.C., White, L.D., Bullen, T.D., and Kennedy, B.M., 1990, Origins of water and solutes in and north of the Norris-Mammoth Corridor, Yellowstone National Park: Geothermal Resources Council Transactions, August 1990 , v. 14, pt. 1, p. 705-714.

Kharaka, Y.K., White, L.D., Ambats, G., and White, A.F., 1988, Origin of subsurface water at Cajon Pass, California: Geophysical Research Letters, v. 15, no. 9, p. 1049-1052.

Kling, G.W., Tuttle, M.L., and Evans, W.C., 1989, The evolution of thermal structure and water chemistry in Lake Nyos: Journal of Volcanology and Geothermal Research, v. 39, p. $151-165$.
Kling, G.W., Tuttle, M.L., and Evans, W.C., 1989, Safety of Cameroonian lakes: Nature (scientific correspondence), v. 337, p. 215.

Krabbenhoft, D.P., Bowser, C.J., Gat, J.R., and Kendall, C., 1991, Stable isotopic approaches to the hydrology of ground-water/lake systems, in Division of Environmental Chemistry, American Chemical Society, Atlanta, Georgia, April 1991, Proceedings: American Chemical Society, v. 31, p. 247-250.

Krabbenhoft, D.P., Bowser, C.J., Kendall, C., and Gat, J.R., in press, Use of oxygen-18 and deuterium to assess the hydrology of groundwater/lake systems, in Baker, L., ed., Environmental chemistry of lakes and reservoirs: American Chemical Society Monograph, chap. 2.

Krohn, M.D., Kendall, C., Evans, J.R., and Fries, T.L., 1993, Relations of ammonium minerals at several hydrothermal systems in the western U.S.: Journal of Volcanology and Geothermal Research, v. 56, p. 401-414.

Mariner, R.H., Kharaka, Y.K., Ambats, G., and White, L.D., 1992, Chemical composition and stable isotopes of thermal waters, NorrisMammoth corridor, Yellowstone National Park, U.S.A., in Kharaka, Y.K., and Maest. A.S., eds., 7th International Symposium on water-rock interaction [Proceedings]: Rotterdam, A.A. Balkema, p. 963.

Mariner, R.H., Presser, T.S., Evans, W.C., and Pringle, M.K.W., 1989, Discharge rates of thermal fluids in the Cascade Range of Oregon and Washington and their relationship to the geologic environment, in Muffler, L.J.P., Weaver, C.S., and Blackwell, D.D., eds., Geological, Geophysical, and Tectonic Setting of the Cascade Range: U.S. Geological Survey Open-File Report 89-178 (data), p. 663-674. 


\section{GROUND-WATER CHEMISTRY}

Mariner, R.H., Young, H.W., Parliman, D.J., and Evans, W.C., 1989, Geochemistry of thermal water from selected wells, Boise, Idaho: Geothermal Resources Council Transactions, v. 13, p. 173-178.

McCarthy, K.A., McFarland, W.D., Wilkinson, J.M., and White, L.D., 1992, The dynamic relationship between ground water and the Columbia River: using deuterium and oxygen18 as tracers: Journal of Hydrology, v. 135. p. 1-12.

McDonnell, J.J., and Kendall, C., 1992, Isotope Tracers and Hydrology: EOS, Transactions of the American Geophysical Union, v. 73, p. 260-261.

Nokleberg, W.J., Aleinikoff, J.N., Lange, I.M., Silva, S.R., Miyaoka, R.T., Schwab, C.E., Zehner, R.E., 1992, Preliminary geologic map of the Mount Hayes Quadrangle, Eastern Alaska Range, Alaska: U.S. Geological Survey Open-File Report 90-594, 39 p., 1 sheet, scale $1: 250,000$.

Thompson, J.M., Mariner, R.H., White, L.D., Presser, T.S., and Evans, W.C., 1992, Thermal waters along the Konocti Bay fault zone, Lake County, California: a re-evaluation: Journal of Volcanology and Geothermal Research, v. 53 , p. 167-183.

Thompson, J.M., Nathenson, M., and White, L.D., 1990, Chemical and isotopic compositions of waters from Crater Lake, Oregon, and nearby vicinity, in Drake, Ellen T., Larson, Gary L., Dymond, Jack and Collier, Robert, eds., Crater Lake an ecosystem study, p. 91-102.

Thompson, J.M., and White, L.D, 1991, Chemical analyses of water from the GTA-1 well, Parkfield, California, and other nearby spring and well waters: U.S. Geological Survey OpenFile Report 91-0003.

Thordsen, J.J., Kharaka, Y.K., Mariner, R.H., and White, L.D., 1992, Controls on the distribution of stable isotopes of meteoric water and snow in the greater Yellowstone National Park region, U.S.A., in Kharaka, Y.K., and Maest, A.S., 7th International Symposium on waterrock interaction [Proceedings]: Rotterdam, A.A. Balkema, p. 591.

Tuttle, M.L., Lockwood, J.P., and Evans, W.C., 1988, The 1986 gas disaster at Lake Nyos, Cameroon, West Africa: U.S. Geological Survey Yearbook Fiscal Year 1987, p. 131-134.

Vallier, T.L., Jenner, G.A., Frey, F.A., Gill, J.B., Davis, A.S., Volpe, A.M., Hawkins, J.W., Morris, J.D., Cawood, P.A., Morton, J.L., Scholl, D.W., Rautenschlein, M., White, W.M., Williams, R.W., Stevenson, A.J., and White, L.D., 1991, Subalkaline andesite from Valu Fa Ridge, a back-arc spreading center in southern Lau Basin-Petrogenesis, comparative chemistry, and tectonic implications: Chemical Geology, v. 91, p. 227-256. 


\title{
GROUND-WATER CHEMISTRY
}

TITLE: Geochemistry of Water in Fine Grained Sediments (WR 76-139)

\author{
PERSONNEL: Yousif K. Kharaka, Project Chief \\ Jacqueline Hamilton, Secretary \\ Gil Ambats, Chemist \\ James J. Thordsen, Geologist
}

\begin{abstract}
ADDRESS: $\quad$ U.S. Geological Survey, 345 Middlefield Road, MS 427, Menlo Park, CA 94025
\end{abstract}

TELEPHONE: (415) 329-4535

PROBLEM: The energy potential of geothermal waters from geopressured systems is enormous. Geochemical data are necessary for delineating favorable exploration areas, estimating the recoverable geothermal resources from a given reservoir, and identifying potential pollution, waste disposal, and corrosion problems.

OBJECTIVE: To study the chemistry and controls on the chemistry of water in geothermal and other subsurface systems. Provide basic data needed to estimate the geothermal energy and other resources and to identify potential pollution, waste disposal, and corrosion problems associated with extraction of energy and other resources from these systems.

APPROACH: Collect water, gas, and rock samples from prospective geopressured and other subsurface systems for chemical, mineralogic, and isotopic analyses. Carry out membrane and water/rock interaction laboratory studies. Data analyses will be performed by available and planned computer programs.

PROGRESS: Most of the project's effort was devoted to completing data analyses and several reports (see publications) on the geochemistry of thermal waters in the Norris-Mammoth Corridor of Yellowstone National Park. The chemical and isotopic compositions of water, solutes and gases in general and the ${ }_{3} \mathrm{He} /{ }_{4} \mathrm{He}$ ratios in particular, indicate that the Mammoth system is not directly connected to the Yellowstone caldera, but probably results from a cooling magmatic intrusion beneath Mammoth. We are continuing to analyze the extensive data set on the isotopic composition of meteoric water in the greater Yellowstone area. In addition to elevations (mean annual temperatures), the isotopic composition of meteoric water in this complex terrane is controlled by the origin and direction of storm tracks, by the "Canyon effect" and by the distance (Continental effect). 


\section{GROUND-WATER CHEMISTRY}

The project is still involved with the Bureau of Reclamation's project on deep injection of brines in Paradox Valley, Colorado; a report (see publications) was completed indicating major precipitation problems with the current plans.

The 7th International Symposium on Water-Rock Interaction attracted about 500 scientists from 40 countries. Yousif Kharaka, as Secretary General, and other personnel devoted some of our time to it. Considerable time was spent on editing the two-volume Proceedings (Y.K. Kharaka, and A.S. Maest, eds.; A.A. Balkema, 1686 p., 1992).

Experimental results show the generation of aliphatic acid anions from hydrous pyrolysis of crude oils. The main manuscript on the results (Kharaka and other, 1993) will appear in Applied Geochemistry. Two reports have already been published on some of the results.

During Fiscal Year 1992, project personnel authored or coauthored nine reports and we gave three presentations at international meetings (two at the Seventh International Symposium on Water-Rock Interaction and one in Tibet), and Kharaka gave a Water Resources Division sẻminar in Menlo Park, California.

\section{REPORTS PUBLISHED 1988-1993:}

Aggarwal, P.K., Gunter, W.D., Hull, R.W., and Kharaka, Y.K., 1988, SOLMNEQF-A computer code for geochemical modeling of water-rock interactions in sedimentary basins-Proceedings Canadian-American Conference on Hydrology of Sedimentary Basins: Applications to Exploration and Exploitation: National Water Well Association, v. 3, p. 173-128.

Bullen, T.D., and Kharaka, Y.K., 1992, Isotope composition of $\mathrm{Sr}, \mathrm{Nd}$, and $\mathrm{Li}$ in thermal waters from the Norris-Mammoth corridor, Yellowstone National Park and surrounding region in Kharaka, Y.K., and Maest, A.S., eds., 7th International Symposium on waterrock interaction [Proceedings]: Rotterdam, A.A. Balkema, v. 2, p. 897-901.

Curiale, J.A., Lundegard, P.D., and Kharaka, Y.K., in press, Hydrous pyrolysis of crude oil in gold-plated reactors: Organic Geochemistry, v. 18 , p. 625-641.

DeBraal, J.D., and Kharaka, Y.K., 1989, SOLINPUT: A computer code to create and modity input files for the geochemical program SOLMINEQ.88: U.S. Geological Survey Open-File Report 89-616, 140 pp.

Evans, W.C., White, L.D., and Y.K., Kharaka, 1988, Dissolved gases in the DOSECC Cajon Pass well-First year results: Geophysical Research Letters, August Supplement 1988, v. 15, no. 9, p. 1041-1044.

Hanor, J.S., Kharaka, Y.K., and Land, L.S., 1988, Geochemistry of waters in deep sedimentary basins: Geology, v. 16, p. 560-561.

Kharaka, Y.K., 1988, Origill and evolution of water and solutes in sedimentary basins, in 


\section{GROUND-WATER CHEMISTRY}

Proceedings Canadian-American Conference on Hydrology-Hydrology of Sedimentary Basins: Application to Exploration and Exploitation, National Water Well Association, v. 3, p. 173-195.

Kharaka, Y.K., Ambats, G., Evans, W.C., and White, A.F., 1988, Geochemistry of water at Cajon Pass, California-Preliminary results: Geophysical Research Letters, Sept. Supplement 1988, v. 15, no. 9, p. 1037-1040.

Kharaka, Y.K., and Barnes, H.L., 1990, Introduction: Memorial volume to honor Ivan Barnes (1931-1989): Applied Geochemistry, v. 5, p. 537-539. Also Guest Editor of the volume with $\mathrm{H}$. Barnes.

Kharaka, Y.K., and Carothers, W.W., 1988, Geochemistry of oil-field waters from the North Slope, Alaska, in Gryc, G., ed., Geology Exploration of The National Reserve in Alaska, 1974-1982: U.S. Geological Survey Professional Paper 1399, p. 551-561.

Kharaka, Y.K., Evans, W.C., Ambats, G., and White, L.D., 1989, Origin of water and solutes in granitic rocks at Cajon Pass, California, U.S.A: International Symposium on Water-Rock Interactions, 6th, Malvern, U.K., [Proceedings], p. 385-3881.

Kharaka, Y.K., Gunter, W.D., Aggarwal, P.K., Perkins, E.H., and DeBraal, J.D., 1988, SOLMINEQ.88-A computer program for geochemical modeling of water-rock interactions: U.S. Geological Survey Water-Resources Investigation Report 88-4227, 420 p.

Kharaka, Y.K., Lundegard, P.D., Ambats, G., Evans, W.C., and Bischoff, J.L., 1993, Generation of aliphatic acid anions and carbon dioxide by hydrous pyrolysis of crude oils: Applied Geochemistry, v. 8.
Kharaka, Y.K., and Mariner, R.H., 1989, Chemical geothermometers and their application to formation waters from sedimentary basins in Naeser, N.D., and McCulloh, T.H., eds., Thermal History of Sedimentary Basins: Methods and Case Histories, Springer-Verlag, No. 6, p. 99-1117.

Kharaka, Y.K., Mariner R.H., Ambats, G., Evans, W.C., White, L.D., Bullen, T.D., and Kennedy, B.M., 1990, Origin of water and solutes in and north of the Norris-Mammoth Corridor, Yellowstone National Park: Transactions of the Geothermal Resources Council, v. 4 , p. $705-714$.

Kharaka, Y.K., Mariner, R.H., Bullen, T.D., Kennedy, B.M., and Sturchio, N.C., 1991, Geochemical investigations of hydraulic connections between the Corwin Springs Known Geothermal Resources Area and adjacent parts of Yellowstone National Park, in Sorey, M.L., ed., Effect of potential geothermal development in the Corwin Springs Known Geothermal Resources Area, Montana, on the thermal features of Yellowstone National Park: U.S. Geological Survey Water-Resources Investigation Report 91-4052, F1-F38.

Kharaka, Y.K., Mariner, R.H., and Evans, W.C., 1992, Composition of gases from the NorrisMammoth corridor, Yellowstone National Park-Evidence for a magmatic source near Mammoth Hot Springs: in Kharaka, Y.K., and Maest, A.S., eds., 7th International Symposium on water-rock interaction [Proceedings]: Rotterdam, A.A. Balkema, v. 2, p. 13031307.

Kharaka, Y.K., and Specht, D.J., 1988, The solubility of noble gases in crude oil at $25-100^{\circ} \mathrm{C}$ : Applied Geochemistry, v. 3, p. 137-144.

Kharaka, Y.K., and Thordsen, J.J., 1992, Origin and geochemistry of water in sedimentary 


\section{GROUND-WATER CHEMISTRY}

basins, in Chauduri, S., and Clauer, C., eds., Isotopic signatures and sedimentary records: Springer-Verlag, p. 411-466.

Kharaka, Y.K., White, L.D., Ambats, G., and White, A.F., 1988, Origin of subsurface water at Cajon Pass, California: Geophysical Research Letters, Sept. Supplement 1988, v. 15, no. 9., p. 1049-1052.

Lundegard, P.D., Kharaka, Y.K., and Rosenbauer, R.J., 1992, Petroleum as a potential diagenetic agent-Expermental evidence in Kharaka, Y.K., and Maest, A.S., eds., 7th International Symposium on water-rock interaction [Proceedings]: Rotterdam, A.A. Balkema, v. 1, p. 329-335.

Lundegard, P.D., and Kharaka, Y.K., 1990, Geochemistry of organic acids in subsurface waters-Field data, experimental data and models, in Melchior D.C., and Bassett, R.L., eds., Chemical Modeling of Aqueous Systems II: ACS Symposium Series 416, p. 87-103.

Mariner, R.H., Kharaka, Y.K., Ambats, G., and White, L.D. 1992, Chemical composition and stable isotopes of thermal waters, NorrisMammoth corridor, Yellowstone National Park, U.S.A. in Kharaka, Y.K., and Maest, A.S., eds., 7th International Symposium on water-rock interaction [Proceedings]: Rotterdam, A.A. Balkema, v. 2, p. 963-966.

Perkins, E.H., Kharaka, Y.K., Gunter, W.D., and DeBraal, J.D., 1990, Geochemical modeling of water-rock interactions using SOLMINEQ.88, in Melchior D.C., and Bassett, R.L., eds., Chemical Modeling of Aqueous Systems II: ACS Symposium Series 416, p. 87-103.

Rosenbauer, R.J., Bischoff, J.L., and Kharaka, Y.K., 1992, Geochemical effects of deep-well injection of the Paradox Valley brines into
Paleozoic carbonate rocks, Colorado, U.S.A: Applied Geochemistry, v. 7, p. 1-14.

Sorey, M.L., Colvart, E.M., Nimick, D.A., Shields, R.R., Thordsen, J.J., and Ambats, G., 1991, Hydrologic investigations in the Corwin Springs Known Geothermal Resources Area and adjacent part of Yellowstone National Park, in Sorey, M.L., ed., Effect of potential geothermal development in the Corwin Springs Known Geothermal Resources Area, Montana, on the thermal features of Yellowstone National Park: U.S. Geological Survey Water-Resources Investigation Report 914052, F1-F38.

Stille, P., Chaudhuri, S., Kharaka, Y.K., and Cluaer, N., 1992, Neodymium, strontium, oxygen, and hydrogen isotope compositions of waters in present and past oceans-A review, in Chauduri, S., and Clauer, N., eds., Isotopic signature and sedimentary records: SpringerVerlag, p. 389-410.

Thordsen, J.J., Kharaka, Y.K., Mariner, R.H., and White, L.D., 1992, Controls on the distribution of stable isotopes of meteoric water and snow in the greater Yellowstone National Park region, U.S.A. in Kharaka, Y.K., and Maest, A.S., eds., 7th International Symposium on water-rock interaction [Proceedings]: Rotterdam, A.A. Balkema, v. 1, p. 591-595. 


\section{GROUND-WATER CHEMISTRY}

TITLE: Chemical and Isotope Studies of Thermal Waters of the Western United States (WR 79-165)

PERSONNEL: Robert H. Mariner, Project Chief

Maria M. Watts, Secretary

William Carothers, Hydrologist

William C. Evans, Chemist

ADDRESS: $\quad$ U.S. Geological Survey, 345 Middlefield Road, MS 434, Menlo Park, CA 94025

TELEPHONE: (415) 329-4507

PROBLEM: Reconnaissance and chemical and isotope sampling of thermal springs in the western United States generally has not provided information of sufficient detail to permit the geothermal potential of most individual areas to be determined with any certainty. This is especially true in the Cascade Mountain Range, where the chemical geothermometers.indicate much lower temperatures of water-rock equilibrium than the sulfate-isotope geothermometer and the geologic setting seem to indicate. This discrepancy could be due to simple mixing of thermal water and freshwater or rapid equilibration of water with surrounding country rock as the fluids rise to the surface; alternatively, the sulfate-isotopic composition could be an artifact reflecting the original source.

OBJECTIVE: Investigate the origin of the dissolved constituents, water, and gases discharging in hot springs and determine their relation to fumaroles and cold mineral springs. Determine the recharge areas for the thermal springs and the amount of mixing of thermal and nonthermal waters.

APPROACH: Do chemical isotopic analyses on samples of water and gas discharging from thermal, cold, and mineral springs. Use the chemical and isotopic data to determine the extent of mixing and ascertain the probable recharge areas for the individual thermal systems. Investigate the factors that control the chemical and isotopic composition of the fluids.

PROGRESS: Periodic sampling of geothermal wells in the Steamboat Springs, Nevada, geothermal system has demonstrated at least short-term chemical and isotopic stability and the chemical similarity of warm water in the outflow plume to the moderate and high temperature wells in the major part of the system. These data provide a stable background with which to compare future changes. Geothermal systems of regional scale occur on the south side of the 


\section{GROUND-WATER CHEMISTRY}

Snake River Plain in southern Idaho. Our study of the thermal springs of the Owyhee Uplands at the western edge of the plain show no chemical or isotopic evidence of a regional scale system nor can the springs be clearly related to the high temperature system at Vale (western end of the Snake River Plain). Studies of dissolved aluminum in the hot springs of the Idaho batholith show that secondary aluminosilicates (stilbite and chabazite) occur only in the springs with the largest free energies with respect to stilbite. A chemically and geologically reasonable model of the mechanism of gas discharge at Lake Nyos, Cameroon, has been worked out that explains the water composition data, dissolved gas data, and physical phenomenon associated with the May 1986 catastrophic release of gas from Lake Nyos. $\mathrm{Ca}-\mathrm{Mg}-\mathrm{CO}_{3}$ synthesis experiments have produced disordered $\mathrm{CAMg}\left(\mathrm{CO}_{3}\right)_{2}$ of dolomite chemical compositin at geologically reasonable $\mathrm{Ca}, \mathrm{Mg}$, and $\mathrm{HCO}_{3}$ concentrations and temperatures. Conditions that produce aragonite, hydromagnesite, and disordered dolomite have been determine experimentally.

\section{REPORTS PUBLISHED 1988-1993:}

Carothers, W.W., Adami, L.H., and Rosenbauer, R.J., 1988, Experimental oxygen isotope fractionation between siderite-water and phosphoric acid liberated $\mathrm{CO}_{2}$-siderite: Geochimica et Cosmochimica Acta, v. 52, p. 2445-2450.

Evans, W.C., Kling, G.W., Tuttle, M.L., Tanyileke, G., and White, L.D., 1993, Gas buildup in Lake Nyos, Cameroon-The recharge process and its consequences: Applied Geochemistry, v. 8, p. 207-221.

Evans, W.C., White, L.D., and Kharaka, Y.K., 1988, Dissolved gases in the DOSECC Cajon Pass well-First year results: Geophysical Research Letters, v. 15, p. 1041-1044.

Evans, W.C., White, L.D., and Rapp, J.B., 1988, Geochemistry of some gases in hydrothermal fluids from the southern Juan de Fuca Ridge: Journal of Geophysical Research, v. 93, no, B12, p. 15,305-15,313.

Goff, Fraser, Gardner, J.N., Solbau, R.D., Adams, Andrew, Evans, W.C., Lippert, D.R., Jacob-sen, Ron, Bayhurst, Greg, Trujillo, P.E., Jr.,
Counce, Dale, and Dixon, Paul, 1990, The "art" of in situ fluid sampling and the remarkable compositional variations in the wellbore fluid of VC-2B, Valles Caldera, New Mexico: Geothermal Resources Council Transactions, v. 14, p. $403-410$.

Guffanti, Marianne, Muffler, L.J.P., Mariner, R.H., Sherrod, D.R., Smith, J.G., Blackwell, D.D., and Weaver, C.S., 1990, Geothermal segmentation of the Cascade Range in the U.S.A: Geothermal Resources Council Transactions, v. 14, p. 1431-1435.

Ingebritsen, S.E., Mariner, R.H., Cassiday, D.E., Shepherd, L.D., Presser, T.S., Pringle, M.K.W., and White, L.D., 1988, Heat-flow and water-chemistry data from the Cascade Range and adjacent areas in nortl-central Oregon: U.S. Geological Survey Open-File Report 88-702, 205 p.

Ingebritsen, S.I., Mariner, R.H., and Sherrod, D.R., in press, Hydrothermal systems of the Cascade Range, north-central Oregon: U.S. Geological Survey Professional Paper 1044-L. 


\section{GROUND-WATER CHEMISTRY}

Ingebritsen, S.E., Sherrod, D.R., and Mariner, R.H., 1989, Heat flow and hydrothermal circulation in the Cascade Range, north-central Oregon: Science, v. 243, p. 1458-1462.

1992, Rates and patterns of goundwater flow in the Cascade Range volcanic arc, and the influence on subsurface temperature: Journal of Geophysical Research, v. 97, no. B4, p. 4599-4627.

Kharaka, Y.K., Ambats, Gil, Evans, W.C., and White, A.F., 1988, Geochemistry of water at Cajon Pass, California-Preliminary results: Geophysical Research Letters, v. 15, p. 10371040.

Kharaka, Y.K., and Mariner, R.H., 1989, Chemical geothermometers and their application to formation waters from sedimentary basins, in Naeser N.D., and McCulloh, T.H., eds., Thermal History of Sedimentary Basins: Springer-Verlag, Methods and Case History, chap. 6, p. 99-1117.

Kharaka, Y.K., Mariner, R.H., Ambats, Gil, Evans, W.C., White, L.D., Bullen, T.D., and Kennedy, B.M., 1990, Origins of water and solutes in and north of the Norris-Mammoth Corridor, Yellowstone National Park: Geothermal Resources Council Transactions, v. 14, p. 705-714.

Kharaka, Y.K., Mariner, R.H., Bullen, T.D., Kennedy, B.M., and Sturchio, N.C., 1991, Geochemical investigations of hydrothermal connections between Corwin Springs Known Geothermal Resource Area and adjacent parts of Yellowstone National Park: U.S. Geological Survey Water-Resources Investigations Report No. 91-4052, p. F1-F38.

Kharaka, Y.K., Mariner, R.H., Evans, W.C., and 1992, Compositions of gases from the NorrisMammoth corridor, Yellowstone National
Park, U.S.A,-Evidence for a magmatic source beneath Mammoth Hot Springs in Kharaka, Y.K., and Maest, A.S., eds., 7th International Symposium on water-rock interaction [Proceedings]: Rotterdam, A.A. Balkema, v. 2, p. 1303-1307.

Kling, G.W., Tuttle, M.L., and Evans, W.C., 1989, Safety of Cameroonian lakes: Nature, v. 337, p. 215.

1989, The evolution of thermal structure and water chemistry in Lake Nyos: Journal of Volcanology and Geothermal Research, v. 39, p. 151-165.

Mariner, R.H., Kharaka, Y.K., Ambats, Gil, and White, L.D., 1992, Chemical composition and stable isotopes of thermal waters, NorrisMammoth corridor, Yellowstone National Park, U.S.A. in Kharaka, Y.K., and Maest, A.S., eds., 7th International Symposium on water-rock interaction [Proceedings]: Rotterdam, A.A. Balkema, v. 2, p. 963-966.

Mariner, R.H., Presser, T.S., and Evans, W.C., 1993, Geothermometry and water-rock interaction in selected thermal systems in the Cascade Range and Modoc Plateau, western United States: Geothermics, v. 22, p. 1-15.

Mariner, R.H., Presser, T.S., Evans, W.C., and Pringle, M.K.W., 1989, Discharge rates of thermal fluids in the, Cascade Range of Oregon and Washington and their relationship to the geologic environment: U.S. Geological Survey Open File Report 89-178, p. 663-694.

1990, Discharge rates of fluid and heat by thermal springs of the Cascade Range, Washington, Oregon, and northern California: Journal of Geophysical Research, v. 95, no. B12, p. $19,517-19,531$. 


\section{GROUND-WATER CHEMISTRY}

Mariner, R.H., Young, H.W., Evans, W.C., and Parliman, D.J., 1991, Chemical, Isotopic, and dissolved gas compositions of the hydrothermal system in Twin Falls and Jerome Counties, Idaho: Geothermal Resources Council Transactions, v. 15., p. 257-263.

Mariner, R.H., Young, H.W., Parliman, D.J., and Evans, W.C., 1989, Geochemistry of thermal waters from selected wells, Boise, Idaho: Geothermal Resources Council Transactions, v. 13, p. 173-178.

Mozley, P.S., and Carothers, W.W., 1992, Elemental and isotopic composition of siderite in the Kuparuk Formation, Alaska-Effect of microbial activity and water/sediment interation on early pore-water chemistry: Journal of Sedimentary Petrology, v. 62, p. 681-692.

Oscarson, R.L., Presser, T.S., and Carothers, W.W., 1992, Ca-Mg carbonate deposits Warnik Canyon, Colusa County, California: U.S. Geological Survey Open-File Report 92-707, 32 p.

Sammel, E.A., Ingebritsen, S.E., and Mariner, R.H., 1988, The hydrothermal system at Newberry Volcano, Oregon: Journal of Geophysical Research, v. 93, no. B9, p. 10,149 10,162 .

Thompson, J.M., Mariner, R.H., White, L.D., Presser, T.S., and Evans, W.C., 1992, Thermal waters along the Konocti Bay fault zone, Lake County, California-A re-evaluation: Journal of Volcanology and Geothermal Research, v. 53, p. 167-183.

Thordsen, J.J., Kharaka, Y.K., Mariner, R.H., and White, L.D., 1992, Controls on the distribution of stable isotopes of meteoric water and snow in the greater Yellowstone National Park region: in Kharaka, Y.K., and Maest, A.S., eds., 7th International Symposium on water- rock interaction [Proceedings]: Rotterdam, A.A. Balkema, v. 1, p. 591-595.

Tuttle, M.L., Briggs, P.H., Evans, W.C., Kling, G.W., and Lockwood, J.P., 1992, Infuence of mafic minerals on water chemistry and watercolumn stability of Lake Nyos, Cameroon in Kharaka, Y.K., and Maest, A.S., eds., 7th International Symposium on water-rock interaction [Proceedings]: Rotterdam, A.A. Balkema, v. 1., p. 449-452.

Young, H.W., Parliman, D.J., and Mariner, R.H., 1988, Chemical and hydrologic data for selected thermal-water wells and nonthermal springs in the Boise area, southwestern Idaho: U.S. Geological Survey Open-File Report 88-471, p. 35 . 


\section{GROUND-WATER CHEMISTRY}

TITLE: Chemistry of Aquatic Organic Matter (WR 84-189)

PERSONNEL: Donald F. Goerlitz, Project Chief

ADDRESS: $\quad$ U.S. Geological Survey, 345 Middlefield Road, MS 421, Menlo Park, CA 94025

TELEPHONE: (415) 329-4561

PROBLEM: The intrusion of industrial, agricultural, and domestically produced organic chemicals and wastes into the aquatic environment is well known and is considered to be one of the most important environmental problems. The widespread distribution of these anthropogenic substances, in addition to naturally occurring organics, and their detrimental impact on the Nation's water resources points to the need to understand how these substances act and react in the environment. Knowledge of transport, persistence, transformation, solubility, sorption, and reaction kinetics is needed to determine the fate of the substances in the hydrosphere.

OBJECTIVE: (1) Identify organic substances associated with a given field problem, in aqueous and nonaqueous phases, sorbed, and in an unsaturated atmosphere; (2) chemically determine any biotic or abiotic degradation or transformations occurring in the field; (3) measure sorption and reaction equilibria and rates within the aqueous system and at the water-mineral interface from field observations and laboratory simulations; and (4) determine the behavior of organic solutes and vapors in the unsaturated zone.

APPROACH: (1) Use high-performance liquid chromatography, capillary gas chromatography, and computerized gas chromatography/mass spectrometry to make qualitative and quantitative organic analyses; (2) do sorption studies by means of column technology previously developed in this laboratory; and (3) conduct work at two field sites on organic wood preservatives, which are ground-water contaminants, and initiate work at two other field sites where the ground water is contaminated by crude and refined petroleum products.

PROGRESS: Cores of aquifer material were collected June 7-10, 1993, at a site at Pensacola, Florida, where the ground water is contaminated by wood preserving chemicals, namely creosote. Aquifer cores and associated water were collected in the aerobic-anaerobic transition interval for the purpose of identifying and measuring the solutes from creosote and 


\section{GROUND-WATER CHEMISTRY}

metabolites in this zone of maximum microbial activity. This is a continuing study that has been in progress during the past $1 \frac{1 / 2}{2}$ years. Individual anaerobic microcosms (digestors) prepared from aquifer materials obtained from the Pensacola site and from selected individual creosote derived chemicals are being analyzed over time by gas chromatography-mass spectrometry. Identification of the metabolites produced from the microbial digestion processes has been successful. These compounds have been identified or related to those found in the aquifer. Proposed metabolic pathways have been confirmed and new ones suggested from these findings. A data base associating contaminants, metabolites and alteration products with depth, distance down the gradient and other chemical and biochemical factors is in preparation. Analytical procedures for identification and measurement of organic chemicals have been developed and validated for purposes of these investigations.

\section{REPORTS PUBLISHED 1988-1993:}

Baedecker, M.J., Franks, B.J., Goerlitz, D.F., and Hopple, J.A., 1988, Geochemistry of a shallow aquifer contaminated with creosote products, in Ragone, S.E., ed., U.S. Geological Survey Toxic Waste-Ground-water Contamination Program-Proceedings of the second technical meeting, Cape Cod, Massachusetts, October 21-25, 1985: U.S. Geological Survey Open-File Report 86-481, chapter A, p. 1720.

Godsy, E.M., and Goerlitz, D.F., 1988, Determination of the rates of anaerobic degradation of the water soluble fraction of creosote, in Ragone, S.E., ed., U.S. Geological Survey Toxic Waste-Ground Water Contamination Program-Proceedings of the second technical meeting, Cape Cod, Massachusetts, October 21-25, 1985: U.S. Geological Survey OpenFile Report 86-481, chap. A, p. 27-31.

Godsy, E.M., Goerlitz, D.F. and Grbic'-Galic', D., 1991 Methanogenic degradation kinetics of phenolic compounds, in Bioremediation of Hazardous Wastes-A symposium: U.S. Environmental Protections Agency Biosystems Technology Development Program, April 16-18, 1991, Falls Church, Va., p. 67-69.
1992, Methanogenic biodegradation of creosote contaminants in simulated ground-water ecosystems: Ground Water, v. 30, p. 232 242.

1992, Methanogenic degradation kinetics of phenolic compounds in aquifer-derived microcosms: Biodegradation v. 2, p. 211-221.

1992, Methanogenic degradation kinetics of phenolic compounds in aquifer-derived microcosms: Symposium on Bioremediation of Hazardous Wastes: U.S. Environmental Protection Agency Biosystems Technology Development Program, 1992, Chicago, Illinois, p. 120-125.

in press, Pathways of methanogenic biodegradation of creosote-derived aromatic compounds in Morganwalp, D.W., and Aronson, D.A., eds., U.S. Geological Survey Toxic Substances Hydrology Program-Proceedings of the technical meeting, Colorado Springs, Colo., Sept. 20-24, 1993: U.S. Geological Survey Water-Resources Investigations Report 944014.

Goerlitz, D.F., 1988, Re-examination of the occurrence and distribution of creosote compounds 


\section{GROUND-WATER CHEMISTRY}

in ground water, in Ragone, S.E., ed., U.S. Geological Survey Toxic Waste-Ground Water Contamination Program-Proceedings of the second technical meeting, Cape Cod, Massachusetts, October 21-25, 1985: U.S. Geological Survey Open-File Report 86-481, chap. A, p. 21-26.

1992, A review of studies of contaminated ground water conducted by the U.S. Geological Survey organics project, Menlo Park, Calif., 1961-1990, in Lesage, S., and Jackson, R., eds., Ground water quality and analysis at hazardous waste sites: New York, Marcel Dekker, p. 295-355.

Goerlitz, D.F., and Franks, B.J., 1989, Use of on-site high performance liquid chromatography to evaluate the magnitude, extent and transport of organic contaminants in aquifers: Ground-Water Monitoring Review, v. 9, No.2, p. 122-130.

Turney, G.L., and Goerlitz, D.F., 1989, Groundwater contamination at an inactive coal and oil gasification plant site, Gas Works Park, Seattle, Washington: U.S. Geological Survey Water-Resources Investigations Report 884224, $31 \mathrm{p}$.

1990, Organic contamination of ground water at Gas Works Park, Seattle, Washington: Ground Water Monitoring Review, v. 10, no. 3, p. 187-198. 


\section{GROUND-WATER CHEMISTRY}

TITLE: Geochemical Reactions Between Water and Mineral Substrates (WR 88-196)

PERSONNEL: Arthur F. White, Project Chief

Gloria M. Castagne, Secretary

Thomas D. Bullen, Hydrologist

Marjorie Schulz, Hydrologist

Theresa S. Presser, Chemist

Alex E. Blum, Hydrologist

ADDRESS: U.S. Geological Survey, 345 Middlefield Road, MS 420, Menlo Park, CA 94025

TELEPHONE: (415) 329-4519

PROBLEM: Water quality and pollution contamination depend strongly on geochemical processes involving reactions with mineral surfaces and substrates. Such processes include weathering reactions that contribute dissolved chemicals, sorption that removes aqueous species, and electron transfer mechanisms that establish redox conditions. Although extensive research has been conducted on the aqueous chemistry, minimal information exists on the corresponding solid phases and their effects on chemical transport.

OBJECTIVE: Investigate the composition and structure of common mineral surfaces and determine the extent of heterogeneity between specific surfaces and the bulk mineral phase. Determine the mechanism and rates of chemical and electron transfer between mineral substrates and surface- and ground-water systems. Determine the nature and extent of temporal changes in surface compositions during natural weathering and contaminant introduction and assess the effects on sorption and retardation. Assess environmental hazards due to the weathering of toxic materials contained in natural minerals and rocks and plan mitigation and cleanup under geologic constraints. Assess the effects of hydrologic parameters on rates of chemical weathering in soil profiles and watersheds and predict impacts of climate change.

APPROACH: Methods used will define concurrent changes in mineral substrates and water during geochemical reactions in natural and contaminated aqueous systems. Characterization of surface chemistry will utilize recent advances in ultra-high vacuum systems including $\mathrm{x}$-ray photoelectron spectroscopy, auger electron spectroscopy, and secondary ion mass spectroscopy. Use also will be made of high-sensitivity solid state electrochemistry. Investigations will include both controlled laboratory studies and natural systems. Detailed field projects will be conducted to quantify the significance of mineral substrates in controlling major element chemistry, $\mathrm{pH}$, and $\mathrm{Eh}$, and as sources of trace toxic components 


\section{GROUND-WATER CHEMISTRY}

such as chromium, copper, selenium and arsenic. Results will permit development of coupled models describing reaction kinetics and mass transport between aqueous and solid phases.

PROGRESS: Work continued assessing the effects of time and climate on chemical weathering rates in soils associated with granitic rock. For the Merced Chronosequence in California, four years of chemical data have been collected for soil waters extracted from suction water samplers in addition to unsaturated hydrologic data including gravimetric water content and matric potentials. Results indicate significant changes based on yearly precipitation differences reflecting significantly above and below average rain fall over the last several years. Preliminary results from a lithium bromide tracer test was initiated this year at two of the Merced sites indicate that this will be a powerful tool in determining hydrologic and chemical fluxes through the system. Characterization of variations in solid phase chemistry and mineralogy with time include detailed analyses of changes of mineral surface areas with time, information that has never been obtained before for such a natural system and data that are critical for calculation of chemical weathering rates. Comparison of rates based on total weathering and current rates of weathering appear comparable suggesting relatively constant geochemical conditions during the last 3 million years. The data indicate weathering rates are approximately 103 times slower than predicted by previous experimental studies. Previous work has indicated that solution composition can retard dissolution rates, but it is uncertain whether this is a consequence of overall solution saturation state or the concentrations of specific ions. New experiments on albite dissolution have been conducted to determine the effect of $\mathrm{Al}$ in solution on retarding the dissolution rate. Results indicate that $\mathrm{Al}$ retards the dissolution rate by a factor of greater than 3 .

A complete year's worth of chemical and hydrologic data has been collected at the Panola, Georgia, and Luquillo, Puerto Rico Water, Energy and Biogeochemical Budget (WEBB) sites. Panola data indicate significant vertical variations in soil zone chemistry that are controlled in part by development of aquitards within the granitic saprolite. Seasonal evapotranspiration occurs above this zone and relatively steady state hydrologic and chemical conditions occur below. Principle weathering mechanisms involve alteration of feldspars to kaolinite and the formation of hydrobiotite. The sampling nest in the Riparian zone permits a detailed picture of hydrochemical interaction between the ground water and unsaturated zone.

The upper meter of soil in Puerto Rico is unsaturated but was found to be saprolitic below 1 meter with well preserved igneous structure and a porosity of 50 percent. Gravimetric water contents and bulk density data indicate that the soils remain 80 percent saturated with matric potentials less than 25 centibars. The mineralogy is predominantly kaolinite and quartz with 


\section{GROUND-WATER CHEMISTRY}

minor biotite below several meters. Concentrations of $\mathrm{Na}, \mathrm{Sr}, \mathrm{Ca}, \mathrm{Cl}$ and $\mathrm{SO}_{4}$ in soil water throughout the saprolite profile are much more dilute than observed in stream flow and are dominated by precipitation. This is supported by ${ }^{87} \mathrm{Sr} /{ }^{86} \mathrm{Sr}$ ratios of 0.710 that are nearly identical to sea water and more radiogenic than ratios of 0.705 for both unreacted granitic and surface water. Si increases with depth from $0.05 \mathrm{mmol} / \mathrm{l}$ (millimol per liter) at 1 meter to $2 \mathrm{mmol} / \mathrm{l}$ at 8 meters along with corresponding increases in $\mathrm{K}$ and $\mathrm{Mg}$. These relatively high concentrations are indicative of dissolution of kaolinite in the upper soil zone and alteration of biotite in the deeper saprolite. Reaction of feldspars occurs at depth within a narrow interface between the fresh granite and the overlying saprolite. Mass balance calculations of soil chemical and volume changes based upon $\mathrm{Zr}, \mathrm{Ti}$ and $\mathrm{Nb}$ indicate less than 10 percent volume decrease, consistent with the saprolite textures. $\mathrm{Na}, \mathrm{Ca}$ and $\mathrm{Sr}$ are nearly completely depleted in the soil, 50 percent of the $\mathrm{Si}$ has been lost, and 30 percent of the $\mathrm{Al}$ and $\mathrm{Fe}$. These results demonstrate a much more intensive weathering regime than associated with temperate zone saprolites and have important ramifications for climate change scenarios.

Continued development of lithogenic isotope capabilities was ongoing during the year. Several hundred $\mathrm{Sr}$ isotope analyses for five WEBB projects were run in addition to a number of $\mathrm{Pb}$ isotope analyses for Panola WEBB. Also, a survey of $\mathrm{Sr}$ isotopic compositions and $\mathrm{Rb} / \mathrm{Sr}$ concentrations in minerals from Merced drainage soil samples was completed to provide quantitative basis for mass balance models. Collaborative studies of $\mathrm{Li}$ and $\mathrm{B}$ isotope systematics in geothermal fluids and solid-phase samples at Valles Caldera (New Mexico) and Clear Lake (California) were started in attempt to understand causes of isotope fractionation. Also studies on $\mathrm{Sr}, \mathrm{Li}$ and $\mathrm{B}$ isotope systematics in fluids and solid phases from two regional carbonate aquifer systems (Ohio-Indiana Regional Aquifer System Assessment (RASA), Upper Floridan) were initiated in attempt to track fluid migration on a regional scale. A new ion counting and negative ion detection on the Finnigan solid-source mass spectrometer was installed, allowing for substantially increased analytical capabilities. Use of the ion counter established analytical protocol for mass spectrometry of uranium, thorium and iron isotopes.

Studies continued defining sources of selenium in the Central Valley of California. Panoche and Silver Creeks have been instrumented with sediment-water collectors. Two years of runoff samples have been collected during the winter rains in the Panoche Creek alluvial fan area to determine the loading of Se to the San Joaquin Valley. Results from major element chemistry and isotopic analyses to distinguish between the two hypotheses of an initial flush of selenium or a later outflow of older ground water.

Two projects have been completed on the presence of $\mathrm{CO}_{2}$ and $\mathrm{Cl}$ springs in the northern Coast Ranges. Approximately 15 highly saline chloride (up to $16,500 \mathrm{mg} / \mathrm{L}$ ) springs of high 


\section{GROUND-WATER CHEMISTRY}

volume discharge out-flow on ridge tops in the Rumsey Hills area in the Sacramento Valley. They have distinctive $\delta^{18} 0$ signatures of plus 5 and are apparently deep basinal fluids subjected to tectonic compression along a fault anticline. Another set of springs to the northwest on the serpentine -Cretaceous border possess both elevated $\mathrm{Cl}$ (up to $42,500 \mathrm{mg} / \mathrm{L}$ (milligrams per liter) and $\mathrm{HCO}_{3}$ (up to $3,500 \mathrm{mg} / \mathrm{L}$ ). These springs are the site of ubiquitous $\mathrm{Ca}-\mathrm{Mg}$ carbonate deposits that vary from aragonite, calcite, $\mathrm{Mg}$-rich calcite and disordered dolomite and will be used to test a hypothesis made concerning the formation of $\mathrm{Ca}-\mathrm{Mg}$ carbonates from fresh water continental terrains.

An atomic force microscope (AFM) was purchased, has been installed, and is now fully functional and available for users. New techniques have been developed for characterization of clay particles using the AFM. Applications of these techniques to illite/smectites have resulted in one publication and another in press that have aroused considerable interest. The AFM system is also being used to characterize surface areas and extent of internal porosity in soil and aquifer materials.

\section{REPORTS PUBLISHED 1988-1993:}

Benson, S., White, A.F., Halfman, S., and Flexser, S., 1991, Groundwater contamination at the Kesterson Reservoir, California; Part I. Hydrologic setting and conservative solute transport: Water Resources Research, v. 27. pp. 1071-1084.

Blum, A.E., and Eberl, D.D., 1992, Determination of clay particle thicknesses and morphology using Scanning Force Microscopy in Kharaka, Y.K., and Maest, A.S., eds., 7th International Symposium on Water Rock Interaction, Park City, Utah, August 1992 [Proceedings]: Rotterdam, A.A. Balkema, p. 133-136.

Blum, A.E. and Lasaga, A.C., 1991, The role of surface speciation in the dissolution of albite: Geochimica et Cosmochimica Acta, v. 55, p. 2193-2201.

Bullen, T.D. and Kharaka, Y.K., 1992, Isotopic composition of $\mathrm{Sr}, \mathrm{Nd}$ and $\mathrm{Li}$ in thermal waters from the Norris-Mammoth corridor, Yellowstone National Park and surrounding region, in Kharaka, Y.K. and Maest, A.S., eds., Proceedings of the 7th International Symposium on Water-Rock Interaction: p. 895-890.

Davisson, M.L., Presser, T.S., and Criss, R.E., 1993, Geochemistry of technonically expelled fluids from the northern coast ranges: Rumsey Hills, California, Lawerence Livermore National Laboratory Report UCRL-JC-112841, $24 \mathrm{p}$.

Hochella, M.F. and White, A.F., 1990, Mineralwater interface geochemistry, an overview, in Hochella, M.F., and White, A.F., eds, Mineral-Water Interface Geochemistry: Reviews in Mineralogy, no. 23, p. 1-15.

Huntington, T.G., Hooper, R.P., Peters, N.E., Bullen, T.D. and Kendall, C., 1993, Water, energy and biogeochemical budgets investigation at Panola Mountain research watershed, Stockbridge, Georgia-A research plan: U.S. Geological Survey Open-File Report 93-55. 


\section{GROUND-WATER CHEMISTRY}

Johnson, P.A., Blum, A.E., Hochella, M.F., Parks, G.A., and Sposito, G., 1992, Direct observation of muscovite basal-plane dissolution and secondary phase formation-An XPS, LEED, and SFM study: Interaction Symposium on Water Rock Interaction, 7th, Park City, Utah, August 1992, Proceedings: Rotterdam, A.A. Balkema, p. 159-162.

Kharaka, Y.K., Ambata, G., Evans, W.C., and White, A.F., 1988, Geochemistry of water at Cajon Pass, California; Preliminary results: Geophysical Research Letter 15, p. 10371040.

Kharaka, Y.K., Mariner, R.H., Bullen, T.D., Kennedy, B.M. and Sturchio, N.C., 1991, Effects of potential geothermal development in the Corwin Springs Known Geothermal Area, Montana, on the thermal features of Yellowstone National Park: U.S. Geological Survey Water-Resources Investigations Report 914052, 23 p.

Oscarson, R.L., Presser, T.S., and Carothers, W.W., 1992, Ca-Mg Carbonate deposits, Warnick Canyon, Colusa County, California: U.S. Geological Survey Open-File Report 92-707.

Plummer, L.N., Busenberg, E., Glynn, P.D. and Blum, A.E., 1992, The dissolution of aragonite-strontianite solid solutions in non-stoichiometric $\mathrm{Sr}\left(\mathrm{HCO}_{3}\right) 2-\mathrm{Ca}\left(\mathrm{HCO}_{3}\right) 2-\mathrm{CO}_{2}-\mathrm{H}_{2} \mathrm{O}$ solutions-A test of stoichiometric saturation: Geochimica et Cosmochimica Acta, v. 56, p. 3045-3072.

Presser, T.S., Swain, W.C. Tidball, R.R., and Severson, R.C., 1990, Geologic sources, mobilization, and transport of selenium from the California Coast Ranges to the Western San Joaquin Valley-A Reconnaissance Study: U.S. Geological Survey Water-Resources Investigation Report 90-4070, 24 p.
White, A.F., 1991, Heterogenous electrochemical reactions associated with oxidation of ferrous oxide surfaces, in Hochella, M.F., and White, A.F., eds., Mineral water interface geochemistry: Reviews in Mineralogy, no. 23, p. 467555.

White, A.F., Benson, S. M., Yee, A. W., Wollenberg, H. A. and Flexser, S., 1991, Groundwater contamination at the Kesterson Reservoir, Calif.; Part II. Geochemical parameters influencing selenium mobility: Water Resources Research, v. 27, p. 1085-1098.

White, A. F., Blum, A.E., Bullen, T.D., Peterson, M.L., and Harden, J.W., 1992, A three million year weathering record for a soil chronosequence developed in granitic alluvium, Merced, California, U.S.A, in Kharaka, Y.K., and Maest, A.S., ed., 7th Interaction Symposium on Water Rock Interaction, Park City, Utah, August 1992 [Proceedings]: Rotterdam, A.A. Balkema, p. 607-610.

White, A.F., Chuma, N.J., and Goff, F., 1992, Mass transfer constraints on the chemical evolution of an active hydrothermal system. Valles caldera, New Mexico: Journal of Volcanology and Geothermal Research, v. 49, p. 233-253.

White, A.F. and Hochella, M.F., 1989, Electron transfer mechanisms associated with surface dissolution and oxidation of magnetite and ilmenite in Miles, D.L., ed., Sixth International Meeting on Water-Rock Interaction, Malven, England [Proceedings]: Rotterdam, A.A. Balkema, p. 765-768.

White, A.F., and Hochella, M.F., 1992, Surface chemistry associated with the cooling and subaerial weathering of recent basalt flows: Geochimica et Cosmochimica Acta, v. 56, p. 3711-3721. 


\section{GROUND-WATER CHEMISTRY}

White, A.F., and Peterson, M.L., 1990, Role of reactive-surface area characterization in geochemical kinetic models, in Melchoi, D.C., and Bass, R.L., eds., Chemical modeling of aqueous systems: American Chemical Society Symposium Series 416, p. 461-475.

1990 , Sources and fractionation processes influenting the isotopic distribution of $\mathrm{H}, \mathrm{O}$, and $\mathrm{C}$ in the Long Valley hydrothermal system, California, U.S.A.: Applied Geochemistry, v. 5, p. 571-585.

White, A.F., Peterson, M.L., and Janik, C., 1991, Chemical equilibrium and mass balance relationships associated with the Long Valley hydrothermal system, California, U.S.A.: Journal of Volcanology and Geothermal Research, v. 48 , p. 283-302.

White, A.F., Peterson, M.L., and Solbau, R.D., 1990, Measurement and interpretation of low levels of dissolved oxygen in ground water: Ground Water v. 28, p. 584-590. 
GROUND-WATER CHEMISTRY

214 NATIONAL RESEARCH SUMMARY 1993 


\section{GROUND-WATER HYDROLOGY}




\title{
GROUND-WATER HYDROLOGY
}

TITLE: The Mathematical Simulation of the Transport and Reaction of Chemical Species in Ground Water (CR 73-085 formerly NR 73-139)

\author{
PERSONNEL: David B. Grove, Project Chief \\ Evelyn R. Warren, Secretary \\ Lana K. Gerlick, Clerk
}

ADDRESS: U.S. Geological Survey, P.O. Box 25046, MS 413, Denver Federal Center, Denver, CO 80225

TELEPHONE: (303) 236-4980

PROBLEM: Mathematical techniques that describe the transport and reactions of dissolved chemical species during their flow through saturated porous media are necessary to the prediction of water-quality changes in ground water. Such predictions are necessary to allow a decision-making capability prior to possible injection of wastes, as well as to provide remedial action in the case of accidental contamination of aquifers.

OBJECTIVE: Demonstrate the applicability of numerical-modeling techniques to the prediction of water-quality changes during transport of solutes through saturated ground-water systems and analyze the effects of these changes on the ground-water environment. Predict the effects of chemical and physical stresses on the quality of ground water.

PROGRESS: A literature review of recent advances in organic species transport and reaction is nearing completion. Computer models have been formulated to describe organic uptake by porous media. The diffusion and reaction of the species within the porous media grains is being simulated. Laboratory data generated from Intragranular Diffusion from a U.S. Geological Survey article published in Science $(1990$, v. 247, p. 1569) are being used to see if this model is appropriate.

Meetings with the Air Force Combat Command in Norfolk, Virginia, and Rocky Mountain Arsenal personnel in Denver, Colorado, are being held on behalf of the U.S. Geological Survey for possible research activities. 


\section{GROUND-WATER HYDROLOGY}

\section{REPORTS PUBLISHED 1988-1993:}

Rathbun, R.E., Shultz, D.J., Stephens, D.W., and Tai, D.Y., 1989, Transport and fate of acetone in an ourdoor model stream, Stennis Space Center, Bay St. Louis, Mississippi: U.S. Geological Survey Water-Resources Investigations Report 89-4141.

Shultz, D.J., 1989, Nitrogen dynamics in the Tidal Freshwater Potomac River, Maryland and Virginia, Water Years 1979-81: U.S. Geological Survey Water-Supply Paper 2234-J, 44 p. 


\section{GROUND-WATER HYDROLOGY}

TITLE: $\quad$ The Role of Lakes in the Hydrologic System, with Emphasis on Their Relation to Ground Water (CR 74-090)

PERSONNEL: Thomas C. Winter; Project Chief

Evelyn R. Warren, Office Auto. Assist.

Lana K. Gerlick, Off. Auto. Clerk

Donald O. Rosenberry, Hydrologist

Renee S. Parkhurst, Hydrologist

ADDRESS: $\quad$ U.S. Geological Survey, P.O. Box 25046, MS 413, Denver Federal Center, Denver, CO 80225

TELEPHONE: (303) 236-4987

PROBLEM: Many hydrological and geochemical processes associated with lakes and wetlands are poorly understood. Characteristics of wind and vapor profiles over lakes, which are basic controls on evaporation, have been studied in detail for only a few large reservoirs in the western United States. Many commonly used methods of estimating surface runoff to lakes and wetlands are inaccurate. Hydrogeologic controls on seepage to and from all surface-water bodies have not been studied adequately, either from theoretical or field perspectives. Research on these components of lake and wetland hydrology is especially critical to individuals responsible for management, protection, and restoration of these resources.

OBJECTIVE: Gain understanding of the basic principles controlling the interaction of lakes and wetlands with ground water, including associated chemical fluxes. Emphasize integration of theoretical and experimental field work. Emphasize the study of ground water, but include state-of-the-art studies of the atmospheric and surface-water components of lake and wetland hydrology as needed for the evaluation of the ground-water component. Evaluate error in hydrologic methodology for the various aspects of water balances of lakes and wetlands.

APPROACH: Construct theoretical and field-related mathematical models of steady-state and transient, variably-saturated ground-water conditions as related to lakes and wetlands. Choose field experimental sites in selected parts of the United States for calibration and modification of models, instruments, and methods. Measure all components of the hydrologic system, as related to the experimental lakes and wetlands, by various methods in support of the ground-water studies. Use multiple-level sensors on the lake for evaporation research. Integrate chemical flux and biological studies with the hydrologic work at selected sites.

PROGRESS: In an effort to determine the spatial distribution of ground-water recharge at Williams Lake, Minnesota, the multivariate statistical method of pattern recognition was used. 


\section{GROUND-WATER HYDROLOGY}

Two distinctive statistical patterns of water-table fluctuations were revealed in a 10-year record of water level measurements in 59 wells. Eighty percent of the variance in the data set was explained by a long-term signal showing climatic cycles of several years duration. Another 12 percent of the variance showed large-magnitude, short-term fluctuation patterns. The long-term signal was characteristic of wells in the higher parts of the area where the water table was deep, therefore responding only to annual recharge events. Wells in this type of setting would be the best candidates for monitoring response of the ground-water system to changes in climate. The second pattern was characteristic of wells located where the water table was near land surface, therefore responding to frequent recharge events throughout spring, summer, and fall.

In an effort to provide guidelines for selecting an appropriate method of determining evaporation for a given study, 11 empirical methods were evaluated against evaporation determined by the energy budget method for Williams Lake, Minnesota. Three different data sources were used from instruments based on a raft in the middle of the lake, a land station 100 meters northwest of the lake, and a weather station 60 kilometers south of the lake. The comparison was based on monthly values for the open-water periods of 1982 through 1986. Of the 11 methods evaluated, the DeBruin-Keijman, Priestley-Taylor, and Penman methods, all of which need site data, resulted in monthly evaporation values that agreed most closely with energy-budget values. If only data from distant climate stations are available, and it includes solar radiation, the Jensen-Haise and Makkink methods would be appropriate choices for determining evaporation. If only data on air temperature are available from a distant climate station, the Hamon method would be the most appropriate empirical method for calculating evaporation.

In an effort to provide a strawman for developing a coordinated national wetlands research program, a framework upon which to base such a program was developed. The framework, which initially considers only hydrology, was derived by combining a classification of hydrogeologic setting with climate. The hydrogeologic settings were determined by identifying the physiographic features within which fundamental ground-water flow systems are generated. Beginning with seven basic physiographic settings and the simple climatic characteristics of wet, dry, warm, and cold, 24 regions were identified in the United States where long-term wetland research sites need to be established. 


\section{GROUND-WATER HYDROLOGY}

REPORTS PUBLISHED 1988-1993:

Hsieh, P.A., Shapiro, A.M., Barton, C.C., Haeni, F.P., Honson, C.D., Martin, C.W., Paillet, F.L., Winter, T.C., and Wright, D.L., 1993, Methods of characterizing fluid movement and chemical transport in fractured rock, in Chaney J.T., and Hepburn, J.C., eds., Field trip guidebook for northeastern United States: Boston, Mass., Geological Society of American, Annual Meeting, October 25-28.

Parkhurst, R.S., Merk, D.A., Rosenberry, D.O., and Winter, T.C., 1992, Climatic data for Williams Lake, Hubbard County, Minnesota, 1987-88: U.S. Geological Survey Open-File Report 92-475, 39 p.

Parkhurst, R.S., Merk, D.A., Rosenberry, D.O., and Winter, T.C., 1993, Climatic data for Shingobee Lake and Williams Lake, Hubbard County, Minn., 1989-91: U.S. Geological Survey Open-File Report 93-127, 34 p.

Rosenberry, D.O., 1990, Effect of sensor error on interpretation of long-term water-level data: Ground Water, v. 28, no. 6, p. 927-936.

Rosenberry, D.O., Sturrock, A.M., and Winter, T.C., 1993, Evaluation of the energy budget method of determining evaporation at Williams Lake, Minnesota, using alternative instrumentation and study approaches: Water Resources Research, v. 29, no. 8, p. 2473-2483.

Rosenberry, D.O., and Winter, T.C., 1993, The significance of fracture flow to the water balance of a lake situated in fractured crystalline rock terrane, in Banks, Sheila, and Banks, David, eds., Hydrologeology of Hard Rocks: Memoirs of the XXIV Congress of the Internation Association of Hydrogeologists, Oslo, Norway, p. 967-977.
Stannard, D.I. and Rosenberry, D.O., 1991, A comparison of short-term measurements of lake evaporation using eddy correlation and energy budget methods: Journal of Hydrology, v. 122 , p. $15-22$.

Sturrock, A.M., Winter, T.C., and Rosenberry, D.O., 1992, Energy-budget evaporation from Williams Lake, a closed lake in north-central Minnesota: Water Resources Research, v. 28, no. 6, p. $1605-1617$.

Swanson, G.A., Winter, T.C., Adomaitis, V.A., and LaBaugh, J.W., 1988, Chemical characteristics of prairie lakes in south-central North Dakota, their potential for influencing use by fish and wildlife: U.S. Fish and Wildlife Service Technical Report 18, 44 p.

Swinehart, J.B., Goeke, James, and Winter, T.C., 1988, Field guide to geology and hydrology of the Nebraska Sandhills, in Holden, G.S., ed., Geological Society of America field trip guidebook, 1988: Colorado School of Mines Professional Contributions no. 12, p. 370-394.

Winter, T.C., 1988, Conceptual framework for assessment of cumulative impacts on the hydrology of non-tidal wetlands: Environmental Management, v. 12, no, 5, p. 605-620.

1988, The interaction of wetlands and ground water in the semi-arid prairie of North America, in International Symposium on Hydrology of Wetlands in Semi-arid and Arid Regions, 1988, Proceedings: Seville, Spain, International Association of Hydrogeologists, p. 173176.

1989, Hydrologic studies of wetlands in the northeru prairie: in van der Valk, Arnold, ed., 


\section{GROUND-WATER HYDROLOGY}

Northern prairie Wetlands: Ames, Iowa, Iowa State University Press, p. 16-54.

1990, Hydrologic function of wetlands: U.S. Geological Survey Yearbook Fiscal Year 1989, p. 29-31.

1992, A physiographic and climatic framework for hydrologic studies of wetlands, in Robards, R.D., and Bothwell, M.L., eds., Aquatic ecosystems in semi-arid regions, implications for resource management: The National Hydrology Research Institute Symposium Series no. 7, Saskatoon, Saskatchewan, Canada, Environment Canada, p. 127-148.

Winter, T.C., Eaton, J.S., and Likens, G.E., 1989, Evaluation of streamflow from the two largest watersheds of Mirror Lake, New Hampshire: Water Resources Bulletin, v. 25, no. 5, p. 991-1008.

Winter, T.C., LaBaugh, J.W., and Rosenberry, D.O., 1988, The design and use of a hydraulic potentiomanometer for direct measurement of differences in hydraulic head between ground water and surface water: Limnology and Oceanography, v. 33, no, 5, p. 1209-1214.

Winter, T.C. and Llamas, M.R., 1993, Introduction to the 28th International Geological Congress Symposium on the Hydrogeology of wetlands: Journal of Hydrology, v. 141, p. 1-3.

Winter, T.C., and Woo, Ming-Ko, 1990, Hydrology of lakes and wetlands, in Wolman, M.G., and Riggs, H.C., eds., Surface Water Hydrology: Boulder, Colo., Geological Society of America, The Geology of North America, v. 0-1, p. 159-187.

Woo, M-K and Winter, T.C., 1993, The role of permafrost and seasonal frost in the hydrology of northern wetlands in North America: Journal of Hydrology, v. 141, p. 5-31. 


\section{GROUND-WATER HYDROLOGY}

TITLE: $\quad$ Borehole Geophysics as Applied to Geohydrology (CR 64-140)

PERSONNEL: Frederick L. Paillet, Project Chief

Patricia A. Stamile, Acct. Tech.

Barbara S. Allen, Hydrological Technician

Alfred E. Hess, Electrical Engineer

Richard E. Hodges, Electrical Technician

Ticie A. Taylor, Computer Programmer

John E. Hutchens, Electrical Technician

Joyce A. Dey, Computer Assistant

Roger Morin, Geophysicist

ADDRESS: $\quad$ U.S. Geological Survey, P.O. Box 25046, MS 403, Denver Federal Center, Denver, CO 80225

TELEPHONE: (303) 236-5913

PROBLEM: A large amount of geophysical data is recorded for water wells and test holes, but interpretation is subject to significant uncertainties. The data are used in ground-water models to evaluate potential waste-disposal sites and the effects of ground-water contamination and to guide development of aquifers, including geothermal reservoirs. The development of quantitative log-interpretation techniques to derive more accurate data and to evaluate the statistical uncertainty in the data will reduce costs in ground-water investigations.

OBJECTIVE: (1) Evaluate presently available logging equipment and log-interpretation techniques, and develop improved instrumentation and analytical techniques for specific ground-water problems, such as site selection and monitoring for disposal of radioactive, municipal, and industrial wastes; (2) improve log-derived data, such as porosity values; (3) attempt to relate the log character of fractures to their hydraulic conductivities and to refine computer techniques for plotting hydraulic-conductivity profiles from logs; (4) develop the capability of making quantitative interpretation of borehole gamma spectra; and (5) do a statistical analysis of the magnitude and sources of errors in log-derived data.

APPROACH: Log selected drill holes, recording data in both analog and digital form, and comparing logs with results of core analyses, hydraulic-test data, and geophysical measurements made in calibration pits and blocks. Develop computer models to predict the behavior of gamma photons, electrical signals of various frequencies, and acoustic wave energy in borehole environments. Compare field-log data, theoretical predictions and hydraulic tests, core analyses, and test-pit values. Modify equipment and develop log corrections on the basis of these comparisons and calculate the statistical accuracy of log data. 


\section{GROUND-WATER HYDROLOGY}

PROGRESS: Experimental procedures have been designed to use transient flow data to infer hydraulic properties of interconnections between permeable beds or fractures in the rock mass adjacent to the borehole, and this procedure is being integrated into a systematic approach to characterize the hydrology of rocks adjacent to boreholes in order to significantly improve the effectiveness and efficiency of sampling and hydraulic testing. These techniques were described by F.L. Paillet in journal articles published in the Journal of Applied Geophysics, Journal of Ground water, and Journal of Hydrology. Four other papers were published by R.H. Morin in scientific journals and proceedings volumes describing the application of these techniques to site characterization and in situ permeability profiling. T.A. Taylor prepared major contributions to two technical reports describing the application of gamma spectral log measurements and other logs to the identification of potential radon contamination sources. F.L. Paillet prepared a generalized framework for log analysis and interpretation in ground-water studies to be used for training manuals; a preliminary discussion of this framework was prepared for publication in the proceedings volume for a technical meeting in October 1993.

\section{REPORTS PUBLISHED 1988-1993:}

Gable, R., Morin, R.H., and Becker, K., 1989, Geothermal state of hole 504B-ODP Leg 111 overview-Proceedings of the Ocean Drilling Program: Scientific Results, v. 111, p. 87-96.

Hess, A.E., 1990, A thermal flowmeter for the measurement of slow velocities in boreholes: U.S. Geological Survey Open-File Report $87-121,70$ p.

1990, Characterizing fracture hydrology using a sensitive borehole flowmeter with a wirelinepowered packer: International Conference on Fluid Flow in Fractured Rock, Atlanta, Ga., May, 1988, [Proceedings], p. 328-345.

Hess, A.E., and Paillet, F.L., 1990, Applications of the thermal-pulse flowmeter in the hydraulic characterization of fractured rocks: ASTM STP 1101, p. 99-112.

1990, Characterizing flow paths and permeability distribution in fractured-rock aquifers using a sensitive, thermal borehole flowmeter, in
Molz, F.J., and others, eds., Proceedings of the conference on new field techniques for quantifying the physical and chemical properties of heterogeneous aquifers: Dublin, Ohio, National Water Well Association, 1989, p. 445-461.

1990 , Measurement of vertical flow in borehole UE-3e 4 using geophysical logs, Nevada Test Site, Nye County, Nevada: U.S. Geological Survey Water-Resources Investigations Report 90-4185, 17 p.

Hodges, R.E., 1988, Calibration and standardization of geophysical well-logging equipment for hydrologic applications: U.S. Geological Survey Water-Resources Investigations Report $88-4058,25 \mathrm{p}$.

Hodges, R.E., and Teasdale, W.E., 1991, Considerations related to drilling methods in planning and performing borehole-geophysical logging for ground-water studies: U.S. Geological 


\section{GROUND-WATER HYDROLOGY}

Survey Water-Resources Investigations Report 91-4090, 17 p.

Molz, F.J., Morin, R.H., Hess, A.E., Melville, J.G., and Guven, O., 1989, The impeller meter for measuring aquifer permeability variations-Evaluation and comparison with other tests: Water Resources Research, v. 25, no. 7, p. 1677-1683.

Moos, D., and Morin, R.H., 1991, Observations of wellbore failure in the Toa Baja well-Implications for the state of stress in the north coast tertiary basin, Puerto Rico: Geophysical Research Letters, v. 18, no. 3, p. 505-508.

Morin, R.H., 1990, Determining the vertical distribution of hydraulic conductivity in situ by concurrent injection and geophysical logging: International Conference on Fluid Flow in Fractured Rock, Atlanta, Ga., May, 1988, [Proceedings], p. 346-354.

1990, Information on stress conditions in the oceanic crust from oval fractures in a deep borehole: Geophysical Research letters, v. 17, no. 9, p. 1311-1314.

1991, Preliminary determination of hydraulic conductivity in a sand and gravel aquifer, Cape Cod, Massachusetts form analysis of nuclear logs in Mallard, G.E., and Aronson, D.A., eds, U.S. Geological Survey Toxic Substance Hydrology Program-Proceedings of the technical meeting, Monterey, Calif., March 11-15, 1991: U.S. Geological Survey Water-Resources Investigations Report 914034, p. 23-28.

Morin, R.H., and others, 1989, Analysis and interpretation of the borehole televiewer log-Information on the state of stress and lithostratigraphy at hole 504B-Proceedings of the Ocean Drilling Program: Scientific Results, v. 111 , p. 109-118.
1990, State of lithospheric stress and bore-hole stability at Deep Sea Drilling Project Site 504B, Eastern Equatorial Pacific: Journal of Geophysical Research, v. 95, no. B6, p. 9293-9303.

Morin, R.H., Barrash, W., Paillet, F.L., and Taylor, T.A., 1993, Geophysical logging studies in the Snake River Plain aquifer at the Idaho National Engineering Laboratory-Wells 44, 45, and 46: U.S. Geological Survey Water-Resources Investigations Report 92-4184, 44 p.

Morin, R.H., Hess, A.E., and Becker, K., 1992, In situ measurements of fluid flow in DSDP holes 395A and 534A-Results from the Dianaut program: Geophysical Research Letters, v. 19 , no. 5 , p. 509-512.

Morin, R.H., Hess, A.E., and Paillet, F.L., 1988, Determining the distribution of hydraulic conductivity in a fractured limestone aquifer, southeastern Nevada, by simultaneous injection and geophysical logging: Ground Water, v. 26 , no. 5 , p. 587-595.

Morin, R.H., LeBlanc, D.R., and Teasdale, W.E., 1988, A statistical evaluation of formation disturbance produced by well-casing installation methods: Ground Water, v. 26, no. 2, p. 207-217.

Morin, R.H., Moos, D., and Hess, A.E., 1992, Analysis of the borehole televiewer $\log$ from DSDP hole 395A-Results from the Dianaut Program: Geophysical Research Letters, v. 19. no. 5, p. 501-504.

Morin, R.H., Olsen, H.W., Nelson, K.R. and Gill, J.D., 1989, Graphical method for determining the coefficient of consolidation, $c v$, from a flow-pump permeability test: Geotechnical Testing Journal, Decémber, p. 302-307. 


\section{GROUND-WATER HYDROLOGY}

Olsen, H.W., Morin, R.H., and Nichols, R.W., 1988, Flow pump applications in triaxial testing, in Donaghe, R., Chaney, R.C., and Silver, M.L., eds., Advanced Triaxial Testing of Soil and Rock, ASTM STP 977: Philadelphia, Pa., American Society for Testing and Materials, p. 68-81.

Paillet, F.L., 1988, Character and distribution of American Chestnut sprouts in southern New England: Bulletin of Torrey Botanical Club, v. 115 , no. 1, p. 32-44.

1988, Fracture characterization and fracturepermeability, estimation at the Underground Research Laboratory in southeastern Manitoba, Canada: U.S. Geological Survey Water-Resources Investigations Report 88-4009, 42 p.

1989, A generalized approach to geophysical well-log analysis and interpretation in hydrogeology, in Molz, F.J., and others, eds., Conference of new field techniques for quantifying the physical and chemical properties of the heterogeneous aquifers, Dublin, Ohio, Proceedings: National Water Well Association, 1989, p. 99-120.

1989, Analysis of geophysical well logs and flowmeter measurements in boreholes penetrating subhorizontal fracture zones, Lac DuBonnet Batholith, Manitoba, Canada: U.S. Geological Survey Water-Resources Investigations Report 89-4211, 30 p.

1989, Genetic diversity in post-blight populations of American Chestnut-Past, present, and future: Journal of the American Chestnut Foundation, v. 3, no. 1, p. 16-30.

1990, Characterization of fracture flow systems using geophysical log estimates of in situ permeability and other hydraulic data: International Conference on Fluid Flow in Fractured
Rock, Atlanta, Ga., May, 1988, [Proceedings], p. 312-327.

1991, The 1st core hole at Mirror Lake, New Hampshire-Comparing geophysical logs to core and cross-hole flow logging in Mallard, G.E., and Aronson, D.A., eds, U.S. Geological Survey Toxic Substance Hydrology Program-Proceedings of the technical meeting, Monterey, Calif., March 11-15, 1991: U.S. Geological Survey Water-Resources Investigations Report 91-4034, p. 162-171.

Paillet, F.L., 1991, Graphical overlay applications in geotechnical log analysis: International MGLS/ KEGS Symposium on Borehole Geophysics for Minerals, Geotechnical and Groundwater Applications, 4th, Toronto, Canada, [Proceedings], p. 249-265.

1991, High-resolution flow logging in observation boreholes during hydraulic testing of fractured-rock aquifers: Society of Professional Well Log Analysts Annual Logging Symposium, 32nd, Midland, Texas, 1991, Transactions, p. L1-L23.

1991, Qualitative and quantitative analysis of fracture permeability using acoustic full-waveform logs: The Log Analyst, v. 32, no. 3, p. 256-270.

1991, Use of geophysical well-logs in evaluating crystalline rocks for siting of radioactive waste repositories: The Log Analyst, v. 33, no. 2 , p. 85-107.

1992, Using cross-borehole flow measurements to define hydraulic connections, in MorelSeytoux, H.J., ed., Annual Hydrology Days, 12th, [proceedings]: American Geophysical Union, p. 198-211.

1993. Integrating geophysical well logs, surface geophysics, and hydraulic test and geo- 


\section{GROUND-WATER HYDROLOGY}

logic data in ground-water studies-Theory and case histories: Symposium on the Application of Geophysics to Engineering and Environmental Problems, San Diego, Calif., [Proceedings], p. 479-495.

in press, Application of borehole geophysics in the characterization of flow in fractured rocks: Trends in Geophysical Research, review volume.

in press, Applications of borehole geophysics in characterizing the hydrogeology of fractured igneous and metamorphic: International Association of hydrogeologists XXIVth Congress on the hydrology of hard rocks, July, Oslo, Norway, [Proceedings].

Paillet, F.L., and others, eds., 1990, Borehole imaging: Society of Professional Well Log Analysts Reprint Volume, 472 p.

Paillet, F.L., and Cheng, C.H., 1991, Acoustic waves in boreholes--The theory and application of acoustic full-waveform logs: Boca Raton, Fla., CRC Press, 264 p.

Paillet, F.L., Cheng, C.H., and Pennington, W.D., 1992, Acoustic waveform logging-advances in theory and application: The Log Analyst, v. 33 , no. 3, p. 239-258.

Paillet, F.L., Cheng, C.H., and Tang; X.M., 1989, Theoretical models relating acoustic tube-wave attenuation to fracture permeabilityReconciling model results with field data: Society of Professional Well Log Analysts Logging Symposium, 30th, Denver, Colo., Paper FF, p. FF1-FF24.

Paillet, F.L., Green, A., and Gurierri, J., 1992, Identification of hydraulically conductive fractures intersecting boreholes in fractured gneiss near Ashford, Connecticut: U.S. Geological
Survey Water-Resources Investigations Report 92-4074, 28 p.

Paillet, F.L., and Goldberg, D., 1991, Acoustic televiewer log images of natural fractures and bedding planes in the Toa Baja borehole, $\mathrm{P}$ uerto Rico: Geophysical Research Letters, v. 18 , no. 3 , p. 501-504.

Paillet, F.L., Hess, A.E., and Morin, R.H., 1990, Estimation of the relative permeability distribution in fractured granitic rocks by means of vertical flow measurements in the Siblingen borehole, Switzerland: U.S. Geological Survey Water-Resources Investigations Report 904034, 26 p.

Paillet, F.L., and Kapucu, K., 1989, Characterization of fracture permeability and fracture flow modeling at Mirror Lake, New Hampshire: U.S. Geological Survey Water-Resources Investigations Report 89-4058, 49 p.

Paillet, F.L., Kay, R.T., Yeskis, D., and Pedler, W.H., 1993, Integrating well logs into a multiple-scale investigation of a fractured sedimentary aquifer: The Log Analyst, v. 34, no. 1, p. 13-23.

Paillet, F.L., and Morin, R.H., 1988, Analysis of geophysical well logs obtained in the State 2-14 borehole, Salton Sea geothermal area, California: Journal of Geophysical Research, v. 93 , no. B11, p. 12,981-12,994.

Paillet, F.L., Novakowski, K., and Lapcevic, P., 1992, Analysis of transient flows in boreholes during pumping in fractured formations, in Society of Professional Well Log Analysts Annual Logging Symposium Transactions, 33rd, Oklahoma City, Okla., 1992, p. S1-21.

Paillet, F.L., and Rutter, P.A., 1989, Replacement of native oak hickory tree species by the introduced American Chestnut in southwestern 


\section{GROUND-WATER HYDROLOGY}

Wisconsin: Canadian Journal of Botany, v. 67, no. 12 , p. $3457-3469$.

Paillet, F.L., Waltz, J., and Boyle, R.E., 1989, Geophysical log investigation of formation changes produced by hydraulic fracture stimulation in a crystalline-bedrock aquifer: Symposium on Borehole Geophysics for Minerals Geotechnical, and Groundwater Applications, 3rd, Las Vegas, Nevada, 1989, Proceedings, p. EE571-594.

Paillet, F.L., Winkler, M.G., and Sanford, P.R., 1991, Relationship between pollen frequency in moss polsters and forest composition in a naturalized stand of American Chestnut: Implications for paleoenvironmental interpretation: Bulletin of Torrey Botanical Club, v. 118, no. 4, p. 432-443.

Paillet, F.L., Zaghloul, E.S., and Daftar, T.E., 1990, Application of geophysical well log analysis to characterization of aquifers in the Sinai Region, Republic of Egypt: U.S. Geological Survey Water-Resources Investigations Report 90-4194, 54 p.

Tarif, P.A., Wilkins, R.H., Cheng, C.H., and Paillet, F.L., 1988, Laboratory studies of the acoustic properties of samples from Salton Sea Scientific Drilling Project and their relation to microstructure and field measurements: Journal of Geophysical Research, v. 93, no. B11, p. $13,057-13,067$.

Taylor, T.A., 1989, Correlation in abnormal gamma readings with fluid movement through fractures in a formation by use of gammaspectral logs: Symposium on Borehole Geophysics for Minerals Geotechnical, and Groundwater Applications, 3rd, Las Vegas, Nevada, 1989, Proceedings, p. AA471-499.

Vernon, J.H., Paillet, F.L., Pedler, W.H., and Griswold, W.J., 1993, Application of borehole geophysics in defining the wellhead protection area for a fractured crystalline bedrock aquifer: The Log Analyst, v. 34, no. 1, p. 41-57. 


\section{GROUND-WATER HYDROLOGY}

TITLE: $\quad$ Mathematical Simulation of Subsurface-Water Flow Using Uncertain and Incomplete Data (CR 76-191)

PERSONNEL: Richard L. Cooley, Project Chief

Evelyn R. Warren, Office Auto. Assist.

Lana K. Gerlick, Office. Auto. Clerk

Mary C. Hill, Hydrologist (Colorado School of Mines, Adjunct Professor)

$\begin{array}{ll}\text { ADDRESS: } & \text { U.S. Geological Survey, P.O. Box 25046, MS 413, Denver Federal Center, } \\ \text { Denver, CO } 80225\end{array}$

TELEPHONE: (303) 236-4995

PROBLEM: Satisfactory formulations and solutions of equations approximately describing (1) movement of fluids and components contained in fluids through consolidated and unconsolidated rocks and (2) interactions of the fluids and rocks accompanying fluid movement are needed for proper understanding and management of ground-water resources. Such formulations and solutions of equations are not generally available for application to general field situations where the flow system is complex and hydrologic data are inexact.

OBJECTIVE: (1) Reformulate, as necessary, the equations describing the flow of fluids through porous or fractured rock to include stochastic processes, emphasizing equations that are suitable for field use; (2) derive techniques to solve for dependent variables and estimate parameters in the equations; (3) assess the degree of reliability and significance of the model formed by the basic equations and the parameters estimated for it in terms of the input data; and (4) assess the degree of reliability and predictive capability of the model.

APPROACH: Develop fundamental equations from methods of mathematical physics, stochastic processes, statistics, and basic physical concepts from geology, geochemistry, geophysics, and so forth. Develop solutions to the equations analytically or numerically, depending on the problem. Analyze error propagation, stability, and convergence by means of techniques of linear and nonlinear algebra if feasible and appropriate. Use techniques of nonlinear regression to estimate parameters so that the reliability and significance of estimated parameters and the predictive capability of the model can be assessed.

PROGRESS: (1) The computer program MODFLOWP, which solves three-dimensional ground-water flow and parameter estimation problems using nonlinear regression (published 1992), was enhanced, taught, and used both within and outside of the USGS. Corrections 


\section{GROUND-WATER HYDROLOGY}

were made as problems came up, a method of including correlations among prior parameter estimates was added to an experimental version of the code, and a method of using travel-time data along one-dimensional flow paths is being tested (see point 2, below). In addition, the National Training Center course was redesigned and taught to a full class, MODFLOWP was taught at the Colorado School of Mines, a lecture on MODFLOWP was delivered to participants at a conference on ground-water modeling sponsored by the International Ground-Water Modeling Center in Golden, Colorado, and MODFLOWP was successfully applied in a USGS district project on Long Island, New York.

(2) A new method for including travel times along one-dimensional flow paths through head dependent boundaries and confining units was developed and applied to a synthetic test case and a field problem. The new method allows the travel time to be included as an observation when estimating parameters using nonlinear regression and when calculating the associated confidence and prediction intervals.

(3) Five post-processing programs for MODFLOWP were developed and documented. These programs support testing of weighted residuals from the program and calculate linear confidence and prediction intervals. The documentation has been through colleague review and is presently awaiting Director's approval.

(4) A paper describing a method of incorporating an unknown range of possible model errors into the method of computing Scheffe-type posterior (Bayes) confidence intervals for output from ground-water models has been submitted to Water Resources Research. In addition, a study developing methodology for calculating posterior confidence and prediction intervals that are simultaneous for finite numbers of functions and (or) locations from nonlinear models was completed and a paper was written. The paper is presently in colleague review.

(5) A general computer package for adaptive nonlinear regression solution of arbitrary modeling problems and computation of simultaneous confidence and prediction intervals for nonlinear regression models was developed. This package also includes a program to generate critical values of the multivariate $t$ random variable, which is needed for the confidence and prediction interval calculations, and a program for interactive model calibration using adaptive nonlinear regression. The package is presently being documented for USGS publication.

(6) The papers on posterior confidence intervals and the Techniques of Water-Resources Investigations (TWRI) on theory of the Modular Finite Element Model that were in press last 


\section{GROUND-WATER HYDROLOGY}

year were published, as was a short supplement to the TWRI "Regression Modeling of Ground-Water Flow."

(7) A new geostatistical model for parameter estimation and nonlinear regression solution of ground-water modeling problems was developed, the procedures needed to incorporate correlations among prior parameter estimates were incorporated into MODFLOWP (see point 1 above), and testing will begin soon.

(8) A synthetic ground-water model developed by Dave Pollock was calibrated using nonlinear regression. This test case was used to develop the five processing codes (see point 3 above) and some experimental software for including realistic spatial variations in groundwater parameters (see point 7 above). The effort was written up and is intended to be completed as a published case study.

(9) Work with Tom Winter's project was initiated to develop a MODFLOWP calibration of the ground-water flow system around Williams Lake, Minnesota.

REPORTS PUBLISHED 1988-1993:

Battaglin, W.A., and Hill, M.C., 1989, Simulated effects of future withdrawals on water levels in the northeastern coastal plain aquifers of New Jersey: U.S. Geological Survey WaterResources Investigations Report 88-4199, 58 p.

Bennett, G.D., Reilly, T.E., and Hill, M.C., 1990, Technical training notes in ground-water hydrology-Radial flow to a well: U.S. Geological Survey Water-Resources Investigations Report 89-4134, 83 p.

Cooley, R.L., 1992, A modular finite-element model (MODFE) for areal and axisymmetric ground-water flow problems-Part 2. derivation of finite-element equations and comparisons with analytical solutions: Techniques of Water-Resources Investigations of the U.S. Geological Survey, book 6, chap. A4, 108 p. 1993, Exact Scheffe-type confidence intervals for output from groundwater flow models, 1, use of hydrogeologic information: Water Resources Research, v. 29, no. 1, p. 17-33.

1993, Exact Scheffe-type confidence intervals for output from groundwater flow models, 2. combined use of hydrogeologic information and calibration data: Water Resources Research, v. 29 , no. 1, p. $35-50$.

1993, Regression modeling of ground-water flow, supplement 1-Modifications to the computer code for nonlinear regression solution of steady-state ground-water flow problems: U.S. Geological Survey Techniques of WaterResources Investigations, book 3, chap. B4, supplement $1,8 \mathrm{p}$.

Cooley, R.L., and Hill, M.C., 1992, A comparison of three Newton-like nonlinear least-squares methods for estimating parameters of groundwater flow models, in Russell, T.F., Ewing, R.E., Brebbia, C.A., Gray, W.G., and Pinder, G.F., eds., Computational methods in 


\section{GROUND-WATER HYDROLOGY}

water resources; IX Numerical methods in water resources, International Conference on Computational Methods in Water Resources, 9th, Denver, Colo., Proceedings: New York, Elsevier, v. 1, p. 379-386.

Cooley, R.L., and Naff, R.L., 1990, Regression modeling of ground-water flow: Techniques of Water-Resources Investigations of the U.S. Geological Survey, book 3, chap. B4, 232 p.

Hill, M.C., 1988, A comparison of coupled freshwater-saltwater sharp-interface and convectivedispersive models of saltwater intrusion in a layered aquifer system, in Celia, M.A., Ferrand, L.A., Brebbia, C.A., Gray, W.G., and Pinder, G.F., eds., Computational methods in water resources, v. 1, modeling surface and sub-surface flows: International Conference on Computational Methods in Water Resources, 7th, Boston, Mass., 1988, [Proceedings], New York, Elsevier, p. 211-216.

1989, An analysis of accuracy of approximate, simultaneous, nonlinear confidence intervals on hydraulic heads in analytical and numerical test cases: Water Resources Research, v. 25, no. 2, p. 177-190.

1990, Relative efficiency of four parameterestimation methods in steady-state and transient ground-water flow models, in Gambolati, G., Rinaldo, A., Brebbia, C.A., Gray, W.G., and Pinder, G.F., eds., Computational methods in subsurface hydrology: International Conference on Computational Methods in Water Resources, 8th, Venice, Italy, 1990, [Proceedings], New York, Springer-Verlag, p. 103-108.

1990, Preconditioned Conjugate-Gradient 2 (PCG2), a computer program for solving ground-water flow equations: U.S. Geological Survey Water-Resources Investigations Report 90-4048, 43 p.
1990, Solving groundwater flow problems by conjugate-gradient methods and the strongly implicit procedure: Water Resources Research, v. 26, no. 9, p. 1961-1969.

1992, A computer program (MODFLOWP) for estimating parameters of a transient, threedimensional groúnd-water flow model using nonlinear regression: U.S. Geological Survey Open-File Report 91-484, 358 p.

Hill, M.C., Lennon, G.P., Hebson, C.S., Brown, G.A., and Rheaume, S.J., 1992, Geohydrology of, and simulation of ground-water flow in, the valley-fill deposits in the Ramapo River Valley, New Jersey: U.S. Geological Survey Water-Resources Investigations Report 904151, $92 \mathrm{p}$.

Schuster, P.F., and Hill, M.C., in press, Hydrogeology and saltwater intrusion in the shallow aquifer system of southern Cape May County, New Jersey: U.S. Geological Survey WaterResources Investigations Report 91-4043. 


\title{
GROUND-WATER HYDROLOGY
}

TITLE: $\quad$ Field Applications of Unsaturated Zone Flow Theory (CR 69-200)

\author{
PERSONNEL: Edwin P. Weeks, Project Chief \\ Evelyn R. Warren, Office Auto. Assist. \\ Lana K. Gerlick, Office Auto. Clerk \\ Richard W. Healy, Hydrologist \\ David I. Stannard, Hydrologist \\ Dean E. Anderson, Hydrologist \\ James A. Tindall, Hydrologist \\ Shawn L. Arbuckle, Student, (Univ. of Colo.)
ADDRESS: U.S. Geological Survey, P.O. Box 25046, MS 413, Denver Federal Center, Denver, CO 80225

TELEPHONE: (303) 236-4981

PROBLEM: Various processes within the unsaturated zone affect ground-water availability and potability, as well as concentrations of water vapor and trace gases in the atmosphere. The rate at which precipitation or applied irrigation water infiltrates, its redistribution following infiltration, and the partitioning of the redistributed soil moisture between ground-water recharge and evapotranspiration affect the rate at which the ground-water reservoir is replenished and the degree to which ground water might be contaminated by chemical applications, spills, or disposal. Consequently, knowledge of and methods to quantitatively measure and predict these processes are needed to determine the impact of such societal practices as irrigation development for agriculture, the use of agricultural chemicals, and the disposal of radioactive and/or hazardous waste in the unsaturated zone on both the availability and potability of ground water. Processes governing transport in the unsaturated zone gas phase are also important in determining the potential for ground-water contamination by volatile compounds, the rate at which water is returned from soil moisture to the atmosphere as vapor, and the fate of other "greenhouse gases," such as carbon dioxide, methane, and chlorofluorocarbons (CFCs). An understanding and quantification of these processes is needed both to assess the hazards of ground-water pollution and to better predict the impact of global change on future climate.

OBJECTIVE: The goals of this project are to develop an improved understanding of the processes governing the movement of liquids and gases in the unsaturated zone, and to develop methods to quantitatively assess and model the phenomena. Processes and phenomena under investigation include those involving the movement of water and chemicals through the unsaturated zone, with particular emphasis on processes that might result in rapid transport of dissolved chemicals to the water table and (or) volatile compounds to the atmosphere. An understanding of the role of various gas-phase transport processes, on soil 


\section{GROUND-WATER HYDROLOGY}

moisture, on the distribution of volatile compounds within the unsaturated zone, and on atmospheric-unsaturated zone exchange is also sought. Processes involving plant-soilatmosphere interactions, including evapotranspiration, plant $\mathrm{CO}_{2}$ uptake, and root respiration of $\mathrm{CO}_{2}$, are being studied to develop measurement and modeling techniques for those phenomena.

APPROACH: Field and laboratory investigations of the movement of water and gas and liquid tracers through both highly structured and unstructured soils are underway. Models are being developed to provide predictive capabilities for assessing the impact of agricultural and waste disposal practices on the potential for ground-water contamination. Gas phase movement is being studied through measurement of flow in open boreholes and models are being developed to simulate the observed phenomena and to assess the importance of various gas-phase transport mechanisms under natural conditions. Evapotranspiration and plant-soilatmosphere interactions are being investigated by the development of various techniques for measuring the interchange of water vapor and other gases between the atmosphere and the plant-soil continuum. These methods include the use of chambers (flux boxes), profile or gradient methods, and eddy correlation techniques. Various modeling techniques are under development to extend such measurement in space and time.

PROGRESS: Evaporation, evapotranspiration (ET), and trace-gas studies were conducted at Williams Lake, Minnesota, and at a multiagency field experimental site near Chickasha, Oklahoma. The lake study indicates that the large winter buildup of $\mathrm{CO}_{2}$ in the ice-covered lake is quickly released to the atmosphere just after ice-out. A paper on modeling ET from sparse phreatophytic vegetation in the San Luis Valley, Colorado, has been published, and another, on ET measured in hilly terrain in the Walnut Gulch watershed, Arizona, has been prepared.

Studies of unsaturated flow and transport of agricultural chemicals is being studied at an intensively instrumented agricultural site underlain by a highly structured claypan soil in Missouri in support of the midcontinent herbicide initiative. These studies indicate that intense summer rains can move herbicides applied earlier in the season through the clay pan to the ground-water reservoir.

A backward method-of-characteristics code for simulation of transport through unsaturated porous media is being developed to avoid problems of numerical dispersion and oscillations inherent in finite-difference codes. The code is operational for one-dimension transport, and is being extended to two dimensions. Numerical simulations made using an axisymmetric diffusion code indicate that flux chamber measurements of trace gas exchange between soil 


\section{GROUND-WATER HYDROLOGY}

and the atmosphere, a widely used method for making such measurements, are substantially lower than those actually occurring, indicating the need for improved methods.

Studies of gas-phase circulation through the fractured rocks comprising Yucca Mountain continue in support of characterizing the site for nuclear waste disposal. Chlorofluorocarbon (CFC) concentrations measured in rock gas from well UZ6s in both March 1992 and March 1993 are about 80 percent of their concentration in the atmosphere, despite the fact that several million cubic meters have been exhausted from well UZ6s since the time of its completion in 1985 . These observations, as well as those of radiocarbon activity, suggest that the exhausted air is a nearly time-invariant mixture of of atmospheric air and residual rock gas.

\section{REPORTS PUBLISHED 1988-199.3:}

Anderson, D.E., Miller, D.R., Wang, Y.S., • Yendol, W.G., and Mierzejewski, K., 1992, Deposition of aerially applied BT in an oak forest and its prediction with the FSCBG model: Journal of Applied Meteorology, v. 31, p. 1457-1466.

Blanford, J.H., and Stannard, D.I., 1991, Spatial variability of energy fluxes at Walnut Gulch: American Meteorological Society Special Session on Hydrometeorology, Salt Lake City, 1991 [Proceedings], p. 158-160.

Healy, R.W., 1990, Results of some geohydrologic studies at the low-level radioactive-waste repository site near Sheffield, Illinois, in Bedinger, M.S., and Stevens, P.R., eds., Safe disposal of radionuclides in low-level radioactive-water repository sites: U.S. Geological Survey Circular 1036, p. 13-16.

1990, Simulation of solute transport in variably saturated porous media with supplemental information on modifications to the U.S. Geological Survey's Computer Program VS2D: U.S. Geological Survey Water-Resources Investigations Report 90-4025, 125 p.
Healy, R.W., Gray, J.R., deVries, M.P., and Mills, P.C., 1989, Water balance at a lowlevel radioactive-waste disposal site: Water Resources Bulletin, v. 25, no. 3, p. 1-10.

Healy, R.W., and Mills, P.C., 1992, Variability of an unsaturated sand unit underlying a radioactive-waste trench: Soil Science Society of America Journal, v. 55, no. 4, p. 899-907.

Healy, R.W., and Russell, T.F., 1989, Efficient implementation of the modified method of characteristics in finite-difference models of solute transport, in Proceedings of Conference on Solving Ground Water Problems with Models: Indianapolis, Indiana, National Water Well Association, p. 483-491.

1992, Solution of the advection-dispersion equation by a finite-volume EulerianLagrangian local adjoint method, in Russell, T.F., Ewing, R.E., Brebbia, C.A., and Pinder, G.F., eds., Computational Methods in Water Resources-Numerical methods in water resources: Boston, Computational Mechanics Publications, chap. 9, v. 1, p. 25-32. 


\section{GROUND-WATER HYDROLOGY}

Healy, R.W., and Russell, T.F., 1993, A finitevolume Eulerian-Lagrangian localized adjoint method for solution of the advection-dispersion equation: Water Resources Research, v. 29, no. 7 .

Healy, R.W., and Warrick, A.W., 1988, A generalized solution to infiltration from a surface point source: Soil Science Society of America Journal, v. 52, no. 5, p. 1245-1251.

Ishii, A.L., Healy, R.W., and Striegl, R.G., 1989, A numerical solution for the diffusion equation in hydrogeologic systems: U.S. Geological Survey Water-Resources Investigations Report 89-4027, 86 p.

Kipp, K.L., and Healy, R.W., 1990, Characterizing and monitoring low-level radioactive-waste repository sites, in Bedinger, M.S., and Stevens, P.R., eds., Safe disposal of radio nuclides in low-level radioactive-waste repository sites: U.S. Geological Survey Circular 1036 , p. $6-8$.

Kustas, W.P., Goodrich, D.C., Moran, M.S., Amer, S.A., Bach, L.B., Blanford, J.H., Chebouni, A., Claassen, H. Clements, W.D., Doraiswamy, P.C., Dubois, P., Clarke, T.R., Daughtry, C.S.T., Gellman, D.I., Grant, T.A., Hipps, L.E., Huete, A.R., Humes, K.S., Jackson, T.J., Keefer, T.O., Nichols, W.D., Parry, R., Perry E.M., Pinker, R.T., Pinter, P.J. Jr., Qi, J., Riggs, A.C., Schmugge, T.J., Shutko, A.M., Stannard, D.I., Swiatek, E., van Leeuwen, J.D., van Zyl, J., Vidal, A., Washburne, J., and Weltz, M.A., 1991, An interdisciplinary field study of the energy and water fluxes in the atmosphere-biosphere system over semiarid rangelands-Description and some preliminary results: Bulletin of the American Meteorological Society, v. 72, no. 11, p. 1683-1705.
Kustas, W.P., Moran, M.S., Pinter, P.J., Hipps, L.E., Swiatek, E., Stannard, D.I., and Blanford, J.H., 1991, Issues in mapping evapotranspiration over large areas with remote sensing data from Monsoon '90: American meteorological Society Special Session on Hydrometeorology, Salt Lake City, 1991, [Proceedings], p. 151-154.

Lodge, D.M., Krabbenhoft, D.P., and Striegl, R.G., 1989, A positive relationship between groundwater velocity and submersed macrophyte biomass in Sparkling Lake, Wisconsin: Limnology and Oceanography, v. 34, no. 1, p. 235-239.

Mills, P.C., and Healy, R.W., 1989, Water and tritium movement through the unsaturated zone at a low-level radioactive-waste disposal near Sheffield, Illinois, 1981-1985: U.S. Geological Survey Open-File Report 89-271.

Moran, M.S., Kustas, W.P., Vidal, A., Stannard, D.I., and Blanford, J.H., 1991, Use of ground-based remotely sensed data for surface energy balance calculations during Monsoon '90: International Geoscience and Remote Sensing Symposium, Espoo, Finland, 1991, [Proceedings], p. 33-37.

Stannard, D.I., 1988, Use of a hemispherical chamber for measurement of evapotranspiration: U.S. Geological Survey Open-File Report $88-452,18 \mathrm{p}$.

1990, Tensiometers-Theory, construction, and use: American Society for Testing and Materials Special Teclnical Publication 1053, p. 34-51.

1990, Energy-budget eddy-correlation technique in Czarnecki, J.B., Geohydrology and evapotranspiration at Franklin Lake Playa, Inyo County, California: U.S. Geological Survey Open-File Report 90-356, p. 32-45. 


\section{GROUND-WATER HYDROLOGY}

1992, Tensiometers-Theory, construction, and use: Geotechnical Testing Journal, v. 15, no. 1, p. $48-58$.

1992, Bowen-ratio measurements at sites $C$ and $\mathrm{F}$ in Wilson, D.H., Reginato, R.J., and Hollett, K.J., eds., Evapotranspiration measurements of native vegetation, Owens Valley, California, June, 1986: U.S. Geological Survey Water-Resources Investigations Report 91-4159, chap. B, p. 19-24.

1993, Comparison of Penman-Monteith, Shuttleworth-Wallace, and modified PriestleyTaylor evapotranspiration models for wildland vegetation in semiarid rangeland: Water Resources Research, v. 29, no. 5, p. 1379-' 1392.

in press, Energy-budget eddy-correlation technique, in Czarnecki, J.B., Geohydrology and evapotranspiration at Franklin Lake Playa, Inyo County, California: U.S. Geological Survey Water-Supply Paper 2377.

Stannard, D.I., and Rosenberry, D.O., 1991, A comparison of short-term measurements of lake evaporation using eddy-correlation and energy-budget methods: Journal of Hydrology, v. 122 , p. $15-22$.

Steffeck, D.W., and Striegl, R.G., 1989, An inventory and evaluation of biological investigations that relate to stream-water quality in the upper Illinois River basin of Illinois, Indiana, and Wisconsin: U.S. Geological Survey WaterResources Investigations Report 89-4041, 54 p.

Striegl, R.G., 1988, Fate of gaseous Tritium and 14-Carbon released from buried low-level radioactive waste, in Annual Participants Information Meeting, DOI Low-Level Waste Management Program, 10th, Denver, Colo., 1988, Proceedings: Idaho Falls, Idaho, U.S.
Department of Energy, CONF 880839-Ses. III, p. 29-34.

1989, Gases in the unsaturated zone, in Ryan, B.J., ed., Results of hydrologic research at lowlevel radioactive waste site near Sheffield, Illinois: U.S. Geological Survey Open-File Report 88-318, p. 69-80 (pending publication as a Water-Supply Paper).

Striegl, R.G., and Healy, R.W., 1990, Transport of 14-carbon dioxide in unsaturated glacial and eolian sediments, in Bassett, R.L. and Melchoir, D.C., eds., Chemical Modeling in Aqueous Systems II: American Chemical Society Symposium Series, No. 416, chap. 15, p. 202-210.

Striegl, R.G., and Ishii, A.L., 1989, Diffusion and consumption of methane in an unsaturated zone in north-central Illinois, U.S.A.: Journal of Hydrology, v. 111 p. 133-143.

Thorstenson, D.C., Weeks, E.P., Haas, H., and Woodward, J.C., 1990, Physical and chemical characteristics of topographically-affected airflow in an open borehole at Yucca Mountain, Nevada: American Nuclear Society Focus 89 Conference [Proceedings], p. 256-270.

Wang, Y.S., Miller, D.R., Anderson, D.E., Cionco, R., and Lin, J.D., 1992, Spatial length scale analysis of turbulent temperature and velocity fluctuations within and above an orchard canopy: Boundary Layer Meteorology, v. 59 , p. $125-139$.

Weeks, E.P., 1990, Thoughts on geohydrologic characterization for prospective low-level radioactive-waste repository sites, in Bedinger, M.S., and Stevens, P.R., eds., Safe disposal of radionuclides in low-level radioactive-waste repository sites: U.S. Geological Survey Circular 1036, p. 104-106. 


\section{GROUND-WATER HYDROLOGY}

in press, Does the wind blow through Yucca Mountain?-Proceedings of the Fifth Workshop on Flow and Transport in Unsaturated

Fractured Rock: Nuclear Regulatory Commission, NUREG, $20 \mathrm{p}$. 


\title{
GROUND-WATER HYDROLOGY
}

TITLE: Ground-Water Solute-Transport Simulation (CR 85-292)

PERSONNEL: Kenneth L. Kipp, Project Chief

Evelyn R. Warren, Office Auto. Assist.

Lana K. Gerlick, Off. Auto. Clerk

Kenneth G. Stollenwerk, Hydrologist

Thomas F. Russell, Professor (University of

Colorado, Denver)

James S. Otto, Professor (University of

Colorado, Denver)

\begin{abstract}
ADDRESS: U.S. Geological Survey, P.O. Box 25046, MS 413, Denver Federal Center, Denver, CO 80225
\end{abstract}

TELEPHONE: (303) 236-4991

PROBLEM: Ground-water solute-transport simulation modeling is an important tool that aids in the analysis of ground-water contamination problems, both actual and potential. Accidental spills, leakage, and waste disposal operations can lead to ground-water contamination. The ability to analyze and predict the movement of solutes in ground-water systems is necessary to assess the effects of a contamination situation or properly design a waste-disposal operation. Laboratory experiments are essential to understanding geochemical reactions in the field and for obtaining the necessary reaction coefficients and rate constants used in transport models. Simulation modeling also is used to compare alternative strategies for aquifer reclamation. In some cases, the transported component of interest is thermal energy. Heat transport simulation is useful in the analysis of geothermal systems, waste heat storage systems, and some deep aquifer systems.

OBJECTIVE: Develop and apply new analytical, quasi-analytical, and numerical techniques to the field of saturated ground-water solute-transport simulation modeling. Develop mathematical representations of solute-porous medium interactions and chemical reactions and develop and apply efficient algorithms for numerical calculation. Apply analytical and numerical simulation modeling to laboratory and field-scale situations, both actual and experimental. Evaluate accuracy of laboratory experiments for predicting geochemical behavior of solutes in the field.

APPROACH: Formulate transport equations for systems being studied, develop or adapt various methods for solving the equations, develop and test various algorithms for numerical computation or simulation calculations, develop methods to identify and model chemical reactions, and apply the methods to laboratory or field-scale experimental situations and 


\section{GROUND-WATER HYDROLOGY}

actual field situations. Work closely with District, other Federal, and State research projects involved in similar studies.

PROGRESS: A journal article on a computer code for simulating multi-species solute transport in one dimension with equilibrium controlled precipitation/dissolution and oxidation/reduction reactions was published. The project report on the Rhode Island low-level nuclear contamination study site was approved for publication as a Water Supply Paper. Extensive consultation on and further development of the HST3D simulator were done with the San Diego Office of the California District working on the Ventura Regional Aquifer System Analysis (RASA) Project. A deficiency in the numerical representation of cross-dispersive flux terms under conditions of diagonal flow was identified, and a possible resolution developed. Use of HST3D on this project was terminated in November when model size exceeded Data General workstation capability of about 25,000 nodes. The new nodal renumbering scheme developed in conjunction with a partitioned, restarted conjugategradient interactive equation solver, was extended to three-dimensional finite-difference meshes. This scheme has low sensitivity of iterations to the renumbering direction. Testing revealed a significant advantage of modified incomplete LU preconditioning over normal incomplete LU preconditioning and the discovery of an optimal number of retained directions that is problem dependent. In April 1992, an agreement was reached whereby the Project Chief will work half-time for the Utah District for 2 years to do the numerical modeling for the Bonneville Salt Flats Study. Preliminary flow and transport modeling has been done, leading to identification of information gaps for quantifying sensitive boundary conditions. A low water-table anomaly along the flank of the Silver Island Mountains could be the result of ground-water pumpage in the area; however, uncertainties about the amount of recharge mean that more data are necessary to understand the cause of this anomaly.

A journal article describing the interaction between a plume of acidic ground water and alluvium at the Pinal Creek site, Arizona, was approved and submitted for publication to Applied Geochemistry. A chapter on the same subject was written for a Water Supply Paper. Two invited talks on simulating transport of molybdate in ground water were given at the Goldschmidt Conference in Reston, Virginia, and at the annual meeting of the American Geophysical Union in San Francisco, California. A one-dimensional solute-transport code was used to successfully simulate the transport of molybdate in portions of the aquifer; work has begun on simulating transport in two dimensions. Consulting continued with the Idaho District concerning the problem of contamination of the Snake River Plain Aquifer beneath the Idaho National Engineering Laboratory. A new study was initiated for the Air National Guard to evaluate transport of phosphate in an aquifer on Cape Cod, Massachusetts. 


\section{GROUND-WATER HYDROLOGY}

Laboratory column experiments are being conducted to evaluate the future mobility of phosphate and to aid in the design of a remediation strategy.

A preprocessing program for the HST3D simulation computer program was developed to evaluate array dimension requirements and create new computer program parameter statements that are dimensioned to meet the requirements of a given simulation problem. A renumbering and reformatting program for FORTRAN-77 program codes was developed. It is menu driven and can clean up statement indentation, renumber statement labels, and preserve format statement numbers in their own number series. It significantly improves the readability of FORTRAN code particularly after extensive code modifications.

REPORTS PUBLISHED 1988-1993:

Engesgaard, Peter, and Kipp, K.L., 1992, A geochemical transport model for redox-controlled movement of mineral fronts in ground-water flow systems-Denitrification by oxidation of pyrite: Water Resources Research, v. 28, no. 10, p. 2829-2843.

Garabedian, S.P., LeBlanc, D.R., Quadri, R.D., Hess, K.M., Stollenwerk, K.G., and Wood, W.W., 1988, Design and implementation of a large-scale natural-gradient tracer test, in Ragone, S.E., ed., U.S. Geological Survey Program on Toxic Waste-Ground-water contamination: U.S. Geological Survey Open-File Report 86-481, p. B-13-B-18.

Glynn, P.D., Engesgaard, Peter, and Kipp, K.L., 1991, Two geochemical mass transport codes: Their use and limitations at the Pinal Creek Toxic Waste sites, in Mallard, G.E., and Aronson, D.A., eds., U.S. Geological Survey Toxic Substances Hydrology Program-Proceedings of the technical meeting, Monterey, Calif., March 11-15, 1991, : U.S. Geological Survey Water-Resources Investigations Report 91-4034, p. 454-460.

Healy, R.W., and Russell, T.F., 1989, Efficient implementation of the modified method of characteristics in finite-difference models of solute transport, in Proceedings of Conference on Solving Ground Water Problems with Models, Indianapolis, Indiana: National Water Well Association, p. 483-491.

Healy, R.W., and Russell, T.F., 1992, Solution of the advection-dispersion equation by a finitevolume Eulerian-Lagrangian localized adjoint method, in Russell, T.F., Ewing, R.E., Brebbia, C.A., and Pinder, G.F., eds., Computational methods in water resources-IX. Numerical methods in water resources: Boston, Computational Mechanics Publications, and London, Elsevier, v. 1, p. 33-39.

Kipp, K.L., and Healy, R.W., 1990, Characterizing and monitoring low-level radioactive-waste repository sites, in Bedinger, M.S., and Stevens, P.R., eds., Safe disposal of radionuclides in low-level radioactive-waste repository sites: U.S. Geological Survey Circular 1036, p. 6-8.

Kipp, K.L., Russell, T.F., and Otto, J.S., 1992, D4Z-A new renumbering for iterative solution of ground-water flow and solute-transport equations, in IX. Computational Methods in Water Resources, in Russell, T.F., Ewing, R.E., Brebbia, C.A., Gray, W.G., and Pinder, G.F., eds., Numerical Methods in 


\section{GROUND-WATER HYDROLOGY}

Water Resources: Southampton, Computational Mechanics Publications, and London, Elsevier Applied Science, v. 1, p. 495-502.

LeBlanc, D.R., Garabedian, S.P., Hess, K.M., Gelhar, L.W., Quadri, R.D., Stollenwerk, K.G., and Wood, W.W., 1991, Large-scale natural-gradient tracer test in sand and gravel, Cape Cod, Massachusetts, (1) Experimental design and observed tracer movement: Water Resources Research, v. 27, no. 5, p. 895-910.

Schumacher, J.G., and Stollenwerk, K.G., 1991, Geochemical controls on the migration of molybdenum, uranium, and other constituents at the Weldon Spring Chemical Plant Site, in Proceedings of the Geosciences Workshop, O'Fallon, Missouri, February 21, 1991: U.S. Dept. of Energy DOE/OR/21548-197, p. 87-140.

Stollenwerk, K.G., 1988, Neutralization of acidic ground water in eastern Arizona, in Ragone, S.E., ed., U.S. Geological Survey Program on Toxic Waste-Ground-water contamination: U.S. Geological Survey Open-File Report 86-481, p. E-7-E-8.

1989, Solubility of aluminum and iron in ground water near Globe, Arizona: U.S. Geological Survey Water-Resources Investigations Report 88-4220, p. 581-591.

1991, Simulation of copper, cobalt, and nickel sorption in an alluvial aquifer near Globe, Arizona, in Mallard, G.E. and Arsonson, D.A., eds., U.S. Geological Survey Toxic Substances Hydrology Program-Proceedings of the technical meeting, Monterey, Calif., March 11-15, 1991: U.S. Geological Survey Water-Resources Investigations Report 914034, p. 502-506.

1991, Simulation of molybdate sorption with the diffuse layer surface-complexation model, in Mallard, G.E. and Arsonson, D.A., eds., U.S. Geological Survey Toxic Substances Hydrology Program-Proceedings of the technical meeting, Monterey, Calif., March 1115, 1991: U.S. Geological Survey WaterResources Investigations Report 91-4034, p. 47-52.

Stollenwerk, K.G., and Kipp, K.L., 1989, Simulation of the rate-controlled transport of molybdate in column experiments: U.S. Geological Survey Water-Resources Investigations Report 88-4220, p. 151-161.

1990, Simulation of molybdate transport with different rate-controlled mechanisms, in Melchior, D.C., and Bassett, R.L., eds., Chemical modeling of aqueous systems II: Washington, D.C., American Chemical Society Symposium Series No. 416, American Chemical Society, chap. 19, p. 243-257. 


\section{GROUND-WATER HYDROLOGY}

TITLE: $\quad$ Application of Stochastic Processes in Hydrogeology (CR 90-319)

PERSONNEL: Richard L. Naff, Project Chief

Evelyn R. Warren, Office Auto. Assist.

Lana K. Gerlick, Office Auto. clerk

ADDRESS: $\quad$ U.S. Geological Survey, P.O. Box 25046, MS 413, Denver Federal Center, Denver, CO 80225

TELEPHONE: (303) 236-4986

PROBLEM: Many aspects of ground-water flow and transport resist standard, deterministic modeling techniques: there exist elements which either are overly complex or which are simply unpredictable. These elements may have either a spatial character, such as heterogeneity in porous media, or a temporal character, such as recharge events to an aquifer. Provided that an adequate representation can be found, these aspects of flow and transport frequently are better modeled by taking the complex or unpredictable element to be a stochastic process. Given an adequate representation, then the following questions may be addressed: (1) What is the implication of these elements for flow and transport in porous media? (2) Given observations of the physical process (hydraulic heads, concentrations, discharges), can the stochastic element be characterized (variances, length scales)? (3) Can an adequate monitoring program be designed when the physical process incorporates complex or unpredictable elements?

OBJECTIVE: The principal objective of this research is a better understanding of flow and transport phenomena when the underlying physical process contains one or more stochastic elements. A subsidiary objective is the development of a network model to evaluate sampling schemes when the physical process contains a stochastic element. An inverse procedure whereby the statistical properties of the stochastic element can be determined from the outputs of the physical process will be a necessity if these models are to be utilized. Where practicable, investigation will include development of usable computer codes.

APPROACH: Use probability theory to investigate those elements of flow and transport in porous media which are overly complex or unpredictable. The primary tools used to date to investigate problems with complex spatial elements can be loosely lumped under perturbation techniques and Monte Carlo simulation. Problems with stochastic inputs are usually best handled with transfer-function techniques. Both of these techniques usually require that a 


\section{GROUND-WATER HYDROLOGY}

model of the system be conceptualized such that inputs and outputs are linked; in most cases, this linkage is in the form of a stochastic partial differential equation (SPDE's). Other techniques for solving SPDE's will be investigated: these include the use of Banach spaces from functional analysis and the use of adjoined sensitivities in numerical schemes.

PROGRESS: Work has been completed on a second-order correct formulation of the spatial moments of the mean tracer cloud. This initial result is limited by the restrictive assumptions concerning the nature of the velocity field correlation structure; however, some initial results were produced for higher moments (third and fourth) that indicate, in exceptional circumstances, the tracer cloud may never become Gaussian. A correction factor for the second central moment and macrodispersivity, which allows for the extension of these quantities to more variable media, was also obtained and investigated. A manuscript, based on this work, has been prepared and has received Director's approval for publication in Water Resources Research.

In conjunction with colleagues at the University of Waterloo, Canada, an investigation of the effect of temporal variation in the velocity field on dispersion in the subsurface has been initiated. The thrust of this research is to investigate the effect of small-scale transients on the dispersive process when these transients are effectively ignored in the modeling process. Results of this investigation indicate that a typical conservative plume is distorted in response to these transients, causing an apparent increase in the effective transverse dispersion, but a decrease in the effective longitudinal dispersion. These results, plus an analysis of the conservative Cape Cod plume, were reported on at a recent conference in Waterloo, Canada, in the honor of the late Dr. T.E. Unny. A manuscript, based on this analysis, is being prepared for journal publication.

In conjunction with researchers at the University of Waterloo, a Monte Carlo simulation of plume movement through a heterogeneous porous medium has also been completed. In these simulations, it was considered that the hydraulic conductivity and retardation factor were correlated, three-dimensional random processes. These simulations largely confirm this investigator's original, first-order result for transport of a conservative tracer in heterogeneous porous media. Through the simulation of reactive tracers, the investigation included the effect of a spatially variable retardation field on transport in the subsurface. The effect of this addition source of velocity variation of a particle on dispersion was investigated, as well as an effective retardation factor for the mean tracer cloud. A manuscript based on this work has been prepared and submitted to the Director's office for approval. 


\section{GROUND-WATER HYDROLOGY}

\section{REPORTS PUBLISHED 1990-1992:}

Cooley, R.L., and Naff, R.L., 1990, Regression modeling of ground-water flow: U.S. Geological Survey Techniques of Water-Resources Investigations, book 3, chap. B4, 232 p.

Gomez, B., Naff, R.L., and Hubbell, D.W., 1989, Temporal variations in bedload transport rates associated with the migration of bedforms: Earth Surface Processes and Landforms, v. 14 , p. $135-156$.

Naff, R.L., 1990, On the nature of the dispersive flux in heterogeneous porous media: Water Resources Research, v. 26, no. 5, p. 10131026.

1991, Radial flow in heterogeneous porous media: an analysis of specific discharge: Water Resources Research, v. 27, no. 3, p. 307-316.

1992, Arrival times and temporal moments of breakthrough curves for an imperfectly stratified aquifer: Water Resources Research, v. 28 , no. 1, p. 53-68.

in press, Temporal and spatial moments for solute transport in heterogeneous porous media -The imperfectly stratified aquifer, in Proceedings of Conference and Workshop on Transport and Mass Exchange Processes in Sand and Gravel Aquifers: Field and Modeling Studies, October 1-4, 1990, Ottawa, Canada.

Naff, R.L., Yel, T.-C. Jim, and Kemblowski, M.W., 1988, A note on the recent naturalgradient tracer test at the Borden site: Water Resources Research, v. 24, no. 12, p. 20992103.
1989, Reply to comment by Gideon Dagan: Water Resources Research, v. 25, no. 12, p. 2523-2525. 


\section{GROUND-WATER HYDROLOGY}

TITLE: $\quad$ Hydrologic Behavior of Cretaceous Shales (NR 81-035)

PERSONNEL: Christopher E. Neuzil, Project Chief

ADDRESS: $\quad$ U.S. Geological Survey, 431 National Center, 12201 Sunrise Valley Drive, Reston, VA 22092

TELEPHONE: (703) 648-5880

PROBLEM: The nature of ground-water flow in low permeability settings is understood poorly because of (1) historic inattention to nonaquifer/nonreservoir rock units, and (2) inherent difficulties, related to time and size scales, of observing the phenomena of interest. Nonetheless, low-permeability units are of great importance because they mediate aquifer/ reservoir behavior, have important roles in the evolution of hydrologic systems and geologic processes over geologic time, and can confine toxic materials for long periods. Cretaceous shales in the midcontinent offer the opportunity of studying, at relatively accessible depths, thick and extensive bodies of low-permeability media.

OBJECTIVE: Develop, through theoretical studies coupled with study of the flow systems in midcontinental Cretaceous shales, a better understanding of the significant flow processes in low-permeability environments. Use this information to extract information about flow history from current conditions and to predict future flow behavior.

APPROACH: Develop or improve techniques for measuring hydraulic, mechanical/hydraulic, and osmotic properties; define existing flow systems, and develop rational theoretical tools for describing flow behavior.

PROGRESS: The first results from the Pierre Shale study have been published (Water Resources Research, July 1993) describing the hydrology of the shale. The paper presents first-hand evidence, from long-term fluid pressure measurements and other data, for a naturally transient flow regime in response to natural stress and temperature changes. It also presents a more rigorous quantitative description of the relevant processes than previously available. This work represents a pioneering effort in shale hydrology; a remarkably similar flow regime in claystone is now being investigated in Switzerland by NAGRA. In both instances anomalously low heads are present in the shale interiors which may be ideal sites for waste confinement. 


\section{GROUND-WATER HYDROLOGY}

A new look at clay and shale permeability was also completed and is in review. Previously overlooked laboratory and inverse results were synthesized with some surprising results. First, it provided direct evidence for the lack of a scale effect in many argillaceous units. Permeabilities at laboratory and regional scales were often comparable. Second, it indicated permeabilities significantly smaller than generally assumed in regional flow studies $\left(10^{-23}\right.$ to $10^{-17}$ meters squared between 0.1 and 0.4 porosity). These results have important implications for our understanding of fluid movement in basins and the ability of geologic processes to affect flow regimes.

A retrospective overview of abnormal pressures is near completion. This study puts abnormal pressures in a hydrodynamic framework which simplifies this complex set of phenomena. It was shown that nearly all abnormal pressures, whether in shallow sediments or midcrustal rock, result from a dynamic balance between geologic forcing and the resulting flow; one need not appeal to concepts such as impermeability and paleopressures. The hydrodynamic framework also clarifies the role of permeability in abnormal pressures and suggests that they are useful for mapping large-scale heterogeneity in crustal permeability.

\section{REPORTS PUBLISHED 1988-1993:}

Neuzil, C. E., 1993, Low fluid pressure within the Pierre Shale-A transient response to erosion: Water Resources Research, no. 29(7), 20072020.

Silliman, S.E., and Neuzil, C.E., 1990, Borehole determination of formation thermal conductivity using a thermal pulse from injected fluid: Journal of Geophysical Research, v. 95, no. B6, p. 8697-8704. 


\section{GROUND-WATER HYDROLOGY}

TITLE: $\quad$ Investigations of Single and Multiphase Fluid Flow, Mass and Energy Transport, and Fluid Phase Change in the Subsurface Environment (NR 78-089)

PERSONNEL: Clifford I. Voss, Project Chief Martin T. Chian, computer assistant, student (University of Virginia) $\begin{array}{ll}\text { ADDRESS: } & \text { U.S. Geological Survey, } 431 \text { National Center, } 12201 \text { Sunrise Valley Drive, } \\ & \text { Reston, VA } 22092\end{array}$

TELEPHONE: (703) 648-5885

PROBLEM: The subsurface environment is subject to both natural and man-imposed stresses, the interaction of which determines both its preservation and its employment as a multifaceted natural resource for water supply, energy production, and subsurface storage of energy and materials. Study of subsurface problems requires synthesis of a theoretical framework of physics of single and multiphase fluid flow, mass and energy transport and fluid phase change as applied to the subsurface environment, and descriptions of subsurface behavior based on measurements in complex heterogeneous environments. Improved understanding is required to solve present subsurface problems.

OBJECTIVE: Elucidate fundamental theory describing flow and transport phenomena in complex heterogeneous geologic environments. Develop quantitative methods for analysis of systems in the subsurface environment involving single and multiphase fluid flow, mass and energy transport and fluid phase change. Apply these methods to field problems in order to illuminate hydrological relationships which are important in both the preservation and optimal employment of the subsurface.

APPROACH: Measure subsurface flow and transport in the field to develop conceptual descriptions of the system. Study system behavior using mathematical models based on either hypothetical or field problem conditions. Develop practical simulation models and analytical methods for quantitative analysis of subsurface problems as well as new measuring techniques as by-products of the investigations.

PROGRESS: Variable-density flow and solute transport simulation analysis of the transition zone in the major coastal aquifer in Oahu, Hawaii, has resulted in identification of major processes controlling regional transition zone dynamics. Field measurements in Oahu, 


\section{GROUND-WATER HYDROLOGY}

Hawaii, to determine scale effects in hydraulic and transport behavior of structured heterogeneous aquifers are complete and isotopic and chemical analysis is underway. . Evaluation of regional ground-water flow in crystalline basement rocks using data collected in Sweden is underway.

\section{REPORTS PUBLISHED 1988-1993:}

Ahlbom, K., Andersson, J-E., Nordqvist, R., Ljunggren, C., Tiren, S., and Voss, C. I., 1991, Gidea study site-Scope of activities and main results: Stockholm, Sweden, Swedish Nuclear Fuel and Waste Management Co. (SKB), SKB Technical Report 91-51, 100 p.

Ahlbom, K., Andersson, J-E., Nordqvist, R., Ljunggren C., Tiren, S., and Voss, C. I., 1991; Fjallveden study site-Scope of activities and main results: Stockholm, Sweden, Swedish Nuclear Fuel and Waste Mangement Co. (SKB), SKB Technical Report 91-52, 104 p.

Ahlbom, K., Andersson, J-E., Nordqvist, R., Ljunggren, C., Tiren, S., and Voss, C. I., 1992, Sterno study site-Scope of activities and main results: Stockholm, Sweden, Swedish Nuclear Fuel and Waste Mangement Co. (SKB), SKB Technical Report 92-02,62 p.

Hunt, C.D., Ewart, C.J., and Voss, C.I., 1988, Region 27, Hawaiian Islands, Chapter 30, in Rosenshein, J., ed., Hydrogeology of North America: Geological Society of America, p. 255-262.

Knopman, D.S., and Voss, C.I., 1988, Further comments on sensitivities, parameter estimation, and sampling design in one-dimensional analysis of solute transport in porous media: Water Resources Research, v. 24-2, p. 225-238.
1988, Discrimination among one-dimensional models of solute transport in porous mediaImplications for sampling design: Water Resources Research, v. 24-11, p. 1859-1876.

1989, Multiobjective sampling design for parameter estimation and model discrimination in groundwater solute transport: Water Resources Research, v. 25-10, p. 2245-2258.

Knopman, D.S., Voss, C.I., and Garabedian, S.P., 1991, Sampling design for groundwater solute transport: Tests of methods and analysis of Cape Cod tracer test: Water Resources Research, v. 27, p. 925-949.

Multhaup, R. A., Voss, C. I., and Souza, W. R., 1989, Subsurface mapping of basalts based on petrographic characterization of cuttings from borehole drilling on Oahu, Hawaii: U.S. Geological Survey Water-Resources Investigations Report 89-4181, 40 p.

Nyberg, G., and Voss, C. I., 1991, Problems in modeling ground-water systems in limited scale: Stockholm, Sweden, Swedish Nuclear Fuel and Waste Management Co. (SKB), SKB Arbetsrapport 91-10, $12 \mathrm{p}$.

Souza, W.R., and Voss, C.I., 1989, Assessment of potable ground water in a freshwater lens using variable-density flow and solute transport simulation, in Solving Ground Water Problems with Models: National Water Well Association, p. 1023-1043. 


\section{GROUND-WATER HYDROLOGY}

Underwood, M. R., Peterson, F. L., and Voss, C. I., Groundwater Lens Dynamics of Atoll Islands: Water Resources Research, v. 28, no. 11, p. 2889-2902.

Voss, C. I., and Andersson, J., 1991, Some aspects of regional flow of variable-density groundwater in crystalline basement rock of Sweden: Stockholm, Sweden, Swedish Nuclear Power Inspectorate (SKI), SKI Technical Report 91:9, $63 \mathrm{p}$.

Voss, C.I., and Knopman, D.S., 1989, Strong classical one-dimensional descriptions of field solute transport exist! Modeling the Cape Cod tracer test, in Solving ground water problems with models: National Water Well Association, p. 209-232.

Voss, C.I., and Souza, W.R., 1991, Modeling a regional aquifer containing a narrow transition between freshwater and saltwater using solute transport simulation-Theory and methods, in De Breuck, W., ed., Selected Papers from SWIM: International Association of Hydrogeologists, Verlag Heize Heise, v. II, p. 189206. 


\title{
GROUND-WATER HYDROLOGY
}

TITLE: Digital Modeling of Transport in the Saturated Zone (NR 81-120)

\author{
PERSONNEL: Leonard F. Konikow, Project Chief \\ Cathy Cather, Secretary \\ Steven C. Lessoff, student (Johns Hopkins Univ.) \\ Gregory E. Granato, Hydrologist \\ Mark Peron, student (University of Minnesota)
ADDRESS: $\quad$ U.S. Geological Survey, 431 National Center, 12201 Sunrise Valley Drive, Reston, VA 22092

TELEPHONE: (703) 648-5878

PROBLEM: Management of ground-water resources requires that the extent and rate of movement of contaminants in the saturated and unsaturated zones be understood. Contaminants have been and will continue to be both accidentally and deliberately introduced into ground-water systems. Some of these contaminants are very hazardous. Because of the immediacy of such contamination problems, understanding of the physical and chemical processes affecting their migration needs to be increased rapidly, and mathematical models derived from this understanding need to be tested and documented.

OBJECTIVE: Investigate the parameters in basic mathematical transport models developed for ground-water systems to increase understanding of the factors influencing these parameters and of the interrelation between parameters.' Derive appropriate two- and threedimensional mathematical models to describe contaminant movement in complex field situations.

APPROACH: Develop numerical models, emphasizing those ground-water systems and contaminants for which transport-models seem most critical. Evaluate the accuracy and efficiency of new and existing modeling techniques through comparisons with analytical solutions, other numerical methods, and observed data from practical field problems.

PROGRESS: A new preprocessor for the USGS method-of-characteristics (MOC) solutetransport model has been developed and documented (in cooperation with the International Ground-Water Modeling Center at the Colorado School of Mines). The preprocessor allows a user to easily create or edit an input data file for the MOC model. The new preprocessor incorporates automatic backup, interactive error and consistency checks, on-line help and hints, and flexible formats for maximum accuracy and precision. 


\section{GROUND-WATER HYDROLOGY}

An analysis of model verification approaches has demonstrated the weakness of the current common philosophy. The analysis focused on one of the base cases of the international HYDROCOIN project, which involved a problem of variable-density ground-water flow and solute transport and was designed to represent a radioactive waste repository in a salt dome. A reanalysis using the USGS MOCDENSE model demonstrated that the HYDROCOIN participants apparently did not recognize some of the processes affecting their numerical solutions and highlighted some reasons why the basic problem was poorly formulated. One conclusion was that consistency among the results of various models during benchmarking is not the same as, and does not demonstrate, model accuracy or reliability. The model analysis also demonstrated some advantages of the method-of-characteristics approach over widely used finite-difference and finite-element methods.

An improved version of the MOC model has been developed. The primary new features include input and output options more compatible with interactive use from a terminal, enhanced formats for 80-character wide printing and viewing, on-screen status messages during execution, and additional input and output options to allow generation of separate output files for easy graphical post-processing of model results (files are written in formats directly readable by many graphical software packages). Work continues on the development and documentation of a three-dimensional version of the method-of-characteristics solute-transport module for the McDonald-Harbaugh modular flow model.

REPORTS PUBLISHED 1988-1993:

Brantley, S.L., Rowe, G.L., Konikow, L.F., and Sanford, W.E., 1992, Natural toxic waters of Poas Volcano, Costa Rica: Journal of Research and Exploration, v. 8, no. 3, p. 328-334.

Bredehoeft, J. D., and Konikow, L. F., 1993 , Ground-water models-Validate or invalidate: Ground Water, v. 31, no. 2. p. 178-179.

Goode, D.J., 1990, Mixed waste leachates in ground water at low-level waste sites, in Safe disposal of radionuclides in low-level radioactive-waste repository sites: U.S. Geol. Survey Circular 1036, p. 49-57.

1990, Particle velocity interpolation in blockcentered finite difference groundwater flow models: Water Resources Research, v. 26, no. 5, p. 925-940.

1990, Governing equations and model approximation errors associated with the effects of fluid-storage transients on solute transport in aquifers: U.S. Geological Survey Water-Resources Investigations Report 90-4156, 20 p.

Goode, D.J., and Konikow, L.F., 1989, Modification of a method-of-characteristics solute-transport model to incorporate decay and equilibrium-controlled sorption or ion exchange: U.S. Geological Survey Water-Resources Investigations Report 89-4030, 65 p. 


\section{GROUND-WATER HYDROLOGY}

1990, Apparent dispersion in transient groundwater flow: Water Resources Research, v. 26, no. 10, p. $2339-2351$.

1990, Re-evaluation of large-scale dispersivities for a waste chloride plume-Effects of transient flow, in Kovar, K., ed., ModelCARE 90-Calibration and reliability in groundwater modeling: IAHS Publication no. 195 , p. $417-426$.

1991, Testing a method-of-characteristics model of three-dimensional solute transport in ground water, in Lennon, G.P., ed., Symposium on Ground Water-Proceedings of the International Symposium: Nashville, Tenn., American Society of Civil Engineers, p. 2127.

Granato, G. E., Konikow, L. F., and Srinivasan, P., 1993, PREMOC (version 4.0), A preprocessor for the two-dimensional method of characteristics (MOC) solute-transport model: Golden, Colo., International Ground Water Modeling Center, $22 \mathrm{p}$.

Konikow, L.F., 1988, Book review of Modeling groundwater flow and pollution, by Bear J., and Veruijt, A.: EOS, v. 69, no. 45, p. 1557.

1988, Present limitations and perspectives on modeling pollution problems in aquifers, in Custudio, E., Gurgui, A., and Lobo Ferreira, J.P., eds., Groundwater Flow and Quality Modeling: Dordrecht, Holland, D. Reidel, p. 643-664.

1988, Application of models, in Custudio, E., Gurgui, A., and Lobo Ferreira, J.P., eds., Groundwater Flow and Quality Modeling: Dordrecht, Holland, D. Reidel, p. 823-827.

1991, Flow and transport problems in groundwater systems, in Proceedings of the International Conference on Nitrogen, Phosphorus, and Organic Matter: Danish Ministry of the Environment, p. 57-66.

1992, Discussion of the "modeling process and model validation," by Chin-Fu Tsang: Ground Water, v. 30, no. 4, p. 622-623.

Konikow, L.F., and Bredehoeft, J.D., 1992, Ground-water models cannot be validated: Advances in Water Resources, v. 15, no. 3, p. 75-83.

Konikow, L.F., and Mercer, J.M., 1988, Groundwater flow and transport modeling: Journal of Hydrology, v. 100, no. 2, p. 379-409.

Konikow, L.F., and Papadopulos, S.S., 1988, Scientific problems, in Back, W., Rosenshein, J.S., and Seaber, P.R., eds., The Geology of North America: Hydrogeology, chap. 49, v. O-2, p. 503-508.

Konikow, L. F., and Rodriguez Arevalo, J., 1993. Advection and diffusion in a variable-salinity confining layer: Water Resources Research, v. 29 , no. 8 , p. $2747-2761$.

Konikow, L.F., and Siegel, D.I., 1988, Meeting report on "Symposium on Paleohydrogeology": EOS, v. 69, no. 42, p. 963.

Konikow, L.F., and Swain, L.A., 1990, Assessment of predictive accuracy of a model of artificial recharge effects in the upper Coachella Valley, California, in Simpson, E.S., and Sharp, J.M., Jr., eds., Selected Papers on Hydrogeology: International Assoc. of Hydrogeologists, IGC Meeting, Washington, D.C., 1989, [Proceedings], v. 1, p. 433-449.

Modeling Project Subcommittee (Science Advisory Board), 1993, An SAB Report-Review of the assessment framework for ground-water model 


\section{GROUND-WATER HYDROLOGY}

applications: Washington, D.C., Environmental Protection Agency, 12 p.

National Research Council, Committee on Ground Water Modeling Assessment, 1990, Ground Water Models-Scientific and regulatory applications: Washington, D.C., National Academy Press, 303 p.

Sacks, L.A., Herman, J.S., Konikow, L.F., and Vela, A.L., in press, Seasonal dynamics of groundwater-lake interactions at Donana National Park, Spain: Journal of Hydrology, v. 136 , no. 2 , p. $123-154$.

Sanford, W.E., and Konikow, L.F., 1989, Porosity development in coastal carbonate aquifers: Geology, v. 17, no. 3, p. 249-252.

1989, Reply to Comment by W.L. Wilson on Porosity development in coastal carbonate aquifers: Geology, v. 17, no. 10, p. 962-963.

1989, Simulation of calcite dissolution and porosity changes in saltwater mixing zones in coastal aquifers: Watęr Resources Research, v. 25 , no. 4, p. 655-667.

Sanford, W.E., and Wood, W.W., 1991, Brine evolution and mineral deposition in hydrologically open evaporite basins: American Journal of Science, v. 291, p. 687-710.

Wood, W.W., and Sanford, W.E., 1990, A model for ground-water control of continental evaporite deposition: Economic Geology, v. 85, no. 6, p. 1226-1235. 


\section{GROUND-WATER HYDROLOGY}

TITLE: $\quad$ Multivariate Statistical Techniques for Assessing Regional Ground-Water Quality and Quantity (NR 84-130)

PERSONNEL: Charles E. Brown, Project Chief

Glenna C. Dahl, Secretary

ADDRESS: U.S. Geological Survey, 431 National Center, 12201 Sunrise Valley Drive, Reston, VA 22092

TELEPHONE: (703) 648-5886

PROBLEM: Regional assessment of the chemical character of ground water requires that unbiased estimates of the chemical species in ground water be obtained. With recent regulations regarding ground-water contamination and disposal of toxic wastes, it is necessary that the methods for assessment of man-induced versus natural chemical character are not biased by experimental design, and that estimates of chemical species present in ground water are not influenced to a large degree by temporal variation and sample collection strategies. It is a requirement as well that populations which are compared are homogeneous in terms of statistical parameters. Implementing statistical design techniques early in the water-quality assessments can lead to maximizing information while minimizing the number of samples needed.

OBJECTIVE: The ultimate objective is to apply and extend statistical design theory to better understand and define ground-water quality parameters. It is the objective also to understand the relations between chemical variables in ground-water systems and to decompose the chemical variability within the system according to contributing sources. The understanding of chemical variability within the ground-water system will provide a basis for application of methodology to other areas with similar hydrogeology.

APPROACH: In order to accomplish this objective, a comprehensive investigation will be undertaken that involves collecting a considerable amount of field data in order to test improved sampling strategies. Multivariate, bivariate, and univariate statistical theory will be applied to all ground-water data collected to improve future sampling designs for ground-water studies. Stochastic and geostatistical analysis will provide better estimates of chemical parameters, which are input to geochemical and transport models.

PROGRESS: Present work activities are related to the overall objectives of the National 


\section{GROUND-WATER HYDROLOGY}

Water-Quality Assessment (NAWQA) Program to characterize the Nation's Ground and Surface waters. Two papers have been published demonstrating (1) a new methodology for defining the radon potential of different suites of rock and (2) a new methodology utilizing multivariate statistics for describing the aquifer productivity potential of carbonate rocks.

\section{REPORTS PUBLISHED 1988-1993:}

Brown, C.E., 1988, Determination of Rock Properties by Borehole Geophysical and Physical Testing Techniques and Ground Water Quality and Movement, Durham Triassic Basin, North Carolina: U.S. Geological Survey Professional Paper 1432, 29 p.

1993, Use of principal-component, correlation, and stepwise multiple-regression analyses to investigate selected physical and hydraulic properties of carbonate-rock aquifers: Journal of Hydrology, v. 147, p. 169-195.

Brown, C.E., Mose, D.G., Mushrush, G.W., Chrosniak, C.E., 1991, Use of Statistical Techniques to Assess the Radon Potential of Rocks in Parts of Virginia and Maryland: National Symposium-Naturally occurring radionuclides in agricultural products: University of Florida, Gainesville, 10 p.

1992, Statistical Analysis of the Radon-222 Potential of Rocks in Virginia: Journal of Environmental Geology and Water Sciences, v. 19 , no. 3, p. 193-203.

Mose, D.G., Mushrush, G.W., Chrosniak, C.E., Brown, C.E., 1989, Carcinogenic Properties of Radon Enriched Piedmont Ground Water in Virginia and Maryland: Conference on Groundwater in the Piedmont of the Eastern United States, Charlotte, N.C., [Proceedings], $12 \mathrm{p}$. 


\title{
GROUND-WATER HYDROLOGY
}

TITLE: $\quad$ Transport Phenomena in Fractured Rock (NR 84-134)

\author{
PERSONNEL: Allen M. Shapiro, Project Chief \\ Glenna C. Dahl, Secretary \\ $\begin{array}{ll}\text { ADDRESS: } & \text { U.S. Geological Survey, } 431 \text { National Center, } 12201 \text { Sunrise Valley Drive, } \\ & \text { Reston, VA } 22092\end{array}$
}

TELEPHONE: (703) 648-5884

PROBLEM: There has been an increasing awareness that, in many circumstances, the theories associated with the description of hydrogeologic phenomena in granular porous media are unacceptable in the description of these same phenomena in fractured rock and geologic formations having similar characteristics. Because of the wide extent of fractured formations and their various uses, including proposed repositories for radioactive waste, a need exists to describe and better understand the physics of fluid movement, deformation, contaminant migration, and energy transport under the broad range of physical situations where fractured formations exist.

OBJECTIVE: Develop mathematical models of transport phenomena in fractured rock. Use alternative conceptualizations of the medium in the development of these models because the description of fractured rock is highly dependent on scale of observation. Investigate the relevant parameters, evaluate physical situations where each conceptualization is applicable, and study the adaptability of field measurements to these conceptualizations.

APPROACH: Consider fractured rock and similar formations as a series of discrete fractures and also in various continuum conceptualizations. Develop mathematical models of transport phenomena. Use hypothetical physical situations and later, if possible, field data and field investigations to examine the applicability of these model conceptualizations and the adaptability of field measurements to these conceptualizations.

PROGRESS: This project coordinates a multidisciplinary research effort to develop field techniques and interpretive methods of characterizing and predicting fluid movement and chemical transport in fractured rock over dimensions that range from meters to kilometers. The multidisciplinary research effort is being conducted in cooperation with six National Research Projects, the New Hampshire and Connecticut District Offices of the Water Resource Division, Geologic Division, and several outside research institutes. The field 


\section{GROUND-WATER HYDROLOGY}

investigations are being conducted in the crystalline rock of the Mirror Lake drainage basin in the Hubbard Brook Experimental Forest in central New Hampshire. These investigations couple geologic and fracture mapping, surface- and borehole-geophysics, ground-water geochemistry, hydraulic and tracer testing, and ground-water and solute-transport modeling. In addition to the overall coordination of this multidisciplinary research effort, this project conducted hydraulic and tracer tests to identify the variability of hydraulic properties of the crystalline rock and to identify transport properties of permeable fractures over dimensions of tens of meters. In addition, water samples for geochemical and isotopic analyses were collected from bedrock wells distributed over 4 square kilometers to investigate fluid movement and chemical transport in fractured crystalline rock over dimensions of kilometers. The interpretation of this data is currently being conducted.

This project has also been involved in a cooperative study conducted in the South Dakota District Office of the Water Resources Division. The cooperative study in the South Dakota office is investigating the water resources of the Madison Aquifer near Rapid City, South Dakota. A method of analyzing prematurely-terminated air-pressurized slug tests in the lower permeability intervals of the Madison Aquifer was developed. The technique is also applicable to other low-permeability subsurface environments. This project also aided in the design of tracer tests to be conducted in the Madison Aquifer to identify transport properties of the formation.

\section{REPORTS PUBLISHED 1988-1993:}

Cvetkovic, V.D., Dagan, G., and Shapiro, A.M., 1991, An exact solution of solute transport by one-dimensional random velocity fields: Stochastic Hydrology and Hydraulics, v. 5, p. 45-54.

Cvetkovic, V.D., and Shapiro, A.M., 1989, Solute advection in stratified formations: Water Resources Research, v. 25, p. 1283-1289.

1990, Mass arrival of sorptive solute in heterogeneous porous media: Water Resources Research, v. 26, p. 2057-2067.

Cvetkovic, V., Shapiro, A. M., and Dagan, G., 1992, A solute flux approach to transport in heterogeneous formations, 2 . Uncertainty analysis: Water Resources Research, v. 28, p. 1377-1388.

Dagan, G., Cvetkovic, V., and Shapiro, A. M., 1992, A solute flux approach to transport in heterogeneous formations, 1 . The general framework: Water Resources Research, v. 28, p. 1369-1376.

Goode, D.J., and Shapiro, A.M., 1991, Comment on Desbarats, A.J., Macrodispersion in sandshale sequences: Water Resources Research, v. 27, p. $135-139$.

1992, Comment on Moreno L., and others, Flow and tracer transport in a single fracture-A stochastic model and its relation to 


\section{GROUND-WATER HYDROLOGY}

some field observations: Water Resources Research, v. 27, p. 129-131.

Shapiro, A.M., 1989, Interpretation of oscillatory water levels in observation wells during aquifer tests in fractured rock: Water Resources Research, v. 25, p. 2129-2137.

1993, The influence of heterogeneity in estimates of regional hydraulic properties in fractured crystalline rock, in Banks, S., and Banks, D., eds.,. Memoires of the 24th Congress: International Association of Hydrogeologists, Hydrogeology of Hard Rocks, Oslo, Norway, June 28-July 2, 1993, p. 125 136.

Shapiro, A.M., and Cvetkovic, V.D., 1988, Stochastic analysis of solute arrival time in heterogeneous porous media: Water Resources Research, v. 24, p. 1711-1718.

1990, A comparison of two- and three-dimensional stochastic models of regional solute movement: Transport in Porous Media, v. 5, p. 1-25.

Shapiro, A.M., and Hsieh, P.A., 1991, Research in fractured-rock hydrogeology-Characterizing fluid movement and chemical transport in fractured rock at the Mirror Lake drainage basin, New Hampshire, in U.S. Geological Survey Toxic Substance Hydrology Program, Proceedings of the technical meeting, Monterey, California, March 11-15, 1991: U.S. Geological Survey Water-Resources Investigations Report 91-4034, p. 155-161.

Shapiro, A.M., and Nicholas, J.R., 1989, Assessing the validity of the channel model of fracture aperture under field conditions: Water Resources Research, v. 25, p. 817-828. 


\section{GROUND-WATER HYDROLOGY}

TITLE: Quantitative Analysis of Heterogeneous Hydrogeologic Controls on Ground-Water Flow and Transport (NR 91-152)

PERSONNEL: Thomas E. Reilly, Project Chief

Cathy Cather, Secretary

ADDRESS: $\quad$ U.S. Geological Survey, 431 National Center, 12201 Sunrise Valley Drive, Reston, VA 22092

TELEPHONE: (703) 648-5006

PROBLEM: Heterogeneous geologic material affects ground-water flow and transport on all scales. On the local scale, changes in hydraulic and geochemical properties can occur over distances on the order of centimeters. On the intermediate scale, the heterogeneity of intra-aquifer depositional layers in unconsolidated material and fractures in-consolidated material influences the pathways of ground-water movement. On a regional scale, the heterogeneities due to extensive aquifers and confining units affect the flow system in a system-wide manner that influences both the boundaries of the system and the generalized pathways of fluid movement in the system.

An assessment of the importance of heterogeneity at all scales is required to better understand and define flow and transport in ground-water systems. In addition, the relationship of field measurements obtained in heterogeneous materials to the actual occurrence and movement of the water and chemical constituents in the system must be defined.

OBJECTIVE: The objective of this project is to quantify the effect of specific heterogeneous geologic controls on ground-water systems. Meeting the objective will entail the development of methods for incorporating the effects of heterogeneous hydrogeologic controls into simulations of ground-water systems. Ideally, the characterization and quantification of the heterogeneous earth material will incorporate basic geologic information on the deposition and history of the materials under study, as well as hydraulic and chemical information.

APPROACH: The general approach is to investigate and quantify the effect of heterogeneous geologic controls on flow and transport in a ground-water system and develop methods of incorporating them in ground-water simulations routinely. The geologic depositional environment will play an important role in defining and describing the heterogeneities to be investigated. 


\section{GROUND-WATER HYDROLOGY}

The general approach to investigate these hydrogeologic controls will be as follows: (a) selection of the geologic control for investigation, (b) development of hypotheses to be tested, (c) selection of one or more field sites, (d) intensive analysis of "generic" hypothetical systems (based on the hydraulic and geologic information from the field sites) to corroborate or refute the hypotheses and give insight into the appropriate field measurements to be obtained to address the hypotheses, (e) specialized data collection, (f) quantitative analysis using simulation of the field sites, and $(\mathrm{g})$ use of the feedback between the results of the field investigations and the hypothetical "generic" analysis to corroborate or refute the hypotheses and give insight into mechanisms that might have been overlooked.

Information on the geologic depositional history will be used in the characterization of the media under investigation at the field sites. This qualitative characterization then will be evaluated and a quantitative characterization will be developed using stochastic and (or) deterministic methodologies, as appropriate, for both the "hypothetical" simulations and the analysis of the field sites themselves. The "generic" simulations should provide much information in the determination of important processes and the indication of which field measurements will be most appropriate to collect for the specific problem under investigation.

After the generic or "hypothetical" investigations, field data will be collected, as appropriate to define the system and geologic controls. These field data required will consist of head data, borehole geophysical logs, geologist logs, surface geophysical information, water quality information, and other ancillary data. These data will be used to characterize in a statistical sense the geologic terrain under investigation. Then methods of analysis, usually simulation techniques (deterministic and (or) stochastic), will be developed to quantify the effect of the geologic control characterized for the geologic terrain under investigation.

PROGRESS: Progress has been made in the analysis of heterogeneous controls on ground-water flow and transport at two different scales, the local well scale and an intermediate system scale. At the well-aquifer interface scale, an understanding of the effect of the heterogeneous nature of the aquifer permeability and chemical distributions in the aquifer on water samples obtained from wells is being pursued. Detailed time series information on the concentration of selected organic chemicals discharging at various points along a well screen were collected and analyzed in collaboration with Jacob Gibs, New Jersey District, using a unique multilevel sampling device. The time series information shows that trends in the quality of water sampled from wells can exist during sampling. Numerical simulation of layered systems indicates that these trends can be the result of the mixing of waters along the screened interval, and the measured trends can provide information on the distribution of the chemical species along the screened interval of the well. Also at the 


\section{GROUND-WATER HYDROLOGY}

well-aquifer interface scale, an experiment on well purging was designed and conducted in August 1992 at Cape Cod, Massachusetts, in collaboration with Denis LeBlanc of the Massachusetts District. Multipoint samplers were installed at the Cape Cod Toxic Hydrology Research Site next to a screened well to analyze the effect of heterogeneity on sample collection. The results are still being analyzed. At the intermediate scale, an analysis of the effect of hydraulic conductivity heterogeneities on flow paths to wells was completed. Hypothetical systems were evaluated under a series of differing permeability distributions, and the variability in the recharge areas of the wells examined. The results indicate that the uncertainty due to heterogeneous hydraulic conductivity distributions can be significant and should be accounted for in any "well-head protection" efforts.

Other accomplishments this year include: The corroboration of numerical flow models through the use of environmental tracers; the publication of a new axisymmetric simulation model that enables the simulation of flow to wells in heterogeneous systems; and the publication of a review chapter on the analysis of ground-water systems in saltwater-freshwater environments.

REPORTS PUBLISHED: $1988-1993$

Appel, C.A., and Reilly, T.E., 1988, Selected reports that include computer programs produced by the U.S. Geological Survey for simulation of ground-water flow and quality: U.S. Geological Survey Water-Resources Investigations Report 87-4271, 64 p.

Bennett, G.D., Reilly, T.E., and Hill, M.C., 1990, Technical training note in ground-water hydrology: Radial flow to a well: U.S. Geological Survey Water-Resources Investigations Report 89-4134, 83 p.

Buxton, H.T., Reilly, T.E., Pollock, D.W., and Smolensky, D.A., 1991, Particle tracking analysis of recharge areas on Long Island, New York: Ground Water, v. 29, no. 1, p. 63-71.

Franke, O.L., Bennett, G.D., Reilly, T.E., Laney, R.L., Buxton, H.T., and Sun, R.J., 1991, Concepts and modeling in ground-water hydrology-A self-paced training course: U.S.
Geological Survey Open-File Report 90-707 $416 \mathrm{p}$., [pending publication as a Techniques of Water-Resources Investigations].

Franke, O.L., Reilly, T.E., Buxton, H.T., and Simmons, D.L., 1993, Study guide for a beginning course in ground-water hydrology-Instructor's guide: U.S. Geological Survey Open-File Report 92-637, pt. 2, 128 p. [pending publication as a Techniques of Water Resourses Investigations].

Franke, O.L., Reilly, T.E., Haefner, R.J., and Simmons, D.L., 1990, A study guide for a beginning course in ground-water lydrologyCourse participants: U.S. Geological Survey Open-File Report 90-183, pt. 1, 184 p. Ipending publication as a Techniques of Water-Resources Investigations].

Nemickas, Bronius, Mallard, G.E., and Reilly, T.E., 1989, Availability and historical development of ground-water resources on Long 


\section{GROUND-WATER HYDROLOGY}

Island, New York-An introduction: U.S. Geological Survey Water-Resources Investigations Report 88-4113, 43 p.

Prince, K.R., Franke, O.L., and Reilly, T.E., 1988, Quantitative assessment of the shallow ground-water flow system associated with Connetquot Brook, Long Island, New York: U.S. Geological Survey Water-Supply Paper 2309, 28 p.

Prince, K.R., Reilly, T.E., and Franke, O.L., 1989, Analysis of the shallow ground-water flow system near Connetquot Brook, Long Island, New York: Journal of Hydrology, v. 107 , p. $223-250$

Reilly, T.E., 1990, Simulation of dispersion in layered coastal aquifer systems: Journal of Hydrology, v. 114, p. 211-228.

1990, Ground-water flow equation-A simplified development, in Franke, O.L., Reilly, T.E., Haefner, R.J., and Simmons, D.L., eds., A study guide for a beginning course in ground-water hydrology-Course participants: U.S. Geological Survey Open-File Report 90-183, pt. 1, p. 57-64 Ipending publication as a Techniques in Water-Resources Investigations].

1993, Analysis of ground-water systems in freshwater-saltwater environments, in Alley, William ed., Regional ground-water quality: New York, Van Nostrand Reinhold, p. 443469.

Reilly, T.E., Franke, O.L., and Bennett, G.D., 1989, Bias in ground-water samples caused by wellbore flow: Journal of Hydraulic Engineering, American Society of Civil Engineers, v. 115 , no. 2, p. 270-276.

Reilly, T.E., and Harbaugh, A.W., 1993, Source code for the computer program and sample data set for the simulation of cylindrical flow to a well using the U.S. Geological Survey Modular Finite-Difference Ground-Water Flow Model: U.S. Geological Survey Open-File Report 92-659, 7 p.

1993, Simulation of cylindrical flow to a well using the U.S. Geological Survey Modular Finite-Difference Ground-Water Flow Model: Ground Water, v. 31, no. 3, p. 489-494.

Reilly, T.E., and Gibs, Jacob, 1993, Effects of physical and chemical heterogeneity on waterquality samples obtained from wells: Ground Water, v. 31 , no. 5, p. $805-813$.

Reilly, Thomas E., and Pollock, David W., 1993, Factors affecting areas contributing recharge to wells in shallow aquifers: U.S. Geological Survey Water-Supply Paper 2412, 21 p.

Scorca, Michael P., Reilly, Thomas E., and Franke, O. Lehn, in press, Hydrogeology and selected water-quality data on Jones Beach Island, Long Island, New York: U.S. Geological Survey Water-Resources Investigations Report 92-4171. 


\section{GROUND-WATER HYDROLOGY}

TITLE Reaction-Transport Phenomena in Hydrogeologic Settings (NR 91-153)

PERSONNEL: Ward Sanford, Project Chief

ADDRESS: $\quad$ U.S. Geological Survey, 431 National Center, 12201 Sunrise Valley Drive, Reston, VA 22092

TELEPHONE: (703) 648-5882

PROBLEM: Ground-water transport and geochemical reactions play a significant role in many geological processes. Such processes include diagenesis, ore deposition, petroleum migration, hydrothermal activity, and evaporite formation. These processes are important in that they produce economic mineral deposits and alter the characteristics of aquifers and reservoirs from which we obtain water supplies and mineral resources. Many of these processes have been studied in terms of the geochemical reactions or the ground-water transport involved. However, in many circumstances the reactions and transport are inseparable. Because of the complexity of coupling equations of transport and chemical reactions, very few studies have been made thus far in which geochemical reactions and ground-water transport are coupled and analyzed simultaneously.

OBJECTIVE: Objectives of this project will be to understand the interaction of ground-water transport and geochemical reactions in hydrogeologic settings, including: interactions between geochemical reactions and solute transport, interactions between geochemical reactions and heat transport, and the effects of heat and solute transport on variable-density flow and transport in natural systems. Additional objectives will be to understand the implications these interactions have for the geologic processes being studied, and to develop more efficient methods for studying processes that involve both ground-water transport and geochemical reactions.

APPROACH: The study of ground-water transport and geochemical reactions in hydrogeologic settings will be done both through field investigations and through the development and use of numerical models. Studies will begin with specific geologic processes in mind; field investigations may then be conducted and numerical models will be developed to address the particular process of interest. Field investigations may aid in constraining the numerical models, and conversely, preliminary modeling results may suggest particular strategies for sampling in the field. It is expected that considerable interaction and collaboration will occur with geochemists on a majority of the studies undertaken. 


\section{GROUND-WATER HYDROLOGY}

PROGRESS: Tritium and chloride data from Double Lakes, Texas, have been used to obtain average recharge rates for both small fresh-water playas and the Southern High Plains as a whole. Chloride data from a profile of well cuttings through the shale beneath Double Lakes shows a record of salinity from the lake over the past 30,000 years. When compared with numerical models of advection and diffusion of solutes through the shale, this data indicates the lake basins began to deflate less than 5,000 years ago-an age that is consistent with thermoluminescence dating of the leeside dunes at the lake.

Computer animations can now be easily generated from output from the USGS method-of-characteristics (MOC) solute transport model. The animations show particles of different colors (representing concentration) moving in a black background representing the aquifer.

A research field site has been chosen in China for cooperation with the Chinese on studying salt-water intrusion. Project implementation plans are being drafted. Tutoring in Mandarin has given the project chief a beginner's skill level in speaking Chinese.

REPORTS PUBLISHED 1988-1993:

Brantley, S.L., Rowe, G.L., Konikow, L..F., and Sanford, W.E., 1993, Natural toxic waters of Poas Volcano, Costa Rica: Journal of Research and Exploration, v. 8, no. 3, p. 328-337.

Sanford, W. E., Wood, W.W., and Councell, T.B., 1992, Calcium-dominated brines: an ion exchange model in Kharaka, Y.K., and Maest A.S., eds., 7th International symposium on water-rock Interaction: Rotterdam, A.A. Balkema, p. 669-672.

Wood, W.W., Sanford, W.E., and Reeves, C.C., 1992, Large lake basins of the Southern High Plains: Ground-water control of their origin?: Geology, v. 20, no. 6, p. 535-538. 


\section{GROUND-WATER HYDROLOGY}

TITLE: $\quad$ Application of the Unsaturated Flow Theory to the Phenomena of Infiltration and Drainage (WR 63-024)

PERSONNEL: David A. Stonestrom, Project Chief

Kim N. Bui, Secretary

Katherine C. Akstin, Hydrologist

ADDRESS: U.S. Geological Survey, 345 Middlefield Road, MS 421, Menlo Park, CA 94025

TELEPHONE: (415) 329-4528

PROBLEM: Surface-runoff and various ground-water processes often are significantly influenced by water movement in the unsaturated zone. For many situations of hydrologic interest, inadequate knowledge prevents these influences from being properly taken into account in water-resource analyses.

OBJECTIVE: Test present theories of water flow through unsaturated porous materials, with particular attention on theories of infiltration and drainage. Use these theories to develop experimental techniques that will facilitate studies of ground-water recharge, runoff generation, and other hydrologic processes involving the unsaturated zone. Study unsaturated zones in various settings, particularly settings with deep unsaturated profiles, to evaluate water-flow rates and explain these rates in terms of soil, geologic, plant, and atmospheric conditions. Use the results of such studies for the assessment of water movement and attendant solute movement towards ground and surface-water supplies.

APPROACH: Test the validity and accuracy of predictive theories of water flow through unsaturated porous media by laboratory and field-scale studies. Devise improved laboratory and field methods to measure such flows and to evaluate the flow-determining characteristics of soils and sediments. Use these methods, in conjunction with unsaturated-flow theory, for field studies of flow rates of water in unsaturated-zone settings relevant to hydrologic problems.

PROGRESS: (1) Laboratory investigations of the ability of current Richards-equation-based theory to describe infiltration events were extended to upper-boundary conditions of stepwise-constant, increasing application rates. The results confirmed previous observations of anomalous transmission-zone matric pressures wherein matric pressures pass through 


\section{GROUND-WATER HYDROLOGY}

maxima, then decrease continuously as wetting fronts propagate downward. The range of conditions under which matric-pressure reversals occur was expanded, and some extreme examples were observed. Reductions in matric pressures were larger, and pressure maxima were higher, when a given rate was preceded by a series of stepwise-increasing rates. These results indicate that inaccuracies can result when current theory is used to predict the conditions under which rain produces positive pore-water pressures, and hence when runoff is initiated. A report detailing the anomalous behavior was submitted to Water Resources Research for publication.

(2) Matric-pressure and water-content profiles were sampled at regular intervals during the past two annual, wet-season-dry-season cycles at three chronosequence sites near Merced, California. The soils at the sites have formed for different lengths of time $(10,250$, and 600 thousand years) from the same parent material (granitic alluvium) on similar topographies (uplifted terraces) with similar vegetation (mixed grasses). The sites are sufficiently close together that climate is essentially the same. The soils support a wide variety of agricultural activity. Data on the attenuation of temporal fluctuations with depth clearly show the influence of different degrees of soil-horizon development on soil-moisture movement. The two older soils, which have well-developed argillic horizons, show strong attenuation of seasonal forcing at relatively shallow depths (one to two meters). The $10 \mathrm{ka}$-old profile, which lacks an argillic horizon, shows comparatively little attenuation in the upper three meters.

Bromide was tested and found suitable as a tracer for water movement at the Merced chronosequence sites. A bromide salt was applied to the surface of 1001 -meter by 1-meter plots at each of the 10 and 250 ka-old sites in August 1992, toward the end of the dry season. The infiltration-driven movement of bromide is being followed through periodic samplings to gain further understanding of the control exerted by soil horizonation on rates of deep (subroot zone) drainage. During each sampling four profiles are determined at each site so that the variability of soil-moisture movement at a given site can be assessed relative to the variability between sites. Preliminary results show that the method can clearly resolve the spatial and temporal structure of soil-moisture movement at such sites.

(3). Potential conditions that might result in preferential flow of water through the unsaturated zone due to wetting-front instabilities were investigated. Theories of preferential flow that predict the development of fingers during wetting-front propagation were not supported by laboratory observations of infiltration events on scales of several centimeters, or by field observations of naturally occurring infiltration on a scale of several meters. 


\section{GROUND-WATER HYDROLOGY}

\section{REPORTS PUBLISHED 1988-1993:}

Nimmo, J.R., and Akstin, K.C., 1988, Hydraulic conductivity of a sandy soil at low water content after compaction by various methods: Soil Science Society of America Journal, v. 52, p. 303-310.

Nimmo, J.R., Akstin, K.C., and Mello, Karen A., 1992, Improved apparatus for measuring hydraulic conductivity at low water content: Soil Science Society of America Journal, v. 56, p. 1758-1761.

Nimmo, J.R., Stonestrom, D.A., and Akstin, K.C., in press, The feasibility of recharge rate determinations using the steady-state centrifuge method: Soil Science Society of America Journal, v. 58 , n. 1 .

Stonestrom, D.A., 1990, Soapfilm flowmeter device for measuring gas flow rates: U.S. Patent no. $4,914,955$.

Stonestrom, D.A., and Rubin, J., 1989, Water-content dependence of trapped air in two soils: Water Resources Research, v. 25, no. 9, p. 1947-1958.

Stonestrom, D.A., and Rubin, J., 1989, Air permeability and trapped-air content in two soils: Water Resources Research, v. 25, no. 9, p. 1959-1969. 


\section{GROUND-WATER HYDROLOGY}

TITLE: $\quad$ Modeling and Monitoring Heat and Fluid Flow in Geothermal Systems (WR 73-102)

PERSONNEL: Michael L. Sorey, Project Chief

Susan P. Bartaluzzi, Secretary

Elizabeth M. Colvard, Hydrologist

ADDRESS: $\quad$ U.S. Geological Survey, 345 Middlefield Road, MS 439, Menlo Park, CA 94025

TELEPHONE: (415) 329-4420

PROBLEM: Analysis of heat and fluid flow in geothermal systems is needed to adequately describe the natural state of such systems and their response to fluid production for energy development. The analysis may involve analytical or numerical solution techniques, but requires delineation of realistic conceptual models for specific geothermal systems. This, in turn, requires the collection and synthesis of geologic, geophysical, geochemical, and hydrologic data. Periodic monitoring of changes in geothermal systems, including surficial thermal manifestations, can aid in understanding the natural conditions of flow and effects caused by crustal unrest and geothermal development.

OBJECTIVE: Elucidate the processes involved in geothermal systems and their response to stresses imposed by geothermal development, earthquakes, and magmatic intrusions. Develop realistic conceptual models of specific systems. Evaluate the level of natural variability in thermal fluid discharge in hot springs and fumaroles at specific geothermal areas.

APPROACH: Collect and synthesize geologic, geophysical, geochemical, and hydrologic data, including data obtainable from drill holes, for specific geothermal systems at Long Valley caldera (California), Lassen Park (California), and elsewhere. Use this information to develop realistic conceptual models of present and past flow within these systems. Apply numerical and analytical modeling techniques to quantify fluid and heat flow within these systems. Develop hydrologic monitoring programs at Long Valley, Lassen Park, and elsewhere to delineate the natural level of variability within these systems and to detect changes induced by crustal processes and geothermal development.

PROGRESS: Research efforts were divided between delineations of the response of the hydrothermal system in Long Valley caldera, California, to magmatic intrusion and to pressure and temperature reductions associated with geothermal development and to 


\section{GROUND-WATER HYDROLOGY}

measurements of heat and fluid discharge at Lassen Park, California. A geo-environmental study was completed on the Island of Hawaii to assess the impacts of potential geothermal development on ground-water resources in and adjacent to the east rift zone of Kilauea. A draft report was submitted to U.S. Department of Energy for its use in completing an Environmental Impact Statement for the proposed 500-megawatt Hawaii Geothermal Project. Followup work on our congressionally mandated study of the Mammoth-La Duke corridor at Yellowstone Park included coauthoring a paper on the age of travertine deposits at Yellowstone Park and their relation to interglacial periods, and data analysis for a journal article on hot spring discharge at Mammoth and La Duke hot springs.

\section{REPORTS PUBLISHED 1988-1993:}

Farrar, C.D., Sorey, M.L., Rojstaczer, S.A., and Steinemann, A.C., 1989: U.S. Geological Survey Water-Resources Investigations Report 89-4033, $70 \mathrm{p}$.

Hill, D.P., Ellsworth, W.L., Johnston, M.J.S., Langbein, J.O., Oppenheimer D.H., Pitt, M.A., Reasonberg, P.A., and Sorey, M.L., 1990, The 1989 earthquake swarm beneath Mammoth Mountain, California-An initial look at the 4 May through 30 September activity: Bulletin of the Seismological Society of America, v. 80, no. 2, p. 325-339.

Ingebritsen, S.E., and Sorey, M.L., 1988, Vapordominated zones within hydrothermal convection systems-Evolution and natural state: Journal of Geophysical Research, v. 93, no. B11, p. 13,635-13,655.

Sorey, M.L., editor, 1991, Effects of potential geothermal development in the Corwin Springs Known Geothermal Resources Area, Montana, on the thermal features of Yellowstone National Park: U.S. Geological Survey WaterResources Investigations Report 91-4052, 205 p.

Sorey, M.L., Colvard, E.M., and Sturchio, N.C., 1990, Geothermal systems within the Mammoth corridor in Yellowstone National Park and the adjacent Corwin Springs KGRA: Transactions of the Geothermal Resources Council, v. 14, p. 729-733.

Sorey, M.L., and Colvard, E.M., 1992, Factors affecting the decline in hot-spring activity in the Steamboat Springs area of critical environmental concern, Washoe County, Nevada: U.S. Geological Survey Administrative Report for the Bureau of Land Management, $109 \mathrm{p}$.

Sorey, M.L., and Farrar, C.D., 1992, A conceptual of the hydrothermal system in Long Valley caldera, California, U.S.A., in Kharaka, Y.K., and Maest, A.S., eds., 7th International Symposium on water-rock interaction [Proceedings], WRI-7, Park City, Utah: Rotterdam, A.A. Belkema, p. 1357-1362.

Sorey, M.L., Kennedy, B.M., Evans. W.C., Farrar, C.D., and Suenmnicht, G.A., in press, Helium isotope and gas discharge variations associated with crustal unrest in Long Valley caldera, California, 1989-1992: Journal of Geophysical Research, v. 98, no. B9.

Sorey, M.L., Suemnicht, G.A., Sturchio, N.C., and Nordquist, G.A., 1991, New evidence on the hydrothermal system in Long Valley caldera, California, from wells, fluid sampling. electrical geophysics, and age determinations 


\section{GROUND-WATER HYDROLOGY}

of hot-spring deposits: Journal of Volcanology and Geothermal Research, v. 48, p. 229-263.

Sturchio, N.C., Murrell, M.T., Pierce, K.L., and Sorey, M.L., 1992, Yellowstone travertines$\mathrm{U}$-series ages and isotope ratios $(\mathrm{C}, \mathrm{O}, \mathrm{Sr}$, U): in Kharaka, Y.K., and Maest, A.S., eds., 7th International Symposium on Water-Rock Interaction, WRI-7, Park City, Utah [Proceedings]: Rotterdam, A.A. Balkema p. 14271430. 


\section{GROUND-WATER HYDROLOGY}

TITLE: Technical Coordination and Support of Water Resources Division Geothermal Studies (WR 72-108)

PERSONNEL: Michael L. Sorey, Project Chief

Susan P. Bartaluzzi, Secretary

ADDRESS: $\quad$ U.S. Geological Survey, 345 Middlefield Road, MS 439, Menlo Park, CA 94025

TELEPHONE: (415) 329-4420

PROBLEM: Geothermal studies in the Water Resources Division are part of a multidivisional nationwide research program of the Geological Survey, funded as a line item in the Geologic Division budget. These studies require planning, technical supervision, logistical support, and coordination between the divisions. Additional coordination is required between the Geothermal Research Program of the USGS and geothermal program activities in other agencies such as the Department of Energy.

OBJECTIVE: Provide required technical, logistical, and funding support for Water Resources Division projects funded under the Geothermal Research Program.

APPROACH: The Water Resources Division (WRD) geothermal coordinator works with the Geologic Division's geothermal coordinator and the WRD Assistant Chief for Research and External Coordination to establish funding levels and program goals. Water Resources Division coordinator represents the geothermal research program in developing and carrying out various interagency projects such as Environmental Impact Analyses. The coordinator also participates in interdivisional program reviews and in the preparation of reports describing the geothermal research program. Technical supervision and assistance is provided where needed.

PROGRESS: Geothermal coordination activities included budget negotiations over distribution of funding for seven Water Resources Division (WRD) projects receiving geothermal funding and participation in an annual review of the U.S. Geological Survey's geothermal program. The WRD geothermal coordinator attended a Congressional hearing on legislation to protect Yellowstone Park from impacts of geothermal development and planned WRD input to an environmental impact study (EIS) being prepared for the Hawaii Geothermal Project. The coordinator also attended several meetings of the Hydrologic 


\section{GROUND-WATER HYDROLOGY}

Advisory Committee in Mammoth Lakes, California, to assist in monitoring the impacts of geothermal development on hot springs in Long Valley caldera. Consultation was provided to the Bureau of Land Management in Reno, Nevada, regarding a proposed monitoring program to accompany an expansion of geothermal development activities at Steamboat Springs, Nevada. 


\title{
GROUND-WATER HYDROLOGY
}

TITLE: Hydrologic Studies of Heat and Mass Transport (WR 74-121)

\author{
PERSONNEL: Steven E. Ingebritsen, Project Chief \\ Susan P. Bartaluzzi, Secretary \\ Martha A. Scholl, Hydrologist \\ ADDRESS: $\quad$ U.S. Geological Survey, 345 Middlefield Road, MS 439 , \\ Menlo Park, CA 94025
}

TELEPHONE: (415) 329-4422

PROBLEM: The presence and circulation of fluids profoundly affect volcanic processes and landforms. Eruption styles and cycles are influenced by volatiles dissolved in magma and pressure-temperature-fluid saturation conditions in the surrounding rock. The presence of magma in turn influences ground-water pressures, temperatures, and chemistry. Advective heat and mass transport affect and locally dominate the thermal and chemical regimes of volcanos. Linkages between fluid flow and mechanical deformation are suggested by observations that subaerial volcanoes deform in response to changes in water-table elevation and that microseismicity can be related to boiling.

OBJECTIVE: The general objective is to characterize selected volcanogenic hydrothermal systems by ascertaining probable recharge and discharge areas; determining modes and quantities of recharge and discharge; interpreting geologic, geochemical, and geophysical data in terms of the size, shape, and hydraulic characteristics of hydrothermal systems; and using analytical and numerical modeling techniques to develop quantitative conceptual models. Research questions include: (1) What are the modes of heat and mass transfer from magma to the shallow subsurface? (2) What are the pressure, temperature, and fluid-saturation conditions between magma and the land surface? (3) What controls the permeability of volcanoes? How does it vary in space and time? What role do temporal variations in permeability play in the evolution of volcanogenic hydrothermal systems? (4) How well-coupled are various fluid flow, transport, and mechanical deformation processes? Do relatively simple models that simulate a subset of these processes provide useful insight into transport processes? (5) How can we evaluate hydrothèrmal systems in composite cones dominated near the surface by cold-water recharge?

APPROACH: (1) Collect available hydrogeologic and geophysical data from the literature and from the files of public and private agencies. (2) Where data are deficient, supplement 


\section{GROUND-WATER HYDROLOGY}

by field inventory, measurement, and sampling. (3) Develop quantitative conceptual models. Current numerical models cannot rigorously simulate the coupled problem of heat and fluid flow, solute transport, and deformation, and may need to be improved.

PROGRESS: Convened Penrose Conference entitled "Fluid-Volcano Interactions" that attracted 87 researchers from 10 countries, including volcanologists, hydrogeologists, geophysicists, economic geologists, and metamorphic petrologists. Completed papers describing new heat-flow data from the Western Cascades, Oregon, and the hydrogeology of Kilauea volcano, Hawaii. Documented the existence of kinetic isograds in contact-metamorphosed basalts hosting the Skaergaard intrusion, Greenland (in collaboration with Craig Manning, University of California, Los Angeles (UCLA) and Dennis Bird, Stanford University). Preliminary indications from deuterium content of ground water and precipitation show that Kilauea's rift zones and summit area comprise leaky boundaries within the regional ground-water flow system, and that the southwest-rift zone also acts a conduit for ground-water recharged at relatively high elevations. Complementary rain-chemistry data show that estimated annual bulk sulfur deposition rates in the Kilauea caldera area exceed 5 grams per'square meter.

\section{REPORTS PUBLISHED 1988-1993:}

Bredehoeft, J.D., and Ingebritsen, S.E., 1990, Degassing of carbon dioxide as a possible source of high pore pressures in the crust, in Bredehoeft, J.D., and Norton, D.L., eds., The role of fluids in crustal processes: Washington, D.C., National Academy Press, p. 158-164.

Forster, C.B., and Ingebritsen, S.E., 1991, How fluids affect volcanoes [meeting report]: EOS Transactions, American Geophysical Union, v. 72, p. 395-396.

Ingebritsen, S.E., Christenson, B.W., Forster, C.B., Heiken, G.H., and Manning, C.E., 1993, Fluid-volcano interactions [meeting report]: GSA Today, v. 3, p. 123.

Ingebritsen, S.E., Mariner, R.H., Cassidy, D.E., Shepherd, L.D., Presser, T.S., Pringle, M.K.W., and White, L.D., 1988, Heat-flow and water-chemistry data from the Cascade
Range and adjacent areas in north-central Oregon: U.S. Geological Survey Open-File Report 88-702, 205 p.

Ingebritsen, S.E., Mariner, R.H., and Sherrod, D.R., 1991, Hydrothermal systems of the Cascade Range, north-central Oregon: U.S. Geological Survey Open-File Report 91-69, $217 \mathrm{p}$. [pending publication as U.S. Geological Survey Professional Paper 1044-L].

Ingebritsen, S.E., and Paulson, K.M., 1990, Numerical simulation of hydrothermal circulation in the Cascade Range, north-central Oregon: Geothermal Resources Council Transactions, v. 14, p. 691-698.

Ingebritsen, S.E., and Rojstaczer, S.A., in press, Controls on geyser periodicity: Science, v. 262. 


\section{GROUND-WATER HYDROLOGY}

Ingebritsen, S.E., and Scholl, M.A., in press, The hydrogeology of Kilauea volcano: Geothermics, v. 22, no. 4.

Ingebritsen, S.E., and Scholl, M.A., 1993, Annotated bibliography-Hydrogeology of Kilauea Volcano: U.S. Geological Survey Open-File Report 93-551-D, 30 p.

Ingebritsen, S.E., Scholl, M.A., and Sherrod, D.R., 1993, Heat flow from four new research drill holes in the Western Cascades, Oregon, U.S.A.: Geothermics, v. 22, p. 151-163.

Ingebritsen, S.E., Sherrod, D.R., and Mariner, R.H., 1989, Heat flow and hydrothermal circulation in the Cascade Range, north-central Oregon: Science, v. 243, p. 1458-1462.

1989, Heat flow and hydrothermal circulation. in the Cascade Range, north-central Oregon, in Muffler, L.J.P., Weaver, C.S., and Blackwell, D.D., eds., Proceedings of workshop XLIV-geological, geophysical, and tectonic setting of the Cascade Range: U.S. Geological Survey Open-File Report 89-178, p. 122-141.

1992, Rates and patterns of groundwater flow in the Cascade Range volcanic arc, and the effect on subsurface temperatures: Journal of Geophysical Research, v. 97, p. 4599-4627.

Ingebritsen, S.E., and Sorey, M.L., 1988, Vapordominated zones within hydrothermal systems-Evolution and natural state: Journal of Geophysical Research, v. 93, p. 13,63513,655 .

Manning, C.E., Ingebritsen, S.E., and Bird, D.K., 1993, Missing mineral zones in contact metamorphosed basalts: American Journal of Science, v. 293, p. 894-938.

Paulson, K.M., and Ingebritsen, S.E., 1991, Sodium and chloride data from selected streams in the Lassen area, north-central California, and their relation to thermal-fluid discharge from the Lassen hydrothermal system: U.S. Geological Survey Water-Resources Investigations Report 90-4201, 29 p.

Sammel, E.A., Ingebritsen, S.E., and Mariner, R.H., 1988, The hydrothermal system at Newberry Volcano, Oregon: Journal of Geophysical Research, v. 93, p. 10,149-10,162.

Scholl, M.A., Ingebritsen, S.E., and Essaid, H.I., 1993, Comment on Consequences of phase separation on the distribution of hydrothermal fluids at ASHES vent field, Axial Volcano, Juan de Fuca Ridge, by Christopher G. Fox: Journal of Geophysical Research, v. 98, p. 1813-1815.

Scholl, M.A., Janik, C.J., Ingebritsen, S.E., Kauahikaua, J.P., and Trusdell, F.A., 1993, Preliminary results from an isotope hydrology study of the Kilauea volcano area, Hawaii: Geothermal Resources Council Transactions, v. 17, p. $187-193$. 


\title{
GROUND-WATER HYDROLOGY
}

TITLE: $\quad$ Analytical Modeling of Flow and Transport in Aquifers and Geothermal Reservoirs (WR 75-127)

\author{
PERSONNEL: Allen F. Moench, Project Chief \\ Vera M. Ayers, Secretary
}

ADDRESS: $\quad$ U.S. Geological Survey, 345 Middlefield Road, MS 496, Menlo Park, CA 94025

TELEPHONE: (415) 329-3322

PROBLEM: Efficient management of ground-water aquifers and geothermal reservoirs requires accurate estimates of the hydraulic properties of water-bearing formations. These are needed to predict water-level changes, aquifer storage capacity, and the rate of movement of chemical species or thermal energy. Analytical models, properly applied, can often be used to estimate the hydraulic and transport properties of complex aquifer systems.

OBJECTIVE: Obtain analytical solutions to specific problems of flow and transport in water-bearing formations that can be used for evaluating the hydraulic and transport properties of aquifers and geothermal reservoirs.

APPROACH: Controlling equations for flow and transport in porous and fractured-rock aquifers are modified, linearized and solved with appropriate boundary conditions. For complex systems, the approach often involves the use of integral transforms and special methods of numerical inversion. Field data are used for case studies.

PROGRESS: A paper that describes a new method of generating type curves for aquifer tests under water-table conditions has been accepted for publication as a journal article. A computer program for this purpose is available to interested readers of the paper. The method has been used by the project to evaluate data from several pumping tests including a detailed test conducted at the Otis site on Cape Cod, Massachusetts. The latter analysis is described in a paper prepared for the September 1993, Toxic Substances Hydrology Technical Meeting. In addition, a journal article is in preparation that uses the computer program to revisit analyses of pumping tests described in the literature. The paper focuses on specific yield as determined by type-curve analysis. 


\section{GROUND-WATER HYDROLOGY}

\section{REPORTS PUBLISHED 1988-1993:}

Moench, A.F., 1988, The response of partially penetrating wells to pumpage from doubleporosity aquifers: International Conference on Fluid Flow in Fractured Rocks, May 16-18, Atlanta, Ga., [Proceedings], p. 208-219.

1989, Convergent radial dispersion-A Laplace transform solution for aquifer tracer testing: Water Resources Research, v. 25, no. 3, p. 439-447.

1991, Convergent radial dispersion-A note on evaluation of the Laplace transform solution: Water Resources Research, v. 27, no. 12, p 3261-3264.

Moench, A.F., LeBlanc, D.R., and Garabedian S.P., in press, Preliminary type-curve analysis of an aquifer test in an unconfined sand and gravel aquifer, Cape Cod, Massachusetts in Morganwalp, D.W., and Aronson, D.A., eds., U.S. Geological Survey Toxics Substances Hydrology Program-Proceedings of the technical meeting, Sept. 20-24, 1993, Colorado Springs, Colo.: U.S. Geological Survey Water Resources Investigation Report 94-4014.

Moench, A.F., 1993, Computation of type curves for partially penetrting wells in water-table aquifers: Ground Water, v. 31 , no. 6, p. 966971. 


\section{GROUND-WATER HYDROLOGY}

TITLE: Water Wells as Strain Meters (WR 75-176)

PERSONNEL: John D. Bredehöeft, Project Chief

Nona Myers, Secretary

Barbara Bekins, Postdoctoral Associate

Francis S. Riley, Hydrologist

Brian McPherson, Student, (University of Utah)

Rufus Getzen, Hydrologist

R. Abrams, Student, (Stanford University)

ADDRESS: $\quad$ U.S. Geological Survey, 345 Middlefield Road, MS 439, Menlo Park, CA 94025

TELEPHONE: (415) 329-4431

PROBLEM: Water wells commonly sho earth-tide fluctuations. Often, the magnitude of the tidal fluctuation in a well is 1 to 2 centimeters. This fluctuation is produced by a tidal dilatation, the sum of the normal strains, of approximately $1 \times 10^{-8}$. This indicates that the water well is as sensitive to strains of the crust as is a strain seismometer. The problem with the water well is that other factors such as changes in barometric pressure, ground-water recharge, and pumping also can cause the water level to fluctuate. Use of a well for crustal-strain measurements requires separation of the strain response (the signal) from the other effects (noise). Such separation requires careful experiments in areas where we know the crustal strain.

OBJECTIVE: Use water wells as indicators of crustal strain.

APPROACH: Enhance the network of wells for the express purpose of sensing crustal strains along the San Andreas fault near Parkfield, California, with additional wells and improved instrumentation.

PROGRESS: The project is subdivided into three distinct efforts:

(1) Fluids deep in the crust: The thrust of this effort is to investigate fluids in the deep sedimentary basins where there are data available. At the moment we are looking at three sedimentary basins-the Uinta Basin in Utah, the Illinois Basin, and the Sacramento Valley. The Uinta Basin has high pore pressure in the Altamont oil-field that is situated in the deepest part of the Basin. This past year we submitted a paper that explains the Altamont high pressure as a result of oil generation from oil shale, deep within the basin. Our initial analysis is based on assuming a single phase-water. The Illinois Basin is interesting because it contains brines that are five times the concentration of sea water, with approximately the 


\section{GROUND-WATER HYDROLOGY}

same ratio of ions as sea water. These brines appear to be concentrated sea water, probably emplaced early in the Basin's history. Many of the current hypotheses concerning the accumulation of oil in the basin, as well as the creation of Mississippi Valley type lead and zinc deposits, involve the movement of fluids through the Illinois Basin. This movement is incompatible with deep brines-at least in our view. The Sacramento Valley contains numerous high-pressure gas fields-fields that are well above hydrostatic pressure. We have accumulated the data to document this fact. The problem is to explain what causes these high pressures? There are several possible explanations-subsidence and sedimentation similar to the Gulf Coast, generation of gas, or tectonic compression.

2. Tectonic Strain Monitoring: Francis Riley is spending much of his time keeping our Parkfield water-well network operating. We continue to record interesting tectonic signals that are mostly associated with creep on the San Andreas fault. There are several lines of evidence that suggests that tectonic strain at a regional scale leads to local earthquakes-this is a basic Russian hypothesis, a paradigm that is viewed with skepticism by much of the western geophysical community. It is possible to test this hypothesis with a regional network of observation wells. The basic argument for regional observation well network is the subject of a paper submitted to Science by G.S. Vartanyan and J. Bredehoeft.

3. The role of microbiology in controlling organic reactions: The evidence is clear that many, if not most, organic contaminants are degraded chemically by reactions that are microbiologically controlled. These reactions need to be included in our basic transport models. Modeling these reactions using a transport framework provides insights into the processes involved. Barbara Bekins continues this research; she started work July 1, 1993. Barbara worked last summer with Mike Godsy on a plume of creosote contamination at Pensacola, Florida. Barbara and Mike have a paper in press on the modeling biodegradation within the Pensacola plume.

\section{REPORTS PUBLISHED 1988-1993}

Avon, L., and Bredehoeft, J.D., 1989, an analysis of trichloroethylene movement in ground water at Castle Air Force Base, California: Journal of Hydrology, 110, p. 23-50.

Bekins, B.A., Godsy, E.M., and Goerlitz, D.F., in press, Steady-state methogenic degradation of phenols in groundwater: Contaminant Hydrology, v. 14 .
Belitz, K., and Bredehoeft, J.D., 1988, Hydrodynamics of Denver Basin-Explanation of subnormal fluid pressures: American Association Petroleum Geologists Bulletin, v. 72, no. 11, p. 1334-1359.

1990, Role of confining layers in controlling large-scale regional ground water flow, in Neuman S.P. and Neretnieks I., eds., Hydrology of Low Permeability Environments: Inter- 


\section{GROUND-WATER HYDROLOGY}

national Association of Hydrogeologists, Hanover, Germany, Verlag Heinz Heise Publisher, v. 2 , p. $7-18$.

Bredehoeft, J.D., 1988, Will repositories be dry?: EOS Transactions, American Geophysical Union, v. 69, no. 9, p. 121 and p. 131.

1990, Microcomputer codes for simulating trnsient ground water flow in two and three space dimensions: U.S. Geological Survey Open-File Report 90-559, 106 p.

1991, Microcomputer codes for simulating transient ground-water flow in two and three space dimensions (JDB2D/3D): International Ground Water Modeling Center-Groundwater modeling software, Colorado School of Mines, Golden, Colo., IGWMC-FOS 50, 110 p.

1992, Response of the ground-water system at Yucca Mountain to an earthquake (Appendix D), in Raleigh, C.B., and Thompson, G.A., chairs, Ground-water at Yucca Mountain-How high can it rise?: NRC Panel on Coupled Hydrologic/Tectonic/Hydrothermal Systems at Yucca Mountain, Washington, D.C., National Academy Press, p. 212-222.

1993, Waste remediation-A 21st century issue: Forum for Applied Research and Public Policy, University of Tennessee, Energy, Environment and Resource Center Publication, Spring 1993, p. 135-139.

Bredehoeft, J.D., Belitz, K., and Sharp-Hansen, S., 1992, The hydrodynamics of the Big Horn Basin-A study in the role of faults: American Association of Petroleum Geologists Bulletin, v. 76, p. $530-546$.

Bredehoeft, J.D., Djevanshir, R.D., and Belitz, K.R., 1988, Lateral fluid flow in a compacting sand-shale sequence-South Caspian Basin:
American Association Petroleum Geologists Bulletin, v. 72, no. 4, p. 416-424.

Bredehoeft, J.D., and Ingebritsen, S.E., 1990, Degassing of carbon dioxide as a possible source of high pore pressure in the crust, in The Role of Fluids in Crustal Processes, NRC Study in Geophysics: NAS Press, p. 158-164.

Bredehoeft, J.D., and Norton, D.L., eds., 1990, The role of fluids in crustal processes: National Research Council Study in Geophysics, National Academy Press, Washington, D.C., $170 \mathrm{p}$.

1990, Mass and energy transport in a deforming earth's crust, in The Role of Fluids in Crustal Processes, NRC Study in Geophysics: NAS Press, p. 27-41.

Hsieh; P.A., Bredehoeft, J.D., and Rojstaczer, S.A., 1988, Response of well aquifer system to earth tides-Problems revisited: Water Resources Research, v. 24, no. 3, p. 468-472.

Konikow, L.F., and Bredehoeft, J.D., 1992, Groundwater models cannot be validated, in Celia, M.A., Gray, W.G., and Hassanizadeh, S.M., eds., Validation of Geo-hydrologic Models: Advances in Water Resources, special issue, Elsevier, v. 15, pt. 1, p. 63-83.

Riley, F.S., 1989, The Parkfield earthquake prediction experiment: Sensors, December 1989, p. 13-16.

Roeloffs, E., Shulz-Burford, S., Riley, F.S., and Records, A.W., 1989, Hydrologic effects on water level changes associated with episodic creep near Parkfield, California: Journal of Geophysical Research, v. 94 , p. 12,38712,402 .

Rojstaczer, S.A., and Bredehoeft, J.D., 1988, Ground water and fault strength, in Back, W., 


\section{GROUND-WATER HYDROLOGY}

Rosenshein, J.S., and Seaber, P.R., eds., Hydrogeology: Boulder, Colo., Geological Society of American, The Geology of North America, v. 0-2, p. 447-460.

Vartanyan, G.S., Bredehoeft, J.D., and Roeloffs, E., 1991, Hydrogeologic methods of investigating tectonic stresses: Moscow, Russia, Soviet Geology, v. 9/1991, p. 3-2. 


\title{
GROUND-WATER HYDROLOGY
}

TITLE: Ground-water Monitoring Network Design (WR 82-178)

\author{
PERSONNEL: Brian J. Wagner, Project Chief \\ Maria M. Watts, Secretary \\ David W. Hyndman, Hydrologist
}

\begin{abstract}
ADDRESS: $\quad$ U.S. Geological Survey, 345 Middlefield Road, MS 421, Menlo Park, CA 94025
\end{abstract}

TELEPHONE: (415) 329-4567

PROBLEM: There are a variety of ground-water resource and contamination problems that involve determining the state of ground water and detecting or predicting changes in the ground-water environment. Most approaches to ground-water monitoring network design avoid a rigorous formulation of the monitoring objectives and fail to consider the important processes controlling the movement of ground water and migration of ground-water contaminants. It is unlikely that such approaches to network design will be able to effectively and efficiently monitor the subsurface environment in the face of limited resources.

OBJECTIVE: This research aims to develop statistically sound and simulation based methods for ground-water monitoring network design. The goal is to develop techniques that unify stochastic ground-water flow and contaminant transport simulation with optimization for studying ground-water monitoring options, and to explore the capabilities and limitations of various network design methods.

APPROACH: Techniques for monitoring network design will be developed using three basic classes of tools-statistically based methods for parameter estimation, stochastic aquifer simulation techniques, and optimization methods. The general approach will be to combine the parameter estimation and stochastic simulation components with techniques from mathematics and statistics to develop statistically sound and simulation based optimal monitoring network design models amenable to a wide range of monitoring objectives.

PROGRESS: Work has proceeded on developing monitoring network design models for ground-water flow and contaminant transport modeling under uncertainty. The problem studied was the design of monitoring strategies in the context of ground-water management. A network design optimization model was coupled with a stochastic ground-water management model to evaluate the economic worth of hydrogeologic information. A second 


\section{GROUND-WATER HYDROLOGY}

problem studied was parameter estimation and the design of sampling strategies for stream tracer studies. A monte carlo parameter-estimate uncertainty analysis was used to develop robust sampling strategies given diffuse prior information regarding the stream flow and transport properties. A simulation-optimization management model for the western San Joaquin Valley was developed to identify pumping alternatives to agricultural drains.

\section{REPORTS PUBLISHED 1988-1993:}

Gomez-Hernandez, J., and Gorelick, S.M., 1989, Effective groundwater model parameter values-Influence of spatial variability of hydraulic conductivity, leakance and recharge: Water Resources Research, v. 15, no. 3, p. 405-419.

Gorelick, S.M., 1988, Incorporating assurance into groundwater quality management, in Custodio, E., Gurgui, A., and Lobo Ferreira, J.P., eds., NATO ASI Series: Mathematical and Physical Sciences, v. 224, p. 135-150.

1988, A review of groundwater management models, in O'Mara, G.T., ed., Efficiency in irrigation-The conjunctive use of surface and groundwater resources: Washington, D.C., The World Bank, p. 103-121.

1989, Large scale nonlinear deterministic and stochastic optimization-Formulations involving simulation of subsurface contamination: Mathematical Programming, v. 48, p. 19-39.

Harvey, J.W., Fuller, C.C., and Wagner, B.J., in press, Interactions between shallow ground water and surface water that affect metal contaminant transport in Pinal Creek Basin, Arizona in Morganwalp, D.W., and Aronson, D.A., eds., U.S. Geological Survey Toxics Substances Hydrology Program--Proceedings of the technical meeting, Sept. 20-24, 1993 , Colorado Springs, Colo.: U.S. Geological Survey Water Resources Investigation Report 94-4014.
Lefkoff, L.J., and Gorelick, S.M., 1990, Benefits of an irrigation water rental market in irrigated agriculture: Water Resources Research v. 26(7), p. 1371-1381.

1990, Simulating physical processes and economic behavior in saline, irrigated agriculture -Model development: Water Resources Research, v. 26(7), p. 1359-1369.

Peck, A.J., Gorelick, S.M., de Marsily, G., Foster, S., and Kovalevsky, V., 1988, Consequences of spatial variability in aquifer properties and data limitations for groundwater modeling practice: IAHS Press, Publication no. $175,272 \mathrm{p}$.

Van Genuchten, M.Th., Gorelick, S.M., and Yel, W. W-G., 1989, Parameter estimation methods for water quality studies, in De Coursey, D.G., ed., Water quality modeling of agriculture non-point sources: Invited paper.

Wagner, B.J., 1992, Simultaneous parameter estimation and contaminant source characterization for coupled ground-water flow and contaminant transport modeling: Journal of $\mathrm{Hy}$ drology, v. 110.

Wagner, B.J., and Gorelick, S.M., 1989, Reliable aquifer remediation in the presence of spatially variable hydraulic conductivity-From data to design: Water Resources Research, v. 25(10), p. 2211-2225. 


\section{GROUND-WATER HYDROLOGY}

TITLE: $\quad$ Nonisothermal Multiphase Flow (WR 82-179)

PERSONNEL: William N. Herkelrath, Project Chief

Vera M. Ayers, Secretary

Clyde F. O'Neal, Hydrologist

Fred Murphy, Hydrologist

ADDRESS: $\quad$ U.S. Geological Survey, 345 Middlefield Road, MS 496, Menlo Park, CA 94025

TELEPHONE: (415) 329-3314

PROBLEM: Understanding multiphase fluid flow in the subsurface is of increasing importance. Large volumes of organic liquids that are not miscible with water (such as gasoline) are being introduced into ground-water systems from leaking storage tanks. Such fluids have become a major source of ground-water contamination. Understanding how immiscible fluids move in the ground, and how they interact with the sediment, the soil gas, and the ground water, is vital to protecting the nation's water supply. Information on 3-phase flow is available in the petroleum engineering literature, but much of this work is not applicable because capillary pressure effects, which are important in small-scale, near-surface ground-water systems, have generally been ignored.

OBJECTIVE: The objective of the project is to determine the adequacy of the present limited description of the mechanisms of multiphase and immiscible flow in porous media, and to develop more general and realistic fluid-flow models that will be useful in analyzing real field situations. Carry out a program of experimentation designed to test theories of multiphase flow in porous media. Develop methodologies required to measure relevant parameters both at the laboratory scale and the field scale. Develop quantitative descriptions of the flow phenomena in terms of differential equations, and seek solutions by analytical and numerical means.

APPROACH: The basic approach is to use results of computer-modeling studies and field observations to identify important problems for study. Hypotheses are developed from the existing mathematical models of multiphase flow, and experiments are designed to test the hypotheses. Tests are then run in the laboratory where all the important variables can be controlled or measured. If the tests are inconsistent with theory, new theoretical descriptions are developed. Measurements of liquid saturations and fluid pressures involve methods developed by soil physicists and petroleum engineers. Limited field experiments are 


\section{GROUND-WATER HYDROLOGY}

performed in order to test the applicability of methodology developed in theoretical and laboratory studies.

PROGRESS: W.N. Herkelrath, in collaboration with H.I. Essaid, carried out laboratory and field investigations of multiphase, immiscible flow of fluids in sediments. As part of an effort to gain insight into the processes controlling the movement of immiscible contaminants in the field, we continued development of techniques for determining the spatial distribution of water, air, and immiscible fluid saturation within a polluted ground-water system. Our approach has been to obtain sediment cores from the field with fluids intact, and then analyze the core in the laboratory to determine fluid saturations. We finished development of a new cryogenic sampler designed to obtain undisturbed sediment cores. In this sampler, the bottom end of the core is frozen downhole by piping liquid carbon dioxide into an expansion chamber built into the outer wall of the drive shoe of a piston corer. Once the end of the core is frozen, the core is retrieved without loss of sediment or redistribution of liquids. The method was tested with great success at the site of a large oil spill near Bemidji, Minnesota. The core barrel was used in an ongoing program of field sampling at Bemidji that is yielding a three-dimensional grid of oil, air and water saturation measurements within the oil-spill zone. The saturation data were used to test a cross-sectional, multiphase numerical flow model. Good agreement between the model predictions and the field results was achieved when representations of observed spatial variability and hysteretic capillary-pressure relations were incorporated into the model. We also continued laboratory investigations of fluid movement caused by the introduction of immiscible hydrocarbon liquid into uncontaminated, unsaturated, water-wet sediments. We found that adding a small amount of hydrocarbon to a sediment sample caused a large shift in the water/air capillary pressure curve. In a closed system with a constant average water content, the water pressure increased. In an open system with a fixed water pressure boundary, drainage of water occurred. We hypothesize that these responses result from a decrease in the water/air surface tension caused by hydrocarbon film spreading and dissolution.

REPORTS PUBLISHED 1988-1993:

Constantz, Jim, Herkelrath, W.N., and Murphy, Fred, 1988, Air encapsulation during infiltration: Soil Science Society of America Journal, v. 52 , no. 1 , p. $10-16$.

Essaid, H.E., Herkelrath, W.N., and Hess, K.M., 1991, Air, oil, and water distributions at a crude-oil spill site, Bemidji, Minnesota, in Mallard G.E., and Aronson D.A., eds., U.S.
Geological Survey Toxic Substances Hyrology Program-Proceedings of the technical meeting: U.S. Geological Survey Water-Resources Investigations Report 91-4034, p. 614-620.

Essaid, H.E., Herkelrath, W.N., and Hess, K.M., 1993, Simulation of fluid distributions observed at a crude oil spill site incorporating hysteresis, oil entrapment, and spatial variabil- 


\section{GROUND-WATER HYDROLOGY}

ity of hydraulic properties: Water Resources

Research, v. 29, no. 6, p. 1753-1770.

Herkelrath, W.N., Essaid, H.I., and Hess, K.M., 1991, Field and modeling studies of immiscible fluid flow above a contaminated watertable aquifer: International Hydrology and Water Resources Symposium, Perth, Australia, 1991, v. 2, p. 424-428.

Herkelrath, W.N., Hamburg, S.P., and Murphy, Fred, 1991, Automatic, real-time monitoring of soil moisture in a remote field area with time-domain reflectometry: Water Resources Research, v. 27, no. 5, p. 857-864.

Hess, K.M., Herkelrath, W.N., and Essaid, H.E., 1992, Determination of subsurface fluid contents at a crude-oil spill site: Journal of Contaminant Hydrology, v. 10, p. 75-96. 


\section{GROUND-WATER HYDROLOGY}

TITLE: Theories of Water Flow and of Solute Transport in the Unsaturated Zone (WR 82-180)

PERSONNEL: Jacob Rubin, Project Chief

Kim N. Bui, Secretary

Gary P. Curtis, Environmental Engineer

ADDRESS: $\quad$ U.S. Geological Survey, 345 Middlefield Road, MS 421, Menlo Park, CA 94025

TELEPHONE: (415) 329-4523

PROBLEM: The unsaturated zone has a significant influence on the quantity and quality of water resources. Current theoretical methods of evaluating and predicting this influence for a particular set of field conditions cannot adequately account for the complexity of the processes involved and for interactions among them. It is necessary to improve the current theoretical approaches to water-flow and solute-transport problems of unsaturated-zone hydrology to achieve such an accounting.

OBJECTIVE: Determine which conditions are or are not essential to realistically refining the commonly used mathematical models for unsaturated flow. Combine water-flow and water-mixing models with models for chemical reactions and biological processes by use of submodels that are rigorous and appropriate to analyses of solute transport in the unsaturated zone. Explore situations of hydrologic interest and those that may be valuable in connection with model validation or parameter determination for both water-flow and solute-transport processes. Test experimentally the theoretical conclusions reached in cooperation with other projects.

APPROACH: Consider model refinements for unsaturated flow that would account for effects of parameter hysteresis, air trapping, pore-geometry transformations and medium heterogeneity. Determine the conditions under which such refinements are essential. Develop computer-aided theoretical analyses of the interactions between unsaturated-zone waters and ground or surface waters. Attempt to integrate, for solute transport, the hydrodynamic-dispersion approach to transport with the chemist's or ecologist's approaches to chemical equilibria, chemical kinetics, and population ecology. Modify the above standard approaches to treat realistically the special conditions characterizing natural unsaturated zones, such as the presence of two fluid phases, changes in water content, wide range of soil-water fluxes, and chemical heterogeneity of the porous medium. Use or adapt existing 


\section{GROUND-WATER HYDROLOGY}

mathematical methods, especially numerical methods, and develop new mathematical methods if necessary.

PROGRESS: Completed and submitted to a journal a study of a chemical mechanism that, in many systems of interacting reactions, brings about unsolvability of equilibrium-determining equations. Such systems cannot reach equilibrium without changing their phase assemblage. This mechanism is a loop-like, ion-sharing-based connection between interacting heterogeneous reactions ("a cycle"). The systems studied contained only simple (but ubiquitous) constituent-reactions (each reaction always had the total of three reactants and reaction products). For such systems it was proven that cycles of reacting, ion-sharing solids are a sufficient condition for equilibrium problem unsolvability. In addition, at least in most cases, these cycles also are a necessary condition for such unsolvability.

Continued to develop further and started critical testing of the Feed-Forward (FF)-method for simulating transport of reacting solutes. Completed the part of this work that involves reactions of classical chemistry and either a single moving boundary or many such boundaries. For the single boundary cases, the testing results showed good internal consistency and compared very well with analytical solutions (even for numerically difficult conditions). Comparisons with a much used alternate method showed identical results, with the FF-method always being significantly faster. For cases with several moving boundaries a new method had to be developed. It combined certain aspects of both the FF-method and the alternate method. Test results showed the new method to be as accurate as the alternate method, but always faster.

Advised the ground-water part of the National Water Quality Assessment program, attempting (1) to assure the soundness of its water-quality assessment; (2) to increase the significance of its explanatory component; (3) to include, even in the initial work, certain longer time-frame considerations.

\section{REPORTS PUBLISHED 1988-1993:}

Bahr, J.M., 1990, Kinetically influenced terms for solute transport affected by heterogeneous and homogeneous classical reactions: Water Resources Research, v. 26, no. 1, p. 21-34.

Friedly, J.C., 1991, Extent of reaction in open systems with multiple heterogeneous reaction: American Institute of Chemical Engineering, v. 37 , p. $687-693$.
Friedly, J.C., and Rubin, J., 1992, Solute transport with multiple, equilibrium or kinetically controlled, chemical reactions: Water Resources Research, v. 28, no. 7, p. 1935-1953.

Rubin, J., 1990, Solute transport with multisegment, equilibrium-controlled reactions: a feed-forward simulation method: Water 


\section{GROUND-WATER HYDROLOGY}

Resources Research, v. 26, no. 9, p. 20292055.

1992, Solute transport with multisegment, equilibrium-controlled, classical reactions: problem solvability and Feed-Forward Method's applicability for complex segments of at most binary participants: Water Resources Research, v. 28 , no. 6, p. 16811702.

Stonestrom, D.A., and Rubin, J., 1989, Watercontent dependence of trapped air in two soils: Water Resources Research, v. 25, no. 9, p. 1947-1958.

1989. Air permeability and trapped-air content in two soils: Water Resources Research, v. 25, no. 9, p. 1959-1969. 


\title{
GROUND-WATER HYDROLOGY
}

TITLE: Hydrology of Fractured Rocks (WR 83-184)

\author{
PERSONNEL: Paul A. Hsieh, Project Chief \\ Vera M. Ayers, Secretary \\ Daniel J. Goode, Hydrologist \\ Claire Tiedeman, Hydrologist
}

ADDRESS: $\quad$ U.S. Geological Survey, 345 Middlefield Road, MS 496, Menlo Park, CA 94025

TELEPHONE: (415) 354-3324

PROBLEM: Fractures often serve as major conduits for movement of water and dissolved chemicals through hard rocks in the underground. Understanding fluid flow and mass transport in fractured rocks is essential for assessing the ground-water resources of hard-rock aquifers, investigating the suitability of underground sites for hazardous waste disposal, and predicting the movement of hazardous chemicals if contamination occurs. Existing theory of fluid flow through porous media is of limited usefulness when applied to fractured rocks. The low permeability and highly heterogeneous nature of fractured rocks require extension of current theory and field methods. It is particularly important that theoretical developments be applicable on a scale commensurate with field measurements.

OBJECTIVE: (1) Develop theoretical model of fluid flow and solute transport in fractured rocks with particular emphasis on characterizing the effects of heterogeneities on different scales. (2) Develop field methods (hydraulic and tracer tests) to characterize the flow and transport properties of fractured rocks. (3) Combine the use of geological, geophysical, and geochemical methods with hydraulic and tracer tests to develop an integrated approach to modeling flow and transport in fractured rocks.

APPROACH: (1).Compare different approaches (equivalent porous media, discrete fracture, stochastic continuum) to modeling flow and transport in fractured rocks by analytical methods and computer simulation. (2) Construct mathematical model of hydraulic and tracer tests in heterogeneous fractured rocks, and apply parameter-estimation techniques to analyze test results with emphasis on detecting heterogeneous features such as a highly-permeable fracture zone. (3) Establish a field site for testing theoretical and method developments, for cooperative work with other research projects with expertise in geological, geophysical and geochemical studies, and to synthesize knowledge obtained from different studies through modeling flow and transport at the field site. 


\section{GROUND-WATER HYDROLOGY}

PROGRESS: (1) During the summer and fall of 1992, field work at the Mirror Lake site in New Hampshire included drilling four wells, collecting water samples, single-hole packer tests, cross-hole hydraulic tests, tracer tests, and seismic tomography surveys. Hydraulic heads in bedrock wells were monitored year round. At the end of the 1992 field season, all bedrock wells had been tested and sampled. Three data bases have been completed: one consisting of rock type, fracturing, and permeability, a second consisting of ground-water ages and chemical constituents, and a third consisting of hydraulic heads measured at packer-isolated intervals in bedrock wells. Analysis of the field data confirms earlier hypothesis that highly permeable fractures occur in local clusters; the clusters are separated from one another by a network of less permeable fractures. Preliminary results were presented in five papers at the U.S. Geological Survey Toxic Substances Hydrology Program Technical Meeting.

(2) A computer model of ground-water flow in the Mirror Lake area has been calibrated to hydraulic head and stream flow data. The calibration yielded regional-scale hydraulic conductivity values that are smaller than those estimated from single-hole packer tests, and the spatial variation in hydraulic conductivity could not be identified. The findings point to the need for additional calibration data such as ground-water ages.

(3) A field guide for the Mirror Lake site has been prepared for a Geological Society of America field trip visit to the Mirror Lake site.

(4) Completed analysis of whether it is possible to use steady state pumping test data to identify the location of a highly permeable fracture zone. Results show that nonlinear regression method can converge to many spurious solutions. However, if a large number of different starting configurations are considered, then the correct solution can usually be found.

REPORTS PUBLISHED 1988-1993:

Barton, C.C., and Hsieh, P.A., 1989, Physical and hydrologic-flow properties of fractures-Field trip guidebook T385, 28th International Geologic Congress: American Geophysical Union, Washington, D.C., $36 \mathrm{p}$.

Christian, S.B., 1992, Well test analysis in a twozone aquifer using the boundary integral method: Stanford University, Stanford, Calif., Masters thesis.
Goode, D.J., 1992, Modeling transport in transient ground-water flow-An unacknowledged approximation: Ground Water, v. 30, no.2, p. 257-261.

Goode, D.J., and Appel, C.A., 1993, Finite-difference interblock transmissivity for unconfined aquifers and for aquifers having smoothly varying transmissivity: U.S. Geological Survey 


\section{GROUND-WATER HYDROLOGY}

Water-Resources Investigations Report 92 4124, $79 \mathrm{p}$.

Goode, D.J., Hsieh, P.A., Shapiro, A.M., Wood, W.W., and Kraemer, T.F., 1993, Concentration history during pumping from a leaky aquifer with stratified initial concentration, in Shen, H.W., ed., Hydraulic Engineering: American Society of Civil Engineers, National Hydraulics Division Conference, San Francisco, Calif., July 25-30, 1993 [Proceedings], v. 1, p. 29-35.

Hsieh, P.A., 1993, Some experience gained from using packers and transducers in ground-water investigations of crystalline-rock aquifers, in Latkovich, V.J., ed., Proceedings of a pressure transducer-packer workshop, June 25-28, 1991: U.S. Geological Survey Open-File Report 93-71, p. 5-7.

Hsieh, P.A., Bredehoeft, J.D., and Rojstaczer, S.A., 1988, Response of well aquifer systems to earth tides-Problem revisited: Water Resources Research, v. 24, no. 3, p. 468-472.

Hsiel, P.A., and Freckleton, J.R., 1993, Documentation of a computer program to simulate horizontal-flow barriers using the Modular Three-Dimensional Finite-Difference GroundWater Flow Model: U.S. Geological Survey Open-File Report 92-477, 32 p.

Hsieh, P.A., Shapiro, A.M., Barton, C.C., Haeni, F.P., Johnson, C.D., Martin, C.W., Paillet, F.L., Winter, T.C., and Wright, D.L., in press, Methods of characterizing fluid movement and chemical transport in fractured rock, in Cheney, J.T., and Hepburn, J.C., eds., Field trip guidebook for the northeastern United States: Boston, Geological Society of America.

Kaehler, C.A., and Hsieh, P.A., 1991, Hydraulic properties of a fractured-rock aquifer, Lee
Valley, San Diego County, California: U.S. Geological Survey Open-File Report 90-592.

Ritzi, R.W., Jr., Sorooshian, S., and Hsieh, P.A., 1991, The estimation of fluid flow properties from the response of water levels in wells to the combined atmospheric and earth tide forces: Water Resources Research, v. 27, no. 5, p. 883-893.

Shapiro, A.M., and Hsieh, P.A., 1991, Research in fractured-rock hydrogeology-Characterizing fluid movement and chemical transport in fractured rock at the Mirror Lake drainage basin, New Hampshire, in Mallard, G.E., and Aronson, D.A., eds., U.S. Geological Survey Toxic Substances Hydrology Program-Proceedings of the technical meeting, Monterey, Calif., March 11-15, 1991: U.S. Geological Survey Water-Resources Investigations Report 91-4034, p. 155-161. 


\title{
GROUND-WATER HYDROLOGY
}

TITLE: $\quad$ Temperature Effects in the Unsaturated Zone (WR 87-193)

\author{
PERSONNEL: James E. Constantz, Project Chief \\ Vera M. Ayres, Secretary \\ Timothy R. Green, Civil Engineer
}

\begin{abstract}
ADDRESS: $\quad$ U.S. Geological Survey, 345 Middlefield Road, MS 496, Menlo Park, CA 94025
\end{abstract}

TELEPHONE: (415) 329-3325

PROBLEM: Transport in the unsaturated zone is strongly dependent upon temperature. However, there is a lack of quantitative information concerning the influence of temperature upon water retention characteristics, unsaturated hydraulic conductivity values, and water fluxes in natural porous materials. When compared to experimental results, existing theories underestimate the magnitude of temperature-induced changes in many pore-water and interfacial properties. Consequently, models incorporating the effects of temperature upon water retention and transport in the unsaturated zone are inadequate.

OBJECTIVE: (1) Measure the influence of temperature upon water retention characteristics, unsaturated hydraulic conductivity, and coefficients derived from these primary parameters, such as water diffusivities and capacities; (2) ascertain whether the behavior of water in close proximity to mineral surfaces is altered sufficiently to result in modified temperature coefficients for gas solubilities, adsorption, viscosity, interfacial surface tensions and contact angles, and other properties important to transport in porous materials; and (3) examine the influence of temperature on primary hydrologic processes in the unsaturated zone, such as infiltration, moisture redistribution, evaporation, and drainage.

APPROACH: Perform laboratory experiments on field cores and repacked samples to measure the temperature dependence of water-retention characteristics and unsaturated hydraulic conductivities in natural porous materials. Examine relations between matric potential, volumetric water content, and temperature in these materials by use of experimental equipment and procedures that have been modified for high temperature. Perform field experiments to determine the influence of temperature on water retention and transport.

PROGRESS: Significant progress has been made in both laboratory and field research in two distinct areas. Laboratory research has focused on the determination of water retention in stratified porous materials and the effects of stratigraphy on pulsating outflow patterns in 


\section{GROUND-WATER HYDROLOGY}

stratified materials. A paper has recently been completed on the results of experiments on water retention in stratified materials. A theory to explain the pulsating outflow patterns is currently being developed. Field work has been performed to examine the effects of stream temperature on stream-flow variations. Our research in New Mexico, Colorado, and Nevada has demonstrated that variations in stream temperature can cause large variations in the rate of seepage loss from streams. A paper is currently being completed on the results of work at these field sites.

\section{REPORTS PUBLISHED 1988-1993:}

Constantz, J., 1989, Distillation irrigation-A lowenergy process for coupling water purification and drip irrigation: Agriculture Water Management Journal, v. 15, 253-264.

1991, Comparison of isothermal and isobaric water retention paths in nonswelling porous materials: Water Resources Research, v. 27. p. 3165-3170.

Constantz, J., 1993, Confirmation of rate-dependent behavior in water retention during drainage in nonswelling porous materials: Water

Resources Research, v. 29, 1331-1334.

Constantz, J., and Herkelrath, W.N., 1988, Field measurements of the influence of entrapped air upon ponded infiltration rates, in Fok, Yu-Si, ed., Infiltration principles and practices: University of Hawaii Press, p. 398-408.

Constantz, J., Herkelrath, W.N., and Murphy, F., 1988, Air encapsulation during infiltration:

Soil Science Society of America Journal, v. 52, p. 10-16.

Constantz, J., and Murphy, F., 1990, Monitoring moisture storage in trees using time-domain reflectometry: Journal of Hydrology, v. 119, p. 31-42.
1991, The temperature dependence of ponded infiltration under isothermal conditions: Journal of Hydrology, v. 122, p. 119-128.

Green, T.R., Green, R.E., and Miller, M.E., 1993, Impacts of vertical heterogeneity on simulated water flow in Hawaiian basaltic saprolite: relations to recharge, in Dagan G., and Russo, D., eds., Water Flow and Solute Transport in Soils: Advanced Agricultural Science, v. 20, p. 233-246. 


\title{
GROUND-WATER HYDROLOGY
}

TITLE: $\quad$ Physical Characteristics that Determine Flow in the Unsaturated Zone (WR 89-198)

\author{
PERSONNEL: John R. Nimmo, Project Chief \\ Kim Bui, Secretary \\ Stephanie M. Shakofsky, student (San Jose State University) \\ Cinzia Rossi, Visiting Scientist
}

\begin{abstract}
ADDRESS: $\quad$ U.S. Geological Survey, 345 Middlefield Road, MS 421, Menlo Park, CA 94025
\end{abstract}

TELEPHONE: (415) 329-4537

PROBLEM: Flow in the unsaturated zone profoundly influences the degradation of water quality as well as the loss and replenishment of available water resources. Unsaturated-zone physical characteristics, such as hydraulic conductivity and water retention, are essential to the determination of water and solute fluxes into ground water and to the understanding of surface-subsurface interactions. The theory describing these unsaturated-zone influences has not been adequately tested and may, in fact, be invalid for certain important cases. Limitations of present laboratory and field techniques are a major hindrance to large-scale hydrological application of unsaturated-flow theory because critical physical characteristics cannot be measured with the required speed and accuracy.

OBJECTIVE: (1) Test the validity of existing theories related to unsaturated-zone fluxes and correct or extend them, where necessary, to develop fast, accurate, practical methods for measuring unsaturated-zone fluxes and the physical characteristics that determine them; (2) apply and promote routine use of these experimental and theoretical methods in hydrological studies where the unsaturated zone plays an important role; (3) assess the importance of complicating influences (temperature gradients, dispersion, hysteresis, and so forth.) on water and solute fluxes.

APPROACH: By inventing new devices, applying newly discovered principles, and adapting technology from related and unrelated fields, develop techniques for measuring unsaturated-zone fluxes and the porous-media characteristics essential to their understanding. Integrate field, theoretical, and laboratory methods into a practical system for solving a variety of specific hydrological problems. Apply this system both to water-resource issues and to fundamental problems of unsaturated flow. Use newly developed experimental 


\section{GROUND-WATER HYDROLOGY}

methods, alone or in combination with others, to test theory. Where necessary or desirable, derive new theory from basic physical principles.

PROGRESS: (1) We have formulated and tested two versions of a new analytical model for representing soil moisture retention with good accuracy at low as well as high water content. This model is the first that provides realistic fits over the entire range of soil moisture, from saturation to oven-dryness. Because of a high degree of physical realism it is also useful for extrapolating data beyond the range of measurements, permitting as much as a five-order-of-magnitude extension.

(2) We completed a set of detailed moisture-retention measurements on soil core samples from the vicinity of a hazardous waste site at the Idaho National Engineering Laboratory (INEL). The results show distinct differences, largely in the degree of variability, in the hydraulic properties of undisturbed soil and a simulated landfill. This suggests that some of the flow-impeding properties of the layered natural soil were destroyed in creating the landfill.

(3) We obtained cores and disturbed samples at a waste-disposal site near Beatty, Nevada, establishing the suitability of this site for detailed unsaturated flow measurements.

(4) We obtained high-quality core samples, using a newly modified technique for minimizing sample disturbance, from a site in southeastern Washington. We have started a series of unsaturated hydraulic conductivity $(\mathrm{K})$ measurements by the steady state centrifuge method (SSCM) using these samples to obtain accurate and conclusive measurements of aquifer recharge rates.

REPORTS PUBLISHED 1988-1993:

Nimmo, Jr., 1990, Experimental testing of transient unsaturated flow theory at low water content in a centrifugal field: Water Resources Research, v. 26, p. 1951-1960.

1991, Comment on the treatment of residual water content in "A consistent set of parametric models for the two-phase flow of immiscible fluids in the subsurface," by L. Luckner and others: Water Resources Researci, v. 27, p. 661-662.
1992, A semiempirical model of soil water hysteresis: Soil Science Society of America Journal, v. 56, p. 1723-1730.

Nimmo, J.R., and Akstin, K.C., 1988, Hydraulic conductivity of a sandy soil at low water content after compaction by various methods: Soil Science Society of America Journal, v. 52, p. 303-310.

Nimmo, J.R., Akstin, K.C., and Mello, K.A., 1992, Improved apparatus for measuring hy- 


\section{GROUND-WATER HYDROLOGY}

draulic conductivity at low water content: Soil Science Society of America Journal, v. 56, p. 1758-1761.

Nimmo, J.R., and Mello, K.A., 1991, Centrifugal techniques for measuring saturated hydraulic conductivity: Water Resources Research, v. 27, p. 1263-1269. 


\title{
GROUND-WATER HYDROLOGY
}

TITLE: $\quad$ The Fate and Transport of Immiscible Contaminants in the Subsurface (WR 89-199)

\author{
PERSONNEL: Hedeff I. Essaid, Project Chief \\ Maria M. Watts, Secretary \\ Leslie Dillard, Geologist, student (Stanford University)
}

$\begin{array}{ll}\text { ADDRESS: } & \text { U.S. Geological Survey, } 345 \text { Middlefield Road, MS 421, } \\ & \text { Menlo Park, CA } 94025\end{array}$

TELEPHONE: (415) 354-3383

PROBLEM: Many highly toxic contaminants commonly found in the subsurface occur as slightly soluble and highly volatile fluids that are immiscible with water. Despite their low solubility, these compounds pose a widespread potential threat to ground-water resources. Such fluids include synthetic organic compounds such as trichloroethylene (TCE) and related chlorinated hydrocarbons, polychlorinated biphenyls, coal tar and creosote wastes, and natural and refined hydrocarbons. Because of the limited knowledge concerning the multiphase nature of transport of such contaminants in the subsurface, the development of methodologies for predicting and controlling the movement and removal of such plumes is still in its infancy.

OBJECTIVE: Understand the migration and fate of immiscible contaminants in the subsurface, including the physics of multiphase flow (that is, the governing equations, the relative permeability and saturation functions, and the effects of hysteresis and porous media heterogeneity); the nature of interphase transfer processes and chemical reactions affecting transport rates and (or) physical-media properties; and the nature of biological processes in the subsurface leading to biodegradation of organic contaminants.

APPROACH: Undertake the study of multiphase contaminant problems through the development of efficient numerical models applicable at laboratory and field scale, in conjunction with experimental and field investigations. Develop methods for incorporating porous-media heterogeneity, mass transfer, and biological processes into numerical simulators. Use these models, ultimately, to simulate and predict the migration of slightly soluble, highly volatile immiscible contaminants in the field.

PROGRESS: We are continuing to study the distribution of oil in the subsurface at the 


\section{GROUND-WATER HYDROLOGY}

Bemidji, Minnesota, research site in order to develop an understanding of the processes influencing the flow of immiscible organic contaminants. At the Bemidji crude-oil spill site, oil ponded on the land surface at two sites approximately 150 meters apart. Oil infiltrated at both locations forming separate pools of oil at the water table. Using our specialized coring and laboratory techniques, we have made detailed determinations of fluid distributions within the two pools. We have noticed marked differences between the measured oil distributions despite the proximity of the locations. At the south oil pool site, where the water table is about 2 meters deep, the maximum observed oil saturation was 0.62 , and very little oil was trapped in the unsaturated zone. At the north oil pool site, where the water table is about 6.5 meters deep, the maximum observed oil saturation was 0.74 , and significant amounts of oil were trapped in the unsaturated zone. Particle-size based Krumbein-Monk estimates of permeability $(\mathrm{k})$ indicate that the distribution of the hydraulic properties of the glacial outwash at the two sites is different. Examination of the north pool cores and particle-size data revealed the presence of thin silt layers interbedded within the coarser outwash materials. The analysis of the first transect taken through the south pool oil lens has been published in Water Resources Research. The analysis of the first transect through the north oil pool has been presented at the Fall 1992 American Geophysical Union meeting and the manuscript is being written. In both cases, geostatistical simulation was used to characterize the spatial variability at the two sites and a cross-sectional multiphase flow model was used to simulate the oil distributions. Simulation results for the south oil pool indicated that hysteresis and representations of spatial variability conditioned to the field data must be included in order to reproduce the general features of the observed oil distribution. At the north pool, incorporation of hysteresis was not crucial; the presence of the silt lenses within the outwash was dominant factor influencing the subsurface oil distribution. Despite the proximity of the two sites, modeling experience gained at one site was not highly transferable to the other site.

\section{REPORTS PUBLISHED 1988-1993:}

Essaid, H. I., 1990, The computer model SHARP, a quasi-three-dimensional finite-difference model to simulate freshwater and saltwater flow in layered coastal aquifer systems: U.S. Geological Survey Water-Resources Investigation Report 90-4130, 182 p.

1990, A multilayered sharp interface model of coupled freshwater and saltwater flow in coastal systems-Model development and application: Water Resources Research, v. 26, no. 7. p. 143I-1454.
1992, Simulation of freshwater and saltwater flow in the coastal aquifer system of the Purisima Formation in the Soquel-Aptos Basin, California: U.S. Geological Survey WaterResources Investigation Report 91-4148, 35 p.

1992, Long term issues in ground water management: Seawater intrusion, in Changing practices in ground water management-The pros and cons of regulations, in 18th Biennial Conference on Ground Water, Sacramento, Calif., Sept. 16-17, 1991, Proceedings: Uni- 


\section{GROUND-WATER HYDROLOGY}

versity of California, Water Resources Center, Report No. 77, p. 75-91.

Essaid, H. I., Herkelrath, W. N., and Hess, K. M., 1991, Air, Oil, and Water Distributions at a Crude-Oil Spill Site, Bemidji, Minnesota, in Mallard, G.E., and Aronson, D.A., eds., U.S. Geological Survey Toxic Substances Hydrology Program-Proceedings of the technical meeting: U.S. Geological Survey WaterResources Investigations Report 91-4034, p. 614-620.

Essaid, H.I., Herkelrath, W.N., and Hess, H.I., 1993, Simulation of fluid distributions observed at a crude-oil spill site incorporating hysteresis, oil entrapment, and spatial variability of hydraulic properties: Water Resources Research, v. 29, no. 6, p. 1753-1770.

Essaid, H.I., and Hess, K.M., 1993, Monte Carlo simulations of multiphase flow incorporating spatial variability of hydraulic properties: Ground Water, v. 31, no. 1, p. 123-134.

Herkelrath, W.N., Essaid, H.I., and Hess, K.M., 1991, Field and modeling studies of immiscible fluid flow above a contaminted water-table aquifer-Proceedings of the International $\mathrm{Hy}$ drology and Water Resources Symposium 1991: Challenges for Sustainable Development, Perth, Australia, 2-4 Oct. 1991, p. 424-428.

Hess, K. M., Herkelrath, W. N., and Essaid, H. I., 1992, Determination of subsurface fluid contents at a crude-oil spill site: Journal of Contaminant Hydrology, v. 10, p. 75-96.

Scholl, M.A., Ingebritsen, S.E., and Essaid, H.I., 1993, Comment on "Consequences of phase separation on the distribution of hydrothermal fluids at ASHES vent field, Axial Volcano, Juan de Fuca Ridge," by Fox, Christopher
G.: Journal of Geophysical Research, v. 98, no. B2, p. 1813-1815. 


\section{SURFACE-WATER CHEMISTRY}




\section{SURFACE-WATER CHEMISTRY}

TITLE: $\quad$ Origin, Characterization, and Quantification of Natural Organic Solutes in Water (CR 68-046)

PERSONNEL: Ronald L. Malcolm, Project Chief

Cathy M. Rubin, Secretary

Kay R. Kennedy, Chemist

ADDRESS: U.S. Geological Survey, P.O. Box 25046, MS 408, Denver Federal Center, Denver, CO 80225

TELEPHONE: (303) 467-8270

PROBLEM: More than 90 percent of the organic solutes in water are of natural origin. These substances are known to complex trace metals, to transport pesticides, to be precursors of carcinogenic compounds upon chlorination, and to be a food source for aquatic organisms; yet, little is known about the chemistry or source of these organic materials.

OBJECTIVE: (1) Identify and quantify organic solutes that affect water-quality processes; (2) measure the amount of different organic solutes in various hydrologic environments; (3) determine the origin, structure, and reactivity of aquatic humic substances; (4) predict the processes that affect the fate and movement of organic solutes in surface and subsurface environments; and (5) determine the effects of natural organic solutes on water purification processes (reverse osmosis, chlorination, activated charcoal, and ozonation).

APPROACH: Conduct intensive sampling of several rivers, lakes, and interstitial waters in the United States and other countries to determine climatic, geologic, and season variations in natural organic substances. Groundwaters from different types of geologic formations will be sampled to determine possible organic variations with aquifer type. Organic substances from brackish and ocean water will be sampled for type and composition, variations from freshwaters, and for possible effects upon $\mathrm{CO}_{2}$ and climatic fluctuations. Cooperate with other researchers and District programs with emphasis on organic contaminant movement in ground water. From the characterization of natural organic matter, correlate and predict the amount and variety of chlorinated compounds in water. 


\section{SURFACE-WATER CHEMISTRY}

PROGRESS: Four reports were published and two others written.

The hydrophilic Dissolved Organic Carbon (DOC) components are the most important sources of $\mathrm{CO}_{2}$ to the atmosphere. The humic and fulvic acids are refractory and account for 50 plus percent of the DOC. Therefore, DOC is a poor indicator of $\mathrm{CO}_{2}$ potential to the atmosphere.

Hydrophilic acids and hydrophilic neutral organic solutes occur in interstitial waters in greater abundance than in soils and stream waters. These compounds appear to be a source of rapid carbon turnover and a large $\mathrm{CO}_{2}$ source. The release of these substances from permafrost during global warming is a large potential supply of $\mathrm{CO}_{2}$.

\section{REPORTS PUBLISHED 1988-1993:}

Chen, Y. Inbar, Y., Hadar, Y., and Malcolm, R.L., 1989, Chemical properties and solidstate CPMAS 13C-NMR of composted organic matter: The Science of the Total Environment, v. 81/82, p. 201-208.

Chiou, C.T., Kile, D.E., and Malcolm, R.L., 1988, Sorption of vapors of some organic liquids by soil humic acid and its relation to partitioning of organic compounds in soil organic matter: Environmental Science and Technology, v. 22, p. 298-303.

Hayes, M.H.B., MacCarthy, P., Malcolm, R.L., and Swift, R.S., 1989, The search for structure-Setting the scene, in Hayes, M.H.B., MacCarthy, P., Malcolm, R.L., and Swift, R.S., eds., Humic substances II-In search of structure: Chichester, England, John Wiley, p. 3-31.

1989. Humic substances-The emergence of structural forms, in Hayes, M.H.B. MacCarthy, P., Malcolm, R.L., and Swift, R.S., eds., Humic substances II-In search of structure: Chichester, England, John Wiley, p. 687-733.
1989, eds., Humic substances II-In search of structure: Chichester, England, John Wiley, $733 \mathrm{p}$.

MacCarthy, P., Bloom, P.R., Malcolm, R.L., and Clapp, C.E., 1990, Humic substances in soil and crop sciences-An overview, in MacCarthy, P., Clapp, C.E., Malcolm, R.L., and Bloom, P.R., eds., Humic substances in soils and agronomy: Madison, Wis., Soil Science Society of America and American Society of Agronomy, p. 211-271.

MacCarthy, P., Clapp, C.E., Malcolm, R.L., and Bloom, P.R., eds., 1990, Humic Substances in Soils and Agronomy: Madison, Wis., Soil Science Society of America and American Society of Agronomy, 281 p.

MacCarthy, P., Hayes, M.H.B., Malcolm, R.L., and Swift, R.S., 1990 Humic Substances IIIComplexation of Inorganic Ions, Organic Solutes, and Clay Minerals: Chichester, England, John Wiley, 680 p.

MacCarthy, P., and Malcolm, R.L., 1989, On the nature of commercial humic acids, in Suffet, I.H., and MacCarthy, P., eds., Aquatic humic 


\section{SURFACE-WATER CHEMISTRY}

substances-influence on fate and treatment of pollutants: Advances in Chemistry Series 219, p. 55-63.

MacCarthy, P., Malcolm, R.L., Clapp, C.E., and Bloom, P.R., 1990, An introduction to soil humic substances, in MacCarthy, P., Clapp, C.E., Malcolm, R.L., and Bloom, P.R., eds., Humic substances in soils and agronomy: Madison, Wis., Soil Science Society of America and American Society of Agronomy, $p$. 1-12.

Malcolm, R.L., 1989, Applications of solid-state 13C-NMR spectroscopy to geochemical studies of humic substances, in Hayes, M.H.B., MacCarthy, P., Malcolm, R.L., and Swift, R.S., eds., Humic substances II-In search of structure: Chichester, England, Joln Wiley, chap. 12 , p. $339-372$.

1989, The relative importance of $\mathrm{pH}$, charge, and water solubility on the movement of organic solutes in soils and ground water, in Gerstl, Z., Chen, Y., Mingelgrin, U., and Yaron, B., eds., Toxic organic chemicals in porous media: Berlin, Germany, SpringerVerlag, p. 288-301.

1990, Evaluation of humic substances from Spodosols, in Kimble, J.M., and Yeck, R.D., eds., Proceedings of the Fifth International Soil Correlation Meeting (ISCOM), Characterization, Classification, and Utilization of Spodosols in Maine, Massachusetts, New Hampshire, New York, Vermont, and New Brunswick, October 1-4, 1988, Part A (papers), (Lincoln, Nebr.,): United States Department of Agriculture-Soil Conservation Service, $p$. 200-210.

1990, Factors to be considered in the isolation and characterization of aquatic humic substances, in Meeting on Humic Substances in the
Environment, Proceedings: Linkoping, Sweden, Linkoping University, p. 390-417.

1990, The uniqueness of humic substances in each of soil, stream, and marine environments: Analytica Chimica Acta, v. 232, p. 19-30.

1990, Variations among humic substances isolated from soils, stream waters, and ground waters, in MacCarthy, P., Clapp, C.E., Malcolm, R.L., and Bloom, P.R., eds., Humic substances in soils and agronomy: Madison, Wis., Soil Science Society of America and American Society of Agronomy, p. 13-35.

1992, 13C-NMR Spectra and Contact Time Experiment for Skjervatjern Fulvic and Humic Acids: Environment International, v. 18, p. 609-620.

Malcolm, R.L., Aiken, G.R., Bowles, E.C., and Malcolm, J.D., 1989, Isolation of fulvic and humic acids from the Suwannee River, in Averett, R.C., Leenheer, J.A., McKnight, D.M., and Thorn, K.A., eds., Humic substances in the Suwannee River, GeorgiaInteractions, properties, and proposed structures: U.S. Geological Survey Open-File Report 87-557, p. 23-36.

Malcolm, R.L., and MacCarthy, P., 1991, The individuality of humic substances in diverse environments, in Wilson, W.S., ed., Advances in Soil Organic Matter Research-The Impact on Agriculture and the Environment: Cambridge, England, the Royal Society of Chemistry, p. 23-34.

1992, Quantitative Evaluation of XAD-8 and $\mathrm{XAD}-4$ resins used in tandem for removing organic solutes from water: Environment International, v. 18 , p. 597-607. 


\section{SURFACE-WATER CHEMISTRY}

Malcolm, R.L., McKnight, D.M., and Averett, R.C., 1989, History and description of the Okefenokee Swamp-Origin of the Suwannee River, in Averett, R.C., Leenheer, J.A., McKnight, D.M., and Thorn, K.A., eds., Humic substances in the Suwannee River, Georgia-Interactions, properties, and proposed structures: U.S. Geological Survey Open-File Report, 87-557, p. 1-22.

Miano, T.M., Senesi, N., and Malcolm, R.L., 1991, Chemical and spectroscopic properties of river and marine fulvic acids and their metal complexes: Humics-uutiset (Finish Humus News), v. 3, no. 3, p. 145-150.

Reckhow, D.A., Singer, P.C., and Malcolm, R.L., 1990, Chlorination of humic substances-By product formation and chemical interpretations: Environmental Science and Technology, v. 24, p. $1655-1664$.

Reddy, M.M., Leenheer, J.A., and Malcolm, R.L., 1989, Elemental analysis and heat of combustion of fulvic acid from the Suwannee River, in Averett, R.C., Leenheer, J.A., McKnight, D.M., and Thorn, K.A., eds., Humic substances in the Suwannee River, Georgia-Interactions, properties and proposed structures: U.S. Geological Survey Open-File Report 87-557, p. 147-162.

Sarkar, J.M., Malcolm, R.L., and Bollag, J.M., 1988, Enzymatic coupling of 2,4-dichloraphenol to stream fulvic acid in the presence of oxidoreductoses: Soil Science Society of America Journal, v. 52 , no. 3 , p. 688-694.

Thurman, E.M., and Malcolm, R.L., 1989, Nitrogen and amino acids in fulvic and humic acids from the Suwannee River, in Averett, R.C., Leenheer, J.A., McKnight, D.M., and Thorn, K.A., eds., Humic substances in the Suwannee River, Georgia-Interactions, properties, and proposed Structures: U.S. Geological Survey Open-File Report 87-557, p. 99-118. 


\section{SURFACE-WATER CHEMISTRY}

TITLE: $\quad$ Behavior of Natural Polyelectrolytes in Water (CR 68-132)

PERSONNEL: Robert L. Wershaw, Project Chief

Nora L. Bender, Secretary

Kevin A. Thorn, Research Chemist

W.S. Goldenberg, Technician

S.J. Younger, Technician.

ADDRESS: U.S. Geological Survey, P.O. Box 25046, MS 408, Denver Federal Center, Denver, CO 80225

TELEPHONE: (303) 467-8280

PROBLEM: Natural organic polyelectrolytes are highly active materials that are present in practically all natural water systems. They interact with organic and inorganic pollutants and nutrients, influencing-and in many instances, controlling-the toxicity, rate of movement, persistence, and rate of degradation of the pollutants and nutrients in aquatic environments. Detailed knowledge of the chemistry of natural organic polyelectrolytes is therefore of primary importance in understanding the chemical changes that affect all of the components of natural water systems. Organic polyelectrolytes are partially eliminated from drinking water by coagulation and chlorination; however, the products of chlorination are not known. Natural and synthetic organic compounds are present in all natural waters. Some of these compounds are toxic or mutagenic and it is therefore important that they be identified and quantified in surface and ground water and in precipitation.

OBJECTIVE: (1) Isolation of the various organic polyelectrolytes present in natural water systems from different environments; (2) determination of the physical and chemical properties of the most abundant organic polyelectrolytes; (3) elucidation of the mechanisms of interaction of pollutants with natural organic polyelectrolytes; (4) determination of the types of chemical compounds that result from the chlorination of natural polyelectrolytes; (5) development of nuclear magnetic resonance (NMR) spectroscopic methods for the characterization of humic substances; (6) determination and characterization of selected organic pollutants in ground water; (7) elucidation of the mechanisms of humification in natural systems; (8) identification of diagnostic NMR bands of different functional groups found in natural organic polyelectrolytes; (9) characterization of the nitrogen containing species in natural organic polyelectrolytes; (10) identification of the carbohydrates in humic substances. 


\section{SURFACE-WATER CHEMISTRY}

APPROACH: (1) Isolate chemically unique polyelectrolyte fractions using column chromatography, electrophoresis, and other techniques; (2) determine the physical and chemical properties of the fractions using small angle X-ray scattering, ultracentrifugation, and atomic, molecular, and magnetic resonance spectroscopy; (3) use carefully characterized organic polyelectrolyte fractions in experiments designed to elucidate the sorption and solubilization reactions of pollutants and nutrients with natural organic polyelectrolytes; (4) characterize the effect of fulvic and humic acids on the activity of $\mathrm{Na}$ ions in solution by ${ }^{23} \mathrm{Na}$ NMR spectroscopy; (5) isolate selected organic pollutants from ground waters; (6) measure the ${ }^{15} \mathrm{~N}$ NMR spectra of humic substances reacted with selected ${ }^{15} \mathrm{~N}$ labelled reagents; (7) measure the ${ }^{14} \mathrm{~N}$ and ${ }^{15} \mathrm{~N}$ NMR spectra of humic isolates; (8) isolate and identify carbohydrates from soil and compost extracts; (9) characterize by ${ }^{13} \mathrm{C}$ NMR spectroscopy humic substances isolated from water treatment plants and composts.

PROGRESS: (1) The collaborative study of compost leachate from a municipal leaf composting operation near Hartford, Connecticut, is continuing. Leachate samples have been collected from lysimeters installed beneath the compost windrows. Chemical analyses of the leachate have been performed. Two wells have been drilled to the water table, and water samples have been collected from the wells. The nutrient levels in these samples were not elevated.

(2) The first phase of a study of the mechanism of sorption of organic carboxylic acids from compost leachate on alumina has been completed. This study has provided evidence for a multidentate mechanism for the interaction of the carboxylic acid groups with aluminum atoms on the alumina surface. Essentially complete coverage of the alumina surface takes place at concentrations as low as 5 milligrams of acid per liter $(2.5 \mathrm{mg} \mathrm{C} / \mathrm{L})$. This complete coverage is the result of the formation of very strong multidentate aluminum-carboxylate complexes. These results provide a much more detailed description of the process of adsorption of humic substances on mineral surfaces than has previously existed.

(3) A collaborative study with the Comprehensive Organic Analyses project on the characterization of carboxylic acid fractions isolated from the Suwanne River fulvic acid has been initiated. We have been doing the nuclear magnetic resonance (NMR) analyses on the fractions.

(4) The collaborative investigation of the interactions of anthropogenic nitrogen compounds with soil organic matter undertaken with scientists from U.S. Environmental Protection Agency and the California State University at Bakersfield, California, has yielded an number of important results. Carbon-13 NMR studies have demonstrated that atrazine and 


\section{SURFACE-WATER CHEMISTRY}

desethylatrazine can form covalent bonds with humic substances via nucleophilic addition of the amine groups of the triazines to carbonyl groups of the humic substances.

Nitrogen-15 NMR studies have demonstrated that aniline forms covalent bonds with soil humic and fulvic acids both in the presence and absence of phenoloxidase enzymes. Kinetic studies of the binding of aniline to whole soils in the absence of enzymes suggest that reversible hydrophobic and cation exchange processes do not contribute significantly, but that irreversible covalent binding to the organic matter of the soil is the dominant process. A wider variety of covalent bonds is formed in the presence of enzymes, but, overall, the forms of nitrogen incorporated into the humic substances are similar.

Nitrogen-15 NMR studies have confirmed the covalent bonding of ammonia and nitrite to soil humic substances. The fulvic acid fraction appears to bind more ammonia and nitrite than the humic acid fraction.

\section{REPORTS PUBLISHED 1988-1993:}

Aiken, G.R., 1988, A critical evaluation of the use of macroporous resins for the isolation of aquatic humic substances, in Christman, R., and Gjessing, E.T., eds., Humic substances and their role in the environment: Dahlem Conference, 1987 [Proceedings], p. 15-30.

Aiken, G.R., Brown, Pat, Noyes, Ted, and Pinckney, D.J., 1989, Molecular size and weight measurements on Suwannee River fulvic acid, in Averett, R.C., Leenheer, J.A., McKnight, D.M., and Thorn, K.A., eds., Humic substances in the Suwannee River, GeorgiaInteractions, properties, and proposed structures: U.S. Geological Survey Open-File Report 87-557, p. 167-178.

Aiken, G.R., Capel, P.D., Furlong, E.T., Hult, M.F., and Thorn, K.A., 1991, Mechanisms controlling the transport of organic chemical in subsurface environments, in Mallard, G.E., and Aronson, D.A., U.S. Geological Survey Toxic Substances Hydrology Program-Proceedings of the technical meeting, Monterey, Calif., March 11-15, 1991: U.S. Geological
Survey Water-Resources Investigations Report 91-4034, p. 633-637.

Aiken, G.R., and Gillam, A., 1989, Determination of molecular weights of humic substances by colligative property measurements, in Hayes. M.H.B., MacCarthy, Patrick, Malcolm, R.L., and Swift, R.S., eds., Humic substances II-In search of structure: Chichester, England, John Wiley and Sons, p. 515-544.

Aiken, G.R., McKnight, D.M., and Harnish, R.A., 1989, Chemical characteristics of aquatic fulvic acid isolated from Lake Fryxell, Antarctica: Antarctic Journal, 1988 Review Issue, v. XXIII, p. 190-192.

Aiken, G.R., McKnight, D.M., Thorn, K.A., and Thurman, E.M., 1992, Isolation of hydrophilic acids from water using macroporous resins: Organic Geochemistry, v. 18, p. 567-573.

Aiken, G.R., McKnight, D.M., Wershaw, R.L., and Miller, Laurence, 1991, Evidence for the diffusion of aquatic fulvic acid from the sedi- 


\section{SURFACE-WATER CHEMISTRY}

ments of Lake Fryxell, Antarctica, in Baker, R.A., ed., Organic substances and sediments in water: Chelsea, Michigan, Lewis Publishers, p. 75-88.

Aiken, G.R., and Thorn, K.A., 1989, Variability in the chemistry of nonvolatile organic acids downgradient of the oil body at Bemidjii, Minnesota, in Mallard, G.E., and Aronson, D.A., eds., U.S. Geological Survey Toxic Substances Hydrology Program-Proceedings of the technical meeting, Phoenix, Ariz., September 26-30, 1988: U.S. Geological Survey Water-Resources Investigations Report 88-4220, p. 35-40.

Averett, R.C., Leenheer, J.A., McKnight, D.M., and Thorn, K.A., eds., Humic substances in the Suwannee River, Georgia-Interactions, properties, and proposed structures: U.S. Geological Survey Open-File Report 87-557, $377 \mathrm{p}$.

Field, J.A., Barber, L.B., Leenheer, J.A., Rostad, C.E., and Thorn, K.A., 1991, Persistence of linear alkylbenzenesulfonates and their metabolites in sewage contaminated groundwater, in Mallard, G.E., and Aronson, D.A., eds., U.S. Geological Survey Toxic Substances Hydrology Program-Proceedings of the technical meeting, Monterey, Calif., March 1115, 1991: U.S. Geological Survey Water-Resources Investigations Report 91-4034, p. 116-122.

Field, J.A., Leenheer, J.A., Thorn, K.A., Barber, L.B., Rostad, C.E., Macalady, D.L., and Daniel, S.R., 199I, Comprehensive approach for identifying anionic surfactant-derived chemicals in sewage effluent and groundwater: Journal of Contaminant Hydrology, v. 9, p. 55-78.

Folan, D.W., 1990, Quantitation of the hydroxyl group functionality in humic substances using solution-state $\mathrm{C}-13$ and $\mathrm{Si}-29$ nuclear magnetic resonance spectroscopy: Golden, Colo. School of Mines, Ph.D. dissertation, $239 \mathrm{p}$.

Goldberg, M.C., Cunningham, K.M., Aiken, G.R., and Weiner, E.R., 1991, Photolytic decomposition of terpenes in environmental waters: Journal of Contaminant Hydrology, $v$. 9, p. 79-89.

Heasley, V.L., Burns, M.D., Kemalyan, N.A., McKee, T.C., Schroeter, Hinako, Teegarden, B.R., Whitney, S.E., and Wershaw, R.L., 1989, Aqueous chlorination of resorcinol: Environmental Toxicology and Chemistry, v. 8, p. 1159-1163.

Leenheer, J.A., Wershaw, R.L., Brown, P.A., and Noyes, T.I., 1991, Detection of poly(ethylene) glycol residues from nonionic surfactants in surface water by ${ }^{1} \mathrm{H}$ and ${ }^{13} \mathrm{C}$ nuclear magnetic resonance spectrometry: Environmental Science and Technology, v. 25, p. 161-168.

Malcolm, R.L., Aiken, G.R., Bowles, E.C., and Malcolm, J.D., 1989, Isolation of fulvic and humic acids from the Suwannee River, in Averett, R.C., Leenheer, J.A., McKnight, D.M., and Thorn, K.A., eds., Humic substances in the Suwannee River, GeorgiaInteractions, properties, and proposed structures: U.S. Geological Survey Open-File Report 87-557, p. 27-35.

McKnight, D.M., Aiken, G.R., Andrews, E.D., Bowles, E.C., Smith, R.L., Duff, J.M., and Miller, L.G., 1988, Dissolved organic material in desert lakes in the dry valleys: Antarctic Journal, 1988 Review Issue, v. XX III, p. 152-153.

McKnight, D M., Aiken, G.R., and Smith, R.L., 1991, Aquatic fulvic acids in microbially based ecosystems: Results from two Antarctic 


\section{SURFACE-WATER CHEMISTRY}

desert lakes: Limnology and Oceanography, v. 36, p. 998-1006.

McKnight, D.M., Bencala, K.E., Aiken, G.R., Zellweger, G.W., Feder, G.L., and Thorn, K.A., 1992, Sorption of dissolved organic material by precipitated hydrous aluminum and iron oxides at the confluence of Deer Creek with the Snake River, Summit County, Colorado: Environmental Science and Technology, v. 26, p. 1388-1396.

McKnight, D.M., Thorn, K.A., Wershaw, R.L., Bracewell, J.M., and Robertson, G.W., 1988, Rapid changes in dissolved humic substances in Spirit Lake and South Fork Castle Lake, Washington: Limnology and Oceanography, v. 33 (6, part 2), p. 1527-1541.

McKnight, D.M., Wershaw, R.L., Bencala, K.E., Zellweger, G.W., Feder, G.L., 1992, Humic substances and trace metals associated with $\mathrm{Fe}$ and $\mathrm{Al}$ oxides deposited in an acidic mountain stream: The Science of the Total Environment, v. $117 / 118$, p. $485-498$.

Nefcy, A.M., 1990, Chemical characterization of humic acid extracted from a Philippines agricultural soil: Denver, University of Colorado, M.S. thesis, $103 \mathrm{p}$.

Steelink, Cornelius, Wershaw, R.L., Thorn, K.A., and Wilson, M.A., 1989, Application of liquid-state NMR spectroscopy to humic substances, in Hayes, M.H.B., MacCarthy, Patrick, Malcolm, R. L., and Swift, R. S., eds., Humic substances II-In search of structure: Chichester, England, John Wiley and Sons, p. 281-308.

Thorn, K.A., 1989, Nuclear magnetic resonance spectrometry investigations of fulvic and humic acids from the Suwannee River, in Averett, R.C., Leenheer, J.A., McKnight, D.M., and Thorn, K.A., eds., Humic sub- stances in the Suwannee River, Georgia-Interactions, properties, and proposed structures: U.S. Geological Survey Open-File Report 87-557, p. 255-309.

Thorn, K.A., and Aiken, G.R., 1989, Characterization of nonvolatile organic acids resulting from the biodegradation of crude oil by nuclear magnetic resonance spectrometry, in Mallard, G.E. and Aronson, D.A., eds., U.S. Geological Survey Toxic Substances Hydrology Program-Proceedings of the technical meeting, Phoenix, Ariz., September 26-30, 1988: U.S. Geological Survey Water-Resources Investigations Report 88-4220, p. 41-51.

1991, Sources in crude oil of nonvolatile organic acids downgradient from an oil body at Bemidji, Minnesota, in Mallard, G.E., and Aronson, D.A., eds., U.S. Geological Survey Toxic Substances Hydrology Program-Proceedings of the technical meeting, Monterey, Calif., March 11-15, 1991: U.S. Geological Survey Water-Resources Investigations Report 91-4034, p. 654-658.

Thorn, K.A., Arterburn, J.B., and Mikita, M.A., $1992,{ }^{15} \mathrm{~N}$ and ${ }^{13} \mathrm{C}$ NMR investigation of hydroxylamine derivatized humic substances: Environmental Science and Technology, v. 26, p. 107-116.

Thorn, K.A., Folan, D.W., Arterburn, J.B., Mikita, M.A., and MacCarthy, Patrick, 1989, Application of INEPT nitrogen-15 and silicon29 nuclear magnetic resonance spectrometry to derivatized fulvic acids: The Science of the Total Environment, v. 81/82, p. 209-218.

Thorn, K.A., Folan, D.W., and MacCarthy, Patrick, 1991, Characterization of the International Humic Substances Society standard and reference fulvic and humic acids by solution state carbon- 13 and hydrogen-1 nuclear magnetic resonance spectrometry: U.S. Geological 


\section{SURFACE-WATER CHEMISTRY}

Survey Water-Resources Investigations Report 89-4196, 93 p.

Thorn, K.A., and Mikita, M.A., 1992, Ammonia fixation by humic substances: a nitrogen-15 and carbon-13 NMR study: The Science of the Total Environment, v. 113, p. 67-88.

Wershaw, R.L., 1989, Sizes and shapes of humic substances by; scattering techniques, in Hayes, M.H.B., MacCarthy, Patrick, Malcolm, R.L., and Swift, R.S., eds., Humic substances II-In search of structure: Chichester, England, John Wiley and Sons, p. 545-559.

1989, Application of a membrane model to the sorptive interactions of humic substances: Environmental Health Perspectives, v. 83, p. 191-203.

1991, The importance of humic substancemineral particle complexes in the modeling of contaminant transport in sediment-water systems, in Baker, R.A., ed., Organic substances and sediments in water: Chelsea, Michigan, Lewis Publishers, p. 23-34.

1992, Membrane-micelle model for humus in soils and sediments and its relation to humification: U.S. Geological Survey Open-File 91-513, $64 \mathrm{p}$.

1993, Model for humus in soils and sediments: Environmental Science and Technology, v. 27, p. 814-816.

Wershaw, R.L., Aiken, G.R., and Imbrigiotta, T.E., 1991, Characterization of high molecular weight, colored compounds in ground water at Picatinny Arsenal, New Jersey, in Mallard, G.E., and Aronson, D.A., eds., U.S. Geological Survey Toxic Substances Hydrology Program-Proceedings of the technical meeting, Monterey, Calif., March 11-15,
1991: U.S. Geological Survey Water-Resources Investigations Report 91-4034, p. 726-730.

Wershaw, R.L., Pinckney, D.J., Llaguno, E.C., and VicenteBeckett, V., 1990, NMR characterization of humic acid fractions from different Philippine soils and sediments: Analytica Chimica Acta, v. 232, p. 31-42.

Wershaw, R.L., Thorn, K.A., and Pinckney, D.J., 1988, Characterization of humic acid fractions by 13 Nuclear Magnetic Resonance Spectroscopy: Environmental Technology Letters, v. 9. p. 53-62. 


\section{SURFACE-WATER CHEMISTRY}

TITLE: Geochemical Kinetics Studies of Silicate Rock Hydrologic Systems (CR 75-189)

PERSONNEL: Hans C. Claassen, Project Chief

Sandra J. Piksa, Secretary

Douglas R. Halm, Hydrologist

ADDRESS: U.S. Geological Survey, P.O. Box 25046, MS 412, Denver Federal Center, Denver, CO 80225

TELEPHONE: (303) 236-5197

PROBLEM: Adequate description of mass transport in hydrologic systems requires knowledge of the rates of the reactions among the gaseous, solid, and liquid phases present. This knowledge of reaction rates is necessary because many chemical reactions occur simultaneously in natural systems, and only a few of these appear to reach equilibrium, even after long contact times. Therefore, a complete description of the chemical processes and their rates will allow realistic modeling of mass transport in natural and perturbed hydrologic systems.

OBJECTIVE: Determine the relative importance of the factors controlling water quality and devise experiments to quantify the process by studying two model systems representing single lithologies-extrusive volcanic and shale. Determine the kinetics and mechanism(s) of these processes and the effects of natural variation on the controlling factors. Suggest reaction models by combining solution chemistry and the results of surface alteration studies.

APPROACH: Monitor water quality from selected sources in the model study areas on a monthly basis. Monitor measurements of precipitation amounts and quality, soil temperature and moisture profiles, gravitational porewater quality and amount, and soilpore carbon dioxide on either a continuous or periodic basis. On the basis of these measurements, (1) describe the relations between variations in input (recharge) and output (discharge) water quality; (2) design controlled laboratory experiments; and (3) use the results of these laboratory experiments to provide data for elucidation of kinetic mechanisms. Determine changes that occur in the solid phase by use of instrumental (nondestructive) and chemical analytical techniques.

PROGRESS: (1) A model that simulates isotopic changes to snow intercepted on evergreens has been completed and a paper on the subject submitted to Water Resources Research for 


\section{SURFACE-WATER CHEMISTRY}

publication. The model considers isotope diffusion and advection in snowpacks of varying permeability and predicts the range of isotopic composition observed in throughfall collected beneath spruce. The median isotope shift in throughfall was observed to be approximately +2.1 approximately in ${ }^{18} \mathrm{O}$ and approximately +13 in ${ }^{2} \mathrm{H}$. Depending on forest cover and fraction of precipitation that falls as snow, in addition to other factors, the composition of precipitation available for recharge may be significantly modified in some watersheds. It may be anticipated that the model could be applied to predicting isotope changes occurring during firnification of glacier ice. Such modification would alter paleoclimate interpretations derived from the isotope composition of glacier ice.

(2) An analysis of NADP/NTN wet deposition data from three sites in western Colorado strongly suggests that operational characteristics of the wet deposition collector may result in significant amounts of solutes not being collected. Standard atmospheric scavenging equations were applied to the NADP/NTN data to obtain estimates of scavenging equation parameters. The resulting equations were used to examine the amounts of solute not collected, assuming a range of collector performance characteristics. It was concluded that 10-30 percent or more of total deposition may not be collected by sampling at semiarid locations, depending on precipitation rate and atmospheric concentration of solute.

(3) The instrumentation phase in the study of atmospheric and hydrologic fluxes at a Sonoran Desert site (Organ Pipe Cactus National Monument, Arizona) is nearing completion. Nearly all meteorological instrumentation has been operational for 9 months. The objective is to examine flux of water, dry and wet flux of solutes contributing to calcrete formation and salinity of desert soils under an "American Monsoon" climate. It is hoped that this knowledge will contribute to more accurate paleoclimate interpretations of soils in desert climates of the American southwest.

\section{REPORTS PUBLISHED 1987-1992:}

Claassen, Hans C., and Halm, Douglas R., 1992, Design and validation of an onsite atmospheric water vapor sampling system to obtain samples for hydrogen and oxygen isotope analysis: U.S. Geological Survey Open-File Report 92-74, 8 p.

Claassen, Hans C., and Riggs, Alan C., 1993, An estimate of the roughness length and displacement height of Sonoran desert vegetation: U.S.
Geological Survey Water-Resources Investigation Report 92-4065, 16 p.

Kustas, W.P., Goodrich, D.C., Moran, M.S., Amer, S.A., Bach, L.B., Blanford, J.H., Chehbouni, A., Claassen, H., Clements, W.E., Doraiswamy, P.C., Dubois, P., Clarke, T.R., Daughtry, C.S.T., Gellman, D.I., Grant, T.A., Hipps, L.E., Huete, A.R., Humes, K.S., Jackson, T.J., Keefer, T.O., Nichols, W.D., Parry, R., Perry, E.M., 


\section{SURFACE-WATER CHEMISTRY}

Pinker, R.T., Pinter, Jr., P.J., Qi, J., Riggs, A.C., Schmugge, T.J., Shutko, A.M., Stannard, D.I., Swiatek, E., Van Leeuwen, J.D., Van Zyl, J., Vidal, A., Washburne, J., and Weltz, M.A., 1991, An interdisciplinary field study of the energy and water fluxes in the atmosphere biosphere system over semiarid rangelands-Description and some preliminary results: Bulletin of the American Meteorological Society, v. 72, no. 11, p. 1683-1705. 


\title{
SURFACE-WATER CHEMISTRY
}

\author{
TITLE: Water Chemistry of Sediment Surface Coatings (CR 76-199) \\ PERSONNEL: Marvin C. Goldberg, Project Chief \\ Patricia A. Stanile, Accounting Technician \\ Anthony George, Physical Scientist \\ Richard Darsky, Student, (Denver University)
}

ADDRESS: U.S. Geological Survey, P.O. Box 25046, MS 424, Denver Federal Center, Denver, CO 80225

PROBLEM: Local chemical composition of natural waters is heavily influenced by sediment surface reactions. This is attributed to sorption phenomena on the sediment surface as the sediments will carry larger concentrations of many materials, such as trace metals, pesticides, and salts, than does the water. These sorbed species are interactive across the solidliquid interface and may move in either direction in response to changes in chemical potential set up on either side of the interface. As is well known, sediments act as sources, sinks and carriers of a variety of chemical species. To understand the processes controlling a main source of materials that enter and exit water systems, one must understand the variety of reactions taking place that govern the distribution of chemical species between the solid and liquid phases. The solid phase acquires coatings as a consequence of its prior reactive history; these coatings are important parameters in determining the current surface chemical reactivity. An understanding of the coating process, the chemical composition of the coating (adsorbate) and the chemical reactivity of the coatings when exposed to various bulk water compositions is a prerequisite for definition, prediction and control of water quality.

OBJECTIVE: (1) Examine natural sediment surfaces to elucidate their surface chemical composition so that the rate determining sorption processes that occur on these surfaces are described for various particle coatings; (2) correlate these sorption reactions with specific molecular species that reside on the surface; (3) examine the chemical processes by which sediment coatings are formed and the nature of the bonding between coatings and sediment surfaces; (4) determine the role that photolysis plays in substratecoating interactions, specifically redox potential, mineral dissolution and decomposition; and (5) determine the applicability of natural fluorescence emanating from surface coatings and materials in water, monitoring movement in the hydrologic system, and identifying the materials being transported.

APPROACH: Spectroscopic methods will be used to determine the surface chemical composition of natural and prepared sediment coatings. Several techniques will be used 


\section{SURFACE-WATER CHEMISTRY}

including Fourier Transform Infrared Spectroscopy, Fluorescence Depolarization Spectroscopy and Ultraviolet Visible absorption spectroscopy. The substrates selected for this work will be iron-oxyhydroxides, preferably Goethite, Manganite and Gibbsite. The redox reactions that are induced by changes in chemical potential or photolysis in the substrate and the coating will be examined. This data should provide fundamental information on the basic chemical and geochemical processes in water, aid in conducting evaluations of water quality, and aid in obtaining a better understanding of the reactions of the chemicals that are suspended or dissolved in water. Molecular properties of ubiquitous materials in water such as the humic and fulvic species will be determined as a step towards understanding the molecular reactivity of these materials and their role in aquatic chemistry. Steady state and dynamic depolarization studies will be carried out to measure size, shape, and molecular bonding energies of selected materials. Further characterization by three dimensional fluorescence spectroscopy of various species will be performed. Iron oxyhydroxides adsorbates of soluble organic materials, such as acids, aldehydes, ketones, and other synthetic and natural products that enter water systems, will be photolysed to determine the interfacial effect between the adsorbate and the aqueous phase and also the adsorbate and the substrate in abiotic reactions such as photolysis. Excitation Emission Matrix (EEM) spectra will be measured on samples from selected sites to determine the applicability of this measurement to hydrologic studies of material transport.

PROGRESS: Samples taken during the past 2 years, both in the summer and winter, in the Sacramento River Delta showed a wide variability in abiotic degradation. Depending on location, the values ranged from $10^{-18}$ to $10^{-14}$ in steady state hydroxyl radical concentration. Correlations indicate a relation between the photolytic activity found in parts of the river and transport of the materials that enter the river via tributaries, channels, and a network of sloughs. The present data are being used to describe the photolytic activity in the main channel of the Sacramento River from the Colusa drain to Isleton. The photolytic activity controlled by materials that enter through sloughs and timed releases are yet to be considered.

Samples taken in Yellowstone Park, Wyoming, of the tributaries to the Gibbon and Firehole Rivers which flow into the Madison River and of the Madison River itself revealed that relatively little organic matter is found in the pools and rivers which are above 30 degrees Centigrade. It was found that some anthropogenic material is injected into the Gibbon River at Elk Park and the Excitation Emission Matrix (EEM) fluorescence signature is detectable until the River enters the Madison River. Continued use of EEM spectroscopy to trace surfacewater and groundwater transport of fluorophoric materials has allowed low cost, rapid measurement of organic fluorophores in these river systems. 


\section{SURFACE-WATER CHEMISTRY}

A continuing surveillance of the effects caused by loss of vegetation in the Yellowstone fire, shows little changes in the photolytic index, measured as sunlight induced steady state hydroxyl radical concentration. The replacement of vegetation is not sufficiently rapid to change the sunlight intensities in the main surface water systems in the park.

Continuing cooperative studies between the U.S. Geological Survey and the Bureau of Reclamation on desalinization of water were vigorously pursued. The Yuma water desalinization plant, operated by the U.S. Bureau of Reclamation, uses reverse osmosis membranes to desalinate water. The practicality of desalinization of water depends upon the lifetime of the reverse osmosis membranes that are responsible for separating the salt from the water. The factors which degrade these membranes while in use is a prime consideration in prolonging the lifetime of the membranes and thus reducing the cost of desalting the water. Studies, using Raman Spectroscopy, on the Reverse Osmosis membranes used in the Yuma pilot plant for water desalinization, were undertaken to evaluate the molecular degradation that occurs to the cellulose acetate membranes during plant operation. Comparison of new membranes to spent membranes showed a loss of acetate moieties in spent membranes. A controlled study of the degradating effects of $\mathrm{pH}$ and hypochlorite, are being evaluated. Preliminary results indicate a strong susceptibility of the membranes to hydrolysis at high $\mathrm{pH}$. With chlorine present, the degradation is more rapid. The ether linkage in the cellulose ring structure is broken and the monomer linkages in the polymer are broken. A rate of acetate loss can be established which seems to correlate with loss of reverse osmosis function. Initial data indicate that, when subject to decomposing chemicals, the membrane retains its character for a given threshold time then degrades at rates dependent upon the concentration of the attacking chemicals.

\section{REPORTS PUBLISHED 1988-1992:}

Cunningham, K.M., Goldberg, M.C., and Weiner, E.R., 1987, An examination of iron oxyhydroxide photochemistry as a possible source of hydroxyl radical in natural waters, in Averett, R.C., and McKnight, D.M., eds., Chemical Quality of Water and the Hydrologic Cycle: Chelsea, Michigan, Lewis Publishers, Inc., p. 359-363.

1988, Mechanisms for the aqueous photolysis of adsorbed benzoate, oxalate and succinate on iron oxyhydroxide (goethite) surfaces: Envi- ronmental Science and Technology, v. 22, no. 9, p. 1090-1097.

Goldberg, M.C., 1987, The use of isosbestic points in the fluorescence excitation spectrum of humic acid to calculate the dissociation constant: Canadian Journal of Soil Science, v. 67, p. 715-717.

1989, Determination of the extent of hydration of macromolecules by use of fluorescence depolarization spectroscopy: Proceedings of the International Syposium on Quantitative 


\section{SURFACE-WATER CHEMISTRY}

Luminescence Spectrometry, 3rd, Ghent, Belgium, May 1989, 9 p.

1989, Luminescence applications in biological, chemical, environmental, and hydrological science, Preface and Introduction: American Chemical Society Symposium, Series 383, Washington, D.C., 1989, 251 p.

1989, Structural components and proposed structural models of fulvic acid from the Suwannee River, Georgia: U.S. Geological Survey Open-File Report 87-557, p. 331-366.

Goldberg, M.C., Cunningham, K.M., and Sigleo, A.C., 1989, Abiotic photolysis in the Calcasieu River, Louisiana, in Mallard, G.E., and Ragone, S.E., eds., U.S. Geological Survey Toxic Substances Hydrology Program-Proceedings of the technical meeting, Phoenix, Ariz., September 1988: U.S. Geological Suvey Water-Resources Investigation Report 88-4220, p. 329-340.

Goldberg, M.C., Cunningham, K.M., and Squillace, P.J., 1992, Photolytic degradation of atrazine in the Cedar River, Iowa, in Mallard, G.E., and Aronson, D.A., eds., U.S. Geological Survey Toxic Substances Hydrology Program-Proceedings of the technical meeting, Monterey, Calif., March 1991: U.S. Geological Survey Water-Resources Investigations Report 97-4034, p. 232-239.

Goldberg, M.C., Cunningham, K.M., and Weiner, E.R., 1992, The aqueous photolysis of alpha pinene in solution with humic acid: Toxicological and Environmental Chemistry, v. 9, p. 79-89.

Goldberg, M.C., Cunningham, K.M., Weiner, E.R., and Aiken, G.R., 1991, Photolytic decomposition of terpenes in environmental waters: Journal of Contaminant Hydrology, v. 7, p. 79-89.
Goldberg, M.C., and Negomir, P.M., 1989, Characterization of aquatic humic acid fractions by fluorescence depolarization spectroscopy: in Goldberg, M.C., ed., Luminescence Applications in Biological, Chemical Environmental and Hydrologic Sciences: American Chemical Society Symposium, Series 383, Washington, D.C., 1989, p. 180-205.

Goldberg, M.C., and Weiner, E.R., 1989, Fluorescence measurements of the volume, shape and fluorophore composition of fulvic acid from the Suwannee River, in Humic Substances in the Suwannee River, Georgia: U.S. Geological Survey Open-File Report 87-557, p. 179-204.

1989, The science of luminescence, in Goldberg, M.C., ed., Luminescence Applications in Biological, Chemical, Environmental and Hydrological Sciences: American Chemical Society Symposium, Series 383, Washington, D.C., 1989, p. 1-22.

Sigleo, A.C., Cunningham, K.M., Goldberg, M.C., and Kimball, B.A., 1988, Hydroxyl radical formation in St. Kevins Gulch, an iron rich stream in Colorado, in Mallard, G.E., and Ragone, S.E., eds., U.S. Geological Survey Toxic Substances Hydrology ProgramProceedings of the technical meeting, Phoenix, Ariz., 1988: U.S. Geological Survey WaterResources Investigations Report 88-4220, p. 125-129. 


\section{SURFACE-WATER CHEMISTRY}

TITLE: $\quad$ Research in Analytical Environmental Trace Element Chemistry and Its Impact on Water Quality (CR 83-282)

PERSONNEL: Howard E. Taylor, Project Chief

Darlene Puhr, Secretary

Terry I. Brinton, Chemist

Dale B. Peart, Hydrologist

David A. Roth, Student, (Colorado State Univ.)

Ronald C. Antweiler, Hydrologist

ADDRESS: $\quad$ U.S. Geological Survey, 3215 Marine Street, Boulder, CO 80303

TELEPHONE: (303) 541-3007

PROBLEM: The determination of inorganic constituents and their impact on water quality requires an in-depth knowledge of interactive water chemistry relationships. The ability to measure trace and ultratrace concentration levels of inorganic constituents as well as their chemical form and speciation plays a significant role in understanding their chemical, toxicological, transport and overall environmental impact on surface- and ground-water hydrology. The development of state-of-the-art analytical chemistry technology for the solution of specific hydrologically related problems requires extensive laboratory and field research and development effort.

OBJECTIVE: (1) Investigate and develop new concepts and approaches to the identification and measurement of inorganic constituents in water and water related materials. (2) Formulate techniques for the utilization of new field and laboratory technology for the assessment on water quality. (3) Participate in multidisciplinary research programs providing expertise in the field of inorganic water chemistry.

APPROACH: (1) Study the occurrence and distribution of inorganic constituents (trace metals, nutrients, molecular ionic species, organic complexes, and so forth) in hydrologic systems. (2) Study water chemical interactive relationships and assess their impact of water quality. (3) Develop field and laboratory technology for sampling and measurement of trace and ultratrace concentrations of toxic and other inorganic constituents in water and waterrelated materials. (4) Define relative importance of various impacts on water quality in specific hydrologic environments (such as, acid rain, geochemical industrial pollution, water treatment, agrichemical, and so forth). (5) Evaluate transport phenomena of inorganic constituents in hydrologic systems. 


\section{SURFACE-WATER CHEMISTRY}

PROGRESS: (1) Development of technology was continued for the direct measurement of ultra-trace (nanogram/liter) concentrations of constituents in hydrologic systems by state-ofthe-art analytical laboratory instrumentation, including but not limited to inductively-coupled plasma mass spectrometry (ICPMS). Techniques and methodology were pioneered for the measurement of stable isotope ratios of selected heavy metals at trace (microgram/liter) concentration levels in natural waters for use as tracers. Instrumentation modifications were investigated to improve measurement precision, stability and sensitivity. (2) Research continues to develop the technique of sedimentation field flow fractionation coupled with ICPMS (SdFFF-ICP-MS) to study the geochemistry of trace elements associated with colloidal and sub-micrometer diameter particulate material from natural surface water systems. (3) Research was performed, including field studies, to measure the occurrence, distribution and fate of trace metals, major water chemistry and nutrients in the Mississippi River system. This includes the investigation of interaction of trace metals with other water chemical parameters, with emphasis on the distribution between various size fractions of suspended material, silts, colloids, and bed sediments. Studies were performed to representatively collect and separate statistically valid and uncontaminated samples. Field studies were also carried out to determine interactions of contaminants with each other and suspended sediment at primary mixing zones below confluences of tributaries. This research included studies of bed sediment materials and pore water samples. Sequential extraction techniques were developed for the study of the partitioning of trace elements between the various chemical fractions of bed sediment materials. (4) Research studies were continued to develop an understanding of the geochemistry of mercury and its fate in large river systems including the Mississippi and Colorado Rivers. (5) Research was performed to measure the relationship between water chemistry constituents and the occurrence and distribution of benthic invertebrate populations in rivers and streams. Field work was performed in the Gibbon and Firehole Rivers in Yellowstone National Park and rivers and streams in the Catskill Mountains, New York. (6) Studies continued to evaluate the chemical composition of ice layers in glaciers from the Wind River Mountain range in Wyoming. These studies will assist in evaluating climatic changes and atmospheric deposition. (7) Research was continued to study the water quality of the Colorado River system and the impacts from Glen Canyon dam operation on the ecology and water quality of the river systems. This included the analysis of samples and interpretation of data collected from two large scale synoptic sampling experiments in November 1990 and June 1991. Results of this research will assist in developing an understanding of the occurrence, distribution and chemistry of water quality constituents related to controlled and variable hydrologic discharge. (8) Studies were undertaken to establish the chemical water quality of tributaries to the Colorado River in the Grand Canyon to develop an understanding of the ecological impacts of land use in the watersheds of the tributaries. (9) Studies were initiated to evaluate the occurrence, distribution and 


\section{SURFACE-WATER CHEMISTRY}

interaction of trace elements in the delta's of the Colorado River and San Juan River arms of Lake Powell. (10) Multi-year research studies were initiated to assess the chemical and biological water quality of the surface waters in Yellowstone National Park using state-of-theart field and laboratory techniques.

\section{REPORTS PUBLISHED 1988-1993:}

Antweiler, R.C., Patton, C.J., and Taylor, H.E., 1993, Automated colorimetric methods for determination of nitrate plus nitrite, ammonium, and orthophosphate ions in natural water samples: U.S. Geological Survey Open-File Report 93-638, 63 p.

Brenner, I.B., Nishri, A., Taylor, H.E., and Garbarino, J.R., 1993, Trace metal distribution in Lake Kinneret waters-Investigation of the mode of occurrence of metals in lake systems: Israel Oceanographics and Limnological Research Report No. TR-GSI/13/93, p. 35.

Brenner, I.B., and Taylor, H.E., 1992, A critical review of inductively coupled plasma-mass spectrometry for geoanalysis, geochemistry and hydrology, Part 1, Analytical performance: Critical Reviews in Analytical Chemistry, v. 11, p. 452-463.

Garbarino, J.R., Taylor, H.E., and Batie, W., 1989, Simultaneous determination of major and trace elements by inductively-coupled plasma mass spectrometry/optical emission spectrometry: Analytical Chemistry, v. 61, p. 793-796.

Leenheer, J.A., Meade, R.H., Taylor, H.E., and Pereira, W.E., 1989, Sampling, fractionation and dewatering of suspended sediment from the Mississippi River for geochemical and trace-contaminant analysis, in Mallard, G.E., and Ragone, S.E., eds., U.S. Geological Survey Toxic Substances Hydrology Program-Proceedings of the technical meeting, Phoenix, Ariz., September 26-30, 1988: U.S.
Geological Survey Water-Resources Investigations Report 88-4220, p. 501-511.

Naftz, D.L., Taylor, H.E., Ranville, J.R., and Rice, J.A., 1989, Glacier-ice geochemistry, Knife Point Glacier, Wind River Range, Wyoming-Reconnaissance-Phase Results: EOS transactions, American Geophysical Union v. 70, no. 43, p. 1084-1085.

Shekiro, J.M. Jr., Skogerboe, R.K. and Taylor, H.E., 1988, Mechanistic characterization of chloride interferences in electrothermal atomization systems: Analytical Chemistry, v. 60 , p. 2578-2582.

1988, Use of Electrothermal Vaporization multiple-wavelength absorption spectrometry to qualitatively screen for the presence of polynuclear aromatic hydrocarbons: Environmental Science and Technology, v. 22, p. 338-344.

Taylor, H.E., 1989, Water resources, in Date, A.R., and Gray, A.L., eds., Applications of inductively-coupled plasma mass spectrometry: London, Blackie, 71 p.

Taylor, H.E., and Averett, R.C., 1991, Description of water quality synoptic experiments in the Colorado River, in Mallard, G.E., and Aronson, D.A., eds., U.S. Geological Survey Toxic Substances Hydrology Program-Proceedings of the technical meeting, Monterey, Calif., March 11-15, 1991: U.S. Geological Survey Water-Resources Investigation Report 91-4034, p. 576-578. 


\section{SURFACE-WATER CHEMISTRY}

Taylor, H.E. and Averett, R.C., 1993, Measuring Colorado River water quality in the Grand Canyon National Park: Park Service, Winter Issue, p. 12-14.

Taylor, H.E., Beaulieu, P.R. and Skogerboe, R.K., 1988, Design and operation of a multielement photodiode-array atomic absorption spectrometer: U.S. Geological Survey Open-File Report No. 87-4206, 19 p.

Taylor, H.E., and Garbarino, J.R., 1988, Assessment of the analytical capabilities of inductively-coupled plasma mass spectrometer: Journal of Research of the National Bureau of Standards, v. 93, p. 433-435.

1989, The Occurrence and Distribution of Selected Trace Metals in the IHHS Standard Humic and Fulvic Acids: U.S. Geological Survey Open-File Report No. 87-557, 14 p.

1991, The Measurement of Trace Metals in Water Resource Monitoring Samples by Inductively-coupled Plasma Mass Spectrometry: Spectrochimica Acta Reviews, v. 14, p. 3343.

1992, Analytical applications of inductively coupled plasma-mass spectrometry, in Montaser, A., and Golightly, D.W., eds., Inductively coupled plasmas in atomic spectrometry: VCH Verlogsgesellschaft, $\mathrm{mbH}$, 2nd Edition, p. 651.

Taylor, H.E., Garbarino, J.R. and Brinton, T.I., 1990 , The occurrence and distribution of trace metals in the Mississippi River and its tributaries: The science of the total environment, $v$. 97/98, p. $369-384$.

Taylor, H.E., Garbarino, J.R., Murphy, D.M., and Beckett, R., 1992, Inductively coupled plasmamass spectrometry as an element specific de- tector for field-flow fractionation: Analytical Chemistry, v. 64, p. 2036-2042.

Taylor, H.E., Garbarino, J.R., and Koirtyohann, S.R., 1991, Flame ionization mass spectrometry, isotope ratio determinations for potassium: Applied Spectroscopy, v. 45, p. 886-889.

Taylor, H.E., Shiller, A.M., Garbarino, J.R., and Brinton, T.I., 1993, Dissolved trace metal data from intercomparison experiments in the Mississippi River and its tributaries between the U.S. Geological Survey's National Research Program and the National Stream Quality Accounting Network and the University of Southern Mississippi: U.S. Geological Survey Open-File Report 93-628, 43 p. 


\section{SURFACE-WATER CHEMISTRY}

TITLE: $\quad$ Aqueous Crystal Growth and Dissolution Kinetics of Earth Surface Minerals (CR 83-284)

PERSONNEL: Michael M. Reddy, Project Chief

Debra A. Litwin, Secretary

Paul F. Schuster, Hydrologist

Charmaine D. Gunther, Computer Asst.

R. Fedors, Hydrologist
S. Leith, Chemist

S. Charlton, Hydrologic Technician

T. Henrikson, Hydrologic Technican

H. Brainerd, Hydrologic Technican

ADDRESS: $\quad$ U.S. Geological Survey, P.O. Box 25046, MS 458, Denver Federal Center, Denver, CO 80225

TELEPHONE: (303) 541-3012

PROBLEM: Accelerated decay of carbonate stone monumental works and building materials is apparent in several areas of the United States. This accelerated weathering has been attributed to air pollution and (or) acid deposition; however, little fundamental understanding of processes involved or quantitative relations between important variables are available.

OBJECTIVE: Determine carbonate stone dissolution processes and rates in natural and polluted environments. Attempt to separate the effects of wet deposition from the effects of dry deposition and normal weathering processes.

APPROACH: Onsite measurements of acid rain dissolution and damage to carbonate stone will be used, with supplemental well-controlled laboratory studies and reaction modeling. Onsite studies involve collection of rainfall leachate solutions from an inert reference surface and from limestone and marble surfaces at five acid rain impacted locations: Chester, N.J.; Newcomb, N.Y.; Research Triangle Park, N.C.; Steubenville, Ohio; and Washington, D.C. Air quality, meteorology, rainfall and rain-runoff quality and changes in the chemical composition of limestone and marble will be used to develop a quantitative description of carbonate stone dissolution and damage due to acid rain and air pollution. Laboratory studies and reaction modeling will be used to identify processes involved in acid rain damage and dissolution.

PROGRESS: A manuscript (Atmospheric Environment, 1992) showing that acid rain and air pollution cause 30 percent of the total carbonate stone dissolution at selected field sites has been published. The remaining 70 percent of carbonate stone dissolution is accounted for by the solubility in rain. These results are for marble and limestone slabs exposed at an angle of 


\section{SURFACE-WATER CHEMISTRY}

the solubility in rain. These results are for marble and limestone slabs exposed at an angle of 30 degrees from horizontal. The relative contribution of sulfur dioxide to chemical erosion is significantly enhanced for stone slabs having an inclination of 60 degrees or 85 degrees. The dry deposition of alkaline particulate material has a mitigating effect at the two urban exposure sites at Washington, D.C. and Stubenville, Ohio.

A recent paper (Journal of Chemical Education, 1993) has examined field experiments designed to estimate carbonate stone dissolution by acid rain. The stoichiometry of the reaction of stone with hydrogen ion is difficult to define from the field data due to scatter in the data attributed to hydrodynamic effects. Laboratory experiments show that the rain solutions reacting with the surface of carbonate stone are close enough to equilibrium for the incremental effect of hydrogen ion to be minor (for example, 24 percent for marble for a rain of $\mathrm{pH} 4.0$ ) relative to dissolution due to water and carbonic acid reactions.

A manuscript reporting that acid dissociation and metal ion complexation equilibria of linear, weak-acid polyelectrolytes responds to changes in solution composition in similar ways to their cross-linked gel analogues was published (Journal of Physical Chemistry, 1991). The Gibbs-Donnan model of ionic distribution in solution explains this observation and indicates that the linear polyelectrolyte in solution develops a counterion-concentrating region that closely resembles the gel phase.

\section{REPORTS PUBLISHED 1988-1993:}

Baedecker, P.A., and Reddy, M.M., 1993, The erosion of carbonate stone by acid rainLaboratory and field investigations and a review of the chemistry of carbonate stone weathering: Journal of Chemical Education, v. 70 , no. 2 , p. $104-114$.

Baedecker, P.A., Reddy, M.M., Reimann, K.J., Sciammarella, C.A., and Sherwood, S.A., 1992, Effects of acidic deposition on the erosion of carbonate stone-Experimental results from the U.S. National Acid Precipitation Assessment Program (NAPAP): Atmospheric Environment, v. 26B, no. 2, p. 147-158.

Baedecker, P.A., Reddy, M.M., Sciammarella, C.A., and Reimann, K.J., 1990, 3.3.3.3 Field experiments-physical measurements of reces-
sion-Results and discussion in acidic deposition: State of Science and Technology, Report 19, Effects of Acidic Deposition on Materials, National Acid Precipitation Assessment Program, Washington, D.C., p. 19-125 to 19131.

Ephraim, J.H., Reddy, M.M., and Marinsky, J.A., 1991, Ion binding by humic substances: Considerations based on the solution chemistry and heterogeneity of humic substances, in Lecture Notes in Earth Sciences, No. 33, Humic Substances in the Aquatic and Terrestrial Environment: International Symposium, Linkoping, Sweden, August 21-23, 1989, [Proceedings], p. 263-275. 


\section{SURFACE-WATER CHEMISTRY}

Johnsson, P. A., and Reddy, M.M., 1990, A monitor for continuous measurement of temperature, $\mathrm{pH}$, and conductance of wet precipitation, Preliminary results from the Adirondack Mountains, New York: Atmospheric Environment, v. 24A, No. 1, p. 233-236.

Leenheer, J.A., Wershaw, R.L., and Reddy, M.M., 1992, Strong-acid, carboxyl-group structures in fulvic acid from the Suwannee River, Georgia: American Chemical Society Meeting, Division of Environmental Chemistry, Denver, Colo., March 29-April 3, 1993. p. 25-27.

Marinsky, J.A., and Reddy, M.M., 1991, Employment of Gibbs-Donnan-based concepts for interpretation of the properties of linear polyelectrolyte solutions: Journal of Physical Chemistry, v. 95, no. 24, p. 10208-10214.

1991, Vapor-pressure osmometric study of the molecular weight and aggregation tendency of a reference-soil fulvic acid: Analytica Chimica Acta, v. 232, p. 123-130.

Marinsky, J.A., Reddy, M.M., Ephraim, J., and Mathuthu, A., 1988, Ion binding by humic and fulvic acids-A computational procedure based on functional site heterogeneity and the physical chemistry of polyelectrolyte solutions: Swedish Nuclear Fuel and Waste Management Company Technical Report 88-04.

Reddy, M.M., 1988, Acid-rain damage to carbonate stone, A quantitative assessment based on the aqueous geochemistry of rainfall runoff: Earth Surface Processes and Landforms, v. 13 , p. $335-344$.

1988, Physical-chemical mechanisms that affect regulation of crystallization, in Sikes, C.S., and Wheeler, A.P., eds., Chemical aspects of regulation of mineralization: Proceedings of the Division of Industrial and
Engineering Chemistry of the American Chemical Society, Mobile, Ala., University of South Alabama Publications Services, p. 1-8.

1989, Ancient works, monuments and historical sites: EOS, February 21, p. 114.

1989, Effects on carbonate-dissolution-runoff experiments in materials and cultural resource effects, Task Group VII, Research Program, Washington, D.C., in Proceedings of Materials and Cultural Resources Effects Program Review: National Acid Precipitation Assessment Program, the Interagency Task Force on Acid Precipitation, Charleston, S.C., January 22-27, 1989, p. 221-228.

1989, Preserving and protecting monuments and historical sites: Environmental Science and Technology, v. 23, no. 3, pp. 264-265.

1991, Acid rain and air pollution effects on car-bonate-stone-Dissolution-runoff experiments in the conservation of monuments, in Zezza, Fulvia, ed., the Mediterranean Basin: Proceedings of the 1st International Symposium, Bari, Italy, p. 359364.

1991, Field experiments run-off measurements, experimental methods, in Acidic deposition: State of science and technology, report 19, Effects of acidic deposition on materials, National Acid Precipitation Assessment Program, Washington, D.C., p. 19-108 to 19-110.

1991, Soil analysis--Modern instrumental techniques, second edition, book review: Journal of the American Chemical Society, v. 113, no. 26, p. 9910.

Reddy, M.M., and Baedecker, P.A., 1991, Field experiments run-off measurements-Results and discussion, in Acidic Deposition: State of Science and Technology, Report 19, Effects of Acidic Deposition on Materials, National Acid 


\section{SURFACE-WATER CHEMISTRY}

Precipitation Assessment Program, Washington, D.C., p. 19-110 to 19-121.

Reddy, M.M., and Caine, Nel, 1989, A small alpine basin budget-Front Range Colorado, in Poppoff, I.G., Goldman, C.R., Loeb, S.L. and Leopold, L.B., eds., International Mountain Watershed Symposium-Subalpine Processes and Water Quality, Tahoe Resource Conservation District, South Lake Tahoe, Calif., p. 370-385.

Reddy, M.M., and Leith, S.D., 1993, Dry deposition of sulfur to limestone and marble-Preliminary evaluation of a process based model: Division of Environmental Chemistry, American Chemical Society National Meeting, Denver, Colo., March 29-April 23, 1993, p. 43-46.

Reddy, M.M., and Mossotti, V.G., 1990, Stone wetness and water transport in limestone in acidic deposition: State of Science and Technology, Report 19, Effects of Acidic Deposition on Materials, National Acid Precipitation Assessment Program, Washington, D.C., p. 19-145 to 19-146.

Reddy, M.M., Schuster, P.F., and Harte, J.J., 1989, Summary of data from onsite and laboratory analysis of precipitation runoff from carbonate-stone surfaces, National Acid Precipitation Assessment Program, June 1984 to November 1987: U.S. Geological Survey Open-File Report 89-246, 19 p.

Schuster, P.F., Reddy, M.M., and Sherwood, S.I., 1992, A quantitative field study of the role of acid rain and sulfur dioxide in marble dissolution: Proceedings of the 2nd International Symposium for the Conservation of Monuments in the Mediterranean Basin, Geneva, Switzerland, November 19-21, 1991, p. 257266.
See, R.B., Reddy, M.M., and Martin, Richard G., 1988, Description and testing of three moisture sensors for measuring surface wetness on carbonate building stones: Review of Scientific Instruments, v. 59, no. 10 , p. 2279-2283.

Sherwood, S.I., and Reddy, M.M., 1988, A field study of pollutant effects on carbonate stone dissolution, in Marinos, P.G., and Koukis, G.C., eds., The Engineering Geology of Ancient Works, Monuments and Historical Sites-Preservation and Protection: Proceedings of an International Symposium Organized by the Greek National Group of IAEG', Athens, 19-23 September, 1988, p. 917-923.

Tipping, E., Reddy, M.M., and Hurley, M.A., 1991, Modeling electrostatic and heterogeneity effects on proton dissociation from humic substances: Environmental Science and Technologý, v. 24 , no. 11, p. 1700-1705. 


\title{
SURFACE-WATER CHEMISTRY
}

TITLE: $\quad$ Comprehensive Organic Analysis of Water (CR 84-285)

\author{
PERSONNEL: Jerry A. Leenheer, Project Chief \\ Cathy M. Rubin, Secretary Ted I. Noyes, Chemist \\ Larry B. Barber, Geologist Gregory K. Brown, Chemist

\begin{abstract}
ADDRESS: $\quad$ U.S. Geological Survey, P.O. Box 25046, MS 408, Denver Federal Center, Denver, CO 80225
\end{abstract}

TELEPHONE: (303) 467-8290

PROBLEM: A disproportionate amount of research in water chemistry has been directed towards defining trace levels of organic contaminants in water, whereas the structures and characteristics of natural organic substances, in the dissolved, suspended, and bed sediment phases, are very poorly understood. A better knowledge of the nature of natural organic substances in water is essential to the advancement of many diverse sciences, such as organic geochemistry, aquatic biology, soil science, hydrology involving contaminant transport, and even atmospheric chemistry involving carbon cycle research. The Water Resources Division is conducting significant research on the nature of humic substances in water, which comprise less than one-half of the total organic carbon in water; a comprehensive study of the entire suite of compound classes comprising natural organic substances has been lacking.

OBJECTIVE: Conduct comprehensive organic analyses of various surface-water samples where comprehensive analyses is defined as "state-of-the-art" organic analyses on as many classes (humic substances, lipids, proteins, carbohydrates, etc.) as possible within the time and resource limitations of the project. Develop chromatographic, selective extraction, and derivatization methods for organic substance characterization by infrared, nuclear magnetic resonance, and mass spectrometric methods. Define the chemical, biologic, and hydrologic processes that both produce and diagenetically alter natural organic substances in water. Conduct interdisciplinary studies with colleagues to determine significance and mechanisms of contaminant binding with natural organic substances.

APPROACH: Characterize phytoplanktonic inputs to natural organic substances in fresh water (Island Lake, Nebraska) and saline water (Big Soda Lake, Nevada); study terrestrial vegetative contributions in the Suwannee River in southern Georgia, a subtropical environment, and in the Sagavanirtok River of Alaska, an arctic environment. Determine spatial and seasonal differences of organic substances in the dissolved, suspended, and bed sediment phases in the Mississippi River, an integrating environment, to determine the nature 


\section{SURFACE-WATER CHEMISTRY}

and importance of these various organic phases with regards to contaminant interactions and transformations. Apply techniques used to characterize natural organic substances to study organic contaminant transport processes in ground water at Cape Cod, Massachusetts, and in the Mississippi River. If unknown organic contaminants are discovered during the above studies, characterize and quantitate the contaminants.

PROGRESS: The major activity for the year was to complete an interdisciplinary study of the water quality of the Mississippi River sampled between Minneapolis-St. Paul, Minnesota, and New Orleans, Louisiana. The project concentrated on defining sewage contaminants and on the natural organic geochemistry of dissolved and particulate phases in the river that affect contaminant transport and fate. Major findings of sewage contamination, specific surfactant analyses, fecal coliform measurements and fecal sterol analyses of bed sediments, found severe contamination from sewage inputs from St. Louis, Missouri, to the confluence with the Ohio River. Lessor amounts of sewage contaminants were found in the Minneapolis-St. Paul region and where the water quality of the river with respect to sewage contaminants appeared to be improving with time.

The colloidal fraction of suspended sediments from the Mississippi River was found by coworkers to be a major transport agent of insoluble contaminants. These colloids were found to be transported in a physically and chemically conservative matter, and organic matter was found to be instrumental in keeping the colloids dispersed in water and in serving as a substrate into which contaminants partitioned. Spectral characterization of the colloids found bacteria, lipids, proteins, and sugars to be major organic constituents of colloids. Both suspended and bed sediments were found to be exceptionally high in nitrogen in the Upper Mississippi River near agricultural input sources in Iowa and Illinois. These high nitrogen sediments may degrade the water quality of the river by contributing to water eutrophication during periods of low flow and high temperatures during the summer.

An ongoing research study of organic functional groups that contribute to the strong-acid characteristics of fulvic acid from the Suwannee River, Georgia, found that carboxyl groups combined with ester and ether functionalities alpha to the carboxyl group explained the strong-acid characteristics. A specific cyclic diglycolic acid functional group structure was detected in fulvic acid that had a dissociation constant (pKal) value near 1 . The finding of $\alpha$ ether polycarboxylic acids for this fulvic acid is especially significant because this functionalgroup arrangement is known to efficiently complex trace metals and calcium in water. Also, the strong acidity findings are important for mineral weathering studies, and nutrient availability studies. 


\section{SURFACE-WATER CHEMISTRY}

\section{REPORTS PUBLISHED 1988-1993:}

Barber, L.B., II, 1990, Geochemical heterogeneity in a glacial outwash aquifer: Effect of particle size and mineralogy on sorption of nonionic organic solutes: Boulder, Colo., University of Colorado, Ph.D. Thesis, 237 p.

1991, Effects of particle size and mineralogy on sorption of nonionic organic solutes to glacial outwash sediments, Cape Cod, Massachusetts, in Mallard, G.E., and Aronson, D.A., eds., U.S. Geological Survey Toxic Substances Hydrology Program-Proceedings of the technical meeting, Monterey, Calif., March 11-15, 1991: U.S. Geological Survey, Water-Resources Investigations Report 914034, p. 111-115.

Barber, L.B., and Leenheer, J.A., 1991, Use of azaarene tracers to evaluate fracture flow from an in situ oil shale retort, Rock Springs, Wyoming, in Mallard, G.E., and Aronson, D.A., eds., U.S. Geological Survey Toxic Substances Hydrology Program-Proceedings of the technical meeting, Monterey, Calif., March 11-15, 1991: U.S. Geological Survey WaterResources Investigations Report 91-4034, p. 175-182.

Barber, L.B., II., Thurman, E.M. Field, J.A., LeBlanc, D.R., Smith, R.L., and Harvey, R.W., 1991, Biogeochemical fate of organic compounds in sewage-contaminated groundwater, Cape Cod, Massachusetts, in Mallard, G.E., and Aronson, D.A., eds., U.S. Geological Survey Toxic Substances Hydrology program-Proceedings of the technical meeting, Monterey, Calif., March 11-15, 1991: U.S. Geological Survey Water-Resources Investigations Report 91-4034, p. 102-105.

Barber, L.B., II, Thurman, E.M., and Rumnells, D.D., 1992, Geochemical heterogeneity in a sand and gravel aquifer-Effects of sediment mineralogy and particle size on the sorption of chlorobenzenes: Journal of Contaminant Hydrology, v. 9, p. 35-54.

Barber, L.B., II, Thurman, E.M., Takahashi, Y., and Noriega, M., 1991, Purgeable organic chloride-A surrogate measurement for screening and monitoring volatile chlorinated hydrocarbons in ground water, in Mallard, G.E., and Aronson, D.A., eds., U.S. Geological Survey Toxic Substances Hydrology Program-Proceedings of the technical meeting, Monterey, Caif., March 11-15, 1991: U.S. Geological Survey Water-Resources Investigations Report 91-4034, p. 106-110.

Brown, P.A., and Leenheer, J.A., 1989, Significance of density determination in molecular structures comprising fulvic acid from the Suwannee River, in Averett, R.C., Leenheer, J.A., McKnight, D.M., and Thorn, K.A., eds., Humic Substances in the Suwannee River, Georgia-Interactions, Properties, and Proposed Structures: U.S. Geological Survey Open-File Report 87-557, p. 311-330.

Field, J.A., 1990, Fate and transformations of surfactants in sewage-contaminated groundwater, Golden, Colo., Colorado School of Mines, Ph.D. Thesis, 207 p.

Field, J.A., Barber, L.B., II, Leenheer, J.A., Rostad, C.E., and Thorn, K.A., 1991, Persistence of linear alkylbenzenesulfonates and their metobolites in sewage-contaminated ground water, in Mallard, G.E., and Aronson, D.A., eds., U.S. Geological Survey Toxic Substances Hydrology Program-Proceedings of the technical meeting, Monterey, Calif., March 11-15, 1991: U.S. Geological Survey WaterResources Investigations Report 91-4034, p. 116-122. 


\section{SURFACE-WATER CHEMISTRY}

Field, J.A., Barber, L.B., II, Thurman, E.M., Moore, B.L., Lawrence, D.L., and Peake, D.A., 1992, Fate of alkylbenzenesulfonates and dialkytetralinsulfonates in sewage-contaminated groundwater: Environmental Science and Technology, v. 26, p. 1140-1147.

Field, J.A., Leenheer, J.A., Thorn, K.A., Barber, L.B., II, Rostad, C.E., Macalady, L.L., and Daniel, S.R., 1992, Comprehensive approach for identifying anionic surfactant-derived chemicals in sewage effluent and ground water: Journal of Contaminant Hydrology, v. 9, p. 55-78.

Harvey, R.W. and Barber, L.B., II, 1992, Associations of free-living bacteria and dissolved organic compounds in a plume of contaminated groundwater: Journal of Contaminant $\mathrm{Hy}-$ drology, v. 9, p, 91-103.

Harvey, R.W., Smith, R.L., Barber, L.B., II, Metge, D.W., Scholl, M.A., and Garabedian, S.P., 1991, The role of physical and chemical heterogeneity in the interpretation of smallscale tracer tests involving microorganisms, in Mallard, G.E., and Aronson,D.A., eds., U.S. Geological Survey Toxic Substances Hydrology Program-Proceedings of the technical meeting, Monterey, Calif., March 11-15, 1991: U.S. Geological Survey WaterResources Investigations Report 91-4034, p. 148-151.

Johnson, K.L., and Leenheer, J.A., 1991, Geochemical controls on resuspension and redeposition of contaminated bed sediments by freshwater inputs into the lower Calcasieu River, in Mallard, G.E., and Aronson, D.A., eds., U.S. Geological Survey Toxic Substances Hydrology Program-Proceedings of the technical meeting, Monterey, Calif., March 11-15, 1991: U.S. Geological Survey Water-Resources Investigations Report 914034, p. 591-596.
Leenheer J.A., 1988, Analysis, association, and effects of organic constituents of aquatic sediment, in Bradford, W., and Horowitz, A.J., eds., The Role of Sediments in the Chemistry of Aquatic System-Proceedings of the Sediment Chemistry Workshop, February 8-12, 1982: U.S. Geological Survey Circular 969, p. 22-32.

1989. Implications of mixture characteristics on humic substance chemistry, in Suffet, I.H., and MacCarthy, P., eds., Aquatic Humic Substances-Influence on Fate and Treatment of Pollutants: Advances in Chemistry Series 219, Washington, D.C., American Chemical Society, chapter 3, p. 41-54.

1989, Methods for determination of structural models of fulvic acid by convergent independent analyses, in Averett, R.C., Leenheer, J.A., McKnight, D.M., and Thorn, K.A., eds., Humic Substances in the Suwannee River, Georgia-Interactions, Properties, and Proposed Structures: U.S. Geological Survey Open-File Report 87-557, p. 135-146.

1991, Organic substance structures that facilitate contaminant transport and transformations in aquatic sediments, in Baker, R.A., ed., Organic Substances and Sediments in Water, Humics and Soils: Chelsea, Michigan, Lewis Publishers, Chapter 1, v. 1, p. 3-22.

1992, Book Review of Allard, B., Boren, H., and Grimvall, A., eds., Humic Substances in the Aquatic and Terrestrial Environment: Journal of Environmental Quality, v. 21, no. 2, p. 291.

in press, Chemistry of dissolved organic matter in rivers, lakes, and reservoirs, in Baker, L.A., ed., Environmental chemistry of lakes and reservoirs: Washington, D.C., American Chemical Society, Advances in Chemistry Series no. 237. 


\section{SURFACE-WATER CHEMISTRY}

Leenheer, J.A., Meade, R.H., Taylor, H.E., and Pereira, W.E., 1989, Sampling, fractionation, and de-watering of suspended sediment from the Mississippi River for geochemical and trace-contaminant analysis, in Mallard, G.E., Ragone, S.E., eds., U.S. Geological Survey Toxic Substances Hydrology Program-Proceedings of the technical meeting, Phoenix, Ariz., September 26-30, 1988: U.S. Geological Survey Water-Resources Investigations Report 88-4220, p. 501-512.

Leenheer, J.A., McKnight, D.M., Thurman, E.M., and MacCarthy, P., 1989, Structural components and proposed structural models of fulvic acid from the Suwannee River, in Averett, R.C., Leenheer, J.A., McKnight, D.M., and Thorn, K.A., eds., Humic Substances in the Suwannee River, Georgia-Interactions, Properties, and Proposed Structures: U.S. Geological Survey Open-File Report 87-557, p. 331360.

Leenneer, J.A., and Noyes, T.I., 1989, Derivatization of humic substances for structural studies, in Hayes, M.H. B., MacCarthy, P. Malcolm, R.L., and Swift, R.S., eds., Humic Substances II-In Search of Structure:

Chichester, England, John Wiley and Sons, p. 257-280.

Leenheer, J.A., Wershaw, R.L., Brown, P.A., and Noyes, T.I., 1991, Detection of polyethyleneglycol residues from nonionic surfactants in surface water by ${ }^{1} \mathrm{H}$ - and ${ }^{13} \mathrm{C}$-nuclear magnetic resonance spectrometry: Environmental Science and Technology, v. 25, p. 161-168.

Noyes, T.I., and Leenheer, J.A., 1989, Proton nuclear magnetic resonance studies of fulvic acid from the Suwannee River, in Averett, R.C., Leenheer, J.A., McKnight, D.M., and Thorn, K.A., eds., Humic Substances in the Suwannee River, Georgia-Interactions, Properties, and Proposed Structures: U.S. Geologi- cal Survey Open-File Report 87-557, p. 231250.

Reddy, M.M., Leenheer, J.A., and Malcolm, R.L., 1989, Elemental analysis and heat of combustion of fulvic acid from the Suwannee River, in Averett, R.C., Leenheer, J.A., McKnight, D.M., and Thorn, K.A., eds., Humic Substances in the Suwannee River, GeorgiaInteractions, Properties, and Proposed Structures: U.S. Geological Survey Open-File Report 87-557, p. 147-162.

Rees, T.F., Leenheer, J.A., and Ranville, J.F., 1991, Use of a single-bowl continuous-flow centrifuge for de-watering suspended sediments-Effect on sediment physical and chemical characteristics: Hydrological Processes, v. 5, p. 201-214.

Spitzy, A., and Leenheer, J.A., 1991, Dissolved organic carbon in rivers, in Degens, E.T. Kempe, S., and Richey, J.F., eds., Biogeochemistry of Major World Rivers: New York, John Wiley and Sons, chapter 9, p. 213-232.

Tabor, C.F., 1993, The occurrence and fate of linear alkylbenzene sulfonate in the Mississippi River: A molecular indicator of sewage contamination: Boulder, Colo., University of Colorado, M.S. Thesis, 78 p.

Writer, J.H., 1992, Sewage contamination in the Upper Mississippi River as measured by the fecal sterol coprostanol: Boulder, Colo., University of Colorado, M.S. Thesis, 99 p.

Zepp, R.G., Braun, A.M., Hoigne, Jurg, and Leenheer, J.A., 1989, Photoproduction of hydrated electrons from natural organic solutes in aquatic environments: Environmental Science and Technology, v. 21, no. 5, p. 485-489. 


\title{
SURFACE-WATER CHEMISTRY
}

TITLE: Organic Carbon Migration in Aquatic Environments (CR 93-331)

\author{
PERSONNEL: George R. Aiken, Project Chief \\ Eva Brown, Secretary \\ Jason Tregellas, Physical Science Aid
}

ADDRESS: $\quad$ U.S. Geological Survey, 3215 Marine Street, Boulder, CO 80303

TELEPHONE: (303)541-3036

PROBLEM: Organic matter in aqueous systems often controls geochemical processes by acting as proton donors/acceptors and $\mathrm{pH}$ buffers, by affecting the transport and degradation of pollutants, and by participating in mineral dissolution/precipitation reactions. To more clearly understand the dynamics of carbon cycling and chemical transport, better definition of geochemical processes as they apply to dissolved organic carbon is required. In particular, understanding the chemical mechanisms controlling the fate and transport of both naturally occurring anthropogenic compounds in ground water and sediments is needed.

OBJECTIVE: To determine the role of chemical processes associated with bulk dissolved organic carbon (DOC) on the transport of both naturally occurring and anthropogenic compounds. These processes include sorption, partitioning, cosolute enhanced transport and colloidal interaction. To demonstrate that nonvolatile organic acids resulting from the degradation of organic matter are interactive components of aquatic environments. To demonstrate that DOC interactions within a given environment control hydrophobic constituent transport in aqueous systems.

APPROACH: Within the conceptual framework of a chromatographic model, a combined field/laboratory approach will be used to study the factors controlling the movement of organic compounds in groundwater and sediment. Samples from a given site will be collected along flow transects to determine the fundamental chemical properties of both dissolved and sorbed organic matter. Established techniques for the isolation and characterization of organic matter will be used. Laboratory studies will be conducted to examine the attenuation of advective transport of organic compounds by sorption, to investigate a number of potentially important interactions involving DOC and other inorganic and organic constituents in water.

PROGRESS: Last year, research continued on the nature of nonvolatile organic acids present in the DOC plume downgradient of the oil spill at Bemidji, Minnesota. A novel technique 


\section{SURFACE-WATER CHEMISTRY}

for obtaining cores of subsurface material along with the pore-water fluids was employed, allowing the investigation of the vertical distribution of both dissolved and sorbed constituents, the relation of the dissolved constituents to the solid phase, and the effects of small-scale heterogeneity on the chemistry of the plume. The results of previous research at the site are presently being written up for publication. Research also continued on the factors controlling the DOC in Williams and Shingobee Lakes (Minnesota). Results to date indicate that the nature of the DOC between the two lakes is different, reflecting the differences in hydrology and sources of DOC between the lakes. During this past year, samples of the organic matter were obtained from the groundwater entering Williams Lake, and from the Shingobee River during the spring flush. These samples represent major inputs of organic matter to each lake. Preliminary results of the analysis of these samples indicate that they differ significantly. In addition, study of the flux of organic matter through the sediments of Williams Lake has begun. The dynamics of carbon cycling in Lake Fryxell (Antarctica) continued last year with the determination of ${ }^{14} \mathrm{C}$ ages of the humic substances from the lake and inflow streams. The results of these measurements suggest that the diffusion of organic matter from the bottom waters and sediments of the lake into the overlying waters is the major source of DOC in the water column of the lake. In addition, new research on the factors controlling the transport and fate of organic matter the South Platte River has begun in conjunction with the South Platte River National Water Quality Assessment (NAWQA) study group. Finally, I was the author or coauthor on five reports published last year.

\section{REPORTS PUBLISHED 1988-1993:}

Aiken, G.R., 1992, Chloride interference in the analysis of dissolved organic carbon by the wet oxidation method: Environmental Science and Technology, v. 26, p. 2435-2439.

Aiken, G.R., McKnight, D.M., Thorn, K.A., and Thurman, E.M., 1992, Isolation of hydrophilic acids from water using macroporous resins: Organic Geochemistry, v. 18, p. 567-573.

Eganhouse, R.P., Baedecker, M.J., Cozzarelli, I.M., Aiken, G.R., Thorn, K.A., and Dorsey, T.F., 1993, Crude oil in a shallow sand and gravel aquifer, II. Organic Geochemistry: Applied Geochemistry, v. 8, p. 551-567.

McKnight, D.M., Aiken, G.R., Andrews, E.D., Bowles, E.C., and Harnish, R.A., 1993, Dis- solved organic material in Dry Valley Lakes-A comparison of Lake Fryxell, Lake Hoare, and I ake Vanda, in Green, W.J. ed., Physical and biogeochemical processes in Antarctic lakes: Washington, D.C., American Geophysical Union, Monograph Series 59, p. 119-133.

McKnight, D.M., Bencala, K.E., Zellweger, G.W., Aiken, G.R., Feder, G.L., and Thorn, K.A., 1992, Sorption of dissolved organic material by hydrous aluminum and iron oxides occurring at the confluence of Deer Creek with the Snake River, Summit County, Colorado: Environmental Science and Technology, v. 26, p. 13881396. 


\section{SURFACE-WATER CHEMISTRY}

TITLE: $\quad$ Sedimentary Geochemical Processes Affecting the Exchange of Nutrients and Transition Metals Between Sediment and Water in Riverine, Estuarine, and Lacustrine Environments (NR 76-065)

PERSONNEL: Edward Callender, Project Chief

Carol Padgett, Secretary

Ruth Deike, Geologist

Brenda Libby, Chemist

ADDRESS: $\quad$ U.S. Geological Survey, 430 National Center, 12201 Sunrise Valley Drive, Reston, VA 22092

TELEPHONE: (703) 648-5826

PROBLEM: Benthic-sediment exchange processes are potentially a very significant sourcesink of nutrients and metals within an aquatic system. Too often, the quantitative effects of these processes are only estimated when biogeochemical cycling and ecological responses are being considered. Understanding geochemical processes that control nutrient and transition metal chemistry of natural waters is requisite for predicting the effects that human-induced events will have upon natural geochemical cycles and for determining the use of natural waters as a resource (for example, estuarine waters as food resources).

OBJECTIVE: (1) Study the important geochemical processes affecting the nutrient and metal composition of, and exchange between, sediment and water in several different aquatic environments; (2) aid in developing methods for determining nutrient and metal fluxes between sediment and water; and (3) assess the influence of human activities on natural geochemical cycles.

APPROACH: Sample and analyze surface water, ground water, and sediment-pore water for nutrient and transition-metal content of aqueous phases and associated solid phases. Measure nutrient and metal exchange in natural and laboratory-controlled environments to determine the effects of changing environmental conditions (temperature, salinity, nature of inorganic and organic substrates, bioturbation). Analyze samples by use of colorimetry, ion chromatography, and flame and flameless atomic absorption spectrophotometry. Model results in terms of solution-mineral equilibria, ion exchange, and advective-diffusive transport through porous sedimentary media. 


\section{SURFACE-WATER CHEMISTRY}

PROGRESS: A paper published recently in Water Resources Research shows that detailed distributions of radionuclides and stable elements in rapidly-accumulating sedimentary environments can be used to reconstruct paleohydrologic events in the drainage basin. An analysis of several cores from Lake Oahe on the Missouri River in South Dakota produced a detailed chronology of reservoir sedimentation from 1959 to 1986 . Times that characterize system-wide processes include an integration time of several years reflecting retention of the sediment-bound tracer in regions within or external to the reservoir and a relaxation time of approximately 15 years reflecting a decreasing rate of sediment accumulation ascribed to shoreline stabilization. The distribution of lithologically discriminating chemical elements, calcium and vanadium, relate to major flow events in the Cheyenne River basin.

Work continues on the geochemistry of Lake Baikal, Russia. Chemical data acquired on sediment pore waters and associated solids are being used to construct mass balance models of nutrients and metals. The residence time of dissolved phosphorus in Lake Baikal is about 185 years, in contrast to 330 years for conservative elements. Phosphorus is a very reactive element in the water column; approximately 95 percent appears to be recycled through the phytoplankton and zooplankton system. Early diagenesis of Lake Baikal surface sediment releases phosphate that is either recycled to the water column by diffusional transport or is incorporated into strongly oxidized sediments. The diagenetic flux of phosphate is approximately equal to the biogenic sedimentation flux of phosphate to the sediment surface minus the burial of phosphorus compounds in the sediment column. The 1991-1992 study of a core from one portion of Lake Baikal (Academician Ridge), indicated that a phosphate phase containing both $\mathrm{Ca}$ and $\mathrm{Fe}^{3+}$ accumulated in a crust a few centimeters below the sediment/water interface at a well-defined redox boundary that formed during a Holocene period of slow sedimentation. Significantly, in many cores, a similar event is indicated in Pleistocene sediments by remnants of a second phosphate-bearing crust. In 1992-1993, crusts of phosphatic composition were confirmed at many locations in the better known and more tectonically stable Northern Basin, and it is here that further effort will be invested to characterize the molar composition and mineral structure of the phase, or phases.

A study developed in collaboration with the Trinity River, Texas, National Water QualityAssessment (NAWQA) study unit has been assessing the use of geochemical analyses from sediment cores to reconstruct past water-quality conditions in the basin. Samples from three cores that penetrated to the pre-reservoir (Lake Livingston) land surface were analyzed for major and minor elements and pesticides. Preliminary results of this study indicate decreases in concentrations of barium (Ba), lead $(\mathrm{Pb})$, sodium $(\mathrm{Na})$, and DDT throughout the length of the core to the present time. Decreases in $\mathrm{Ba}$ and $\mathrm{Na}$ are probably caused by improved regulation of discharges of oil-field brines in the Trinity River Basin. Decreases in $\mathrm{Pb}$ are 


\section{SURFACE-WATER CHEMISTRY}

probably caused by the phasing out of leaded gasoline. Historical water-quality data are insufficient to evaluate change in $\mathrm{Pb}$ concentrations in the Trinity River. Concentrations of DDT and it's metabolites decrease with time of deposition of sediments from the early 1970's to the early 1990's. These same decreases were apparent in the water-quality database for the Trinity River.

\section{REPORTS PUBLISHED 1988-1993:}

Callender, E. and Ficklin, W.H., 1988, Remobilization of arsenic in sediments from the Cheyenne River Arm of Lake Oahe, South Dakota, in G.E. Mallard ed., U.S. Geological Survey, Toxic Substances Hydrology Program Surface Water Contamination-Proceedings of the technical meeting, Denver, Colo., Feb. 2-4, 1987: U.S. Geological Survey Open-File Report 87-764, p. 41-48.

Callender, E., Ficklin, W.H., Kimball, B.A., and Edelmann, P.P., 1989, Heavy metal geochemistry of sediments in the Pueblo Reservoir, Colorado, in Mallard, G.E., and Ragone, S.E., eds., U.S. Geological Survey, Toxic Substances Hydrology Program-Proceedings of technical meeting, Phoenix, Ariz., Sept. 26-30, 1988: U.S. Geological Survey, WaterResources Investigations Report 88-4220, p. 81-91.

Callender, E., and Granina, L., 1992, Transition metal geochemistry of sedimentary pore fluids associated with hydrothermal activity in Lake Baikal, Russia, in Kharaka, Y.K., and Maest, A.S., eds., 7th International Symposium on Water-Rock Interaction, Park City, Utah [Proceedings]: Rotterdam, A.A. Balkema, p. 621626.

Callender, E., Kimball, B.A., and Axtmann, E.V., 1991, Transition-metal geochemistry of the Upper Arkansas River, Colorado, in Mallard G.E., and Aronson, D.A., eds., U.S. Geological Survey, Toxic Substances Hydrology Pro-
gram-Proceedings of technical meeting, Monterey, Calif., March 11-15, 1991: U.S. Geological Survey, Water-Resources Investigation Report 91-4034, p. 392-397.

Callender, Edward and Robbins, J.A., 1993, Transport and accumulation of radionuclides and stable elements in a Missouri River reservoir: Water Resourčes Resarch, v. 29, no. 6, p. 1787-1804.

Callender, E., and Smith, R.A., 1989, Deposition of organic carbon in upper Missouri River reservoirs, in Degens, E.T., Kempe S., and Eisma, D., eds., Transport of carbon and minerals in rivers, lakes, estuaries and coastal seas: Mitteilungen aus dem Geologisch-Paläontologischen Instut, der Universitat Hamburg, SCOPE/UNEP Sonderband, Heft, v. 70, pt. 6 , p. 1-15.

Deike, Ruth G. 1990a, Dolomite dissolution rates and possible Holocene dedolomitization of water-bearing units in the Edwards Aquifer, south-central Texas: Journal of Hydrology, $v$. 112 , p. 335-373.

Deike, Ruth G., 1990b, Dolomite dissolution rates and possible Holocene dedolomitization of water-bearing units in the Edwards Aquifer, south-central Texas-A Summary, in Simpson E., and Sharp, J., eds., Selected papers on hydrogeology from the 28th International Geological Congress: International Association 


\section{SURFACE-WATER CHEMISTRY}

Hydrologists, Hydrogeology Selected Papers, v. 1, p. 97-107.

Ficklin, W.H., and Callender, E., 1988, Speciation of arsenic in sediments and intersitial water from the Cheyenne River Arm of Lake Oahe, South Dakota, in Mallard, G.E., ed., U.S. Geological Survey Toxic Substances Hydrology Program, Surface-Water Contamination-Proceedings of the technical meeting, Denver, Colo.: U.S. Geological Survey Open-File Report 87-764, p. 44-54.

1989, Arsenic geochemistry of rapidly accumulating sediments, Lake Oahe, South Dakota, in Mallard, G.E., and Ragone, S.E., eds., U.S. Geological Survey Toxic Substances Hydrology Program-Proceedings of the technical meeting, Phoenix, Ariz., Sept. 26-30, 1988: U.S. Geological Survey Water-Resources Investigations Report 88-4220, p. 217-222.

Horowitz, A.J., Elrick, K.A., and Callender, E., 1988, The effect of mining on the sedimenttrace element geochemistry of cores from the Cheyenne River Arm of Lake Oahe, South Dakota, U.S.A.: Chemical Geology, v. 67, p. $17-33$.

Shanks, W.C., and Callender, E., 1992, Thermal springs in Lake Baikal: Geology, v. 20, p. 495-497. 


\section{SURFACE-WATER CHEMISTRY}

TITLE: $\quad$ Carbon Fluxes in Hydrologic and Geologic Processes (NR 79-099)

PERSONNEL: Eric T. Sundquist, Project Chief

Gregory C. Winston, Chemist

ADDRESS: $\quad$ U.S. Geological Survey, 432 National Center, 12201 Sunrise Valley Drive, Reston, VA 22092

TELEPHONE: (508) 457-2397

PROBLEM: Carbon fluxes are an important aspect of many hydrologic and geologic processes. For example, on a global scale, rising atmospheric $\mathrm{CO}_{2}$ concentrations and the increasing use of fossil fuels have led to concern for the future effects of atmospheric $\mathrm{CO}_{2}$ on global climate. Anticipating the effects of atmospheric $\mathrm{CO}_{2}$ requires an understanding of the role of natural hydrologic and geologic processes in the global carbon budget. On a more local scale, ground-water and surface-water contamination problems are often associated with locally significant changes in the transport and sedimentation of carbon. This project evaluates carbon fluxes by studying the hydrologic and geologic processes responsible for them. These studies emphasize the need to understand both human impacts and the evidence for natural changes in local to global carbon fluxes before man's influence.

OBJECTIVE: Evaluate local to global carbon fluxes associated with hydrologic and geologic processes. Determine the geochemical mass balance for carbon in selected hydrologic/geologic systems. Determine the processes most important in controlling carbon fluxes. Investigate the possibility of past variations in the world's (natural) $\mathrm{CO}_{2}$ balance, and apply this information to the prediction of future global $\mathrm{CO}_{2}$ fluxes. Understand the role of fluxes of carbon compounds in selected local ground water and (or) surface water contamination problems.

APPROACH: Estimates of carbon fluxes and quantities are derived from direct measurements, published literature, and computer models of hydrologic and geologic processes. Analytical methods utilized by this project include infrared gas analysis, gas chromatography, high performance liquid chromatography, and coulometric and potentiometric titration techniques. Stable isotope and ${ }^{14} \mathrm{C}$ measurements are acquired where appropriate. Available data are used to constrain computer models based on chemical thermodynamic and kinetic relationships and the conservation of mass and charge. 


\section{SURFACE-WATER CHEMISTRY}

PROGRESS: Project activities have included both field measurements and modeling. An infrared photosynthesis analyzer has been adapted to measure $\mathrm{CO}_{2}$ concentrations in small soil gas samples and $\mathrm{CO}_{2}$ fluxes through soil and snow surfaces. Soil $\mathrm{CO}_{2}$ field monitoring programs have been established at the Sleepers River Experimental Watershed in Vermont and at the Harvard Forest Long-Term Ecological Research site in Massachusetts. The initial focus of these studies is to understand the processes that control $\mathrm{CO}_{2}$ fluxes over diurnal to seasonal time scales.

Modeling studies have focused on aspects of the carbon cycle that are related to the geochemical effects of $\mathrm{CO}_{2}$ and to long-term geochemical predictions. To analyze the soil and sediment records of carbon-cycle change, and to assist in long-term $\mathrm{CO}_{2}$ predictions, modeling techniques have been developed to accommodate pedogenesis, carbonate dissolution, and other sediment interactions. These models suggest that, contrary to widely held assumptions, the global carbon cycle was not at a steady state prior to modern human influences. The models also imply that, if humans burn all of the world's fossil fuel reserves, atmospheric and oceanic $\mathrm{CO}_{2}$ concentrations may remain perturbed for thousands to tens of thousands of years.

This project has also contributed substantially to bureau and division climate and global change program development.

\section{REPORTS PUBLISHED 1988-1993:}

Harden, J.W., Sundquist, E.T., Stallard, R.F., and Mark, R.K. 1992, Dynamics of soil carbon during deglaciation of the Laurentide Ice Sheet: Science, v. 258, p. 1921-1924.

Sarmiento, J.S., and Sundquist, E.T., 1992, Revised budget for the oceanic uptake of anthropogenic carbon dioxide: Nature, v. 356, p. 589-593.

Shackleton, N.J., van Andel, T.H., Boyle, E.A., Jansen, E., Labeyrie, L., Leinen, M., McKenzie, J., Mayer, L., and Sundquist, E.T., 1990, Contributions from the oceanic record to the study of global change on three time scales-Report of Working Group 1, Interlaken Workshop for Past Global Changes: Palaeogeography, Palaeoclimatology, Palaeo- ecology, Global and Planetary Change Section, v. 82 , p. $5-37$.

Shanley, J.B., Sundquist, E.T., and Denner, J.C., 1991, Water, energy, and biogeochemical budgets at Sleepers River, Danville, Vermont-A research plan: Eastern Snow Conference, 48th, Guelph, Ontario, June 7-8, 1991 [Proceedings], p. 81-90.

Sundquist, E.T., 1988, The greenhouse effect and global warming, in Lins, H.F., Sundquist, E.T., and Ager, T.A., Information on selected climate and climate-change issues: U.S. Geological Survey Open-File Report 88-718, p. 11-21. 


\section{SURFACE-WATER CHEMISTRY}

1990, Long-term aspects of future atmospheric $\mathrm{CO}_{2}$ and sea-level changes, in Revelle, R., ed., Sea Level Change: Washington, National Research Council, p. 193-207.

1990, Pliocene atmospheric $\mathrm{CO}_{2}-$ some preliminary observations, in Gosnell, L.B., and Poore, R.Z., eds., Pliocene ClimatesScenario for Global Warming: U.S. Geological Survey Open-File Report 90-64, p. 37-38.

1990, Influence of deep-sea benthic processes on atmospheric $\mathrm{CO}_{2}$ : Philosophical Transactions of the Royal Society, A, v. 331, p. 155165.

1991, Steady- and non-steady-state carbonatesilicate controls on atmospheric $\mathrm{CO}_{2}$ : Quaternary Science Reviews, v. 10, p. 283-296.

Sundquist, E.T., 1992, Terrestrial implications and uncertainties in the atmospheric carbon dioxide budget, in Kelmelis, J.A., and Snow, M., eds., Proceedings of the U.S. Geological Survey Global Change Research Forum, March 18-20, 1991, Herndon, Va.: U.S. Geological Survey Circular 1086, Denver, U.S. Geological Survey, p. 33-36.

Sundquist, E.T., 1993, The global carbon dioxide budget: Science, v. 259, p. 934-941. 


\section{SURFACE-WATER CHEMISTRY}

TITLE: Geochemical Cycling of Trace Elements and Nutrients inatural Water Systems (NR 81-109)

PERSONNEL: Owen P. Bricker, Project Chief Laura Bricker, Clerical Assistant Philip M. Shackelford, Hydrological Technician Robert T. Anderson, Hydrologist

Anne K. O'Brien, Hydrologist Margaret M. Kennedy, Chemist

ADDRESS: $\quad$ U.S. Geological Survey, 432 National Center, 12201 Sunrise Valley Drive, Reston, VA 22092

TELEPHONE: (703) 648-5824

PROBLEM: Natural water systems provide a wide range of conditions within which to examine the geochemical behavior and cycling of trace elements and nutrients relative to hydrochemically important mineral reactions. Processes of mineral dissolution, alteration, and genesis exert strong controls on the concentrations of chemical species in natural water systems and thus on water quality. Chemical composition of atmospheric precipitation input to terrestrial watersheds affects mineral reaction rates and may regulate reaction pathways and products. Knowledge of the geochemical behavior and cycles of major elements, trace elements, and nutrients is essential in order to understand and predict the consequences of deliberate or accidental anthropogenic additions of these substances to the environment.

OBJECTIVE: Define the role of mineral-water interactions in determining the chemical composition of natural waters with emphasis on major elements, trace elements, and nutrients. Quantitatively describe the geochemical behavior of these species in fresh-water, estuarine, and marine environments. Assess the impacts of anthropogenic contributions on natural cycles in these systems and evaluate the hydrogeochemistry of major elements, trace elements, and nutrients as it relates to water resource utilization.

APPROACH: Geochemical mass balance studies of the flux of major elements, trace elements, and nutrients in natural water systems are developed by detailed sampling and chemical analysis of input waters and outflow waters. The critical reactions that control changes in water chemistry are identified and quantified through examination of the solids that the waters contact and react with and through laboratory studies of rock soil-water interactions. 


\section{SURFACE-WATER CHEMISTRY}

PROGRESS: Investigations of atmospheric deposition che histry and biogeochemical processes in watersheds are continuing. Episodic stream acidification was examined in five Mid-Atlantic watersheds representing three physiographic provinces and four different types of bedrock. The net effect of episodic changes on the acid-base status differed among the streams. Greater losses of acid-neutralizing capacity (ANC) were observed during storms in watersheds underlain by reactive bedrock than in watersheds underlain by quartzite and quartz sands. The role of $\mathrm{SO}_{4}^{2-}$ in contributing to episodic acidification in these watersheds is similar to that documented in studies conducted in other regions of the United States, Scandinavia, Canada, and the United Kingdom. The importance of $\mathrm{SO}_{4}^{2-}$ in Mid-Atlantic U.S. streams, contrasts with northeastern United States streams, in which $\mathrm{NO}_{3}{ }^{-}$derived from snowpack is more important in causing episodic acidification. These investigations show the importance of (1) shallow subsurface processes in determining storm-flow chemistry, (2) regional climatic characteristics in determining the different sources of acidity during episodes, and (3) bedrock geology in determining the amount of ANC loss during episodes.

\section{- REPORTS PUBLISHED 1988-1993:}

Acker, J.G., and Bricker, O.P., in press, The influence of $\mathrm{pH}$ on biotite dissolution and alteration kinetics at low temperature: Geochimica et Cosmochima Acta, v. 56.

Baron, J., and Mast, M.A., 1991, Regional characterization and setting, in Baron, J., ed., Biogeochemistry of a subalpine ecosystem-Loch Vale Watershed: New York., Springer-Verlag Ecological Studies Series, No. 90, p. 12-27.

Baron, J., Walthall, P.M., Mast, M.A., and Arthur, M., 1991, Soils, in Baron, J., ed., Biogeochemistry of a subálpine ecosystemLoch Vale Watershed: New York, SpringerVerlag Ecological Studies Series, chap. 7, p. 108-141.

Bricker, O.P., Paces, T., Johnson, C.E., Sverdrup, H., 1992, Weathering and erosion aspects of small catchment research, in Moldan B., and Cerny J., eds., Biogeochemistry of Small Catchment-A Tool for Environmental Research: New York, Joln Wiley and Sons, p. $87-108$.
Bricker, O.P., and Rice, K.C., 1989, Acid deposition to streams a geology-based method predicts their sensitivity: Environmental Science Technology, v. 23, p. 379-385.

1993. Acid rain: Annual Reviews of Earth and Planetary Science, v. 21, p. 151-174.

Denning. S.A., Baron, J., Mast, M.A., and Arthur, M., 1991, Hydrologic pathways and chemical composition of runoff during snowmelt at Loch Vale Watershed, Rocky Mountain National Park, Colorado, U.S.A.: Soil, Water, Air Pollution, p. 107-123.

Donoghue, J.F., Bricker, O.P., and Olsen, C.R., 1989, Particle-borne radionuclides as tracers for sediment in the Susquehanna River and Chesapeake Bay: Estuarine, Coastal and Shelf Science, v. 29, p. 341-360.

Johnson, C.E., Litaor, M.I., Billett, M.F., Bricker, O.P., 1992, Chemical weathering in small catchments-Climatic and anthropogenic influences, in Moldan B., and Cerny, J., eds., 


\section{SURFACE-WATER CHEMISTRY}

Biogeochemistry of small Catchments-A tool for environmental research: New York, John Wiley and Sons, p. 313-328.

Kendall, Carol, Mast, M.A., and Rice, K.C., 1992, Tracing watershed weathering reactions with ${ }^{13} \mathrm{C}$ in Kharaka, Y.K., and Maest, A.S., eds., 7th International Symposium on WaterRock Interactions, Park City, Utah, July 1319, 1992 [Proceedings]: Rotterdam, A.A. Balkema, v. 1, p. 569-572.

Mast, M.A., Drever, J.I., and Baron, J., 1990, Chemical weathering in the Loch Vale Watershed Rocky Mountain National Park, Colorado: Water Resources Research, v. 26, no. 12 , p. 2971-2978.

Mast, M.A., 1991, Geochemical characteristics of Loch Vale Watershed, in Baron, J., ed., Biogeochemistry of a subalpine ecosystem-Loch Vale Watershed: New York, Springer-Verlag Ecological Studies Series, p. 93-107.

O'Brien, A.K., Rice, K.D., Kennedy, M.M., Bricker, O.P., 1993, Comparison of episodic acidification of Mid-Atlantic Upland and Coastal Plain streams: Water Resources, v. 29, p. 3029-3039.

Olson, C.G., 1988, Clay-mineral contribution to the weathering mechanisms in two contrasting watersheds: Journal of Soil Science, v. 39, p. 457-467.

Puckett, L.J., 1988 Biological, chemical, and physical factors controlling the chemistry of throughfall precipitation: Fairfax, Va., George Mason University, Biology Department, Ph.D. thesis, $161 \mathrm{p}$.

1990, Time- and pH-dependent leaching of ions from deciduous and coniferous foliage: Canadian Journal of Forest Research, v. 20, no. 11, p. 1779-1785.
1990, Estimates of ion sources in deciduous and coniferous throughfall: Atmospheric Environment, v. $24 \mathrm{~A}$, no. 3 , p. 545-555.

1991, Spatial variability and collector requirements for sampling throughfall volume and chemistry under a mixed-hardwood canopy: Canadian Journal of Forest Research, v. 21, p. 1581-1588.

Puckett, L.J., and Bricker O.P., 1992, Factors controlling the major ion chemistry of streams in the Blue Ridge and Ridge and Valley physiographic provinces of Virginia and Maryland: Hydrological Processes, v. 6, p. 79-98.

Puckett, L.J., Woodside, M.D., Libby, B., and Schenning, M.R., in press, Sinks for trace metals, nutrients, and sediments in wetlands of the Chickahominey River near Richmond, Va.: Wetlands, v. 13 , no. 12.

Rice, K.C., and Bricker O.P., 1991, Geologybased method of assessing sensitivity of streams to acidic deposition in Charles and Anne Arundel counties, Maryland: Chesapeake Bay Research and Monitoring Division, Tidewater Administration, Maryland Department of Water Resources, AD-90-06, p. 15.

Rice, K.C. and Bricker, O.P., 1992, Acid rain induced changes on stream-water quality during storms on Catoctin Mountain, Maryland: U.S. Geological Survey Open-File Report 92-649.

1992, Acid rain and its effect on stream water quality on Catoctin Mountain, Maryland: U.S. Geological Survey Open-File Report 92-168. [Water Fact Sheet]

1993, Hydrologic, chemical, and isotopic characterization of two small watersheds on Catoctin Mountain, north-central Maryland, U.S.A.: Chemical Geology, v. 107. 


\section{SURFACE-WATER CHEMISTRY}

Rice, K.C., Kennedy, M.M., Bricker, O.P., and Donnelly, C.A., 1993, Data on the quantity and chemical quality of precipitation, Catoctin Mountain, north-central Maryland, 1982-91:

U.S. Geological Survey Open-File Report 93169. 


\section{SURFACE-WATER CHEMISTRY}

TITLE: Distribution and Speciation of Metals in Sedimentary Environments (NR 86-135)

PERSONNEL: Nancy S. Simon, Project Chief

Bonnie Hower, Secretary

Kristin O. Dennen, Geologist

ADDRESS: $\quad$ U.S. Geological Survey, 432 National Center, 12201 Sunrise Valley Drive, Reston, VA 22092

TELEPHONE: (703) 648-5863

PROBLEM: Total concentrations of metals in water and sediment samples are of limited use because they provide no direct information about biological impact. To be of the most use in environmental studies, descriptive information about the metal concentrations in samples must be determined. Descriptive information should include determination of the speciation or chemical form of the metal in samples and identification of the physical phase, (aqueous or solid), geochemical fraction, (organic fraction or mineral fraction, which can include oxides, carbonates, sulfides), and particle size distribution of the metals in the samples. In addition to information about the biological impact of metals, the descriptive data specified above provides the information needed to model the transport and transformation of metals in the environment. More is known about the inorganic chemistry of metals than is known about the relationship between organic compounds and metals in the environment. The work by this project focuses on an understanding of the relationship between naturally-occurring organic matter and the metals in sedimentary systems. The role of metallo-organic compounds in the biogeochemical cycling of metals is of particular interest.

OBJECTIVE: Determine inorganic-organic reactions by which toxic metals are retained in, or mobilized from, the sediment, and the rates at which these processes occur. The primary emphasis of this work is an understanding of the relationship between naturally-occurring organic matter and the metals in sedimentary systems. Metal species need to be separated from complex matrices. Free metal ions need to be distinguished from complexed metal ions. Naturally-occurring metallo-organic complexes should be isolated to determine the molecular structure and functionality of these compounds.

APPROACH: Determine (1) the distribution or partitioning of metals between the solution and solid phases, and (2) the species or chemical form of the metal in the phase(s) with which it is associated. Metal speciation includes determination of the free metal ion, the inorganically complexed metal and the organically complexed metal. Total metal 


\section{SURFACE-WATER CHEMISTRY}

concentrations are determined with atomic absorption spectroscopy. Concentrations of organically-bound metals are highest in solid sediment material, therefore, preliminary work emphasizes the separation of metallo-organic compounds from sediments. Supercritical fluid extraction (SFE) is the method used for separation. Liquid chromatography with electrochemical detection is used for fractionating and quantifying the extracted metalloorganic compounds. The redox chemistry, mobility, and bioavailability of the metals are assessed using adsorption-desorption studies, modified supercritical fluid extractions, and electrochemical techniques.

PROGRESS: The Speciation of Metals project uses supercritical fluid extraction (SFE) to separate compounds of interest from complex natural matrices (sediments, plants, biological tissue). The method developed on this project for extracting organometallics, but not inorganic metals, from natural samples using SFE is currently being used in a mercury biogeochemistry study at a National Water Quality Assessment (NAQWA) study site. In Florida, an environmental problem with mercury in the biogeochemical cycle has been established. Work is being done with the Florida District office in developing a hypothesis for the entry of mercury into the food-chain via organo-mercury compounds. Preliminary data suggests that atmospherically transported mercury is being scavenged by plants that are a source of food for fish. Small minnow-like fish collected on one field trip contained mercury at concentrations that are unacceptable in larger sport fishes. Supercritical fluid extraction is being used by this project to fractionate organo-mercury compounds, including methyl mercury, from sediment and tissue samples. Mercury is known to be 10 to 100 times more toxic when organically-complexed than when in the inorganic state.

The Speciation of Metals project is working in cooperation with the Water Resources Division, Idaho District Office, on a study of Lake Couer d'Alene. The lake is heavily impacted with mine drainage and has elevated concentrations of metals in the sediment. These metals can be toxic to the ecosystem if there is a flux of them from the sediment to the overlying water column. This project is addressing the question of whether the metals are diffusing from the sediment interstitial water to the water column. Data for metal and major ion concentrations in interstitial water samples collected from both diffusion-controlled samplers and from sediment collected by hand-coring are being evaluated.

REPORTS PUBLISHED 1988-1993:

Committee on Analytical Reagents, 1993, Reagent Chemicals, (8th ed.), American Chemical Society Specifications: Washington, D.C., American Chemical Society, 806 p.
Simon, N.S., 1988, The rapid determination of phosplate, sulfate, and chloride in riverine interstitial waters by ion chromatography: Analytical Letters, v. 21, p. 319-330. 


\section{SURFACE-WATER CHEMISTRY}

1988, The effect of different methods for removal of organic matter from material on $\mathrm{HCl}$ extraction of metals from sediment-Calcasieu River, Louisiana, in Mallard, G.E., and Ragone, S.E., eds., U.S. Geological Survey Toxic Substances Hydrology Program-Sur face-Water Contamination-Proceedings of the technical meeting, Denver, Colo., February 2-4, 1987: U.S. Geological Survey Open-File Report 87-764, p. 73-80.

1988, Nitrogen cycling between the sediment and the shallow-water column in the transition zone of the Potomac River and Estuary, I. Nitrate and ammonium fluxes: Estuarine, Coastal and Shelf Science, v. 26, p. 483-497.

1989, Phase association of trace metals in sediments from the Calcasieu River, Louisiana. in Mallard, G.E., and Ragone, S.E., eds., U.S. Geological Survey Toxic Substances Hydrology Program-Proceedings of the technical meeting, Phoenix, Ariz., September 26-30, 1988: U.S. Geological Survey Water-Resources Investigations Report 88-4220, p. 301-308.

1989, Nitrogen cycling between the sediment and the shallow-water column in the transition zone of the Potomac River and Estuary, II. The role of wind-driven resuspension and adsorption of ammonium: Estuarine, Coastal and Shelf Science, v. 28, p. 531-547.

Simon, N.S., Hatcher, S.A., and Demas, C., 1992, Comparison of methods for the recovery of chromium, managanese, and iron from an estuarine sediment standard and sediment from the Calcasieu River Estuary, Louisiana: Chemical Geology, v. 100, p. 175-189.

Simon, N.S. and Morrison, J.F., 1991, The role of bed sediments and drift in the transport and fate of metallo-organic compounds in the Calcasieu River Estuary, Louisiana, in Mallard, G.E., and Aronson, D.A., eds., U.S.
Geological Survey Toxic Substance Hydrology Program-Proceedings of the technical meeting, March 11-15, 1991, Monterey, Calif.: U.S. Geological Survey Water Resources Investigations Report 91-4034, p. 579-582. 


\section{SURFACE-WATER CHEMISTRY}

TITLE: Chemistry of Hydrosolic Metals and Related Constituents of Natural Water (WR 57-076)

PERSONNEL: John D. Hem, Project Chief

Jacqueline A. Hamilton, Secretary

Carol J. Lind, Chemist

Davison V. Vivit, Chemist

ADDRESS: $\quad$ U.S. Geological Survey, 345 Middlefield Road, MS 427, Menlo Park, CA 94025

TELEPHONE: (415) 329-4531

PROBLEM: Hydrosolic metals are elements that form hydroxides with low aqueous solubilities. They may form colloidal suspensions (hydrosols). Some of these elements are toxic and they may interfere in various ways in practical utilization of water. Understanding the occurrence and behavior of these elements in water is complicated by effects of $\mathrm{pH}$, oxidation and reduction, formation of complex ions, coprecipitation with other elements, and intricate chemical kinetic relationships. Because natural aqueous geochemical systems generally are not at equilibrium, although some are at steady states, development of models and concepts appropriate for treatment of nonequilibrium systems has been a major objective in recent project studies.

OBJECTIVE: Define dilute-solution chemistry of elements of interest in the detail that is sufficient to apply findings to natural water systems; the final reports should be useful in predicting the behavior and fate of hydrosolic metals and associated substances, either in natural or polluted systems, as guides for designing optimal data collection programs and aids in the interpretation of water analyses and related hydrologic data.

APPROACH: Develop a predictive inorganic chemical model for behavior of the element of interest in dilute solution. Models are based on chemical thermodynamic and kinetic data from literature and appropriate laboratory experiments and may postulate either equilibrium closed-system or irreversible open-system conditions. Theoretical concepts are used in these models to predict and explain structural and electronic bonding behavior of the elements studied: Models are tested in chemical laboratory experiments and by applying them at appropriate field sites. Models are modified as necessary to allow for kinetic and biochemical factors. 


\section{SURFACE-WATER CHEMISTRY}

PROGRESS: Final editing was completed on a chapter by J.D. Hem to be published in U.S. Geological Survey Water-Supply Paper 2400, the 1990-91 National Water Summary. This deals with time-trends in major anion concentrations in four large United States river basins from 1905 to the present, and emphasizes the hydrologic complexity of large river systems. Some aspects of this subject were described in an invited oral presentation at the 1993 spring meeting of the American Geophysical Union. It is evident that some stream systems are much more sensitive to changing environmental factors than are others, and each system has unique characteristics.

Further studies of aluminum hydroxide polymeric species prepared by titration of $\mathrm{AlClO}_{4}$ solutions with $\mathrm{NaOH}$ at $\mathrm{pH} 4.90$ were made. The rate of conversion of polymers to microcrystalline gibbsite was measured during aging, using both ferron and ${ }^{27} \mathrm{Al}$ nuclear magnetic resonance (NMR) procedures. Both procedures showed first order rates with halftimes of 6 to 7 weeks, which also agrees with findings of Smith and Hem as reported in U.S. Geological Survey Water-Supply Paper 1827-D in 1972. These results do suggest however

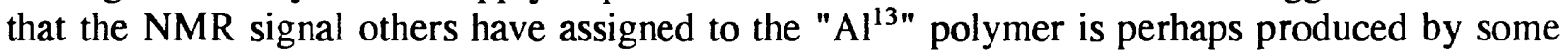
other structural configuration. Further studies of this are needed. These findings were presented orally at the national American Chemical Society meeting in Denver in April by Dave Vivit. A written version of this paper had been approved for submission to the American Chemical Society's symposium series.

Work on composition of precipitated metal species in Pinal Creek, Arizona, was continued by Carol Lind. A paper on earlier findings was published in Appied Geochemistry. A second paper containing results of laboratory studies of redox processes in creek and ground-water samples by John Hem was approved for submission to Geochimica et Cosmochimica Acta.

REPORTS PUBLISHED: 1988-1993

Davis, J.A., and Hem, J.D., 1989, The surface chemistry of aluminum oxides and hydroxides, in Sposito, Garrison, ed., The environmental chemistry of aluminum: Boca Raton, Fla., CRC Press Inc., p. 185-219.

Hem, J.D., 1989, Some nonequilibrium processes in water-rock interaction, in Miles, D.L. ed., Water-rock Interaction WRI-6: International Symposium on Water-Rock Interaction, 6tll, Malvern, England, 3-8, August 1989, Proceedings, p. 297-300.
1993, Factors affecting stream water quality and water-quality trends in four drainage basins in the conterminous United States. 1905-1990, in Paulson, R.W., and Chase, E.B., eds., National Water Summary 199091: U.S. Geological Survey Water Supply Paper 2400, p. 67-92.

Hem, J.D., Demayo, Adrian, and Smith, R.A., 1990, Hydrogeochemistry of rivers and lakes, in Wolman, M.G., and Riggs, H.C., eds., Surface Water Hydrology, The Geology of 


\section{SURFACE-WATER CHEMISTRY}

North America: Boulder, Colo., Geological Society of America, v. 0-1, chap. 9, p. 189231.

Hem, J.D., and Lind, C.J., 1991, Coprecipitation mechanisms and products in manganese oxidation in the presence of cadmium: Geochimica et Cosmochimica Acta, v. 55, p. 2435-2451.

Hem, J.D., Lind, C.J., and Roberson, C.E., 1989, Coprecipitation and redox reactions of manganese oxides with copper and nickel: Geochimica et Cosmochimica Acta, v. 53, p. 28112822.

Hem, J.D., and Roberson, C.E., 1990, Aluminum hydrolysis reactions and products in mildly acidic aqueous systems, in Melchior, D.C., and Bassett, R.L., eds., Chemical modeling of aqueous systems II: Washington, D.C., American Chemical Society, ACS Symposium Series No. 416, chap. 33, p. 429-446.

Lind, C.J., 1988, Hausmannite $\left(\mathrm{Mn}_{3} \mathrm{O}_{4}\right)$ conversion to manganite (gamma $\mathrm{MnOOH}$ ) in dilute oxalate solution: Environmental Science and Technology, v. 22 , p. $62-70$ :

1991, Copper-mining-related acid drainage, in Konsten, C.J.M., ed., Report of the international workshop on delayed environmental effects of chemical pollution with focus on the Nordic countries: Uppsala, Sweden, Foundation for Ecodevelopment "Stichting Mondiaal Alternatief, September 14-15, 1991, p. 42-43.

1991, Manganese minerals and associated fine particulates in the Pinal Creek stream bed, in Mallard, G.E., and Aronson, D.A., eds., U.S. Geological Survey Toxic Substances Hydrology Program-Proceedings of the technical meeting, Monterey, Calif., March 11-15, 1991: U.S. Geological Survey WRI report 91-4034, p. 486-491.
Lind, C.J. and Anderson, L.D., 1992, Trace metal scavenging by precipitating $\mathrm{Mn}$ and $\mathrm{Fe}$ oxides, in Kharaka, Y.K., and Maest, Ann, eds., 7th International Symposium on Water-Rock Interaction, WRI-7, Park City Utah, U.S.A.: Rotterdam, A.A. Balkema, v. 1, p. 397-402.

Lind, C.J. and Hem, J.D., 1993, Manganese minerals and associated fine particulates in the streambed of Pinal Creek, Arizona, U.S.A.A mining-related acid drainage problem: Applied Geochemistry, v. 8, no. 1, p. 67-80.

Nordstrom, D.K., and May, H.M., 1989, Aqueous equilibrium data for mononuclear aluminum species, in Sposito, Garrison, ed., The environmental chemistry of aluminum: Boca Raton, Fla., CRC Press Inc. p. 29-53.

Nordstrom, D.K., Plummer, L.N., Langmuir, Donald, Busenberg, Eurybiades, May, H.M., Jones, B.F., and Parkhurst, D.L., 1990, Revised chemical equilibrium data for major water-mineral reactions and their limitations. in Melchior, D.C., and Bassett, R.L., eds., Chemical modeling of aqueous systems II: Washington, D.C., American Chemical Society ACS Symposium Series No. 416, chap. 31 , p. $398-413$. 


\section{SURFACE-WATER CHEMISTRY}

TITLE: $\quad$ Origin, Fate, and Transport of Organic Compounds in Surface and Ground Waters and Their Effect on Water Quality (WR 83-204)

PERSONNEL: Wilfred E. Pereira, Project Chief

Lucenia Thomas, Secretary

Frances D. Hostettler, Research Chemist

ADDRESS: $\quad$ U.S. Geological Survey, 345 Middlefield Road, MS 496, Menlo Park, CA 94025

TELEPHONE: (415) 354-3336

PROBLEM: There is a general lack of knowledge of fundamental processes governing the fate and transport of anthropogenic organic compounds in surface and ground waters. Interactions of organic contaminants with natural organic coatings on sediments and porous aquifer media are not well understood. Furthermore, abiotic and biological transformations of organic contaminants in surface and ground waters require extensive fundamental investigations if their effects on water quality are to be understood.

OBJECTIVE: (1) Determine physicochemical and biological processes, controlling the fate and transport of organic compounds in surface and ground waters. (2) Determine bioavailability of hydrophobic organic contaminants to stream biota. (3) Study transport of organic compounds from rivers through estuarine systems.

APPROACH: (1) Water, suspended sediments, biota (plant and benthic invertebrate tissues) and bed sediments, will be collected from the San Joaquin and Sacramento Rivers and Delta, and from San Francisco Bay. (2) Samples will be analyzed using electron-impact and chemical ionization ion-trap mass spectrometry. (3) Seasonal variations in organic contaminant loads, as affected by fresh-water influxes and salinity gradients, will be investigated. (4) Bioconcentration of selected hydrophobic organic contaminants will be studied.

PROGRESS: (a) Mississippi River Study. A water quality study was conducted on the Mississippi River and its major tributaries 1991-1992. Three sampling cruises were made, and water samples were collected from the entire navigable reach of the Mississippi River and its major tributaries. These samples were analyzed for pesticides and other organic contaminants. About 23 different pesticides and their degradation products were detected, and mass transport for these compounds was determined at all the different sampling sites. 


\section{SURFACE-WATER CHEMISTRY}

Transport of the compounds was controlled by seasonal variations and hydrologic conditions. The upper and middle Mississippi River basin farmland are major sources of herbicides applied to corn, soybeans, and sorghum. Farmlands in the lower Mississippi River Basin are a major source of rice and cotton herbicides. Inputs of the five major herbicides to the Mississippi River are mainly from the Minnesota, Des Moines, Missouri and Ohio Rivers. In effect, the tributaries have a point-source impact on the Mississippi, which acts as an integrator of water quality. The water quality of the Mississippi River is directly related to farming practices in the midwestern states. Ratio's of desethylatrazine/atrazine potentially are useful indicators of ground- and surface-water interactions in the Mississippi River. These ratios suggested that during base-flow conditions, there is a significant ground-water contribution to the river. Alluvial aquifers in the upper Mississippi River basin probably serve as interim sinks for herbicides and their degradation products during periods of excessive rainfall in spring and early summer. During fall and winter months, when the upper Mississippi River and tributaries generally are at or near base-flow conditions, these compounds are released into the river in ground water. Two publications resulted. One report was sent to the Journal of Environmental Science and Technology (in press). A comprehensive data report covering the period 1987-1992 also was completed and submitted for Director's approval.

(b) San Francisco Bay-Delta Study: A study of historical inputs of contaminants in San Francisco Bay has shown the presence of polynuclear aromatic hydrocarbons (PNA'S), and DDT, DDE, and DDD in sediment cores taken from Richardson Bay. The utility of DDT as a stratigraphic marker is currently being investigated. A preliminary synoptic survey of surficial bed sediments taken from about 20 stations in San Francisco Bay has shown the presence of PNAs, DDT, DDE, DDD, and polychlorinated biphenyls (PCBs). In addition, a collaborative study with Dr. Cashman of IGEN, Washington, has shown that Striped Bass (Morone Saxatilis) taken from the Sacramento River bioaccumulate PNAs, DDT, DDD, DDE, cis and trans chlordane, and PCBs in their livers. The results of this study may explain the dwindling population of striped bass in San Francisco Bay-Delta Estuary.

REPORTS PUBLISHED: 1988-1993

Pereira, W.E., Hostettler, F.D., 1993, Nonpoint source contamination of the Mississippi River and its tributaries by herbicides: Environmental Science Technology, v. 27, p. 1542-1552.

Pereira, W.E., Hostettler, F.D., and Rapp, J.B., 1992, Bioaccumulation of hydrocarbons de- rived from terrestrial and anthropogenic sources in the Asian clam Potamocorbula amurensis in San Francisco Bay Estuary: Marine Pollution Bulletin, v. 24, p. 103-109.

Pereira, W.E., and Rostad, C.E., 1990, Occurrence, distributions and transport of herbicides 


\section{SURFACE-WATER CHEMISTRY}

and their degradation products in thelower Mississippi River and its tributaries: Journal of Environmental Science and Technology, v. 24, no. 9, p. 1400-1406.

1992, Synthetic Organic agrochemicals in the lower Mississippi River and its major tributaries-Distributions, transport and fate: International Journal of Contaminant Hydrology, v. 9, p. 175-188.

Pereira, W.E., Rostad, C.E., Chiou, C.T., 1988, Contamination of estuarine sediments, water and biota by halogenated organic compounds, Calcasieu River Estuary, Louisiana, in Mallard, G.E., ed., U.S. Geological Survey Toxics Substance Hydrology Program-Surface-Water Contamination, Proceedings of technical meeting, Denver, Colo., February 2-4, 1987: U.S. Geological Survey Open-File Report 87-764, p. 87-97.

Pereira, W.E., Rostad, C.E., Chiou, C.T., Brinton, T.I., Barber, L.B., II, Demcheck, D.K., and Demas, C.R., 1988, Contamination of estuarine water biota and sediment by haloarenes-a field study: Journal of Environmental Sciences and Technology, v. 22, no. 7, p. 772-778.

Pereira, W.E., Rostad, C.E., and Leiker, T.J., 1989, Preliminary assessment of the Fate and transport of synthetic organic agrochemicals in the lower Mississippi River and its tributaries, in Ragone, S., and Mallard, G., Ed., eds. U.S. Geological Survey Toxic Substances Hydrology Program--Proceedings of the technical meeting, Phoenix, Ariz., Sept. 2630, 1988: U.S. Geological Survey, WaterResources Investigation Report, 88-4220, p. 453-464.

1990, Determination of trace levels of herbicides and their degradation products in surface and ground waters by gas chromatographic-ion trap mass spectrometry: Analytica Chimica Acta, v. 228, p. 69-75.

1990, Distribution of agrochemicals in the lower Mississippi River and its tributaries: Science of the Total Environment, v. 97/98, p. 41-53.

Pereira, W.E., Rostad, C.E., Leiker, T.J., Updegraff, D.M. and Bennett, J.L., 1988, Microbial hydroxylation of quinoline in contaminated ground water-Evidence for incorporation of the oxygen atom of water: Applied and Environmental Microbiology, v. 54, no. 3 p. $827-829$.

Pereira, W.E., Rostad, C.E., Updegraff, D.M., and Bennett, J.L., 1988, Microbial transformation of azaiarenes in creosote contaminated soil and ground water-Laboratory and field studies: International Conference on Water and Wastewater Microbiology, Newport Beach, Calif., February 8-11, 1988, [Proceedings], v. I, p. 5-1 to 5-7.

1988, Microbial transformations of azaarenes in creosote-contaminated soil and ground water-Laboratory and field studies: Water Science and Technology, v. 20, no. 11-12, p. 17-23.

Rostad, C.E. and Pereira, W.E., 1989, Analysis of chlorinated organic compounds in estuarine biota and sediments by chemical ionization tandem mass spectrometry: Biomedical and Environmental Mass Spectrometry, v. 18, p. 464-470.

1992, Distribution of selected anthropogenic organic compounds on suspended sediment in the Mississippi River, in Mallard, G.E., and Aronson, D.A., eds., U.S. Geological Survey, Toxic substances hydrology Program, Proccedings of the technical meeting, Monterey Calif., March 11-15, 1991: U.S. Geological Survey 


\section{SURFACE-WATER CHEMISTRY}

Water-Resources Investigation Report 914034, 348 .

Rostad, C.E., Pereira, W.E., and Leiker, T.J., 1989, Determination of herbicides and their degradation products in surface water by gas chromatography/positive chemical ionization/tandem mass spectrometry: Biomedical and Environmental Mass Spectrometry, v. 18, p. $820-827$. 


\section{SURFACE-WATER HYDROLOGY}




\title{
SURFACE-WATER HYDROLOGY
}

TITLE: $\quad$ Precipitation-Runoff Modeling of Watershed Systems (CR 77-228)

PERSONNEL: George H. Leavesley, Project Chief

Sandra J. Piksa, Secretary

Robert W. Lichty, Hydrologist

Gregory J. McCabe, Physical Scientist

Andrew G. Fountain, Hydrologist
Lauren E. Hay, Hydrologist

Larry D. Beaver, Hydrological Technician

Linda G. Stannard, Hydrologist (Physics)

Charles G. Bierbaum, Hydrologist, Student, (University of Colorado, Boulder)

\begin{abstract}
ADDRESS: U.S. Geological Survey, P.O. Box 25046, MS 412, Denver Federal Center, Denver, CO 80225
\end{abstract}

TELEPHONE: (303) 236-5027

PROBLEM: Modeling of watershed response to normal and extreme climatic conditions or to changes in the physical conditions of a watershed requires the simulation of a variety of complex hydrologic processes and process interactions. Some of these processes are well understood at a point or for a small area; others are poorly understood at all scales. Increasing spatial and temporal variability in climate and watershed characteristics with an increase in watershed area adds significantly to the degree of difficulty in investigating and understanding these processes. Research is needed to better define these processes and to develop techniques to simulate these processes and their interactions at all watershed scales.

OBJECTIVE: Investigate watershed hydrologic processes and processes interactions to (1) improve understanding of watershed system dynamics; (2) develop computer models to simulate and evaluate the effects of various combinations of precipitation, climate, and land use on streamflow, sediment yield, and other hydrologic components; and (3) develop procedures and techniques to estimate model parameters using measurable watershed-and climatic characteristics.

APPROACH: Develop, test, and verify model components of individual hydrologic processes using data from watershed studies conducted by the U.S. Geological Survey (USGS), other Federal Agencies, and universities. Model components will be coupled in a modular-design watershed modeling system that supports both operational applications and further research work. For hydrologic processes that are poorly defined or for which there is insufficient data, field studies will be conducted to investigate these processes and develop new or improved simulation capabilities. 


\section{SURFACE-WATER HYDROLOGY}

PROGRESS: Development of the Modular Hydrologic Modeling System (MHMS) continued. Modules were added to the modular library from the TOPMODEL, DA FLOW model, CATMO model, and Root Zone Water Quality Model. Development of a glacier simulation module was initiated. A Geographic Information System (GIS) interface was developed for MHMS to provide graphical display capabilities for model input, output, and state variables.

The Rhea-Colorado State University (RHEA-CSU) model was linked with a GIS to automate development of elevation grids, facilitate model application to new study areas, and facilitate simulation of precipitation over a range of spatial scales (2.5-, 5-, and 10-kilometer grids). This capability is being used to analyze effects of a change in grid-cell size on model results and to develop new methods of model calibration and verification on a daily basis.

Collaborative work with Internation Business Machine's (IBM) research group resulted in development of the ability to visualize, through space and time, RHEA-CSU model output at three spatial resolutions in a format that can be understood by both scientists and nonscientists.

Coupled the RHEA-CSU model with the MM4 mesoscale atmospheric model by using MM4 output to run the RHEA-CSU model. For a 1-month test period, the MM4 data produced 17 percent less precipitation over the Gunnison River basin than did data from observed atmospheric soundings.

Determined the reliability of general circulation model (GCM) simulations of incident solar radiation in the southwestern United States. Results indicated that GCMs reliably simulated the annual solar cycle, but generally underestimated incident solar radiation. In addition, the GCMs studied estimated only small increases in incident solar radiation for climatic conditions resulting from a doubling of atmospheric carbon dioxide.

Identified relations between 700-millibar height anomalies and snowpack accumulations in the Gunnison River basin. Variations in 700-millibar height anomalies accounted for over 50 percent of the variability in April 1 snowpack accumulations in the Gunnison River basin. A regression model was developed to estimate April 1 snowpack accumulations in the Gunnison River basin from 700-millibar height anomalies over the western United States.

Evaluated the relations between GCM-simulated atmospheric circulation and GCM-simulated precipitation for the winter months for eight locations in the conterminous United States. Results indicate that the Geophysical Fluid Dynamics Laboratory (GFDL) GCM simulates relations between atmospheric circulation and winter precipitation that are similar to relations 


\section{SURFACE-WATER HYDROLOGY}

found in observed data for most of the locations analyzed in this study. GFDL GCM simulations of the relations between atmospheric circulation and winter precipitation are most similar to observed relations for locations near sources of atmospheric moisture, and are least similar to observed relations for locations far from sources of atmospheric moisture.

The hydrochemistry of snowmelt at the Rabbit Ears Pass site was analyzed for the 1991 and 1992 melt seasons. Ionic composition was dominated by $\mathrm{Ca}_{2}{ }^{+}$and the acidic ions $\mathrm{SO}_{4}^{-2}$ and $\mathrm{NO}_{3}{ }^{-}$. The solutes in the meltwater were differentially and preferentially eluted from the snowpack and concentrations of all solutes generally decreased as snowmelt progressed.

\section{REPORTS PUBLISHED 1988-1993:}

Ayers, M., and Leavesley, G.H., 1988, Assessment of the potential effects of climate change on the water resources of the Delaware River basin: Work Plan 1988-90, U.S. Geological Survey Open-File Report 88-478, 50 p.

Ayers, M.A., Tasker, G.D., Wolock, D.M., McCabe, G.J., and Hay, L.E., 1990, Simulated effects of climatic change on runoff and drought in the Delaware River basin-Supplying water and saving the environment for 6 billion people, [Proceedings]: New York, American Society of Civil Engineers, p. 3137.

Ayers, M.A., Wolock, D.M., McCabe, G.J., and Hay, L.E., 1990, Simulated hydrologic effects of climatic change in the Delaware River basin-Aspects of groundwater in New Jersey: Geological Association of New Jersey, 7th, [Proceedings], p. 01-08.

Ayers, M.A., Wolock, D.M., McCabe, G.J. Jr., and Hay, L.E., 1990, Simulated hydrologic effects of climatic change in the Delaware River basin: U.S. Geological Survey Yearbook, Fiscal Year 1989, p. 31-33.

Ayers, M.A., Wolock, D.M., McCabe, G.J., and Hay, L.E., 1990, Simulated hydrologic effects of climatic change in the Delaware River basin, in Proceedings of the Symposium on International and Transboundary Water Resources Issues: Bethesda, Md., American Water Resources Association, p. 587-594.

Ayers, M.A., Wolock, D.M., McCabe, G.J., Hay, L.E., and Tasker, G.D., 1993, Sensitivity of water resources in the Delaware River basin to climate variability and change: U.S. Geological Survey Open-File Report 92-52, 68 p.

Battaglin, W.A., Hay, L.E., Parker, R.S., and Leavesley, G.H., 1993, Application of a GIS for modeling the sensitivity of water resources to alterations in climate in the Gunnison River basin, Colorado, in Harlin, J.M., and Lanfear, K.J., eds., Proceedings of the Symposium on GIS and Water Resources, Mobile, Alabama, 1993: Bethesda, Md., American Water Resources Association Technical Publication, TPS-93-1, p. 203-210.

Driedger, C.L. and Fountain, A.G., 1989, An analysis of recent glacial outburst floods at Mount Rainier, Washington State, U.S.A.: Annals of Glaciology, v. 13, p. 69-75.

Fountain, A.G., 1989, The storage of water in, and hydraulic claracteristics of, the firn of South Cascade glacier, Washington State U.S.A.: Annals of Glaciology, v. 13, p. 51-55. 


\section{SURFACE-WATER HYDROLOGY}

1991, Glacier mass-balance standards: EOS, v. 72 , no. 46, p. 511 and 514.

1991, Review of The hydrology of ice caps in volcanic regions by Helgi Bjornson [book review]: EOS. v. 72, no. 24, p. 261.

1991, Shape, length and flow conditions of conduits at South Cascade glacier, Washington State, U.S.A., in Prowse, T., and Ommanney, C., Proceedings of the Northern Hydrology Symposium, Saskatoon, Saskatchewan, July 1990: National Hydrology Research Institute, p. 89-104.

1992, Analysis of streamflow records from South Cascade glacier, Washington State, U.S.A., and implications for subglacial water flow: Journal of Glaciology, v. 38, no. 128, p. 51-64.

1992, Automatic system for measuring and recording fluorometry data from multiple sources: Selected Papers in Hydrological Sciences, U.S. Geological Survey Water-Supply Paper 2340, 39-47.

1993, Geometry and flow conditions of subglacial water at South Cascade glacier, Washington State, U.S.A.: Journal of Glaciology, v. 131, p. 143-156.

Hay, L.E., Battaglin, W.A., Branson, M.D., and Leavesley, G.H., 1993, Application of GIS in modeling orographic precipitation, Gunnison River basin, Colorado, U.S.A., in Application of Geographic Information Systems in Hydrology and Water Resources Management, Baden, Austria, April 19-22, 1993, Proceedings: Baden, Austria, HydroGIS 93, p. 491500 .

Hay, L.E., Battaglin, W.A., Parker, R.S., and Leavesley, G.H., in press, Modeling the effects of climate change on water resources in the Gunnison River basin, Colorado, using GIS technology: First International Conference/ Workshop on integrating geographic information systems and environmental modeling, September 15-19, 1991, Boulder, Colo. [Proceedings].

Hay, L.E., Branson, M.D., and Leavesley, G.H., 1992, Simulation of precipitation in the Gunnison River basin using an orographic-precipitation model, in Managing Water Resources During Global Change: Bethesda, Md., American Water Resources Association Annual Conference and Symposium, 28th, Reno, Nev., November 1-5, 1992, p. 651-660.

Hay, L.E., and Campbell, J.P., 1990, Water-quality trends in New Jersey streams: WaterResources Investigations Report 90-4046, 297 p.

Hay, L.E., and Knapp, L., 1993, Visualization techniques for hydrologic modeling, in Burton, J.S., compiler, Proceedings of the Federal interagency workshop on hydrologic modeling demands for the 90's, Fort Collins, Colo., June 1993: U.S. Geological Survey WaterResources Investigations Report 93-4018, sec. 3, p. 1-8.

Hay, L.E., McCabe, G.J., Wolock, D.M., and Ayers, M.A., 1991, Simulation of temperature and precipitation by weather-type analysis: Water Resources Research, v. 27, p. 493-501.

1992, Use of weather type analysis to disaggregate general circulation model predictions: Journal of Geophysical Researcl, Atmospheres, v. 97, p. 2781-2790.

Heim, R.R., and McCabe, G.J., 1991, Seasonal summaries of hydrologic conditions, water year 1988, in U.S. Geological Survey, National Water Summary 1988-89--Hydrologic Events and Floods and Droughts: U.S. 


\section{SURFACE-WATER HYDROLOGY}

Geological Survey Water-Supply Paper 2375, p. 26-33.

Heim, R.R., McCabe, G.J., and Brown, W.O., 1993, Seasonal summaries of hydrologic conditions, water year 1991, in U.S. Geological Survey National Water Summary 1990-91Stream Water Quality: U.S. Geological Survey Water-Supply Paper 2400, p. 56-63.

Jarrett, R.D., 1989, Hydraulics of mountain rivers in Yen B.C., ed., International conference on channel flow and catchment runoff-Centennial of Manning's formula, and Kuichling's rational formula, Charlottesville, Virginia: Proceedings, v. 1, p. 599-608.

1989, Hydrology and paleohydrology used to improve the understanding of flood hydrometeorology in Colorado, in Albertson, M.L., and Kia, R.L., eds., Design of hydraulic structures 89-Proceedings of the Second International Symposium on the design of hydraulic structures, Brookfield, Vermont: A.A. Balkema Publishers, p. 9-16.

Latkovich, V.J., and Leavesley, G.H., 1993, Automated data acquisition and transmission, in Maidment, D.R., ed., Handbook of Hydrology: New York, McGraw-Hill, p. 25.1-25.21.

Leavesley, G.H., 1988, A modular modeling system to forecast snowmelt runoff and utilize remotely-sensed data: Snow Hydrology Workshop, Manali, India, [Proceedings], sec. VII, p. 1-37.

1989, Problems of snowmelt-runoff modeling for a variety of physiographic and climatic conditions: Hydrological Sciences Journal v. 34 , no. 6, p. 617-634.

Leavesley, G.H., Beasley, D.B., Pionke, H.B., and Leonard, R.A., 1990, Modeling of agricultural nonpoint-source surface runoff and sediment
yield-A review from the modeler's perspective, in DeCoursey, D.G., ed., Proceedings of the International Symposium on Water Quality Modeling of Agricultural Non-Point Sources: U.S. Department of Agriculture, Agricultural Research Service, ARS-81, p. 171-194.

Leavesley, G.H., Branson, M.D., and Hay, L.E., 1992, Using coupled atmospheric and hydrologic models to investigate the effects of climate change in mountainous regions, in Managing water resources during global change: American Water Resources Association Annual Conference and Symposium, 28th, Reno, Nevada, November 1-5, 1992, Bethesda, Md., p. 691-700.

Leavesley, G.H., Lusby, G.C., and Lichty, R.W., 1989, Infiltration and erosion characteristics of selected teplira deposits from the 1980 eruption of Mount St. Helens, Washington: Hydrological Sciences Journal v. 34, no. 3, p. 339353.

Leavesley, G.H., Restrepo, P., Stannard, L.G., and Dixon, M., 1992. The modular hydrologic modeling system-MHMS: Bethesda, Md., American Water Resources Association Annual Conference and Symposium, 18th, Managing water resources during global change, Reno, Nevada, November 1-5, 1992, p. 263-264.

Leavesley, G.H., Restrepo, P., Stannard, L.G., and Dixon, M., 1993, The modular hydrologic modeling system-MHMS, in Burton, J.S., compiler, Proceedings of the Federal Interagency Workshop on Hydrologic Modeling Demands for the 90's: U.S. Geological Survey Water-Resources Investigations Report 934618 , sec. 4 , p. $40-42$.

Leavesley, G.H., and Stannard, L.G., 1989, A modular watershed-modeling and data-management system, in Proceedings United 


\section{SURFACE-WATER HYDROLOGY}

States/Peoples Republic of China Flood Forecasting Symposium/Workshop, Portland, Oregon: National Weather Service, U.S. Department of Commerce, v. 1, p. 71-95.

1990, Application of remotely sensed data in a distributed-parameter watershed model: in Kite, G.W. and Wankiewicz, A., eds., Proceedings of Workshop on Applications of Remote Sensing in Hydrology, National Hydrologic Research Centre, Environment Canada, p. 47-64.

1990, A modular watershed-modeling system for use in mountainous regions: Schweizer Ingenieur und Architekt, no. 18, p. 380-383.

Legates, D.R., and McCabe, G.J., 1991, The reliability of general circulation model-simulated doubled $\mathrm{CO}_{2}$ precipitation scenarios, in Proceedings of the 10th Conference on Biometeorology and Aerobiology: American Meteorological Society, p. 200-203.

1992, General circulation model estimates of regional precipitation, in Majumdar, S.K., Rosenfeld, L.M., Yarnal, B., Miller, W., and Kalkstein, L.S., eds., Global Climate Change--Implications, Challenges and Mitigation Measures: Lafayette, Pa., Pennsylvania Academy of Sciences, p. 302-314.

Lichty, R.W., and Karlinger, M.R., 1990, Climate factor for small-basin flood frequency: Water Resources Bulletin, v. 26, no. 4, p. 577-586.

McCabe, G.J., 1991, Book review of The rising tide-Global warming and world sea levels, by L.T. Edgerton: Water Resources Bulletin, v. 27, p. 871 .

McCabe, G.J., Barker, J.L., and Chase, E.B., 1991, Review of water year 1988 hydrologic conditions and water-related events, in U.S. Geological Survey, National Water Summary
1988-1989-Hydrologic Events and Floods and Droughts: U.S. Geological Survey WaterSupply Paper 2375, p. 13-25.

1991, Review of water year 1989 hydrologic conditions and water-related events, in U.S. Geological Survey, National Water Summary 1988-1989-Hydrologic Events and Floods and Droughts: U.S. Geological Survey WaterSupply Paper 2375, p. 34-49.

McCabe, G.J., Brown, W.O., and Heim, R.R., in press, Seasonal summaries of hydrologic conditions, water year 1990, in U.S. Geological Survey National Water Summary 1989-90Stream Water Quality: U.S. Geological Survey Water-Supply Paper 2400, p. 32-39.

McCabe, G.J., Fretwell, J.D., and Chase, E.B., 1993, Review of water year 1990 hydrologic conditions and water-related events, in U.S. Geological Survey National Water Summary 1989-90-Stream Water Quality: U.S. Geological Survey Water-Supply Paper 2400, p. 14-31.

McCabe, G.J., Fretwell J.D., and Chase, E.B., 1993, Review of water year 1991 hydrologic conditions and water-related events, in U.S. Geological Survey National Water Summary 1990-91-Stream Water Quality: U.S. Geological Survey Water-Supply Paper 2400, p. 40-55.

McCabe, G.J., and Heim, R.R., 1991, Seasonal summaries of hydrologic conditions, water year 1989, in U.S. Geological Survey, National Water Summary 1988-1989-Hydrologic Events and Floods and Droughts: U.S. Geological Survey Water-Supply Paper 2375, p. 50-57.

McCabe, G.J., and Legates, D.R., in press, General circulation model simulations of winter and summer sea-level pressures over 


\section{SURFACE-WATER HYDROLOGY}

North America: International Journal of Climatology, v. 12.

McCabe, G.J., and Wolock, D.M., 1991, Detectability of the effects of a hypothetical temperature increase on the Thornthwaite Moisture Index: Journal of Hydrology, v. 125, p. 2335.

1992, Effects of climatic change and climatic variability on the Thornthwaite moisture index in the Delaware River basin: Climatic Change, v. 20, p. $143-153$.

1992, Development of scenarios for the simulation of the effects of climate change on water resources-Proceedings of the Workshop on the Effects of global climate change on hydrology and water resources at a catchment scale, February 3-6, 1992, Tsukuba, Japan: JapanU.S. Committee on Hydrology, Water Resources, and Global Climate Change, no. 1, p. 49-56.

in press, Sensitivity of irrigation demand in a humid-temperate region to hypothetical climatic change: Water Resources Bulletin, v. 28, no. 3 .

McCabe, G.J., Wolock, D.M., Hay, L.E., and Ayers, M.A., 1990, Effects of climatic change on the Thornthwaite moisture index: WaterResources Bulletin, v. 26, no. 4, p. 633-643.

McCabe, G.J., Wolock, D.M., Tasker, G.D., and Ayers, M.A., 1991, Uncertainty in climate change and drought: Hydraulic Division of the American Society of Civil Engineers, [Proceedings], p. 1-6.

McCabe, G.J., Wolock, D.M., Tasker, G.D., Ayers, M.A., and Hay, L.E., 1993, Sensitivity of water resources in the Delaware River basin to climate clrange, in Kelmelis, J.A., and Snow, M., eds., U.S. Geological Survey,
Global Change Research Forum, Proceedings: U.S. Geological Survey .Circular 1086, p. 56-62.

Parker, R.S., Kuhn, G., Hay, L.E., and Elliot, J.G., 1992, Effects of potential climate change on the hydrology and the maintenance of channel morphology in the Gunnison River basin, Colorado-Proceedings of the Workshop on the Effects of global climate change on hydrology and water resources at a catchment scale, February 3-6, 1992, Tsukuba, Japan: JapanU.S. Committee on Hydrology, Water Resources, and Global Climate Change, p. 399410.

Peters, N.E., and Leavesley, G.H., in press, Hydrogeochemistry of snowmelt at Rabbit Ears Pass, Rocky Mountains, Colorado: Proceedings of the 1993 Eastern Snow Conference, Quebec City, Quebec, Canada, June 1993.

Stannard, L.G. and Kuhn, G., 1988, Summary of selected research on the hydrologic effects of coal mining-Watershed modeling, in Britton, L.J., Anderson, C.L., Goolsby, D.A., and Van Haveren, B.P., Summary of the U.S. Geological Survey and U.S. Bureau of Land Management National Coal-Hydrology Program 1974-1984: U.S. Geological Survey Professional Paper 1464, p. 120-125.

Tangborn, W.V., Fountain, A.G., and Sikonia, W.D., 1990, Effect of altitude-area distribution on glacier mass balance-A comparison of North and South Klawatti Glaciers, Washington State, U.S.A.: Annals of Glaciology, v. 14 , p. $278-282$.

Tasker, G.D., Ayers, M.A., Wolock, D.M., and McCabe, G.J., 1991, Sensitivity of drought risks in the Delaware River basin to climate change: Technology and Business Exposition and Symposium, Huntsville, Ala., Huntsville 


\section{SURFACE-WATER HYDROLOGY}

Association of Technical Societies [Proceed-

ings], p. 153-159.

Wolock, D.M., Ayers, M.A., Hay, L.E., and McCabe, G.J., 1989, Prediction of the effects of climate change on watershed runoff in the Delaware River basin, Proceedings: New York, American Society of Civil Engineering, p. 673-678.

Wolock, D.M., McCabe, G.J., Tasker, G.D., Ayers, M.A., and Hay, L.E., in press, Sensitivity of a watershed model of the Delaware River basin to projected climatic changeProceedings of the Workshop on the Effects of global climate change on hydrology and water resources at a catchment scale, February 3-6, 1992, Tsukuba, Japan: Japan-U.S. Committee on Hydrology, Water Resources, and Global Climate Change, p. 219-329. 


\section{SURFACE-WATER HYDROLOGY}

TITLE: $\quad$ Statistical Analysis of Errors in Hydrologic Models (CR 83-279)

PERSONNEL: Brent M. Troutman, Project Chief

Jeanea Shown, Secretary $\quad$ D. Phillip Guertin, Hydrologist

Michael R. Karlinger, Hydrologist - Thomas M. Over, Student, (Colorado School of

Aldo V. Vecchia, Statistician Mines)

ADDRESS: U.S. Geological Survey, P.O. Box 25046, MS 418, Denver Federal Center, Denver, CO 80225

TELEPHONE: (303) 236-5038

PROBLEM: Uncertainty in application of physically based surface-water hydrologic models is a function of adequacy of the conceptualization of the processes involved and of the quantity and quality of data available to use as input to the model. In any type of modeling exercise, even if the physical processes are well understood, spatial heterogeneities make application of the model on a basin-wide scale problematic, and it is almost always necessary to use some form of spatial averaging to obtain "effective" input variables. The over-all goal of our research is to investigate (1) model output errors as a function of model complexity and uncertainty in model input; (2) derivation of simplified yet physically based models that are appropriate to use with limited data; (3) ways of evaluating and coping with uncertainty caused by spatial variability of input variables.

OBJECTIVE: Develop unified approach to analyzing and partitioning errors in hydrologic modeling with particular attention to scale and spatial averaging problems; develop improvements to existing practices; and develop new approaches to managing error levels within the constraints of reduced budgets.

APPROACH: Use probabilistic and statistical techniques to estimate the individual contributions of various sources of error in hydrologic modeling.

PROGRESS: (1) Investigations of properties of the random topology channel network model, especially for large networks (our strategy in looking at the effect of model input error has been to randomize various components of model input, including channel segment properties, such as length, and channel segment configuration. This has been done primarily via the random topology model used by geomorphologists since the 60's. Hence, our investigations into model input error have led to a number of related studies on the properties of this and other random network models): (a) Continued investigations of properties of the width 


\section{SURFACE-WATER HYDROLOGY}

function; and (b) Studied distribution of subnetwork magnitudes for randomly selected points in a topologically random network.

(2) Investigations of spatial random network models (the random topology model does not give a unique spatial definition to networks being modeled. Hence, we have seen the need to look at random models that are well-defined spatially; we have used rectangular grids to do this): (a) studied application of the one-parameter Gibbsian family of distributions (wellknown for applications in thermodynamics and statistical mechanics) for modeling spatial behavior of channel networks; the parameter is a measure of drainage efficiency of the network: (i) developed Markov chain procedure for simulating networks under the Gibbsian distribution; (ii) developed parameter estimation procedures for networks defined using digital elevation data (for example, for "topographic trees"); (iii) developed regionalization methods for predicting the Gibbsian parameter as a function of map scale; (iv) looked at methods for using this model to predict network width function; (v) applied methods developed using digital elevation data for Willow Creek, Montana; (b) Investigated extension of Gibbsian family of distributions to a two-parameter family: (i) worked on inference problems for this family, including point and interval estimation using bootstrap procedures; (ii) developed goodness-of-fit tests for evaluation of model; (iii) applied methods to Willow Creek data again: (c) Investigated fractal and scaling properties of spatial models as measured by the behavior as the grid spacing grows smaller: (i) refined fat fractal analysis of channel geometric properties; (ii) investigated other geomorphological scaling laws, such as Hack's law.

(3) work with Bob Lichty on error analysis of regionalized flood magnitudes: (a) Investigated influence of climatic factors on regionalization error; (b) Mapped flood distribution moments based on ensemble averaging; (c) collaborated with Marshall Moss on accuracy of spatial precipitation estimation for climate models.

(4) Work by Skip Vecchia: (a) developed new methods for model identification analysis for periodic autoregressive moving average time-series models (these models are extremely useful for characterizing stochastic properties of seasonal time-series, such as monthly streamflows); (b) developed a new efficient method of prediction for spatial regression models with correlated errors using maximum likelihood methods. The methods can be used for evaluating uncertainty in spatially distributed inputs to hydrologic models; (c) as part of the global change research initiative: (i) developed a stochastic model for generation of jointstation monthly streamflows on the Upper Gunnison River Basin. The model will be used for studies on the sensitivity of the Gunnison River Basin to climatic change; (ii) developed a 


\section{SURFACE-WATER HYDROLOGY}

statistical model for interpolating snowpack in western Colorado; and (iii) worked with Andrew Fountain on improving methods for estimating glacier mass change.

\section{REPORTS PUBLISHED 1988-1993:}

Anderson, P.L., and Vecchia, A.V., 1993, Asymptotic results for periodic autoregressive-moving average processes: Journal of Time-Series Analysis, v. 14, p. 1-18.

Driver, N.E., and Troutman, B.M., 1989, Regression models for estimating urban storm runoff quality and quantity in the United States: Journal of Hydrology, v. 109, no. 109, p. 221236.

Karlinger, M.R., Guertin, D.P., and Troutman, B.M., 1988, Regression estimates for topological hydrograph input: Journal of Water Resources Planning and Management: American Society of Civil Engineers, v. 114, no. 4, p. 446-456.

Karlinger, M.R., and Troutman, B.M., 1989, A random spatial network model based on elementary postulates: Water Resources Research, v. 25, no. 5, p. 793-798.

1992 Fat fractal scaling of drainage networks from a random spatial network model: Water Resources Research, v. 28 , no. 7, p. 19751981.

Lichty, R.W., and Karlinger, M.R., 1990, Climate factor for small-basin flood frequency: Water Resources Bulletin, v. 26, no. 4, p. 577-586.

Moody, J.A., and Troutman, B.M., 1992, Evaluation of the depth-integration method of measuring water discharge: Journal of Hydrology, v. 135, p. 201-236.

Parker, R.S., and Troutman, B.M., 1989, Frequency distribution for suspended sediment loads: Water Resources Research, v. 25, no. 7, p. 1567-1574.

Troutman, B.M., and Karlinger, M.R., 1988, Asymptotically Rayleigh instantaneous unit hydrographs: Stochastic Hydrology and $\mathrm{Hy}-$ draulics, v. 2, p. 73-78.

1990, Reply to comment on Predictors of the peak width for networks with exponential links by Agnese, C., and D'Asaro, F.: Stochastic Hydrology and Hydraulics, v. 4, no. 1, p. 87-88.

1992, Gibbs' distribution on drainage networks: Water Resources Research, v. 28, no. 2, p. 563-577.

1993. A note on subtrees rooted along the primary path of a binary tree: Discrete Applied Mathematics, v. 42, p. 87-93.

Troutman, B.M., Karlinger, M.R., and Guertin, D.P., 1989, Basin-scale relations via conditioning: Stochastic Hydrology and Hydraulics, v. 3, p. 111-133.

Vecchia, A.V., 1988, Estimation and model identification for continuous spatial processes: Journal of the Royal Statistical Society, v. B-50, no. 2, p. 297-312.

1990, An innovations approach for interpolating a random surface based on sparse data in Proceedings of the 22nd Symposium on the Interface Between Computing Science and Statistics: New York, Springer-Verlag, p. 215-224. 


\section{SURFACE-WATER HYDROLOGY}

1992 a, A new method of prediction for spatial regression models with correlated errors: Journal of the Royal Statistical Society, v. B-54, no. 3 , p. $813-830$.

Vecchia, A.V., and Ballerini, R., 1991, Testing for periodic autocorrelations in seasonal time series data: Biometrika, v. 78 , no. 1, p. $53-$ 63.

Williams, G.P., and Troutman, B.M., 1990, Comparison of structural and least-squares lines for estimating geologic relationships: Mathematical Geology, v. 22, no. 8, p. 1027-1049. 


\title{
SURFACE-WATER HYDROLOGY
}

TITLE: $\quad$ Transport and Degradation of Organic Substances in Streams (CR 77-301)

\author{
PERSONNEL: Ronald E. Rathbun, Project Chief \\ Nora L. Bender, Secretary LaDonna M. Bishop, Chemist \\ Colleen E. Rostad, Research Chemist Geoffrey S. Ellis, Student, (Colorado School of Mines)
ADDRESS: U.S. Geological Survey, P.O. Box 25046, MS 408, Denver Federal Center, Denver, CO 80225

TELEPHONE: (303) 467-8250

PROBLEM: Organic substances in streams affect the quality and uses of the water. To determine the effect of organic substances on water quality, the physical, chemical, and biological processes involved in the transport and degradation of these substances must be understood. Procedures for measuring or estimating the rate coefficients describing these processes must be developed. Models incorporating these coefficients then must be developed for predicting the fate of organic substances in streams and their effects on water quality.

OBJECTIVE: (1) Study the fundamentals of volatilization, dispersion, and sorption on sediments of organic substances in water; (2) develop submodels of these processes, including methods for measuring or estimating the process rate coefficients; and (3) integrate these submodels into overall transport and fate models for organic substances in streams.

APPROACH: (1) Conduct controlled laboratory studies to determine the volatilization and sediment sorption of specific organic compounds, both as single components and as mixtures; (2) conduct controlled field studies to test, adapt, and (or) develop transport and fate models for organic substances in streams; and (3) apply the models to field problems.

PROGRESS: Laboratory experiments to determine the potential for the formation of disinfection byproducts when water from the Mississippi River is chlorinated were completed. Combinations of three $\mathrm{pH}$ values and three initial free-chlorine concentrations were used, giving nine' formation potential determinations for each water sample. Samples were collected at 12 sites along the Mississippi River between Minneapolis, Minnesota, and New Orleans, Louisiana, and one site each on the Missouri and Ohio Rivers during summer, fall, and spring sampling trips. The formation potentials for the volatile trihalomethane compounds and the nonvolatile total organic halide compounds decreased with distance downstream, approximately paralleling the decrease with distance downstream of the dissolved-organic carbon concentration of the river water. Values of $\mathrm{pH}$ that minimized the formation of the 


\section{SURFACE-WATER HYDROLOGY}

trihalomethane compounds maximized the formation of the total organic halide compounds. Formation potentials for both types of compounds increased slightly as the initial free-chlorine concentration increased. Formation potentials for the brominated trihalomethane compounds were larger for the Missouri River sample than for the Mississippi River samples because of the higher bromide concentrations in the Missouri.

Work continued on the analysis and interpretation of data on the concentrations of agricultural and industrial organic chemicals in the suspended silt, colloid, and fish tissue phases of the Mississippi River. Some of the toxic organic compounds found include chlordane, dacthal, trifluralin, hexachlorobenzene, and polychlorinated biphenyls (PCBs). The organic carbon content of the colloid phase ranged from 10 to 30 percent by weight, which is higher than the previously reported 5 to 10 percent by weight. The organic carbon content of the suspended silt phase ranged from about 2 to 5 percent by weight. The colloidal phase averaged 10 percent by weight of the total suspended matter, but averaged about 25 percent of the total transported organic carbon. Because the toxic organic compounds are associated with the organic carbon, neglecting the colloid phase could result in significant underestimation of the quantities of toxic organic compounds being transported by the Mississippi River. Trioleinstrip integrators designed to simulate the absorption of toxic organic compounds by fish tissue successfully concentrated the same organic compounds found in the silt and colloid phases.

\section{REPORTS PUBLISHED 1988-1993:}

Kilpartick, F.A., Rathbun, R.E., Yotsukura, N., Parker, G.W., and DeLong, L.L., 1989, Determination of stream reaeration coefficients by use of tracers: U.S. Geological Survey Techniques of Water-Resources Investigations, book 3, chap. A18, 52 p.

Rathbun, R.E., 1988, Discussion of Wind function for a sheltered stream: American Society of Civil Engineers Journal of Environmental Engineering, v. 114, no. 1, p. 229-231.

1988, Discussion of Flume tests on hydrocarbon reaeration tracer gases: American Society of Civil Engineers Journal of Environmental Engineering, v. 114, no. 2, p. 473-475.

1989, Discussion of Effect of temperature on oxygen transfer-Laboratory studies: American
Society of Civil Engineers Journal of Environmental Engineering, v. 115 , no. 2, p. 482484.

1989, Discussion of Influence of temperature on oxygen transfer: American Society of Civil Engineers Journal of Environmental Engineering, v. 115 , no. 4 , p. 868-869.

1990. Prediction of stream volatilization coefficients: American Society of Civil Engineers Journal of Environmental Engineering, v. 116, no. 3 , p. $615-631$.

1992, Discussion of Aeration at Ohio River basin navigation dams: American Society of Civil Engineers Journal of Environmental Engineering, v. 118, no. 3, p. 446-447. 


\section{SURFACE-WATER HYDROLOGY}

1992, Discussion of Gas-transfer measurements using headspace analysis of propane: American Society of Civil Engineers Journal of Environmental Engineering, v. 118, no. 3, p. 454-456.

Rathbun, R.E., and Bishop, L.M., 1993, Trihalomethane and nonpurgeable total organic halide formation potentials for the Mississippi River and some of its tributaries, June-August 1991: U.S. Geological Survey Open-File Report 93-158, $57 \mathrm{p}$.

Rathbun, R.E., and Tai, D.Y., 1988, Application of the two-film model to the volatilization of acetone and $t$-butyl alcohol from water as a function of temperature: U.S. Geological Survey Water-Supply Paper 2318, 41 p.

1988, Volatilization of benzene and eight alkyl-substituted benzene compounds from water: U.S. Geological Survey Water-Supply Paper 2342, $24 \mathrm{p}$.

Rathbun, R.E., Shultz, D.J., Stephens, D.W., and Tai, D.Y., 1989, Transport and fate of acetone in an outdoor model stream, Stennis Space Center near Bay St. Louis, Mississippi: U.S. Geological Survey Water-Resources Investigations Report 89-4141, 101 p.

Rathbun, R.E., Stephens, D.W., Shultz, D.J., and Tai, D.Y., 1989, Fate of acetone in an outdoor model stream in southern Mississippi, U.S.A.: Journal of Hydrology, v. 104, p. 181-209.

Rathbun, R.E., Steplens, D.W., and Tai, D.Y., 1991, Fate of acetone in an outdoor model stream with a nitrate supplement, southern Mississippi, U.S.A.: Journal of Hydrology, v. 123 , p. $225-242$.
1993, Bacterial degradation of acetone in an outdoor model: Stream Environmental Pollution, v. 79, p. 153-162.

Rathbun, R.E., White, K.D., and Evaldi, R.D., 1992 , Trihalomethane formation potential of Kentucky River water: U.S. Geological Survey Water-Resources Investigations Report 924057, $16 \mathrm{p}$.

Rostad, C.E., and Pereira, W.E., 1991, Distribution of selected anthropogenic organic compounds on suspended sediments in the Mississippi River, in Mallard, G.E., and Aronson, D.A., eds., U.S. Geological Survey Toxic Substances Hydrology Program-Proceedings of the technical meeting, Monterey, Calif., March 11-15, 1991: U.S. Geological Survey Water-Resources Investigations Report 914034, p. 347-348.

Tai, D.Y., and Rathbun, R.E., 1988, Photolysis of rhodamine-WT dye: Chemosphere, v. 17, no. 3 , p. 559-573. 


\title{
SURFACE-WATER HYDROLOGY
}

TITLE: $\quad$ Paleohydrology and Climate Change (CR 90-321)

PERSONNEL: Robert D. Jarrett, Project Chief

Jeanea Shown, Secretary

Thompson, Douglas, student (Colo. State

Capesius, Joe, student, (Univ. of Denver) University)

Julie K. Sueker, student, (Univ. of Colo.) Pruess, Jon, student, (Colorado State University)

\begin{abstract}
ADDRESS: U.S. Geological Survey, P.O. Box 25046, MS 418, Denver Federal Center, Denver, CO 80225
\end{abstract}

TELEPHONE: (303) 236-6447

PROBLEM: To anticipate the effects of potential climate change (natural or anthropogenic) on hydrology and to assess hydrologic trends will require an understanding of past long-term hydrologic variability. There also is a critical need for data on extreme floods for engineering hydrology and flood-hazard mitigation. Probably the best information on hydrologic variability and extreme floods is provided by paleohydrologic and other proxy data analyzed with the help of hydrologic models. Methods for extending existing climatic and hydrologic records over long-time scales are needed. A relatively new approach, one that complements hydrologic modeling efforts, involves the application of paleohydrology to determine regional scale hydrologic variability over relatively long-time intervals (100 to 10,000 years). Existing techniques for paleohydrologic reconstruction have large errors; hence, there is a critical need to improve paleohydrologic techniques.

OBJECTIVE: The primary goals of this project are to (1) improve techniques to reconstruct the fluvial history of river basins, particularly for extreme floods; (2) improve the understanding of hydrologic and hydraulic processes to improve numerical models of rivers; and (3) improve the understanding of links between climate and hydrology. These goals are closely related because the development and use of paleohydrologic techniques require an understanding of geomorphic response to climate change and an improved understanding of hydrologic and hydraulic processes.

APPROACH: Interdisciplinary, process-oriented research is used to study past and present hydrologic and climatic conditions in mountainous and prairie environments, particularly the Rocky Mountains. The research includes (1) paleohydrologic research that consists of selecting several basins in different climatic regions to construct the fluvial history of each river basin. Using different methods (such as step-backwater, critical depth, and tractive 


\section{SURFACE-WATER HYDROLOGY}

force), estimate paleoflood discharges. Using a variety of geochronologic techniques (dendrochronology, carbon-14, thermoluminescense, and other absolute- and relative-age dating techniques), improve methods to make high-resolution time sequences of alluvial stratigraphy; (2) conduct instream, laboratory and numerical modeling studies to improve hydrologic and paleohydrologic methods of estimating velocity and discharge; and (3) analyze hydrologic, paleohydrologic, and climatic data to quantify long-term variability and to improve the understanding of the links between climate, fluvial processes, and hydrology. To better understand extreme floods, mitigate flood hazards, and decrease the uncertainty of paleoflood techniques, an interdisciplinary study of floods during or immediately after floods is being made.

PROGRESS: The study of the paleoflood hydrology of Arthurs Rock Gulch, Colorado Front Range, is finished and the report has been forwarded for Director's approval, and one journal article has been accepted for publication. The study investigates the fluvial history of the river basin, and the development and testing of methods used to conduct paleofluvial studies in mountain rivers. Additional paleohydrologic research in the Rocky Mountains has begun, including a study at the Rocky Mountain Arsenal in Denver in conjunction with Colorado District studies. Research also includes a study recently completed (Master's thesis) . of the Bear Creek watershed west of Denver, and of the Gunnison River Basin in Colorado in collaboration with the Global Change program. Hydraulic data for the North Saint Vrain Creek at the Rocky Mountain Hydrologic Research Center is being analyzed to improve methods to estimate velocity, discharge, and paleodischarge in mountain rivers. Waterchemistry studies of headwater basins in the Colorado Rocky Mountains related to the National Water-Quality Assessment (NAWQA) program are in progress by a Ph.D. student. Sediment-transport studies in mountain rivers are in progress by a M.S. student. Studies of the hydroclimatology of extreme storms in conjunction with paleoflood investigations are being conducted by a M.S. student. An interdisciplinary research study of two flash floods that occurred in Colorado during 1991 is being conducted.

REPORTS PUBLISHED 1990-1993

Jarrett, R.D., 1990, Hydrologic and hydraulic research in mountain rivers: Water Resources Bulletin, v. 26, no. 3, p. 419-429.

1990, Paleohydrology techniques used to define the spatial occurrence of floods: Geomorphology, v. 3, no. 2, p. 181-195.
1990, Hydrologic and hydraulic research in mountain rivers, in Molnar, Ludovit, ed., Hydrology of Mountainous Areas, Stebske Pleso Workshop, Czechoslovakia, June, 1988, Proceedings: Brateslava, Czechoslovakia, International Association of Hydrological Sciences Publication, no. 190, p. 107-117. 


\section{SURFACE-WATER HYDROLOGY}

1991, Wading measurements of vertical velocity profiles: Geomorphology, v. 4, no. 3-4, p. 243-247.

1991, Paleohydrology and its value in analyzing floods and droughts: U.S. Geological Survey Water-Supply Paper 2375, p. 105-116.

1992, Hydraulics of mountain rivers-Channel flow resistance-centennial of Mannings' formula, in Yen, B.C., ed., International conference on channel flow and catchment runoffCentennial of Mannings' and Kuichling's Rational Formula, Charlottsville, Virginia, Proceedings: Littleton, Colo., Water Resources Publications, p. 287-298.

1992, Paleohydrology and its value in analyzing floods and droughts, in Kite, G.W., and Harvey, K.D., eds., Using Hydrometric Data to Detect and Monitor Climatic Change, Saskatoon, Saskatchewan, Canada, April 8-9, 1992, Proceedings: Saskatoon, Saskatchewan, Canada, National Hydrology Research Institute Workshop no. 8, p. 89-106.

1993, Flood elevation limits in the Rocky Mountains, in Kuo, C.Y., ed., Engineering hydrology-Proceedings of the symposium sponsored by the Hydraulics Division of the American Society of Civil Engineers, July 25-30, 1993, San Francisco, Calif.: New York, American Society of Civil Engineers, p. 180-185.

1993, Paleohydrology and its value in analyzing floods and droughts: Electric Power Research Institute, TR-101242, v. 3, 15 p.

Jarrett, R.D., and Costa, J.E., 1993, Hydrology and geomorphology of the 1982 Lawn Lake Dam failure, Colorado, in McCutchen, H.E., Hermann, Raymond, and Stevens, D.R., eds., Ecological effects of the Lawn Lake flood of 1982: Rocky Mountain National Park Scien- tific Monograph NPS/NRROMO/NRSM93/21, U.S. Department of the Interior, National Park Service, p. 1-17.

Waythomas, C.F., Jarrett, R.D., and Osterkamp, W.O., 1991, Late Quaternary fluvial activity and climate variability in the Colorado Front Range foothills and piedmont: Current Research in the Pleistocene, v. 8, p. 122-124. 


\section{SURFACE-WATER HYDROLOGY}

TITLE: $\quad$ Mathematical Modeling Principles (CR 93-343 formerly WR 73-197)

PERSONNEL: James P. Bennett, Project Chief

Aleta R. Moores, Secretary

Jackie Walters, Clerk

ADDRESS: $\quad$ U.S. Geological Survey, P.O. Box 25046, MS 413, Denver Federal Center, Denver, CO 80225

TELEPHONE: (303) 236-4992

PROBLEM: The development of models of hydrologic systems requires the description of individual processes in mathematical terms and the solution of sets of complex equations in differential form. Research is needed on application of mathematical theory to the modeling of transport of sediments, including mudflows and hyperconcentrations such as occur after natural disasters such as volcanic eruptions or dam failures.

OBJECTIVE: Develop mathematical descriptions of flow and water-quality processes that can be linked together to form models of hydrologic systems. Develop mathematical techniques for efficient solution of equations on digital computers. Develop techniques for studying sensitivity of parameters.

APPROACH: The approach to the problem will be by theoretical study, model development, and model testing.

PROGRESS: Formulated general physics-based sand transport and resistance to flow algorithms for one-dimensional wide channels. Developed regression equations from more than 2,000 field and flume data sets for description of roughness height and Meyer-Peter-type transport parameter for 4 bedform regimes. Began field investigation of transport and geomorphology of an actively meandering segment of the Virgin River, Nevada.

REPORTS PUBLISHED 1988-1993:

Bennett, J.P., 1988, Simulation of transport-related properties, in Bradford, W.L., and Horowitz, A.J., eds, The role of sediments in the chemistry of aquatic systems-Proceedings of the sediment chemistry workshop, February 8-12, 1982: U.S. Geological Survey Circular 969, 64-75.
Bennett, James P., 1993, Sediment transport simulations for two reaches of the Colorado River, Grand Canyon, Arizona: U.S. Geological Survey Water-Resources Investigations Report 93-4034, 42 p. 


\section{SURFACE-WATER HYDROLOGY}

TITLE: $\quad$ Numerical Simulation of Hydrodynamic Processes in Rivers, Estuaries, and Coastal Embayments (NR 69-019)

PERSONNEL: Robert A. Baltzer, Project Chief

Mary E. Abel, Secretary

Harry Jenter, Hydrologist

ADDRESS: $\quad$ U.S. Geological Survey, 430 National Center, 12201 Sunrise Valley Drive, Reston, VA 22092

TELEPHONE: (703) 648-5894

PROBLEM: Technical solutions to the problem of investigating and managing waste movement and disposal in regulated rivers, estuaries, and embayments require qualitative and quantitative assessments of the interactions among waste constituents undergoing dynamic transport. Mathematical, numerical, computer-simulation models offer one very powerful solution. Because water is both the vehicle by which the waste constituents are transported and the media in which the constituent interactions occur, the temporal and spatial variations of the flow appreciably govern the interactions qualitatively and quantitatively. Design of the desired simulation models depends in large measure on accurate mathematical-numerical representation of the hydrodynamics of the transient-flow process.

OBJECTIVE: (1) Explore thoroughly the hydrodynamics of one-, two-, and three-space dimensional transient flows (including the transport and interaction of constituents) in water ways and waterbodies; (2) develop mathematical-numerical techniques with which to simulate these processes; and (3) provide the hydrologist with a simulation system comprised of rational mathematical-numerical models for evaluating the effect of past, present, and projected changes in prototype-waterbody systems.

APPROACH: Derive mathematical models comprised of sets of nonlinear, partial differential equations representing various transient flow conditions. Develop numerical techniques to simulate the various flow regimens represented by the models. Use field data gathered at specific field sites and (or) hypothetical data reflecting a projected change to provide the necessary boundary-condition information and driving function with which to particularize model solution. Use large-capacity, high-speed digital computers and videographic output equipment in making the simulations. 


\section{SURFACE-WATER HYDROLOGY}

PROGRESS: (1). Continued calibration and operational utilization of a full, threedimensional, flow/transport model of Massachusetts and Cape Cod Bays. The capability to account for atmospheric radiation in the model has been ended. Currently the code is being restructured to permit computation by parallel processor.

(2). Prepared and presented an intensive week-long, hands-on, two-dimensional flow-withtransport modeling course at the Federal Training Center in Denver, Colorado, November $2-6,1992$. The was a new course, prepared and presented with three colleagues. The course focused upon the implementation and operation of the SWIFTZD flow and transport model, and was very well received.

(3). Completed a two-dimensional vertically averaged, investigation of the impact of right-ofway road embankments on estuarine circulation and transport in tidal marshlands and across tidal flats. Circulation changes can be profound, particularly during high tide. This effect also demonstrated the use of "model nesting" to abstract detailed circulation patterns, as well as investigative power of such model utilization.

(4). Two higher-order schemes for numerical simulations of an integrally combined transport process in flow/transport models have now been extended to two-dimensional, vertically averaged conditions. The schemes are each being implemented and evaluated in BRANCH (1-D) and SWIFT (2-D).

\section{REPORTS PUBLISHED 1988-1993:}

Baltzer, R.A., Regan, R.S., and Schaffranek, R.W., 1989, Time dependent data systemOverview: U.S. Geological Survey Open-File Report 293, 5 p.

Butman, B., Bothner, M. H., Hatliway, J. C., Jenter, H. L., Knebel, H. J., Manheim, F.T., and Signell, R.P., 1992, Contaminant transport and accumulation in Massachusetts Bay and Boston Harbor-A summary of U.S. Geological Survey studies, Woods Hole, Massachusetts: U.S. Geological Survey Open-File Report 92-202, 42 p.

Jenter, H.L., Rybicki, N.B., Baltzer, R.A., and Carter, V., 1991, Tidal mass exchange between a submersed aquatic vegetation bed and the main clannel of the Potomac River: American Society of Civil Engineers, 1991 National Conference, Hydraulics Division, Nashville, Tennessee, August 2-7, 1991 [Proceedings], p. 298-304.

Jenter, H.L., and Signell, R.P., 1992, NetCDF-A public-domaine software solution to data-access problems for numerical modelers: American Society of Civil Engineers, 2nd International Conference on Estuarine and Coastal Modeling, Tampa, Fla., November 13-15, 1991 [Proceedings], p. 72-82.

Jenter, H.L., Signell, R.P., and Blumberg, A.F., in press, Modeling the Tides of Massachusetts and Cape Cod Bays, in National Conference 


\section{SURFACE-WATER HYDROLOGY}

on Hydraulic Engineering, San Francisco, Calif., July 25-30, 1993: American Society of Civil Engineers.

Lai, C., Schaffranek, R.W., and Baltzer, R.A., 1989, Frictional resistance treatment in unsteady open-channel flow simulation: International Conference on Channel Flow and Catchment Runoff, Centennial of Manning's Formula and Kuichling's Rational Formula, Charlottesville, Va., University of Virginia, May 22-26, 1989 [Proceedings], p. 688-698.

1992, Frictional resistance treatment in unsteady open-channel flow simulation, in Yen, B.C. ed., Channel Flow Resistance-Centennial of Manning's Formula: Littleton, Colo., Water Resources Publications, p. 409-420.

Lee, J.K., Schaffranek, R.W., and Baltzer, R.A., 1989, Convergence experiments with a hydrodynamic model of Port Royal Sound, South Carolina: American Society of Civil Engineers, Hydraulics Division, National Conference on Hydraulic Engineering, New Orleans, La., August 14-18, 1989 [Proceedings], p. $434-$ 441.

in press, Simulation of the effects of highway embankments on circulation and transport in Port Royal Sound, South Carolina: American Society of Civil Engineers, Sixth Symposium on Coastal and Ocean Management-Coastal Zone '89, New York, N.Y., [Proceedings], v. VI, 19.p.

Schaffranek, R.W., and Baltzer, R.A., 1988, A simulation technique for modeling flow on floodplains and in coastal wetlands: American Society of Civil Engineers, 1988 National Conference, Hydraulics Division, Colorado Springs, Colo., August 8-12, 1988 [Proceedings|, p. 733-739.
1989, Implementation of a hydrodynamic model for the Upper Potomac Estuary: American Society of Civil Engineers, Hydraulics Division, National Conference on Hydraulic Engineering, New Orleans, La., August 14-18, 1989 [Proceedings], p. 484-492.

1990, Horizontal density-gradient effects on simulation of flow and transport in the Potomac Estuary: New York, N.Y., American Society of Civil Engineers, 1990 National Conference, Hydraulics Division [Proceedings], v. II, p. 1251-1256. 


\section{SURFACE-WATER HYDROLOGY}

TITLE: $\quad$ Simulation Modeling of Hydrodynamic Systems (NR 80-104)

PERSONNEL: Raymond W. Schaffranek, Project Chief

ADDRESS: $\quad$ U.S. Geological Survey, 430 National Center, 12201 Sunrise Valley Drive, Reston, VA 22092

TELEPHONE: (703) 648-5891

PROBLEM: Managing water use in riverine and estuarine systems requires an understanding of the governing supply, circulation, mixing, and flushing processes. Qualitative and quantitative estimates of the hydrodynamic and transport properties of water bodies can be computed by means of mathematical-numerical simulation models. To accurately simulate temporal and spatial variations of flow, which significantly define the transport processes, the simulation model must be capable of accounting for hydraulic and tide-induced fluctuations, water withdrawals, discharges, winds, nonuniform geometric configurations, and other human-induced or natural factors.

OBJECTIVE: (1) Investigate and develop various mathematical-numerical techniques with which to simulate the hydrodynamics of one-, two-, and three-space dimensional transient flows in various water bodies; (2) evaluate and (or) develop methods to describe the transport of solutes in such water bodies on the basis of the comprehensive flow information derived from flow simulation models; and (3) develop and implement an operational system in support of flow/transport simulation models.

APPROACH: Use large-capacity, high-speed digital computers and various supporting peripheral equipment. Derive and develop mathematical models, constituting approximate numerical solutions to the governing nonlinear, partial differential equations to simulate the transient flow and transport processes. Use data, collected at specific locations or hypothetically imposed, to provide the required boundary-condition information with which to effect the numerical solution.

PROGRESS: Modified computational method of the branch-network simulation model to numerically treat hydraulic structures in the interior domain of open-channel networks. Extended Lagrangian transport component to provide full network-racking capability and continuity in interconnected-channel systems. 


\section{SURFACE-WATER HYDROLOGY}

Continued investigation into the numerical treatment of hydrodynamic and constituent transport processes in one- and two-dimensional finite-difference model formulations. Examined behavior of varied types, mixed combinations, and alternate formulation methods for treatment of open boundary conditions in open-channel flow models; model sensitivity and numerical model results are shown to be highly correlated to open-boundary treatment in freesurface unsteady flow simulation. Completed extensive numerical model experiments and prepared paper on "Frictional Resistance Treatment in Unsteady Flow Simulation" for submission to American Society of Civil Engineers (ASCE) Journal of Hydraulic Engineering. Completed numerical experiments with a two-dimensional hydrodynamic/ transport model, formulated on the alternating-direction-implicit solution method, for analyzing circulation and transport effects of highway crossings in wetland areas. Investigated improved methods for open boundary-condition treatment. Reported results in paper with colleagues entitled "Simulating the Effects of Highway Embankments on Estuarine Circulation," accepted for publication in ASCE Journal of Waterway, Port, Coastal, and Ocean Engineering.

Consulted with several Water Resources Division district offices on surface-water modeling projects and varied hydrologic investigations. Included among these are projects involving investigation of saltwater intrusion in the Hudson River, water-quality conditions in the Foster Creek and Back River tributaries of Cooper River, and freshwater influence on saline conditions in Indian River Lagoon. Extended the branch-network model to allow for culverttype hydraulic structures to assist the South Carolina District in the Foster Creek/Cooper River project. Consulted and advised South Carolina District Office on preparation of cooperator report summarizing numerical findings in Cooper River modeling project. Developed two-dimensional model of Hudson River transition zone and conducted initial model simulations and analyses. Consulted and advised Albany Subdistrict project chief on model approach and additional field requirements. Reviewed Indian River Lagoon project proposal and advised Orlando Subdistrict project chief on data requirements and field layout. Wrote paper on applications of the branch-network dynamic flow/transport model for addressing environmental problems for presentation at ASCE Water Forum '92 Conference.

Responded to inquiries from national and international governmental agencies, academic institutions, and private consulting companies on surface-water models, modeling problems, and hydrologic investigations. Provided source code and test data sets for models developed within the scope of research project in response to requests.

Provided model for development of coupled surface-water and ground-water flow model for simulation of stream-aquifer interaction. Prepared and packaged material on branch-network 


\section{SURFACE-WATER HYDROLOGY}

simulation model at the request of the World Meteorological Organization to make model available internationally component.

Served as corresponding member of the Tidal Hydraulics technical committee of the ASCE Hydraulics Division; reviewed proposal for institution of Task Committee to investigate flowsalinity relationships in estuaries. Developed, coordinated, and conducted a 1-week training course entitled "Surface Water Flow and Transport using a Two-Dimensional Depth Integrated Model" held November 2-6, 1992, at the USGS National Training Center, Denver, Colorado. Developed and chaired technical sessions and presented paper at the Hydraulic Engineering component of the ASCE Water Forum '92 Conference. Reviewed papers for colleagues on the development of new numerical methods for solution and simulation of free-surface flows.

REPORTS PUBLISHED 1988-1993:

Lai, C., Schaffranek, R.W., and Baltzer, R.A., 1989, Frictional resistance treatment in unsteady open-channel flow simulation: International Conference on Channel Flow and Catchment Runoff, Centennial of Manning's Formula and Kuichling's Rational Formula, Charlottesville, Va., University of Virginia, May 22-26, 1989 [Proceedings], p. 688-698.

1992, Frictional resistance treatment in unsteady open-channel flow simulation, in Yen, B.C., ed., Channel Flow ResistanceCentennial of Manning's Formula: Littleton, Colo., Water Resources Publications, p. 409420 .

Lee, J.K., Schaffranek, R.W., and Baltzer, R.A., 1989, Convergence experiments with a hydrodynamic model of Port Royal Sound, South Carolina: American Society of Civil Engineers, Hydraulics Division, National Conference on Hydraulic Engineering, New Orleans, La., August 14-18, 1989 |Proceedings|, p. 434-441.

in press, Simulating the effects of highway embankments on estuarine circulation: Ameri- can Society of Civil Engineers, Sixth Symposium on Coaastal and Ocean Management-Coatal Zone '89, New York, N.Y. [Proceedings] $22 \mathrm{p}$.

Schaffranek, R.W., 1989, Proceedings of the advanced seminar on one-dimensional, openchannel flow and transport modeling: U.S. Geological Survey Water-Resources Investigations Report 89-4061, 99 p.

1992, Network applications of the USGS BRANCH model: American Society of Civil Engineers, Water Forum '92, Hydraulic Engineering Conference, New York, N.Y., [Proceedings], p. 1159-1164.

Schaffranek, R.W., and Baltzer, R.A., 1988, A simulation technique for modeling flow on floodplains and in coastal wetlands: American Society of Civil Engineers, 1988 National Conference, Hydraulics Division, Colorado Springs, Colo., August 8-12, 1988, [Proceedings|, p. 733-739.

1989, Implementation of a hydrodynamic model for the upper Potomac Estuary: American 
Society of Civil Engineers, Hydraulics Division, National Conference on Hydraulic Engineering, New Orleans, La., August 14-18, 1989 [Proceedings], p. 484-492.

1990, Horizontal density-gradient effects on simulation of flow and transport in the Potomac Estuary: New York, N.Y., American Society of Civil Engineers, 1990 National Conference, Hydraulics Division [Proceedings], v. II, p. 1251-1256. 


\section{SURFACE-WATER HYDROLOGY}

TITLE: $\quad$ Hydrologic Regression and Data-Network Design (NR 82-125)

PERSONNEL: Gary D. Tasker, Project Chief

Carol Padgett, Secretary

ADDRESS: $\quad$ U.S. Geological Survey, 430 National Center, 12201 Sunrise Valley Drive, Reston, VA 22092

TELEPHONE: (703) 648-5892

PROBLEM: Methods for objective evaluation of USGS hydrologic data-collection activities are needed so that activities can be modified when necessary, and the efficiency of USGS operations maximized.

OBJECTIVE: Produce objective methods for hydrologic network design and methods for information transfer.

APPROACH: Use cross-validation and computer simulation of hydrologic processes to evaluate the statistical and economic measures of the hydrologic data-collection programs.

PROGRESS: (a) With Dick Smith (Systems Group), New Jersey District personnel, and Dale White (Ohio State University professor), regression models were developed to predict the probability of a water quality constituent being above a threshold. The regression models are based on observed water-quality data and Geographic Information System (GIS) land-use information. These models are potentially useful for describing the general water quality of a region. These models were presented at Watershed '93 in Alexandria, Virginia, and at the American Geophysical Union spring meeting in Baltimore.

(b) With Gus Ludwig (Arkansas District) a new method of low-flow regionalization was developed using logistical and generalized least squares regression to account for observations of zero flow and give proper weight to partial-record sites.

(c) With Dave Holtschlag (Michigan District) developed a generalized least squares regression model for estimating average annual recharge for a region based on observed rainfall and streamflow records. 


\section{SURFACE-WATER HYDROLOGY}

(d) A monthly water-balance model was developed for the Apalachicola-Chattahoochee-Flint River basin to study the effects of possible climate change in the basin.

(e) With Ray Slade (Texas District) a new computer-intensive method for estimating flood characteristics at ungaged sites has been developed and is being tested. The method makes use of cluster analysis and weighted least-squares regression to derive a new regression model each time an estimate is to be made at an ungaged site.

\section{REPORTS PUBLISHED 1988-1993:}

Ayers, M., Tasker, G., Wolock, D., McCabe, G., and Hay, L., 1990, Simulated effects of climate change on runoff and drought in the Delaware River basin, in Singh and Helweg eds., Supplying and saving the environment for six billion people: American Society of Civil Engineers Conference, November 1990 [Proceedings], San Francisco, Calif., p. 3140.

Ayers, M.A., Wolock, D.M., McCabe, G.J., Hay, L.E., and Tasker, G.D., 1993, Sensitivity of water resources in the Delaware River basin to climate variability and change: U.S. Geological Survey Open-file Report 92-52, 68 p.

Driver, N.W., and Tasker, G.D., 1988, Techniques for estimating storm-runoff loads, volumes and selected constituent concentrations in urban watersheds in the United States: U.S. Geological Survey Open-File Report 88-191, $80 \mathrm{p}$.

1990, Techniques for estimation of stormrunoff loads, volumes, and selected constituent concentrations in urban watersheds in the United States: U.S. Geological Survey WaterSupply Paper 2363, 44 p.

Gilroy, E.J., and Tasker, G.D., 1990, Multicollinearity and influential observations in hydrologic model selection, in Berk, K., and Malone, L., ed., Computing Science and Sta- tistics: Symposium on the Interface, 21st, Orlando, Fla., April 1990, p. 350-354.

Jennings, M.E., and Tasker, G.D., 1988, Estimating of urban stormwater quality: American Society of Civil Engineers, Hydrologic Division National Conference [Proceedings], Colorado Springs, Colo., p. 78-83.

Ludwig, A.H., and Tasker, G.D., 1993, Regionalization of low-flow characteristics of Arkansas streams: U.S. Geological Survey Water-Resources Investigations Report 934013, 26 p.

McCabe, G.J., Wolock, D.M., Tasker,G.D., and Ayers, M.A., 1991, Uncertainty in climate change and drought, in Shane, R.M., ed., Hydraulic Engineering: 1991 National Conference, American Society of Civil Engineers, Nashville, Tenn., [Proceedings], p. 1-6.

McCabe, G.J., Wolock, D.M., Tasker, G.D., Ayers, M.A., and Hay, L.E., 1993. Sensitivity of water resources in the Delaware River basin to climate change, in Kelmelis, J.A., and Snow, M., (eds.), Proceedings of the U.S. Gelogical Survey Global Change Research Forum, Herndon, Virginia: U.S. Geological Survey Circular 1086, p. 56-62.

Moss, M.E., and Tasker, G.D., 1990, Manual for comparing methods of designing hydrologic- 


\section{SURFACE-WATER HYDROLOGY}

data-collection networks: U.S. Geological Survey Open-File Report 90-389, 111 p.

1991, An intercomparison of hydrological network-design.technologies: Hydrological Sciences Journal, v. 36,3,6, p. 201-213.

Smith, R.A., Alexander, R.B., Tasker, G.D., Price, C.V., Robinson, K.W., and White, D.A., in press, Statistical modeling of water quality in regional watersheds: Watershed '93 [Proceedings], Alexandria, Va.

Tasker, G.D., 1989, Regionalization of low flows using logistic and GLS regression, in Kavvas, M.L., ed., New Directions for Surface Water Modeling: International Association of Hydrological Sciences Publication Number 181, p. 323-331.

1990, Some hydrological impacts of climate change for the Delaware River basin, in Khanbilvardi, R., and Gooch, T., eds., Optimizing the Resources for Water Management, New York: 17th Annual National Conference, American Society of Civil Engineers, Fort Worth, Texas, April 1990 [Proceedings], p. 541-544.

1991, Identifying stream gages to operate for regional information: Transportation Research Record, Bridge and Hydrology Research, No. 1319, Washington, D.C., National Research Council, p. 131-136.

1991, Evaluating drought risks for large highly regulated basins using monthly water-balance modeling, in Kirby, W.H., and Tan, W.Y.. eds., Proceedings of the United States-China Bilateral Symposium on Droughts and SemiArid Region Hydrology: U.S. Geological Survey Open-file Report 91-244, p. 317-322.

1991, Estimating low-flow characteristics of streams at ungaged sites, in Kirby, W. H., and
Tan, W.Y., eds., Proceedings of the United States-China Bilateral Symposium on Droughts and Semi-Arid Region Hydrology: U.S. Geological Survey Open-file Report 91-244, p. 215-219.

1993, Some hydrologic effects of climate change for the Apalachicola, Chattahoochee, and Flint River basins, in Hatcher, K.J. (ed.), Proceedings of the 1993 Georgia Water Resources Conference: Athens, Georgia, Institute of Natural Resources, University of Georgia, p. 61-64.

Tasker, G.D., Ayers, M., Wolock, D., and McCabe, G., 1991, Sensitivity of drought risks in the Delaware River basin to climate change: Technical and Business Exhibition and Symposium, Huntsville, Alabama, Huntsville Association of Technical Societies, [Proceedings], p. 153-159.

Tasker, G.D., and Driver, N.E., 1988, Nationwide regression models for predicting urban runoff water quality at unmonitored sites: Water Resources Bulletin, v. 24, no. 5, p. 1091.

Tasker, G.D., Gilroy, E.J., and Jennings, M.E., 1990 , Estimation of urban stormwater loads at unmonitored sites by regression, in Jennings, M.E., ed., Urban Hydrology: American WaterResources Association Conference, Denver, Colo., [Proceedings], p. 127-137.

Tasker, G.D., and Stedinger, J.R., 1989, An operational GLS model for hydrologic regression: Journal of Hydrology, v. III, no. 1-4, p. 361375.

1992, Generalized least squares analyses for hydrologic regionalization, in Jennings, M., and Bhowmik, N.G., (eds.), Hydraulic Engineering, Saving a Threatened Resource-In Search of Solutions: Water Forum `92, Hy- 


\section{SURFACE-WATER HYDROLOGY}

draulic Engineering Sessions, Baltimore, Md., August 2-6, 1992, p. 7-12.

Wolock, D.M., McCabe, G.J., Tasker, G.D., Ayers, M.A., and Hay, L.E., 1992, Sensitivity of Water Resources in the Delaware River Basin to Climate Change-Proceedings of the Workshop on the Effects of global climate change on hydrology and water resources at a catchment scale, February 3-6, 1992, Tsukuba, Japan: Japan-U.S. Committee on Hydrology, Water Resources, and Global Climate Change, p. 319-329. 


\title{
SURFACE-WATER HYDROLOGY
}

\author{
TITLE: $\quad$ Regional Hydrologic Processes (NR 84-133)
}

PERSONNEL: Jurate M. Landwehr, Project Chief

Glenna Dahl, Secretary

ADDRESS: U.S. Geological Survey, 431 National Center, 12201 Sunrise Valley Drive, Reston, VA 22092

TELEPHONE: (703) 648-5893

PROBLEM: The regional nature of hydrologic processes is generally defined in terms of shared meteorologic and basin (geologic and land cover) characteristics. Inferences have been attempted by regressing the measures of hydrologic interest against such characteristics. Such treatment has been insufficient to fully explain the variations or extremes in discharge patterns observed within a geographic area. Long-term influences, such as decadal to centennial climatic fluctuations, need to be considered, and the stochastic structure of the hydrologic process itself needs to be better defined.

OBJECTIVE: Develop hydrologic statistics within a regional context and identify the effect of persistence due to long-term climatic fluctuations.

APPROACH: Use the statistical theory of extremes and time-series analysis to analyze the distribution of flows as expressed through the spectrum of flow regimes. Consider several measures of persistence, treating this statistic as a random variable in itself, as well as giving it traditional treatment as a constant property of the underlying stochastic process. Examine empirical-flow information from both national and international data bases that will be and have been developed for this project. Use other surrogate hydrologic records, such as dendrochronologic records, ice core records, and so forth, as needed and available.

PROGRESS: The definition of the HCDN (Hydro-Climatic Data Network) was initiated by this project as a necessity for the investigation the inter-relationship and persistence of climatic and hydrologic seasonal to decadal patterns on a regional scale. The development of the HCDN represents the first continental-scale data set identified by the USGS which satisfies a single consistent set of criteria to support a particular research question. All of the U.S.Geological Survey's surface water streamflow holdings were reviewed in order to identify the complete set possible of appropriate records. The discharge data itself went through a rigorous quality assurance analysis in anticipation of the changes that will be 


\section{SURFACE-WATER HYDROLOGY}

necessary to convert WATSTORE to NWIS-II. The HCDN had been widely requested even before its release and serves as an information resource for hydrologists, climatologists, planners, modelers, and engineers whose work concerns the variations of surface water resources in concert with climate fluctuations.

A great deal of effort has been expended in the analysis of the Devils Hole oxygen-18 isotope record, as well as other records that have appeared in the paleoclimatic literature. As noted by W. Broecker in Nature (1992), the Devils Hole record is the best-dated paleotemperature record through the last several Pleistocene interglacial/glacial events that exists anywhere. The publication of the dating and analysis of the oxygen-18 isotope has engendered a great deal of interest in both the scientific and lay press, as it has provided a challenge to the most widely accepted theory for the occurrence of Pleistocene glacial epochs.

\section{REPORTS PUBLISHED 1988-1993:}

Cayan, Daniel R., Gardner, James V., Landwehr, Jurate M., Namias, Jerome, and Peterson, David H., 1989, Introduction, in Peterson, David H., ed., Aspects of Climate Variability in the Pacific and the Western Americas: Washington, D.C., American Geophysical Union, Geophysical Monograph Series Number 55 , p. xi-xvi.

Landwehr, J.M., 1988, U.S.Geological Survey Climate Research Activities: Global Climate Change Research Plan Workshop, U.S. Environmental Protection Agency, Office of Research and Development, Washington, D.C., Proceedings, 200 p.

1988, Long-Term Weather Records and Trends-Implications for Water Resources, on Cassette Tape of Panel F., Back to Basics: Public Concern Over Climate Change Places New Emphasis on Water Resources Programs, of the 1988 Annual Meeting, National Waterways Conference, Inc., Nashville, Tennessee, September 21-23, 1988. [Tape distributed by Personalized Cassette Service of Nashville, Tenn., for National Waterways Conference, Inc. Paper copy of presentation summary with illustrations was distributed at meeting by conveners.]

Landwehr, Jurate M. and Slack, James R., 1990, HCDN (Hydro-Climatic Data Network) - A U.S. Geological Survey Discharge Data Set for Climatological Impact Analysis, in Preprints of Symposium on Global Change Systems, Special Sessions on Climate Variations and Hydrology, Anaheim, Calif., February 5-9,1990: American Meteorological Society, Boston, Mass., 192 p.

1992, FACT SHEET-Hydro-climatic data network (HCDN)-A U.S. Geological Survey streamflow data set for the United States for the study of climate fluctuations, 1874-1988: U.S. Geological Survey Open-File Report 92-632, 2 p.

Ludwig, Kenneth R., Simmons, Kathleen R., Szabo, Barney J., Winograd, Isaac J., Landwelur, Jurate M., Riggs, Alan C., and Hoffman, Ray J., 1992, Mass-spectrometric ${ }^{230} \mathrm{Th}-{ }^{234} \mathrm{U}-{ }^{238} \mathrm{U}$ Dating the Devils Hole calcite vein: Science, v. 258, p. 284-287. 


\section{SURFACE-WATER HYDROLOGY}

Ludwig, K.R., Simmons, K.R., Winograd, I.J., Szabo, B.J., Landwehr, J.M., and Riggs, A.C., 1993, Scientific Correspondence-Last interglacial in Devils Hole: Nature, v. 362, p. 596.

Peterson, David, ed., Aubrey, David, Cayan, Daniel R., Gardner, James V., Keeling, Charles D., Landwehr, Jurate M., Mulloch, David S., McGowan, John A., and Roden, Gunnar, associate eds., 1989, Aspects of Climate Variability in the Pacific and the Western Americas: Washington, D.C., American Geophysical Union, Geophysical Monograph Series Number 55, 445 p.

Slack, J.R., and Landwehr, Jurate Maciunas, 1992, HCDN (Hydro-Climatic Data Network)-A U.S. Geological Survey streamflow data set for the United States for the study of climate variations 1987-1988: U.S. Geological Survey Open-File Report 92-129, 193 p. and computer diskette.

Slack, J.R., Lumb, Alan M., and Landwehr, Jurate Maciunas, 1993, Hydro-climatic data network (HCDN)-Streamflow data set, 1874-1988: U.S. Geological Survey Water-Resources Investigations Report 93-4076, CD-ROM.

Winograd, Isaac J., Coplen, Tyler B., Landwehr, Jurate M., Riggs, Alan C., Ludwig, Kenneth R., Szabo, Barney J., Kolesar, Peter T., and Revesz, Kinga M., 1992, Continuous 500,000year climate record from vein calcite in Devils Hole, Nevada: Science, v. 258, p. 255-260. 


\section{SURFACE-WATER HYDROLOGY}

TITLE: $\quad$ Continental Hydrology and Global Climate (NR 88-144)

PERSONNEL: P.C.D. Milly, Project Chief

Krista A. Dunne, Physical Scientist

ADDRESS: $\quad$ U.S. Geological Survey, Geophysical Fluid Dynamics Laboratory/NOAA, Forrestal Campus, Route 1, P. O. Box 308, Princeton, NJ 08542

TELEPHONE: (609) 452-6507

PROBLEM: The hydrology of the continents helps determine the global climate. The hydrosphere and the atmosphere are tightly coupled due to the role of water in the radiation and heat budgets of the atmosphere. Future progress in studies of global hydrology and climate dynamics will require interdisciplinary analyses of the dynamics of this coupled system.

OBJECTIVE: (1) Develop improved models of the global climate system by improving the parameterization of hydrologic response of the land surface in those models. (2) Develop an improved understanding of the global hydrologic cycle and its interlationship with global climate.

APPROACH: Much of the research uses the numerical climate model of the Climate Dynamics Project at the Geophysical Fluid Dynamics Laboratory of the National Oceanic and Atmospheric Administration. It is the subject of model development, and one of the tools for studying coupled dynamics.

PROGRESS: (1) Previous project work on the sensitivity of climate to continental evaporation was extended, and implications of the investigation for certain problems in climate dynamics were explored. The analyses of the climatic simulations suggested that global development of water resources during the last century may be the cause of an apparent increase in precipitation during the same time period; that the mean value of the water-holding capacity of the plant-root zones of the earth's soils is near the value necessary to maximize evaporation from land and to miminimize runoff to the oceans; and that the change in volume of soil accessible to plant roots is probably an important factor for the climatic effects of tropical deforestation. 


\section{SURFACE-WATER HYDROLOGY}

(2) A storage hypothesis concerning the control of partitioning of annual precipitation into runoff and evaporation was developed and evaluated. Mathematical elaboration of the hypothesis suggests that this partitioning is controlled by seven dimensionless numbers that depend on the temporal characteristics of the climate and on the mean and variability of the water-holding capacity of the plant-root zone of the soil. The model was tested for the area of the United States east of the Rocky Mountains. The successful test supported the underlying hypothesis of the model that finite infiltration capacity is not an important factor for the annual water balance.

(3) The areal extent and ocean outlet points of the river basins of the world were determined from topographic analysis. This information was provided to the Geophysical Fluid Dynamics Laboratory of the National Oceanic and Atmospheric Administration, for use in its coupled ocean-atmosphere climate model. (Freshwater inflows from the continents to the oceans are an important factor in the salinity balance of the oceans, and recent research has suggested that salinity changes and associated ocean circulation changes are a critical factor in decadal to century time-scale climate variability.)

REPORTS PUBLISHED 1990-1993:

Blain, C.A., and Milly, P.C.D., 1991, Development and application of a hillslope hydrologic model: Advances in Water Resources, v. 14, p. 168-174.

Kienitz, G., Milly, P.C.D., van Genuchten, M.Th., Rosbjerg, D., Shuttleworth, W.J., eds., 1991, Hydrological interactions between atmosphere, soil and vegetation: International Association of Hydrological Sciences, no. 204, $494 \mathrm{p}$.

Milly, P.C.D., 1990, A refinement of the combination equations for evaporation: Surveys in Geophysics, v. 12, p. 145-154.

1991, Some current themes in physical hydrology of the land-atmosphere interface, in Kienitz, G., Milly, P.C.D., van Genuchten, M.Th., Rosbjerg, D., Shuttleworth, W.J., eds., Hydrological Interactions between Atmosphere, Soil and Vegetation: International
Association of Hydrological Sciences, no. 204, p. 3-10.

1992, Potential evaporation and soil moisture in general circulation models: Journal of Climate, v. 5, p. 209-226.

1993. An analytic solution of the stochastic storage problem applicable to soil water: Water Resources Research, v. 11, no. 11, p. 3755-3758.

1993, Sensitivity of the global water cycle to the water holding capacity of soils, in Bolle, H.J., Feddes, R.A., Kalma, J.D., eds., Exchange processes at the land surface for a range of space and time scales: International Association of Hydrological Sciences, 10. 212, p. 495-501. 


\section{SURFACE-WATER HYDROLOGY}

TITLE: $\quad$ Transport of Dissolved and Suspended Materials in Surface Waters (NR 90-147)

\section{PERSONNEL: Jonathan Lee, Project Chief}

Mary Abel, Secretary

Lara M. Lewis, Computer Specialist, student, (Univ. of Washington)

Amy C. Wheeless, Computer Clerk, student, (Virginia Polytechnic Institute)

ADDRESS: U.S. Geological Survey, 430 National Center, 12201 Sunrise Valley Drive, Reston, VA 22092

TELEPHONE: (703) 648-4033

PROBLEM: Although a major effort has been made to understand the hydrodynamics of surface waters, less effort has been devoted to the study of transport mechanisms and to the development and validation of computational models for simulating the transport of dissolved and suspended materials. Recent progress in hydrodynamics has created additional opportunities for advances in surface-water transport. It may be possible to develop and validate more physically correct descriptions of transport processes in terms of flow characteristics than have been previously available. Microscale processes must be expressed at the macroscale level by algorithms which can be validated in computational models using laboratory and field data.

OBJECTIVE: (1) The evaluation of existing methods and techniques; (2) the development, or validation, or both, by the use of laboratory and field data, of algorithms describing dissolved- and suspended-material transport processes; (3) the development, or validation, or both, of computational techniques for solving the partial-differential equations describing surface-water transport processes; (4) the development and validation of multidimensional, computational models for the transport of dissolved and suspended materials in surface waters; and (5) the development of techniques for the application of computational, surfacewater transport models to field problems.

APPROACH: Algorithms that quantify relationships between flow characteristics and transport processes will be selected from the literature or developed on the basis of concepts derived from the study of laboratory and field data. Computational schemes for the solution of the convective-dispersion equation in two and three dimensions will be analyzed for efficiency and accuracy. Advanced turbulence-closure schemes, necessary for the proper simulation of certain transport processes, will be studied in two- and three-dimensional 


\section{SURFACE-WATER HYDROLOGY}

models. Two- and three-dimensional flow and transport models will be developed for use in validating transport algorithms for both dissolved and suspended materials.

PROGRESS: A journal article, "Simulating the effects of highway embankments on estuarine circulation," by Lee, Schaffranek, and Baltzer, was accepted for publication by the Journal of Waterway, Port, Coastal, and Ocean Engineering. This work demonstrated the use of the Surface-Water, Integrated, Flow and Transport Model, SWIFT2D, in quantifying the effect on flow and transport of highway embankments in Port Royal Sound, a South Carolina estuary. A nested submodel of the global model was used to show, among other things, that there was a major change in the flow pattern in Battery Creek, a branch of Port Royal Sound, during flood tide because of a jet-like effect at one of the embankment openings.

Development continued of a hydrodynamic model to be used as a basis for transport modeling. After studying finite-difference models in detail, It was decided to develop a more geometrically flexible model on the basis of the finite-element method. Initial codes have been developed for vertically averaged flow. Two codes were developed, both using nonconforming elements for velocity on triangular elements (the velocity nodes are located at the midsides of the element sides). The use of nonconforming shape functions for velocity has not been extensively explored in the literature. These elements offer the advantage of diagonal mass matrices (the matrices multiplying the time derivative terms) in the momentum equations, which facilitates the use of a semi-implicit formulation. The first of the two codes uses a constant representation of the water-surface elevation on an element; the second uses a linear, conforming representation of the water-surface elevation on an element, with the water-surface elevations at the element vertices. It was found during testing of the first code that because of the coarse representation of water-surface elevation, the water-surface gradient terms in the momentum equations created distorted velocity fields unless an extremely fine grid was used. The second code uses a more accurate representation (linear as opposed to piecewise constant) of the velocity field and is still being tested.

Development of a UNIX-based scientific, interactive, extensible, visualization environment, SIEVE, continued, mostly by summer student Lara Lewis. SIEVE is based on the Graphical Kernel System (GKS), the X Window system, and the Network Common Data Form (netCDF). SIEVE produces plots of input to and output from hydrodynamic/transport models. 


\section{SURFACE-WATER HYDROLOGY}

TITLE: $\quad$ Ice and Climate (WR 70-064)

PERSONNEL: William J. Campbell, Project Chief

Jo Eggers, Secretary

Robert M. Krimmel, Hydrologist

Edward G. Josberger, Oceanographer

Steven M. Hodge, Geophysicist

Sheila K. Doppelhammer, Geophysicist

Robert C. Paradise, Mathematician

David R. Hirst, Photographer

ADDRESS: $\quad$ U.S. Geological Survey, University of Puget Sound, Tacoma, WA 98416

TELEPHONE: (206) 593-6516

PROBLEM: Snow, ice sheets, glaciers, and sea ice are key components of the earth's hydrologic cycle and climate system. No other component varies as dramatically, both spatially and temporally, and yet has such a profound impact on global climate. However, because of great spatial extent, remote location and rapid variability, and the lack of adequate observational techniques, the relationship between the snow and ice and both climate change and water resources is not well understood.

OBJECTIVE: The objective is to understand the role of snow and ice masses in the hydrologic cycle, and the complex interactions that take place between snow and ice and the global climate system, through the development and application of remote sensing techniques. The combination of active and passive microwave observations, observations in the visual range, and new aircraft techniques provide powerful tools to determine the regional, continental and global distributions of these key components of the hydrological cycle. This task will involve the development of new approaches, algorithms, and processing schemes as well as implementation and verification of established techniques in new situations.

APPROACH: Recent scientific and technological advances have now made it possible to obtain scientifically meaningful measurements of snow and ice masses on appropriate spatial and temporal scales. These efforts will be carried out in close collaboration with other USGS scientists, as well as scientists from other agencies and universities, through both new and well-established cooperative programs.

PROGRESS: Continued to collect in situ snowpack data at key sites in the Upper Colorado River Basin and also acquired the SNOTEL data from the Soil Conservation Service, as required by the joint U.S. Geological Survey-National Aeronautics and Space AdministrationU.S. Department of Agriculture (USGS-NASA-USDA) satellite snow research program. 


\section{SURFACE-WATER HYDROLOGY}

Analysis of the 8-year record of snowpack properties has clearly shown the importance of grain size on the passive microwave signatures of snowpacks. The presence of large depth hoar crystals present in Wyoming yield a stronger signal than that observed from the Colorado and Utah regions, despite the thinner snowpacks. These observations are being used as input to a multiple layer electromagnetic scattering model to develop more accurate algorithms for water equivalent determinations. Because of the strongly nonlinear brightness temperature dependence on grain size, a two-layer snowpack model provides significantly improved water equivalent estimates from the satellite observations.

Collection of geophysical and glaciological data for the National Science Foundation (NSF)-funded project in west Antarctica was completed, and analyses of these data has started. Image processing software and workstations were installed, image processing techniques were learned, and satellite images of west Antarctica were obtained. All five images of our study area have been enhanced and mosaiced together, and preliminary registration to an earth-fixed coordinate system has been done. A new high-pass filtering technique has been developed; it very successfully enhances surface features while eliminating the overall brightness gradient. Airborne radar and laser measurements of surface topography have been broken out of the main data streams and are being analyzed for features which can be used to register the satellite images precisely to our airborne coordinate system.

A Benchmark Glacier Monitoring plan was written in conjunction with USGS colleagues in Fairbanks, Alaska, and Denver, Colorado, to standardize the variables that will be measured at selected glaciers. The first of the reports specified in this plan was completed for the 1992 balance year at South Cascade Glacier. The monitoring of this glacier was continued through the 1993 balance year.

The drastic retreat of Columbia Glacier was documented by means of aerial photography through the year during which there was a 1,200 meter retreat, with ice speeds of up to 23 meters per day. A similar sequential photographic set was obtained for several other major nearby tidewater glaciers for a comparative study. The surge of Bering Glacier was documented with three sets of vertical photography.

The final draft of NASA Special Publication 511 was completed, and is in press. This is an analysis of the 9-year Scanning Multichannel Microwave Radiometer (SMMR) observations of the Arctic and Antarctic sea ice.

Working collaboratively with the Nansen Center and the Environmental Research Institute of Michigan, a study of the "Odden" was completed (a large-scale sea ice feature that occurs 


\section{SURFACE-WATER HYDROLOGY}

in the Greenland Sea). This study compared the results of active and passive microwave sensors and then determined both the inter- and intra-annual variations of this event from 1979 to 1987 . The results were presented a an international conference and will be included in an American Geophysical Union (AGU) monograph on the role of polar oceans in determining global climate. At the same conference, and to appear in the same monograph, a study of the Southern Ocean winter wind and wave fields, and their variability, as determined by the GEOSAT radar altimeter for the period 1985 to 1989 was presented.

\section{REPORTS PUBLISHED 1988-1993:}

Armstrong, R.L., Chang, A.T.C., Rango, A., and Josberger, E.G., 1993, Snow depths and grain size relationships with relevance for passive microwave studies: Annals of Glaciology, v. 17, p. 171-176.

Barthel, K., Haugan, P.M., Johannessen, J.A., Johannessen, O.M., Johansen, T.A., Kloster, K., Olaussen, T.I., Pettersson, L.H., Sandven, S., Skagseth, X., Onstott, R., Rufenach, C., Shuchman, R.A., Sutherland, L., Fetterer, F., Johnson, D., Livingstone, C., Mognard, N.M., Johnsen, H., Campbell, W.J., Eltoft, T., Essen, H.H., Olsen, R.B., Gloersen, P., Davidson, K.L., Trizna, D., Terje, K., Breivik, L.A., and Schyberg, H., 1989, NORCSEX '88, a Pre-Launch ERS-1 Experiment: EOS, v. 70 , no. 49 , p. 1528 $1530,1538-1539$.

Blankenship, D.D., Bell, R.E., Hodge, S.M., Brozena, J.M., Behrendt, J.C., and Finn, C.A., 1993, Active volcanism beneath the west Antarctic ice sheet and implications for ice-sheet stability: Nature, v. 361, p. 526-529.

Campbell, W.J., Gloersen, P., Josberger, E.G., Johannessen, O.M., Guest, P.S., Mognard, N., Shuchman, R., Burns, B.A., Lannelongue, N., and Davidson, K.L., 1987, Variations of mesoscale and large-scale sea ice in MIZEX84 as observed by microwave remote sensing: Journal of Geophysical Research, Special
Edition on Marginal Ice Zones, v. 92, no. C7, p. 6805-6824.

Cang, A.T.C., Foster, J.L., Rango, A., and Josberger, E.G., 1991, The use of microwave radiometry for characterizing snow storage in large river basins, in Bergmann, H., Lang, H., Frey, W., Issler, D., and Salm, B., eds., Snow, hydrology and forests in high Alpine areas: Symposium held during General Assembly of the Internation Union of Geodesy and Geophysics, 20th, Vienna, Austria, August 11-24, 1991 [Proceedings], IAHS Publication, no. 205 , p. $73-80$.

Gloersen, P., and Campbell, W.J., 1988, Satellite and aircraft passive microwave observations during the Marginal Ice Zone Experiment in 1984: Journal of Geophysical Research, v. 93, no. C6, p. 6837-6846.

1988, Variations in the Arctic, Antarctic, and global sea ice covers during 1978-1987 as observed with the Nimbus 7 Scanning Multichannel Microwave Radiometer: Journal of Geophysical Research, v. 93, no. C9, p. $10,666-10,674$.

1991, Variations of extent, area, and open water of the polar sea ice covers-1978-1987: International Conference on the Role of the Polar Regions in Global Change, Fairbanks, Alaska, 18 p. 


\section{SURFACE-WATER HYDROLOGY}

1991, Recent variations in Arctic and Antarctic sea-ice covers: Nature, v. 352 , no. 6330 , p. 33-36.

Gloersen, P., Campbell, W.J., Cavalieri, D.J., Comiso, J.C., Parkinson, C.L., and Zwally, H.J., 1992, Arctic and Antarctic Sea Ice, 1978-1987: Satellite Passive-Microwave Observations and Analysis: NASA SP-511, 183 p.

Hodge, S.M., Wright, D.L., Bradley, J.A., Jacobel, R.W., Skou, N., and Vaughn, B.H., 1990, Determination of the surface and bed topography in central Greenland: Journal of Glaciology, v. 36, no. 122, p. 17-30.

Jacobel, R.W., Hodge, S.M., and Wright, D.L., 1990, Studies of internal layering and bedrock topography on ice stream C, West Antarctica: Antarctic Journal of the United States, v. $\mathrm{XXV}$, no. 5, p. 82-85.

Johannessen, O.M., Campbell, W.J., Shuchman, R., Sandven, S., Gloersen, P., Johannessen, J.A., Josberger, E.G., and Haugen, P.M., 1992, Microwave study programs of air-iceocean interactive processes in the seasonal ice zone of the Greenland and Barents Seas, in Microwave Remote Sensing of Sea Ice: American Geophysical Union, Geophysical Monograph 68, chap. 13, p. 261-289.

Josberger, Edward G., 1990, Temporal and spatial scales of ice edge thermodynamics: Workshop on Regional and Mesoscale Modeling of Ice Covered Oceans, Os, Norway, 1989, NRSC Conference Report No. 3, [Proceedings], p. 143-147.

Josberger, E.G., and Beauvillain, E., 1989, Snow cover of the Upper Colorado River Basin from satellite passive microwave and visual imagery: Nordic Hydrology, v. 20, p. 73-84.
Josberger, E.G., Campbell, W.J., Gloersen, P., Chang, A.T.C., and Rango, A., 1993, Snow conditions and hydrology of the Upper Colorado River basin from satellite passive microwave observations: Annals of Glaciology, v. 17 , p. $322-326$.

Josberger, Edward G., Ling, Chi-Hai, Campbell, William J., Gloersen, Per, Chang, A.T.C., and Rango, Al, 1989, Correlations of scanning multichannel microwave radiometer (SMMR) observations with snowpack properties of the Upper Colorado River Basin for Water Year 1986: IGARSS' 89 Symposium, July 10-14, 1989, Vancouver, BC, Canada, [Proceedings], v. 3, p. $1239-1242$.

Krimmel, R.M., 1988, Terminus of Glaciar O'Higgins, southern Chile: Journal of Glaciology, v. 34, no. 116 , p. 142.

1988, Surging ahead: EOS, v. 69, no. 1, 1 p. (Cover photo and caption).

1989, Mass balance and volume of South Cascade Glacier, Washington, 1958-1985, in Oerlemans, J., ed., Glacier fluctuations and climatic change: Kluwer Academic Publishers, p. 193-206.

1992, Photogrammetric determination of surface altitude, velocity, and calving rate of Columbia Glacier, Alaska, 1983-91: U.S. Geological Survey Open-File Report 92-104, $72 \mathrm{p}$.

1993, Glaciers of the conterminous U.S.A., in Satellite Image Atlas of Glaciers: U.S. Geological Survey Professional Paper 1386.

Krimmel, R.M., and Meier, M.F., 1989, Glaciers and glaciology of Alaska: 28th International Geological Congress, Washington, D.C., July 9-19, 1989, Field Trip T301. 


\section{SURFACE-WATER HYDROLOGY}

Krimmel, R.M., and Trabant, D.C., 1992, The terminus of Hubbard Glacier, Alaska: Annals of Glaciology, v. 16, p. 151-157.

Mognard, N.M., Campbell, W.J., and Josberger, E.G., 1988, Geosat surface wind speed estimates and comparisons in the North Atlantic for March 1987-Appendix to U.S. WOCE Technical Report No. 2, in Chelton, D.B., ed., WOCE/NASA Altimeter Algorithm Workshop: Oregon State University, Corvallis, Oregon, August 24-26, 1987, [Proceedings].

1989, Geosat derived winds, waves, and swells in the 'North Atlantic during NORCSE X-88: IGARSS' 89 Symposium, July 10-14, 1989, Vancouver, BC, Canada, [Proceedings], v. 2 , p. $742-746$.

Rasmussen, L.A., 1989, Surface velocity variations of the lower part of Columbia Glacier, Alaska, 1977-1981: U.S. Geological Survey Professional Paper 1258-H, $52 \mathrm{p}$.

Trabant, D.C., Krimmel, R.M., and Post, A., 1991, A preliminary forecast of the advance of Hubbard Glacier and its influence on Russell Fiord, Alaska: U.S. Geological Survey WaterResources Investigations Report 90-4172, 34 p.

Walters, R.A., Josberger, E.G., and Driedger, C.L., 1988, Columbia Bay, Alaska-An "up side down" estuary: Estuarine, Coastal and Shelf Science, v. 26, p. 607-617.

Wright, D.L., Bradley, J.A., and Hodge, S.M., 1989 , Use of a new high-speed digital data acquisition system in airborne ice-sounding: IEEE Transactions on Geoscience and Remote Sensing, v. 27, no. 5, p. 561-567.

Wright, D.L., Hodge, S.M., Bradley, J.A., Grover, T.P., and Jacobel, R.W., 1990, A digital low-frequency, surface-profiling ice radar system: Journal of Glaciology, v. 36, no. 122 , p. $112-121$. 


\section{SURFACE-WATER HYDROLOGY}

TITLE: $\quad$ Hydrodynamics and Mathematical Modeling of Circulation and Transport Phenomena in Tidal Estuaries (WR 76-140)

PERSONNEL: Ralph T. Cheng, Project Chief

Gwendolyn J. Lewis, Secretary

Jeffrey W. Gartner, Oceanographer

Jon R. Burau, Civil Engineer

Ellen T. McDonald, Hydrologist

Edward Gross, Hydrologist

Richard E. Smith, Hydrologist

ADDRESS: $\quad$ U.S. Geological Survey, 345 Middlefield Road, MS 496, Menlo Park, CA 94025

TELEPHONE: (415) 354-3358

PROBLEM: The ecosystem of a tide-affected estuary consists of an extremely complicated balance of natural processes and human-induced activities. Some of the basic characteristics of such a system, for example, the San Francisco Bay estuarine system, are not well understood. A comprehensive description of the hydrodynamics and the related transport phenomena is still lacking. A better understanding of the effects among the interactive natural and human-induced processes on this system requires advances in basic science relating the physical, chemical, and biological estuarine processes. Circulation in a tidal estuary is generated in response to astronomical tides, inflow of freshwater, winds, and stratification due to salinity. The basin topography (bathymetry), air-water interaction, watersedimentation interface, mixing characteristics, frictional loss at the bottom, and the rotational effects of the earth, together with the above-mentioned driving forces, constitute an extremely complicated balance that conserves mass, momentum, energy, and conservative solutes in the system.

OBJECTIVE: (1) Understand processes and rates by which water, salt, and other solutes interact; (2) develop methods to enable quantification of the relative importance of river inflow, winds, tides and other dynamic forcings that act upon the system; and (3) develop and verify conceptual and numerical models of these interactions.

APPROACH: Include intensive field-data collection and mathematical-model development and implementation in project activities. Collect long-term current and stage data. Develop effective methods of solution to the equations that govern the basic hydrodynamic processes, that is, the conservation equations of mass, momentum, energy, and salt. Treat field datacollection and numerical-modeling research as complementary parts of a well-integrated program; use field data to calibrate and verify numerical models, and use numerical-model 


\section{SURFACE-WATER HYDROLOGY}

results to guide future data-collection activities. Use numerical models as research tools for investigations of short- and long-term transport phenomena after the models are calibrated and verified.

PROGRESS: This project continues to provide technical guidance and support to the Interagency Ecological Study Plan (IESP) for San Francisco Bay/Delta, and to other districts. Continuing progress has been made in both two-dimension and three-dimension estuarine hydrodynamic modeling research. A depth-averaged, Tidal, Residual, and Intertidal Mudflat Model (TRIM), which was developed in collaboration with Professor Vincenzo Casulli of the University of Trento, Italy, has been calibrated and verified against an extensive data set collected in San Francisco Bay. Using the TRIM model as a research tool, the hydrodynamic characteristics of San Francisco Bay have been defined and reported (see bibliography). The TRIM-2D model has been applied to San Diego Bay in a demonstration of the utility of this numerical módel for assessing the impact due to an accidental spillage of sewage near San Diego coast. This demonstration has received wide attention. Subsequently, we have been asked to conduct further modeling research for San Diego Bay. Using this model as the basis, our research efforts have been expanded to cover sediment transport processes in San Francisco Bay. Our preliminary results appear to be very encouraging.

The formulation and numerical algorithm for an efficient TRIM-3D model has been reported and published (see bibliography). Collaboration on three-dimensional estuarine modeling with Professor Vincenzo Casulli continues. The present focus is placed on the treatment of salt field (baroclinic forcing), which is the major driving force for the generation of gravitational circulation. Further improvements on computational efficiency for TRIM-3D has been achieved; the model permits detailed three-dimensional simulations at a modeling scale unprecedented in the literature. Fine resolutions are needed in order to properly resolve the topographically generated mixing and flow induced turbulent mixing. The Project Chief and Jeffrey W. Gartner continue to collaborate with staff of California District Office on numerical modeling and in field data collection and processing. A major field data collection effort was carried out in an attempt to define the mechanisms that balance the salt field in the northern reach of San Francisco Bay. The field study took place between January and May 1993 and used nearly all oceanographic instruments in this project and in the District Office. Jon Burau of the District Office and Jeffrey Gartner played the major role in this study. 


\section{SURFACE-WATER HYDROLOGY}

\section{REPORTS PUBLISHED 1988-1993:}

Burau, J.R., and Cheng, R.T., 1989, A vertically averaged spectral model for tidal circulation in estuaries, Part (I), Model formulation: U.S. Geological Survey Water-Resources Investigation Report, WRI-88-4126.

1989, A general method for generating bathymetric data for hydrodynamic computer models-Computer program documentation and application to San Francisco Bay, California: U.S. Geological Survey Open-File Report, Report 89-28.

1988, Predicting tidal currents in San Francisco Bay using a spectral model: Colorado Springs, Colo., ASCE Hydraulics Division Annual Conference, p. 634-639.

Casulli, V., Bertolazzi, E., and Cheng, R.T., in press, TRIM_3D-A three-dimensional model for accurate simulation of shallow water flow: 1993 National Conference on Hydraulic Engineering, American Society of Civil Engineers, San Francisco, Calif., July 1993 [Proceedings].

Casulli, V. and R. T. Cheng, 1992, Semi-implicit finite difference methods for three-dimensional shallow water flow: Internation Journal for Numerical Methods in Fluids, v. 15, p. 629648.

Casulli, V., and Cheng, R.T., 1990, Stability analysis of Eulerian-Lagrangian methods for the one-dimensional shallow-water equations: Applied Mathematical Modelling, v. 14, p. 122-131.

Casulli, Vincenzo, and Cheng, Ralph T., 1992, A semi-implicit finite-difference model for threedimensional tidal circulation, in Spaulding, M.L., Bedford, K., Blumberg, A.F., Cheng,
R.T., and Swanson, C., eds., Estuarine and Coastal Modeling: International Conference on Estuarine and Coastal Modeling, 2nd, Tampa, Fla., November 13-15, 1991, p. 620-631.

Cheng, R.T., 1988, Eulerian and Lagrangian Modeling of Estuarine Hydrodynamics, in Kjerfve, B., ed., Hydrodynamics of estuaries: CRC Press, v. 1, chap. 9, p. 149-159.

1990, ed., Residual Currents and Long-term transport: Springer-Verlag, Coastal and Estuarine Studies, v. 38,554 p.

Cheng, R.T., and Burau, J.R., 1988, System considerations in numerical modeling of estuarine problems: International Conference on Computational Methods in Flow Analysis, Okayama, Japan, [Proceedings], p. 1025-1032.

Cheng, R.T., Burau, J.R., and Gartner, J.W., 1991, Interfacing data analysis and numerical modeling for tidal hydrodynamic phenomena, in Parker, B., Tidal hydrodynamics: John Wiley, p. 201-219.

Cheng, R.T., and Casulli, V., 1992, Dispersion in tidally averaged transport equation, in Prandle, D., ed., Dynamics and exchanges in estuaries and the coastal zone: Coastal and Estuarine Studies, v. 40 , p. $409-428$.

Cheng, Ralph T., and Casulli, Vincenzo, 1992. Tidal, Residual, Intertidal Mudflat (TRIM) model using a semi-implicit EulerianLagrangian Method: U.S. Geological Survey, Open-File Report 92-62, 43 p.

Cheng, R.T., Casulli, V., and Gartner, J.W., 1993, Tidal, residual, intertidal mudflat (TRIM) model and its applications to San 


\section{SURFACE-WATER HYDROLOGY}

Francisco Bay, California: Estuarine, Coastal, and Shelf Science, v. 36, p. 235-280.

Cheng, R.T., Feng, S., and Xi, P., 1989, On intertidal transport equation, in Neilson, Kuo, and Brubaker, eds. Estuarine Circulation: Humana Press, p. 133-156.

Cheng, R. T., P. E. Smith, and V. Casulli, in press, Recent development in three-dimensional numerical estuarine models: National Conference on Hydraulic Engineering, American Society of Civil Engineers, San Francisco, Calif., July 1993.

Cheng, R.T., and Smith, P.E., 1990, A survey of three-dimensional numerical estuarine models, in Spaulding, M., ed. Estuarine and coastal modeling: American Society of Civil Engineers Specialty Conference, p. 1-15.

Feng, S., Cheng, R.T., Xi, Sun, and Son, 1990, Lagrangian residual circulation and long-term transport processes in a weakly nonlinear baroclinic system, in Physics of Shallow Oceans, Wang Huatong and others, eds.: China Ocean Press, p. 1-20.

Ford, M., Wang, J., and Cheng, R.T., 1990, Predicting the vertical structure of tidal current and salinity in San Francisco Bay, California: Water Resources Research, v. 26, no. 5, p. 1027-1045.

Gartner, J.W., and Oltmann, R.N., 1990, Comparison of recording current meters in shallow waters of San Francisco Bay, California: U.S. Geological Survey Water-Resources Investigation Report 90-4018, 84 p.

Gartner, J.W., and Yost, B.T., 1988, Tides and tidal and residual currents in San Pablo and Suisun Bays, California--Results of measurements, 1986: U.S. Geological Survey WaterResources Investigation Report 88-4027.
Kamrath, Anke, Cheng, Ralph T., and Jovanovic, Marsha, 1991, Scientific visualization techniques applied to water quality and transport: ASCE, National Conference on Hydraulic Engineering, Nashville, Tenn., August 1991, p. $375-381$.

Smith, P.E., and Cheng, R.T., 1990, Recent progress on hydrodynamic modeling of San Francisco Bay, in Spaulding, M., ed., Estuarine and Coastal Modeling: American Society of Civil Engineers Specialty Conference, p. 502 -510 .

Smith, P.E., Cheng, R.T., Burau, J.R., and Simpson, M.R., 1991, Gravitational circulation in a tidal strait: ASCE, National Conference on Hydraulic Engineering, Nashville, Tenn., August 1991, [Proceedings], p. 429-434.

Spaulding, M.L, Bedford, K., Blumberg, A.F., Cheng, R.T., and Swanson, C., eds., 1992. Estuarine and Coastal Modeling-Proceedings of the Second International Conference on Estuarine and Coastal Modeling, Tampa, Florida, November 1991: New York, American Society of Civil Engineers, 786 p. 


\section{SURFACE-WATER HYDROLOGY}

TITLE: $\quad$ Research Vessel Polaris Operations in San Francisco Bay and Adjacent Coastal Ocean (WR 77-156)

PERSONNEL: T. John Conomos, Project Chief

Mary S. Conger, Secretary

Byron J. Richards, Master R/V Polaris

William S. Conard, Chief Engineer R/V Polaris

ADDRESS: $\quad$ U.S. Geological Survey, 345 Middlefield Road, MS 977, Menlo Park, CA 94025

TELEPHONE: (415) 329-4414

PROBLEM: A stable moving platform is needed to house at least 10 scientists throughout the year (for periods of weeks) so that large volumes of complex and continuous data can be carefully and rapidly collected and precisely measured and analyzed immediately after collection.

OBJECTIVE: Provide scientific platform (research vessel) for estuarine studies, platform functions, and measurement, collection, and subsequent analysis of geological, chemical, physical, and biological data throughout the year for extended time periods.

APPROACH: Provide support for research vessel, including operating support for dockage fees, boat maintenance, diesel fuel, and food for scientists and crew.

PROGRESS: Provided research vessel support for routine field sampling by personnel in several projects within the Branch of Regional Research (WR) and the California District. For example, the Polaris has been used in the "San Francisco Bay River-Estuary Toxic Contaminant Study." 


\section{SURFACE-WATER HYDROLOGY}

TITLE: $\quad$ Analysis and Modeling of Conservative and Nonconservative Transport Processes (WR 83-183)

PERSONNEL: Roy A. Walters, Project Chief

Margaret E. Sullivan, Physical Scientist

ADDRESS: $\quad$ U.S. Geological Survey, 1201 Pacific Ave., Suite 600, Tacoma, WA 98402

TELEPHONE: (206) 593-6505

PROBLEM: The biological and chemical characteristics of aquatic environments depend on a generally complicated balance of physical, chemical, and biological processes. Basic tom describing these characteristics is an understanding of transport processes including both advection and mixing. For a given water body, these processes depend heavily on the mass, momentum, and energy transfers at boundaries and the internal response of the system. Many of these transfers and responses are poorly understood.

OBJECTIVE: Broad goals of this project are to quantitatively understand the physical processes responsible for the transport of conservative and nonconservative solutes of biological and chemical importance. Through the use of time series analysis and other methods, conceptual, statistical, and numerical models of these processes are being developed.

APPROACH: Use data analysis, including the application of digital filters, to examine daily to interannual time-scale phenomena, spectral analysis, empirical orthogonal function analysis, regression analysis, and numerical models. Use numerical models, including box and finiteelement models, in one, two, and three dimensions.

PROGRESS: Development of a three-dimensional, finite-element tidal and residual circulation model and finite-element network generation software has allowed a quantitative analysis of circulation in several estuaries and coastal seas. Emphasis has been placed on salinity intrusion into Delaware Bay and River where salt flux processes have been examined in detail.

\section{REPORTS PUBLISHED 1988-1993:}

Foreman, M.G.G, Baptista, A.M., and Walters, R.A., 1992, Tidal model studies of particle trajectories around a shallow coastal bank, Atmosphere-Ocean, v. 30, no. 1, p. 43-69.
Foreman, M.G.G., Henry, R.F., Walters, R.A., and Ballantyne, V.A., 1993, A finite element model for tides and resonance along the north coast of British Columbia: Journal of Geophysical Research, v. 98, no. C2, p. 25092531. 


\section{SURFACE-WATER HYDROLOGY}

Foreman, M.G.G., Thomson, R.E, Lynch, D.R., and Walters, R.A., 1992, A finite element model for three-dimensional flows along the west coast of Vancouver Island, in Spaulding, M.L., ed., Estuarine and Coastal Modeling, proceedings, 2nd International Conference, Tampa, Fla.: American Society of Civil Engineers publication, p. 574-585.

Foreman, M.G.G., and Walters, R.A., 1990, A finite element tidal model for the southwest coast of Vancouver Island: Atmosphere-Ocean, v. 28, p. $261-287$.

Henry, R.F., and Walters, R.A., 1991, User manual for PC TRIGRID: Sidney, B.C., Canada V8L 4B2, Institute of Ocean Sciences.

Walters, R.A., 1988, A finite element model for tides and currents with field applications: Communications in Applied Numerical Methods, v. 4, p. 401-411.

1989, A tale of two estuaries: Columbia Bay, Alaska and San Francisco Bay, California, in Nielson, Kuo, and Brubaker, eds., Estuarine Circulation: Humana Press, p. 183-200.

1989, Small-amplitude, short-period variations in speed of a tidewater glacier in south-central Alaska: Annals of Glaciology, v. 12, p. 187191.

1992, A 3D, finite element model for coastal and estuarine circulation, Continental Shelf Research, v. 12, no. 1, p. 83-102.

1992, A Study of Salt Transport Processes in Delaware Bay, in Spaulding, M.L., ed., Estuarine and Coastal Modeling: Estuarine and Coastal Modeling 2nd International Conference, American Society of Civil Engineers, Tampa, Fla., November 13-15, 1991, [Proceedings], p. 240-251.

Walters, R.A., and Foreman, M.G.G., 1992, A 3D finite element model for the baroclinic circula- tion on the Vancouver Island Shelf: Journal of Marine Systems, v. 3, p. 507-518.

Walters, R.A., Josberger, E.G., and Driedger, C.L., 1988, Columbia Bay, Alaska: an "upside down" estuary: Estuarine, Coastal, and Shelf Science, v. 26, p. 607-617.

Walters, R.A., and Meier, M.F., 1989, Variability of glacier mass balances in western North America, in Peterson, D.H., ed., Aspects of climate variability in the Pacific and the Western Americas: Geophysical Monograph 55. American Geophysical Union, p. 365-374.

Walters, R.A., and Werner, F.E., 1989, A comparison of two finite element models of tidal hydrodynamics using a North Sea data set: Advances in Water Resources, v. 12, p. 184193.

Walters, R.A., and Werner, F.E., 1991, Nonlinear generation of overtides, compound tides, and residuals, in Parker B.B., ed., Tidal hydrodynamics: New York, John Wiley and Sons, p. 297-320. 


\section{SURFACE-WATER HYDROLOGY}

TITLE: $\quad$ Coupled Transport and Geochemical Processes Determining the Fate of Chemicals in Surface Waters (WR 84-187)

PERSONNEL: Kenneth E. Bencala, Project Chief Carolyn Harden-Jekelian, Secretary

Gary W. Zellweger, Hydrologist

Elizabeth W. Boyer, Physical Science Technician

Judson W. Harvey, Postdoctoral Associate $\begin{array}{ll}\text { ADDRESS: } & \text { U.S. Geological Survey, } 345 \text { Middlefield Road, MS 496, } \\ \text { Menlo Park, CA } 94025\end{array}$

TELEPHONE: (415) 354-3326

PROBLEM: Coupled transport and biogeochemical processes determine the fate of chemicals both naturally present in surface waters and those introduced through anthropogenic activities. In mountainous environments, coupled processes operate at scales which can be years and kilometers in watersheds or minutes and decimeters in the hyporheic zone. Although individual processes are often well understood in isolation, the ability to quantify chemical fate across the stream-watershed continuum requires development in design of field experiments and mechanistic formulations to integrate interpretation of multiple processes.

OBJECTIVE: Develop experimental field techniques and mechanistic formulations to quantitatively identify rates and extents of transport within the stream-watershed continuum. Focus on transport processes which most influence the fate of chemicals introduced from the surrounding watershed into pristine streams (for example, natural dissolved organic materials and nutrients, as well as, acid mine drainage).

APPROACH: Cooperate with hydrologists, geochemists, and ecologists to identify the processes of environmental fluid mechanics exerting significant influence on the fate of chemicals in mountainous watersheds. Study these processes (for example, transient storage of solutes in the hyporheic zone) specifically to estimate hydrologic parameters needed for quantitative determinations of solute transport. Dynamic field experimentation is the primary mode of study, augmented with detailed sampling studies and numerical simulations.

PROGRESS: In St. Kevin Gulch, which carries acid mine drainage, variation in streambed topography causes localized recharge of streamwater along well-defined substream flow paths in the hyporheic zone. The substream flow paths maintain the stream-watershed continuum for solute transport. Measurements of groundwater heads, tracer movement through the 


\section{SURFACE-WATER HYDROLOGY}

hyporheic zone, and simulations of steady-state flow support this identification of substream flow paths. Recent extensions have quantified the complementary role of catchment scale driving forces (Leadville, Colorado-Upper Arkansas River Toxic Substances Hydrology Site; J. Harvey working with Kimball). Improved assessments of the transport of sulfide oxidation products have resulted from collaboration with the University of Colorado's Center for Advanced Decision Support for Water and Environmental System (CADSWES) to develop capabilities for simulation analysis within the Modular Hydrologic Modeling System. (Leadville, Colorado-Upper Arkansas River Toxic Substances Hydrology Site; Bencala working with McKnight, Kimball, Broshears, and Runkel). Multiple tracer injections have been used to measure net flow losses as low as 0.8 liters per second (Leadville, ColoradoUpper Arkansas River Toxic Substances Hydrology Site; Zellweger working with Kimball). In the Deer Creek and Snake River watersheds (Summit County, Colorado) Boyer and Hornberger (University of Virginia), have collaborated with Bencala and McKnight to apply the TOPMODEL watershed topography concepts to field studies verifying source zones of dissolved organic material.

\section{REPORTS PUBLISHED 1988-1993:}

Bencala, K.E., 1993, A perspective on streamcatcliment connections: Journal of the North American Benthological Society, v. 12, p.44 $-47$.

Bencala, K.E., Kimball, B.A., and McKnight, D.M., 1991, Use of variation in solute concentration to identify interactions of the substream zone with instream transport, in Mallard, G.E., and Aronson, D.A., ed., 1991, U.S. Geological Survey Toxic Substances Hydrology Program-Proceedings of the technical meeting, Monterey, Calif., March 1115, 1991: Water-Resources Investigations Report 91-4034, p. 377-379.

Bencala, K.E., McKnight, D.M., and Zellweger, G.W., 1990, Characterization of transport in an acidic and metal-rich mountain stream based on a lithium tracer injection and simulations of transient storage: Water Resources Research, v. 26, p. 989-1000.
Bencala, K.E., McKnight, D.M., Zellweger, G.W., and Kimball, B.A., 1988, Monitoring acidic streams for transport studies, in Mallard, G.E., ed., U.S. Geological Survey Toxic Substances Hydrology Program-SurfaceWater Contamination, Technical meeting, Denver, Colo., February 2-4, 1987, Proceedings: U.S. Geological Survey Open-File Report 87-764, p. 119-124.

Broshears, R.E., Bencala, K.E., Kimball, B.A., and McKnight, D.M., in press, Characterization of plysical transport in a mountain stream based on a tracer injection and solute-transport simulations: U.S. Geological Survey WaterResources Investigation Report 92-4081.

Fuller, C.C., Davis, J.A., Zellweger, G.W., and Goddard, K.E., 1989, Coupled chemical, biological and physical processes in Whitewood Creek, South Dakota: evaluation of the controls of dissolved arsenic, in Mallard, G.E., and Ragone, S.E., ed., U.S.Geological Survey Toxic Substances Hydrology Program- 


\section{SURFACE-WATER HYDROLOGY}

Proceedings of the technical meeting, Phoenix, Ariz., September 26-30, 1988: U.S. Geological Survey Water-Resources Investigations Report 88-4220, p. 235-246.

Harvey, J.W., 1993, Measurement of variation in soil-solute tracer concentration across a range of effective pore sizes: Water Resources Research, v. 29, p. 1831-1837.

Harvey, J.W. and Bencala, K.E., 1993, The effect of streambed topography on surface-subsurface water exchange in mountain catchments: Water Resources Research, v. 29(1), p. 89-98.

Harvey, J.W., Bencala, K.E., and Zellweger, G.W., 1991, Preliminary investigation of the effect of hillslope hydrology on the mechanics of solute exchange between streams and subsurface gravel zones, in Mallard, G.E., and Aronson, D.A., ed., U.S. Geological Survey Toxic Substances Hydrology Program-Proceedings of the technical meeting. Monterey, Calif., March 11-15, 1991: Water-Resources Investigations Report 91-4034, p. 413-418.

Jakeman, A.J., Hornberger, G.M., Littlewood, I.G., Whitehead, P.G., Harvey, J.W., and Bencala, K.E., 1992, A systematic approach to modeling the dynamic linkage of climate, physical catchment descriptors, and hydrologic response components: Mathematics and Computers in Simulation, v. 33, p.359-366.

Kimball, B.A., Bencala, K.E., and McKnight, D.M., 1989, Research on metals in acid mine drainage in the Leadville, Colorado, area, in Mallard, G.E., and Ragone, S.E., ed., U.S. Geological Survey Toxic Substances Hydrology Program-Proceedings of the technical meeting, Phoenix, Ariz., September 26-30, 1988: U.S. Geological Survey Water-Resources Investigations Report 88-4220, p. 65-70.
Kimball, B.A., Bencala, K.E., McKnight, D.M., and Maura, W.S., 1988, Geochemistry of dissolved metals in St. Kevin Gulch, an acidic mountain stream near Leadville, Colorado, in Mallard, G.E., ed., U.S. Geological Survey Toxic Substances Hydrology ProgramSurface-Water Contamination, technical meeting, Denver, Colo., February 2-4, 1987, Proceedings: U.S. Geological Survey OpenFile Report 87-764, p. 137-144.

Kimball, B.A., Broshears, R.E., Bencala, K.E., and McKnight, D.M., 1991, Comparison of rates of hydrologic and chemical processes in a stream affected by acid mine drainage, in Mallard, G.E., and Aronson, D.A., ed., 1991, U.S. Geological Survey Toxic Substances Hydrology Program-Proceedings of the technical meeting, Monterey, Calif., March 1115, 1991: U.S. Geological Survey WaterResources Investigations Report 91-4034, p. 407-412.

Kimball, B.A., Broshears, R.E., McKnight, D.M., and Bencala, K.E., 1992, Effect of instream $\mathrm{pH}$ modification on aluminum in Kharaka, Y.K., and Maest, A., eds., Proceedings of the Seventh International Symposium on WaterRock Interaction: Rotterdam, A.A. Balkema, p. 393-396.

Kimball, B.A., Broshears, R.E., McKnight, D.M., and Bencala, K.E., in press, Preliminary evaluation of the effects of an instream $\mathrm{pH}$ modification on transport of sulfide-oxidation products, in Alpers, C.L., and Bowles, D., eds., The environmental geochemistry of sulfide oxidation: Washington, D.C., Americal Chemical Society Symposium Series.

Kuwabara, J.S., Triska, F.J., and Bencala, K.E., 1990, Concepts and methods for assessing solute dynamics in stream ecosystems: Journal North American Benthological Society, [Stream Solute Workshop] v. 9, p. 95-119. 


\section{SURFACE-WATER HYDROLOGY}

McKnight, D.M., and Bencala, K.E., 1988, Diel variations in iron chemistry in an acidic stream in the Colorado Rocky Mountains: Arctic and Alpine Research, v. 20, p. 492-500.

1989, Reactive iron transport in an acidic stream in Summit County, Colorado-A hydrologic perspective: Geochimica et Cosmochimica Acta, v. 53, p. 2225-2234.

1990, The chemistry of iron, aluminum, and dissolved organic material in three acidic,. metal-enriched, mountain streams, as controlled by watershed and in-stream processes: Water Resources Research, v. 26, p. 30873100.

McKnight, D.M., Bencala, K.E., Zellweger, G.W., Aiken, G.R., Feder, G.L., and Thorn, K.A., 1992, Sorption of dissolved organic carbon by hydrous aluminum and iron oxides occurring at the confluence of Deer Creek with the Snake River, Summit County, Colorado: Environmental Science and Technology, v. 28, p. 1388-1396.

McKnight, D.M., Kimball, B.A., and Bencala, K.E., 1988, Photoreduction of hydrous iron oxides in acidic mountain streams, in Mallard, G.E., ed., U.S. Geological Survey Toxic Substances Hydrology Program, SurfaceWater Contamination, Proceedings of the technical meeting, Denver, Colo., Feb. 2-4, 1987, Proceedings: U.S. Geological Survey Open-File Report 87-764, p. 131-135.

1988, Iron photoreduction and oxidation in an acidic mountain stream: Science, v. 240 , no. 4852, p. 637-640.

McKnight, D.M., Wershaw, R.L., Bencala, K.E., Zellweger, G.W., and Feder, G.L., 1992, Humic substances and trace metals associated with $\mathrm{Fe}$ and $\mathrm{Al}$ oxides deposited in an acidic mountain stream: Science of the Total Environment, v. 117 , p.485-498.

Slack, J.R., and Bencala, K.E., 1988, Book review, Stochastic hydrology by MacNeill, A.I., and Umphrey, G.J.: Journal of Hydrology, v. 103, p. 393-396.

Triska, F.J., Kennedy, V.C., Avanzino, R.J., Zellweger, G.W., and Bencala, K.E., 1989, Retention and transport of nutrients in a thirdorder stream in northwestern Californiahyporheic processes: Ecology, v. 70, p. 18931905.

1989, Retention and transport of nutrients in a third-order stream-Channel processes: Ecology, v. 70, p. $1877-1892$.

1990, In-situ retention-transport response to nitrate loading and storm discharge in a thirdorder stream: Journal North American Benthological Society, v. 9, p. 229-239.

Zellweger, G.W., Avanzino, R.J., and Bencala, K.E., 1989, Comparison of tracer-dilution and current-meter discharge measurements in a small gravel-bed stream, Little Lost Man Creek, California: U.S. Geological Survey Water Resources Investigation Report 894150.

Zellweger, G.W., Bencala, K.E., McKnight, D.M., Hirsch, R.M., and Kimball, B.A., 1988, Practical aspects of tracer experiments in acidic, metal enriched streams, in Mallard, G.E., ed., U.S. Geological Survey Toxic Substances Hydrology Program-SurfaceWater Contamination, Technical meeting, Denver, Colo., February 2-4, 1987, Proceedings: U.S. Geological Survey Open-File Report 87-764, p. 125-130.

Zellweger, G.W., and Maura, W.S., 1991, Calculation of conservative-tracer and flume-dis- 


\section{SURFACE-WATER HYDROLOGY}

charge measurements on a small mountain stream, in Mallard, G.E., and Aronson, D.A., ed., U.S. Geological Survey Toxic Substances Hydrology Program-Proceedings of the technical meeting, Monterey, Calif., March 1115, 1991: U.S. Geological Survey WaterResources Investigations Report 91-4034, p. 434-438. 


\section{SURFACE-WATER HYDROLOGY}

TITLE: $\quad$ Fluvial Processes and River Mechanics (WR 83-194)

PERSONNEL: Cheng-lung Chen, Project Chief

Gwendolyn J. Lewis, Secretary

Chi-Hai Ling, Hydrologist

ADDRESS: $\quad$ U.S. Geological Survey, 345 Middlefield Road, MS 496, Menlo Park, CA 94025

TELEPHONE: (415) 354-3352

PROBLEM: Many difficult problems in river mechanics may have stemmed from inadequate understanding of the multiplicity and interaction of fluvial processes. Some of the problems may have been solved, but in a very simplified, approximate way. Many efforts have been directed, but without apparent success, to fully account for the causes, occurrences, and mechanisms of catastrophic events, such as flash floods, debris flows, and channel changes resulting from torrential storms, sudden snow or glacier melt, dam break, volcanic eruptions, and earthquakes. Such failures may be partially attributed to the deficiency and incompleteness of existing empirical formulas (or models) representing the relationships between various processes and responses.

OBJECTIVE: Seek a full understanding of various fluvial processes on hillslopes and in river channels, which undergo changes in response to rapid disturbances, such as torrential storms, sudden snow or glacier melt, dam break, volcanic eruptions, and earthquakes. Improve or generalize existing empirical formulas that do not accurately describe the process-response relationships. Develop new relationships for various soils and highly-concentrated sedimentwater mixtures, such as those posed in the form of rheological or constitutive equations. Build mathematical models, using such relationships, for flash floods, debris flows, channel changes, and so forth. Ultimately apply these models to minimize the loss of life and property that may result from such catastrophic events.

APPROACH: Assess the validity and applicability of existing formulas for various fluvial processes, such as rainfall, infiltration, runoff, and sediment movement (erosion and deposition) on hillslopes and in river channels. Modify or generalize the existing formulas to the utmost extent that they will become more representative under a wider spectrum of field conditions. Formulate rheological or constitutive equations for various soils and highlyconcentrated sediment-water mixtures, and determine the values of rheological parameters and material constants using available field or laboratory data. Build mathematical models for 


\section{SURFACE-WATER HYDROLOGY}

flash floods, debris flows, channel changes, etc. and solve them on digital computers using optimum numerical schemes. Verify the models using actual events.

PROGRESS: Debris-flow research has progressed in both theoretical and experimental phases. For the theoretical phase, a series of journal papers have been prepared to document significant results obtained from the reassessment of the generalized viscoplastic fluid (GVF) model. The first paper in series is to examine the concept and rationale behind the formulation of the GVF model. The follow-up paper is to appraise the GVF model in the light of both the classical relative-viscosity versus concentration relation (for the macroviscous regime) and the dimensionless stress versus shear-rate squared relations based on kinetic theory (for the grain-inertia regime). The windup paper is to evaluate the rheological parameters of the GVF model using Bagnold's data, thereby showing the validity and practical usefulness of the GVF model in debris-flow modeling. For the experimental phase, a series of experiments were conducted in the conveyor-belt flume to study roll waves in simulated debris flow using $5 \mathrm{~mm}$ glass spheres. Also conducted were a series of experiments in the conveyor-belt flume to study the effects of variously mixed ratios of two different particle sizes on the movement of simulated debris flow with a single particle size. Because both series of experiments were preliminary in nature, significant results could not be obtained from an analysis of such preliminary data. Other areas of research investigated are mainly concerned with high-gradient river hydraulics. Continued efforts were made to apply some mathematical techniques to analyzing flow stability. Two papers on the instability (or roll waves) of flow in open channel were prepared and published in the Journal of Hydraulic Engineering.

REPORTS PUBLISHED 1988-1993:

Chen, C.L., 1988, Power formula for open-channel flow resistance: National Conference on $\mathrm{Hy}-$ draulic Engineering, American Society of Civil Engineers, Colorado Springs, Colo., 1988 [Proceedings], p. 25-35.

1988, Generalized viscoplastic modeling of debris flow: Journal of Hydraulic Engineering, American Society of Civil Engineers, v. 114, no. 3 , p. 237-258.

1988, General solutions for viscoplastic debris flow: Journal of Hydraulic Engineering,
American Society of Civil Engineers, v. 114, no. 3, p. 259-282.

1989, Power law of flow resistance in open channels-Manning's formula revisited: International Conference on Channel Flow and Catchment Runoff: University of Virginia, Charlottesville, Va., [Proceedings], p. 817848.

1991, Power law of flow resistance in open channels-Manning's formula revisited, in Yen, B.C., ed., Channel Flow ResistanceCentennial of Manning's Formula: Water 


\section{SURFACE-WATER HYDROLOGY}

Resources Publications, Littleton, Colo., p. 206-240.

1991, Unified theory on power laws for flow resistance: Journal of Hydraulic Engineering, American Society of Civil Engineers, v. 117, no. 3, p. 371-389.

1992, Momentum and energy coefficients based on power-law velocity profile: Journal of Hydraulic Engineering, American Society of Civil Engineers, v. 118, no. 11, p. 15711584.

1992, Issues in debris flow research-Personal views: U.S. Geological Survey Water-Supply Paper Series, Selected Papers in the Hydrologic Sciences WSP 2340, p. 137-143.

1992, Discussion of "Derivation of infiltation equation using systems approach" by Singh, V.P., and Yu, F.X.: Journal of Irrigation and Drainage Engineering, Amerrican Society of Civil Engineers, v. 118, no. 6, p. 996-999.

1993, Unique laminar-flow stability limit based on shallow-water theory: Journal of Hydraulic Engineering, American Society of Civil Engineers, v. 119 , no. 7 , p. 816-829.

Chen, C.L., Ling, C.H., and Jan, C.D., 1991, Rheological model for ring-shear type debris flows: Federal Interagency Sedimentation Conference, Subcommittee on Sedimentation of the Interagency Advisory Committee on Water Data, 5th, Las Vegas, Nev., [Proceedings], v. 1, p. 5-1 to 5-8.

Jan, C.D., Shen, H.W., Ling, C.H., and Chen, C.L., 1992, A sphere moving down an inclined bumpy surface: Conference on Engineering Mechanics, American Society of Civil Engineers, 9th, College Station, Tex., [Proceedings], p. 768-771.
Ling, C.H., and Chen, C.L., 1989, Idealized debris flow in flume with bed driven by a conveyor belt: National Conference on Hydraulic Engineering, American Society of Civil Engineers, New Orleans, La., 1989 [Proceedings], p. 1144-1149.

Ling, C.H., Chen, C.L., and Jan, C.D., 1990, Rheological properties of simulated debris flows in the laboratory environment: International Symposium on the Hydraulics and $\mathrm{Hy}-$ drology of Arid Lands, American Society of Civil Engineers, San Diego, Calif., [Proceedings], p. 218-224.

Ling, C.H., and Jan, C.D., 1992, Computer simulation of dry layered granular flow down an incline composed of grains: Conference on Engineering Mechanics, American Society of Civil Engineers, 9th, College Station, Tex., [Proceedings], p. 760-763.

Ling, C.H., Jan, C.D., Chen, C.L., and Shen, H.W., 1992, Numerical simulation of a sphere moving down an incline with identical spheres placed equally apart: Conference on Engineering Mechanics, American Society of Civil Engineers, 9th, College Station, Tex., [Proceedings], p. 764-767. 


\title{
SURFACE-WATER HYDROLOGY
}

TITLE: $\quad$ Resolution of Hydroclimatic Uncertainty (WR 89-201)

\author{
PERSONNEL: Marshall E. Moss, Project Chief \\ Ana M. MacKay, Administration Operations Assistant \\ Douglas Wellington, Computer Program Analyst \\ David A. Pratt, Student, (University of Arizona)
}

ADDRESS: $\quad$ U.S. Geological Survey, 1675 W. Anklam Road, Tucson, AZ 85745

TELEPHONE: (602) 670-6821

PROBLEM: There is a great deal of uncertainty about future climates on a decadal scale. This uncertainty has strong implications on the water-resources planning and management decisions that are being made now and will be made in the future. Information about the hydrologic implications of climate uncertainty is minimal.

OBJECTIVE: Develop technology that can be used to evaluate hydrologic information generated by climate models and to incorporate that information into strategies for monitoring the potential hydrologic effects of climate change.

APPROACH: Use a combination of geostatistics and Bayesian models of data errors to develop a data base of hydrologic variables aggregated at the spatial scales of the climate models. Use these data to evaluate the information content of the hydrologic components of existing climate models. Incorporate significant information into a scheme for monitoring regional hydrologic effects of climate change.

PROGRESS: During the past year, the Project Chief has completed the task of editing a 60 chapter publication, titled "Guide to Hydrological Practice" for the World Meteorological Organization (WMO) and has served for 4 months as visiting scientist at the New Zealand National Institute of Water and Atmosphere (NIWA). The Guide was drafted by individual authors and working groups from around the world and will be published in two volumes by WMO. The Fellowship to NIWA resulted in two publications that are in review-one, titled "The Southern Oscillation Index as a predictor of the probability of low flows in New Zealand", will be submitted to Water Resources Research, and the other, titled "Analysis of the accuracy of the discharge records at the Cropp River at Gorge", is to be published in an internal reports series of NIWA. 


\section{SURFACE-WATER HYDROLOGY}

The Project Chief also coauthored a paper, titled "Effects of climate change on water resources of the Delaware River Basin, U.S.A.", which has been submitted to the Water Resources Bulletin.

\section{REPORTS PUBLISHED 1988-1993:}

Moss, M.E., 1989, Water-quality data in the information age: Proceedings of the International Symposium on the Design of Water Quality Information Systems, Colorado Water Resources Research Institute, Ft. Collins, Colo., Information Series No. 61, p. 8-15.

1991, Hydrologic implications of climate uncertainty in the western United States: Proceedings of Colloquium on Managing Water Resources under Conditions of Climatic Uncertainty, National Academy Press, Washington, D.C., p. 148-157.

1992, Bayesian relative information measureA tool for analyzing the outputs of general circulation models: Journal of Geophysical Research, v. 97, no. D3, p. 2743-2756.

Moss, M.E., and Tasker, G.D., 1990, Manual for comparing methods of designing hydrologicdata-collection networks: U.S. Geological Survey Open-File Report 90-389, 104 p.

1991, An intercomparison of hydrological network-design technologies: Hydrological Sciences Journal, v. 36, no. 3, p. 209-221. 


\section{APPENDIXES}




\begin{tabular}{|c|c|c|c|}
\hline PROJECT CHIEF & DISCIPLINE & $\begin{array}{l}\text { PROJECT } \\
\text { NUMBER }\end{array}$ & PROJECT TITLE \\
\hline Aiken, George R. & SW Chemistry & CR 93-331 & $\begin{array}{l}\text { Organic Carbon Migration in Aquatic } \\
\text { Environments } \ldots \ldots \ldots \ldots \ldots \ldots\end{array}$ \\
\hline Andrews, Edmund D. & $\begin{array}{l}\text { Geomorphology/ } \\
\text { Sediment }\end{array}$ & CR 82-273 & River Mechanics . . . . . . . . . . . . . 98 \\
\hline Averett, Robert C. & Ecology & CR 88-312 & $\begin{array}{l}\text { Ecological Interactions of Lakes } \\
\text { and Streams . . . . . . . . . . . } 19\end{array}$ \\
\hline Back, William & GW Chemistry & NR 57-034 & $\begin{array}{l}\text { Spatial Distribution of Chemical } \\
\text { Constituents in Ground Water . . . . . . } 147\end{array}$ \\
\hline Baedecker, Mary Jo & GW Chemistry & NR 83-129 & $\begin{array}{l}\text { Comparative Study of Organic Degradation } \\
\text { in Selected Hydrogeologic Environments } \quad 172\end{array}$ \\
\hline Baltzer, Robert A. & SW Hydrology & NR 69-019 & $\begin{array}{l}\text { Numerical Simulation of Hydrodynamic } \\
\text { Processes in Rivers, Estuaries, and Coastal } \\
\text { Embayments } \ldots \ldots \ldots \ldots \ldots \ldots \ldots \ldots\end{array}$ \\
\hline Bencala, Kenneth E. & SW Hydrology & WR 84-187 & $\begin{array}{l}\text { Coupled Transport and Geochemical } \\
\text { Processes Determining the Fate of } \\
\text { Chemicals in Surface Waters ...... } 405\end{array}$ \\
\hline Bennett, James P. & SW Hydrology & CR 93-343 & Mathematical Modeling Principles . . . . . 374 \\
\hline Benson, Larry V. & GW Chemistry & CR 82-207 & Arid Regions Climate and Chemistry . . . 122 \\
\hline Betancourt, Julio L. & Ecology & WR 76-145 & $\begin{array}{l}\text { Biotic Response to Climatic Variability } \\
\text { and Human Impacts in Arid Lands } \ldots\end{array}$ \\
\hline Bredehoeft, John D. & GW Hydrology & WR 75-176 & Water Wells as Strain Meters . . . . . . 278 \\
\hline Bricker, Owen P. & SW Chemistry & NR $81-109$ & $\begin{array}{l}\text { Geochemical Cycling of Trace Elements } \\
\text { and Nutrients in Natural Water Systems . . } 341\end{array}$ \\
\hline Brown, Charles E. & GW Hydrology & NR 84-130 & $\begin{array}{l}\text { Multivariate Statistical Techniques for } \\
\text { Assessing Regional Ground-Water Quality } \\
\text { and Quantity } \ldots \ldots \ldots \ldots \ldots \ldots \ldots\end{array}$ \\
\hline Callender, Edward & SW Chemistry & NR 76-065 & $\begin{array}{l}\text { Sedimentary Geochemical Processes } \\
\text { Affecting the Exchange of Nutrients } \\
\text { and Transition Metals Between Sediment } \\
\text { and Water in Riverine, Estuarine, and } \\
\text { Lacustrine Environments . . . . . . . . } 334\end{array}$ \\
\hline
\end{tabular}




\begin{tabular}{|c|c|c|c|}
\hline PROJECT CHIEF & DISCIPLINE & $\begin{array}{l}\text { PROJECT } \\
\text { NUMBER }\end{array}$ & PROJECT TITLE \\
\hline Campbell, William J. & SW Hydrology & WR 70-064 & Ice and Climate $\ldots \ldots \ldots$ \\
\hline Carter, Virginia P. & Ecology & NR 73-090 & $\begin{array}{l}\text { Remote Sensing and Ecological Research } \\
\text { in Wetlands } \ldots \ldots \ldots \ldots \ldots \ldots\end{array}$ \\
\hline Chen, Cheng-lung & SW Hydrology & WR 83-194 & Fluvial Processes and River Mechanics . . 410 \\
\hline Cheng, Ralph T. & SW Hydrology & WR 76-140 & $\begin{array}{l}\text { Hydrodynamics and Mathematical } \\
\text { Modeling of Circulation and Transport } \\
\text { Phenomena in Tidal Estuaries ...... } 398\end{array}$ \\
\hline Chiou, Cary T. & GW Chemistry & CR 83-283 & $\begin{array}{l}\text { Environmental Dynamics of Persistent } \\
\text { Organic Compounds } \ldots \ldots \ldots \ldots\end{array}$ \\
\hline Claassen, Hans C. & SW Chemistry & CR 75-189 & $\begin{array}{l}\text { Geochemical Kinetics Studies of Silicate } \\
\text { Rock Hy Sologic Systems . . . . . . } 312\end{array}$ \\
\hline Cloern, James E. & Ecology & WR 79-164 & Plankton Dynamics in Tidal Estuaries . . . . 68 \\
\hline Conomos, T. John & SW Hydrology & WR 77-156 & $\begin{array}{l}\text { Research Vessel Polaris Operations in } \\
\text { San Francisco Bay and Adjacent Coastal } \\
\text { Ocean } \ldots \ldots \ldots \ldots \ldots \ldots \ldots \ldots \ldots \ldots \ldots \ldots\end{array}$ \\
\hline Constantz, James E. & GW Hydrology & WR $87-193$ & $\begin{array}{l}\text { Temperature Effects in the Unsaturated } \\
\text { Zone } \ldots \ldots \ldots \ldots \ldots \ldots \ldots \ldots \ldots \ldots\end{array}$ \\
\hline Cooley, Richard L. & GW Hydrology & CR 76-191 & $\begin{array}{l}\text { Mathematical Simulation of Subsurface- } \\
\text { Water Flow Using Uncertain and } \\
\text { Incomplete Data } \ldots \ldots \ldots \ldots \ldots \ldots \ldots\end{array}$ \\
\hline Coplen, Tyler B. & GW Chemistry & NR 75-064 & $\begin{array}{l}\text { Physical Chemistry of Stable Isotope } \\
\text { Fractionation in Hydrologic Processes . . } 160\end{array}$ \\
\hline Davis, James A., III,, & GW Chemistry & WR 70-065 & $\begin{array}{l}\text { Partitioning of Solutes between Solid and } \\
\text { Aqueous Phases } \ldots \ldots \ldots \ldots \ldots\end{array}$ \\
\hline Eberl, Dennis D. & GW Chemistry & CR 82-276 & Geochemistry of Clay-Water Reactions . . 126 \\
\hline Eganhouse, Robert P. & GW Chemistry & NR 91-151 & $\begin{array}{l}\text { Transport and Biogeochemical Fate of } \\
\text { Organic Substances in Aquatic } \\
\text { Environments } \ldots \ldots \ldots \ldots \ldots \ldots 181\end{array}$ \\
\hline Emmett, William W. & $\begin{array}{l}\text { Geomorphology/ } \\
\text { Sediment }\end{array}$ & CR 74-187 & $\begin{array}{l}\text { Hydraulics and Mechanics of Bedload- } \\
\text { Transport Processes . . . . . . . . . } 95\end{array}$ \\
\hline
\end{tabular}




\begin{tabular}{|c|c|c|c|}
\hline PROJECT CHIEF & DISCIPLINE & $\begin{array}{l}\text { PROJECT } \\
\text { NUMBER }\end{array}$ & PROJECT TITLE \\
\hline Essaid, Hedeff I. & GW Hydrology & WR 89-199 & $\begin{array}{l}\text { The Fate and Transport of Immiscible } \\
\text { Contaminants in the Subsurface . . . . . } 298\end{array}$ \\
\hline Feder, Gerald L. & GW Chemistry & NR 79-132 & $\begin{array}{l}\text { Relationship Between Chemical Quality } \\
\text { of Natural Waters and Human Health } \\
\text { and Disease } \ldots \ldots \ldots \ldots \ldots \ldots \ldots\end{array}$ \\
\hline Godsy, Edward M. & Ecology & WR 71-068 & $\begin{array}{l}\text { Fate of Organic Chemicals in Subsurface } \\
\text { Environments } \ldots \ldots \ldots \ldots \ldots \ldots\end{array}$ \\
\hline Goerlitz, Donald F. & GW Chemistry & WR 84-189 & Chemistry of Aquatic Organic Matter . . . 205 \\
\hline Goldberg, Marvin C. & SW Chemistry & CR 76-199 & $\begin{array}{l}\text { Water Chemistry of Sediment Surface } \\
\text { Coatings } \ldots \ldots \ldots \ldots \ldots \ldots \ldots \ldots\end{array}$ \\
\hline Grove, David B. & GW Hydrology & CR 73-085 & $\begin{array}{l}\text { The Mathematical Simulation of the } \\
\text { Transport and Reaction of Chemical } \\
\text { Species in Ground Water . . . . . } 216\end{array}$ \\
\hline Harvey, Ronald W. & Ecology & CR 91-327 & $\begin{array}{l}\text { Interaction of Bacteria with Environmental } \\
\text { Contaminants and Solid Surfaces in the } \\
\text { Aquatic Environment } \ldots \ldots \ldots \ldots\end{array}$ \\
\hline Hem, John D. & SW Chemistry & WR 57-076 & $\begin{array}{l}\text { Chemistry of Hydrosolic Metals and } \\
\text { Related Constituents of Natural Water }\end{array}$ \\
\hline Herkelrath, William N. & GW Hydrology & WR $82-179$ & Nonisothermal Multiphase Flow . . . . . 284 \\
\hline Hsieh, Paul A. & GW Hydrology & WR 83-184 & Hydrology of Fractured Rocks \\
\hline Hupp, Cliff R. & Ecology & NR 90-145 & $\begin{array}{l}\text { Vegetation and Hydrogeomorphic } \\
\text { Relations ............... } 45\end{array}$ \\
\hline Ingebritsen, Steven E. & GW Hydrology & WR 74-121 & 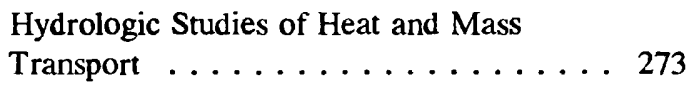 \\
\hline James, Ronald V. & GW Chemistry & WR $68-036$ & $\begin{array}{l}\text { Factors Determining Solute Transfer } \\
\text { in the Unsaturated Zone } \ldots \ldots \ldots 184\end{array}$ \\
\hline Jarrett, Robert D. & SW Hydrology & CR 90-321 & Paleohydrology and Climate Change $\ldots .371$ \\
\hline Jones, Blair F. & GW Chemistry & NR 69-020 & $\begin{array}{l}\text { Mineral-Water Interaction in Saline } \\
\text { Environments . . . . . . . . . . . } 144\end{array}$ \\
\hline
\end{tabular}




\begin{tabular}{|c|c|c|c|}
\hline PROJECT CHIEF & DISCIPLINE & $\begin{array}{l}\text { PROJECT } \\
\text { NUMBER }\end{array}$ & PROJECT TITLE \\
\hline Kendall, Carol & GW Chemistry & WR 91-080 & $\begin{array}{l}\text { Stable Isotope Tracers of Biogeochemical } \\
\text { and Hydrologic Processes } \ldots \ldots \ldots \ldots 191\end{array}$ \\
\hline Kharaka, Yousif K. & GW Chemistry & WR 76-139 & $\begin{array}{l}\text { Geochemistry of Water in Fine Grained } \\
\text { Sediments } \ldots \ldots \ldots \ldots \ldots \ldots \ldots 197\end{array}$ \\
\hline Kipp, Kenneth L. & GW Hydrology & CR 85-292 & $\begin{array}{l}\text { Ground-Water Solute-Transport } \\
\text { Simulation } \ldots \ldots \ldots \ldots \ldots\end{array}$ \\
\hline Konikow, Leonard F. & GW Hydrology & NR $81-120$ & $\begin{array}{l}\text { Digital Modeling of Transport in the } \\
\text { Saturated Zone } \ldots \ldots \ldots \ldots \ldots\end{array}$ \\
\hline Kraemer, Thomas F. & GW Chemistry & NR $82-138$ & $\begin{array}{l}\text { Uranium-Thorium Series Radioisotopes } \\
\text { in Ground-Water and Surface-Water } \\
\text { Systems } \ldots \ldots \ldots \ldots \ldots \ldots \ldots \ldots\end{array}$ \\
\hline Kuwabara, James S. & Ecology & WR $86-190$ & $\begin{array}{l}\text { Solute Transport Involving Biological } \\
\text { Processes in Surface Waters . . . . . }\end{array}$ \\
\hline LaBaugh, James W. & Ecology & CR 85-293 & $\begin{array}{l}\text { The Role of Chemical Fluxes in the } \\
\text { Biogeochemistry of Inland Surface } \\
\text { Waters, Including Lakes, Reservoirs, } \\
\text { and Wetlands } \ldots \ldots \ldots \ldots \ldots\end{array}$ \\
\hline Landa, Edward R. & GW Chemistry & NR 78-092 & $\begin{array}{l}\text { Hydrogeochemical Controls on the } \\
\text { Migration of Radionuclides from Uranium } \\
\text { Mill Tailings } \ldots \ldots \ldots \ldots \ldots \ldots \ldots 6 . \ldots \ldots\end{array}$ \\
\hline Landwehr, Jurate $\mathbf{M}$. & SW Hydrology & NR $84-133$ & Regional Hydrologic Processes \\
\hline Leavesley, George H. & SW Hydrology & CR 77-228 & $\begin{array}{l}\text { Precipitation-Runoff Modeling of } \\
\text { Watershed System } \ldots \ldots \ldots \ldots \ldots 356\end{array}$ \\
\hline Lee, Jonathan & SW Hydrology & NR $90-147$ & $\begin{array}{l}\text { Transport of Dissolved and Suspended } \\
\text { Materials in Surface Waters . . . . . . }\end{array}$ \\
\hline Leenheer, Jerry A. & SW Chemistry & CR 84-285 & 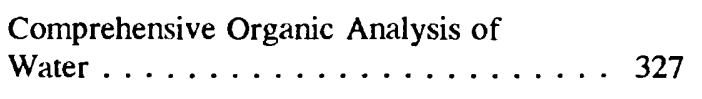 \\
\hline Leland, Harry V. & Ecology & CR 92-337 & $\begin{array}{l}\text { Effects of Toxic Substances on Aquatic } \\
\text { Communities } \ldots \ldots \ldots \ldots \ldots\end{array}$ \\
\hline Lovley, Derek R. & Ecology & NR $87-136$ & $\begin{array}{l}\text { Modeling of Microbially Catalyzed } \\
\text { Geochemical Reactions in Aquatic } \\
\text { Environments . . . . . . . . }\end{array}$ \\
\hline
\end{tabular}




\begin{tabular}{|c|c|c|c|}
\hline PROJECT CHIEF & DISCIPLINE & $\begin{array}{l}\text { PROJECT } \\
\text { NUMBER }\end{array}$ & PROJECT TITLE \\
\hline Luoma, Samuel N. & Ecology & WR 75-125 & $\begin{array}{l}\text { Availability of Trace Elements in } \\
\text { Sediments to Aquatic Organisms ......558 }\end{array}$ \\
\hline Malcolm, Ronald L. & SW Chemistry & CR 68-046 & $\begin{array}{l}\text { Origin, Characterization, and } \\
\text { Quantification of Natural Organic } \\
\text { Solutes in Water } \ldots \ldots \ldots \ldots . \ldots \ldots 2\end{array}$ \\
\hline Mariner, Robert $\mathrm{H}$. & GW Chemistry & WR 79-165 & $\begin{array}{l}\text { Chemical and Isotope Studies of Thermal } \\
\text { Waters of the Western United States . . . } 201\end{array}$ \\
\hline Marzolf, G. Richard & Ecology & CR 91-325 & $\begin{array}{l}\text { Limnological Phenomena in Impounded } \\
\text { Rivers } \ldots \ldots \ldots \ldots \ldots \ldots \ldots \ldots\end{array}$ \\
\hline McKnight, Diane M. & Ecology & CR 84-286 & $\begin{array}{l}\text { Interactions Between Organic Solutes } \\
\text { and Trace Metals in Natural Waters, and } \\
\text { Their Ecological Role } \ldots \ldots \ldots \ldots \ldots\end{array}$ \\
\hline Meade, Robert H. & $\begin{array}{l}\text { Geomorphology/ } \\
\text { Sediment }\end{array}$ & CR 75-102 & $\begin{array}{l}\text { Movement and Storage of Sediment in } \\
\text { River Systems } \ldots \ldots \ldots \ldots \ldots\end{array}$ \\
\hline Meade, Jr., Robert H. & $\begin{array}{l}\text { Geomorphology/ } \\
\text { Sediment }\end{array}$ & CR 87-309 & $\begin{array}{l}\text { Sediment-Transported Pollutants in the } \\
\text { Mississippi River . . . . . . . . . } 102\end{array}$ \\
\hline Milly, P.C.D. & SW Hydrology & NR 88-144 & $\begin{array}{l}\text { Continental Hydrology and Global } \\
\text { Climate . . . . . . . . . }\end{array}$ \\
\hline Moench, Allen F. & GW Hydrology & WR 75-127 & $\begin{array}{l}\text { Analytical Modeling of Flow and Transport } \\
\text { in Aquifers and Geothermal Reservoirs . . } 276\end{array}$ \\
\hline Moss, Marshall E. & SW Hydrology & WR 89-201 & Resolution of Hydroclimatic Uncertainty . . 413 \\
\hline Naff, Richard L. & GW' Hydrology & CR 90-319 & $\begin{array}{l}\text { Application of Stochastic Processes in } \\
\text { Hydrogeology } \ldots \ldots \ldots \ldots 242\end{array}$ \\
\hline Neuzil, Christopher E. & GW Hydrology & NR 81-035 & Hydrologic Behavior of Cretaceous Shales . 245 \\
\hline Nichols, Frederic H. & Ecology & WR 86-192 & $\begin{array}{l}\text { Environmental Influences on Estuarine } \\
\text { Benthic Community Dynamics } \ldots \ldots .85\end{array}$ \\
\hline Nimmo, John R. & GW Hydrology & WR, $89-198$ & $\begin{array}{l}\text { Physical Characteristics that Determine } \\
\text { Flow in the Unsaturated Zone ...... } 295\end{array}$ \\
\hline
\end{tabular}




\begin{tabular}{llcl} 
PROJECT CHIEF & DISCIPLINE & $\begin{array}{r}\text { PROJECT } \\
\text { NUMBER }\end{array}$ & PROJECT TITLE \\
\hline Nordstrom, Darrell K. & GW Chemistry & CR 92-326 & $\begin{array}{l}\text { Chemical Modeling and Thermodynamic } \\
\text { Data Evaluation of Major and Trace } \\
\text { Elements in Acid Mine Waters and Ground } \\
\text { Waters . . . . . . . . . . . . }\end{array}$ \\
& & &
\end{tabular}

PAGE

Oremland, Ronald S. Ecology

WR 81-174 Microbial Biogeochemistry of Aquatic

Environments . . . . . . . . . . 73

Osterkamp, Waite R.

Geomorphology/ Sediment

Paillet, Frederick L. $\quad$ GW Hydrology

Parkhurst, David L. GW Chemistry

Pereira, Wilfred E.

SW Chemistry

Peterson, David H.

Ecology

GW Chemistry

SW Hydrology

SW Chemistry

Reddy, Michael M.

Reilly, Thomas E.

GW Hydrology

Rubin, Jacob

Sanford, Ward

Schaffranek, Raymond W. SW Hydrology
GW Hydrology

GW Hydrology

NR 91-153

NR 80-104
Sediment Impacts from Disturbed and Undisturbed Lands . . . . . . . . 106

CR 64-140 Borehole Geophysics as Applied to Geohydrology ............ 222

CR 89-318 Reaction-Transport Modeling in GroundWater Systems . . . . . . . . . 135

WR 83-204 Origin, Fate, and Transport of Organic Compounds in Surface and Ground Waters and Their Effect on Water Quality ..... 351

WR 68-046 Geochemistry of Riverine and Estuarine Waters .............. 51

NR 76-056 Kinetics and Thermodynamics of Chemical Evolution in Ground-Water Systems . . . . 154

CR 77-301 Transport and Degradation of Organic Substances in Streams . . . . . . 368

CR 83-284 Aqueous Crystal Growth and Dissolution Kinetics of Earth Surface Minerals . . . 323

NR 91-152 Quantitative Analysis of Heterogeneous Hydrogeologic Controls on Ground-Water Flow and Transport . . . . . . . . 259

WR 82-180 Theories of Water Flow and of Solute Transport in the Unsaturated Zone . . . . 287

Reaction-Transport Phenomena in Hydrogeologic Settings . . . . . . . . . 263

Simulation Modeling of Hydrodynamic

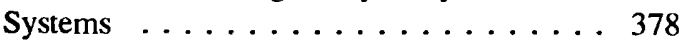




\begin{tabular}{|c|c|c|c|}
\hline PROJECT CHIEF & DISCIPLINE & $\begin{array}{l}\text { PROJECT } \\
\text { NUMBER }\end{array}$ & PROJECT TITLE \\
\hline Shapiro, Allen M. & GW Hydrology & NR 84-134 & Transport Phenomena in Fractured Rock . . 256 \\
\hline Simon, Nancy S. & SW Chemistry & NR 86-135 & $\begin{array}{l}\text { Distribution and Speciation of Metals in } \\
\text { Sedimentary Environments . . . . . . } 345\end{array}$ \\
\hline Slack, Keith V. & Ecology & WR 61-012 & $\begin{array}{l}\text { Limnology: Controls on Distribution and } \\
\text { Composition of Benthic Communities of } \\
\text { Inland Aquatic Ecosystems } \ldots \ldots \ldots \ldots\end{array}$ \\
\hline Smith, J. Dungan & $\begin{array}{l}\text { Geomorphology/ } \\
\text { Sediment }\end{array}$ & CR 91-324 & $\begin{array}{l}\text { Applications of Fluid and Sediment } \\
\text { Mechanics to Basin and Regional Scale } \\
\text { Hydrologic and Geomorphic Problems ... } 113\end{array}$ \\
\hline Smith, Richard L. & Ecology & CR 86-295 & $\begin{array}{l}\text { Microbial Transformation of Dissolved } \\
\text { Organic Carbon in Aquatic Environments . } 15\end{array}$ \\
\hline Sorey, Michael L. & GW Hydrology & WR 72-108 & $\begin{array}{l}\text { Technical Coordination and Support of } \\
\text { Wäter Resources Division Geothermal } \\
\text { Studies } \ldots \ldots \ldots \ldots \ldots \ldots \ldots \ldots \ldots\end{array}$ \\
\hline Sorey, Michael L. & GW Hydrology & WR 73-102 & $\begin{array}{l}\text { Modeling and Monitoring Heat and Fluid } \\
\text { Flow in Geothermal Systems . . . . . } 268\end{array}$ \\
\hline Stallard, Robert F. & Geomorphology/ & CR $88-313$ & $\begin{array}{l}\text { Sediment-Water Chemistry in Large } \\
\text { River Sediment Systems: Biogeochemical, } \\
\text { Geomorphic, and Human Controls .... } 109\end{array}$ \\
\hline Stonestrom, David A. & GW Hydrology & WR 63-024 & $\begin{array}{l}\text { Application of the Unsaturated Flow } \\
\text { Theory to the Phenomena of Infiltration } \\
\text { and Drainage } \ldots \ldots \ldots \ldots \ldots \ldots \ldots \ldots\end{array}$ \\
\hline Striegl, Robert G. & Ecology & CR 91-320 & $\begin{array}{l}\text { Characterization of Biotic and Biogeo- } \\
\text { chemical Interactions at Environmental } \\
\text { Interfaces } \ldots \ldots \ldots \ldots \ldots \ldots \ldots \ldots \ldots\end{array}$ \\
\hline Sundquist, Eric T. & SW Chemistry & NR 79-099 & $\begin{array}{l}\text { Carbon Fluxes in Hydrologic and Geologic } \\
\text { Processes . . . . . . . . . . } 338\end{array}$ \\
\hline Tasker, Gary D. & SW Hydrology & NR 82-125 & $\begin{array}{l}\text { Hydrologic Regression and Data-Network } \\
\text { Design . . . . . . . . . . . } 382\end{array}$ \\
\hline Taylor, Howard E. & SW Chemistry & CR 83-282 & $\begin{array}{l}\text { Research in Analytical Environmental } \\
\text { Trace Element Chemistry and Its Impact } \\
\text { on Water Quality } \ldots \ldots \ldots \ldots \ldots\end{array}$ \\
\hline
\end{tabular}


APPENDIX 1.-Alphabetical Listing by Project Chief-continued

\begin{tabular}{|c|c|c|c|}
\hline PROJECT CHIEF & DISCIPLINE & $\begin{array}{l}\text { PROJECT } \\
\text { NUMBER } \\
\end{array}$ & PROJECT TITLE \\
\hline Thorstenson, Donald C. & GW Chemistry & NR 79-093 & Chemical Models of Natural Systems . . . 142 \\
\hline Triska, Frank J. & Ecology & WR 84-186 & $\begin{array}{l}\text { Biotic Interface with Fluvial Transport: } \\
\text { Processes Associated with Dissolved } \\
\text { Solutes in Transport ............. }\end{array}$ \\
\hline Troutman, Brent $\mathbf{M}$. & SW Hydrology & CR 83-279 & 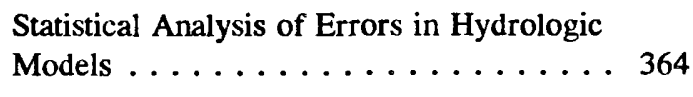 \\
\hline Voss, Clifford I. & GW Hydrology & NR 78-089 & $\begin{array}{l}\text { Investigations of Single and Multiphase } \\
\text { Fluid Flow, Mass and Energy Transport, } \\
\text { and Fluid Phase Change in the Subsurface } \\
\text { Environment } \ldots \ldots \ldots \ldots \ldots \ldots \ldots \ldots\end{array}$ \\
\hline Wagner, Brian J. & GW Hydrology & WR $82-178$ & $\begin{array}{l}\text { Ground-water Monitoring Network } \\
\text { Design } \ldots \ldots \ldots \ldots \ldots \ldots \ldots \ldots \ldots \ldots\end{array}$ \\
\hline Walters, Roy A. & SW Hydrology & WR 83-183 & $\begin{array}{l}\text { Analysis and Modeling of Conservative } \\
\text { and Nonconservative Transport Processes . } 403\end{array}$ \\
\hline Webb, Robert H. & $\begin{array}{l}\text { Geomorphology/ } \\
\text { Sediment }\end{array}$ & WR 89-200 & $\begin{array}{l}\text { Response of Fluvial Systems to Climatic } \\
\text { Variability } \ldots \ldots \ldots \ldots \ldots \ldots \ldots \ldots\end{array}$ \\
\hline Weeks, Edwin P. & GW Hydrology & CR 69-200 & $\begin{array}{l}\text { Field Applications of Unsaturated Zone } \\
\text { Flow Theory } \ldots \ldots \ldots \ldots \ldots\end{array}$ \\
\hline Wershaw, Robert L. & SW Chemistry & CR 68-132 & $\begin{array}{l}\text { Behavior of Natural Polyelectrolytes } \\
\text { in Water } \ldots \ldots \ldots \ldots \ldots \ldots \ldots\end{array}$ \\
\hline White, Arthur F. & GW Chemistry & WR 88-196 & $\begin{array}{l}\text { Geochemical Reactions Between Water } \\
\text { and Mineral Substrates } \ldots \ldots \ldots 208\end{array}$ \\
\hline Williams, Garnett P. & $\begin{array}{l}\text { Geomorphology/ } \\
\text { Sediment }\end{array}$ & CR 65-105 & $\begin{array}{l}\text { Effects of Water and Sediment Discharges } \\
\text { on Channel Morphology } \ldots \ldots \ldots 9\end{array}$ \\
\hline Winograd, Isaac J. & GW Chemistry & NR 74-041 & $\begin{array}{l}\text { Interface of Paleoclimatology and } \\
\text { Aquifer Geochemistry } \ldots \ldots \ldots 152\end{array}$ \\
\hline Winter, Thomas C. & Ecology & CR 90-323 & $\begin{array}{l}\text { Interdisciplinary Research Initiative (IRI) } \\
\text { at the Shingobee Headwaters Research } \\
\text { Area, Minnesota } \ldots \ldots \ldots \ldots \ldots \ldots \ldots \ldots\end{array}$ \\
\hline Winter, Thomas C. & GW Hydrology & CR 74-090 & $\begin{array}{l}\text { The Role of Lakes in the Hydrologic } \\
\text { System, with Emphasis on Their } \\
\text { Relation to Ground Water ........ }\end{array}$ \\
\hline Wood, Warren W. & GW Chemistry & NR 81-122 & $\begin{array}{l}\text { Dispersion of Toxic and Radioactive } \\
\text { Wastes in Ground-Water Systems . . . }\end{array}$ \\
\hline
\end{tabular}


424 NATIONAL RESĖARCH SUMMARY 1993 
APPENDIX 2.-Topical Listing-continued

\begin{tabular}{|c|c|c|c|}
\hline TOPIC & $\begin{array}{l}\text { PROJECT } \\
\text { CHIEF }\end{array}$ & $\begin{array}{l}\text { PROJECT } \\
\text { NUMBER }\end{array}$ & $\begin{array}{c}\text { PAGE } \\
\text { NUMBER }\end{array}$ \\
\hline \multirow[t]{4}{*}{ Acid rain: } & Bricker, Owen P. & NR109 & 341 \\
\hline & Malcolm, Ronald L. & CR046 & 302 \\
\hline & Reddy, Michael M. & CR284 & 323 \\
\hline & Taylor, Howard E. & CR282 & 319 \\
\hline \multirow[t]{6}{*}{ Acid Mine Drainage: } & Bencala, Kenneth E. & WR187 & 405 \\
\hline & Hem, John D. & WR076 & 348 \\
\hline & Kipp, Kenneth L. & CR292 & 238 \\
\hline & Luoma, Samuel N. & WR125 & 58 \\
\hline & McKnight, Diane M. & CR286 & 8 \\
\hline & Nordstrom, Darrell K. & CR326 & 138 \\
\hline \multirow[t]{13}{*}{ Aquatic Habitat: } & Andrews, Edmund D. & CR273 & 98 \\
\hline & Averett, Robert C. & CR312 & 19 \\
\hline & Carter, Virginia P. & NR090 & 36 \\
\hline & Cloern, James E. & WR164 & 68 \\
\hline & Hupp, Cliff R. & NR145 & 45 \\
\hline & Leland, Harry V. & CR337 & 34 \\
\hline & Luoma, Samuel N. & WR125 & 58 \\
\hline & Marzolf, G. Richard & CR325 & 26 \\
\hline & McKnight, Diane M. & CR286 & 8 \\
\hline & Nichols, Frederic $\mathrm{H}$. & WR192 & 85 \\
\hline & Slack, Keith V. & WR012 & 48 \\
\hline & Triska, Frank J. & WR186 & 77 \\
\hline & Webb, Robert H. & WR200 & 117 \\
\hline \multirow[t]{12}{*}{ Carbon Cycle: } & Aiken, George R. & CR331 & 332 \\
\hline & Betancourt, Julio L. & WR145 & 63 \\
\hline & Bricker, Owen P. & NR109 & 341 \\
\hline & Carter, Virginia & NR090 & 36 \\
\hline & Cloern, James E. & WR164 & 68 \\
\hline & Coplen, Tyler B. & NR064 & 160 \\
\hline & Kendall, Carol & WR080 & 191 \\
\hline & Leenheer, Jerry A. & CR285 & 327 \\
\hline & Lovley, Derek R. & NR136 & 40 \\
\hline & McKnight, Diane M. & CR286 & 8 \\
\hline & Oremland, Ronald S. & WR174 & 73 \\
\hline & Reddy, Michael M. & CR284 & 323 \\
\hline
\end{tabular}




\begin{tabular}{|c|c|c|c|}
\hline TOPIC & $\begin{array}{l}\text { PROJECT } \\
\text { CHIEF }\end{array}$ & $\begin{array}{l}\text { PROJECT } \\
\text { NUMBER }\end{array}$ & $\begin{array}{c}\text { PAGE } \\
\text { NUMBER }\end{array}$ \\
\hline & Smith, Richard L. & CR295 & 15 \\
\hline & Stallard, Robert F. & CR313 & 109 \\
\hline & Striegel, Robert G. & CR320 & 21 \\
\hline & Sundquist, Eric T. & NR099 & 338 \\
\hline & Thorstenson, Donald C. & NR093 & 142 \\
\hline & Weeks, Edwin P. & CR2O0 & 232 \\
\hline \multirow[t]{14}{*}{ Estuaries: } & Baltzer, Robert A. & NR019 & 375 \\
\hline & Bricker, Owen P. & NR109 & 341 \\
\hline & Carter, Virginia P. & NR090 & 36 \\
\hline & Cheng, Ralph T. & WR140 & 398 \\
\hline & Cloern, James, E. & WR164 & 68 \\
\hline & Conomos, T. John & WR156 & 402 \\
\hline & Eganhouse, Robert $P$. & NR151 & 181 \\
\hline & Kuwabara, James S. & WR190 & 81 \\
\hline & Luoma, Samuel N. & WR125 & 58 \\
\hline & Nichols, Frederic $\mathrm{H}$. & WR192 & 85 \\
\hline & Pereira, Wilfred E. & WR204 & 351 \\
\hline & Peterson, David H. & WR046 & 51 \\
\hline & Schaffraneck, Raymond W. & NR104 & 378 \\
\hline & Walters, Roy A. & WR183 & 403 \\
\hline \multirow[t]{2}{*}{ Evapotranspiration: } & Weeks, Edwin P. & CR200 & 232 \\
\hline & Winter, Thomas C. & WR090 & \\
\hline \multirow[t]{7}{*}{ Fractured Rock: } & Hsieh, Paul A. & WR184 & 290 \\
\hline & Nordstrom, Darrell K. & CR326 & 138 \\
\hline & Paillet, Frederick L. & CR140 & 222 \\
\hline & Shapiro, Allen M. & NR134 & 256 \\
\hline & Voss, Clifford I. & NR089 & 247 \\
\hline & Winter, Thomas C. & WR090 & \\
\hline & Wood, Warren W. & NR122 & 169 \\
\hline \multirow[t]{5}{*}{ Geochemistry Isotopic tracers: } & Coplen, Tyler B. & NR064 & 160 \\
\hline & Kendall, Carol & WR080 & 191 \\
\hline & Kharaka, Yousif K. & WR139 & 197 \\
\hline & Kraemer, Thomas F. & NR138 & 178 \\
\hline & Landa, Edward R. & NR092 & 166 \\
\hline
\end{tabular}




\begin{tabular}{|c|c|c|c|}
\hline TOPIC & $\begin{array}{l}\text { PROJECT } \\
\text { CHIEF }\end{array}$ & $\begin{array}{l}\text { PROJECT } \\
\text { NUMBER }\end{array}$ & $\begin{array}{c}\text { PAGE } \\
\text { NUMBER }\end{array}$ \\
\hline & Plummer, L. Niel & NR056 & 154 \\
\hline & White, Arthur F. & WR196 & 208 \\
\hline \multirow[t]{2}{*}{ Geophysics: } & Brown, Charles E. & NR130 & 254 \\
\hline & Paillet, Frederick L. & CR140 & 222 \\
\hline \multirow[t]{6}{*}{ Geothermal Resources: } & Sorey, Michael L. & WR102 & 268 \\
\hline & Sorey, Michael L. & WR108 & 271 \\
\hline & Mariner, Robert $\mathrm{H}$. & WR165 & 201 \\
\hline & Ingebritsen, Steven E. & WR121 & 273 \\
\hline & Kharaka, Yousif K. & WR139 & 197 \\
\hline & Paillet, Frederick L. & CR140 & 222 \\
\hline \multirow[t]{23}{*}{$\begin{array}{l}\text { Ground-water Flow, Transport, } \\
\text { and Reactions: }\end{array}$} & $\begin{array}{l}\text { Baedecker, Mary Jo } \\
\text { Bredehoeft, John D. }\end{array}$ & $\begin{array}{l}\text { NR129 } \\
\text { WR176 }\end{array}$ & $\begin{array}{l}172 \\
278\end{array}$ \\
\hline & Coplen, Tyler B. & NR064 & 160 \\
\hline & Davis, James A., III & WR065 & 186 \\
\hline & Eganhouse, Robert P. & NR151 & 181 \\
\hline & Eberl, Dennis D. & CR276 & 126 \\
\hline & Essaid, Hedeff I. & WR199 & 298 \\
\hline & Herkelrath, William N. & WR179 & 284 \\
\hline & Ingebritsen, Steven E. & WR121 & 273 \\
\hline & Jones, Blair F. & NR020 & 144 \\
\hline & Kendall, Carol & WR080 & 191 \\
\hline & Kharaka, Yousif K. & WR139 & 197 \\
\hline & Kipp, Kenneth L. & CR292 & 238 \\
\hline & Konikow, Leonard F. & NR120 & 250 \\
\hline & Neuzil, Christopher E. & NR035 & 245 \\
\hline & Nordstrom, Darrell K. & CR326 & 138 \\
\hline & Parkhurst, David L. & CR318 & 135 \\
\hline & Plummer, L. Niel & NR056 & 154 \\
\hline & Reilly, Thomas E. & NR152 & 259 \\
\hline & Rubin, Jacob & WR180 & 287 \\
\hline & Sanford, Ward & NR153 & 263 \\
\hline & Thorstenson, Donald C. & NR093 & 142 \\
\hline & Voss, Clifford I. & NR089 & 247 \\
\hline & Wagner, Brian J. & WR178 & 282 \\
\hline
\end{tabular}


APPENDIX 2.-Topical Listing-continued

\begin{tabular}{|c|c|c|c|}
\hline TOPIC & $\begin{array}{l}\text { PROJECT } \\
\text { CHIEF }\end{array}$ & $\begin{array}{l}\text { PROJECT } \\
\text { NUMBER }\end{array}$ & $\begin{array}{c}\text { PAGE } \\
\text { NUMBER }\end{array}$ \\
\hline & Weeks, Edwin P. & CR200 & 232 \\
\hline & White, Arthur F. & WR196 & 208 \\
\hline & Wood, Warren W. & NR122 & 169 \\
\hline \multirow[t]{11}{*}{ Ground-water Hydraulics: } & $\begin{array}{l}\text { Bredehoeft, John D. } \\
\text { Brown, Charles E. }\end{array}$ & $\begin{array}{l}\text { WR176 } \\
\text { NR130 }\end{array}$ & $\begin{array}{l}278 \\
254\end{array}$ \\
\hline & Essaid, Hedeff I. & WR199 & 298 \\
\hline & Herkelrath, William N. & WR179 & 284 \\
\hline & Hsieh, Paul A. & WR184 & 290 \\
\hline & Konikow, Leonard F. & NR120 & 250 \\
\hline & Moench, Allen F. & WR127 & 276 \\
\hline & Neuzil, Christopher E. & NR035 & 245 \\
\hline & Paillet, Frederick L. & CR140 & 222 \\
\hline & Reilly, Thomas E. & NR152 & 259 \\
\hline & Shapiro, Allen M. & NR134 & 256 \\
\hline & Voss, Clifford I. & NR089 & 247 \\
\hline \multirow[t]{20}{*}{ Hydroclimatology: } & Benson, Larry V. & CR207 & 122 \\
\hline & Betancourt, Julio L. & WR145 & 63 \\
\hline & Campbell, William J., & WR064 & 393 \\
\hline & Coplen, Tyler B. & NR064 & 160 \\
\hline & Jarrett, Robert D. & CR321 & 371 \\
\hline & Kendall, Carol & WR080 & 191 \\
\hline & Landwehr, Jurate $\mathrm{M}$. & NR133 & 386 \\
\hline & Leavesley, George H. & CR228 & 356 \\
\hline & Luoma, Samuel N. & WR125 & 58 \\
\hline & Milly, P.C.D. & NR144 & 389 \\
\hline & Moss, Marshall E. & WR201 & 413 \\
\hline & Peterson, David H. & WR046 & 51 \\
\hline & Striegl, Robert G. & CR320 & 21 \\
\hline & Walters, Roy A. & WR183 & 403 \\
\hline & Webb, Robert H. & WR200 & 117 \\
\hline & Weeks, Edwin P. & CR200 & 232 \\
\hline & White, Arthur F. & WR196 & 208 \\
\hline & Winograd, Isaac J. & NR041 & 152 \\
\hline & Winter, Thomas C. & CR090 & 218 \\
\hline & Wood, Warren W. & NR122 & 169 \\
\hline
\end{tabular}




\begin{tabular}{|c|c|c|c|}
\hline TOPIC & $\begin{array}{l}\text { PROJECT } \\
\text { CHIEF }\end{array}$ & $\begin{array}{l}\text { PROJECT } \\
\text { NUMBER }\end{array}$ & $\begin{array}{c}\text { PAGE } \\
\text { NUMBER }\end{array}$ \\
\hline \multirow[t]{20}{*}{ Hydrogeology: } & Back, William & NR034 & 147 \\
\hline & Bredehoeft, John D. & WR176 & 278 \\
\hline & Bricker, Owen P. & NR109 & 341 \\
\hline & Brown, Charles E. & NR130 & 254 \\
\hline & Cooley, Richard L. & CR191 & 228 \\
\hline & Coplen, Tyler B. & NR064 & 160 \\
\hline & Hsieh, Paul A. & WR184 & 290 \\
\hline & Ingebritsen, Steven E. & WR121 & 273 \\
\hline & Jones, Blair F. & NR020 & 144 \\
\hline & Konikow, Leonard F. & NR120 & 250 \\
\hline & Neuzil, Christopher E. & NR035 & 245 \\
\hline & Plummer, L. Niel & NR056 & 154 \\
\hline & Reilly, Thomas E. & NR152 & 259 \\
\hline & Shapiro, Allen M. & NR134 & 256 \\
\hline & Sorey, Michael L. & WR102 & 268 \\
\hline & Voss, Clifford I. & NR089 & 247 \\
\hline & Weeks, Edward P. & CR200 & 232 \\
\hline & Winograd, Isaac J. & NR041 & 152 \\
\hline & Winter, Thomas C. & CR090 & 218 \\
\hline & Wood, Warren W. & NR122 & 169 \\
\hline \multirow[t]{13}{*}{ Lakes: } & Averett, Robert C. & CR312 & 19 \\
\hline & Winter, T.C. & CR323 & 24 \\
\hline & Benson, Larry V. & CR2O7 & 122 \\
\hline & Callender, Edward & NR065 & 334 \\
\hline & Cloern, James E. & WR164 & 68 \\
\hline & Kuwabara, James S. & WR190 & 81 \\
\hline & LaBaugh, James W. & CR293 & 13 \\
\hline & Oremland, Ronald S. & WR174 & 73 \\
\hline & Smith, Richard L. & CR295 & 15 \\
\hline & Striegl, Robert G. & CR320 & 21 \\
\hline & Taylor, Howard E. & CR282 & 319 \\
\hline & Winter, Thomas C. & CR090 & 218 \\
\hline & Wood, Warren W. & NR122 & 169 \\
\hline \multirow[t]{2}{*}{ Metals: } & Bricker, Owen P. & NR109 & 341 \\
\hline & Callender, Edward & NR065 & 334 \\
\hline
\end{tabular}




\begin{tabular}{|c|c|c|c|}
\hline TOPIC & $\begin{array}{l}\text { PROJECT } \\
\text { CHIEF } \\
\end{array}$ & $\begin{array}{l}\text { PROJECT } \\
\text { NUMBER } \\
\end{array}$ & $\begin{array}{c}\text { PAGE } \\
\text { NUMBER }\end{array}$ \\
\hline & Davis, James A., III & WR065 & 186 \\
\hline & Hem, John D. & WR076 & 348 \\
\hline & Hupp, Cliff R. & NR145 & 45 \\
\hline & Kuwabara, James S. & WR190 & 81 \\
\hline & Leland, Harry V. & CR337 & 34 \\
\hline & Lovley, Derek R. & NR123 & 40 \\
\hline & Luoma, Samuel N. & WR125 & 58 \\
\hline & McKnight, Diane M. & CR286 & 8 \\
\hline & Meade, Robert H., Jr. & CR309 & 102 \\
\hline & Nordstrom, DarreiPK. & CR326 & 138 \\
\hline & Oremland, Ronald S. & WR174 & 73 \\
\hline & Simon, Nancy S. & NR135 & 345 \\
\hline & Stallard, Robert F. & CR313 & 109 \\
\hline & Taylor, Howard E. & CR282 & 319 \\
\hline & White, Arthur F. & WR196 & 208 \\
\hline \multicolumn{4}{|l|}{ Microbiology } \\
\hline \multirow[t]{2}{*}{ Aerobic: } & Oremland, Ronald S. & WR174 & 73 \\
\hline & Smith Richard L. & CR295 & 15 \\
\hline \multirow[t]{5}{*}{ Anaerobic: } & Godsy, Edward M. & WR068 & 55 \\
\hline & Harvey, Ronald W. & CR327 & 29 \\
\hline & Lovley, Derek R. & NR123 & 40 \\
\hline & Oremland, Ronald S. & WR174 & 73 \\
\hline & Smith, Richard L. & CR295 & 15 \\
\hline \multirow[t]{12}{*}{ Nutrients: } & Averett, Robert C. & CR312 & 19 \\
\hline & Bricker, Owen P. & NR109 & 341 \\
\hline & Callender, Edward & NR065 & 334 \\
\hline & Feder, Gerald L. & NR132 & 176 \\
\hline & Kendall, Carol & WR080 & 191 \\
\hline & LaBaugh, James W. & CR293 & 13 \\
\hline & Leland, Harry V. & CR337 & 34 \\
\hline & Meade, Robert H., Jr. & CR309 & 102 \\
\hline & Peterson, David H. & WR046 & 51 \\
\hline & Smith, Richard L. & CR295 & 15 \\
\hline & Taylor, Howard E. & CR282 & 319 \\
\hline & Triska, Frank J. & WR186 & 77 \\
\hline
\end{tabular}




\begin{tabular}{|c|c|c|c|}
\hline TOPIC & $\begin{array}{l}\text { PROJECT } \\
\text { CHIEF }\end{array}$ & $\begin{array}{l}\text { PROJECT } \\
\text { NUMBER }\end{array}$ & $\begin{array}{c}\text { PAGE } \\
\text { NUMBER }\end{array}$ \\
\hline \multirow[t]{7}{*}{$\begin{array}{l}\text { Organic Compounds } \\
\text { (natural): }\end{array}$} & $\begin{array}{l}\text { Aiken, George R. } \\
\text { Chiou, Cary T. }\end{array}$ & $\begin{array}{l}\text { CR331 } \\
\text { CR283 }\end{array}$ & $\begin{array}{l}332 \\
130\end{array}$ \\
\hline & Eganhouse, Robert P. & NR151 & 181 \\
\hline & Leenheer, Jerry A. & CR285 & 327 \\
\hline & Malcolm, Ronald L. & CR046 & 302 \\
\hline & McKnight, Diane M. & CR286 & 8 \\
\hline & Meade, Robert H., Jr. & CR309 & 102 \\
\hline & Wershaw, Robert L. & CR132 & 306 \\
\hline \multirow[t]{14}{*}{$\begin{array}{l}\text { Organic Compounds } \\
\text { (man-made): }\end{array}$} & $\begin{array}{l}\text { Aiken, George R. } \\
\text { Baedecker, Mary Jo }\end{array}$ & $\begin{array}{l}\text { CR331 } \\
\text { NR129 }\end{array}$ & $\begin{array}{l}332 \\
172\end{array}$ \\
\hline & Chiou, Cary T. & CR283 & 130 \\
\hline & Eganhouse, Robert P. & NR151 & 181 \\
\hline & Essaid, Hedeff I. & WR199 & 298 \\
\hline & Feder, Gerald L. & NR132 & 176 \\
\hline & Godsy, Edward M. & WR068 & 55 \\
\hline & Goerlitz, Donald F. & WR189 & 205 \\
\hline & Goldberg, Marvin C. & CR199 & 315 \\
\hline & Herkelrath, William N. & WR179 & 284 \\
\hline & Leenheer, Jerry A. & CR285 & 327 \\
\hline & Meade, Robert H., Jr. & CR309 & 102 \\
\hline & Pereira, Wilfred E. & WR204 & 351 \\
\hline & Rathbun, Ronald E. & WR301 & 368 \\
\hline & Wershaw, Robert L. & WR132 & 306 \\
\hline \multirow[t]{6}{*}{ Radionuclides: } & Coplen, Tyler B. & NR064 & 160 \\
\hline & Davis, James A., III & WR065 & 186 \\
\hline & Kraemer, Thomas F. & NR138 & 178 \\
\hline & Landa, Edward R. & NR092 & 166 \\
\hline & McKnight, Diane & CR286 & 8 \\
\hline & Nordstrom, Darrell K. & CR326 & 138 \\
\hline \multirow[t]{4}{*}{ Reservoirs: } & Andrews, Edmund D. & CR273 & 98 \\
\hline & Averett, Robert C. & CR312 & 19 \\
\hline & Callender, Edward & NR065 & 334 \\
\hline & LaBaugh, James W. & CR293 & 13 \\
\hline
\end{tabular}


APPENDIX 2.-Topical Listing-continued

\begin{tabular}{|c|c|c|c|}
\hline TOPIC & $\begin{array}{l}\text { PROJECT } \\
\text { CHIEF }\end{array}$ & $\begin{array}{l}\text { PROJECT } \\
\text { NUMBER }\end{array}$ & $\begin{array}{c}\text { PAGE } \\
\text { NUMBER }\end{array}$ \\
\hline & Leland, Harry V. & CR337 & 34 \\
\hline & Marzolf, G. Richard & CR325 & 26 \\
\hline & Taylor, Howard E. & CR282 & 319 \\
\hline \multirow[t]{34}{*}{ Rivers and Streams: } & Aiken, George R. & CR331 & 332 \\
\hline & Andrews, Edmund D. & CR273 & 98 \\
\hline & Bencala, Kenneth E. & WR287 & \\
\hline & Bennett, James P. & CR343 & 374 \\
\hline & Bricker, Owen P. & NR109 & 341 \\
\hline & Callender, Edward & NR065 & 334 \\
\hline & Chen, Cheng-lung & WR194 & 410 \\
\hline & Classen, Hans C. & CR189 & 312 \\
\hline & Emmett, William W. & CR187 & 95 \\
\hline & Hem, John D. & WR076 & 348 \\
\hline & Jarrett, Robert D. & CR321 & 371 \\
\hline & Kuwabara, James S. & WR190 & 81 \\
\hline & Landwehr, Jurate M. & NR133 & 386 \\
\hline & Leavesley, George H. & CR228 & 356 \\
\hline & Lee, Jonathan & NR147 & 391 \\
\hline & Leenheer, Jerry A. & CR285 & 327 \\
\hline & Luoma, Samuel N. & WR125 & 58 \\
\hline & Malcolm, Ronald L. & CR046 & 302 \\
\hline & McKnight, Diane M. & CR286 & 8 \\
\hline & Meade, Robert H. & CR102 & 90 \\
\hline & Milly, P.C.D. & NR144 & 389 \\
\hline & Moss, Marshall E. & WR201 & 413 \\
\hline & Osterkamp, Waite R. & CR311 & 106 \\
\hline & Pereira, Wilfred E. & WR204 & 351 \\
\hline & Rathbun, Ronald E. & CR301 & 368 \\
\hline & Reddy, Michael M & CR284 & 323 \\
\hline & Schaffranek, Raymond W. & NR104 & 378 \\
\hline & Simon, Nancy S. & NR135 & 345 \\
\hline & Smith, J. Dungan & CR324 & 113 \\
\hline & Stallard, Robert F. & CR313 & 109 \\
\hline & Sundquist, Eric T. & NR099 & 338 \\
\hline & Tasker, Gary D. & NR125 & 382 \\
\hline & Taylor, Howard E. & CR282 & 319 \\
\hline & Triska, Frank J. & WR186 & 77 \\
\hline
\end{tabular}


APPENDIX 2.-Topical Listing-continued

\begin{tabular}{|c|c|c|c|}
\hline TOPIC & $\begin{array}{l}\text { PROJECT } \\
\text { CHIEF }\end{array}$ & $\begin{array}{l}\text { PROJECT } \\
\text { NUMBER }\end{array}$ & $\begin{array}{c}\text { PAGE } \\
\text { NUMBER }\end{array}$ \\
\hline & Troutman, Brent M. & CR279 & 364 \\
\hline & Walters, Roy A. & WR183 & 403 \\
\hline & Webb, Robert H. & WR200 & 117 \\
\hline & Wershaw, Robert L. & CR132 & 306 \\
\hline & Williams, Garnett P. & CR105 & 93 \\
\hline \multirow[t]{7}{*}{ Sediment Chemistry: } & $\begin{array}{l}\text { Aiken, George R. } \\
\text { Benson, Larry V. }\end{array}$ & $\begin{array}{l}\text { CR331 } \\
\text { CR207 }\end{array}$ & $\begin{array}{l}332 \\
122\end{array}$ \\
\hline & Bricker, Owen P. & NR109 & 341 \\
\hline & Callender, Edward & NR065 & 334 \\
\hline & Chiou, Cary T. & CR283 & 130 \\
\hline & Davis, James A., III & WR065 & 186 \\
\hline & Eganhouse, Robert P. & NR151 & 181 \\
\hline & Goldberg, Marvin C. & CR199 & 315 \\
\hline \multirow[t]{9}{*}{. } & James, Ronald V. & WR036 & 184 \\
\hline & Jones, Blair F. & NR020 & 144 \\
\hline & Leenheer, Jerry A. & CR285 & 327 \\
\hline & Luoma, Samuel N. & WR125 & 58 \\
\hline & Meade, Robert H., Jr. & CR309 & 102 \\
\hline & Pereira, Wilfred E. & WR204 & 351 \\
\hline & Stallard, Robert, F. & CR313 & 109 \\
\hline & Taylor, Howard E. & CR282 & 319 \\
\hline & White, Arthur F. & WR196 & 208 \\
\hline \multirow[t]{13}{*}{ Sediment Transport: } & Andrews, Edmund D. & CR273 & 98 \\
\hline & Bennett, James P. & WR197 & 374 \\
\hline & Chen, Cheng-lung & WR194 & 410 \\
\hline & Emmett, William W. & CR187 & 95 \\
\hline & Hupp, Cliff R. & NR145 & 45 \\
\hline & Jarrett, Robert D. & CR321 & 371 \\
\hline & Meade, Robert H. & CR102 & 90 \\
\hline & Meade, Robert H., Jr. & CR309 & 102 \\
\hline & Osterkamp, Waite R. & CR311 & 106 \\
\hline & Smith, J. Dungan & CR324 & 113 \\
\hline & Stallard, Robert F. & CR313 & 109 \\
\hline & Webb, Robert H. & WR200 & 117 \\
\hline & Williams, Garnett P. & CR105 & 93 \\
\hline
\end{tabular}


APPENDIX 2.-Topical Listing-continued

\begin{tabular}{|c|c|c|c|}
\hline TOPIC & $\begin{array}{l}\text { PROJECT } \\
\text { CHIEF }\end{array}$ & $\begin{array}{l}\text { PROJECT } \\
\text { NUMBER }\end{array}$ & $\begin{array}{c}\text { PAGE } \\
\text { NUMBER }\end{array}$ \\
\hline \multirow[t]{7}{*}{ Snow, Ice, Glaciers: } & Campbell, William J. & WR064 & 393 \\
\hline & Claassen, Hans C. & CR189 & 312 \\
\hline & Coplen, Tyler B. & NR064 & 160 \\
\hline & Leavesley, George H. & CR228 & 356 \\
\hline & Reddy, Michael M. & CR284 & 323 \\
\hline & Taylor, Howard E. & CR282 & 319 \\
\hline & Walters, Roy A. & WR183 & 403 \\
\hline \multirow[t]{8}{*}{ Statistical Hydrology: } & Brown, Charles E. & NR130 & 254 \\
\hline & Cooley, Richard L. & CR191 & 228 \\
\hline & Landwehr, Jurate M. & NR133 & 386 \\
\hline & Moss, Marshall E. & WR201 & 413 \\
\hline & Naff, Richard L. & CR319 & 242 \\
\hline & Tasker, Gary D. & NR125 & 382 \\
\hline & Troutman, Brent $\mathrm{M}$. & CR279 & 364 \\
\hline & Wagner, Brian J. & WR178 & 282 \\
\hline \multirow[t]{9}{*}{ Surface Chemistry: } & Chiou, Cary T. & CR283 & 130 \\
\hline & Davis, James A., III & WR065 & 186 \\
\hline & Eberl, Dennis D. & CR276 & 126 \\
\hline & Goldberg, Marvin C. & CR199 & 315 \\
\hline & Jarrett, Robert D. & CR321 & 371 \\
\hline & Plummer, L. Niel & NR056 & 154 \\
\hline & Reddy, Michael M. & CR284 & 323 \\
\hline & Wershaw, Robert L. & CR132 & 306 \\
\hline & White, Arthur F. & WR196 & 208 \\
\hline \multirow[t]{8}{*}{ Surface-water Hydraulics: } & Baltzer, Robert A. & NR019 & 375 \\
\hline & Bennett, James P. & WR197 & 374 \\
\hline & Chen, Cheng-lung & WR194 & 410 \\
\hline & Cheng, Ralph T. & WR140 & 398 \\
\hline & Jarrett, Robert D. & CR321 & 371 \\
\hline & Lee, Jonathan & NR147 & 391 \\
\hline & Schaffranek, Raymond W. & NR104 & 378 \\
\hline & Walters, Roy A. & WR183 & 403 \\
\hline $\begin{array}{l}\text { Surface-water Transport and } \\
\text { Reactions: }\end{array}$ & $\begin{array}{l}\text { Bencala, Kenneth E. } \\
\text { Chen, Cheng-lung }\end{array}$ & $\begin{array}{l}\text { WR187 } \\
\text { WR194 }\end{array}$ & $\begin{array}{l}405 \\
410\end{array}$ \\
\hline
\end{tabular}




\begin{tabular}{|c|c|c|c|}
\hline TOPIC & $\begin{array}{l}\text { PROJECT } \\
\text { CHIEF }\end{array}$ & $\begin{array}{l}\text { PROJECT } \\
\text { NUMBER } \\
\end{array}$ & $\begin{array}{c}\text { PAGE } \\
\text { NUMBER }\end{array}$ \\
\hline & Cheng, Ralph T. & WR140 & 398 \\
\hline & Leavesley, George $\mathrm{H}$. & CR228 & 356 \\
\hline & Nordstrom, Darrell K. & CR326 & 138 \\
\hline & Rathbun, Ronald E. & CR301 & 368 \\
\hline & Triska, Frank J. & WR186 & 77 \\
\hline & Walters, Roy A. & WR183 & 403 \\
\hline \multirow[t]{15}{*}{ Unsaturated Zone: } & Chiou, Cary T. & CR283 & 130 \\
\hline & Claassen, Hans C. & CR189 & 312 \\
\hline & Constantz, James E. & WR193 & 293 \\
\hline & Essaid, Hedeff I. & WR199 & 298 \\
\hline & Herkelrath, William N. & WR179 & 284 \\
\hline & James, Ronald V. & WR036 & 184 \\
\hline & Kendall, Carol & WR080 & 191 \\
\hline & Milly, P.C.D. & NR144 & 389 \\
\hline & Nimmo, John R. & WR198 & 295 \\
\hline & Rubin, Jacob & WR180 & 287 \\
\hline & Striegl, Robert G. & CR320 & 21 \\
\hline & Stonestrom, David A. & WRO24 & 265 \\
\hline & Thorstenson, Donald C. & NR093 & 142 \\
\hline & Voss, Clifford I. & NR089 & 247 \\
\hline & Weeks, Edwin P. & CR2O0 & 232 \\
\hline \multirow[t]{2}{*}{ Volcanic Hazards: } & Chen, Cheng-lung & WR194 & 410 \\
\hline & Sorey, Michael L. & WR102 & 268 \\
\hline \multirow[t]{5}{*}{ Wetlands: } & Carter, Virginia P. & NR090 & 36 \\
\hline & Hupp, Cliff R. & NR145 & 45 \\
\hline & LaBaugh, James W. & CR293 & 13 \\
\hline & Webb, Robert H. & WR200 & 117 \\
\hline & Winter, T.C. & CR323 & 24 \\
\hline
\end{tabular}




